\author{
Universidade de São Paulo \\ Faculdade de Filosofia, Letras e Ciências Humanas \\ Programa de Pós-graduação em Geografia Física
}

\title{
Ilha de calor em cidade de pequeno porte: Caso de Viçosa, na Zona da Mata Mineira
}

\author{
Edson Soares Fialho
}

Julho de 2009 


\author{
Universidade de São Paulo \\ Faculdade de Filosofia, Letras e Ciências Humanas \\ Programa de Pós-graduação em Geografia Física
}

\title{
Ilha de calor em cidade de pequeno porte: Caso de Viçosa, na Zona da Mata Mineira
}

\author{
Edson Soares Fialho
}

Tese de Doutorado apresentada ao Programa de Pós-graduação em Geografia, área de concentração: Geografia Física - Departamento de Geografia da Faculdade de Filosofia, Letras e Ciências Humanas, da Universidade de São Paulo, como parte dos requisitos necessários para a obtenção do título de Doutor em Geografia Física.

Orientador: Tarik Rezende de Azevedo.

Julho de 2009 


\section{Fialho, Edson Soares}

Ilha de calor em cidade de pequeno porte: Um caso de Viçosa, na Zona da Mati Mineira. Edson Soares Fialho. São Paulo: FFLCH/USP, 2009, ?p. il.

Orientador: Tarik Rezende de Azevedo.

Tese (doutorado) Universidade de São Paulo, PPGG

1. Climatologia urbana. 2. Cidade de pequeno porte. 3. Ilha de calor 
Às razões da minha vida:

Meus pais (José Fialho da Silva e Maria das Graças Soares da Silva); Minha esposa (Edmar Maria do Bomfim Fialho);

Minha filha (Letícia Maria do Bomfim Fialho) e a todos amigos e entes queridos que contribuíram com esta minha caminhada 
“...Não é a força, mas a perseverança que realiza grandes coisas...".

(Samuel Johnson) 


\section{Sumário}

RESUMO vii

ABSTRACT Viii

LISTA DE SIGLAS ix

LISTA DE FIGURAS Xi

LISTA DE TABELAS Xii

LISTA DE QUADROS Xiii

Prólogo e Agradecimentos 14

$\begin{array}{ll}\text { Introdução } & 18\end{array}$

1. A opção pela área de estudos, hipóteses e objetivos. 23

1.1. A escolha da área de estudo. 23

1.2. Hipótese de trabalho. 24

1.2.1. Ao nível campo-cidade. 26

1.2.2. Ao nível intra-urbano. 27

1.2.3. Ao nível da área central. 29

1.2.4. Objetivo geral e específico. 30

2. O clima urbano: Estado da arte. 31

2.1. A cidade: Uma prostituta devassa? 31

2.2. Evolução dos estudos de clima urbano. 35

2.3. A ilha de calor. 48

2.3.1. A llha de calor atmosférica. $\quad 51$

2.3.1.1. A influência do sítio urbano. 51

2.3.1.2. As causas da drenagem do ar frio nas vertentes. $\quad 54$

2.3.1.3. Variabilidade diária da ilha de calor atmosférica. 60

2.3.1.4. Variabilidade sazonal ilha de calor atmosférica. 62

2.3.1.5. Variabilidade espacial da ilha de calor atmosférica. $\quad 63$

2.3.1.6. Métodos de observação da ilha de calor. $\quad 64$

2.3.2. Ilha de calor vertical: Urban Boudary Layer. 67

2.3.3 Ilha de calor de superfície. $\quad 70$

2.3.3.1. Estudos sobre ilha de calor urbana de superfície. $\quad 71$

2.3.4. Estudos de ilha de calor: O método dos transetos fixos e móveis. $\quad 76$

2.3.4.1. No Mundo. 76

2.3.4.2. No Brasil. $\quad 95$ 
3. Apresentando a área de estudo.

3.1. A floresta que um dia existiu no sertão do rio Doce. 117

3.2. Caracterização climática. 123

3.3. De Santa Rita do Turvo à Viçosa. 127

3.4. Viçosa: Uma cidade de pequeno porte. 140

4. Materiais e Métodos. 151

4.1. Análise da tendência da temperatura do ar em Viçosa-MG. 151

4.2. Análise da temperatura do ar em diferentes escalas. 152

4.3. Entre o campo e a cidade. 153

4.4. Dentro da área urbana. 161

4.5. Dentro da área central da cidade. 172

4.6. Análise da condição sinóptica do tempo. 179

4.7. Tratamento e correção dos dados de campo. 180

4.7.1. Correção dos dados de campo noturno. 179

4.8. Uso de recursos técnicos e análise dos dados. 181

5. Resultados e Discussões. 183

5.1. Variação da temperatura média do ar no período de 1968-2006. 183

5.2. Transetos noturnos entre o campo e a cidade. 188

$\begin{array}{ll}\text { 5.2.1. Outono de } 2008 . & 189\end{array}$

5.2.5. Inverno de 2008.

5.2.6. Verão de 2009.

5.3. Transetos dia-noite entre o campo e a cidade. 194

5.4. O campo térmico na área urbana de Viçosa. 199

5.4.1. O campo térmico às 9:00 horas. 202

5.4.2. O campo térmico às 15:00 horas. 203

5.4.3. O campo térmico às 21:00 horas. 204

5.5. O campo térmico na área central. 205

5.5.1. O campo térmico às 5:00 horas. 205

5.5.2. O campo térmico às 12:00 horas. 212

5.5.3. O campo térmico às 19:00horas. 218

6. Discussões e considerações finais. 224

7. Desdobramentos futuros. 228

8. Lista de Referências 234

9. Anexos

9.2. Anexos 2 - Temperatura às $15 \mathrm{~h}$. 260

9.3. Anexos 3 - Temperatura às $21 \mathrm{~h} \quad 270$ 


\section{Resumo}

Com a crescente evolução da mancha urbana das cidades, o ser humano intensificou o seu uso sobre o espaço, ocasionando certas conseqüências socioambientais, intensificadas através de fenômenos climáticos, tais como: enchentes, a piora da qualidade do ar e do aumento da temperatura nas cidades, comparada a sua área entorno. Este último, também é conhecido como llha de calor. A área de estudo contemplada nesta pesquisa se justificativa pelo fato de apresentar: a) um crescimento acelerado da população urbana a partir de meados da década de 1970; b) um Intenso processo de verticalização iniciado na década de 1980 e c) por conseguinte a expansão da malha urbana da cidade, que convive com uma arborização muito reduzida. A partir destes argumentos, o presente trabalho procurou investigar a hipótese da constituição de um clima urbano associado ao crescimento da cidade sede do município de Viçosa. Para isto, primeiramente, analisou-se a série histórica da estação climatológica de Viçosa entre 1968 e 2006. E, em seguida, utilizou-se da técnica de transetos móveis, com a utilização de um termohigrômetro digital de leitura direta (MINIPA-MT-241), envolvido em tubo PVC recoberto por papel alumínio e colocado do lado de fora do carro há uma altura de aproximadamente $2,0 \mathrm{~m}$ de altura. Este procedimento foi realizado em três escalas de análise: campo-cidade, área urbana e o centro da cidade e estações sazonais distintas. Depois de realizados os experimentos e analisado os registros históricos de temperatura do ar, pode-se dizer que Viçosa ainda não constitui um clima urbano, muito embora, possa ter sido possível identificar ilhas de calor na cidade, principalmente à noite.

Palavras-chave: clima urbano, ilha de calor e cidade de pequeno porte. 


\begin{abstract}
With the increasing development of urban stain of cities, the human being intensified its use on the area, causing certain social consequences, intensified by climatic phenomena, such as flooding, the worsening air quality and increasing the temperature in cities compared to its surrounding area. The latter is also known as heat island. The study area included in this search was justified because the present: a) an accelerated growth of urban population from the mid-1970s, b) a Intensy verticalisation process started in the 1980s and c) therefore the expansion of urban network of the city, living with a very limited stock. From these arguments, this study sought to investigate the possibility of setting up a climate associated with the urban growth of the city headquarters of the municipality of Viçosa. For this, first analyzes the historical series of the climatological station of Viçosa between 1968 and 2006. And then it was used the technique of mobile transects, using a digital direct reading termohigrômetro (MINIPA-MT-241), involved in PVC pipe covered by aluminum foil and placed outside the car there is a height of approximately $2.0 \mathrm{~m}$ high. This procedure was performed on three scales of analysis: country-city, urban area and the city center and seasonal distinct seasons. After the experiments performed and analyzed the historical records of air temperature, we can say that Viçosa still not an urban environment, though, might have been possible to identify islands of heat in the city, mainly at night.
\end{abstract}

Keywords: climate, urban heat island and city of small size 


\section{Lista de Siglas}

ACP - Análise de Componentes Principais.

AIRJ - Aeroporto Internacional do Rio de Janeiro.

AM - Amazonas.

APP - Área de Preservação Permanente.

CBD - Center Business District (Área central de Negócios).

CPTEC - Centro de previsão do tempo e estudo do clima.

DAH - Departamento de Artes e Humanidades.

DCE - Diretório Central dos Estudantes.

DEA - Departamento de Engenharia Agrícola.

DHN - Diretoria de Hidrografia e Navegação.

EMBRAPA - Empresa Brasileira de Pesquisa Agropecuária.

ENG - Encontro Nacional de Geografia.

ESAV - Escola Superior de Agricultura e Veterinária.

ESUV - Escola de Ensino Superior de Viçosa.

EUA - Estados Unidos da América.

FCT/UNESP -Faculdade de Ciência e Tecnologia da Universidade Estadual Paulista

FDV - Faculdade de Viçosa.

IAUC - International Association for Urban Climate.

IBGE - Instituto Brasileiro de Geografia e Estatística.

IDH - Índice de Desenvolvimento Humano.

INMET - Instituto Nacional de Meteorologia.

INPE - Instituto de Pesquisas Espaciais.

IPEA - Instituto de Pesquisas Econômicas e Aplicadas.

IT - Índice de Terceirização.

LANDSAT - Land Remote Sensing Satellite (Sensoriamento Remoto por Satélite da Terra).

LNCC - Laboratório Nacional de Computação Científica.

LPC - Laboratório de Papel e Ceulose.

MEC - Ministério da Educação.

MG - Minas Gerais.

MPA - Massa Polar Atlântica.

MPT - Massa Polar Tropicalizada.

MTA - Massa Tropical Atlântica.

NOAA/AVHRR - Nacional Oceanic and Atmosphere Administration/ Advanced Very Higt Resolution Radionater (Administração da atmosfera e oceano nacional/Radiometria de alta resolução avançada). 
OMM - Organização Meteorológica Mundial.

PIB - Produto Interno Bruto.

PR - Paraná

PUC-Rio - Pontifícia Universidade Católica do Rio de Janeiro.

REDEMET - Rede de Meteorologia do Comando da Aeronáutica.

RMBH - Região Metropolitana de Belo Horizonte.

RS - Rio Grande do Sul.

SAAE - Serviço de Abastecimento de água e esgoto.

SBCG - Simpósio Brasileiro de Climatologia Geográfica.

SCU - Sistema Clima Urbano.

SP - São Paulo.

SVF - Sky View Factor (Fator de obstrução do céu).

ONU - Organização das Nações Unidas.

OMM - Organização Meteorológica Mundial.

SBCG - Simpósio Brasileiro de Climatologia Geográfica

UBL - Urban Boundary-layer (Camada Limite Urbana).

UCL - Urban Canopy-layer (Camada Intra-Urbana).

UEA - Universidade do Estado do Amazonas.

UERJ - Universidade do Estado do Rio de Janeiro.

UFJF - Universidade Federal de Juiz de Fora.

UFG - Universidade Federal de Goiás.

UFMG - Universidade Federal de Minas Gerais.

UFV - Universidade Federal de Viçosa.

UFPR - Universidade Federal do Paraná.

UFSC - Universidade Federal de Santa Catarina.

UNESP-RC - Universidade Estadual de São Paulo-Rio Claro.

UNIVIÇOSA - Universidade de Viçosa.

UNICAMP - Universidade de Campinas.

UNISC - Universidade de Santa Cruz do Sul.

UREMG - Universidade Rural do Estado de Minas.

UIA - União Internacional dos Arquitetos.

USP - Universidade de São Paulo.

$\mu \mathrm{m}-$ microns. 


\section{Lista de Figuras}

Figura 1. Evolução quantitativa dos trabalhos publicados em clima urbano.

Figura 2. Hipótese da variação da temperatura do ar ao longo do transeto

Figura 3. Espacialização hipotética da ilha de calor na área urbana de Viçosa para o período da manhã e noturno.

Figura 4. Espacialização hipotética da ilha de calor na área urbana de Viçosa para o período da tarde...............

Figura 5. Hipsometria em 3D da área central de Viçosa..

Figura 6. Mapa de radiação direta global $(\mathrm{HWH})$ da área central de Viçosa.

Figura 7. Proposta de criação zonas de clima urbano desenvolvida por Oke, 2006.

Figura 8. Identificação da ilha de calor em Paris.

Figura 9. Variação e expansão da ilha de calor urbana em Phoenix, EUA, decorrente da expansão mancha urbana.................

Figura 10. Albedo de materiais de construção.

Figura 11. Variáveis controladas ou não responsáveis pela formação da ilha de calor.

Figura 12. Comparação dos resultados obtidos da intensidade máxima da ilha de calor em cidades brasileiras comparado ao contingente populacional.

Figura 13. Fotografias obtidas por lentes olho de peixe no centro de Göteborg - Suécia -. A fotografia (A) foi obtida em uma área aberta e tem um SVF de 0,96; A fotografia (B) foi obtida junto a um vale urbano com prédios de um lado da rua e cobertura vegetal da outra o SVF é de 0.52

Figura 14. Tipos de ilhas de calor.

Figura 15. Tipos de sítios (topografia-cidade)...

Figura 16. Séries de mapas que mostram sombras de terreno modeladas na bacia de Tekapo, Nova Zelândia, para os horários das 6:00, 9:00 e 12:00 GMT, no dia 12/2/1999

Figura 17. Mecanismos de circulação terciária em fundo de vale.

Figura 18. Ciclo diário da temperatura do ar e o balanço de radiação da superfície terrestre.

Figura 19. Nevoeiro de resfriamento noturno, localizado no bairro de silvestre, visto a partir da rua Tiradentes. 67 do bairro do João Brás, no município de Viçosa-MG.

Figura 20. Modelo de drenagem do ar rio.

Figura 21. Localização de temperaturas mínimas no fundo do vale em decorrência do mecanismo de brisa de montanha ao longo da noite.

Figura 22. Comportamento diário da temperatura do ar entre o ambiente rural e urbano e sua diferença, mais evidente após às 18:00 e se intensificando até às 21:00 horas, quando sofre um decaimento constante até o alvorecer.

Figura 23. Perfil de intensidade da ilha de calor associado ao mapeamento bidimensional.

Figura 24. Estratificação vertical da atmosfera urbana proposta por Oke (1978) e os processos de formação da ilha de calor

Figura 25. Imagem panorâmica do Maciço da Tijuca sob condição de céu claro e poucas nuvens com predomínio da massa tropical atlântica.

Figura 26. Imagem obstruída pela inversão térmica, criando uma atmosfera carregada de poluentes, que obstrui a vista do Maciço da Tijuca.

Figura 27. Ilha de calor: Possíveis configurações da circulação sobre a cidade em condições sinóticas de ventos fracos.

Figura 28. Demonstração dos tipos de ilha de calor de acordo com o local de obtenção da temperatura.

Figura 29 Perfil da temperatura do ar ao longo do transeto móvel, na cidade de Regina, Canadá..................

Figura 30. Variação da temperatura do ar ao longo das seis observações móveis de campo, realizado numa sessão leste-oeste de parte da bacia do rio Jinghong......

Figura 31. Mapeamento do campo térmico no dia 12 de fevereiro de 1986, às 21 horas e 35 minutos na região metropolitana de Barcelona

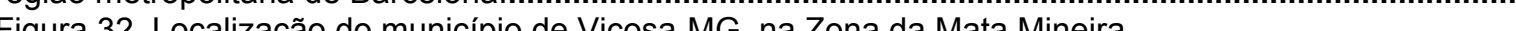

Figura 33. Hipsometria do município de Viçosa.

Figura 34. Uso da terra e ocupação no município de Viçosa-MG.

Figura 35. Rede ferroviária da Leopoldina nos Estados de MG, RJ e ES

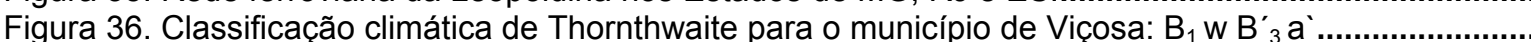

Figura 38. Sistemas de circulação atmosférica pertubada na região sudeste.................................................

Figura 39. Núcleo inicial, vendo-se a antiga Igreja Matriz, à direita, 1898.

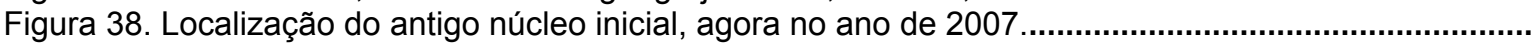

Figura 40. Limite territorial do município de Viçosa antes da década de 1950.

Figura 41. Vista parcial do município de Viçosa, privilegiando a área urbana e o entorno imediato, com base no Modelo Digital de Elevação (MDE)...

Figura 42. Visão parcial da área urbana e a demonstração do limite entre a UFV e a cidade...................... Figura 43. A área urbana e o campus da UFV, no município de Viçosa-MG................................................ Figura 44. Localização dos núcleos de verticalização em Viçosa-MG.

Figura 44a. Visão do edifício Burle Marx 
Figura 45. Visão parcial da cidade de Viçosa.

Figura 46. Evolução da mancha urbana de Viçosa.

Figura 47: Minas Gerais: 2003. Índice de terceirização dos municípios mineiros........................................ 143

Figura 48. Minas Gerais: 2005.Cidades médias de Minas Gerais, segundo o índice de terceirização......... 143

Figura 49: Nível hierárquico das cidades médias no Estão de Minas Gerais.............................................. 147

Figura 50. Localização dos pontos de medidas ao longo do transeto Paula Cândido-Porto Firme.................. 154

Figura 51. Partes do equipamento utilizado juntamente com o termohigrômetro digital.................................... 155

Figura 52. Veículo equipado para a realização das medidas de campo.............................................................155

Figura 53. Localização dos pontos de medida de temperatura do ar dentro da área urbana de Viçosa. ..... 163

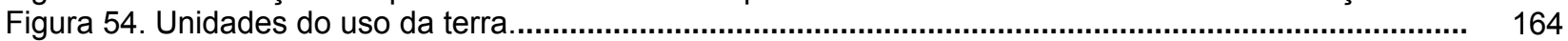

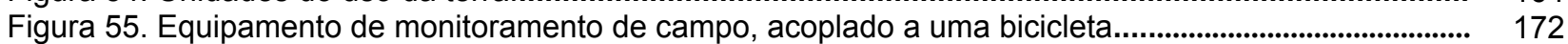

Figura 56. Localização dos pontos de coleta de temperatura na área central de Viçosa ............................. 173

Figura 57. Diferença entre a temperatura observada e registrada.............................................................1 181

Figura 58. Classificação climática de Koppen para a porção leste da região sudeste do Brasil.................. 184

Figura 59. Evolução da temperatura media do ar na estação meteorológica de Viçosa entre 1970 e 2006............ 185

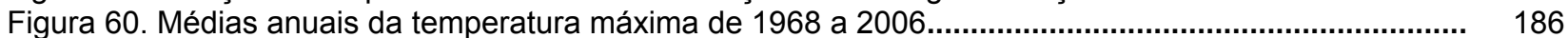

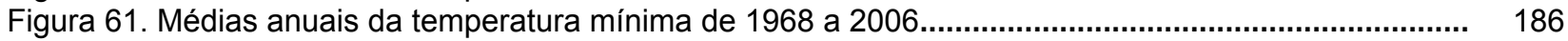

Figura 62. Teste de Mann-Kendall para a temperatura máxima mensal.................................................. 187

Figura 63 Evolução da temperatura do ar e da umidade relativa horária entre os dias 6/5/2008 e 12/5/2008 para estação meteorológica de Viçosa...

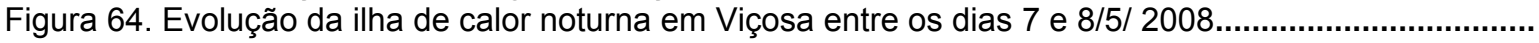

Figura 65. Evolução da ilha de calor noturna em Viçosa entre os dias 12 e 13/5/ 2008.

Figura 66. Evolução da ilha de calor noturna em Viçosa entre os dias 27 e 28/8/ 2008.

Figura 67. Evolução da ilha de calor noturna em Viçosa entre os dias 27 e 28/3/ 2009....

Figura 68. Variabilidade da temperatura do ar no transeto campo-cidade sentido Paula Cândido-Porto Firme (S-N) durante as estações de inverno, verão e outono.

Figura 69. Variabilidade da umidade relativa no transeto campo-cidade sentido Paula Cândido-Porto Firme (S-N) durante as estações de inverno, verão e outono...

Figura 70. Mapeamento da temperatura do ar no dia 17/3/2009, às 21:00 horas.............

Figura 71. Mapeamento da temperatura do ar no dia 17/3/2009, às 21:00 horas.......

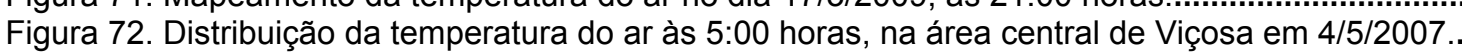

Figura 73. Distribuição da temperatura do ar às 5:00 horas, na área central de Viçosa em 5/5/2007..........

Figura 74. Distribuição da temperatura do ar às 5:00 horas, na área central de Viçosa em 6/5/2007..........

Figura 75. Distribuição da temperatura do ar às 5:00 horas, na área central de Viçosa em 7/5/2007..........

Figura 76. Distribuição da temperatura do ar às 5:00 horas, na área central de Viçosa em 6/9/2008..........

Figura 77. Distribuição da temperatura do ar às 5:00 horas, na área central de Viçosa em 7/9/2008.........

Figura 78. Distribuição da temperatura do ar às 5:00 horas, na área central de Viçosa em 9/9/2008..........

Figura 79. Distribuição da temperatura do ar às 5:00 horas, na área central de Viçosa em 13/9/2008.......

Figura 80. Distribuição da temperatura do ar às 5:00 horas, na área central de Viçosa em 7/3/2009..........

Figura 81 Distribuição da temperatura do ar às 5:00 horas, na área central de Viçosa em 8/3/2009...........

Figura 82. Distribuição da temperatura do ar às 12:00 horas, na área central de Viçosa em 5/5/2007........

Figura 83. Distribuição da temperatura do ar às 12:00 horas, na área central de Viçosa em 5/5/2007.......

Figura 84. Distribuição da temperatura do ar às 12:00 horas, na área central de Viçosa em 6/5/2007.......

Figura 85. Distribuição da temperatura do ar às 12:00 horas, na área central de Viçosa em 7/5/2007........

Figura 86. .Distribuição da temperatura do ar às 12:00 horas, na área central de Viçosa em 13/9/2008.....

Figura 87. Distribuição da temperatura do ar às 12:00 horas, na área central de Viçosa em 7/3/2009.......

Figura 88. Distribuição da temperatura do ar às 12:00 horas, na área central de Viçosa em 8/3/2009........

Figura 89. Distribuição da temperatura do ar às 19:00 horas, na área central de Viçosa em 4/5/2007........

Figura 90. Distribuição da temperatura do ar às 19:00 horas, na área central de Viçosa em 5/5/2007.......

Figura 91. Distribuição da temperatura do ar às 19:00 horas, na área central de Viçosa em 6/5/2007........

Figura 92. Distribuição da temperatura do ar às 19:00 horas, na área central de Viçosa em 7/5/2007........

Figura 93. Distribuição da temperatura do ar às 19:00 horas, na área central de Viçosa em 6/8/2008........

Figura 94. Distribuição da temperatura do ar às 19:00 horas, na área central de Viçosa em 7/9/2008........

Figura 95. Distribuição da temperatura do ar às 19:00 horas, na área central de Viçosa em 9/9/2008........

Figura 96. Distribuição da temperatura do ar às 19:00 horas, na área central de Viçosa em 13/9/2008......

Figura 97. Distribuição da temperatura do ar às 19:00 horas, na área central de Viçosa em $7 / 3 / 2009 . . . . . .$.

Figura 98. Distribuição da temperatura do ar às 19:00 horas, na área central de Viçosa em 8/3/2009........

Figura 99. Representação esquemática da dimensão da mancha urbana de Viçosa...

188

191

191

192

193

197

198

200

201

206

207

207

208

209

210

210

211

211

212

214

214

215

215

216

216

217

219

220

220

221

221

222

222

223

223

224

226 


\section{Lista de Tabelas}

Tabela 1. Processo de Urbanização. Consumo e Recurso para a população mundial.

Tabela 2. Trabalhos de revisão bibliográfica de clima urbano após o ano de 2000 .

Tabela 3. Evolução Percentual Trabalhos de acordo com os temas apresentados no

Simpósios Brasileiros de Climatologia (1992-2008)

Tabela 4. Trabalhos publicados por região do Brasil no SBCG (1992-2008).

Tabela 5. Velocidade crítica do vento na atenuação da ilha de calor..

Tabela. 6. Levantamento de alguns trabalhos que utilizaram transetos móveis.

Tabela 7. Observações realizadas por meio de Pontos Fixos e Transetos Móveis.

Tabela 8: Observações realizadas por meio de transeto (Fixos e móveis) no Brasil.....................

Tabela 9. Relação dos maiores produtores de café na Zona da Mata, com as respectivas datas de criação do município e de elevação a categoria de cidade

Tabela 10. Evolução da população urbana e urbana de Viçosa de 1950 à 2000.

Tabela 11. Comparação entre a dimensão demográfica da maior aglomeração e a dimensão demográfica das cidades médias, em alguns países da União Européia.

Tabela 12. Minas Gerais: 2005. População Residente. PIB em 2003. relação média trienal (2001. 2001 e 2003) entre o Valor Adicionado pelo Serviço e o PIB e Índice de Terceirização. Municípios Mineiros selecionados.

Tabela 11. Caracterização dos pontos de coleta do transeto campo-cidade....

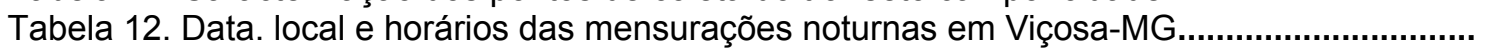

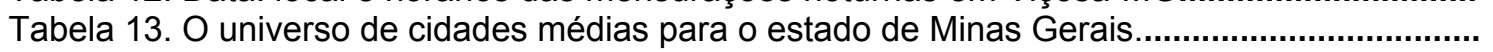

Tabela 14. Níveis hierárquicos das cidades médias de Minas Gerais

Tabela 15. Caracterização dos pontos de coleta do transeto campo-cidade....

Tabela 16. Data, local e horários das mensurações noturnas em Viçosa-MG.

Tabela 17. Tipos do uso da Terra urbana.

Tabela 18. Caracterização dos pontos de coleta do transeto campo-cidade...

Tabela 19. Caracterizaç̃̃o dos pontos de coleta dos pontos na área central de Viçosa...........................

Tabela 20. Exemplo de correção da temperatura do ar.

Tabela 21. Resultados das análises de tendência para a temperatura média mínima de cada mês.........

Tabela 22. Comparação dos resultados obtidos, a partir da diferença de temperatura do ar entre o campo e a cidade com outros estudos, que utilizaram transetos móveis.

Tabela 23. Comparação entre as diferenças temperatura do ar entre o campo e a cidade, que utilizaram pontos fixos.

Tabela 24. Intensidades das amplitudes térmicas máximas observadas ao longo do

transeto Paula Cândido-Porto Firme...

\section{Lista de Quadros}

Quadro 1. Ambientes rurais e urbanos para alguns estudos de clima urbano.

Quadro 2. Estágio de urbanização e freqüência da ocorrência das ilhas de calor.

Quadro 3. Vantagens e desvantagens no processo de mensuração por meio de pontos fixos ou transetos móveis.

Quadro 4. Hierarquização das escalas climáticas segundo Monteiro (1976)

Quadro 5. Hierarquização das escalas climáticas segundo Linacre (1981) 


\section{Prólogo e Agradecimentos.}

A opção em cursar a pós-graduação em Geografia Física da Universidade de São Paulo (USP) se deve ao fato desta instituição apresentar um histórico de pesquisa consolidado na área de climatologia urbana, capitaneado pelo Laboratório de Climatologia e Biogeografia, que sempre esteve na vanguarda das pesquisas relacionadas à atmosfera intra-urbana ao longo dos seus 30 anos de atividades. Tanto assim, que no levantamento realizado por Fialho (2006) os coordenadores dos Laboratórios de clima urbano nas demais universidades federais e estaduais brasileiras, cerca de 50,0\% fizeram sua pós-graduação (mestrado e/ou doutorado) no programa de pós-graduação em Geografia Física da USP.

Ao trabalhar com a questão climato-ambiental, envolvendo o espaço urbano. Este demonstra suas contradições quando se altera a forma de percebê-lo e verifica-se um grande contingente populacional urbano "excluído" de quase tudo que ela pode oferecer. A cidade é hoje o reflexo da atualidade, tornando-a, conseqüentemente, alvo de diversos estudos, inclusive os de cunho geográfico.

A urbanização e o crescimento acelerado das cidades vêm transformando a configuração de grandes áreas do globo de maneira abrupta sem precedentes na história da humanidade.

A interdependência entre o meio urbano e a sociedade, prenunciou - o homem é um ser pertencente à cidade, pois é um possuidor da palavra (CASÉ, 2000, p. 92). Partindo desse pressuposto, a mesma não pode ser vista como um mal em si, mas um bem que nos pertence e que deve ser cuidada. Embora, não se possa negar que à medida que o ser humano se apropria do espaço físico, cria uma nova condição na composição da baixa troposfera, dependendo do tamanho da cidade.

O projeto de pesquisa, inicialmente, apresentado se tratava da: “...Definição de Unidades Climáticas Urbanas com base na Metodologia de Interpretação de Imagens Aster para a Região Metropolitana do Rio de Janeiro...". Porém, em agosto de 2005, fui chamado para ocupar a vaga de professor Assistente I na Universidade Federal de Viçosa (UFV). Contudo, em razão de problemas administrativos e burocráticos, minha designação publicada no Diário oficial foi cancelada junto ao Ministério da Educação (MEC), que alegara que o prazo de publicação do segundo colocado no concurso para a vaga de Geografia Física havia expirado. 
A partir daí, iniciou-se uma batalha jurídica. No dia 6 de outubro de 2005, quando foi aberto um novo concurso para a área de Geografia Física, impetrei um mandato de segurança junto ao Tribunal de Justiça de Belo Horizonte. Nesse meio tempo, que o concurso foi suspenso. Retornei aos trabalhos, todavia, quando tudo parecia estar voltando à normalidade, o professor da Pontifícia Universidade Católica do Rio de Janeiro (PUC-Rio), responsável pelos programas e imagens de satélite, que seriam utilizados iniciou um processo de obstrução.

Logo a seguir, em meados de dezembro de 2005, o mandado de segurança foi acolhido. E no dia 5 de janeiro de 2006 fui convocado pela UFV a realizar exames médicos para assumir a vaga de Professor, que havia requerido via judicial.

Após esse momento inicial, no dia 25 de janeiro de 2006 tomei posse. Mesmo com os recursos impetrados pelo MEC, que ainda recorre, prolongando a disputa judicial até os dias de hoje.

Durante o ano de 2006 procurei contornar os problemas decorrentes da distância da família e da estrutura de trabalho, já consolidados no Rio de Janeiro. Durante o mês de maio participei do $4^{\circ}$ Encontro de Usuários de Imagens digitais e sensoriamento remoto, entre os dias 22 e 24 de maio de 2006, realizado pelo Instituto de Pesquisas Espaciais (INPE), no Laboratório Nacional de Computação científica (LNCC), situado na cidade de Petrópolis-RJ.

No evento, ao participar de um mini-curso de imagens de satélite, foi possível verificar alguns problemas que deveriam ser superados ao longo do projeto. Ao voltar ao trabalho na UFV, esperançoso de superar os obstáculos identificados, me deparei com tentativas fracassadas de estreitamento de laços com outros profissionais da universidade, que me permitiriam utilizar os laboratórios de outros departamentos não frutificaram e o trabalho cada vez mais foi se tornando inviável.

No mês de setembro de 2006, a comissão coordenadora do curso de Geografia, concedeu a dois professores efetivos (um da área de Geografia Humana e outro da Geografia Física), uma licença remunerada para finalizarem seus treinamentos (doutoramento). A partir deste instante, comecei a pensar em mudar o foco do trabalho. Mas não sabia para onde ir. Até que um graduando de final de curso, interessado pela temática de clima urbano, me fez pensar se a cidade de Viçosa teria ou não um clima urbano.

A reflexão resultante me instigou a procurar os dados da estação meteorológica de Viçosa. O resultado desta primeira investigação foi uma 
publicação no VI Simpósio Brasileiro de Climatologia Geográfica (SBCG), realizado entre 20 e 25 de agosto de 2006 em Rondonópolis-MT, intitulado: As alterações climáticas e o crescimento desordenado das cidades - Um estudo de caso da cidade de Viçosa-MG.

Apesar dos afazeres, ao longo do segundo semestre de 2006 resolvi assumir os riscos da mudança do projeto de doutorado, com a compreensão e o consentimento do meu orientador.

Após este momento de impasse, as reflexões acerca da existência ou não de Clima urbano em Viçosa, iniciadas pela questão colocada pelo acadêmico Vinícius Machado Rocha foram se desdobrando, contanto com a ajuda do mesmo na realização dos primeiros experimentos de campo em Viçosa ${ }^{1}$, que se envolveu de tal maneira, a ponto de desenvolver seu trabalho final de curso ligado à questão inicial de nossa conversa. Hoje o mesmo aluno encontra-se terminando o mestrado na Universidade Estadual do Amazonas (UEA), em parceria com o INPE, no Programa de Pós-Graduação Clima e Meio Ambiente, focado nas questões climáticas da Amazônia.

Este trabalho desenvolvido foi publicado no IX Encontro Internacional de Humboldt, em setembro de 2007 na cidade de Juiz de Fora-MG, sob o título: $A$ questão climato-ambiental em cidades médias brasileiras: Um estudo de caso em Viçosa-MG; as pesquisas e os levantamentos de campo continuaram com a participação de outros alunos que nos auxiliaram no desenvolvimento dos trabalhos.

Felizmente, o envolvimento de alguns destes acadêmicos também resultaram em monografias na área de climatologia urbana ${ }^{2}$, como: Jaime Augusto Alves dos Santos, que versou sobre o campo térmico na área central da cidade de ViçosaMG em situação sazonal de outono em 2007; Paula Portela de Andrade com o trabalho: Análise temporal da ilha de calor noturna, no município de Viçosa em situação sazonal de outono-2008 e Vinícius Genaro abordando a diferença térmica dentro da área urbana de Viçosa-MG, sob influência de diferentes condições sinóticas, durante o outono de 2008.

Além destes, outros alunos vem nos auxiliando ao longo desta trajetória, tais como: Pedro Assis Neto, Thainá Godoy e Rosilene Aparecida do Nascimento. Aos

\footnotetext{
${ }^{1}$ Infelizmente os registros de campo do acadêmico Vinícius Machado Rocha não foram incluídos no corpo da tese, pois o trajeto definido para a realização do transeto campo-cidade é diferente do que definimos para coleta de dados neste trabalho.

${ }_{2}^{2}$ Disponíveis no sítio www.geo.ufv.br/monografias.
} 
meus companheiros de longa data, como a Professora Érika Collischonn da Universidade de Santa Cruz do Sul (UNISC), que nos emprestou um termohigrômetro digital, quando o nosso começou a apresentar problemas. Ao professor Eduardo Maia do Departamento de Geografia da UFV, que nos emprestou o seu querido Beethoven (Fusca azul), infelizmente raptado de nosso convívio, quando excursionava na cidade do Rio de Janeiro. A experiência e ao companheirismo do Professor Luís Alberto Martins da Universidade Federal de Juiz de Fora (UFJF), que nos escutou nos momentos de devaneio. A camaradagem do longínquo Weellington Lopes Assis, professor da Universidade de Belo HorizonteUNI-BH, por me enviar o programa Surfer v. 8, imprescindível na elaboração dos gráficos espaço temporais.

Ao acadêmico de última hora que se prontificaram a auxiliar na resolução de problemas técnicos relacionado à produção cartográfica, o meu agradecimento, a Brunno Resck. A graduanda Raquel Zacchi e ao seu ex-orientador, professor do antigo Departamento de Artes e Humanidade (DAH) Ronan Eustáquio Borges (hoje na Universidade Federal de Goiás - UFG) por compartilhar de suas pesquisas sobre o processo de verticalização da cidade de Viçosa.

Não poderia esquecer, também, dos amigos e entes queridos envolvidos nos registros térmicos noturnos durante as férias de verão de 2009, como: Maria das Graças Soares da Silva (mãe), César Piva (cunhado), Edna Piva (irmã), Ana Luiza Piva (sobrinha), Seu Lopes (taxista), Edmar Maria do Bomfim Fialho (esposa) e Letícia Maria do Bomfim Fialho (filha). Estas duas últimas os meus mais sinceros agradecimentos por aturarem um homem, muitas vezes, alienado dos problemas domésticos e conflitos familiares, a fim de cumprir as etapas do trabalho proposto.

E ao meu orientador, Tarik Rezende de Azevedo, um grande pesquisador e pessoa incrível, que conheci em 2000, no $4^{\circ}$ Simpósio Brasileiro de Climatologia Geográfica (SBCG) e que desde 2002, vínhamos conversando sobre a possibilidade de realizar o doutorado sob sua orientação, no Encontro Nacional de Geografia (ENG) em João Pessoa. O meu agradecimento por sua confiança e compreensão dos obstáculos que atrapalharam a caminhada no processo de elaboração e realização da pesquisa. E o meu pedido de desculpas por não ter investido tanto como gostaria e por não ter contribuído pelas suas insônias. 


\section{Introdução}

A cidade é tida como o local onde os problemas socioambientais ocorrem com maior intensidade. Entre os principais problemas, os relacionados ao clima são mais evidentes, pois o processo de urbanização cria um novo ambiente e influencia nas condições de manutenção da saúde do urbanita, mesmo que de maneira imprevista. Por exemplo, através da emissão de gases poluentes pelos veículos automotores e da modificação no balanço de energia.

Embora, muitos (LYNCH, 1972; LIMA e RONCAGLIO, 2001; DREW, 2005 e TROPPMAIR, 2004) definam a cidade como o local da degradação física e humana, em razão dos problemas por ela gerados, a mesma, é o lugar da possibilidade de superação dos infortuitos inerentes ao seu próprio crescimento.

Segundo Flannery (2007, p. 93) a própria cidade já é o resultado da alteração na organização humana sobre o espaço, a fim de atender uma necessidade de melhor conforto, como ocorrido no sul da Mesopotâmia, por causa das condições climáticas mais secas. Segundo o mesmo autor, o ser humano ao longo da história estabelece uma batalha constante para manter o bem estar térmico, o que tem custado tempo e energia.

Esta se manifesta nas centenas de pequenas mudanças na posição do corpo e na postura que fazemos a cada dia e noite - retirando e colocando casacos, chapéus - que são manifestações simples dessa luta. Mas, esta visão de conflito constante com o tempo é distorcida, pelo fato do ser humano ser dotado da capacidade de adaptação as condições predominantes, não se estabelecendo uma batalha diária.

Para Monteiro (2008, p. 76) embora seja reconhecido que a cidade é o centro do espaço humanizado e que, num mundo simbolicamente organizado, o papel da mesma é de conferir uma imagem ordenada do universo.

A Geografia, como não poderia deixar de ser, sempre dispensou atenção ao estudo das cidades que se vem mostrando, cada vez mais, como a morada por excelência do homem na face da Terra. Dentre inúmeras razões, duas delas respondem por esse interesse: de um lado pela concentração populacional, organização social e dinamização econômica; de outro porque os espaços urbanizados são aqueles onde mais avultam as mudanças que o ser humano inflige ao meio natural (MONTEIRO, 2008, p. 78). 
Com base no levantamento realizado pelo World Resource Institute, as áreas urbanas concentram $49,0 \%$ da população mundial. Isto equivale dizer que quase metade da população mundial ocupa uma área de $0,05 \%$ da superfície da Terra (MASSON, 2006, p. 35) ${ }^{3}$. Porém seu crescimento ao longo do século $X X$ se apresentou intenso e desigual espacialmente.

As cidades dos países tropicais registraram um ritmo mais intenso, em decorrência do processo de urbanização e industrialização tardia, muito embora, ainda nos países desenvolvidos, as cidades concentrem um maior percentual de população, com $72,0 \%$, do que nos países em desenvolvimento, com $42,6 \%$. Estes últimos apresentam um conjunto de população residente nas cidades maiores, conforme demonstra a Tabela 1.

Em razão da preocupação com aumento da população urbana no mundo. a partir do início do século $\mathrm{XX}$, o estudo do clima das cidades vem ganhando importância. Contudo, apenas na década de 1970, começa a se identificar publicações de estudos de clima urbano em latitudes tropicais (JAUREGUI, 1973; 1993 e MONTEIRO, 1984).

Tabela 1. Processo de urbanização, consumo e recurso para a população mundial.

\begin{tabular}{|l|c|c|c|c|}
\hline \multicolumn{1}{|c|}{ Parâmetros } & $\begin{array}{c}\text { Cidades } \\
\text { desenvolvidas }\end{array}$ & $\begin{array}{c}\text { Cidades em } \\
\text { desenvolvimento }\end{array}$ & Mundo & Brasil \\
\hline População Urbana - 2005 (milhões) & 971,0 & 2185,0 & 3150,0 & 84,2 \\
\hline Porcentagem de Pop. Urbana (2005) & 72,0 & 42,6 & 49,0 & 83,0 \\
\hline Taxa de Crescimento (2000-2005) & 0,42 & 1,46 & 1,4 & 1,41 \\
\hline Consumo de Gasolina, 2005 (Litros/hab). & 601,2 & 61,4 & 173,5 & 90,6 \\
\hline Carros de passeio, 2000 (por 1000 hab). & 326,0 & 15,0 & $176,0^{*}$ & $79,0^{*}$ \\
\hline
\end{tabular}

Fonte: Disponível em World Resource Institute (www.wri.org). Acessado em abr. 2008

*Disponível em Population Reference Bureau (www.prb.org). Acessado em 28 out. 2008.

No Brasil, de acordo com Brandão et. al. (2000) o interesse pelo estudo do clima urbano no Brasil vem aumentando (Figura 1), desde a década de 1980, em função da problemática ambiental em nosso país.

Num esforço de sintetizar a situação atual da produção científica brasileira referente ao clima urbano, a partir de 1970 em um quadro preliminar, constata-se que grande parte dos trabalhos desenvolvidos privilegia as cidades das regiões Sul e Sudeste do Brasil, com cerca de 70,0\%.

\footnotetext{
${ }^{3} \mathrm{O}$ valor da proporção de área urbana que ocupa a superfície da Terra, não apresenta um consenso, variando entre 0,3\% (GUIDUGLI, 1984, p. 81) a 3,0\% (OKE, 1974).
} 


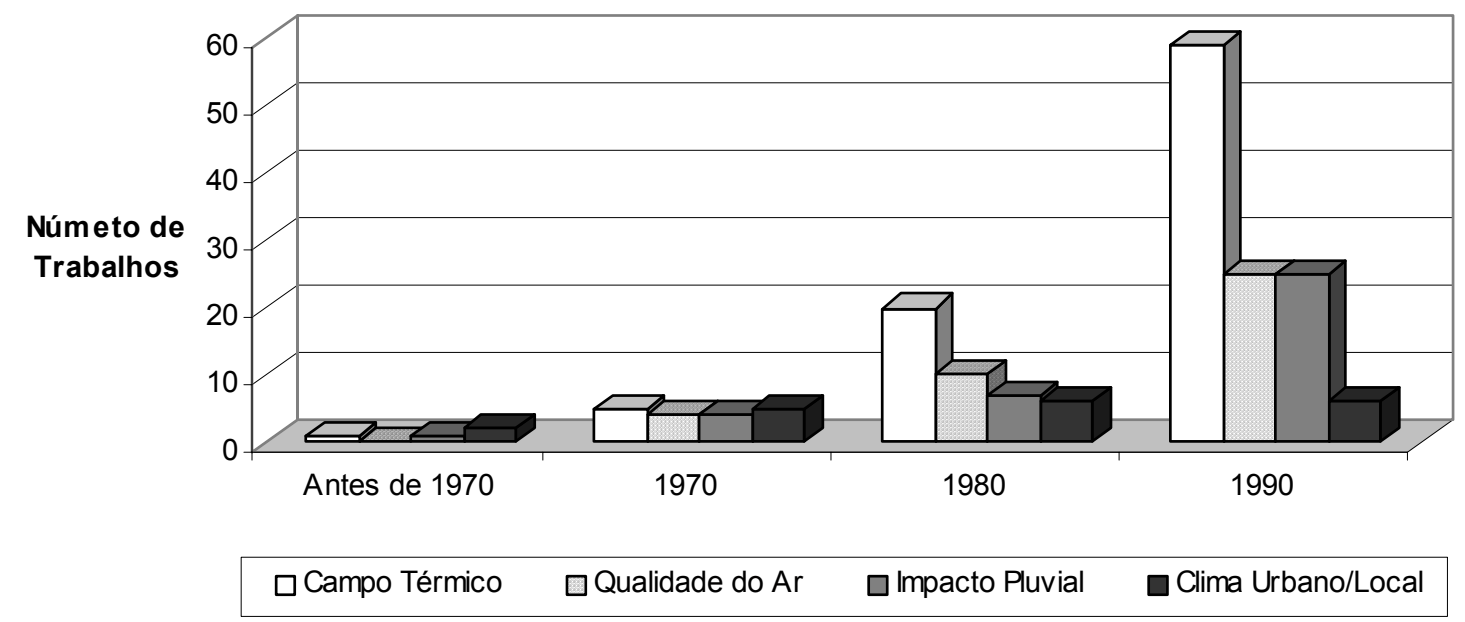

Figura 1. Evolução quantitativa dos trabalhos publicados em clima urbano.

Fonte: Brandão, Russo e Fialho (2000, p. 19).

Tal informação é confirmada por meio do trabalho desenvolvido por Zavatini (2002), quando o autor realiza um levantamento das dissertações e teses da USP que abordam o paradigma do ritmo.

Apesar do esforço de alguns pesquisadores de países tropicais, a distribuição espacial dos estudos de clima urbano continua concentrada nas cidades de latitudes médias, com cerca de 80,0\% (GOLDREICH, 1992; ARNIFIELD, 2003 e ROTH, 2007). Este valor tem como base os levantamentos realizados a partir do ano de 2000, conforme pode ser visto na Tabela 2.

Cabe destacar que os estudos referentes ao levantamento de trabalhos publicados acerca da temática urbana, apenas contabilizam os trabalhos publicados em língua inglesa, nos periódicos de referência internacional sobre o assunto.

Esse critério desconsidera o aumento da produção brasileira, que registrou um incremento do número de publicações, após a criação do SBCG, conforme estudos realizados por Fialho e Azevedo (2006). Os mesmos autores identificaram que ao longo de 14 anos de realização do evento 959 contribuições científicas foram apresentadas, que somadas aos 149 trabalhos apresentados no $8^{\circ} \mathrm{SBCG}$, em Alto Caparaó-MG, ultrapassa-se a barreira dos 1.000 artigos (Tabela 3).

Cabe destacar, que esta produção em grande parte é mantida por graduandos e pós-graduandos em fase de desenvolvimento de pesquisa. Isto quer dizer que são poucos os trabalhos completos apresentados. Caso este critério fosse considerado o número de publicações seria menor. 
Tabela 2. Trabalhos de revisão bibliográfica de clima urbano após o ano de 2000.

\begin{tabular}{|l|l|}
\hline \multicolumn{1}{|c|}{ Referência } & \multicolumn{1}{c|}{ Tópico } \\
\hline Sturman, A. P. (2000) & Revisão dos trabalhos de ilha de calor (mitigação. efeitos e implicações). \\
\hline Brandão et. al. (2000) & Revisão dos trabalhos de clima urbano publicados até 1990. \\
\hline Mendonça, F. (2003) & Evolução dos estudos de clima urbano no Brasil. \\
\hline Mckendry, I. G. (2003) & Levantamento dos trabalhos de clima urbano publicados entre 1998 e 2003. \\
\hline Arnfield, A. J. (2000) & Levantamento de estudos de clima urbano publicados em 1998. \\
\hline Arnfield, A. J. (2001a) & Revisão dos estudos relacionados a canyons urbanos publicados em 1999. \\
\hline Arnfield, A. J. (2001b) & Revisão dos estudos relacionados ao clima urbano publicados em 2000. \\
\hline Zavatini, J. A. (2002) & Revisão dos estudos que consideraram o paradigma do ritmo. \\
\hline Arnfield, A. J. (2003) & Revisão dos trabalhos de clima urbano publicados entre 1990 e 2002. \\
\hline Arnfield, A. J. (2006) & Revisão dos trabalhos de clima urbano publicados em 2003. \\
\hline Ely, D. . . (2006) & Revisão de teses que utilizaram a perspectiva do ritmo entre 1944 e 2003. \\
\hline Fialho, E. S. e Azevedo, T. R. (2006) & Revisão dos estudos de clima publicados entre 1992 e 2004 nos SBCG. \\
\hline Fialho, E. S. (2006) & Revisão dos estudos de clima publicados entre 1992 e 2006 nos SBCG. \\
\hline Souch, C. e Grimmond, S. (2006) & Revisão dos trabalhos de clima urbano publicados em 2004 e 2005. \\
\hline Roth, M. (2007) & Revisão de trabalhos de clima urbano em regiões sub-tropicais. \\
\hline Kanda, M. (2007) & Uma revisão dos progressos em trabalhos de meteorologia urbana. \\
\hline
\end{tabular}

Organizado por Edson Soares Fialho (2009).

Segundo Fialho (2006), embora o crescimento da produção científica tenha sido considerável, a concentração do número de publicações na região Sudeste é de cerca de $50,0 \%$, seguido pela região Sul com 20,0\%, conforme pode ser visto na Tabela 4. Por conta disto, o desenvolvimento conhecimento climatológico, ainda é limitado, uma vez que muitas realidades ainda são desconhecidas ou pouco estudadas.

Tabela 3. Evolução Percentual Trabalhos de acordo com os temas apresentados no Simpósios Brasileiros de Climatologia (1992-2008).

\begin{tabular}{|c|c|c|c|c|c|c|c|c|c|}
\hline Categorias & 1992 & 1996 & 1998 & 2000 & 2002 & 2004 & 2006 & 2008 & Total \\
\hline $\begin{array}{c}\text { Número de traba } \\
\text { publicados }\end{array}$ & $\begin{array}{l}74 \\
00,0 \%\end{array}$ & $0,0 \%$ & $\begin{array}{c}119 \\
100,0 \%\end{array}$ & $\begin{array}{c}129 \\
100,0 \%\end{array}$ & $\begin{array}{l}134 \\
00,0 \%\end{array}$ & $\begin{array}{c}197 \\
100,0 \%\end{array}$ & $\begin{array}{c}215 \\
100,0 \%\end{array}$ & $\begin{array}{c}159 \\
100,0 \%\end{array}$ & 08 \\
\hline & , U\%) & & $7,0 \%)$ & $(20,0 \%)$ & $\begin{array}{l}24 \\
8,0 \%)\end{array}$ & $\begin{array}{l}31 \\
16,0 \%)\end{array}$ & $\begin{array}{c}30 \\
14,0 \%)\end{array}$ & $\begin{array}{c}33 \\
(21,0 \%)\end{array}$ & \\
\hline Qualidade do ar & $\begin{array}{c}1 \\
(1,5 \%)\end{array}$ & $\begin{array}{l}3 \\
3,0 \%)\end{array}$ & 1 & $\begin{array}{c}4 \\
(3,0 \%)\end{array}$ & $\begin{array}{c}9 \\
8,0 \%)\end{array}$ & $\begin{array}{c}8 \\
4,0 \%)\end{array}$ & $\begin{array}{c}3 \\
(1,0 \%)\end{array}$ & $\begin{array}{c}0 \\
(0,0 \%)\end{array}$ & $\begin{array}{c}29 \\
(2,5 \%)\end{array}$ \\
\hline $\begin{array}{r}\text { Recursos } \\
\text { seca } \\
\text { impacto }\end{array}$ & $\begin{array}{c}24 \\
(32,0 \%)\end{array}$ & $\begin{array}{c}25 \\
27,0 \%)\end{array}$ & $\begin{array}{c}40 \\
34,0 \%)\end{array}$ & $\begin{array}{c}40 \\
(31,0 \%)\end{array}$ & $\begin{array}{c}30 \\
23,0 \%)\end{array}$ & $\begin{array}{c}64 \\
32,0 \%)\end{array}$ & $\begin{array}{c}48 \\
22,0 \%)\end{array}$ & $\begin{array}{c}45 \\
(28,0 \%)\end{array}$ & 31 \\
\hline $\begin{array}{l}\text { Estudos climáti } \\
\text { regionais e loc }\end{array}$ & $\begin{array}{c}7 \\
(9,0 \%)\end{array}$ & $\begin{array}{c}20 \\
(22,5 \%)\end{array}$ & $\begin{array}{c}18 \\
(15,0 \%)\end{array}$ & $\begin{array}{c}15 \\
(12,0 \%)\end{array}$ & $\begin{array}{c}19 \\
(14,0 \%)\end{array}$ & $\begin{array}{c}32 \\
(16,0 \%)\end{array}$ & $\begin{array}{c}17 \\
(8,0 \%)\end{array}$ & $\begin{array}{c}7 \\
(5,0 \%)\end{array}$ & $\begin{array}{c}135 \\
(12,5 \%)\end{array}$ \\
\hline $\begin{array}{c}\text { Dinâmica da } \\
\text { atmosfera }\end{array}$ & $\begin{array}{c}5 \\
(7,0 \%)\end{array}$ & $\begin{array}{c}0 \\
(0,0 \%)\end{array}$ & $\begin{array}{c}14 \\
(12,0 \%)\end{array}$ & $\begin{array}{c}4 \\
(4,0 \%)\end{array}$ & $\begin{array}{c}7 \\
(5,0 \%)\end{array}$ & $\begin{array}{c}13 \\
(7,0 \%)\end{array}$ & $\begin{array}{c}15 \\
(7,0 \%)\end{array}$ & $\begin{array}{c}26 \\
(16,0 \%)\end{array}$ & $\begin{array}{c}84 \\
(8,0 \%)\end{array}$ \\
\hline Clima & $\begin{array}{c}6 \\
(8,0 \%)\end{array}$ & $\begin{array}{c}11 \\
(12,5 \%)\end{array}$ & $\begin{array}{c}4 \\
(3,0 \%)\end{array}$ & $\begin{array}{c}6 \\
(5,0 \%)\end{array}$ & $\begin{array}{c}12 \\
(9,0 \%)\end{array}$ & $\begin{array}{c}12 \\
(6,0 \%)\end{array}$ & $\begin{array}{c}8 \\
(4,0 \%) \\
\end{array}$ & $\begin{array}{c}18 \\
(11,0 \%) \\
\end{array}$ & $\begin{array}{c}77 \\
(7,0 \%)\end{array}$ \\
\hline Clima e & $\begin{array}{c}1 \\
(1,5 \%)\end{array}$ & $\begin{array}{c}4 \\
(4,0 \%)\end{array}$ & $\begin{array}{c}4 \\
(3,0 \%)\end{array}$ & $\begin{array}{c}6 \\
(5,0 \%)\end{array}$ & $\begin{array}{c}8 \\
(6,0 \%)\end{array}$ & 10 & $\begin{array}{c}38 \\
(18,0 \%)\end{array}$ & $\begin{array}{c}5 \\
(3,0 \%)\end{array}$ & $\begin{array}{c}76 \\
(7,0 \%)\end{array}$ \\
\hline $\begin{array}{l}\text { Desertificação, Neve, } \\
\text { vento e saúde) }\end{array}$ & $\begin{array}{c}24 \\
32,0 \%)\end{array}$ & $\begin{array}{l}15 \\
6,5 \%)\end{array}$ & $\begin{array}{c}18 \\
15,0 \%)\end{array}$ & $\begin{array}{c}24 \\
(20,0 \%)\end{array}$ & $\begin{array}{c}25 \\
(17,0 \%)\end{array}$ & $\begin{array}{c}27 \\
(14,0 \%)\end{array}$ & $\begin{array}{c}56 \\
(26,0 \%)\end{array}$ & $\begin{array}{c}25 \\
(16,0 \%)\end{array}$ & $\begin{array}{c}214 \\
(18,0 \%)\end{array}$ \\
\hline
\end{tabular}

Fonte: Cadernos de Resumo dos SBCG de 1992. 1996. 1998. 2000. 2002. 2004. 2006 e 2008.

Organizado por Edson Soares Fialho (2009). 
Tabela 4. Trabalhos publicados por região do Brasil no SBCG (1992-2008).

\begin{tabular}{|c|c|c|c|c|c|c|cc|}
\hline Regiões & 1992 & 1996 & 1998 & 2000 & 2002 & 2004 & 2006 & 2008 \\
\hline Sul & $25,0 \%$ & $24,0 \%$ & $10,0 \%$ & $18,0 \%$ & $35,0 \%$ & $21,0 \%$ & $23,0 \%$ & $20,0 \%$ \\
\hline Sudeste & $54,0 \%$ & $50,0 \%$ & $47,0 \%$ & $62,0 \%$ & $47,0 \%$ & $46,0 \%$ & $38,0 \%$ & $52,0 \%$ \\
\hline Nordeste & $8,0 \%$ & $4,0 \%$ & $26,0 \%$ & $9,0 \%$ & $7,0 \%$ & $17,0 \%$ & $9,0 \%$ & $10,0 \%$ \\
\hline Centro-Oeste & $5,0 \%$ & $13,0 \%$ & $1,0 \%$ & $8,0 \%$ & $8,0 \%$ & $12,0 \%$ & $25,0 \%$ & $12,0 \%$ \\
\hline Norte & $7,0 \%$ & $8,0 \%$ & $15,0 \%$ & $1,0 \%$ & $3,0 \%$ & $2,0 \%$ & $5,0 \%$ & $5,0 \%$ \\
\hline Brasil & $1,0 \%$ & $1,0 \%$ & $1,0 \%$ & $2,0 \%$ & $0,0 \%$ & $2,0 \%$ & $0,0 \%$ & $1,0 \%$ \\
\hline
\end{tabular}

Fonte: Cadernos de Resumo dos SBCG de 1992, 1996, 1998, 2000, 2002, 2004, 2006 e 2008. Organizado por Edson Soares Fialho (2009).

Os estudos relacionados ao campo térmico registraram um grande crescimento, contudo os $17,0 \%$ das publicações referentes ao clima urbano privilegiam pesquisas em cidades de grande porte. Fato este, não somente observado no Brasil, mas no mundo.

Neste cenário, urge estudar o clima de cidades de médio e pequeno porte, pois o número de estudos é restrito na literatura internacional e nacional (HUTCHEON, 1967; KOPEC, 1970; ENDLICHER, 1981; DU et. al, 1990/91; BELLO FUENTES, 1994; ZAMPARONI, 1995; TAVARES et. al., 1995; GUIMARD, 1997; PINHO; MANSO ORGAZ, 2000; SILVA et. al., 2002; HINKEL et. al., 2003. MINAKI; AMORIM, 2005; AMORIM,. 2005; VIANNA, 2006 e COLLISCHONN, 2007).

Em razão do número exíguo de trabalhos produzidos sobre o clima urbano em cidades de pequeno porte e ainda localizado em região de clima tropical de altitude, o presente trabalho se propõe estudar a área urbana do município de Viçosa-MG, localizado na Zona da Mata Mineira, que requer uma reflexão sobre a influência do ritmo de seu crescimento populacional sobre o seu espaço. 


\section{A opção pela área de estudo, hipótese e objetivos.}

Neste item, o presente trabalho procura apresentar a hipótese de trabalho, e justificar a escolha da cidade a ser investigada, no caso, Viçosa, cidade de pequeno Porte. Além disto, apresentar os motivos pelos quais a mancha urbana a ser investigada possa desenvolver a formação de ilhas de calor, com base na revisão de literatura.

\subsection{A escolha da área de estudo.}

O município de Viçosa é um dos 12 primeiros a serem instituídos no sertão do rio Doce (ESPÍNOLA, 2005), com dimensão inicial de cerca de $700 \mathrm{~km}^{2}$, agregava os antigos distritos de: Araponga, Cajuri, Teixeiras, Coimbra, Cannaã e São Miguel do Anta. Neste município, o distrito sede era menor que os demais, que apresentavam uma atividade econômica mais exuberante, baseada na agricultura, como por exemplo, Araponga com a produção de café e Teixeiras com a produção de arroz, feijão e milho.

Essa competência econômica dos antigos distritos lhes deram a capacidade de requisitar a emancipação entre as décadas de 1930 e 1950. Assim, Viçosa foi reduzida a $300 \mathrm{~km}^{2}$. Ao perder o seu caráter agrícola, restou ao município a atividade comercial, voltada a atender a demanda dos funcionários e alunos da Universidade Federal de Viçosa (UFV).

Esta associação entre a cidade e a UFV, criada em 1926, como Escola Superior de Agricultura e Veterinária (ESAV) e federalizada em 1969 criou um vínculo umbilical, tanto assim, que o crescimento urbano verificado na área urbana é entrelaçado ao processo de expansão do número de vagas oferecidas pela Universidade, que atua como centro de atração de contingente populacional.

A conseqüência disto é o desenvolvimento forçado do espaço urbano, favorecendo, o surgimento de uma série de problemas de ordem ambiental e social, que se evidenciam em $14 \mathrm{~km}^{2}$ de área urbana ${ }^{4}$, concentradora $90,0 \%$ da população de 70.704 habitantes 5 .

\footnotetext{
${ }^{4}$ Isto equivale a $4,6 \%$ dos $300 \mathrm{~km}^{2}$ área total do município de Viçosa-MG.

${ }^{5}$ Segundo o último censo realizado pelo IBGE em 2007.
} 
A construção de um cenário urbano, altamente densificado se consubstancia entre a década de 1970 e 1980, quando Viçosa registrou um forte ritmo de crescimento da população urbana. De 17.000 habitantes para 31.179 habitantes, um incremento de $83,2 \%$. Neste ínterim, inicia o processo de verticalização, produzindo mudanças significativas no espaço urbano do município cada vez mais perceptíveis.

Existem hoje na área central da cidade cerca de 23 edifícios com 10 ou mais andares, além de outros 7 em fase de construção, somente na Av. P. H. Rolfs entre os anos de 2007 e 2009 (ZACCHI, 2009).

A explicação para esse fenômeno está associada aos projetos de expansão institucional da UFV, que planeja desde o início do ano de 2000 (quando o número de alunos era de 10.000), a ampliação do número de vagas, através da criação de novos cursos de graduação como: a História, Dança, Comunicação Social, Geografia e mais recentemente (2008/2009), a recém aprovação da criação dos cursos de: Enfermagem, Medicina, Ciências Sociais e Licenciaturas (Física, Química, Ciências Biológicas e Matemática).

Também foram criadas vagas para pós-graduação em Agroecologia, Conservação da Natureza e Recuperação ambiental, Fitossanidade vegetal, Recursos florestais, Tecnologia de celulose e papel, Engenharia de produção, Matemática, Estatística, Administração, Direito, Educação e Letras. Conseqüentemente, a população estudantil, que atualmente é de 12.000 alunos atingirá os 15.000 discentes.

Cabe destacar, que a localização do campus universitário impediu a expansão da malha urbana ao longo do vale do rio São Bartolomeu, fato esse que contribuiu para a intensa especulação imobiliária dos terrenos próximos ao campus, o que se tornou um fator de valorização, encarecendo a manutenção do antigo casario, nas proximidades da UFV.

\subsection{Hipótese do Trabalho.}

Quanto aos aspectos físicos e territoriais, o município se insere na área do domínio morfoclimático de mares de morros (AB'SABER, 1970). Este domínio concede uma particularidade aos municípios da Zona da Mata Mineira de relevo acidentado. No caso de Viçosa, $85,0 \%$ de sua área é montanhosa, $12,0 \%$ ondulada 
e 3,0\% plana (RESENDE, 1971) e apresenta, na escala regional, um clima tropical de altitude.

A mancha urbana por sua vez, depende em grande parte da sua situação topográfica, pois é evidente que, numa situação onde a cidade se encontra abrigada dos ventos, num vale, o clima de dentro e de fora da cidade apresentará naturalmente maiores diferenças do que se estivesse situada num planalto exposto ao vento. Ou localizadas junto ao sopé de serras ou beira-mar favorecerão determinadas características de seu clima.

Com base na colocação de Geiger (1961), Viçosa apresentaria uma alteração do seu clima, inerente a condição do seu sítio convergente: porém, com o crescimento da cidade ao longo dos vales e seu espraiamento pelas vertentes adjacentes associadas às modificações produzidas na paisagem pela urbanização surge uma questão: a área urbana do município de Viçosa, já desenvolveu a capacidade de gerar uma diferenciação entre o ambiente da cidade do seu entorno rural?

Para Landsberg (2006, p. 25) a identificação da mudança no clima ao nível da cidade causada por uma transformação urbana/social é muito difícil de ser identificada. Isto se deve ao fato de que muitas vilas e cidades foram construídas em áreas nas quais as condições que governam o clima são muito complexas. Locais na costa que permitam a construção de bons portos, vales que favoreçam o tráfego e o comércio e promontórios que sejam fortalezas naturais, normalmente já apresentam um clima bem distinto do seu entorno. Assim, o desenvolvimento das cidades pode tender a acentuar ou eliminar estas diferenças causadas pela posição ou topografia.

Porém, mesmo com essas dificuldades, este trabalho procura investigar a hipótese da constituição de um clima urbano associado ao crescimento da cidade sede do município de Viçosa.

Para isto, o trabalho aborda três escalas: campo-cidade, área urbana e o centro da cidade. A escolha se justifica pelo mosaico dos tipos de uso da terra incrustada em um sítio convergente que pode ou não amenizar ou fazer desaparecer a existência de ilhas de calor. 


\subsubsection{Ao nível campo-cidade.}

Considerando que a topografia é um fator relevante na diferenciação topoclimática, em razão da orientação das encostas, isso implicará numa maior ou menor incidência de raios solares, ao longo do dia, mesmo não apresentando a presença de ocupação humana.

Os vales direcionados para o quadrante norte, no hemisfério sul são verdadeiros núcleos armazenadores de calor durante o dia, mas à noite, o resfriamento irradiativo cria uma homogeneidade no campo térmico.

Caso uma cidade se instale neste sítio, a mesma poderá vir a potencializar o armazenamento de calor ao longo do dia, porém a velocidade do resfriamento do vale será modificada, mas isso não significa que a diferença de temperatura entre o campo e a cidade ou entre pontos internos à própria cidade sejam maiores do que o período da tarde ou da manhã para cidades de climas tropicais.

Considerando que parte da área rural é composta por pastagem, intercalados por fragmentos de mata secundária em topos de morros, selecionou-se um percurso, que abarque tanto a área rural, quanto à urbana.

Para se estabelecer uma comparação entre os diferentes tipos de uso da terra, optou-se pela leitura ao longo de registros móveis, com intuito de identificar possíveis diferenças no ritmo de perda e ganho de temperatura dentro do vale do rio São Bartolomeu, onde se concentra uma grande parte da cidade.

Os estudos de clima urbano até então desenvolvidos sugerem que, durante o dia, o campo tende a se aquecer mais rápido do que a área urbana, ocasionando maiores temperaturas no meio rural durante o dia (manhã e tarde). Apesar disso, a hipótese levantada é de que o modelo observado em outros estudos não seja possível, em razão da orientação das encostas, que influenciam na maior ou menor exposição do fundo do vale, por onde segue o percurso do transeto ao sol.

Por conta disso, se espera que de acordo com a ilustração da Figura 2, pela manhã os primeiros pontos de coleta na área rural, como locais de temperaturas menores, que vão se intensificando, à medida que se aproxima da cidade; porém, ao sair da área urbana a temperatura, continua apresentando um acréscimo.

No período da tarde, a expectativa é de que a cidade apresente temperaturas superiores em relação ao campo, enquanto o último trecho do percurso já apresenta temperaturas menores em relação à cidade, comparado ao primeiro horário. 
No terceiro horário, o resultado aguardado é que o contraste entre o campo e a cidade, seja mais evidente, com os registros das menores temperaturas do ar no fim do trajeto, pelo fato da menor altitude, cerca de 30 metros, em relação aos primeiros pontos de coleta, o que favorece a drenagem e o acúmulo de ar frio nas partes mais baixas do vale.

Marhã

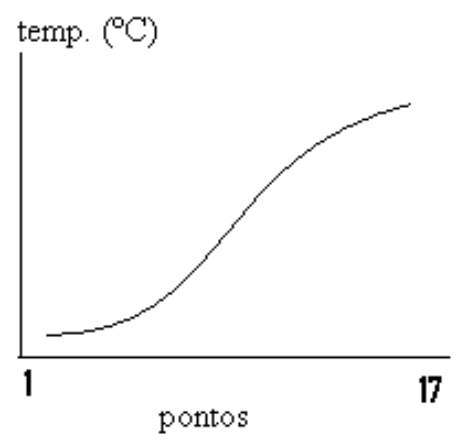

Tarde

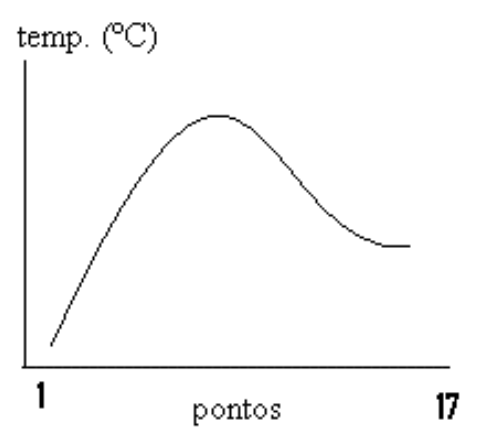

Noite

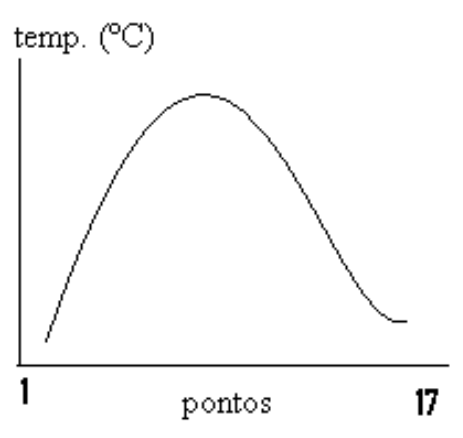

Figura 2. Hipótese da variação da temperatura do ar ao longo do transeto.

Além desta estratégia de registro, o presente percurso também serviu para desenvolver um experimento noturno, a fim de poder conhecer em que hora da noite ou madrugada que a ilha de calor noturna alcança ou seu ápice. Esta preocupação decorre do fato da maioria dos trabalhos aceitarem como referência às 21:00 horas de Brasília (3 horas após o pôr-do-sol), como sendo o momento de pico máximo da ilha de calor. Esta referência horária de 2 a 3 horas após o crepúsculo foi inicialmente proposta por Oke (1973) para cidades de latitudes médias, mas isto não quer dizer que todas as cidades do mundo se comportem da mesma maneira, como muito bem observaram Chow e Roth (2006) em Singapura, que registrou a intensidade máxima da ilha de calor 6 horas após o pôr-do-sol.

\subsubsection{Ao nível intra-urbano.}

A área urbana de Viçosa apresenta um vetor de expansão para o norte (sentido Ponte Nova), disposta de forma alongada, no sentido sudoeste-nordeste e estreito no sentido leste-oeste, especificamente nos vales do rio São Bartolomeu e Turvo Sujo.

Por conta disto, tem se a expectativa de que a espacialidade da ilha de calor não seja concêntrica, mas que a intensidade máxima se localize na área central, em 
razão do: a) centro conter a maior concentração da atividade humana; b) o município não apresenta um distrito industrial com indústrias poluidoras e consumidoras de grande quantidade de energia e c) uma área suburbana pouco desenvolvida, conforme demonstrado na Figura 3 (período da manhã e da noite) e na Figura 4 (período da tarde). Além disso, outro fator que corrobora esta observação empírica da localização da população dos sem teto de Viçosa à noite, quando procuram ambientes favoráveis para dormir.

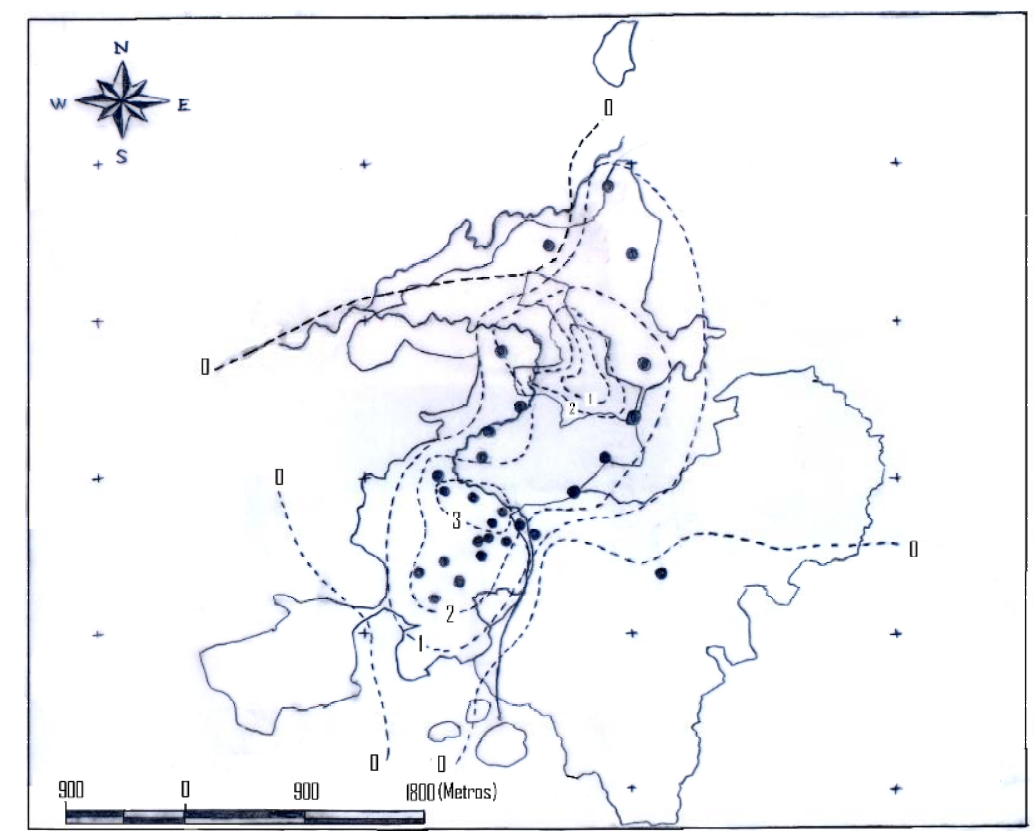

Figura 3. Espacialização hipotética da ilha de calor na área urbana de Viçosa-MG para o período noturno e da manhã.

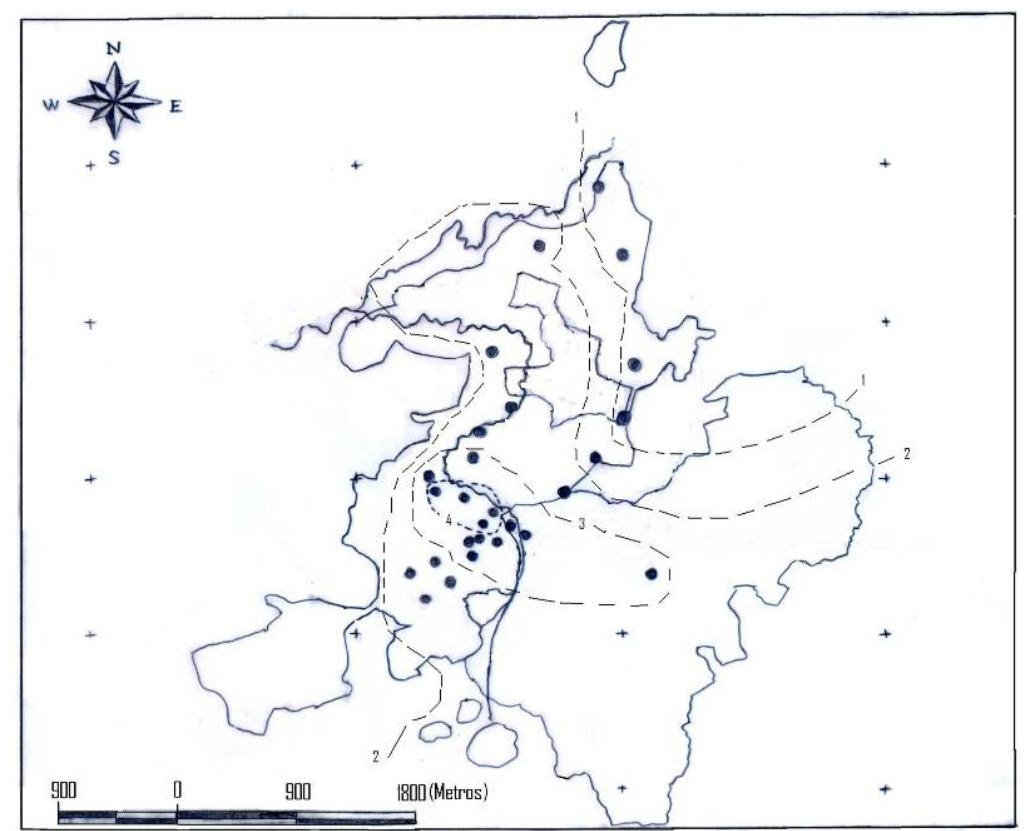

Figura 4. Espacialização hipotética da ilha de calor na área urbana de Viçosa-MG para o período à tarde. 


\subsubsection{Ao nível da área central.}

O interesse de investigar a área central de negócios de Viçosa se deve ao fato de poder verificar a ou não, a mobilidade do campo térmico em função do ritmo das atividades humanas (fatores endógenos), da condição sinótica do tempo (fator exógeno) e da condição do sítio (fator endógeno).

Partindo do princípio que o centro está incrustado em três vales (Figura 5): o primeiro ao longo da Av. P. H. Rolfs, por onde passa o rio São Bartolomeu e o segundo no vale do córrego Conceição, que segue ao longo da Avenida Santa Rita, que recebem a mesma quantidade de radiação solar (Figura 6).
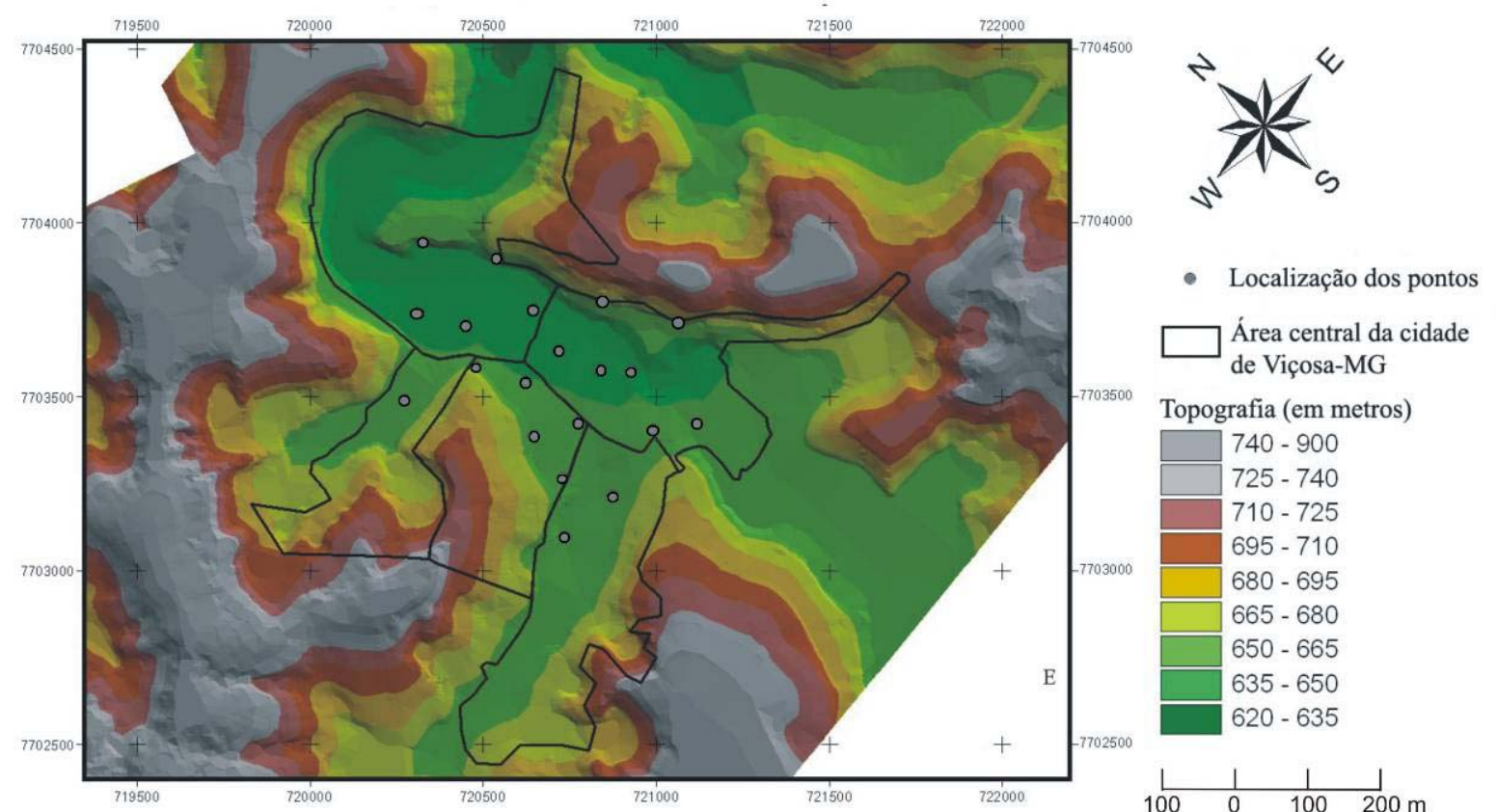

Topografia (em metros)

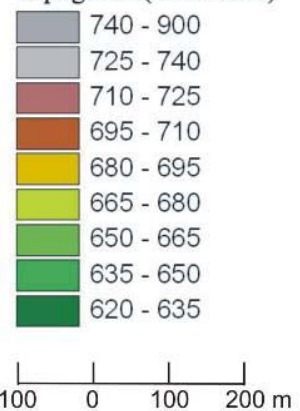

Figura 5. Hipsometria em terceira dimensão da área central de Viçosa.

Fonte: Santos (2007, p. 14. Adaptado.)

A mobilidade das atividades humanas no centro se torna importante. $O$ intenso fluxo de veículos e pessoas é mais forte ao longo da Avenida P. H. Rolfs, no calçadão e na Praça Silviano Brandão (local onde se localiza o Santuário de Santa Rita) entre segunda-feira a sexta-feira. Contudo, no sábado, em razão da feira livre, que se localiza na periferia da área central, mais precisamente, ao longo da Avenida Santa Rita, o núcleo de calor tenderá a se localizar nesta área. 

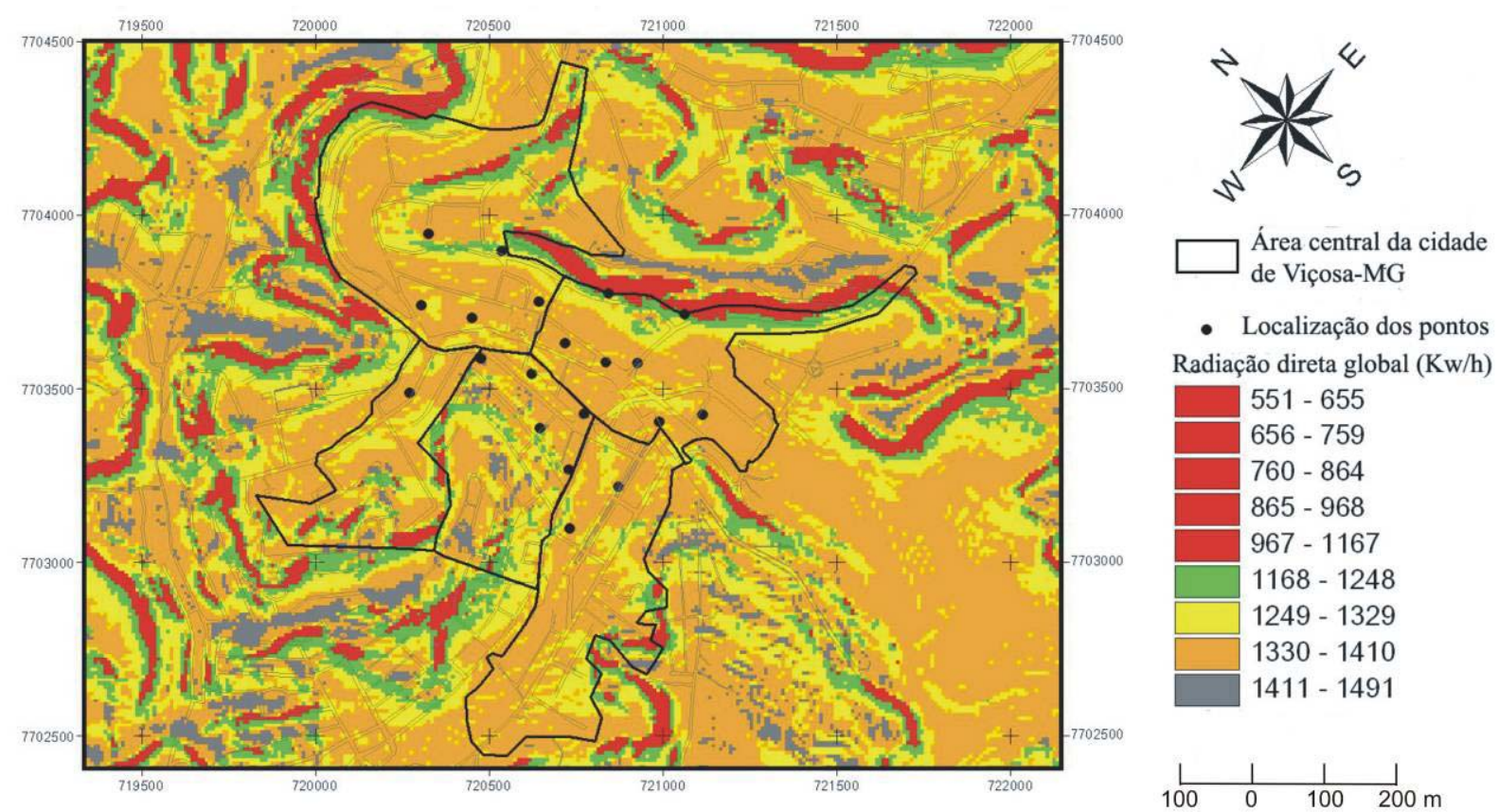

Figura 6. Mapa de radiação direta global $(\mathrm{KWH})$ da área central de Viçosa.

Fonte: Santos (2007, p. 15. Adaptado.)

Em relação à condição sinótica, espera-se que a maior intensidade da ilha de calor ocorra em situação de tempo anticiclônico, céu claro e poucos ventos, nos horários da tarde. Todavia, esta especulação se baseia no fato de que tanto o vale do córrego da Conceição e da Av. P. H. Rolfs recebam a mesma quantidade de radiação solar.

\subsubsection{Objetivo geral e específico.}

Analisar o campo termohigrométrico, na cidade de Viçosa, de acordo com os diferentes tipos de usos da terra, visando diagnosticar a ocorrência do fenômeno ilha de calor, ao longo das estações do ano.

b) OBJETIVOS ESPECÍFICOS:

$\checkmark$ Caracterizar o enquadramento climático de Viçosa no contexto da Zona da Mata Mineira;

$\checkmark$ Analisar a tendência da temperatura do ar do município entre 1968 até 2006;

$\checkmark$ Caracterizar os tipos de uso da terra para os pontos de mensuração;

$\checkmark$ Identificar e caracterizar os tipos de tempo predominante ao longo dos dias da realização dos experimentos de campo. 


\section{O clima urbano: Estado da arte.}

\subsection{A cidade: Uma prostituta devassa?}

O hábito de considerar a natureza e o homem universos distintos induz ao a pensar no ambiente natural após a intervenção humana com um ambiente ferido, na linguagem contemporânea dos ambientalistas, um ambiente impactado, ou, conforme a situação, degradado. A idéia de impacto e degradação ambiental produz alguns mal-entendidos. Quando um local é considerado impactado, a referência básica é o ambiente anterior à ação humana. Só que este ambiente não existe, mas foi alterado.

Ao não existir mais, mesmo que ação humana correspondesse às formas aceitas como de uso sustentável. Partindo desse princípio, os argumentos contra a cidade e os princípios assim formulados são antes morais que fundados na conexão do real e do possível.

Costuma-se dizer que o ser humano não usa a natureza em seu próprio benefício. Claro que sim, e não poderia ser diferente. Para prover a vida, o único caminho é a incorporação da natureza. Ao fazer isto, o ser humano opta em construir novos ambientes. Nesse sentido, volto à questão do parágrafo anterior. Estaríamos degradando a natureza?

O crescimento das aglomerações humanas estaria apenas gerando e ampliando o processo de degradação ambiental. Dessa forma, as cidades e os problemas ambientais teriam entre si uma relação de causa e efeito rígida.

A incorporação da estrutura de classes à análise possibilita perceber quem se apropria dos benefícios das atividades econômicas cujos custos são divididos com toda a sociedade. Ou, ainda, os impactos ambientais decorrentes de tais atividades são mais percebidos pelos setores menos favorecidos da população, que confinados às áreas mais suscetíveis às transformações próprias dos processos ecológicos, porém, aceleradas pela ação humana, não podem enfrentar os custos da moradia em áreas ambientalmente mais seguras ou beneficiadas por obras mitigadoras de impactos ambientais.

Apesar disso, a cidade, que não cria nada, continua a ser o local que tudo atrai para si. Tudo o que nasce da natureza e do trabalho, noutros lugares - frutos e objetos, produtos e produtores, obras e criações, atividades e situações. 
A expansão da cidade é muitas vezes vista como um símbolo do progresso do mundo moderno, que se distingue do mundo rural, representante da imagem do retrocesso ${ }^{6}$. Entretanto, na medida em que as cidades crescem em tamanho e população, as alterações inerentes ao processo de modificação da paisagem afetam as condições essenciais à vida urbana, tais como a água, o solo e o ar, afetando o clima.

Dolfus (1991, p. 47) identifica que nas cidades industriais por apresentarem um clima diferente das áreas rurais, na zona temperada, a vida urbana se desenvolveu de modo indiferente as estações do ano, uma vez que, os locais onde o urbanita passa a maior parte do seu tempo são aquecidos no inverno e eventualmente refrigerados no verão, além da própria alimentação apresentar cada vez menos vestígios da diversidade de produção decorrente da sucessão das estações, sendo bastante uniforme ao longo do ano. Mas, apesar da semelhança comportamental dos cidadãos urbanos do mundo, o que define a cidade?

$\mathrm{Na}$ visão histórica dominante, a cidade, constitui o resultado do aprofundamento da divisão sócio-espacial do trabalho em uma sociedade, no sedentarismo e na hierarquia sócio-espacial interna à comunidade. Localmente, exige uma estrutura de poder sustentada pela extração de um excedente regular da produção situada no campo. Assim, a cidade implica a emergência de uma classe dominante que extrai e controla este excedente coletivo através de processos ideológicos acompanhados, certamente, pelo uso da força.

Com base em Souza (2003) a cidade é o centro das atividades econômicas, que não se caracteriza pelo setor primário. Isto é o centro gestor do território, por sediar o poder econômico das empresas, político e religioso.

De acordo com Azevedo (2001, p. 448):

“...a cidade é um conceito carregado de diferentes concepções e significados pelo fato de fazer parte da linguagem cotidiana que foi apropriada tardiamente pela ciência. Do ponto de vista histórico, o conceito corrente de cidade é oriundo de períodos em que havia uma nítida delimitação entre a mesma e o campo por muralhas e no qual a divisão técnica e social do trabalho era muito mais simples. $O$ conceito de cidade origina-se da oposição ao conceito de campo..."

\footnotetext{
${ }^{6}$ Segundo Williams (1990, p. 11) a cidade associou-se a idéia de realizações - de saber, comunicações, luz. Também constelaram-se poderosas associações negativas: a cidade como lugar do barulho, mundanidade e ambição; o campo como lugar do atraso, ignorância e limitação. O contraste entre o campo e a cidade, enquanto formas de vida fundamentais, remontam à Antiguidade.
} 
Como se percebe, a partir dos três autores citados, não há uma definição capaz de agregar os vários pensamentos acerca da cidade, mas do ponto de vista climatológico, a dificuldade de utilizar este o conceito, gera como conseqüência a impossibilidade de se estabelecer comparações entre os resultados de estudos de clima urbano entre cidades distintas, como você pode observar em alguns exemplos identificados no Quadro 1, uma vez que o cada autor opta por uma definição que melhor the atende, não permitindo o avanço dos estudos do clima urbano.

Esta limitação ainda não foi resolvida, mas propostas para a solução desta questão estão em curso como a proposta confeccionada por Oke (2006), em que sugere o estabelecimento de uma padronização do critério de definição do que seja urbano e rural, a partir da taxa de impermeabilização ou (área construída) da superfície, conforme a Figura 7.

Quadro 1. Ambientes rurais e urbanos para alguns estudos de clima urbano.

\begin{tabular}{|c|c|c|}
\hline Urbano & Rural & Urbano e rural \\
\hline $\begin{array}{c}\text { Jardim Botânico } \\
\text { (SYRAKOVA; ZAHARIEVA, 1998). }\end{array}$ & $\begin{array}{c}\text { Campos de arrozais } \\
\text { (SAKAKIBARA; MATSUI, 2005). }\end{array}$ & $\begin{array}{c}\text { Aeroportos } \\
\text { (ADEBAYO, 1991). }\end{array}$ \\
\hline $\begin{array}{c}\text { Parque urbano } \\
\text { (GEDZELMAN et. al., 2005). }\end{array}$ & $\begin{array}{c}\text { Reserva ecológica } \\
\text { (JAUREGUI, 1997). }\end{array}$ & $\begin{array}{l}\text { Campus universitário. } \\
\text { (PARRY. 1956). }\end{array}$ \\
\hline $\begin{array}{c}\text { Subúrbio } \\
\text { (NASRRALLAH, 1990) }\end{array}$ & $\begin{array}{c}\text { Deserto } \\
\text { (NASRRALLAH, 1990) }\end{array}$ & $\begin{array}{l}\text { Observatórios do tempo } \\
\text { (ZHOU, 1990). }\end{array}$ \\
\hline $\begin{array}{c}\text { Subúrbio } \\
\text { (HAGE, 1972) }\end{array}$ & $\begin{array}{c}\text { Aeroporto } \\
\text { (HAGE, 1972) }\end{array}$ & $\begin{array}{l}\text { Jardins de escola } \\
\text { (OKOOLA, 1980). }\end{array}$ \\
\hline $\begin{array}{c}\text { Jardim Botânico } \\
\text { (ALCOFORADO,1993) }\end{array}$ & $\begin{array}{l}\text { Campos de cultivo irrigado } \\
\text { (ROBAA, 2003) }\end{array}$ & $\begin{array}{l}\text { Instituto meteorológico } \\
\text { (ROBAA, 2003). }\end{array}$ \\
\hline $\begin{array}{l}\text { Observatório meteorológico } \\
\text { (BULUT et. al., 2008) }\end{array}$ & $\begin{array}{c}\text { Aeroporto } \\
\text { (BULUT et. al., 2008) }\end{array}$ & $\begin{array}{c}\text { Instituto Meteorológico } \\
\text { (CUNHA; BRANDÃO, 1995) }\end{array}$ \\
\hline $\begin{array}{c}\text { Centro urbano } \\
\text { (SCHMIDLIN, 1989) }\end{array}$ & $\begin{array}{c}\text { Aeroporto } \\
\text { (Schmidlin. 1989) }\end{array}$ & \\
\hline $\begin{array}{c}\text { Hospital } \\
\text { (TUMANOV et. al., 2005). }\end{array}$ & $\begin{array}{c}\text { Tundra ártica } \\
\text { (HINKEL et. al., 2003). }\end{array}$ & \\
\hline $\begin{array}{c}\text { Shopping center } \\
\text { (LANDSBERG; MAISEL, 1972). }\end{array}$ & $\begin{array}{c}\text { Deserto } \\
\text { (HEDQUIST; BRAZEL, 2006). }\end{array}$ & \\
\hline $\begin{array}{c}\text { Postos de Bombeiros } \\
\text { (BOWLING; BENSO,. 1978). }\end{array}$ & $\begin{array}{c}\text { Florestas tropicais } \\
\text { (CHOW; ROTH, 2006). }\end{array}$ & \\
\hline $\begin{array}{l}\text { Quadra urbana } \\
\text { (UNGER, 1996). }\end{array}$ & $\begin{array}{c}\text { Seringais } \\
\text { (EMMANUEL; JOHANSSON, 2006). }\end{array}$ & \\
\hline $\begin{array}{l}\text { Canyon urbano } \\
\text { (ELIASSON, 1994). }\end{array}$ & $\begin{array}{c}\text { Pomares } \\
(\text { TSO, 1996). }\end{array}$ & \\
\hline $\begin{array}{c}\text { Estaleiro } \\
\text { (MORENO-GARCIA, 1994). }\end{array}$ & $\begin{array}{c}\text { Fazendas experimentais } \\
\text { (BOHM, 1988). }\end{array}$ & \\
\hline
\end{tabular}

Organizado por Edson Soares Fialho (2009). 


Zona do clima Urbano
$\begin{aligned} & \text { 1. Desentrolvimento urbano } \\ & \text { intenso. Exemplo: área central } \\ & \text { da cidade }\end{aligned}$

Figura 7. Proposta de criação de Zonas de clima Urbano desenvolvida por Oke.

Fonte: Oke (2006, p. 185. Adaptado.) 


\subsection{Evolução dos estudos de clima urbano.}

O contraste térmico entre os ambientes urbano e rural, identificado por Evelyn (1661) e Howard (1818) em Londres (MORENO GARCIA, 1999 e MILLS, 2008), corroboraram a observação que a cidade à noite se apresenta mais quente em relação ao seu entorno, utilizando-se para isto estações meteorológicas urbanas e rurais, que muitas são restritas no espaço.

A partir da década de 1920, quando os estudos do clima da cidade ganharam destaque, procurou-se ampliar o número de pontos amostrais, com a utilização de transetos móveis ou por meio de uma rede de monitoramento experimental temporária, a fim de favoreceu o melhor entendimento da configuração espacial da temperatura do ar nos centros urbanos.

O mapeamento das isotermas por sua vez, se equivale à leitura de um mapa topográfico, que comunica ao leitor através das curvas de nível, as cotas altimétricas de maior e menor valor. Tendo com base esta analogia. Gordon Manley, em 1960, cunhou o termo ilha de calor (ALCOFORADO, 1993), conforme pode ser visualizado pela Figura 8.

As modificações produzidas pela cidade segundo Oke (1978, p. 247), produziram uma diferenciação do ambiente urbano em comparação à área rural ao provocarem alterações nos parâmetros do clima, como temperatura do ar e umidade relativa - os mais investigados desde o século XIX.

As alterações na composição atmosférica ocasionada pelos efeitos da rugosidade da superfície (GRIMMOND, 1998), elemento responsável pela modificação do balanço de energia (MORGAN, et. al. 1977; OJIMA; MORIYAWA, 1982 e OKE, 1988), que de acordo com East (1968), pode atenuar a chegada da radiação solar à superfície urbana, quanto dificultar a perda irradiativa (ESCOURROU, 1990). Além disso, Roth (2000) coloca que a turbulência do ar pode favorecer a formação de tempestades nas áreas urbanas, Bornstein e Lin (2000) e Yow e Carbone (2008) verificaram para Atlanta e Orlando, respectivamente, os fatores responsáveis pela formação do clima urbano criam condições de dotar a cidade de características particulares, que se diferenciam da área entorno, a conseqüência principal do processo de urbanização é a criação do fenômeno de ilha de calor, intensificado, na medida em que, haja um processo de expansão da mancha urbana. 


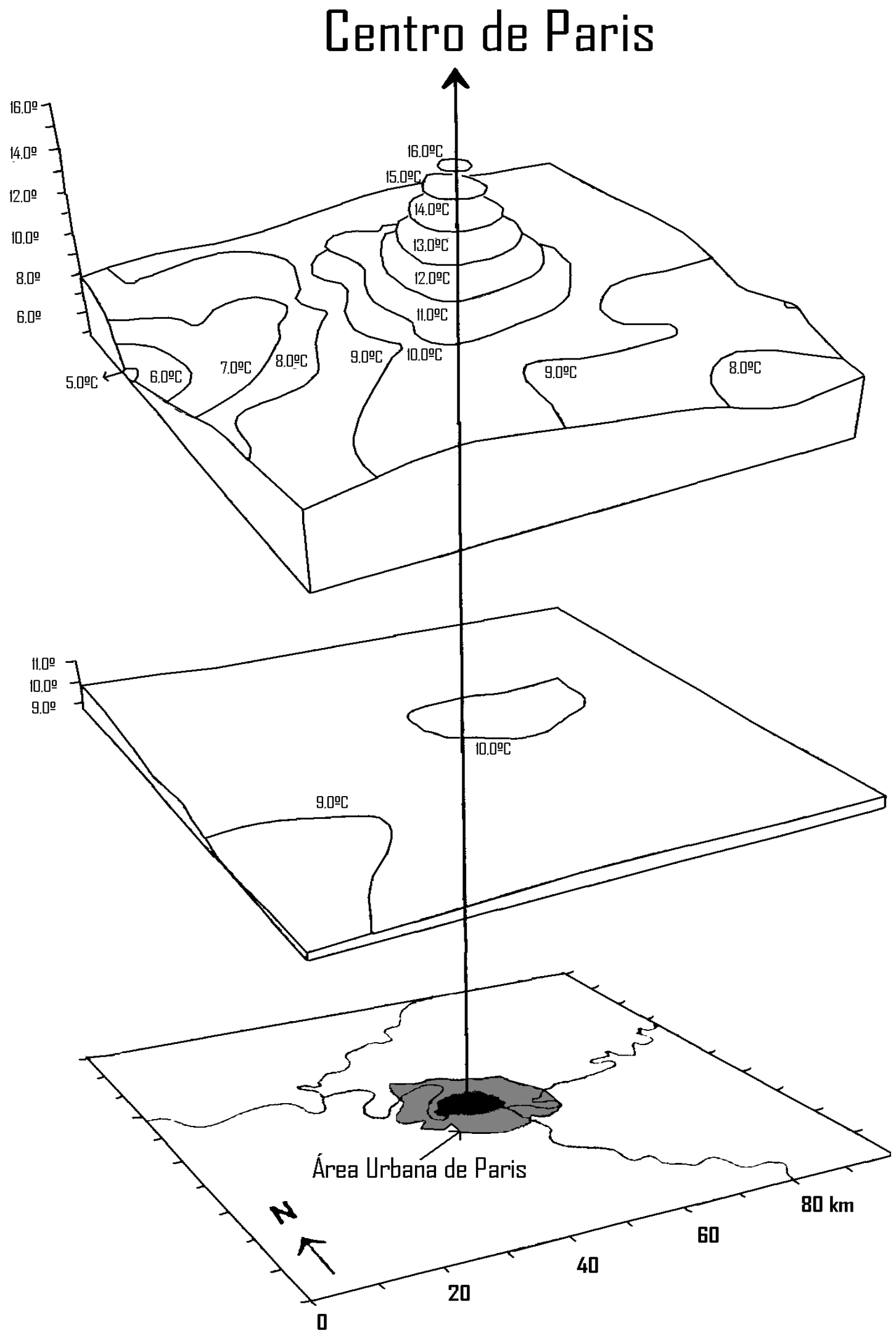

Figura 8. Identificação da ilha de calor em Paris.

Fonte: Contat (2004, p. 78. Adaptado.) 
De acordo com Landsberg (1970, p. 1270) e Nishizawa (1983, p. 57), demonstram no Quadro 2, desenvolvido pelo segundo autor, esta observação é corroborada pelos estudos desenvolvidos por Lansberg e Maisel (1972), em Maryland; Hsu (1984) em Phoenix (Figura 9); Lee (1992) em Londres; Magee et. al. (1999) no Alaska; e Philandras et. al. (1999) em Atenas comprovam esta relação ao também identificarem o aumento da Intensidade da llha de calor, após a expansão da área construída da cidade.

Quadro 2. Estágio de urbanização e freqüência da ocorrência das ilhas de calor.

\begin{tabular}{|c|c|c|c|c|}
\hline \multirow[b]{2}{*}{ Estágio } & \multicolumn{3}{|c|}{ Mudanças no Sistema } & \multirow{2}{*}{$\begin{array}{c}\text { Freqüência da } \\
\text { ocorrência } \\
\text { das ilhas de } \\
\text { calor }\end{array}$} \\
\hline & Entrada & Regulagem & Retenção & \\
\hline I & $\begin{array}{c}\text { Consumo de energia } \\
\text { para o aquecimento do } \\
\text { espaço }\end{array}$ & - & - & $\begin{array}{l}\text { Noite calma e } \\
\text { clara no } \\
\text { inverno }\end{array}$ \\
\hline II & $\begin{array}{c}\text { Consumo de energia } \\
\text { para o aquecimento do } \\
\text { espaço }\end{array}$ & $\begin{array}{l}\text { Calçamento } \\
\text { Edifícios }\end{array}$ & $\begin{array}{l}\text { Tijolos. } \\
\text { Pedras. } \\
\text { Concreto. }\end{array}$ & $\begin{array}{l}\text { Noite clara no } \\
\text { inverno e no } \\
\text { verão }\end{array}$ \\
\hline III & $\begin{array}{c}\text { Consumo de energia } \\
\text { para aquecimento do } \\
\text { espaço. } \\
\text { condicionamento do ar, } \\
\text { para a indústria e } \\
\text { automóveis. }\end{array}$ & $\begin{array}{l}\text { Pavimentação. } \\
\text { Edificação. } \\
\text { Aerossol. }\end{array}$ & $\begin{array}{l}\text { Asfalto. } \\
\text { Tijolo. } \\
\text { Pedra. } \\
\text { Concreto. } \\
\text { Redução da } \\
\text { umidade do } \\
\text { solo. }\end{array}$ & $\begin{array}{c}\text { Durante o dia } \\
\text { de todas as } \\
\text { estações (tipo } \\
\text { de poluição } \\
\text { térmica). }\end{array}$ \\
\hline IV & $\begin{array}{c}\text { Consumo de energia } \\
\text { para o resfriamento do } \\
\text { espaço. } \\
\text { condicionamento do ar, } \\
\text { para indústria. } \\
\text { automóveis e vias } \\
\text { subterrâneas (metrô). }\end{array}$ & $\begin{array}{l}\text { Pavimentação. } \\
\text { Edificação. } \\
\text { Aerossol. }\end{array}$ & $\begin{array}{l}\text { Asfalto. } \\
\text { Tijolo. } \\
\text { Pedra. } \\
\text { Concreto. } \\
\text { Redução da } \\
\text { umidade do } \\
\text { solo. }\end{array}$ & $\begin{array}{c}\text { Durante o dia } \\
\text { inteiro em } \\
\text { todas as } \\
\text { estações e } \\
\text { ilhas de calor } \\
\text { ocorrentes em } \\
\text { superfície (tipo } \\
\text { de poluição } \\
\text { térmica). }\end{array}$ \\
\hline
\end{tabular}

Fonte: Nishizawa (1983, p. 57. Adaptado.)

Dentre outros fatores que poderiam auxiliar na formação da ilha de calor urbana estão a impermeabilização das superfícies, favorece a diminuição da evapotranspiração, o tamanho da cidade (OKE, 1973 e 1987), a velocidade do vento (OKE, 1982), a geometria dos vales urbanos (OKE, 1981) e a diferença das propriedades físicas como, por exemplo, o albedo dos materiais de construção, como pode ser visto na Figura 10. 


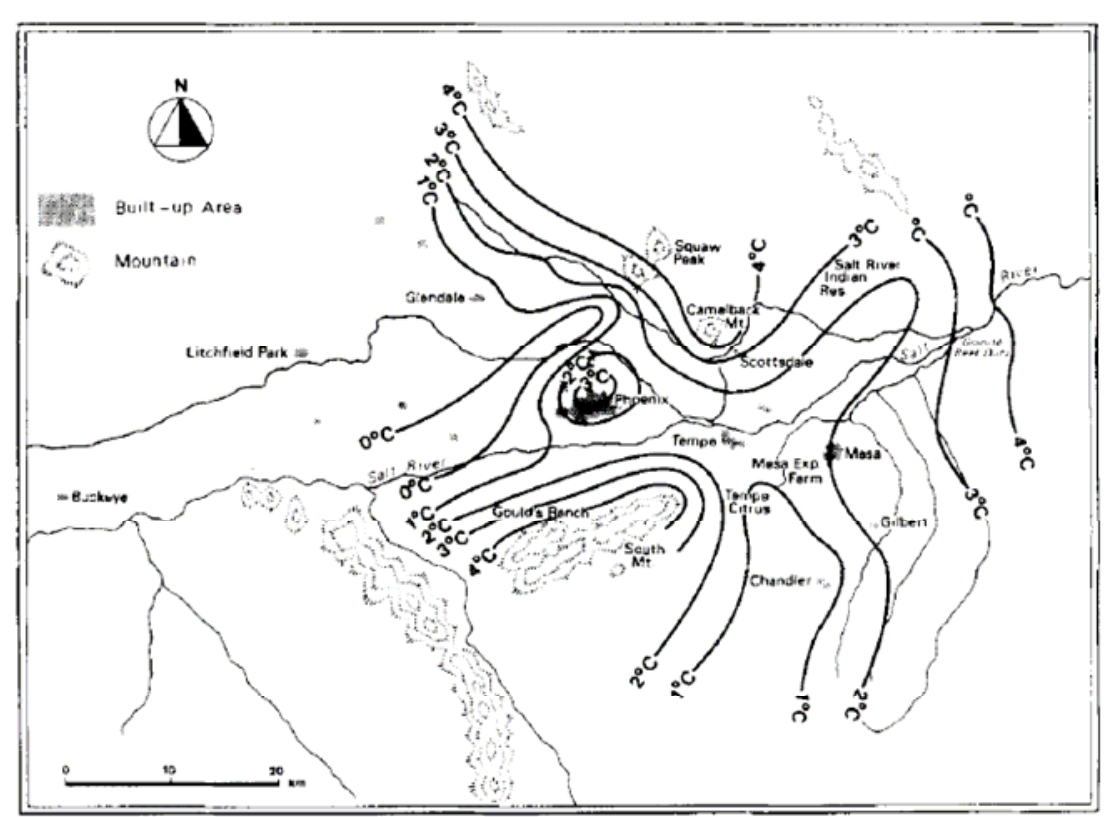

Período de 1901-1920

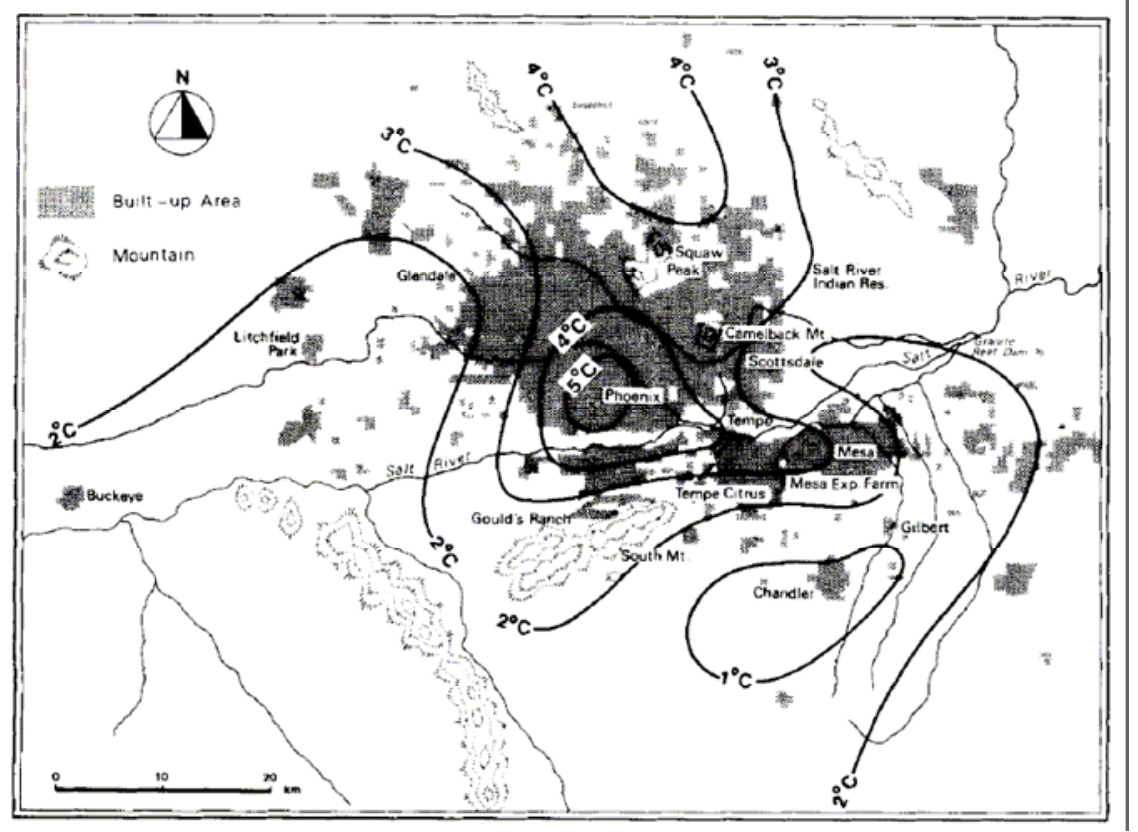

Período de 1961 a 1977

Figura 9. Variação e expansão da ilha de calor urbana em Phoenix, EUA, decorrente da expansão mancha urbana.

Fonte: Hsu (1984, p. 197 e 198). 


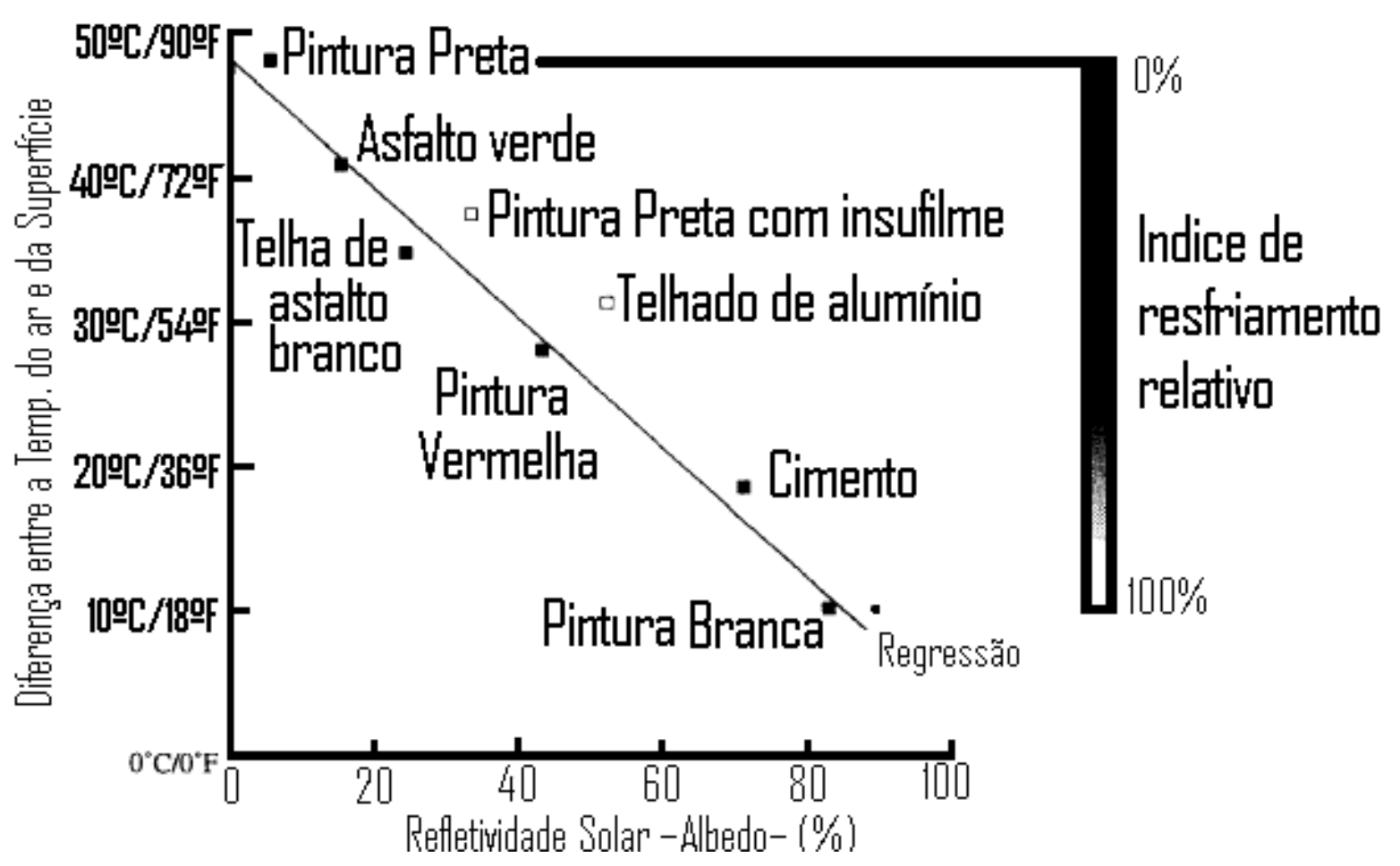

Figura 10. Albedo de materiais de construção.

Fonte: Rosenfeld et. al. (1995, p. 256. Adaptado.)

Estas seriam algumas das causas primárias da formação do fenômeno de ilha de calor, que podem ser ou não controlados, como Rizwan et. al. (2008) representam na Figura 11 síntese ilustrada, que na maioria dos estudos de clima urbano é identificado por meio da utilização de transetos móveis ou fixos.

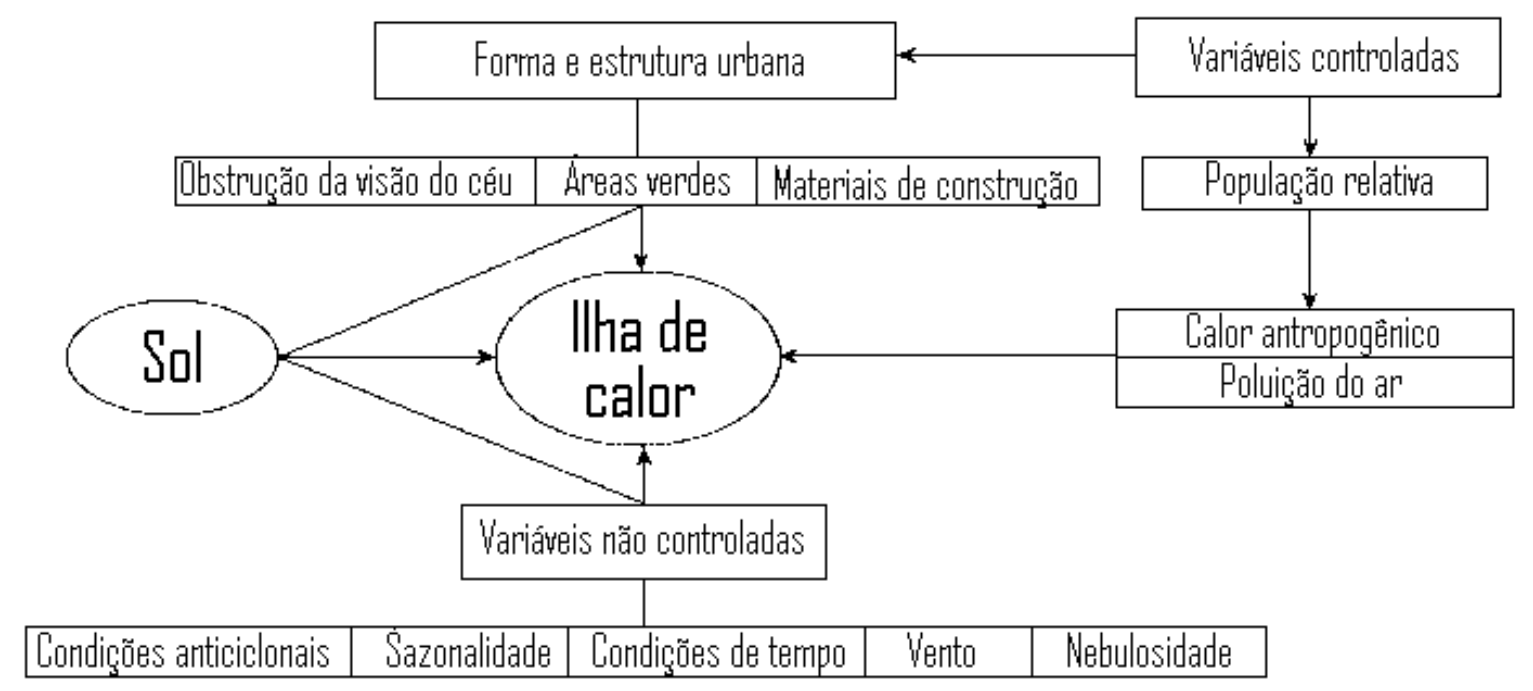

Figura 11. Variáveis controladas ou não responsáveis pela formação da ilha de calor. Fonte: Rizwan et. al. (2008, p. 121. Adaptado.) 
Dentre as variáveis citadas na Figura 11, algumas são parametrizáveis, permitindo a utilização de simulações, tendo como base uma correlação entre um elemento e um fator controlador do clima (modelos matemáticos), com base em análise estatística, que auxiliam nos estudos de planejamento praticados na atualidade.

Embora, esta perspectiva analítica seja criticada por alguns autores, tal procedimento tem o seu valor, de acordo com Dolfus (1991, p. 48) ao dizer que:

“...Ao analisar um espaço, deve o geógrafo integralizar o conjunto de dados, buscar correlações nos diferentes níveis. calcular as interações. A utilização da matemática poderá ser então indispensável para lidar com um número muito importante de dados, assim como calcular múltiplas correlações e para movimentar as interações. Contudo. a matemática é apenas um instrumento...".

Apesar disto, o uso da linguagem matemática foi duramente criticado, na década de 1970, com o advento da Geografia Crítica, que a elegeu como o símbolo da alienação, gerando, por conseguinte, o aumento o esvaziamento da utilização da matemática na ciência geográfica.

Entretanto, cabe relativizar esta pseudo-crítica, na medida em que, ao analisar a utilização da matemática no campo do saber geográfico, verifica-se que este instrumento sempre foi pouco explorado, mesmo pelo ramo do saber geográfico voltado às ciências naturais.

A conseqüência imediata disto é a não inserção de Geógrafos em estudos e atividades profissionais, que poderiam perfeitamente desempenhar, como constata Assis (2006), ao discorrer sobre a transferência do campo de atuação dos Geógrafos brasileiros. Por conta disto, outras áreas do saber relacionadas à Engenheira, Meteorologia, Agronomia e Arquitetura vem desenvolvendo estudos relacionados ao clima.

Esta afirmativa da autora, apesar de verdadeira no aspecto quantitativo, merece ser repensada. Isto por que, a diminuição da participação deste profissional em estudos do clima não significa que outros profissionais estejam desenvolvendo estudos climáticos de cunho geográfico, apenas que há uma valorização da questão 
climática pelos demais campos do saber, daí o aumento do número de publicações a respeito da temática.

Independentemente das discussões anteriores, os Geógrafos do clima, na Europa e na América do Norte, sempre adotaram as simulações em seus estudos, principalmente, no meio urbano.

Dentre estes, o pesquisador de maior renome internacional, segundo Arnfield (2006) em sua apresentação, intitulada: How to do Urban Climatology: a Personal View of the Legacy of Professor Tim Oke. na $6^{a}$ Conferência Internacional de clima urbano, realizada em Göteborg. Suécia é Tim Oke que desenvolveu ao longo de sua carreia uma pesquisa consistente na busca de melhor compreender a dinâmica do clima urbano, sendo referência de várias pesquisas desenvolvidas hoje pelo mundo.

Um dos primeiros trabalhos de importância desenvolvido por Oke ocorreu em 1973, quando o mesmo autor estabeleceu correlação entre a intensidade da ilha de calor com o contingente populacional de cidades canadenses (Equação 1) e européias (Equação 2).

Cidades canadenses.

Equação 1:

$\Delta T_{u-r}=2,96 \log P-6,41\left(r^{2}=0,96\right)$.

Cidades européias.

Equação 2:

$\Delta \mathrm{T}_{\mathrm{u}-\mathrm{r}}=2,01 \log \mathrm{P}-4,06\left(\mathrm{r}^{2}=0,74\right)$.

Estas seriam muito questionáveis, pelo fato de não considerar outros fatores atuantes e acabou por gerar resultados superestimados para cidades tropicais, como verificou Tarifa (1977, p. 74) para a cidade de São José dos Campos, São Paulo, ao utilizar as fórmulas para uma cidade entre 150 e 200 mil habitantes.

Para a equação das cidades do Canadá obteve um resultado entre $7,0^{\circ} \mathrm{C}$ e $9,0^{\circ} \mathrm{C}$ e com a da Europa de $5,0^{\circ} \mathrm{C}$ a $6,5^{\circ} \mathrm{C}$. Enquanto a diferença máxima registrada em campo foi de $3,4^{\circ} \mathrm{C}$, embora as condições de vento tenham sido de 3 a $4 \mathrm{~m} . \mathrm{s}^{-1}$, o que atenua a formação da ilha de calor.

Além da verificação de Tarifa (op. cit.) ao se observar a Figura 12, que identifica o número de habitantes da cidade e a intensidade máxima da ilha de calor para cidades brasileiras, se constata que a cidade de Salvador, apresenta uma intensidade da ilha de calor de $6,5^{\circ} \mathrm{C}$ de acordo com os estudos de Sampaio (1981), 
enquanto Martins (1996) para a cidade de Juiz de Fora, registrou uma intensidade máxima de $12,6^{\circ} \mathrm{C}$.

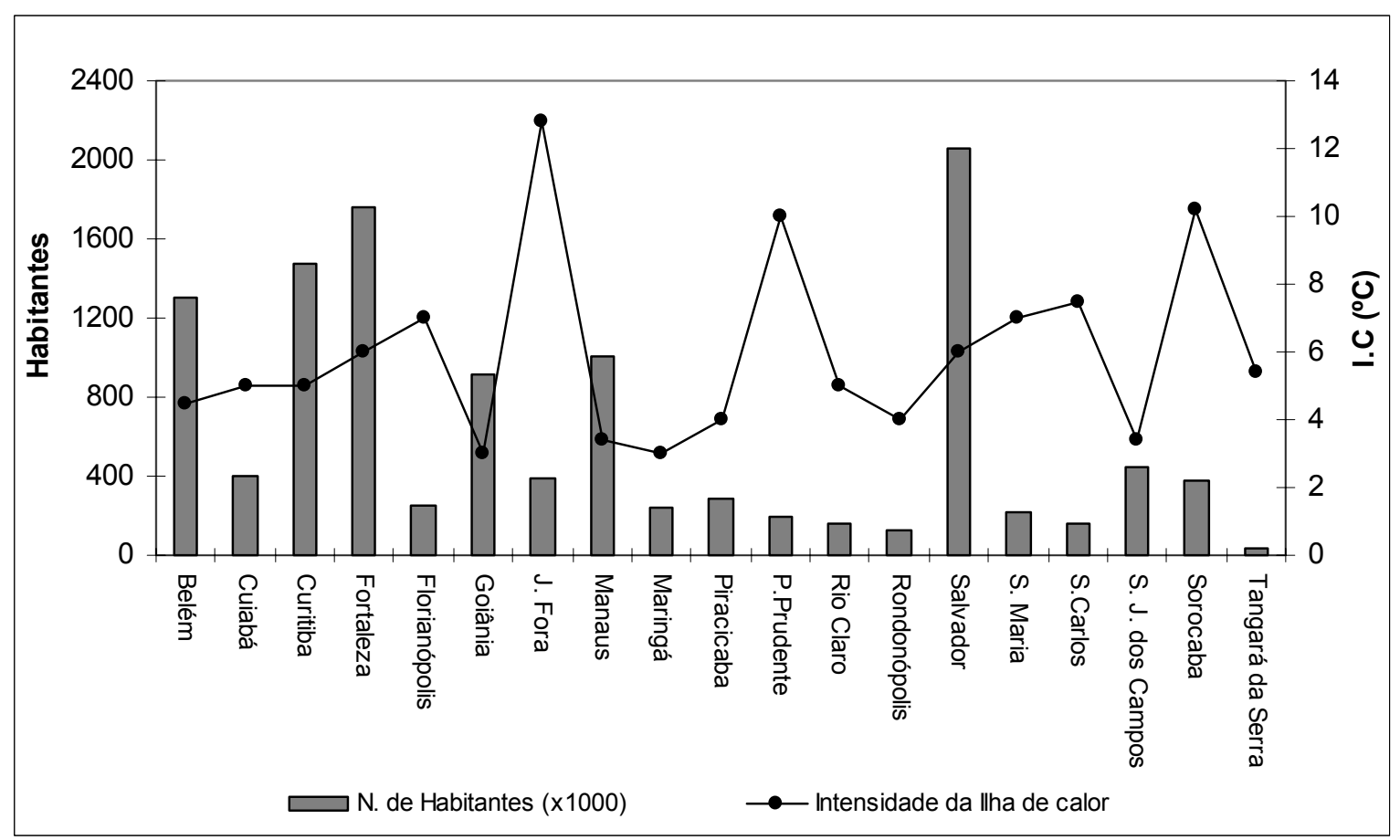

Figura 12. Comparação dos resultados obtidos da intensidade máxima da ilha de calor em cidades brasileiras comparado ao contingente populacional.

Fonte: Fialho e Souza (2007, p. 33).

Apesar de suas limitações, esta correlação é ainda muito empregada em vários estudos de clima urbano, destacando-se os desenvolvidos nas cidades coreanas com menos -Equação 3- e mais -Equação 4- de 300 mil habitantes (PARK, 1986); australianas -Equação 5- (TOROK et. al. 2001) e norte-americanas (KARL et. al. 1988) - Equação 6.

Cidades coreanas.

Equação 3:

$\Delta T_{u-r}=1,46 \log P-5,93\left(r^{2}=0.98 ;\right.$ população $\left.<300.000\right)$.

$\Delta T_{u-r}=3,43 \log \mathrm{P}-16,58\left(r^{2}=0.98 ;\right.$ população > 300.000).

Equação 4:

Cidades australianas.

Equação 5:

$\Delta T_{u-r}=1,42 \log P-2,02$. 
Equação 6:

Cidades norte-americanas.

$\Delta \mathrm{T}_{\mathrm{u}-\mathrm{r}}=\mathrm{a}(\mathrm{POP})^{0,45}$

O coeficiente a depende do elemento:

$a=-3,9 \times 10^{-4}-$ Temperatura máxima.

$a=3,61 \times 10^{-3}-$ Temperatura mínima.

$a=-0,77 \times 10^{-3}-$ Temperatura máxima - população $>10.000$.

$a=5,12 \times 10^{-3}-$ Temperatura mínima - população $>10.000$.

Porém, antes mesmos destes autores, Sundborg (1950) desenvolveu fórmulas empíricas para a variação termal entre o campo e a cidade, por meio de elementos climáticos, como a cobertura de nuvens e a intensidade dos ventos. Sua fórmula para Uppsala, Suécia, representava as condições do período diurno Equação 7 - e noturno -Equação 8-.

Equação 7:

$\Delta \mathrm{T}=1,4^{\circ} \mathrm{C}-0,01 \mathrm{n}-0,09 \mathrm{~V}-0,01 \mathrm{~T}+0,04 \mathrm{e}$

$\Delta \mathrm{T}$ - diferencial térmico.

$\mathrm{n}$ - nebulosidade em décimos.

$\mathrm{V}$ - intensidade do vento em $\mathrm{m} \cdot \mathrm{s}^{-1}$.

$\mathrm{T}$ - temperatura em ${ }^{\circ} \mathrm{C}$.

e - umidade absoluta em $\mathrm{g} / \mathrm{m}^{3}$.

Equação 8:

$\Delta \mathrm{T}=2,8^{\circ} \mathrm{C}-0,10 \mathrm{n}-0,38 \mathrm{~V}-0,02 \mathrm{~T}+0,03 \mathrm{e}$

$\Delta T$ - diferencial térmico.

$\mathrm{n}$ - nebulosidade em décimos.

$\mathrm{V}$ - intensidade do vento em $\mathrm{m} . \mathrm{s}^{-1}$

$\mathrm{T}$ - temperatura em ${ }^{\circ} \mathrm{C}$.

e- umidade absoluta em $\mathrm{g} / \mathrm{m}^{3}$.

No caso da Equação 8 para o período noturno Landsberg (2006, p.104) propôs uma simplificação - Equação 9 -, uma vez que, à noite, a influência tanto do vento quanto da nebulosidade é mais importante do que outros fatores. Sendo assim. Landsberg (op. cit.) considerando apenas estes dois fatores reduziu a fórmula, inicialmente, elaborada por Sundborg (op. cit.).

Equação 9:

$$
\Delta T=\underline{4,6-0,28 n}
$$

$\mathrm{V}$

$\Delta \mathrm{T}$ - diferencial térmico.

$\mathrm{n}$ - nebulosidade em décimos.

$\mathrm{V}$ - intensidade do vento em $\mathrm{m} \cdot \mathrm{s}^{-1}$. 
Outra correlação desenvolvida por Oke (1981) foi estabelecida entre a intensidade do vento e o tamanho da população - Equação 10-. Segundo o autor há uma velocidade crítica do vento na qual a ilha de calor seria desfigurada ou atenuada. Esses valores variam de cidade para cidade, como pode ser visto na Tabela 5.

Tabela 5. Velocidade crítica do vento na atenuação da ilha de calor.

\begin{tabular}{|lcc|}
\hline \multicolumn{1}{|c}{ Cidades } & $\begin{array}{c}\text { Número de } \\
\text { habitantes }\left(\mathbf{x} \mathbf{1 0}^{\mathbf{3}}\right)\end{array}$ & $\begin{array}{c}\text { Velocidade crítica } \\
\text { do vento }\left(\mathbf{m . s}^{-1}\right)\end{array}$ \\
Bremem (Alemanha) & 400 & 8.0 \\
Londres (Inglaterra) & 8.250 & 12.0 \\
Montreal (Canadá) & 2.000 & 11.0 \\
Reading (Canadá) & 120 & 4.7 \\
Palo Alto (EUA) & 33 & 3.5 \\
Seoul (Coréia do Sul) & 8.400 & 11.1 \\
Seongnam (Coréia do Sul) & 380 & 6.9 \\
Kwangmyng (Coréia do Sul) & 150 & 4.2 \\
Kumagaya (Japão) & 50 & 5.0 \\
Szeged (Hungria) & 160 & 6.2 \\
\hline
\end{tabular}

Fonte: Park (1986), Ayoade (1998) e Unger (1998).

$\Delta \mathrm{T}_{\mathrm{u}-\mathrm{r}}=\mathrm{AP}^{1 / 4} \cdot \mathrm{U}^{1 / 2}$

Equação 10:

onde:

$\Delta \mathrm{T}_{\mathrm{u}-\mathrm{r}}=$ Intensidade da ilha de calor $\left({ }^{\circ} \mathrm{C}\right)$

$A=$ coeficiente empírico

$\mathrm{P}=$ População

$\mathrm{U}=$ Velocidade do vento regional $\left(\mathrm{m} . \mathrm{s}^{-1}\right)$

Oke (1981) sugeriu uma terceira correlação, associando a geometria dos vales urbanos com a intensidade máxima da ilha de calor - Equação 11-. Esta pode ser expressa através da relação entre altura dos edifícios $(\mathrm{H})$ e a distância entre eles (W), cujo cálculo é:

$$
\Delta T_{u-r}=7,45+3,97 .(H / W)
$$

Equação 11:

Por último, a relação estabelecida entre altura-distância dos edifícios, gerando os chamados "canyons" urbanos, também suscitou a utilização de outra técnica denominada de "Sky View Factor" (SVF) -Figura 13-. Esta mede o nível de obstrução do céu, expressa através da Equação 12. 
Alguns estudos, usando o SVF, confirmam a correlação existente entre as áreas de pico de ilha de calor e a densidade de construção em diferentes cidades (OKE, 1981 e HASENACK; FLORES, 1994), enquanto outros não, como SalviSakamoto (1994 e 2001) para a cidade de São Paulo.

$$
\Delta \mathrm{T}_{\mathrm{u}-\mathrm{r}}=15,27-13,88 . \mathrm{SVF}
$$

Equação 12:

Segundo Grimmond (2006), a partir da utilização de novas inovações tecnológicas, a climatologia urbana se desenvolveu muito, através do uso de novos instrumentais, empregados nos experimentos de campo, assim como na utilização de modelos matemáticos, conforme Kanda (2007).

Apesar dos avanços, muitos trabalhos, atualmente, assim como nos primeiros estudos de clima urbano se dedicam a identificar as diferenças dos parâmetros climáticos (principalmente temperatura do ar e umidade relativa do ar) entre o meio urbano e o rural, em decorrência da expansão das cidades, que propiciaram a formação de um clima local diferente da área do entorno (OKE, 1973; CHANDLER, 1970; LANDSBERG, 1981; BEJARÁN; CAMILLONI, 2003; YOW; CARBONE, 2008).

Assim, em função da relativa facilidade de se obter dados climatológicos, visto que a cidade dispõe de informações de estações meteorológicas da rede oficial localizadas na área urbana, além daquelas instaladas em aeroportos, que são tomadas como representativas de ambientes rurais, muitos estudos vêm se desenvolvendo.
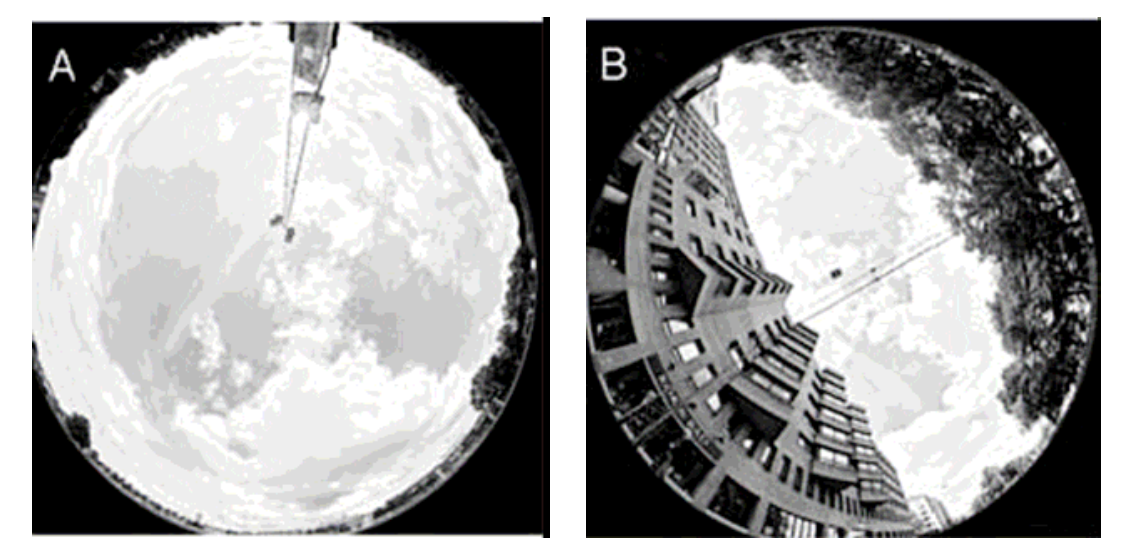

Figura 13. Fotografias obtidas por lentes olho de peixe no centro de Göteborg Suécia - A fotografia (A) foi obtida em uma área aberta e tem um SVF de 0,96; A fotografia (B) foi obtida junto a um vale urbano com prédios de um lado da rua e cobertura vegetal da outra o SVF é de 0,52.

Fonte: Holmer et. al. (2007, p. 240). 
De uma maneira geral, estes estudos demonstram que as diferenças de temperatura entre o urbano e o rural podem alcançar valores superiores a $10,0^{\circ} \mathrm{C}$, principalmente durante noites de calmaria e nebulosidade baixa (OKE; EAST, 1971; KATSOULIS; THEOHARATOS, 1985; CARRERAS, et. al., 1990; YAMASHITA, 1990; BEJARÁN; CAMILLONI, 2003 e ALCOFORADO; ANDRADE, 2006).

As cidades com uso da terra variado se constituem em mosaicos de áreas mornas e frias. Por exemplo, a mudança do uso entre parque e área construída pode produzir diferenças intra-urbanas na temperatura de até $7,0^{\circ} \mathrm{C}$ (BERKATZKY, 1982 e ALONSO et. al., 2003).

Em relação à umidade do ar nas cidades, Landsberg (2006, p. 107) afirma que esta (absoluta e relativa) é menor que o campo. Enquanto seu ritmo sazonal as diferenças campo-cidade são menores no inverno do que no verão. Isto não é um efeito da temperatura do ar nas cidades, mas o rápido escoamento da pluviosidade pelo sistema de drenagem e pela grande área da superfície impermeabilizada.

Clandler (1965 e 1967) ao comparar a umidade do ar entre o campo em Londres verificou que a umidade absoluta e relativa é menor na cidade. Sendo que a diferença máxima da umidade relativa ocorria nas noites de verão, quando a ilha de calor era intensa, enquanto a umidade absoluta geralmente alcançava a diferença máxima durante à tarde na estação do verão e primavera.

Tarifa (1977, p. 67) em seu estudo desenvolvido em São José dos Campos, São Paulo, constatou que os valores de umidade relativa são mais baixos do que na área rural entre $2,0 \%$ e $12,0 \%$ em média e de $7,0 \%$ a $16,0 \%$ nos valores instantâneos. E que estas diferenças muitas vezes eram regidas pela mudança do domínio do sistema produtor de tempo. Kopec (1973) por sua vez, identificou que em condições de céu claro e calmaria, que a pressão do vapor urbano é maior à noite e menor pela manhã e a tarde em comparação com as áreas suburbanas e rurais, enquanto Sisterson e Dirks (1978) mostraram que a redução de 10,0 a 20,0\% da umidade específica na cidade talvez resulte da combinação entre a superfície de evaporação e o incremento da camada de mistura.

Lee (1991, p. 581) ao mensurar os valores de pressão de vapor e a umidade absoluta, durante 10 anos, para Londres conclui que: a) a atmosfera urbana é menos úmida que o meio rural, apenas no verão; b) o excesso de umidades da cidade em relação ao campo ocorre durante as noites de verão e c) que o excesso e 
o déficit de umidade pode ser explicado pelo balanço de energia e as fontes de calor antropogênicas da cidade.

Unkašević et. al. (2001) ao estudarem a diferença da pressão de vapor e umidade relativa em horas fixas (7:00, 14:00 e 21:00 horas) para 4 estações meteorológicas (1 urbana;. 2 suburbanas e 1 rural) em Belgrado (1976-1980), Romênia, constataram que a atmosfera urbana é mais úmida que as áreas suburbanas e rurais às 7:00 e 21:00 horas, entre setembro e fevereiro, enquanto de fevereiro a setembro a atmosfera da cidade é mais seca. Às 14:00 horas, o meio urbano está menos úmido, durante o ano. De maneira geral, pode-se dizer que as diferenças de umidade relativa indicam que o ar urbano é mais seco que o ar no suburbano e áreas rurais ao longo do ano.

A partir dos estudos supracitados, muitos destes identificam a ilha de calor, como algo apenas negativo, contudo, estes estudos não consideram a percepção da população, como ocorrera na pesquisa coordenada por Brandt (2006, p. 444) em seu trabalho realizado em 2006 , o referido autor verificou que $88,0 \%$ da população dos 8.000 indivíduos entrevistados em 10 cidades alemãs, declararam não se incomodar com temperaturas maiores na cidade, afirmando que as mesmas propiciam possibilidades de atividades ao ar livre. Como as cidades dos países desenvolvidos, hoje não mais centros industriais, mas relacionados ao setor de serviço, o autor vê o clima da cidade como importante fator para promover o lazer.

Por outro lado, Oke (1978, p. 162), atesta que o clima urbano é responsável pela germinação e florescimento antecipado de árvores das cidades de clima temperado. Tal fato demonstrado na pesquisa de Brandt (op. cit) pode estar relacionado à questão da menor radiação solar nas cidades de latitudes médias e altas, reforçando os estudos de Wienert e Kuttler (2003), que constataram a influência maior das atividades humanas como fator responsável para geração das ilhas de calor.

Segundo Ayoade (1998, p. 303), apesar das cidades de latitudes tropicais, apresentarem menores intensidades da ilha de calor, isso não quer dizer que a questão do desconforto térmico seja menor do que nas cidades de países desenvolvidos. Muito pelo contrário, pois nestas se verificam uma grande preocupação com esta questão, via planejamento urbano (ASSIS, 2006), até mesmo porque o processo de urbanização se apresenta em um ritmo de crescimento acelerado. 


\subsection{Ilha de calor.}

O termo ilha de calor se transformou em um conceito, apesar disto, este carrega em si muitas incertezas, em razão da vulgarização de sua utilização, muitas vezes empregada como sendo o elemento definidor do clima urbano, o que não é verdade. Tanto assim, que Jardim (2007, p. 307) em sua tese de doutoramento reafirma esta preocupação ao dizer que:

“...a ilha de calor não representa a realidade do clima urbano, mas um de seus aspectos, traduzida por uma situação momentânea ou horária, motivada pela convergência pontual de fatores ligados às características de conformação do relevo, disposição dos equipamentos e dinâmica urbanos, sob a influência de determinados tipos de tempo, associados aos sistemas atmosféricos em dado estágio de sua evolução temporal...".

Conseqüentemente, essa consideração de Jardim (op. cit.) nos remete a uma questão recorrente nos estudos de clima urbano: A partir de que momento uma cidade cria condições para a geração de um clima urbano?

Para Landsberg (2006, p. 95), há uma grande dificuldade de se objetivar a partir de que densidade de população e edificações alguma influência sobre o clima começa a ser notada. O mesmo constata Monteiro (2003, p. 19) ao afirmar que não tem um momento preciso a partir de que grau de urbanização e características geoecológicas locais se poderia definir o surgimento de um clima urbano.

Assim sendo, qualquer diferença de temperatura do ar entre dois pontos não significa que há uma ilha de calor. Por exemplo, ao se comparar dois pontos da superfície com o mesmo uso da terra, mas em vertentes distintas, isso acarretaria uma diferenciação da temperatura do ar, contudo, isso não é suficiente para dizer que exista uma ilha de calor. Neste caso, acredito que a melhor terminologia seria núcleo de calor, uma vez que a orientação das vertentes é o fator responsável pela diferença que possa existir entre ambientes homogêneos.

Outro exemplo retirado de Jardim (2002) em sua dissertação de mestrado é muito esclarecedor, pois ao identificar uma diferença de $3,0^{\circ} \mathrm{C}$ dentro da sua área de estudo (Bacia do rio Aricanduva), como indício de uma possível transformação da 
atmosfera da cidade, suas análises revelaram que isto não era verdadeiro. A causa deste gradiente estava associada à entrada de um sistema atmosférico com características diferentes.

O mesmo foi identificado por Fialho e Imbroisi (2005, p. 5177) para o seu estudo no Alto do rio Joana (bairros do Andaraí e Grajaú), Rio de Janeiro, entre os dias 13 e 14 de maio de 2004, em situação sinótica de predomínio da Massa tropical Atlântica (MTA) substituída por aquecimento pré-frontal, no dia 14 pela manhã, favoreceu o desenvolvimento de uma diferença térmica de $4,0^{\circ} \mathrm{C}$ e $3,0^{\circ} \mathrm{C}$ às 9:00 e 12:00 horas, respectivamente, que veio a desaparecer às 15:00 horas em razão do aumento da nebulosidade e velocidade do vento, condições de prenúncio de chuva, que se iniciara logo após o término das medidas.

Apesar dos autores terem observado que as diferenças encontradas, no dia 14 , tenham sido motivadas pela invasão de um sistema extra-tropical, em nenhum momento os mesmos chegam a mencionar que o urbano não foi responsável por estes gradientes, assumindo que os resultados configuram um indício de transformação na atmosfera urbana.

Além dessa vulnerabilidade conceitual, hoje ainda existem novas formas de identificar a ilha de calor, tais como: registradores contínuos de temperatura do ar e umidade relativa, balões meteorológicos e imagens de satélites, que permitem novas possibilidades de observações, bem como a compreensão de suas causas e combinações com os arranjos urbanos. Sendo assim, as inovações tecnológicas favorecem o desenvolvimento do estudo da ilha de calor. Contudo, as diferenças inerentes aos novos métodos de monitoramento identificam tipos diferentes de ilhas de calor?

Arnfield (2003, p. 4) demonstra em seu trabalho de revisão sobre o clima urbano que a aplicação da técnica de sensoriamento remoto alavancou o interesse pela temática do clima urbano, entretanto a disseminação desta, não significou um avanço na reflexão crítica a respeito do tema.

Isto é tão grave, que na literatura brasileira, o termo ilha de calor ainda é utilizado em estudos de clima urbano de maneira indiscriminada, mesmo com aplicação de técnicas de monitoramento distintas (utilizam medidas fixas ou móveis, balões atmosféricos e/ou imagens de satélite). A conseqüência é a impressão de que estamos analisando o mesmo fenômeno. Porém, não é isto que ocorre, na medida em que as 
formas desenvolvidas para se medir a ilha de calor não permitem dizer o mesmo, conforme pode ser visualizado na Figura 14.

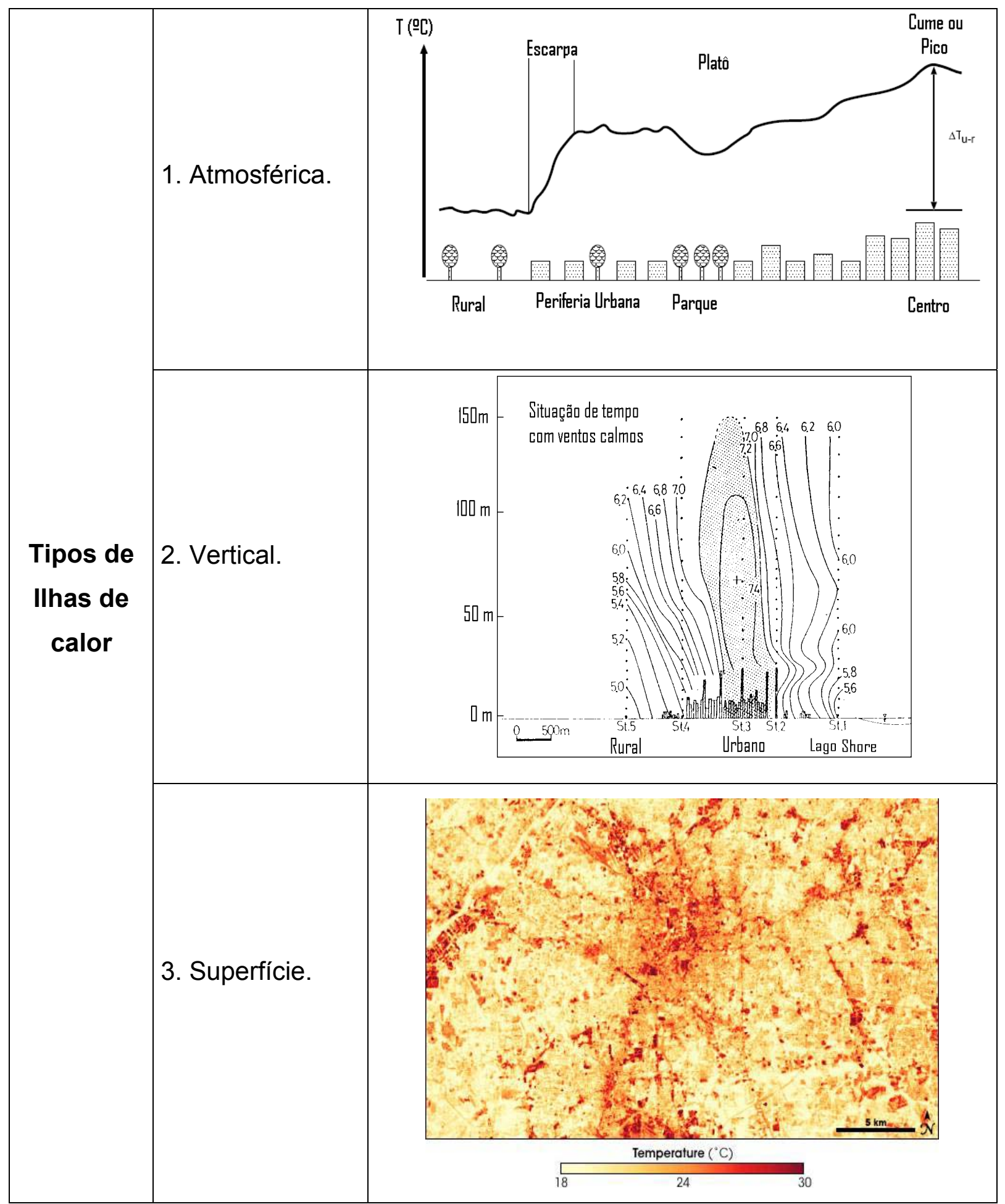

Figura 14. Tipos de ilhas de calor

Elaborado por Edson Soares Fialho (2008). 
Cabe salientar que os tipos de ilha de calor identificados no quadro 3, não são reconhecidos por Oke (1978), que de acordo com sua proposta inicial observa apenas dois tipos: atmosférica e de superfície. Arrau e Peña (2009) reconhecem 3 tipos: ilha de calor de superfície, ilha de calor micro-urbana e ilha de calor negativa, quando a cidade mais fria que as zonas rurais.

A opção deste trabalho em assumir a existência de 3 tipos se deve em reconhecer, que os métodos de observação e a estrutura espacial serem distintos. Enquanto Oke (op. cit.) reconhece apenas duas em razão de observar a natureza ou o meio de propagação do calor, no caso, a atmosfera ou a superfície.

\subsubsection{A ilha de calor atmosférica.}

A ilha de calor termodinâmica denuncia as modificações de certos parâmetros da camada basal da atmosfera, por meio da diferença dos tipos de usos da terra e cobertura entre as paisagens urbanas e rurais.

\subsubsection{A influência do sítio urbano.}

Para melhor compreender o ambiente climático intra-urbano, é necessário compreender as relações existentes entre o sítio urbano e as diversas funções desenvolvidas no espaço urbano, expressas através do uso e ocupação da terra, na análise climática local e no planejamento urbano.

A maioria dos estudos relacionados ao clima urbano desenvolveu-se sem considerar as diferentes características do espaço urbano. Monteiro (1990) enfatiza a importância do conhecimento das particularidades do sítio e do meio urbano para a compreensão e análise climática, bem como a detalhada representação cartográfica como suporte ao estudo do clima urbano.

O entendimento de como se formam as condições climáticas urbanas, derivadas da heterogeneidade tanto do sítio (Figura 15) quanto da estruturação e funcionalidade urbanas, carece ainda de mais atenção dos estudiosos do clima das cidades $^{7}$. O conhecimento do sítio em que o espaço urbano se insere é pré-requisito para toda e qualquer análise do clima da cidade, uma vez que o sítio urbano assume importante papel nas diversas funções que o espaço urbano apresenta.

\footnotetext{
${ }^{7}$ Entende-se neste trabalho que o clima urbano aparece como uma categoria à parte, pois o clima local numa cidade é influenciado pelos materiais constituidores da superfície urbanas, muito diferentes dos materiais das superfícies não construídas, além de outros fatores supracitados.
} 


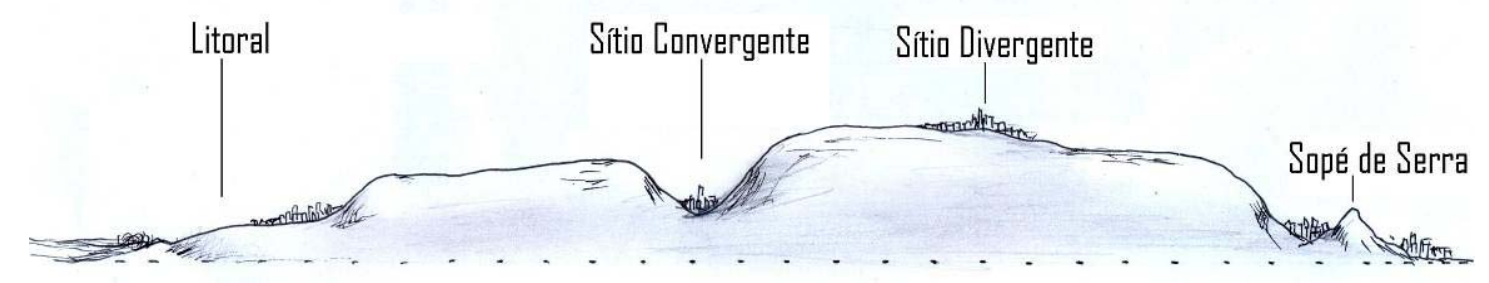

Desenho: Silvano Souza Dias. 2008.

\section{Topo de montanha}

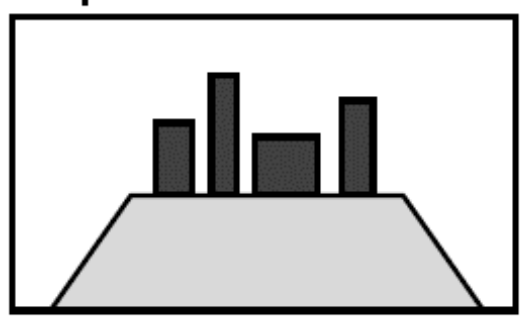

Encosta

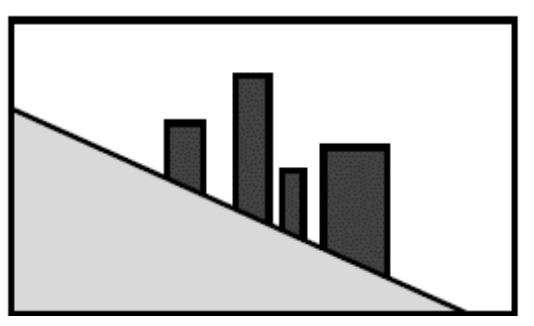

Vale

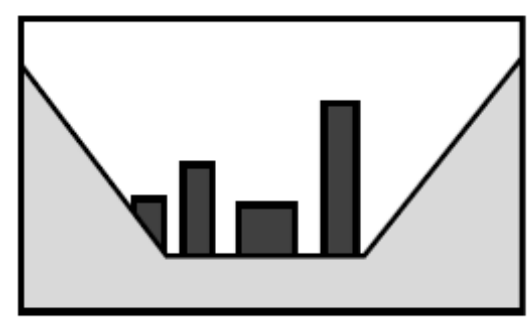

Sopé da encosta

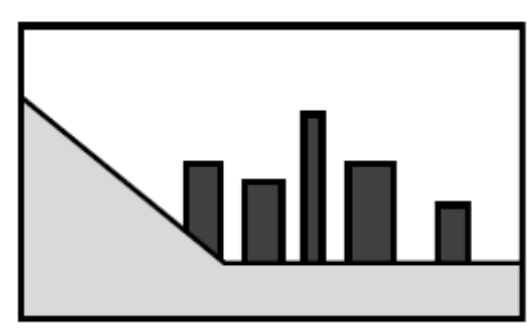

Platô

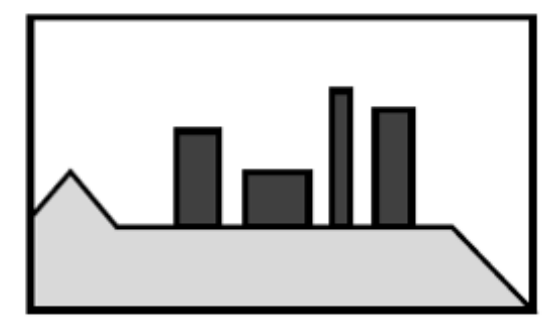

Terraço da encosta

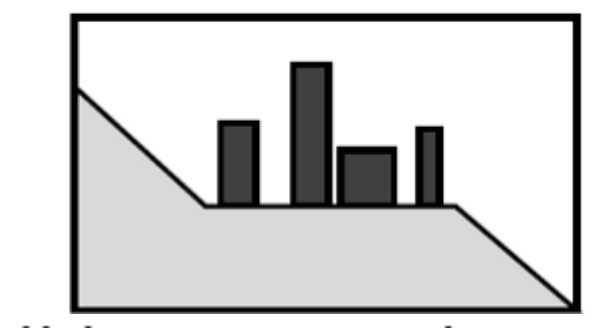

Vale com ára urbana

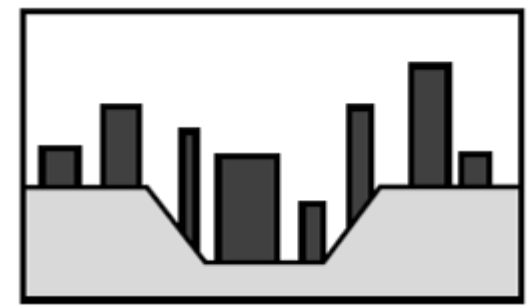

Pequenas colinas com área urbana

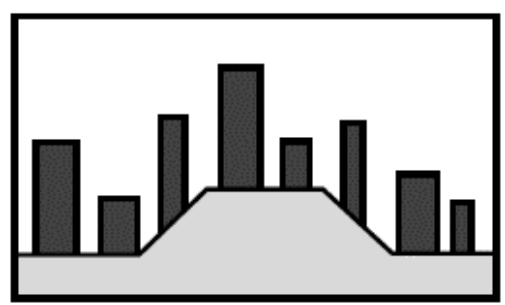

Fonte: Oke (2006, p. 183. Adaptado.)

Organizado por Edson Soares Fialho (2009).

Figura 15. Tipos de sítios (Topografia-Cidade). 
Cabe destacar que o sítio urbano, é onde se assenta a cidade, ou melhor, é a localização exata do espaço construído, em suas relações com a topografia local (DOLFUS, 1991, p. 84-85). Isto confere à mancha urbana características particulares, pois os aspectos relacionados à orientação e inclinação das vertentes e a posição geográfica, conjugados com a trajetória aparente do sol podem gerar uma diferenciação no balanço de energia, por meio do sombreamento das encostas, modificando os padrões espaciais e temporais dos elementos do clima, como pode ser visto na Figura 16 e corroborado por Gustavson et. al. (1998) e Oliphant et. al. (2003), que constataram que as vertentes mais sombreadas durante o dia se esfriam mais rapidamente do que as que receberam maior quantidade de luz solar.

O conhecimento das feições topográficas do sítio é de extrema importância nos estudos climáticos, porque em pequenas distâncias dentro da própria estrutura interna das cidades existem significativas diferenças de microclima, oriundas da morfologia do solo e a presença ou não de vegetação. Tais fatores geram alterações térmicas que comprometem a qualidade de vida e o conforto térmico das cidades.
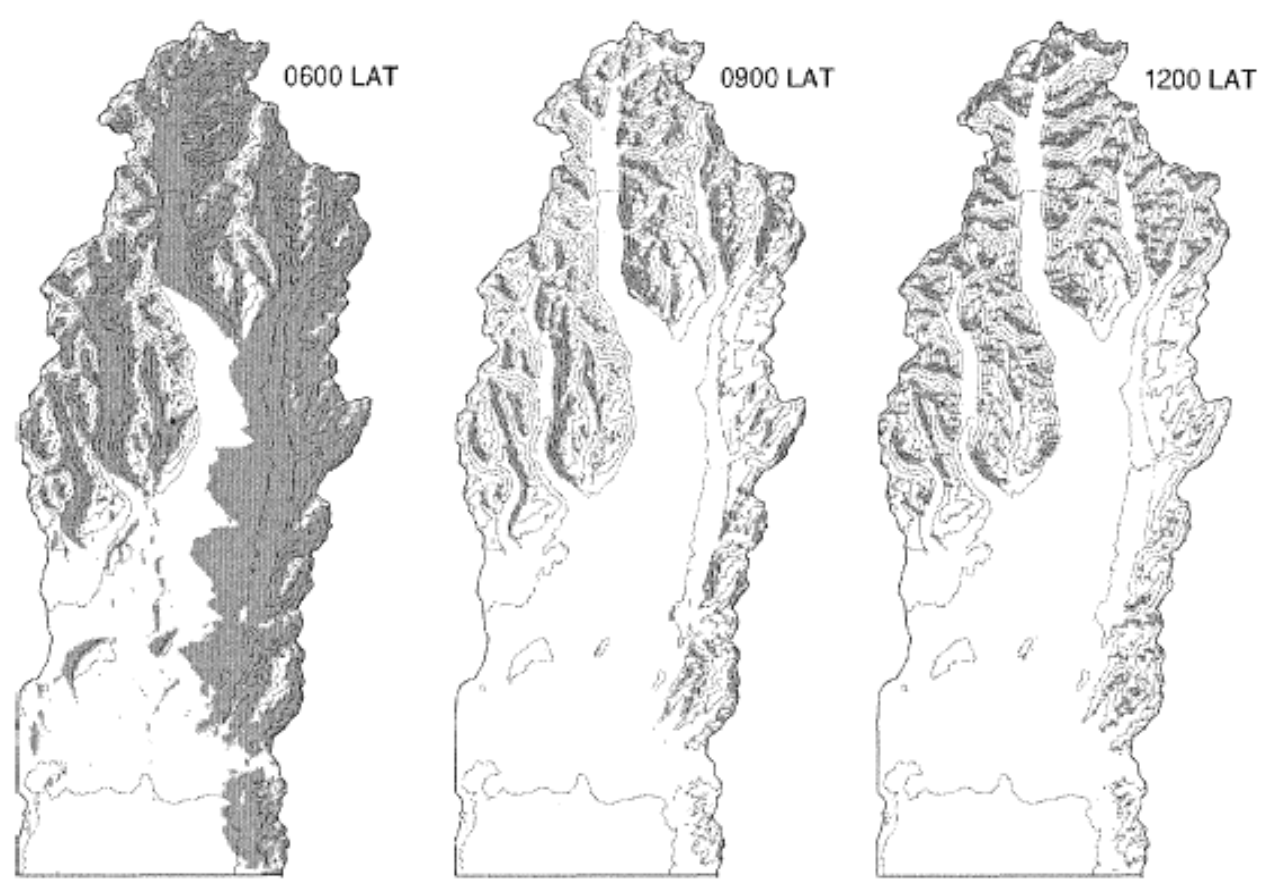

Figura 16. Séries de mapas que mostram sombras de terreno modeladas na bacia de Tekapo, Nova Zelândia, para os horários das 6:00, 9:00 e 12:00 GMT, no dia 12/2/1999.

Fonte: Oliphant et. al. (2003, p. 124). 


\subsubsection{As causas da drenagem do ar frio nas vertentes.}

Os sítios convergentes, em forma de vales, apresentam uma estrutura morfológica capaz de condicionar a drenagem do ar frio, que tende a ser drenado durante à noite em condições de tempo com ausência de ventos e de baixa nebulosidade, dinamizando uma circulação terciária (local) denominada de brisa de montanha (noite) e ao alvorecer a brisa de vale (dia), pode ser visto na Figura 17.

A teoria de formação da piscina de ar frio nos vales e bacias (GEIGER, 1961) enfatiza o papel da perda de radiação de ondas longas e o fluxo descendente de calor sensível da atmosfera. Isto produz uma camada de ar frio em cima dos declives que subseqüentemente escoam ao longo da vertente na piscina de ar frio. A drenagem do ar frio produz a acumulação nos fundos de vale e depressões, o que acaba ocasionando a formação de nevoeiros nas noites de forte resfriamento radiativo (calmas e sem nebulosidade), que segundo Yoshino (1984, p. 239) pode ocasionar os efeitos prejudiciais para a agricultura.

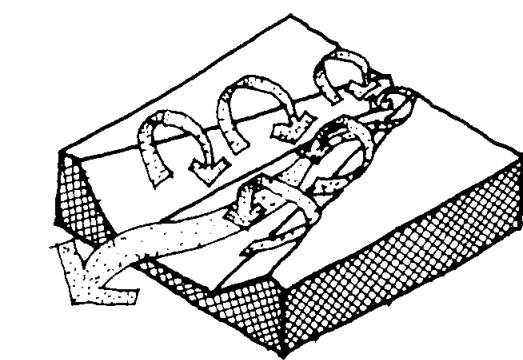

Nascer do sol início dos fluxos ascendentes

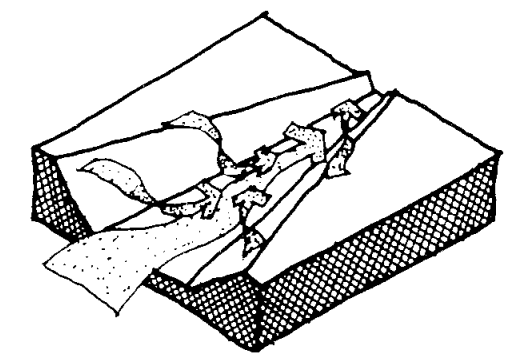

Pôr-do-sol

$o$ ar começa a descer pelas laterais do vale

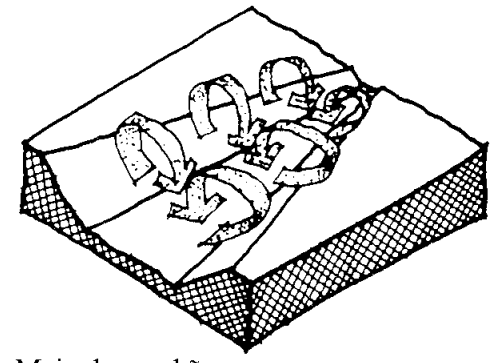

Meio da manhã

termociclo transversal ao vale

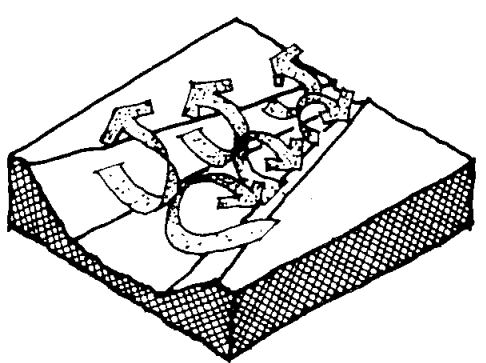

Noite (tarde)

termociclo transversal ao vale e inverso

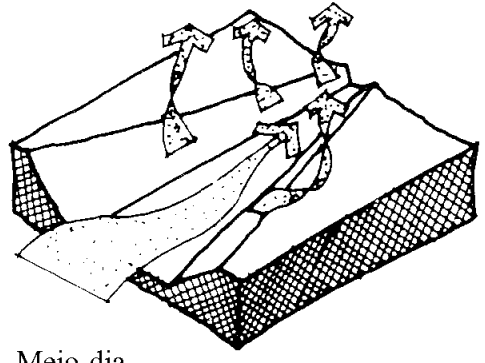

Meio-dia

fluxos ascendentes

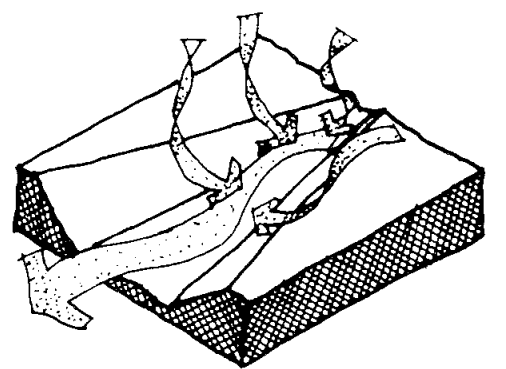

Meia-noite

fluxos descendentes

Figura 17. Mecanismo de circulação terciária em fundo de vale

Fonte: Brown e Dekay (2004, p. 42. Adaptado.) 
Em Portugal alguns pesquisadores têm estudado este fenômeno climático, em vales da região de Lisboa e da Arrábia, como Alcoforado et. al. (1993) procuraram identificar a acumulação de ar frio no fundo do vale da Ribeira da Ajuda, e determinar o risco de geada e nevoeiro de irradiação nessa área.

Durante o dia, as principais trocas radiativas entre a atmosfera e a superfícies terrestre fazem-se essencialmente à custa da radiação solar direta e difusa. Esta radiação, de pequeno comprimento de onda é absorvida pela superfície e depois é reemitida sob a forma de radiação terrestre (onda longa). Esse balanço de entrada e saída de ondas curtas e longas, respectivamente, determina os horários de maior e menor temperatura ao longo do dia, conforme pode ser visto na Figura 18.

$\mathrm{Se}$ a atmosfera contiver grande quantidade de gases absorventes (vapor d'agua, gás carbônico, metano, monóxido de carbono, dentre outros), e/ou nuvens, nevoeiro e brumas, a perda de energia irradiada não será tão significativa para a atmosfera, tanto para o dia, quanto à noite. Mas, se a atmosfera estiver mais seca, as perdas energéticas da superfície são elevadas, principalmente, à noite quando a irradiação terrestre é responsável pela diminuição das temperaturas junto ao solo, constituindo o motor do resfriamento radiativo noturno.

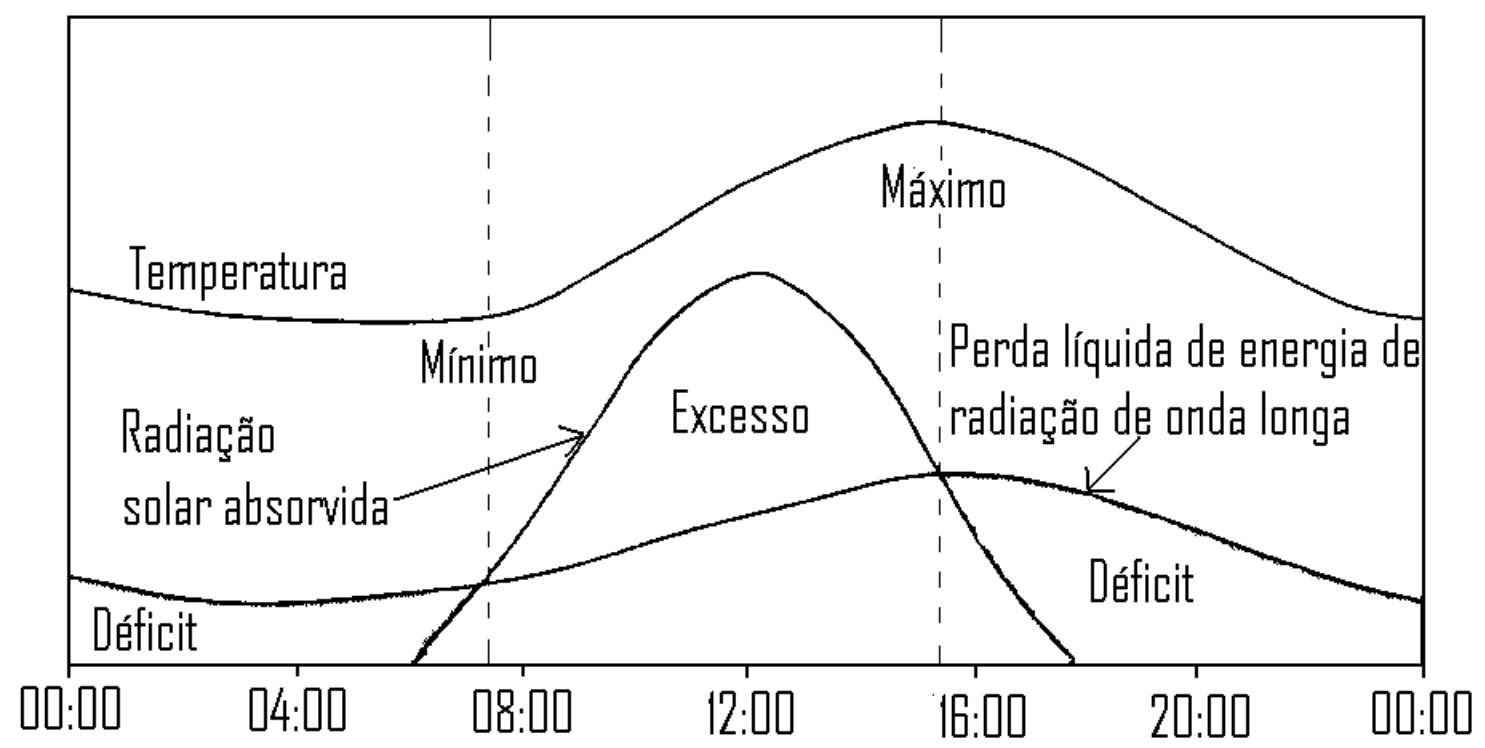

Figura 18. Ciclo diário da temperatura do ar e o ao balanço de radiação da superfície terrestre.

Fonte: Cuadrat e Pita (2000, p. 84. Adaptado.)

Em noites que apresentam condições de tempo determinadas por sistemas sinóticos anticiclonais, a característica predominante será a calmaria e baixa 
nebulosidade. Situação favorável a formação de inversão térmica radiativa na camada de ar junto ao solo e, nas vertentes, ocorre à movimentação do ar no sentido descendente, induzida pela gravidade. Esse movimento do ar é denominado brisa de montanha ou ventos catabáticos.

Se a irradiação terrestre e as conseqüentes inversões térmicas que se formam nas noites anticiclonais, conforme demonstra a Figura 19 para o bairro de Silvestre, localizado na calha do rio Turvo Sujo, na cidade de Viçosa, é a causa do resfriamento radiativo noturno junto ao solo, a gravidade é o principal motor da drenagem do ar frio ao longo da encosta.

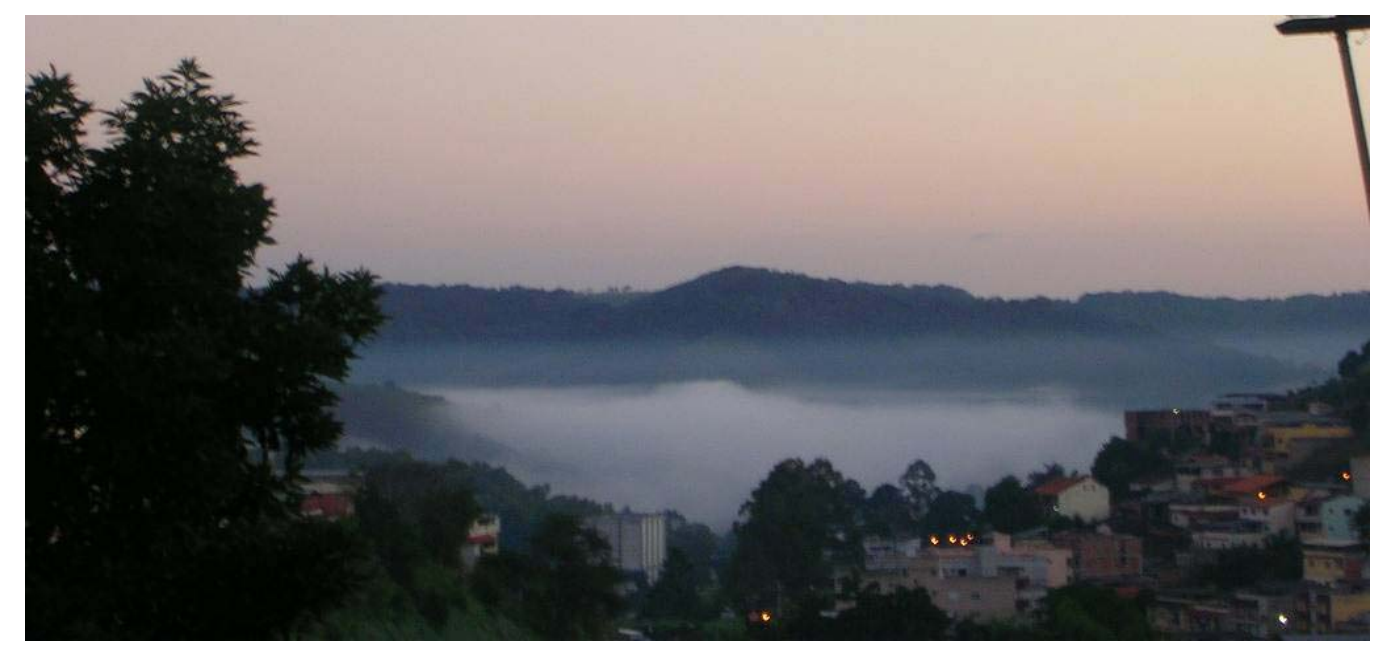

Figura 19. Nevoeiro de resfriamento noturno, localizado no bairro de silvestre, visto a partir da rua Tiradentes. 67 do bairro do João Brás, no município de Viçosa-MG.

Foto: Edson Soares Fialho, obtida em 8 de maio de 2008.

O ar frio começa lentamente a escoar pelas vertentes, pouco depois do pôrdo-sol, período em que, geralmente, se começa a definir a inversão térmica e o nevoeiro na base das vertentes, que foi se desenvolvendo durante a noite. A sua dissipação ocorre, primeiramente, nas vertentes expostas, para pouco depois da alvorada. De acordo com Yoshino (apud LOPES, 1995, p. 152), dependendo das condições de tempo e da topografia, o escoamento do ar frio ocorre freqüentemente uma ou duas vezes entre o pôr-do-sol e a meia a noite e duas ou três vezes entre meia-noite e o amanhecer, coincidindo a última com a temperatura mínima.

A intermitência da drenagem do ar frio pode ser explicada pelo aumento da velocidade do ar ao descer à vertente, que sofre um aquecimento adiabático, retardando o fluxo, em razão da fricção criada pelos obstáculos, como a vegetação, 
que reduz a velocidade do ar. Uma vez vencido o atrito, o resfriamento radiativo incrementa a pressão e o ciclo se repete.

Segundo Nakamura (1989), a velocidade da drenagem do ar frio depende da velocidade e direção do vento regional, da intensidade da inversão térmica junto ao solo, do efeito de fricção da superfície e do declive da vertente. A direção do vento de gravidade junto superfície, nunca se desvia mais de $22,5^{\circ}$ da linha de maior declive do terreno.

Depois de cada fase de drenagem de ar frio, caracterizado por um decréscimo de temperatura, surgem localmente alguns núcleos de ar mais quente sobre o ar arrefecido, que possuem um movimento contrário ao escoamento do ar frio junto ao solo. Geiger (1961) havia notado que se formam circulações isoladas de ares nas encostas, que constituíam pequenos redemoinhos sobre o ar que escoa pelas vertentes. Segundo Yoshino et. al. (1981, p. 13), as características da drenagem do ar frio em cada um dos setores das vertentes e no vale, retratado na Figura 20, podem ser sumarizadas como se segue:

1. Os setores mais elevados da vertente são áreas onde gera o ar frio e se inicia a sua drenagem.

2. No meio da vertente, a drenagem de ar frio é caracterizada pelas mudanças de temperatura, direção e velocidade do vento ao longo da noite. Depois da passagem do ar mais arrefecido, a temperatura aumenta ligeiramente.

3. $\mathrm{Na}$ base da vertente gera-se uma contracorrente contrária à drenagem do ar frio. $\mathrm{O}$ ar que sobe encontra-se menos frio que o ar junto à superfície, que é resfriada pela irradiação.

4. No fundo dos vales e superfícies topograficamente deprimidas origina-se um lago de ar frio, caracterizado por uma forte inversão de temperatura.

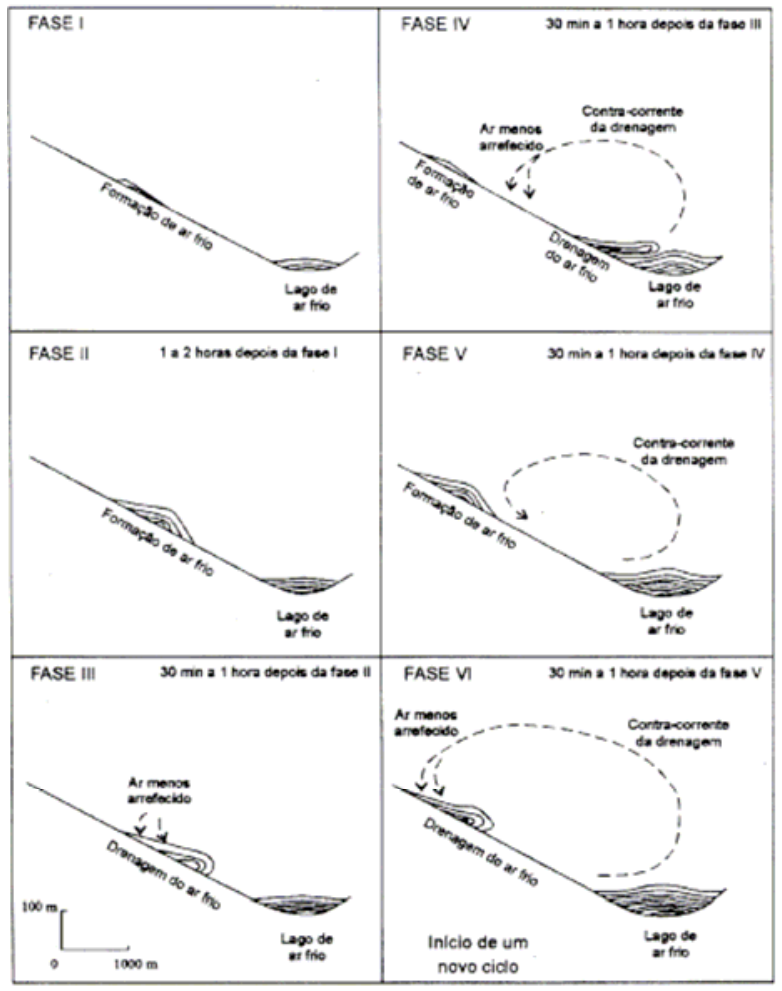

Figura 20 - Modelo de drenagem do ar frio Fonte: Nakamura (1989). 
A forma de alimentação do fundo do vale com ar frio é um dos aspectos mais interessantes no conjunto do sistema. Uma das questões que se levanta é a de saber se ele se forma exclusivamente pelo resfriamento radiativo do fundo do vale, ou se também é alimentado pela drenagem do ar que escoa por gravidade. Outra é a de determinar qual a relação entre a intermitência da drenagem e a periodicidade da acumulação do ar frio no fundo dos vales $e$ depressões, que irá ao longo da noite produzir uma concentração maior de ar frio no fundo do vale, favorecendo a localização das temperaturas mínimas, conforme a Figura 21.

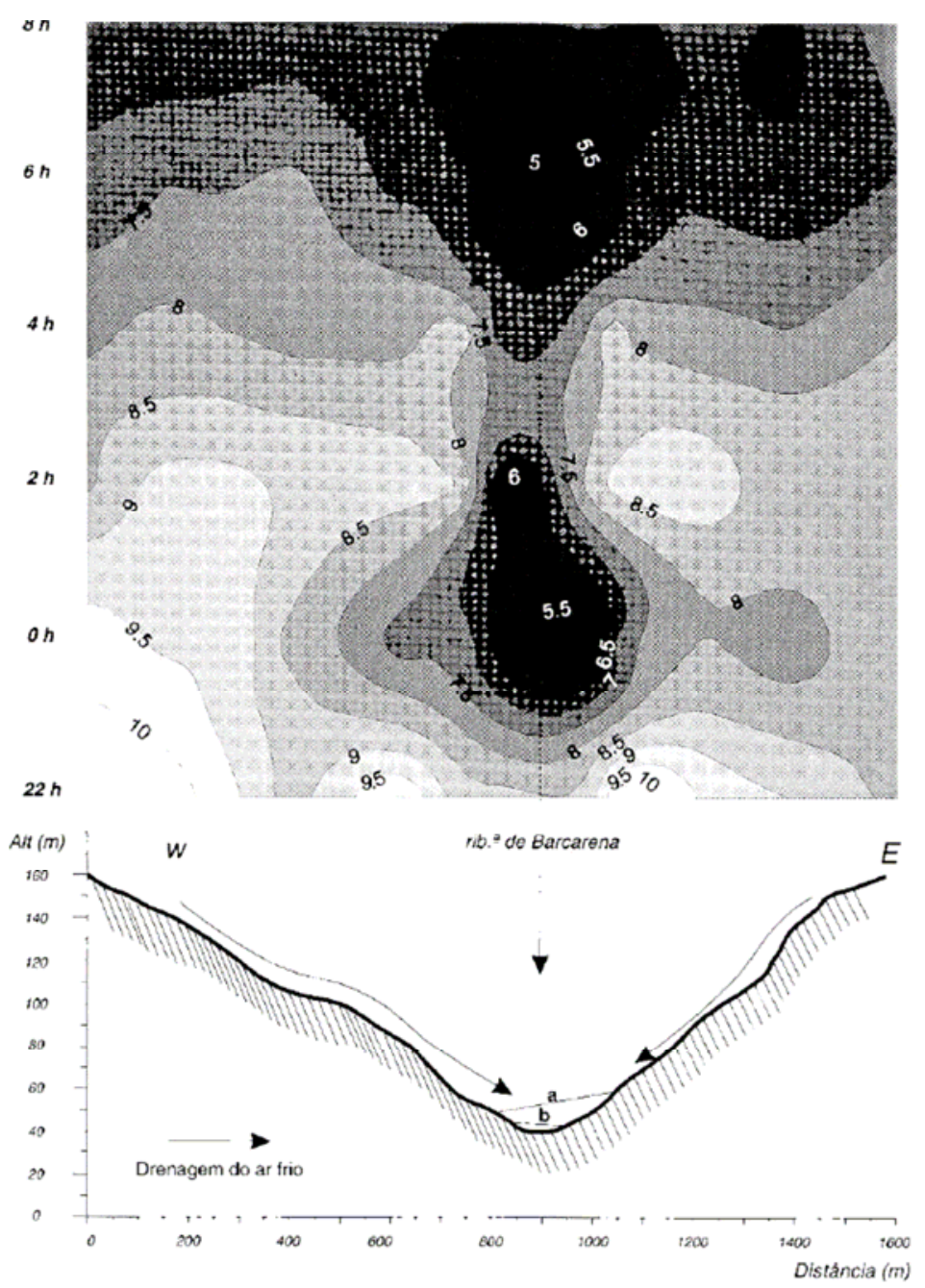

Figura 21. Localização de temperaturas mínimas no fundo do vale em decorrência do mecanismo de brisa de montanha ao longo da noite.

Fonte: Lopes (1995, p. 161).

Para Yoshino (op. cit), o resfriamento irradiativo noturno somente irá alimentar o fundo do vale se a temperatura que se encontra nos divisores for superior em relação ao fundo do vale.

A altura do lago de ar frio atinge, freqüentemente, cerca de um terço da altura das vertentes, correspondendo a sua parte superior ao limite da camada de inversão térmica junto ao solo. O lago assim poderá ter, em certos casos, um grande desenvolvimento vertical. 
Através de vários estudos efetuados em áreas urbanas e suburbanas, tem-se procurado identificar algumas limitações climáticas que afetam os indivíduos e que o planejamento urbano e o ordenamento biofísico do território não devem ignorar.

Em primeiro lugar, o resfriamento nas noites anticiclonais de inverno pode ocasionar episódios de frio, nas áreas topograficamente deprimidas, que levam ao desconforto térmico dos indivíduos ou um excesso de consumo de energia para o aquecimento. Segundo, como os nevoeiros tendem a se formar da noite (entre 21:00 e 23:00 horas) e início da manhã (5:00 às 8:00 horas). Troppmair (2004, p. 34-35) chama a atenção para o número de acidentes provocados por este fenômeno nas estradas brasileiras, principalmente, na região Sudeste.

Por outro lado, as noites anticiclonicas, calmas, sem nebulosidade e com uma forte estabilidade atmosférica, são propícias ao aparecimento de ventos fracos (inferiores a $3 \mathrm{~m} . \mathrm{s}^{-1}$ ), que podem estagnar a atmosfera e favorecer a concentração de poluentes na atmosfera, no caso de uma grande cidade.

No entanto, quando se observa que as condições de tempo ideal para a formação de um nevoeiro ${ }^{8}$, as mesmas também responsáveis pelo desenvolvimento do processo de formação de uma ilha de calor. Porém, como observaram Sachweh e Koepke (1997) em Munich, Alemanha, nos últimos 30 anos, ambos os processos são excludentes, pois se verificou a redução do número de dias de formação de nevoeiro, na medida em que, o processo de urbanização possibilitou o crescimento da mancha urbana. Tal constatação é conforme a afirmativa de Landsberg (1970, p. 1269).

Como as cidades registram grandes fluxos de veículos automotores, capazes de incrementar a quantidade de núcleos higroscópicos (núcleos de condensação) e uma densidade urbana, responsável por um aquecimento da superfície e da atmosfera mais lento do que nas áreas adjacentes.

Estas condições, por sua vez, não impedem a impedem a formação de nevoeiros (fogs), conforme Sachweh e Koepke (op. cit.) identificaram para Munich, mas diminui a intensidade dos mesmos, na medida em que, o campo de visão não é reduzido a menos de $1 \mathrm{~km}$, mas a cerca de $11 \mathrm{~km}$, segundo Suckling e Mitchell (1988) verificaram em Sacramento, EUA, ou seja, os nevoeiros ainda persistem em ocorrer nas cidades, mesmo que grandes, porém a redução da visibilidade não é tão grande.

\footnotetext{
${ }^{8}$ O nevoeiro ou névoa é uma nuvem stratus cuja base está no solo ou perto dele e reduz a visibilidade até 1 quilômetro (com visiblilidade maior a $1 \mathrm{~km}$, ocorre uma neblina).
} 


\subsubsection{Variabilidade diária da ilha de calor atmosférica.}

Nos primeiros estudos de clima urbano, a ilha de calor urbana atmosférica apresenta uma variabilidade temporal, sendo mais evidente, no período noturno (Figura 22). Cabe salientar que o método de identificação do fenômeno da ilha de calor então usado, era a comparação entre duas estações meteorológicas.

Este método tem como fator limitante, a restrição do número de pontos amostrais, que geralmente fica restrito a dois, localizados: um ambiente rural e urbano. Apesar deste procedimento não representar de maneira fiel as influências da escala da cidade, estas observações podem vir a sub ou superestimar as diferenças dos elementos do clima analisados, em razão da localização das mesmas, tem um ponto positivo, pois a comparação dos dados irá refletir o ritmo de ganho e perda de energia solar (balanço de energia).

À noite, tanto o campo, como a cidade perdem calor por irradiação terrestre à atmosfera, na faixa do infravermelho. Contudo, o fluxo de energia se manterá mais tempo no labirinto do meio urbano, com sua geometria de edificações, que dificultam a dissipação desta energia, aprisionando-a por mais tempo dentro da cidade, que resulta em um resfriamento do ar mais lento do que o ambiente rural ou com menor densidade de construção urbana.

Estudos recentes realizados sobre a temática da ilha de calor urbana em Buenos Aires, Argentina (BEJARÁN; CAMILLONI, 2003), Nova lorque, Estados Unidos da América (GEDZELMAN et. al., 2003), Lisboa, Portugal (ALCOFORADO; ANDRADE. 2006) e Debrecen, Hungria (BOTTYÁN et. al. 2005) reforçam a característica do fenômeno ser eminentemente noturno, com ocorrência de sua máxima intensidade entre 3 a 5 horas após o pôr-do-sol.

Além destes, estudos realizados em Vancouver, Canadá (RUNNALS; OKE. 2000), Szeged, Hungria (SUMEGHY; UNGER. 2003) e Singapura, China (CHOW; ROTH, 2006) identificaram que a intensidade máxima da ilha de calor ocorreu entre 6 e 7 horas após o pôr-do-sol, diferente das observações de Oke (1981 e 1982) que estipulava entre 2 e 3 horas.

Os estudos em cidades de latitudes médias confirmam o caráter noturno do fenômeno da ilha de calor, porém algumas pesquisas realizadas em cidades tropicais identificaram a intensidade máxima da ilha de calor no período diurno como em Temuco, Chile (STEFFES et. al., 2001), Toluca, México (MÉNDEZ, 1993 e 
MÉNDEZ et. al., 2008), Juiz de Fora (MARTINS, 1996), Rio de Janeiro (BRANDÃO, 1996, 2001 e FIALHO, 2002), Zona Oeste do Rio de Janeiro (LUCENA, 2005) e Guararapes (MINAKI; AMORIM, 2005).

Cabe salientar, que estas diferenças podem estar associadas a dois fatores: o primeiro é a própria localização latitudinal, determinante na variabilidade sazonal da duração do dia e da noite, e, por conseguinte da oscilação diária da temperatura. O segundo, relacionado a escala topoclimática, ou seja, a orientação das encostas, fator que facilita ou não a chegada dos raios do sol ao longo do dia, por conta da influência do sombreamento e do acúmulo de ar frio no fundo do vale ao longo da madrugada.

Este fator é tão relevante, que caso uma cidade esteja situada em um eixo de vale orientado para o quadrante norte, no hemisfério sul, a mesma apresentará uma grande incidência de raios solares, o que definirá um topoclima distinto, capaz de registrar temperaturas mais elevadas ao longo do dia, mesmo não apresentando a presença de ocupação humana, se comparado a outros vales de orientações voltadas para o quadrante sul (OLIPHANT et. al., 2003).

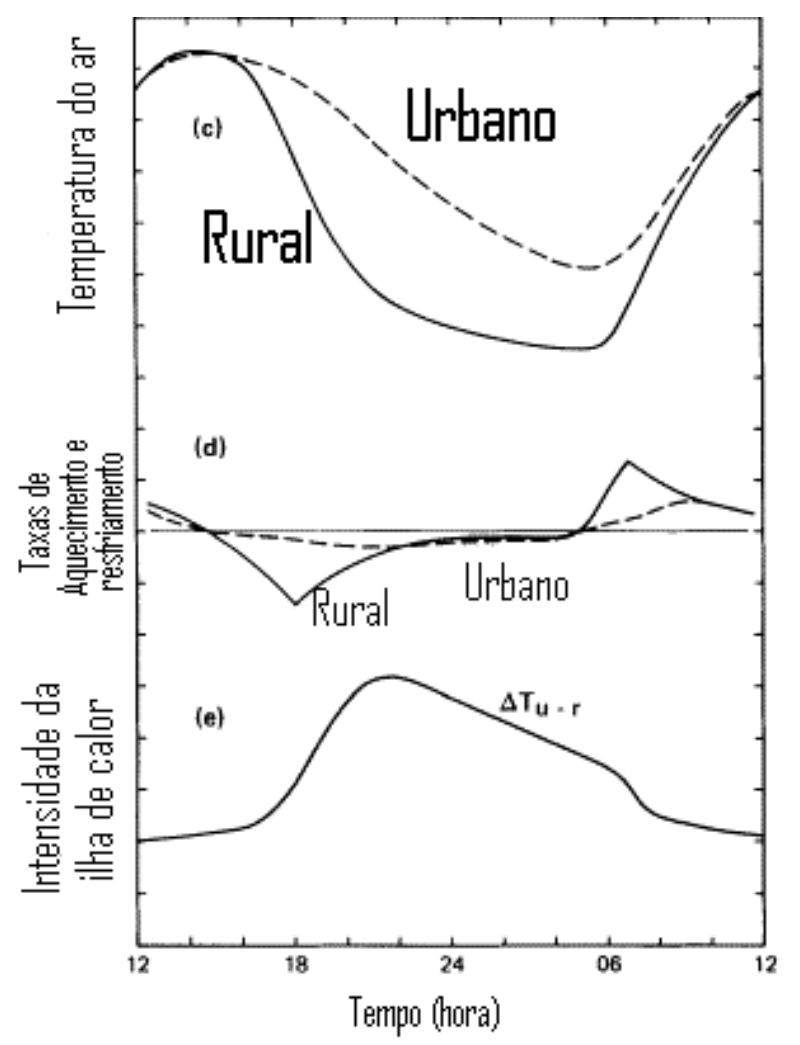

Figura 22. Comportamento diário da temperatura do ar entre o ambiente rural e urbano e sua diferença, mais evidente após às 18:00 e se intensificando até às 21:00 horas, quando sofre um decaimento constante até o alvorecer.

Fonte: Oke (1982, p. 3. Adaptado.) 


\subsubsection{Variabilidade sazonal da ilha de calor atmosférica.}

Tomando como base às observações comparativas longas entre estações meteorológicas urbanas e rurais, muito utilizadas para definir a intensidade da ilha de calor como nos estudos realizados em Edmonton, Canadá (HAGE, 1972) Londres, Inglaterra (UNWIN, 1980), Chicago, EUA (ACKERMAN, 1985), Ohio, EUA (SCHMILDLIN, 1989), Cidade do México, México (JAUREGUI, 1993 e OSTOS, 2004), Tangará da Serra e Barra do Bugres, Mato Grosso (ZAMPARONI, 1995), Rondonópolis, Mato Grosso do Sul (SETTE, 1996), Buenos Aires, Argentina (FIGUEROLA; MAZZEO, 1998), Cairo, Egito (ROBAA, 2003), Szeged, Hungria, (SÜMEGHY; UNGER, 2003), Salamanca, Espanha (ALONSO et. al., 2003) dentre outros, pode-se dizer que há variabilidade sazonal, e que a mesma é mais bem identificada com o uso da informação da temperatura mínima.

Considerando o comportamento ao longo das estações do ano, a intensidade da ilha de calor é mais evidente na estação seca (inverno), uma vez que a atmosfera tende a conter menos água no estado gasoso. A conseqüência disto é o aumento da velocidade da perda de energia irradiada da superfície da terra para a atmosfera. Tanto assim, que nos meses de inverno, em localidades continentais, como Brasília e até mesmo Viçosa, a queda de temperatura do ar seja muito rápida logo após o pôr-do-sol, chegando a uma oscilação térmica de $8,0^{\circ} \mathrm{C}$. Mas, isto não quer dizer que não exista a possibilidade da intensidade máxima da ilha de calor não ocorrer fora do inverno, muito pelo contrário, Sofer e Potchter (2006) observaram que em Eilat, Israel, é mais evidente à tarde no verão do que no inverno.

Ainda em relação variabilidade sazonal da ilha de calor, é importante lembrar que o inverno em regiões de clima temperado, as horas de insolação sofrem uma alteração significativa ao longo do ano, diferente das cidades tropicais. Por conta disto, as noites mais longas, no inverno sob condições de tempo ideais (pouco vento e baixa nebulosidade) poderiam produzir ilha de calor.

Além das noites longas, outro fator contribui para a formação da ilha de calor. O consumo de energia é tão importante que Santamouris et. al. (2001) observaram em Atenas, Grécia, ao longo de medidas climáticas de quase 30 estações meteorológicas urbanas e suburbanas como também medidas específicas executadas em 10 canyos urbanos, que o clima urbano é fortemente influenciado pelo consumo de energia de edifícios e não pelo contingente populacional. $O$ 
resultado demonstrou que em Atenas, quando a ilha de calor excede aos $10,0^{\circ} \mathrm{C}$ a carga de eletricidade pode ser triplicada para atender a demanda de consumo de energia para refrescar o ar, via condicionadores de ar. E que durante o inverno período, a carga de aquecimento de edifícios urbanos localizados no centro da cidade tem seu consumo de energia reduzido em até $30,0 \%$.

\subsubsection{Variabilidade espacial da ilha de calor atmosférica.}

A partir da identificação de alguns fatores formadores da ilha de calor já citados anteriormente, pode-se definir que a cidade altera o ritmo de aquecimento e resfriamento da superfície em função do adensamento urbano, associado à atividade humana e as propriedades físicas dos materiais de construções.

Desta feita, ao se traçar um perfil da temperatura em uma cidade de grande porte que se inicie na área rural ao centro urbano, passando pelo subúrbio ou periferia, será possível identificar uma mudança nos registros de temperatura, conforme as Figuras 23.

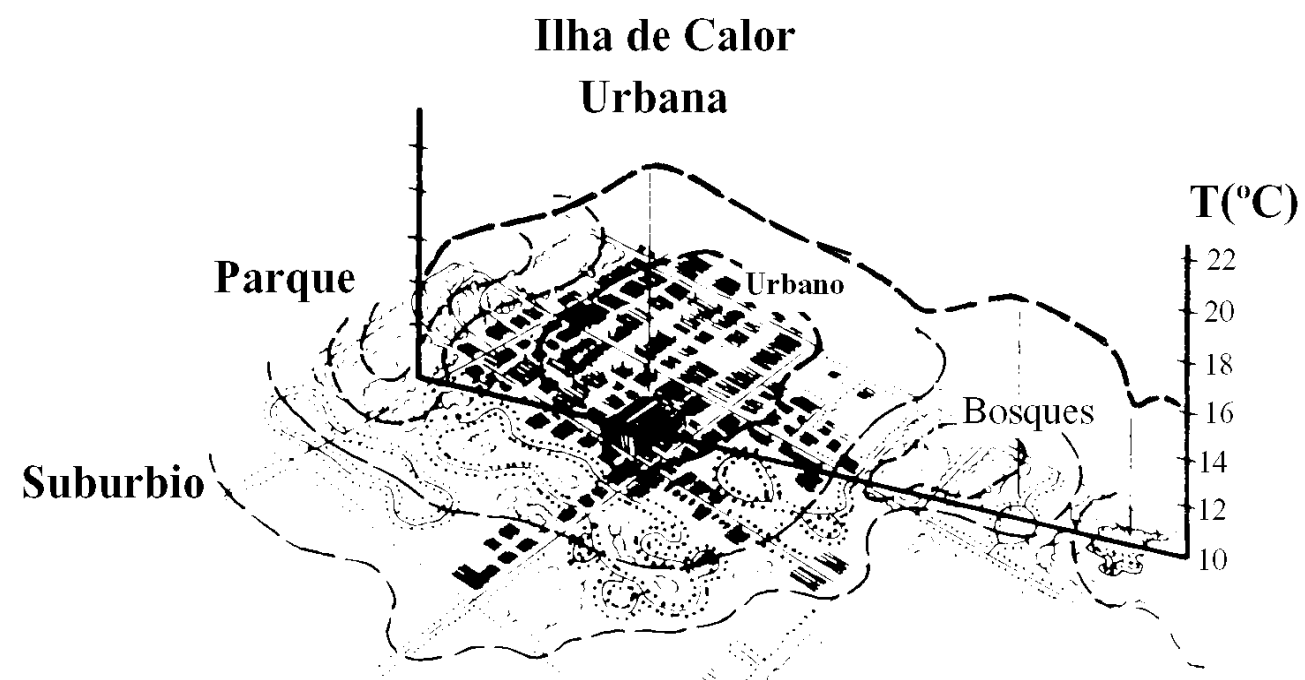

Semi- rural

Figura 23. Perfil de intensidade da ilha de calor associado ao mapeamento bidimensional.

Fonte: Marsh (1991, p. 231. Adaptado.) 


\subsubsection{Métodos de observação da ilha de calor atmosférica.}

A ilha de calor atmosférica é definida a partir da diferença de temperatura do ar observada dentro da área urbana ou em comparação com a área rural. Inicialmente, os pontos de observação utilizados para se definir esta distinção eram as estações meteorológicas padrões, que a princípio são constituídas para se observar a condição do ar livre na escala regional.

Com o processo de urbanização, muitas das estações meteorológicas foram incorporadas às manchas urbanas, por conta do processo de expansão das cidades, enquanto algumas poucas ainda conservam suas características originais desde a sua implantação.

As observações da ilha de calor podem ser definidas por meio de estudo de tendência a partir de uma estação padrão inserida em uma cidade, como o Rio de Janeiro, que registra dados meteorológicos desde 1850 (BRANDÃO, 1987 e 1992), São Paulo (CABRAL, 1997), Bologna, Itália (VENTURA et. al., 2002) ou por meio de registros da temperatura do solo (DETTWILLER, 1970).

Uma segunda possibilidade é comparar a tendência da temperatura observada entre estações urbanas e rurais, a fim de identificar o aumento ou não da intensidade da ilha de calor, conforme os estudos desenvolvidos em Nova York, (ACKERMAN, 1985), Ohio (SCHIMIDLIN, 1989), Kuwait (NASRALLAH et. al., 1990) e Cidade do México (JAUREGUI, 1993).

A terceira alternativa é criar uma rede de monitoramento de pontos fixos dentro da área urbana, que pode ser por meio de mini-abrigos meteorológicos, conforme foram utilizados para cidade de Curitiba (DANNI, 1987), Manaus, Amazonas -AM (AGUIAR, 1995), Juiz de Fora, Minas Gerais -MG (MARTINS, 1996), Londrina, Paraná -PR (MENDONÇA, 2001), Belo Horizonte, Minas Gerais MG (ASSIS, 2001), Rio de Janeiro -RJ (BANDÃO, 2001), Penápolis, São Paulo -SP (SILVA et. al., 2002), Florianópolis, Santa Catarina -SC (MENDONÇA, 2002), Santa Maria, Rio Grande do Sul -RS, Santa Cruz do Sul, Rio Grande do Sul -RS (COLLISCHONN, 2007); com o uso de psicrômetros de funda, utilizados em trabalhos realizados na cidade do Rio de Janeiro por (BRANDÃO, 1996, FIALHO, 2002 e LUCENA, 2005), ou uma rede de estações automáticas com data-loggers, realizado em Barrow, Alasca (HINKEL et. al., 2003), Sendai, Japão (SAKAIDA; EGOSHI, 2006), Shangai, China (BAI; MIKAMI, 2006), Orlando, Flórida-EUA (YOW; CARBONE, 2006) e Singapura, China (CHOW; ROTH, 2006). 
A quarta alternativa é usar transetos móveis, iniciada por Schimidt, em 1929, de acordo com Smith (1975, p. 54) objetivou ampliar os pontos de observação dentro da mancha urbana e, assim, melhor verificar espacialmente as oscilações intra-urbanas da temperatura mínima para a cidade de Viena, Aústria. por sua vez, este método foi adotado por vários outros pesquisadores (Tabela 6), incluindo Chandler (1960) em Londres, que identificou uma influência cumulativa horizontal da cidade sobre a temperatura do ar, sob condição sinóptica anticiclonal. Além deste, outros realizaram adaptações, com utilizar outros tipos de veículos tais como: a bicicleta (MELHUISH; PEDDER, 1998; SANTOS, 2007 e PEREIRA; BRANDÃO, 2008), helicóptero (BORNSTEIN, 1968 e HAGE, 1972), avião (PEASE, et. al., 1976) e automóvel (CARRERAS, 1990; BELLO FUENTES, 1994; MAITELLI, 1994; MAITELLI et. al., 2008; MONTEIRO, 1997; IZQUIERDO et. al., 1998; DEOSTHALI, 2002; FIALHO, 2002, LIVADA, 2002; AMORIM, 2005; ARRUDA et. al., 2005 e VIANNA, 2006).

Cabe ressaltar que ao se comparar os métodos de coleta de dados, tais como os pontos fixos com os transetos móveis, de maneira geral identificam-se algumas vantagens e desvantagens em ambos os procedimentos, mas isso não significa que um é melhor do que o outro, mas complementares, conforme o Quadro 3.

Quadro 3. Vantagens e desvantagens no processo de mensuração por meio de pontos fixos ou transetos móveis.

\begin{tabular}{|c|c|c|c|}
\hline \multicolumn{2}{|c|}{ Pontos Fixos } & Transetos Móveis \\
\hline Vantagem & Desvantagem & Vantagem & Desvantagem \\
\hline $\begin{array}{c}\text { Permite observações } \\
\text { simultâneas }\end{array}$ & $\begin{array}{c}\text { Dificuldade em definir } \\
\text { pontos representativos. }\end{array}$ & $\begin{array}{c}\text { Descreve melhor a } \\
\text { heterogeneidade do } \\
\text { meio urbano }\end{array}$ & $\begin{array}{c}\text { Refazer o percurso, } \\
\text { algumas vezes com } \\
\text { intuito de criar uma } \\
\text { maior confiabilidade. }\end{array}$ \\
\hline $\begin{array}{c}\text { Favorece o registro } \\
\text { temporal da ilha de } \\
\text { calor. }\end{array}$ & $\begin{array}{c}\text { Custo operacional e } \\
\text { logístico. }\end{array}$ & $\begin{array}{c}\text { Aumenta o número de } \\
\text { pontos de coleta dentro } \\
\text { da área de estudo. }\end{array}$ & $\begin{array}{c}\text { Não é apropriado para } \\
\text { grandes distâncias }\end{array}$ \\
\hline & $\begin{array}{c}\text { Preparar equipes para } \\
\text { registro dos parâmetros } \\
\text { e compatibilizar } \\
\text { horários de leituras }\end{array}$ & $\begin{array}{c}\text { Permite uma maior } \\
\text { agilidade no processo } \\
\text { de monitoramento }\end{array}$ & $\begin{array}{c}\text { Restrito apenas a } \\
\text { estradas de rodagem. }\end{array}$ \\
\hline & $\begin{array}{c}\text { Dificuldade de definir } \\
\text { pontos representativos }\end{array}$ \\
\hline & $\begin{array}{c}\text { Não mensuração } \\
\text { simultânea dos } \\
\text { elementos do clima }\end{array}$ \\
\hline
\end{tabular}

Organizado por Edson Soares Fialho (2009). 
Tabela 6. Levantamento de alguns trabalhos que utilizaram transetos móveis.

\begin{tabular}{|c|c|c|c|c|c|}
\hline Autor & Ano & Parâmetro & $\begin{array}{l}\text { Tempo } \\
\text { (h) }\end{array}$ & $\begin{array}{c}\text { Altura do } \\
\text { equipamento(m) }\end{array}$ & $\begin{array}{c}\text { Velocidade } \\
\left(\mathrm{Km} \cdot \mathrm{h}^{-1}\right)\end{array}$ \\
\hline Peppler, A. & 1929 & $\mathrm{~T}$ & - & - & $20-30$ \\
\hline Schmidt, W. & 1930 & $\mathrm{~T}$ & 1 & 1,2 & - \\
\hline Sundborg, A. & 1950 & $\mathrm{~T}$ & - & 1,5 & 0 \\
\hline Winter, $F$. & 1955 & $\mathrm{~T}$ & 6 & $0,6-1,6$ & 40 \\
\hline Junghans, $\mathrm{H}$. & 1957 & $T$ & $1-3$ & 1,0 & 0 \\
\hline Lawrence, F. N. & 1958 & $\mathrm{~T}$ & $1-2$ & $0,3-1,2$ & 0 \\
\hline Junghans, $\mathrm{H}$. & 1959 & $T$ & $2-3$ & 1,0 & 0 \\
\hline Huovila, S. & 1964 & $\mathrm{~T}$ & 1 & 1,7 & 40 \\
\hline Chandler, T. J. & 1965 & $T-U$ & 1 & $1,2-1,5$ & 30 \\
\hline Harrison, A. A. & 1967 & $\mathrm{~T}$ & $2-3$ & 1,2 & 0 \\
\hline Lomas, J. et al. & 1969 & $\mathrm{~T}$ & 1 & 0,5 & 10 \\
\hline Lindqvist, S. & 1970 & $A$ & 1 & $0,5-2,0-4,0$ & 0 \\
\hline Hocevar, et. al. & 1971 & $\mathrm{~T}$ & $1-2$ & 1,0 & 40 \\
\hline Oke, T. R. et. al. & 1972 & $\mathrm{~T}-\mathrm{RL}$ & $1-2$ & 1,5 & 50 \\
\hline Lindqvist, $\mathrm{S}$. & 1976 & $T-S$ & 1 & $0,2-2,0$ & 50 \\
\hline Mattson, J. O. et al. & 1978 & $T$ & 1 & 1,75 & $30-55$ \\
\hline Davis, R. L. & 1978 & $\mathrm{~T}$ & - & 1,5 & $30-50$ \\
\hline Parlow, E. & 1983 & $T-U$ & $1-2$ & $0,7-2,0$ & 20 \\
\hline Kuttler, W. et. al & 1984 & $T-U$ & 5 & $0,5-2,0$ & - \\
\hline Bogren, J. et. al. & 1989 & $\mathrm{~T}-\mathrm{S}-\mathrm{U}$ & - & $0,3-2,0$ & - \\
\hline Persson, $\mathrm{P}$. & 1989 & $T-U$ & 1 & $0,2-1,0-2,0-3,0$ & 40 \\
\hline Bärring, L. et. al. & 1995 & $\mathrm{~T}-\mathrm{S}-\mathrm{U}$ & - & $0,5-1,0-2,0-4,0$ & 40 \\
\hline Brandão, A. M. P. M. & 1996 & $T-U$ & 1 & 1,5 & 40 \\
\hline Persson, $\mathrm{P}$. & 1997 & $T$ & 1 & $0,2-1,0-2,0-3,0$ & 40 \\
\hline Sümeghy e Unger & 2003 & $T-U$ & $0: 50$ & 1,5 & $20-30$ \\
\hline Fialho, E. S. & 2002 & $\mathrm{~T}-\mathrm{U}$ & 1 & 1,5 & 50 \\
\hline Fialho, E. S.; Imbroisi & 2005 & $T-U$ & 1 & 1,7 & 50 \\
\hline Lucena, A. J. & 2005 & $T-U$ & 1 & 1,5 & 50 \\
\hline Amorim & 2005 & $T-U$ & $0: 45$ & 1,5 & 30 \\
\hline Correa et. al. & 2005 & $T-U$ & 1 & 1,7 & 50 \\
\hline Pezzuto et. al. & 2006 & $T-U$ & 1 & 1,5 & 50 \\
\hline Vianna, S. S. M. & 2006 & $T-U$ & $0: 30$ & 1,5 & 30 \\
\hline Machado e Fialho & 2007 & $T-U$ & $0: 50$ & 1,7 & 50 \\
\hline
\end{tabular}

Legenda: $\mathrm{T}$ - Temperatura do ar. U - Umidade. S - Temperatura de superfície. RL - Radiação líquida Fontes: Persson (1997) Fialho (2002) e Mendonça (2003) e International Association for Urban Climate-IAUC- (2008). Organizado por Edson Soares Fialho, 2009. 


\subsubsection{Ilha de calor vertical: Urban Boudary Layer.}

O clima da cidade de acordo com o modelo proposto por Oke (1981) apresenta uma divisão compreendida em duas escalas: a camada de cobertura urbana (UCL - Urban Canopy Layer) e a camada limite urbana (UBL - Urban Boundary Layer), como pode ser visto na Figura 24.

O UCL (camada intra-urbana) é a camada de "cobertura" urbana, que se estende desde o solo até aproximadamente ao nível médio das coberturas das edificações. É produzida pelos processos em micro-escala localizados nas ruas, entre os prédios, etc.

O UBL (camada limite da influência urbana) estende-se acima do nível dos telhados. É um fenômeno localizado, com características produzidas pela natureza da superfície urbana, cuja rugosidade, proporcionada pela presença de prédios relativamente altos, provoca uma aerodinâmica particular. A velocidade do vento é reduzida, mas ocorre um aumento da turbulência e no arrasto produzido pela fricção do ar.
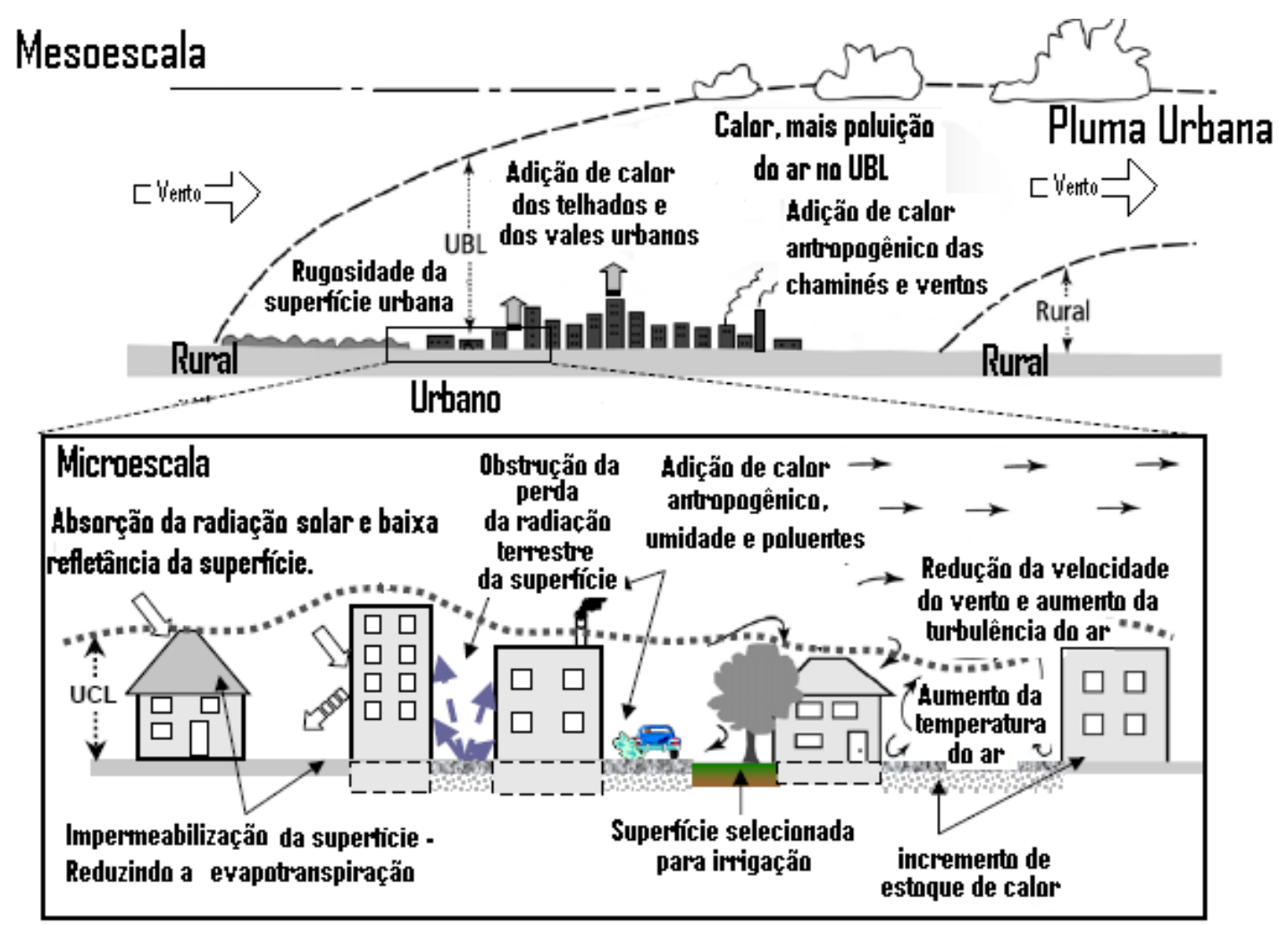

Figura 24. Estratificação vertical da atmosfera urbana proposta por Oke (1978) e os processos de formação da ilha de calor.

Fonte: http://www.epa.gov/heatisland/resources/pdf/EPA_How_to_measure_a_UHI.pdf (Adaptado.). Acesso em 15 nov. 2008 
O modelo proposto por Oke (op. cit.) permite observar que a camada limite urbana é influenciada, em função das atividades humanas intra-urbanas e do horário do dia, o que irá influenciar no processo convectivo da atmosfera urbana, a área de influência da camada limite urbana (UBL), com pode ser visto nas Figuras 25 e 26.

À noite, a camada limite se contrai devido à estabilização vertical; a convecção forçada é capaz de desestabilizar o ar da zona rural, produzindo advecção (ventos horizontais) sobre a cidade. Assim, pode-se dizer que a camada limite urbana apresenta um perfil vertical térmico diferente das áreas rurais, conseqüência do fluxo de calor sensível ou antropogênico, liberado pela camada intra-urbana, além de um previsível arrasto do ar friccionado em movimentações provocadas pela ilha de calor e das condições de tempo, conforme a Figura 27.

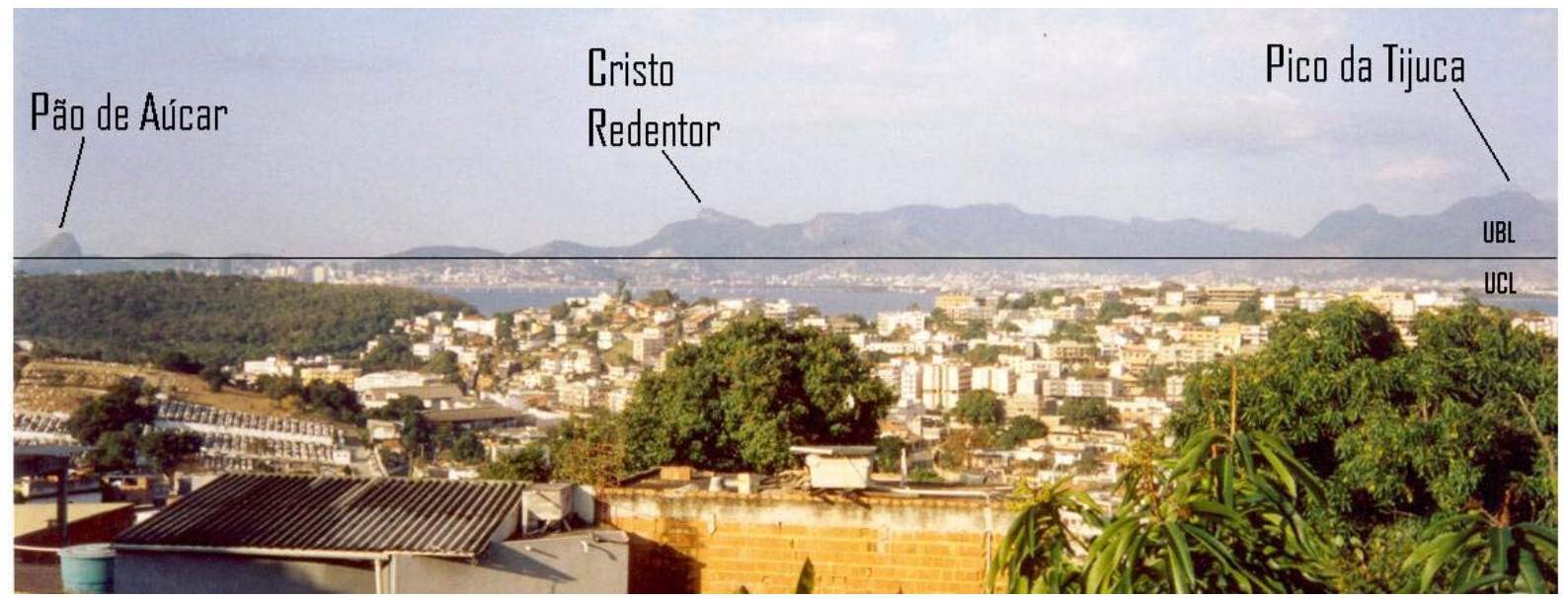

Figura 25. Imagem panorâmica do Maciço da Tijuca sob condição de céu claro e poucas nuvens com predomínio da massa tropical atlântica.

Foto: Edson Soares Fialho, obtida no Rio de Janeiro em outubro de 2003.

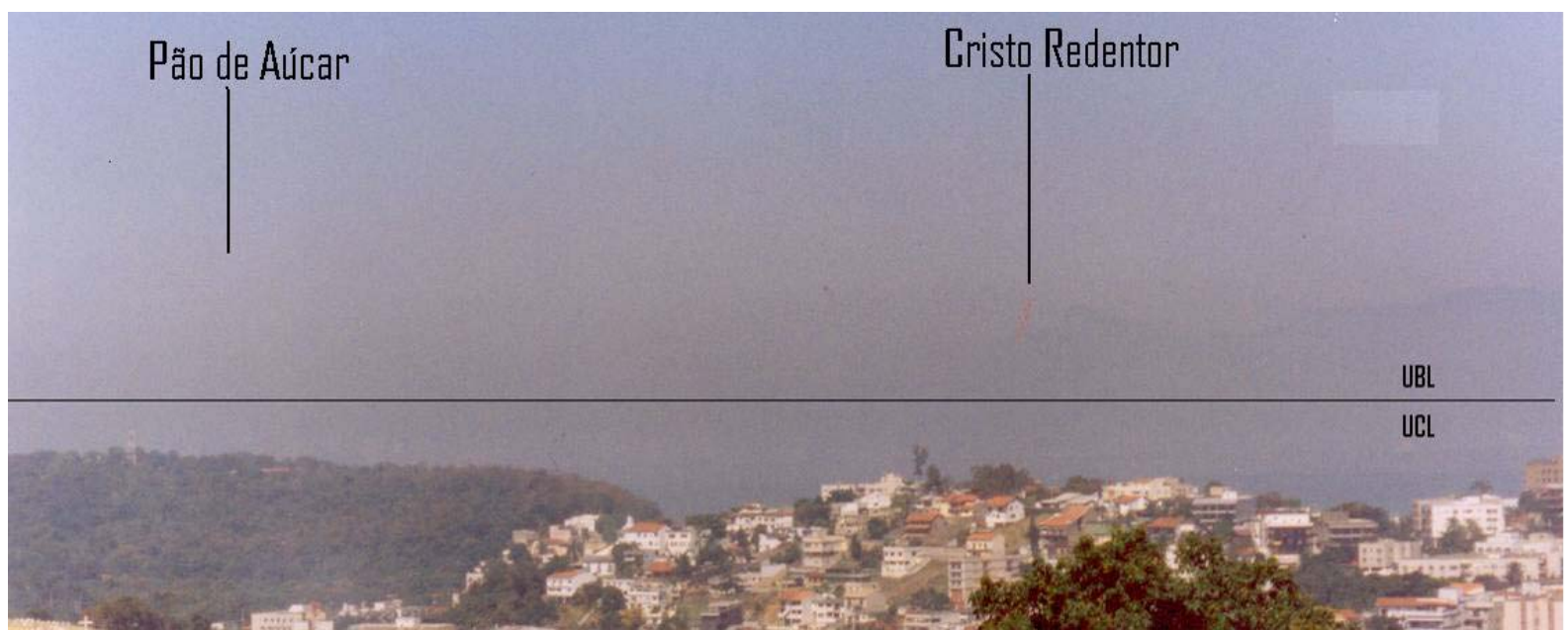

Figura 26. Imagem obstruída pela inversão térmica, criando uma atmosfera carregada de poluentes, que obstrui a vista do Maciço da Tijuca.

Foto: Edson Soares Fialho, obtida no Rio de Janeiro em agosto de 2003. 

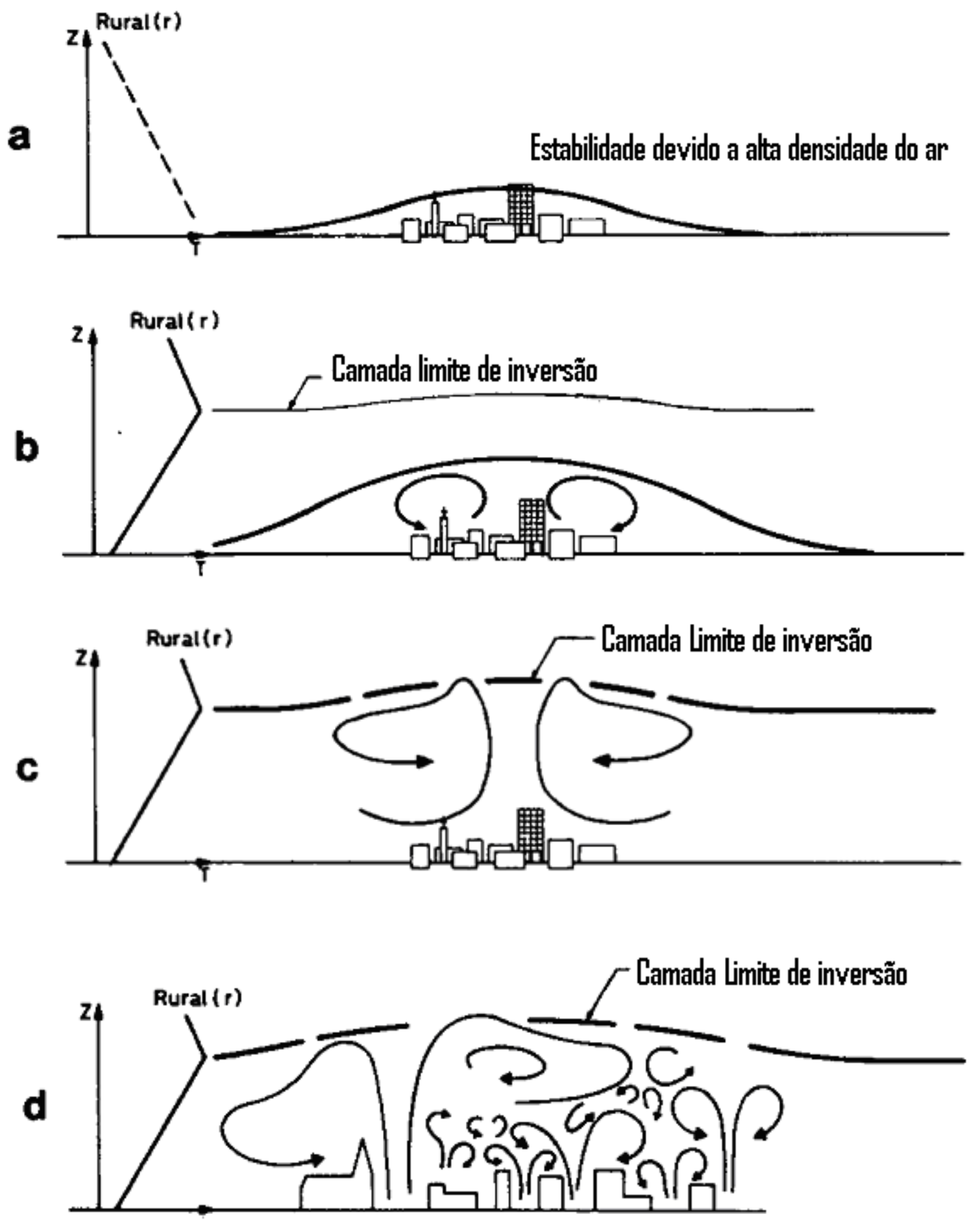

Figura 27. Ilha de calor: Possíveis configurações da circulação sobre a cidade em condições sinóticas de ventos fracos.

A - Ilha de calor estável com uma célula de convecção.

B - Pequenas células de convecção. Vórtex anelar ao nível da superfície.

C - Ilha de calor com duas clássicas plumas de célula de convecção.

D - Ilha de calor configurada com várias células de convecção.

Fonte: Wanner e Hertig (1984, p. 1621. Adaptado.) 


\subsubsection{Ilha de calor de superfície.}

Com o advento da informática e o crescente emprego de seus recursos na pesquisa geográfica, o sensoriamento remoto tem lugar de destaque nos estudos de ordem ambiental. A utilização de imagens de satélite tem evoluído nas últimas décadas, nos estudos relativos a esta temática, principalmente no que se refere ao seu mapeamento sistemático.

O sensoriamento remoto pode ser definido de maneira mais ampla, como a obtenção de informações de um objeto, ou alvo, sem que haja contato físico ou direto com o mesmo.

As informações em sensoriamento remoto podem ser oriundas de uma fonte externa aos alvos (por exemplo, o Sol), interna (como a energia térmica dos mesmos), ou ainda ser produzida por fontes artificiais, como os pulsos de microondas do próprio sensor.

Um sistema de sensoriamento remoto consiste em um modo de aquisição de informações, podendo ser dividido em dois subsistemas: um de coleta de dados e outro de análise destes dados. O sistema responsável pela coleta dos dados opera na detecção da radiação proveniente da superfície terrestre, e na transformação desta radiação, para sua transmissão e posterior registro. Para que seja possível a detecção da radiação proveniente da superfície, é necessário que haja uma fonte de radiação eletromagnética.

O sensoriamento remoto caracteriza-se pelo desenvolvimento de uma multiplicidade de sistemas sensores, desenvolvidos para vários sistemas de obtenção de dados orbitais e sub-orbitais em modernos satélites. Diversos obstáculos ainda têm impossibilitado sua maciça utilização. Apesar dos atuais sensores já possuírem boa resolução espacial que garantem um melhor detalhamento das informações da superfície, ainda não possuem uma resolução temporal adequada para determinados levantamentos, sobretudo de monitoramentos. As condições climáticas adversas no momento do registro das imagens pelos sensores, também têm inviabilizado seu uso, além dos altos custos para a aquisição das mesmas.

No Brasil, o sensoriamento remoto teve seu impulso a partir da década de 1960, através do projeto Radam-Brasil, cujo objetivo era realizar um amplo mapeamento dos recursos naturais do país. 


\subsubsection{Estudos sobre ilha de calor de superfície.}

De acordo com Mendonça (1994, p. 51), “...o campo térmico das cidades, enquanto sub-divisão do clima urbano tem sido aquele no qual mais se tem empregado as imagens de satélites, notadamente no estudo das ilhas de calor urbano...".

Isto se deve ao desenvolvimento de satélites com alta resolução espacial. As imagens provenientes do satélite NOAA/AVHRR (Nacional Oceanic and Atmosphere Administration/ Advanced Very Hight Resolution Radionater), com resolução espacial de 1,1km (no Nadir), são aplicáveis aos estudos climáticos de grandes centros urbanos e em escala regional.

Já as imagens do satélite LANDSAT (Land Remote Sensing Satellite) 5 e 7 (banda 6 - canal termal infravermelho - resoluções espaciais de 120 e 60 metros, respectivamente) têm se tornado importante ferramenta no estudo da configuração e da variação térmica no ambiente intra-urbano de cidades de médio e pequeno porte.

O emprego de imagens do LANDSAT no estudo das cidades tem sido considerado, de acordo com Mendonça (op. cit), satisfatório para a identificação e análise do uso e ocupação da terra.

Na literatura internacional, é vasta a aplicabilidade destes recursos, derivados de satélites, na identificação da termografia infravermelha das cidades. Oke e Voogt (2003) afirmam que o advento da tecnologia de sensoriamento remoto termal, através de satélites e de plataformas em aeronaves, permitiu novas possibilidades de observações sobre as ilhas de calor, bem como a compreensão de suas causas e combinações com os arranjos urbanos.

Sabe-se que o desenvolvimento das ilhas de calor é mais bem definida junto ao limite do teto máximo das edificações, e suas observações tradicionais, através de transetos e redes móveis, permitem apenas uma detecção ao nível pontual das condições térmicas da estrutura urbana.

O uso de dados de satélites permite uma melhor apreensão das condições térmicas no contexto de toda a cidade, o que favorece o estabelecimento de relações entre as características térmicas dos elementos da superfície com a do ar, através de dados obtidos em observações de campo (OKE; VOOGT, 1997 e 2003). 
Porém, esta nova alternativa se limita a apreensão das condições termográficas da cidade ao nível da superfície dos objetos urbanos da cidade, diferindo das observações intra-urbanas.

Buscando avançar na solução deste impasse Oke e Voogt (1997) desenvolveram um novo conceito para os estudos de clima urbano denominado de temperatura de superfície urbana completa, que procura agregar as observações ao nível dos telhados, como da superfície terrestre, conforme pode ser visualizado na Figura 28.

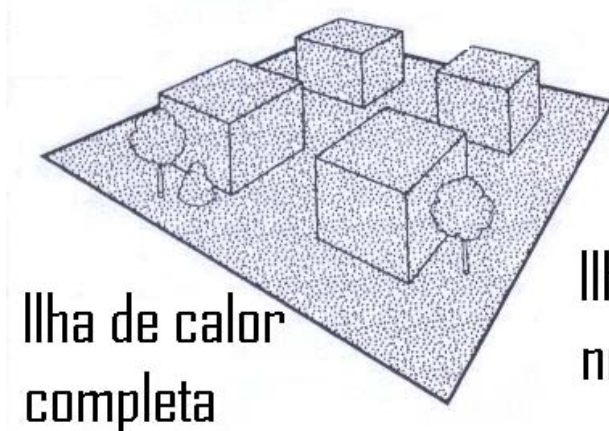

Wha de calor an nível do chãa
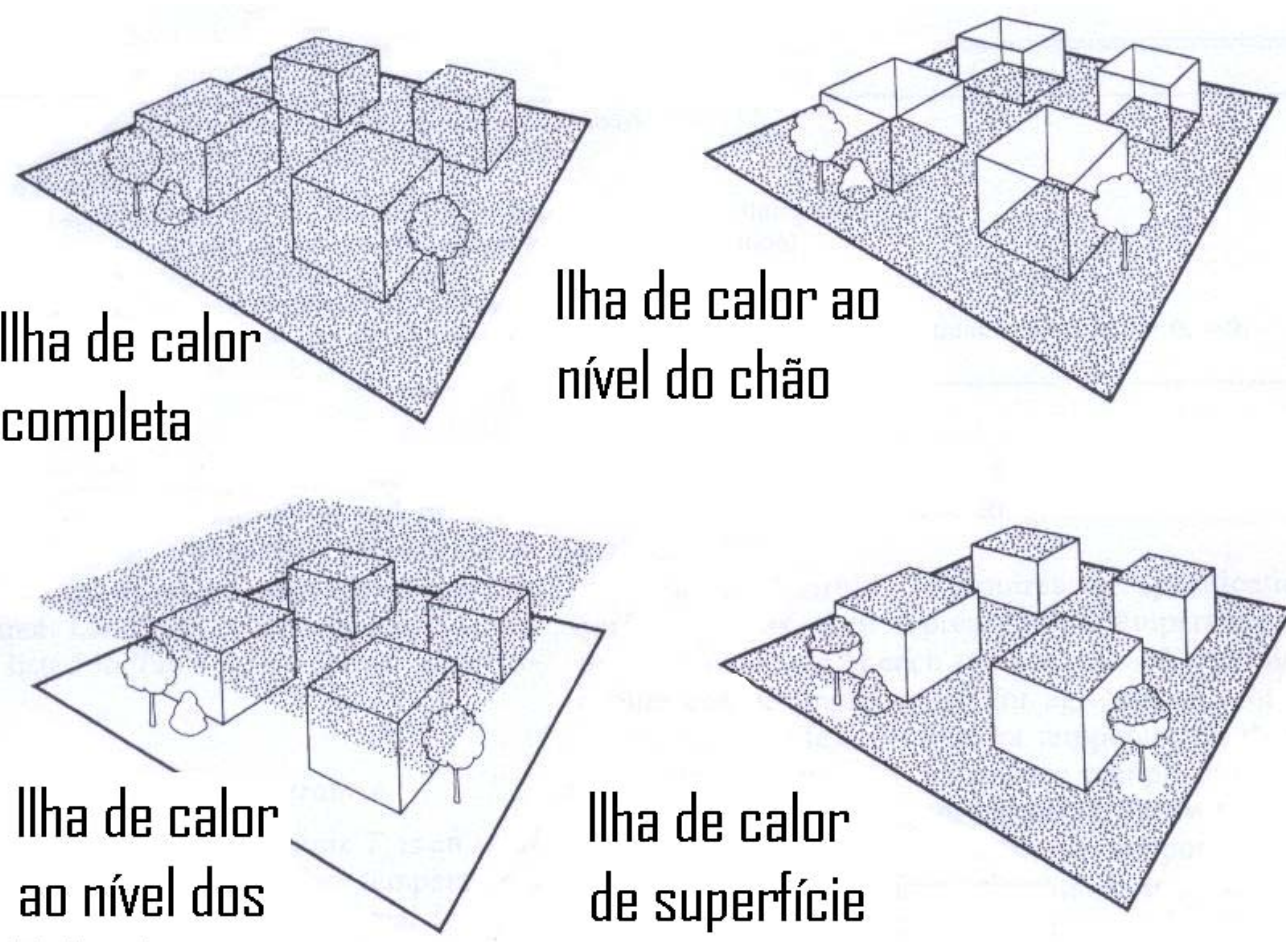

llha de calor a nível dos de superfície

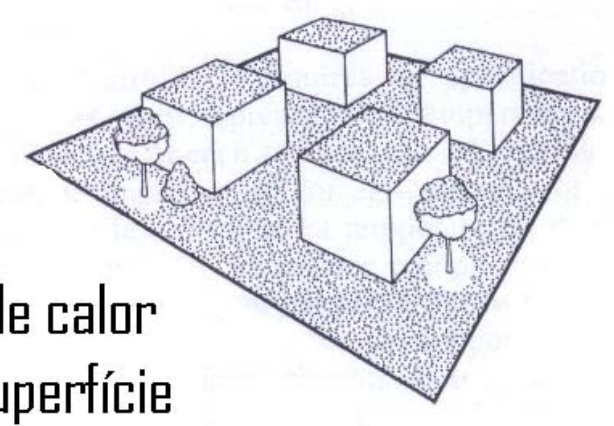

\section{Telhados}
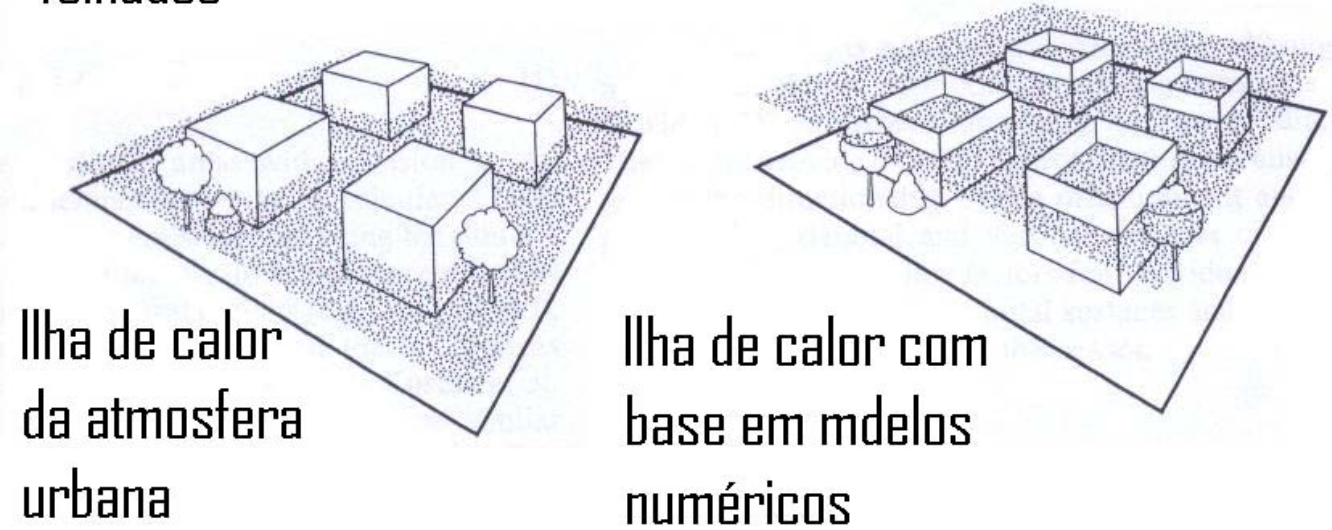

urbana

\section{numéricos}

Figura 28. Demonstração dos tipos de ilha de calor de acordo com o local de obtenção da temperatura.

Fonte: Voogt e Oke (1997, p. 1118. Adaptado.) 
De acordo com os autores, este trabalho é uma tentativa de estimar o verdadeiro impacto térmico nas três dimensões do sistema climático urbano, fugindo dos limites inerentes aos sensores remotos, que calculam temperatura de superfície sobre a superfície áspera da cidade. Para calcular uma temperatura de superfície completa é necessário levar em conta as superfícies horizontais e verticais dos diferentes tipos de uso da terra.

O estudo pioneiro das ilhas de calor urbano, por meio de imagens termais, foi realizado, por Rao (1972), combinou dados de satélite com medições de temperatura junto à superfície urbana. A partir deste, com o desenvolvimento dos satélites NOAA/AVHRR e do LANDSAT (no infravermelho termal), muitos estudos sobre o campo térmico das cidades foram realizados.

No Brasil, apesar de ser ainda pouco explorado, existem alguns estudos, dos quais pode ser destacado o de Lombardo (1985), considerado por muitos como pioneiro, no Brasil, nos estudos do fenômeno das ilhas de calor com uso de imagens termais.

Lombardo (op. cit.) utilizou imagens do satélite NOAA/AVHRR, que permitiram a identificação de áreas de maiores temperaturas no centro da cidade. Este estudo, em razão da dimensão resolução da imagem termal do NOAA é bastante generalizado, não permitindo um detalhamento das características térmicas do ambiente intra-urbano.

Mendonça (1994), ao estudar o clima urbano da cidade de Londrina-PR, também utilizou imagens do NOAA/AVHRR para individualização das manchas urbanas. $\mathrm{E}$ as imagens do LANDSAT foram utilizadas para um estudo mais detalhado das características da paisagem intra-urbana através do uso solo urbano e, principalmente, no emprego da termografia infravermelha (banda 6) no estudo do campo térmico dos materiais urbanos, os quais serviram de comparação aos dados levantados em mini-estações meteorológicas, posicionados a 1,5 metros da superfície.

Atualmente, o número de trabalhos relacionados à ilha de calor que utilizam o sensoriamento remoto é significativo, quando pesquisamos os anais do simpósio brasileiro de sensoriamento remoto, onde se encontram pesquisas desenvolvidas para as regiões metropolitanas (TEZA; BAPTISTA, 2005; SOUSA; BAPTISTA, 2005), Distrito Federal (BIAS, et. al., 2005), São José dos Campos (ANDRADE, et. al., 2007) e Piracicaba (COLTRI et. al., 2007). 
Apesar do esforço em se utilizar novas tecnologias nos estudos de clima urbano, os trabalhos de Lombardo (op. cit.) e Mendonça (op. cit.) e os demais citados não distinguem a temperatura de superfície da temperatura do ar. Ambas podem ser utilizadas como parâmetros diferentes para a definição, por exemplo, de unidades climáticas intra-urbanas, mas não podem ser consideradas iguais, pois enquanto a temperatura do ar é mensurada dentro do meio urbano a temperatura de superfície é obtida pela leitura de sensores à distância, que captam a temperatura da superfície dos objetos, em uma área (dependendo da resolução) que corresponde a um "pixel" na imagem, é a soma das componentes individuais (árvores, vias, edifícios, zonas de sombra, etc.) ponderada por suas respectivas superfícies, refletindo, portanto a temperatura do elemento mais representativo que o compõe.

Além disto, conforme observa Azevedo (2001, p. 179 do anexo) no trabalho de Lombardo (op. cit.) seja possível distinguir um expressivo contraste entre o urbano e do entorno do ponto de vista da radiação, não é imediata a assertativa de que haveria um aumento da temperatura do ar nas proporções sugeridas pela autora, pois a atmosfera não é capaz de absorver quantidades expressivas de calor irradiado, ou seja, não há qualquer evidência de que, pelo fato do ar estar imerso em um campo de radiação de onda longa mais intensa, rapidamente responda com aumento de temperatura expressivo.

Embora as observações de Azevedo (op. cit.) sejam claras, ainda se identifica equívocos graves, quando alguns autores buscam justificar a pertinência de seus estudos ou a gravidade do fenômeno, comparando seus resultados com estudos que utilizaram métodos de observação distintos. Como pode ser identificado no trabalho de Coltri et. al. (op. cit., p. 5153), que escreve:

“...O trabalho obteve uma amplitude de $8,6^{\circ} \mathrm{C}$ semelhante a Mendonça (1994), porém muito elevada se comparada aos estudos realizados por Tarifa (1977) e Sampaio (1981), que encontraram $3,4^{\circ} \mathrm{C}$ e $4,6^{\circ} \mathrm{C}$ para as cidades de São José dos Campos, São Paulo, e Salvador, Bahia, respectivamente..."

Para Collischonn (1998, p.113) a análise de um meio heterogêneo, como o urbano, estará mais relacionada à resposta térmica das principais estruturas da paisagem (centro urbano, loteamentos, parques, área industrial, etc.), do que às 
variações térmicas de detalhe existentes, mas que o sensor não pode registrar em função do limite de resolução espacial.

A intensidade da radiação térmica recebida pelo satélite é o resultado de três componentes: a emissão própria do solo, a emissão da atmosfera e a fração de energia térmica refletida (COLLISCHONN, op. cit.).

O sensor do satélite registra seqüencialmente para cada pixel em um dado instante, a intensidade da radiação eletromagnética emitida por diferentes objetos na superfície da terra, que por sua vez resulta diretamente da temperatura da superfície e de sua emissividade. Assim, para se obter a temperatura de fato de uma determinada superfície a partir da termografia infravermelha, é preciso estimar as emissividades $^{9}$ (Tabela 7) para cada objeto imageado.

Neste aspecto, muitos trabalhos divergem em suas metodologias empregadas na conversão das imagens termais, pois quando se trabalha com áreas urbanas muito heterogêneas torna-se muito difícil estimar todas as emissividades dos alvos imageados, sendo que, na maioria das vezes, redunde na generalização por áreas e interpretações não condizentes com a realidade da superfície em estudo.

Tabela 7. Emissividade de objetos não metais.

\begin{tabular}{||l|c|c||}
\hline \multicolumn{1}{|c|}{ Materiais } & \multicolumn{2}{c|}{ Emissividades } \\
\cline { 2 - 3 } & $\mathbf{1 . 0} \mathbf{~} \mathbf{m}$ & $\mathbf{8 - 1 4 \mu m}$ \\
\hline \hline Asfalto & - & 0,95 \\
\hline \hline Basalto & - & 0,7 \\
\hline \hline Grafite & $0,8-0,9$ & $0,7-0,8$ \\
\hline \hline Cerâmica & 0,4 & 0,95 \\
\hline Concreto & 0,65 & 0,95 \\
\hline \hline Tecido & - & 0,95 \\
\hline \hline Papel (qualquer cor) & - & 0,95 \\
\hline Borracha & - & 0,95 \\
\hline Areia & - & 0,9 \\
\hline Neve & - & 0,9 \\
\hline \hline Água & - & 0,93 \\
\hline Madeira, (natural) & - & $0,9-0,95$ \\
\hline \hline
\end{tabular}

Fonte: http://www.vortex.com.br/raytek/emissividade.html\#anchor120842. Acesso em 10 abr. 2009 Organizado por Edson Soares Fialho (2009).

9 Emissividade é a relação entre a emissão de radiação eletromagnética da superfície de um objeto e a emissão teoricamente máxima de um corpo negro. A emissividade pode variar entre 0,0 (não emissora) até 1,0 (corpo negro). As emissividades dos objetos reais situam-se entre os dois extremos. 


\subsubsection{Estudos de ilha de calor: $O$ método dos transetos fixos e móveis.}

De maneira geral, os estudos referentes ao clima da cidade privilegiam em grande parte o elemento climático: temperatura do ar. A razão para isto se deve ao menor custo de aquisição dos equipamentos necessários para a criação de uma rede de monitoramento. Muito embora, não seja tão simples medir a temperatura do ar em comparação aos demais elementos do clima.

Nesse sentido, apresentar-se-á uma seqüência sumária de alguns trabalhos referentes à temática da ilha de calor, sem necessariamente apresentar uma cronologia dos estudos clássicos, mas privilegiando pesquisas que analisem 0 fenômeno em cidades de grande, médio e pequeno porte em diferentes latitudes.

\subsubsection{No mundo.}

Hinkel et. al.(2003) ao analisarem a ilha de calor em Barrow, Alasca-EUA, a maior comunidade nativa localizada no Ártico, com uma população de 300 residentes em 1900, e mais de 4600 em 2000 - utilizou 54 mini-abrigos meteorológicos instalados em uma área de $150 \mathrm{~km}^{2}$, registrando a temperatura horária do ar e do solo, durante o inverno (março de 2001 a dezembro de 2002). Segundo o autor, a intensidade média da ilha de calor foi de $2,2^{\circ} \mathrm{C}$, sendo que, sob calmaria $\left(<2 \mathrm{~m} \cdot \mathrm{s}^{-1}\right)$, alcançava os $3,2^{\circ} \mathrm{C}$, chegando ao máximo de $6,0^{\circ} \mathrm{C}$, geralmente no final da noite e início da alvorada.

Em Fairbanks, Alaska-EUA, Magge et. al. (1999) utilizaram os dados climáticos de três localidades, sendo duas no interior (base aérea e Eielson) e a de Fairbanks (área urbana) para o período de 1949 a 1997. A população de Fairbanks, hoje com 15 mil habitantes, registrou um crescimento de 500,0\%, enquanto a população de Eielson permaneceu relativamente constante. Acompanhando as diferenças de temperatura entre a área rural interiorana e a urbana, verifica-se que a ilha de calor apresenta um incremento, principalmente, no inverno, com diferença média de $1,2^{\circ} \mathrm{C}$ para a temperatura mínima do ar.

Sundborg (1950) desenvolveu um estudo do clima urbano em Uppsala, Suécia, por meio o uso dos transetos móveis, num percurso de $5 \mathrm{~km}$ com uma velocidade média de $40 \mathrm{~km} \cdot \mathrm{h}^{-1}$ em 20 situações, em diferentes momentos sazonais ao longo de um ano. Com base no conjunto de dados obtidos nos experimentos de 
campo desenvolveu uma fórmula empírica (ver página 38) estabelecendo uma comparação entre as diferenças dos elementos do clima, temperatura do ar, vento e nebulosidade entre o campo e a cidade.

Eliasson e Holmer (1990) ao estudarem Göteborg, Suécia, recorreram aos registros comparativos entre 5 estações meteorológicas para o período de 1981 e 1986, optaram em analisar 22 situações anticiclonais. Dentre os resultados interessantes, observa-se que o fenômeno, geralmente ocorreu de 4 a 6 horas após a meia noite e para alguns dias depois do amanhecer. A intensidade média para situações de ventos com velocidade inferior a $3 \mathrm{~m} \cdot \mathrm{s}^{-1}$ foi de $2,5^{\circ} \mathrm{C}$. Para o período de análise a intensidade máxima foi de $4,5^{\circ} \mathrm{C}$.

Lokoshchenko e Isaev (2006) utilizaram 20 postos meteorológicas na região de Moscou, Rússia, entre os anos de 1951 e 1965 e constataram que cidade apresenta $1,5^{\circ} \mathrm{C}$ superior a área adjacente. Em relação à intensidade máxima da ilha de calor, os autores selecionaram 30 casos entre 2000 e 2002 em situações sinópticas anticiclonais e identificaram valores superiores a $10,0^{\circ} \mathrm{C}$, alcançando o máximo de $14,0^{\circ} \mathrm{C}$, durante os dias de maior atividade (quarta-feira, quinta-feira e sexta-feira).

Ripley et. al. (1996) identificaram em Saskatoon, Canadá, localizada na porção sul do rio Saskatchewan, pequenas ilhas de calor sob céu claro e ventos de baixa fracos $\left(<2 \mathrm{~m} \cdot \mathrm{s}^{-1}\right), \mathrm{A}$ intensidade máxima registrada foi de $8,0^{\circ} \mathrm{C}$ pela manhã em condições ideais de tempo (céu claro e ventos de baixa intensidade). A coleta foi realizada por meio de transeto móvel, equipado com termistor a $1,5 \mathrm{~m}$ de altura utilizada, ao longo de alguns pontos determinados, durante cada estação. A velocidade média do veículo era de $15 \mathrm{~km} . \mathrm{h}^{-1}$, totalizando 110 pontos.

Parry (1956) ao estudar as variações locais da temperatura do ar em Reading, Inglaterra, até então com 12 mil habitantes, entre junho de 1951 e novembro de 1952. Para isto contou com 10 estações meteorológicas localizadas em sítios distintos, porém com altitudes semelhantes. A comparação demonstrou que a diferença entre as temperaturas máximas foram média de $0,3^{\circ} \mathrm{C}$, mas suprimidas quando pela turbulência do ar. Enquanto as temperaturas mínimas, o contraste atingiu a média de $0,8^{\circ} \mathrm{C}$. Apesar destes valores ínfimos, o autor conseguir demonstrar a relação direta entre a densidade da área construída, associada à menor velocidade de perda de energia pela cidade em relação ao campo. Tanto 
assim que os sítios urbanos caracterizados por um SVF maior revelaram os maiores valores de temperatura mínima do ar (aproximadamente $0,9^{\circ} \mathrm{C}$ ).

Klysik e Fortuniak (1999) após investigações conduzidas em Lodz, Polônia, desde 1992, utilizando-se estações meteorológicas rurais e urbanas permitiram constatar a ocorrência de ilha de calor. Em de $80,0 \%$ das noites foi detectada uma intensidade entre $2,0^{\circ} \mathrm{C}$ e $4,0^{\circ} \mathrm{C}$, esporadicamente, $8,0^{\circ} \mathrm{C}$, em noites de verão com céu claro. Além desta abordagem, lançou-se mão das medidas móveis (5 transetos), realizadas em dois dias, iniciando depois do pôr-do-sol até a manhã seguinte, identificou-se uma intensidade de $12,0^{\circ} \mathrm{C}$ da ilha de calor, quanto à espacialidade, o campo térmico durante o dia apresenta uma estrutura polinucleada, em condições de calmaria.

Stewart (2000) ao investigar a influência das condições meteorológicas na intensidade e configuração espacial da ilha de calor em Regina, Saskatchewan, Canadá, utilizou-se de uma amostra de 31 leituras noturnas para a estação de inverno, com a realização de 2 percursos simultâneos, sempre três horas após o pôr-do-sol, totalizando 42 pontos de medida. Dentre os resultados alcançados, o autor identificou intensidade média de $3,0^{\circ} \mathrm{C}$, com máximo de $7,5^{\circ} \mathrm{C}$, sob condições de noites de céus claros e ventos calmos. A forma do perfil de temperatura campocidade, pode-se dizer que é caracterizada por um precipício definido, entre o limite campo e a cidade, planalto, nas periferias entorno do centro, e o cume, na área central de negócios (Figura 29). Analisando a influência dos demais parâmetros do clima, o referido autor, observou que a intensidade da ilha de calor é altamente sensível a mudanças nas condições de vento e nebulosidade, e relativamente insensível para mudanças de umidade e pressão atmosférica.

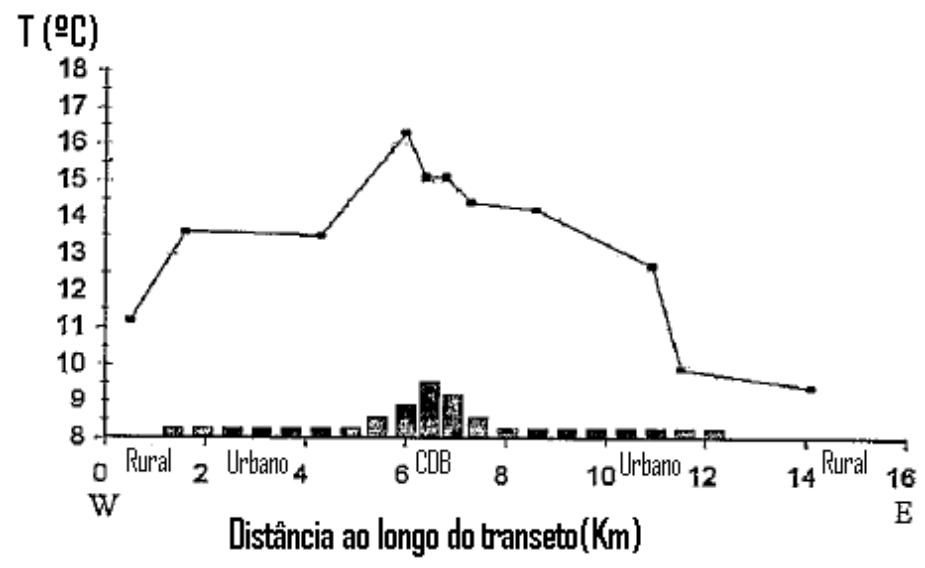

Figura 29. Perfil da temperatura do ar ao longo do transeto móvel, na cidade de Regina, Canadá. Fonte: Stewart (2000, p. 279). 
Contat (2004) ao estudar a ilha de calor, enquanto manifestação concreta da região metropolitana parisiense evidenciou uma intensidade média noturna de $3,0^{\circ} \mathrm{C}$, oscilando entre $3,4^{\circ} \mathrm{C}$, no verão e $2,5^{\circ} \mathrm{C}$, no inverno. Nas últimas 5 décadas (19501990), a maior intensidade ocorreu $34,0 \%$ no verão e $6,0 \%$ no inverno, enquanto as de baixa magnitude tem $56,0 \%$ dos caos no inverno contra $8,0 \%$ no verão.

Sümeghy e Unger (2003) investigaram a dinâmica temporal noturna da ilha de calor, durante a noite em Szeged, Hungria. Um percurso campo-cidade, ao longo 17 células de $0,5 \mathrm{~km} \times 0,5 \mathrm{~km}$ foi desenvolvido por um veículo equipado com um sensor que registrava a temperatura do ar a cada 10 segundos, para cada área pré-definida foi calculada a temperatura média para cada célula. $O$ horário das leituras se iniciava duas horas após o pôr-do-sol prolongando-se até as 3:00 horas da madrugada do dia seguinte. Os resultados obtidos permitiram dizer que a ilha de calor é muito similar a proposta teórica de Oke (1978), embora possa ainda apresentar alguma assimetria ao longo da curva isotérmica, atribuída a influência da maior densidade urbana no final do percurso.

Petrali et. al. (2006) ao investigarem a distribuição da temperatura de ar em Florença, Itália, cujo objetivo era verificar a influência de áreas de pátios e jardins, durante dias quentes de verão do ano de 2005, optou por 4 pontos de coleta, com sensores de temperatura subdivididos em áreas concêntricas instalados em três lugares diferentes: rua, pátio e jardim. Ao longo de um perfil que se distanciava da área central. Os resultados demonstraram que o pico de temperatura foi encontrado na área central da cidade e em sua vizinhança. Estas zonas são caracterizadas por uma quantidade menor de área verde, por um número mais alto e altura de edifícios. Além disso, nestes pontos de maior temperatura, também se registrou a maior diferença entre rua e jardins. Em comparação com aos pontos amostrais mais perto e distante do centro, Florença registrou uma diferença máxima de $3,0^{\circ} \mathrm{C}$, no verão.

Izquierdo et. al. (1998) ao analisarem o microclima da cidade de Logroño, Espanha, cidade de porte médio, durante o inverno, utilizou-se de 3 transetos móveis em três horários (7:00, 14:00 e 21:00 horas) ao longo de 4 dias, observou-se que intensidade máxima da ilha de calor nunca excedeu aos $3,0^{\circ} \mathrm{C}$, e seu ápice era sempre registrado no horário da tarde.

Pratis Cuadrat et. al. (1993) estabeleceram dois níveis de análise para abordarem o clima urbano de Zaragoza, Espanha. O primeiro utilizando um posto meteorológico urbano e o Aeroporto, considerado como ambiente rural. Nesta escala 
de análise a temperatura mínima do ar foi utilizada como elemento de comparação. $O$ resultado demonstrou que ao longo do ano a cidade apresentou uma diferença superior a $1,0^{\circ} \mathrm{C}$ em média. Em relação ao segundo nível intra-urbano, utilizou-se de transetos móveis, totalizando 82 pontos de coleta, que cobriam tanto a área rural quanto a urbana. As observações foram apenas noturnas (três horas após o pôr-dosol), durante 27 dias, cuja intensidade máxima da ilha de calor verificada foi de $4,9^{\circ} \mathrm{C}$.

Lopez Gomez et. al. (1995) caracterizaram a variabilidade espacial da ilha de calor em Madrid, Espanha, identificada a partir de transetos móveis repetidos 79 vezes ao longo dos três percursos entre 1992 e 1993 em dois horários. No período da manhã, a intensidade máxima da ilha de calor foi de $8,1^{\circ} \mathrm{C}$, enquanto a máxima foi noturna, ultrapassando aos $10,0^{\circ} \mathrm{C}$.

Bello Fuentes (1994) ao estudar Guadalajara, Espanha, com 66 mil habitantes, recorreu aos transetos térmicos móveis entre novembro de 1992 e março de 1994, realizados no período noturno, verificou uma elevada correlação entre os valores da ilha de calor com as diferentes situações sinóticas e densidades de edificações, com cerca de $80,0 \%$.

Por outro lado, a elevada correlação inversa entre os valores da ilha de calor com as porcentagens de espaços verdes $(90,0 \%)$ aparece na periferia da cidade, que registrou os menores valores do fenômeno. A partir destas correlações, o autor estimou que em diferentes situações atmosféricas, para um máximo teórico de edificações de $100,0 \%$ a ilha de calor alcançaria um valor médio de $2,5^{\circ} \mathrm{C}$, diminuindo para $1,9^{\circ} \mathrm{C}$ com tempo instável e alcançando $3,7^{\circ} \mathrm{C}$ com tempo estável.

Bello Fuentes (1995) agora analisando a cidade de Alcalá, Espanha, utilizou os mesmos métodos de registro, porém agora ao longo de 2 percursos diferentes, uma vez que a cidade apresenta uma população de 160 mil habitantes, quase o triplo de Guadalajara, registrou uma correlação positiva de 85,0\% entre ilha de calor e densidade de edificações. A partir da mesma, foi possível estabelecer a intensidade média da ilha de calor, que seria de $2,7^{\circ} \mathrm{C}$ com tempo instável, $4,2^{\circ} \mathrm{C}$ para ma condição de intensidade média e $5,0^{\circ} \mathrm{C}$ para condições de tempo estável.

Alonso e Fidalgo (2003) ao procurarem examinar a ilha de calor na cidade de Salamanca, Espanha, por meio da comparação entre as temperaturas de uma área urbana e rural entre os anos de 1996 e 1998 identificaram que a ilha de calor noturna é positiva, cuja intensidade média mais alta ocorre no outono, com $3,2^{\circ} \mathrm{C}$. Utilizando o método dos transetos móveis durante a noite entre, janeiro e maio de 
1999, em dois percursos, identificou $6,7^{\circ} \mathrm{C}$ como a intensidade máxima de ilha de calor, coincidente em locais de maior poluição do ar.

Pinho e Manso Orgaz (2000) ao pesquisaram a existência de ilha de calor na cidade de Aveiro, Portugal, cidade de pequeno porte, situada no litoral, identificaram a presença do fenômeno com uso do método de transetos móveis ao longo de 48 noites entre o verão e outono de 1996, às 23:00 horas. A forma e intensidade, segundo os autores são uma resposta à interação de três fatores principais: a morfologia urbana, as condições meteorológicas e a proximidade da laguna litoral.

Caselles et. al. (1991) em trabalho desenvolvido em Valência, Espanha, procuraram analisar o efeito da ilha de calor por meio da técnica tradicional (transetos móveis, medindo a temperatura do ar) e pelas imagens térmicas do satélite NOAA. A análise inclui às noites de 27 e 28 de fevereiro de 1998. Os autores identificaram uma boa correlação entre os métodos. Muito embora, a comparação dos valores encontrados destoa. A partir da temperatura de superfície com dados do NOAA corrigidos constatou o efeito da ilha de calor de intensidade $1,5^{\circ} \mathrm{C}$ superior as medidas realizadas por transetos.

Martin e Powel (1977) procuraram descrever o comportamento da ilha de calor em Akron, Ohio-EUA, com mensurações entre 21:00 e 22:00 GMT em quatro noites, em estações sazonais distintas (17 abril, 11 julho, 10 outubro, e 2 janeiro de 1975), cujas características do tempo fossem propícias a ocorrência do núcleo de calor urbano. As temperaturas na área central oscilaram entre $3,3^{\circ} \mathrm{C}$ a $17,7^{\circ} \mathrm{C}$ em relação à área rural. $O$ centro de calor da ilha de calor sempre esteve localizado na área residencial, nas quatro ocasiões, distante da área rural cerca de $3 \mathrm{~km}$. A intensidade da ilha de calor é diferente em cada estação, variando de $5,0^{\circ} \mathrm{C}$ na primavera, $3,3^{\circ} \mathrm{C}$ no verão, $7,7^{\circ} \mathrm{C}$ no outono e $3,8^{\circ} \mathrm{C}$ no inverno.

Livada et. al. (2002) ao analisarem a cidade de Atenas, Grécia, rodeada por altas montanhas ao norte e a leste e influenciada pelo mar ao sul, observou que a topografia experimenta variações significativas em seus padrões de ventilação. Esta peculiaridade incumbiu os autores a buscarem identificar os lugares na área central, onde o efeito de ilha de calor pode ocorrer. Foram examinados vários parâmetros climáticos importantes em combinação com a aplicação de vários testes estatísticos. De acordo com a análise, as áreas mais industrializadas da cidade desenvolveram uma ilha de calor de maneira intensa. Enquanto nos distritos, situados a leste, caracterizados por vegetação apresentaram registros de temperaturas mais amenas. 
Sakaida e Egoshi (2006) realizaram em Sendai, Japão, uma cidade litorânea uma análise da influência do mecanismo das brisas marinhas sobre a ilha de calor. $\mathrm{O}$ período de observação foi de 4 anos (2001 a 2005) em 25 pontos amostrais (miniabrigos) instalados em escolas primárias, com leituras em intervalos de 10 minutos. Apesar disto, o número de dias analisados foi selecionado de acordo com a existência de brisas. Com o resultado foram selecionados 95 dias na primavera (março-abrilmaio), 88 no verão (junho-julho-agosto), 80 dias no outono (setembro-outubronovembro). Baseado na análise do conjunto de dados observados pode-se dizer que a influência da brisa marinha na ilha de calor urbana é forte. Tanto assim, que Sendai é esfriada pela brisa marinha, durante a primavera e verão.

O efeito de amenização reduz, à medida que se aumenta a distância do litoral. Para se investigar as variações diárias e sazonais de intensidade de ilha de calor, a diferença de temperatura, entre o centro urbano e a área suburbana é calculada, com base em uma localidade suburbana, o qual se localiza na área de cultivo de arrozais, e o com a distância quase igual do litoral para o urbano centro. De dia, lá exista um calor leve $\left(0,5^{\circ} \mathrm{C}\right.$ mais quente) no verão e no outono, mas desaparece em primavera devido à brisa marinha. A intensidade da ilha de calor aumenta às 16:00 horas no outono, e às 18:00 horas na primavera, coincidente com o fim da brisa marinha. A ilha de calor desenvolvido à noite (entre 22:00 horas e 7:00 horas da manhã do dia seguinte), oscilando entre $2,7^{\circ} \mathrm{C}$ e $3,0^{\circ} \mathrm{C}$ na primavera e outono.

Potchter et. al. (2006) desenvolveram pesquisas de clima urbano, em Berr Sheva, Israel, por meio de dois métodos. O primeiro se pautou no exame de temperaturas e tendências de umidade durante os últimos 50 anos para os meses de janeiro e julho. O segundo é à realização de registros de campo em estações do ano diferentes (inverno, primavera e verão), ao longo de dois anos (2004-2005). Utilizou-se 5 transetos móveis que atravessaram a cidade ao amanhecer e ao entardecer. Em relação ao primeiro método, a tendência da temperatura máxima e mínima, entre 1950-2005, para o mês de janeiro (inverno) e julho (verão), constatouse que a temperatura mínima aumentou quase $2,0^{\circ} \mathrm{C}$ ao longo dos últimos 55 anos e que o mês de julho registrou o maior aumento com $1,2^{\circ} \mathrm{C}$, enquanto a máxima diminuiu por $0,2^{\circ} \mathrm{C}$.

A segunda estratégia demonstrou que a ilha de calor é significante, localizando-se ao redor da área de maior atividade humana (centro empresarial e parte velha da cidade). A intensidade máxima foi de $7,0^{\circ} \mathrm{C}$, pelo amanhecer. À tarde, 
no período de inverno em comparação ao verão, há forte influência da direção e intensidade dos ventos na distribuição espacial do campo térmico na cidade. Em dias com forte velocidade do vento superior a $4 \mathrm{~m} \cdot \mathrm{s}^{-1}$ e direção oeste, durante o verão, ilha de calor foi de até $2,5^{\circ} \mathrm{C}$, ao meio dia. No inverno, sob ventos de norte e velocidade de $3 \mathrm{~m} . \mathrm{s}^{-1}$, a intensidade foi de $3,5^{\circ} \mathrm{C}$, ao meio-dia. Durante o amanhecer no verão com velocidade do vento a $1 \mathrm{~m}^{-\mathrm{s}^{-1}}$ a cidade desenvolveu uma ilha de calor de $4,5^{\circ} \mathrm{C}$ e no inverno com ventos de sul a uma velocidade de $1 \mathrm{~m} . \mathrm{s}^{-1}$, a intensidade foi de $6,9^{\circ} \mathrm{C}$. Parece que a direção de vento determina a forma e padrão da distribuição da ilha de calor. Durante os ventos de sul, a mesma se desloca para o norte, enquanto sob ventos de oeste, se desloca para o leste.

Bai e Mikami (2006) propuseram estudar o clima urbano de Shanghai, China, utilizando-se das observações das séries temporais da estação meteorológica padrão e das técnicas de mensuração da ilha de calor atmosférica. Em relação à tendência da temperatura média do ar, entre 1984 e 2004, constatou-se um incremento de $1,8^{\circ} \mathrm{C}$ em 20 anos. A análise dos dados da rede de mini-abrigos instalada em 38 escolas, com registros a cada 10 minutos durante o ano de 2005, identificaram que a ilha de calor não só surge claramente em dias sem nuvens em outono e inverno, mas também na primavera e verão. Além disto, nos meses de verão, há uma variabilidade dos horários de picos máximos. Em junho, a ilha de calor é evidente durante o dia do que à noite, alcançando uma intensidade média de $5,0^{\circ} \mathrm{C}$. Em julho a mesma alcançou a maior intensidade em noites sem nuvens entre 22:00 e 23:00 horas, sem ultrapassar os $3,5^{\circ} \mathrm{C}$. Já em agosto, a maior intensidade ocorreu por volta das 3:00 horas da madrugada, com um máximo de $2,0^{\circ} \mathrm{C}$. A explicação para esta variabilidade temporal está relacionada à velocidade e direção do vento, uma vez que Shanghai tem um clima de monção. Como a cidade se localiza a leste do mar da China e a Baía de Hangzhou se situa ao sul, com freqüência dos ventos de ESSE-SE e SSE, proveniente do mar em alto verão.

Cardosa et. al. (2008) como objetivo principal de investigar a existência da ilha de calor em Cidade Juarez, México, empregaram a metodologia comparativa entre a zona urbana e rural, pela análise do parâmetro da temperatura do ar. Este parâmetro foi obtido em 5 estações meteorológicas automatizadas. Os registros foram realizados durante os meses de janeiro e fevereiro (inverno) e de junho a setembro (verão). A intensidade máxima da ilha de calor é negativa quando a temperatura de La Montada localizada na área rural é mais quente do que o meio 
urbano. Esta diferença alcançou a intensidade máxima de $6,0^{\circ} \mathrm{C}$. Por outro lado a ilha de calor é positiva, à noite, quando o meio urbano registrou um valor de máximo noturno de $7,0^{\circ} \mathrm{C}$.

Robaa (2003) investigou durante 5 anos (1995-2000) a temperatura do ar, a pressão de vapor e a umidade relativa em horas fixas (6:00; 14:00 e 22:00 horas) em 3 áreas (urbano, subúrbio e rural) no Cairo, Egito. A análise permitiu identificar que a atmosfera urbana está mais seca ao longo do ano, com exceção dos meses de dezembro, janeiro, maio e setembro. À tarde, está mais úmida se comparado à área suburbana e durante os meses de outubro a janeiro além de maio se comparou à área rural. Em relação à umidade relativa, a atmosfera urbana está sempre mais seca que o ambiente rural, menos à tarde, quando as diferenças urbano-rurais flutuaram entre positivo e negativo. A atmosfera urbana sempre está mais quente que seu entorno, menos em novembro quando há uma ilha frescor.

Sofer e Potchter (2006) ao analisarem as características da ilha de calor na cidade de Eilat, Israel, situada em clima quente e árido, na costa do norte do Mar Vermelho ao longo de 2 anos, com medidas realizadas antes do amanhecer e no meio da tarde, durante o inverno e o verão ao longo de 2 anos.

Os resultados denunciam o desenvolvimento de uma ilha de calor moderada, localizando-se ao redor da área de maior atividade humana, local do centro empresarial e hoteleiro, principalmente, perto do meio-dia, durante o período de verão, enquanto inversões térmicas matutinas no inverno têm um efeito de enfraquecimento de sua intensidade. Dentre os fatores locais que influenciam decisivamente na formação do fenômeno estão à topografia e o regime de vento, enquanto o mar tem um papel marginal.

Yow e Carbone (2006) analisaram as temperaturas do ar na camada intraurbana de Orlando, Flórida-EUA, com uma rede de 29 pontos fixos entre setembro de 1999 e dezembro de 2001. As melhores condições que se identificaram o fenômeno foram sob situação anticiclonal (ausência de ventos e noites claras durante os meses secos). A magnitude máxima excedeu aos $8,0^{\circ} \mathrm{C}$ e seu horário de maior ocorrência é à noite, às vezes, à tarde, estes relacionados às tempestades isoladas que causam variações extremas de temperatura entre o urbano e o rural.

Ruiz Flaño et. al. (2008) em suas pesquisas realizadas em 2004, na cidade de Las Palmas, Espanha, utilizaram a técnica de transetos móveis em dois percursos, totalizando 42 pontos amostrais, escolhidos em função da heterogeneidade da 
morfologia dos edifícios, o uso da terra e o fluxo de veículos. A cada local, temperatura e umidade relativa do ar era registrada, usando um Termohigrômetro (Hanna Digital, modelo HI 8564), a cada duas semanas. Os resultados confirmam a existência de uma ilha de calor com intensidade média de $3,4^{\circ} \mathrm{C}$ com valores ligeiramente mais altos pelos meses de inverno. A intensidade máxima registrada foi em 2001 com $5,3^{\circ} \mathrm{C}$, em dezembro, e o mínimo em junho, com $2,1^{\circ} \mathrm{C}$. Em geral, a intensidade máxima da ilha de calor era coincidente com situações anticiclonais.

Szegedi e Kircsi (2003) analisaram a influência das condições de tempo no desenvolvimento e padrão de espaço da ilha de calor em Debrecen, Hungria. Foram realizadas medidas com o uso de transetos móveis ente abril de 2002 e março de 2003. As análises provaram a existência da ilha de calor sob condições de anticiclone e ventos calmos, com intensidade média de $2,3^{\circ} \mathrm{C}$, alcançando a intensidade máxima de $5,8^{\circ} \mathrm{C}$. A formação das ilhas de calor desenvolveu em casos da predominância de sistemas.

Szegedi (2006) procurou analisar a ilha de calor em cidades de pequeno e médio porte, na Hungria, localizadas sob o mesmo sítio plano e sem a existência de rios ou lagos. A técnica utilizada para adquirir os registros necessários para as cidades de Debrecen (220.000 habitantes) Hajdúböszörmény (31.993 habitantes) Hajdúnánás (18.185 habibantes) Hajdúdorog (9.959 habitantes) e Hajdúvid (809 habitantes) foi a do transeto móvel, montado em um carro a uma altura de $1,70 \mathrm{~m}$. As campanhas de campos foram realizadas entre os anos de 2003 e 2004, sob diferentes condições sinópticas. A maioria dos 24 trabalhos de campo foi sob condição anticiclonal. Durante ou logo após a passagem de uma frente fria forte foram observadas apenas ilhas de calor de baixa magnitude.

Em situação de tempo favorável, que prevalecesse 48 a 72 horas antes das medidas, mesmo que no dia do experimento a nebulosidade alcançava cerca de $50,0 \%$, a ilha de calor era forte, porém quando este valor ultrapassava aos $75,0 \%$ a mesma se tornou fraca em Debrecen. A velocidade do vento teve um impacto forte, enquanto a direção do vento afetara somente a forma.

Os ventos de 1,0 a $1,5 \mathrm{~m} . \mathrm{s}^{-1}$ (medido a uma altura de 2 metros) poderiam prevenir a formação da ilha de calor cidades com 10.000 habitantes ou menos, Já em cidades de 20 e 30 mil habitantes apenas ventos de 2,5 a $3,0 \mathrm{~m}^{-1} \mathrm{~s}^{-1}$ seriam capazes de arejar a ilha de calor em Drebcen. Os resultados enfatizam a importância da condição do tempo que condiciona de 2 a 3 dias antes das medidas. 
Desde então superfícies artificiais acumulam quantias significantes de calor de um dia para outro, sendo capazes de armazenar e desenvolver com mais punjância a ilha de calor. Por isto um evento de tempo desfavorável curto (por exemplo, uma frente fria sem uma chuva pesada) não pode eliminar uma ilha de calor bem desenvolvida completamente.

De maneira geral, as cidades que apresentaram a maior média e pico da ilha de calor, são correspondentes ao tamanho da cidade, como esperado. Em Debrecen, a intensidade média da ilha de calor e a máxima absoluta foram $2,4^{\circ} \mathrm{C}$ e $4,5^{\circ} \mathrm{C}$. Para Hajdúböszörmény foi de $0,9^{\circ} \mathrm{C}$ e $2,1^{\circ} \mathrm{C}$; Hajdúnánás registrou $0,7^{\circ} \mathrm{C}$ e $2,4^{\circ} \mathrm{C}$, Hajdúdorog com $0,3^{\circ} \mathrm{C}$ de intensidade média e Hajdúvid com $0,1^{\circ} \mathrm{C}$ (média da intensidade da ilha de calor) e $0,5^{\circ} \mathrm{C}$ (pico da ilha de calor).

Evans e Schiller (2005) ao estudarem a ilha de calor em Tampico, México, de clima quente e úmido, utilizou-se 5 pontos de coleta percorridos por um veículo, à noite (20:00 às 21:00 horas) do dia 6 de junho de 2005. Os resultados indicam que há coincidência das áreas mais quentes com as mais urbanizadas, onde o pico da ilha de calor alcançou os $3,0^{\circ} \mathrm{C}$. Além disso, foi verificada a influencia da superfície de água, constituída pelo rio Pamuco e a laguna de carpinteiro, donde se verifica uma redução significativa da temperatura do ar nas áreas urbanas adjacente.

Du et. al. (1990) estudaram a cidade de Jinghong, uma cidade de pequeno porte na China Tropical, que apresenta formação de nevoeiros em mais de 80,0\% dos dias do inverno. Em janeiro de 1989 foram realizadas observações móveis, a fim de identificar os possíveis efeitos do meio urbano sobre o fenômeno de nevoeiro.

A cidade se localiza na porção noroeste da bacia do rio Jinghong, que tem uma área de $76 \mathrm{~km}^{2}$. A população é de 40.000 habitantes (1988), mas até a década de 1960 a mesma não chegava a 10.000. As medidas de campo se concentraram entre os dias 9 e 10 de janeiro de 1989 ao longo de 6 medidas -13:00, 18: e 21:00 horas do dia 9 e às 24:00, 6:00 e 9:00 horas do dia 10- (Figura 30).

A intensidade máxima encontrada foi de $1,0^{\circ} \mathrm{C}$ observado claramente na cidade, neste mesmo momento, a formação do nevoeiro de radiação também foi observado simultaneamente no declive localizado dentro o nordeste parte da bacia, acima da cidade se espalhando sobre a bacia inteira no prazo de uma hora, mas o seu desaparecimento ocorreu primeiramente sobre a mancha urbana. 


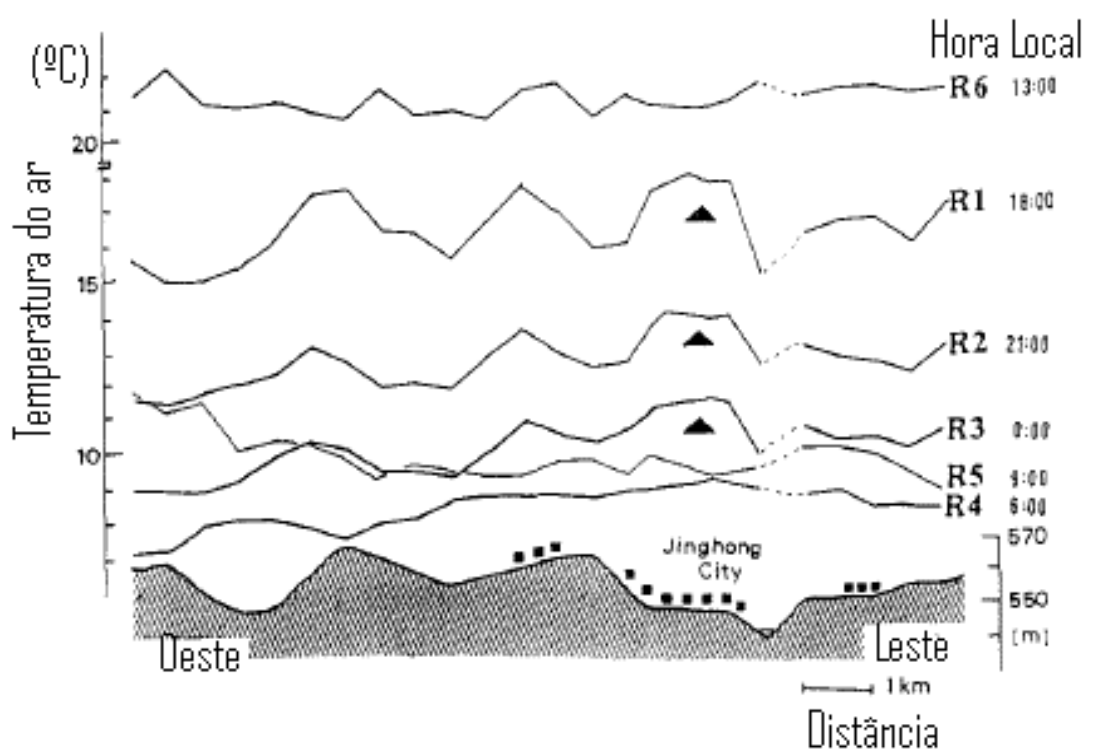

Figura 30. Variação da temperatura do ar ao longo das seis observações móveis de campo, realizado numa sessão leste-oeste de parte da bacia do rio Jinghong.

Fonte: Du et. al. (1990/1991, p. 158).

Para Mendéz et. al. (2008) a cidade de Toluca, México, tem apresentado um significativo crescimento da população e das dimensões territoriais. As variações atmosféricas são mais evidentes em espaços urbanos, que tem uma redução de áreas verdes e o aumento da calefação em casas e edifícios. Para identificar as áreas de maior do ar 7 estações meteorológicas, durante dias típicos de inverno (15 de julho de 2005) e verão (13 de janeiro de 2005) ao longo de 24 horas.

Muito embora, Jauregui (apud MÉNDEZ et. al. op. cit.) tenha encontrado uma intensidade de $8,0^{\circ} \mathrm{C}$ para a ilha de calor a noite, os referidos autores registraram uma ilha de calor mais forte durante o dia com $3,0^{\circ} \mathrm{C}$ e a noite a mesma enfraqueceu, alcançando $1,5^{\circ} \mathrm{C}$.

Deosthali (2000) conduziu sua pesquisa na cidade de Pune, Índia, durante a noite do dia 12 para o dia 13 de abril de 1997, utilizando-se de 9 percursos, totalizando 170 pontos de mensuração da temperatura e da umidade do ar. Às 20:00 horas do dia 12 , identificou-se uma intensidade de $2,0^{\circ} \mathrm{C}$ e $3,1^{\circ} \mathrm{C}$, às $5: 00$ horas da manhã, durante uma noite de céu claro e ventos catabáticos de oeste, uma vez que, a cidade se localiza dentro uma bacia com topografia muito acidentada.

Carreras et. al. (1990) buscaram compreender o comportamento térmico da área urbana de Barcelona, Espanha. Os dados colhidos durante os anos de 1985 a 1987, por meio de 5 transetos na região metropolitana. Os resultados indicam a 
existência de Ilha de calor, cuja sua intensidade máxima foi de $8,0^{\circ} \mathrm{C}$, e a causa primordial é a morfologia e funcionalidade da cidade, junto com uma condição de tempo estável, conforme demonstram as isotermas que bem revelam a conformidade concêntrica da ilha de calor em Barcelona (Figura 31).

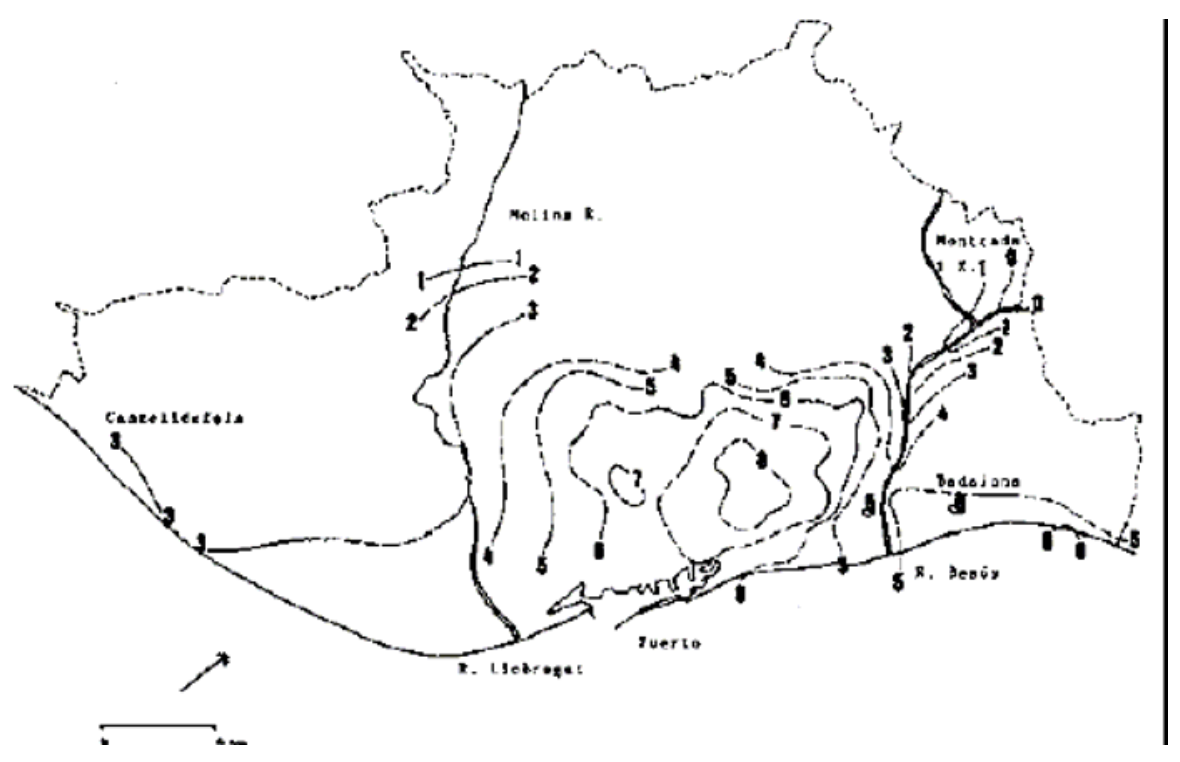

Figura 31. Mapeamento do campo térmico no dia 12 de fevereiro de 1986, às 21 horas e 35 minutos na região metropolitana de Barcelona.

Fonte: Carreras et. al. (1990, p. 67).

Monteiro (1997) ao pesquisar o clima da cidade do Porto, Portugal, procurou combinar várias campanhas de medição itinerante de temperatura e umidade relativa do ar, entre 1989 e 1992, com base em 2 transetos. O primeiro, com 16 experimentos, apresentavam 24 pontos e era realizado em 1:00 hora, enquanto segundo, com 4 experimentos, registrava 57, demorava entre 2:00 horas e 2 horas e 30 minutos. Associado a isto, também foram distribuídos pela cidade 7 pontos fixos em residências, cujos horários de medida foram: 9:00, 12:00, 14:00, 18:00, 21:00 e 24:00 horas, com um prazo de tolerância de 5 minutos, entre 1991 e 1992.

A partir dos dados obtidos, se constatou que a cidade apresenta ilha de calor noturna em todas as estações do ano, mesmo não tendo uma grande vitalidade econômica. A intensidade máxima ocorreu em situações depressionais, como nos dias em que a atmosfera apresentava estabilidade, foi extremamente variável. Desde um dia em que toda a cidade apresentou uma grande homogeneidade até outros exemplos, em que o centro registrou diferenças de temperatura do ar acima 
dos $7,0^{\circ} \mathrm{C}$. Os dias de predomínio de circulação anticiclônica, a intensidade da ilha de calor, nem sempre se apresentou tão significativa, chegando a registrar valores inferiores a $2,0^{\circ} \mathrm{C}$.

Kifle (2003) em seu trabalho abordou o clima da cidade de Addis Ababa, Etiópia, utilizando a perspectiva temporal, relacionando a expansão da mancha urbana com os registros de temperatura do ar da estação meteorológica localizada na área urbana entre 1960 e 2000. A segunda perspectiva adotada foi a comparação da temperatura do ar entre três pontos fixos (áreas rural, Aeroporto e a área central) ao longo de um transeto para dois dias (29 de novembro de 1999 e 29 de novembro de 2000) entre às 6:00 e 21:00 horas, com leituras a cada 3 horas.

Em relação à linha de tendência, constatou-se um incremento de $1,7^{\circ} \mathrm{C}$ para a temperatura mínima e máxima. Já os resultados dos experimentos de campo identificaram uma ilha de calor máxima às 6:00 horas, na área central, com $3,0^{\circ} \mathrm{C}$. Nos demais horários, a intensidade foi oscilando, alcançando o segundo pico às 15:00 horas, com $2,2^{\circ} \mathrm{C}$.

Chow e Roth (2006) analisaram a variabilidade temporal da ilha de calor urbana em Singapura, China, ao longo de um ano em 4 áreas com dados de temperatura do ar por meio de estações automáticas (zona comercial, centro, área de alta densidade e baixa densidade de edifícios). Os resultados indicaram que o cume da magnitude da ilha de calor ocorre 6 horas depois de pôr-do-sol na área comercial, (em outros locais urbanos).

As condições de maior intensidade geralmente aconteceram em situações de monção sudoeste de maio-agosto, com um máximo de $7,0^{\circ} \mathrm{C}$ observado no CBD sob condições de tempo ideais. Variações na precipitação sazonal explicam algumas das diferenças esfriando urbano-rural. Nenhuma relação clara entre geometria urbana e intensidade da ilha de calor pode ser vista, e também são mostradas variações intra-urbanas de temperatura para ser influenciado através de outros fatores de local, por exemplo, a extensão de espaço verde e calor antropogênico.

Correa et. al. (2005) ao monitorarem região metropolitana de Mendoza, Argentina, demonstraram que a relação entre a topografia e o desenvolvimento urbano. Os resultados obtidos para o inverno indicam que a maior freqüência e intensidade ocorrem durante a noite alcançando $9,6^{\circ} \mathrm{C}$. Os dados correlacionados demonstram que o fenômeno pode ser explicado em $75,0 \%$ pela combinação de três 
grupos de variáveis, que são as propriedades termofísica dos materiais, a inércia térmica e as condições de tempo.

Figuerola e Mazzeo (1998) analisaram as diferenças de temperatura em Buenos Aires, Argentina, por meio de duas estações. Uma na cidade e a segunda no aeroporto de Ezeiza. Os dados utilizados horários ao longo de 3 anos de dados permitiram identificar uma ilha de calor que varia com os dias da semana, estações do ano, nebulosidade, direção e velocidade de vento.

$\mathrm{O}$ valor mais freqüente da ilha de calor máxima se encontrou inverno com $4,6^{\circ} \mathrm{C}$, com ventos calmos e baixa nebulosidade e $3,6^{\circ} \mathrm{C}$ com condições ventosas e nubladas. Ventos fortes da cidade para áreas rurais e ventos do rio em cima da cidade facilitaram a ocorrência de uma ilha de calor inversa (área rural mais morno que cidade). A ilha de calor inversa (negativa) aconteceu 20,0\% do tempo (22.000 horas estudadas). Outro fator importante pode ser destacado é a redução da intensidade da ilha de calor nos fins de semana, na casa de $1,0^{\circ} \mathrm{C}$ com ventos fracos e pequenas condições de cobertura de céu.

Erell e Williamson (2007) registraram dados detalhados em dois canyons urbanos na área central de Adelaide, Austrália, um no subúrbio e outro em local exposto, perto do centro da cidade para um período de um ano. Os registros revelaram diferenças significativas entre temperatura de ar em ambos os locais de referência.

A ilha de calor noturna observada na maioria das cidades, também se verifica em Adelaide, nos vales urbanos. Mas, a ocorrência freqüente de dia é de ilha fresca, durante o verão, embora fraca do que o fenômeno de noite. São atribuídos pelo menos em parte ao aumento em área de superfície que participa em trocas de energia com a atmosfera em um vale urbano comparada para um local rural típico, e conseqüentemente em um aumento na massa térmica efetiva.

Steffens et. al. (2004) ao analisarem a ilha de calor em Temuco, Chile, efetivou a pesquisa de campo por meio de 2 transetos móveis em dois horários (14:00 e 21:00 horas), no da 18 de março de1997, ao longo de 2 horas, constatou uma intensidade máxima foi de $6,3^{\circ} \mathrm{C}$ durante o dia e $1,2^{\circ} \mathrm{C}$ à noite.

Dentre os trabalhos descritos previamente (Tabela 8), identifica-se uma padronização nos estudos de clima urbano desenvolvidos na Espanha. Em quase todos se utilizam a técnica de transetos móveis, no máximo dois, ao longo do percurso campo-cidade, associados à descrição do tipo de uso da terra em poucos dias de coleta, geralmente, de um a três dias. 
Uma particularidade verificada nestas pesquisas de campo é a não preocupação em correlacionar as condições do tempo, uma vez que procuram sempre realizar seus experimentos sob condições "ideais".

Os horários de registro, geralmente, são noturnos, não se preocupando em acompanhar a variação diária da temperatura entre o campo e a cidade, com as medidas de estações meteorológicas próximas.

Já os estudos em cidades da Europa central, nórdica, juntamente, com as cidades norte-americanas e o Japão procuram acompanhar o fenômeno da ilha de calor numa escala temporal maior, instalando uma rede mini-abrigos, por um período, quase sempre superior a um ano de registros contínuos.

Em alguns casos específicos se constata uma associação da técnica de transetos móveis que registram as diferenças intra-urbanas, com técnicas de sensoriamento remoto, a fim de comparação ou complementação.

Os trabalhos referentes às cidades do hemisfério sul, em número bem reduzido, não são tão diferentes dos estudos das cidades do hemisfério norte, guardando as devidas proporções; apenas se distinguem quanto ao tempo de registro, maiores, em razão dos equipamentos serem digitais e de acompanhamento contínuo.

Em relação ao tamanho das cidades, ainda se percebe uma predominância de trabalhos em cidades grandes, embora se registre um número expressivo de estudos em cidades médias e ainda, inexpressivos, em cidades de pequeno porte.

De maneira geral, estes trabalhos, nos inspiraram, em certa medida, por apresentar semelhanças com a pesquisa que vem sendo realizada em Viçosa, que procura adotar uma perspectiva de integrar as mensurações móveis e fixas, associadas ao acompanhamento da sucessão dos tipos de tempo para a semana dos experimentos. 
Tabela 7. Observações realizadas por meio de Pontos Fixos e Transetos Móveis.

\begin{tabular}{|c|c|c|c|c|c|c|c|c|c|c|c|c|}
\hline Cidade. & Latitude. & Autor. & $\begin{array}{l}\text { Pop, } \\
\left(\times 10^{3}\right)\end{array}$ & \multicolumn{2}{|c|}{$\begin{array}{l}\text { Ilha de calor } \\
\text { Máxima. }\end{array}$} & $\begin{array}{l}\text { Intensida } \\
\text { de média } \\
\text { da I.C. }\end{array}$ & $\begin{array}{l}\mathrm{N}^{\circ} \text { de } \\
\text { dias de } \\
\text { coleta. }\end{array}$ & $\begin{array}{c}\mathrm{N}^{\circ} \mathrm{de} \\
\text { pontos } \\
\text { de } \\
\text { coleta. }\end{array}$ & $\begin{array}{l}\text { Método } \\
\text { de coleta. }\end{array}$ & Horários. & $\begin{array}{l}\text { Tempo. } \\
\text { (minutos) }\end{array}$ & $\begin{array}{l}\text { Vel, } \\
\left(\mathrm{Km} \cdot \mathrm{h}^{-1}\right)\end{array}$ \\
\hline & & & & Diurna & Noturna & & & & & & & \\
\hline Barrow-Alasca & $71^{\circ} \mathrm{N}$ & Hinkel e. al., 2003 & 45 & - & $\begin{array}{l}6,0^{\circ} \mathrm{C} \\
\text { inverno }\end{array}$ & $2,2^{\circ} \mathrm{C}$ & 120 & 54 & Pontos fixos & $\begin{array}{l}\text { A cada } 1 \\
\text { hora }\end{array}$ & - & - \\
\hline $\begin{array}{l}\text { Fairbanks- } \\
\text { Alasca }\end{array}$ & $64^{\circ} \mathrm{N}$ & Magee et al, 1999 & 30 & - & $\begin{array}{l}1,0^{\circ} \mathrm{C} \\
\text { inverno }\end{array}$ & $0,4^{\circ} \mathrm{C}$ & $\begin{array}{c}17,885 \\
49 \text { anos }\end{array}$ & 3 & Pontos Fixos & $\begin{array}{l}24 \text { horas } \\
\text { diárias }\end{array}$ & - & - \\
\hline Uppsala & $59^{\circ} \mathrm{N}$ & Sundborg, 1950 & - & - & $\begin{array}{l}1,0^{\circ} \mathrm{C} \\
\text { inverno }\end{array}$ & - & 20 & 79 & $\begin{array}{l}1 \text { Transeto } \\
\text { Móvel }\end{array}$ & - & - & 40 \\
\hline Göteborg & $57^{\circ} \mathrm{N}$ & $\begin{array}{c}\text { Eliasson e } \\
\text { Holmer, } 1990\end{array}$ & 460 & - & $4,5^{\circ} \mathrm{C}$ & - & 34 & 5 & Pontos Fixos & - & - & - \\
\hline Moscow & $55^{\circ} \mathrm{N}$ & $\begin{array}{l}\text { Lokoshchenko e } \\
\text { Isaev, } 2006\end{array}$ & 8500 & - & $\begin{array}{l}14,3^{\circ} \mathrm{C} \\
\text { inverno }\end{array}$ & $1,5^{\circ} \mathrm{C}$ & $\begin{array}{c}3650 \\
10 \text { anos }\end{array}$ & 5 & Pontos Fixos & - & - & - \\
\hline Saskatoon & $52^{\circ} \mathrm{N}$ & Ripley et. al, 1996 & 200 & $\begin{array}{l}8^{\circ} \mathrm{C} \\
\text { verão }\end{array}$ & $\begin{array}{c}3^{\circ} \mathrm{C} \\
\text { verão }\end{array}$ & $4,6^{\circ} \mathrm{C}$ & 9 & 110 & $\begin{array}{l}1 \text { Transeto } \\
\text { Móvel }\end{array}$ & - & - & 15 \\
\hline Reading & $51^{\circ} \mathrm{N}$ & Parry, 1956 & 120 & & & $0,8^{\circ} \mathrm{C}$ & 365 & 10 & Pontos Fixos & & & \\
\hline Lodz & $51^{\circ} \mathrm{N}$ & $\begin{array}{c}\text { Klysik e Fortuniak, } \\
1999\end{array}$ & 850 & - & $\begin{array}{l}12,0^{\circ} \mathrm{C} \\
\text { inverno }\end{array}$ & $4,0^{\circ} \mathrm{C}$ & 3 & 5 & $\begin{array}{c}5 \text { Transetos } \\
\text { móveis }\end{array}$ & - & - & - \\
\hline Regina & $50^{\circ} \mathrm{N}$ & Stewart, 2000 & 190 & - & $\begin{array}{l}7,5^{\circ} \mathrm{C} \\
\text { inverno }\end{array}$ & $3,0^{\circ} \mathrm{C}$ & 31 & 42 & $\begin{array}{l}2 \text { Transetos } \\
\text { móveis }\end{array}$ & $\begin{array}{l}3 \text { horas } \\
\text { após o } \\
\text { pôr-do-sol }\end{array}$ & - & - \\
\hline Paris & $48^{\circ} \mathrm{N}$ & Cantat, 2004 & 9000 & - & $\begin{array}{c}6,0^{\circ} \mathrm{C} \\
\text { inverno }\end{array}$ & $3,0^{\circ} \mathrm{C}$ & 5 décadas & 55 & Pontos Fixos & - & - & \\
\hline Szeged & $46^{\circ} \mathrm{N}$ & $\begin{array}{l}\text { Sümeghy e } \\
\text { Unger, } 2003\end{array}$ & 160 & - & $\begin{array}{l}7,5^{\circ} \mathrm{C} \\
\text { inverno }\end{array}$ & - & 12 & $55-83$ & $\begin{array}{l}1 \text { Transeto } \\
\text { Móvel }\end{array}$ & $\begin{array}{l}19 \text { PM até } \\
4 \mathrm{AM}\end{array}$ & $50-60$ & $20-30$ \\
\hline Florence & $43^{\circ} \mathrm{N}$ & Petralli et. al, 2006 & 365 & $3,0^{\circ} \mathrm{C}$ & - & $1,8^{\circ} \mathrm{C}$ & 90 & 4 & Pontos Fixos & $\begin{array}{c}4-6 \mathrm{PM} \mathrm{e} \\
10-12 \mathrm{PM}) \\
\end{array}$ & - & - \\
\hline Logroño & $42^{\circ} \mathrm{N}$ & Izquierdo et. al. 1998 & 126 & $\begin{array}{l}2,8^{\circ} \mathrm{C} \\
\text { inverno }\end{array}$ & - & $1,7^{\circ} \mathrm{C}$ & 6 & 83 & $\begin{array}{l}3 \text { Transetos } \\
\text { Móveis }\end{array}$ & $\begin{array}{l}\text { 7-14-20 } \\
\text { hs. }\end{array}$ & 60 & - \\
\hline Zaragoza & $41^{\circ} \mathrm{N}$ & $\begin{array}{l}\text { Pratis Cuadrat et. al., } \\
1993\end{array}$ & 600 & - & $5,0^{\circ} \mathrm{C}$ & - & 27 & 82 & $\begin{array}{l}2 \text { Transetos } \\
\text { Móveis }\end{array}$ & $\begin{array}{c}3 \text { horas } \\
\text { após o } \\
\text { pôr-do-sol }\end{array}$ & - & - \\
\hline
\end{tabular}




\begin{tabular}{|c|c|c|c|c|c|c|c|c|c|c|c|c|}
\hline Madrid & $40^{\circ} \mathrm{N}$ & $\begin{array}{l}\text { Lopes Gomez } \\
\text { et. al., } 1995\end{array}$ & 4000 & $\begin{array}{c}8,1^{\circ} \mathrm{C} \\
\text { inverno }\end{array}$ & $\begin{array}{l}10,1^{\circ} \mathrm{C} \\
\text { inverno }\end{array}$ & - & 79 & 110 & $\begin{array}{l}3 \text { Transetos } \\
\text { Móveis }\end{array}$ & $\begin{array}{l}\text { 8-12 e } 20 \\
\text { UTC }\end{array}$ & $\begin{array}{l}\text { Entre } 1 \mathrm{e} \\
2 \text { horas. }\end{array}$ & - \\
\hline Guadalajara & $40^{\circ} \mathrm{N}$ & Bello Fuentes, 1994 & 66 & - & $\begin{array}{c}4,5^{\circ} \mathrm{C} \\
\text { inverno }\end{array}$ & $2,5^{\circ} \mathrm{C}$ & 46 & - & $\begin{array}{l}2 \text { Transetos } \\
\text { Móveis }\end{array}$ & - & - & - \\
\hline Alcalá & $40^{\circ} \mathrm{N}$ & Bello Fuentes, 1994 & 164 & - & $5,2^{\circ} \mathrm{C}$ & - & 50 & 24 & $\begin{array}{l}2 \text { Transetos } \\
\text { Móveis }\end{array}$ & 23 hs. & - & - \\
\hline Salamanca & $40^{\circ} \mathrm{N}$ & $\begin{array}{c}\text { Alonso e } \\
\text { Fidalgo, } 2003\end{array}$ & 190 & 1,4 & $5,3^{\circ} \mathrm{C}$ & - & - & 30 & $\begin{array}{l}3 \text { Transetos } \\
\text { Móveis }\end{array}$ & $\begin{array}{c}24-7-13- \\
18 \text { UTC }\end{array}$ & - & - \\
\hline Aveiro & $40^{\circ} \mathrm{N}$ & $\begin{array}{c}\text { Pinho e Manso } \\
\text { Orgaz, } 2000\end{array}$ & 38 & - & $\begin{array}{c}7,5^{\circ} \mathrm{C} \\
\text { inverno }\end{array}$ & - & 48 & - & $\begin{array}{l}1 \text { Transeto } \\
\text { Móvel }\end{array}$ & $\begin{array}{c}23 \text { PM até } \\
1 \mathrm{AM}\end{array}$ & - & - \\
\hline Valência & $39^{\circ} \mathrm{N}$ & Caselles et al., 1991 & 729 & - & $\begin{array}{c}3,6^{\circ} \mathrm{C} \\
\text { inverno }\end{array}$ & - & 2 & 8 & $\begin{array}{l}1 \text { Transeto } \\
\text { Móvel }\end{array}$ & 5 UTC & - & - \\
\hline Ohio & $40^{\circ} \mathrm{N}$ & Martin e Powell, 1977 & - & - & $\begin{array}{c}7,7^{\circ} \mathrm{C} \\
\text { outono }\end{array}$ & - & 4 & - & $\begin{array}{l}1 \text { Transeto } \\
\text { Móvel }\end{array}$ & 21:00 GMT & 60 & - \\
\hline Atenas & $38^{\circ} \mathrm{N}$ & Livada et. al., 2002 & 5000 & - & $\begin{array}{c}4,5^{\circ} \mathrm{C} \\
\text { inverno }\end{array}$ & - & $\begin{array}{c}730 \\
2 \text { anos }\end{array}$ & 20 & Pontos Fixos & 24 horas & - & - \\
\hline Sendai & $38^{\circ} \mathrm{N}$ & $\begin{array}{l}\text { Sakaida e Egoshi, } \\
2006\end{array}$ & 1000 & $1,0^{\circ} \mathrm{C}$ & $3,0^{\circ} \mathrm{C}$ & $2,0^{\circ} \mathrm{C}$ & 261 & 25 & Pontos Fixos & $\begin{array}{l}\text { Leitura a } \\
\text { cada } 10 \\
\text { minutos }\end{array}$ & - & - \\
\hline Berr Sheva & $34^{\circ} \mathrm{N}$ & Potchter et. al., 2006 & 200 & $7,0^{\circ} \mathrm{C}$ & - & - & - & - & $\begin{array}{l}5 \text { Transetos } \\
\text { Móveis }\end{array}$ & - & 60 & - \\
\hline Shanghai & $31^{\circ} \mathrm{N}$ & Bai e Mikami, 2006 & $\begin{array}{c}1300 \\
0\end{array}$ & $5,0^{\circ} \mathrm{C}$ & $3,5^{\circ} \mathrm{C}$ & $3,0^{\circ} \mathrm{C}$ & 365 & 38 & Pontos Fixos & $\begin{array}{l}\text { Leitura a } \\
\text { cada } 10 \\
\text { minutos }\end{array}$ & - & - \\
\hline Cuidad Juarez & $31^{\circ} \mathrm{C}$ & Cardosa, et. al., 2008 & 1500 & $\begin{array}{c}6,0^{\circ} \\
\text { Inverno }\end{array}$ & $\begin{array}{c}7,0^{\circ} \mathrm{C} \\
\text { inverno }\end{array}$ & - & 120 & 5 & Pontos Fixos & - & - & - \\
\hline Cairo & $30^{\circ} \mathrm{N}$ & Robaa, 2003 & 293 & $\begin{array}{c}2,2^{\circ} \mathrm{C} \\
\text { primav. }\end{array}$ & - & - & $\begin{array}{r}1.825 \\
5 \text { anos } \\
\end{array}$ & 3 & Pontos Fixos & $6-14-21$ & - & - \\
\hline Eilat & $29^{\circ} \mathrm{N}$ & $\begin{array}{l}\text { Sofer e Potchter, } \\
2006\end{array}$ & 43 & $\begin{array}{l}1,6^{\circ} \mathrm{C} \\
\text { verão }\end{array}$ & - & - & 13 & 45 & $\begin{array}{l}3 \text { Transetos } \\
\text { Móveis }\end{array}$ & 5-13- 21 & - & - \\
\hline Orlando & $28^{\circ} \mathrm{N}$ & Yow e Carbone, 2006 & - & - & $\begin{array}{c}8,0^{\circ} \mathrm{C} \\
\text { inverno }\end{array}$ & $3,0^{\circ} \mathrm{C}$ & 120 & 29 & Pontos Fixos & Horário & - & - \\
\hline Las palmas & $28^{\circ} \mathrm{N}$ & $\begin{array}{l}\text { Ruiz Flaño et. al., } \\
2008\end{array}$ & 377 & - & $\begin{array}{c}5,3^{\circ} \mathrm{C} \\
\text { inverno }\end{array}$ & $3,4^{\circ} \mathrm{C}$ & - & 42 & $\begin{array}{l}2 \text { Transetos } \\
\text { móveis }\end{array}$ & - & - & - \\
\hline Debrecen & $21^{\circ} \mathrm{N}$ & $\begin{array}{c}\text { Szegedi e Kircsi, } \\
2003\end{array}$ & 220 & - & $\begin{array}{c}5,8^{\circ} \mathrm{C} \\
\text { inverno }\end{array}$ & $2,3^{\circ} \mathrm{C}$ & 10 & - & $\begin{array}{l}2 \text { Transetos } \\
\text { Móveis }\end{array}$ & - & 90 & - \\
\hline Debrecen & $21^{\circ} \mathrm{N}$ & Szegedi, 2006 & 220 & - & $4,5^{\circ} \mathrm{C}$ & $2,4^{\circ} \mathrm{C}$ & - & 24 & $\begin{array}{l}1 \text { Transeto } \\
\text { Móvel }\end{array}$ & - & - & - \\
\hline Hajdúböszörmény & $21^{\circ} \mathrm{N}$ & Szegedi, 2006 & 31 & - & $2,1^{\circ} \mathrm{C}$ & $0,9^{\circ} \mathrm{C}$ & - & 24 & $\begin{array}{l}1 \text { Transeto } \\
\text { Móvel }\end{array}$ & - & - & - \\
\hline
\end{tabular}




\begin{tabular}{|c|c|c|c|c|c|c|c|c|c|c|c|c|}
\hline Hajdúnánás & $21^{\circ} \mathrm{N}$ & Szegedi, 2006 & 18 & - & $2,4^{\circ} \mathrm{C}$ & $0,7^{\circ} \mathrm{C}$ & - & 24 & $\begin{array}{l}1 \text { Transeto } \\
\text { Móvel }\end{array}$ & - & - & - \\
\hline Hajdúdorog & $21^{\circ} \mathrm{N}$ & Szegedi, 2006 & 9 & - & $0,3^{\circ} \mathrm{C}$ & - & - & 24 & $\begin{array}{l}1 \text { Transeto } \\
\text { Móvel }\end{array}$ & - & - & - \\
\hline Hajdúvid & $21^{\circ} \mathrm{N}$ & Szegedi, 2006 & 0,08 & - & $0,5^{\circ} \mathrm{C}$ & $0,1^{\circ} \mathrm{C}$ & - & 24 & $\begin{array}{l}1 \text { Transeto } \\
\text { Móvel }\end{array}$ & - & - & - \\
\hline Tampico & $21^{\circ} \mathrm{N}$ & $\begin{array}{c}\text { Evans e } \\
\text { Schiller, } 2005\end{array}$ & 500 & - & $\begin{array}{l}4,0^{\circ} \mathrm{C} \\
\text { verão }\end{array}$ & - & 1 & 43 & $\begin{array}{l}5 \text { Transeto } \\
\text { Móveis, }\end{array}$ & $20 \mathrm{hs}$. & 60 & - \\
\hline Xishuangbanna & $21^{\circ} \mathrm{N}$ & Du et. al., 1990 & 40 & - & - & $1,0^{\circ} \mathrm{C}$ & 2 & 6 & $\begin{array}{l}1 \text { Transeto } \\
\text { Móvel }\end{array}$ & - & - & - \\
\hline Toluca & $19^{\circ} \mathrm{N}$ & Mendéz et. al., 2008 & 475 & $\begin{array}{c}3,0^{\circ} \mathrm{C} \\
\text { inverno }\end{array}$ & $\begin{array}{c}1,5^{\circ} \mathrm{C} \\
\text { inverno } \\
\end{array}$ & - & 2 & 7 & Pontos Fixos & $\begin{array}{c}\text { A cada } 1 \\
\text { hora }\end{array}$ & - & - \\
\hline Pune & $18^{\circ} \mathrm{N}$ & Deosthali, 2000 & 5000 & $\begin{array}{c}3,1^{\circ} \mathrm{C} \\
\text { inverno }\end{array}$ & - & - & 2 & 170 & $\begin{array}{l}9 \text { Transetos } \\
\text { Móveis }\end{array}$ & - & 120 & - \\
\hline Barcelona & $16^{\circ} \mathrm{N}$ & Carreras, 1990 & 2738 & - & $6,9^{\circ} \mathrm{C}$ & - & - & 121 & $\begin{array}{l}5 \text { Transetos } \\
\text { Móveis }\end{array}$ & $22: 30$ hs. & 30 a 40 & - \\
\hline Porto & $16^{\circ} \mathrm{N}$ & Monteiro, 1997 & 300 & - & $\begin{array}{c}7,9^{\circ} \mathrm{C} \\
\text { inverno }\end{array}$ & $\begin{array}{l}2,5^{\circ} \mathrm{C}- \\
3,0^{\circ} \mathrm{C}\end{array}$ & $16 / 4$ & 101 & $\begin{array}{l}2 \text { Transetos } \\
\text { Móveis }\end{array}$ & - & - & - \\
\hline Addis Ababa & $9^{\circ} \mathrm{N}$ & Kifle, 2003 & 3627 & $\begin{array}{l}3,0^{\circ} \mathrm{C} \\
\text { outono }\end{array}$ & - & - & 2 & 3 & Pontos Fixos & $\begin{array}{l}\text { 6-9-12-15- } \\
18-21 \text { hs. }\end{array}$ & - & - \\
\hline Singapore & $1^{\circ} \mathrm{N}$ & Chow e Roth, 2006 & 4000 & - & $\begin{array}{c}7,1^{\circ} \mathrm{C} \\
\text { primaver } \\
a \\
\end{array}$ & - & 635 & 4 & Pontos Fixos & $\begin{array}{l}24 \text { horas } \\
\text { diárias }\end{array}$ & - & - \\
\hline Mendoza & $32^{\circ} \mathrm{S}$ & Correa et. al., 2005 & 900 & - & $\begin{array}{l}9,60^{\circ} \mathrm{C} \\
\text { inverno }\end{array}$ & - & 6 & 69 & $\begin{array}{c}1 \text { Transeto } \\
\text { Móvel }\end{array}$ & 6-13-20hs. & - & - \\
\hline Buenos Aires & $34^{\circ} \mathrm{S}$ & $\begin{array}{c}\text { Figuerola e Mazzeo, } \\
1998\end{array}$ & 712 & $\begin{array}{l}6,0^{\circ} \mathrm{C} \\
\text { inverno }\end{array}$ & $\begin{array}{c}4,6^{\circ} \mathrm{C} \\
\text { inverno }\end{array}$ & $4,3^{\circ} \mathrm{C}$ & 315 & 3 & Pontos Fixos & $\begin{array}{l}24 \text { horas } \\
\text { diárias }\end{array}$ & - & - \\
\hline Adelaide & $34^{\circ} \mathrm{S}$ & $\begin{array}{c}\text { Erell e Williamson, } \\
2007\end{array}$ & 1124 & - & $\begin{array}{c}9,4^{\circ} \mathrm{C} \\
\text { inverno }\end{array}$ & $4,8^{\circ} \mathrm{C}$ & 134 & 3 & Pontos Fixos & $\begin{array}{l}24 \text { horas } \\
\text { diárias }\end{array}$ & - & - \\
\hline Temuco & $38^{\circ} \mathrm{S}$ & Steffens et, al., 2004 & 210 & $\begin{array}{c}6,3^{\circ} \mathrm{C} \\
\text { inverno }\end{array}$ & $\begin{array}{c}1,2^{\circ} \mathrm{C} \\
\text { inverno }\end{array}$ & - & 1 & - & $\begin{array}{l}2 \text { Transetos } \\
\text { Móveis }\end{array}$ & $14-19$ hs. & 120 & - \\
\hline
\end{tabular}

Organizado por Edson Soares Fialho (2008). 


\subsubsection{No Brasil}

Nas cidades brasileiras os estudos de clima urbano, que abordam a questão da temperatura do ar, ainda são escassos, mas felizmente, a persistência de alguns pesquisadores e laboratórios, como o de Climatologia e Biogeografia da USP, promove ainda a continuidade desta pesquisa, que se expande de modo intermitente, por meio de defesas de dissertações de mestrado e teses de doutorado, em grande parte, sendo difícil ainda encontrar trabalhos publicados em forma de livro, a fim de facilitar o acesso à informação.

Apesar das dificuldades inerentes as pesquisas em clima urbano, o levantamento de estudos da temática em questão para o Brasil, embora não seja completo, procurou abarcar quase todas as principais referências, encontradas em bibliotecas de pós-graduação da Universidade Estadual de São Paulo de Rio Claro (UNESP-RC), Universidade Federal de Minas Gerais (UFMG), Universidade Federal do Rio de Janeiro (UFRJ), Universidade do Estado do Rio de Janeiro (UERJ), Universidade Federal Fluminense (UFF), Universidade de Campinas (UNICAMP), Universidade Federal de Santa Catarina (UFSC), Universidade Federal do Rio Grande do Sul (UFRGS), Universidade Federal do Paraná (UFPR) e USP.

Inicialmente, Nascimento (1995) analisou as condições térmicas da cidade de Belém, Pará, a partir da temperatura do ar, umidade relativa, direção e intensidade do vento. Os dados foram obtidos em experimentos de campo realizados em maio (dias 27 e 28) e outubro (dias 11 e 12) de 1990 em 16 pontos amostrais no outono e 28 na primavera, com leituras a cada 3 horas entre às 6:00 e 21:00 horas. Os dados ao serem comparados com as estações meteorológicas do Aeroporto e da Empresa Brasileira de Pesquisa Agropecuária (EMBRAPA), revelaram que a intensidade máxima da ilha de calor foi de $2,0^{\circ} \mathrm{C}$ entre às $12: 00$ e 15:00 horas para as duas situações sazonais analisadas.

Costa e Mattos (1998) estudaram o comportamento da ilha de calor, na cidade de Bragança, Pará, localizada a nordeste do Estado do Pará, distante cerca de $200 \mathrm{~km}$ de Belém, apresenta uma população de aproximadamente 50 mil habitantes. Para a realização deste trabalho utilizaram-se psicrômetros convencionais sem aspiração, com precisão de $0,2^{\circ} \mathrm{C}$, os quais foram colocados no interior de abrigos meteorológicos de madeira e distribuídos em dois locais distintos, sendo um dentro da área urbana da cidade de Bragança e o segundo em uma área rural, distante aproximadamente $8 \mathrm{~km}$ do primeiro. 
As leituras realizadas em intervalos horários, durante 7 dias consecutivos, na estação seca. Os resultados indicaram a existência, apesar de pequena, da ilha de calor urbana, cujas maiores intensidades ocorreram após as 18:00 horas, prolongando-se até aproximadamente as 23:00 horas, quando tais valores tornaramse desprezíveis.

De um modo geral, as temperaturas observadas na área urbana apresentaram-se sempre superiores. Apesar das pequenas diferenças encontradas (até $1,0^{\circ} \mathrm{C}$ ), a área urbana apresentou em todas as horas do dia valores sempre maiores de temperatura do ar, quando comparadas com a área rural, evidenciando a influência, embora pequena, da estrutura urbana no comportamento térmico daquela cidade. Na realização deste trabalho pode-se constatar a influência da estrutura urbana no comportamento termohigrométrico em uma cidade de pequeno porte na região Equatorial. No que se referem à umidade relativa do ar, estes valores foram sempre menores na área urbana em relação à área rural, evidenciando a grande influência das características de uso e ocupação da terra.

Moura et. al. (2008) com o objetivo caracterizar o clima urbano de Fortaleza, tomaram numa dimensão linear 12 pontos amostrais na urbana, que serviram de base para o levantamento de dois experimentos em regimes sazonais distintos e com registros horários e simultâneos em perfis de 24 horas (7:00 às 6:00 horas). 0 primeiro experimento realizado no outono, período chuvoso, nos dias 04 e 05/05/2007, e o segundo na primavera, período seco, entre os dias 9 e 10/11/2007. Os resultados encontrados seguem o ritmo da habitualidade climática dos episódios sazonais analisados, sendo os sistemas de circulação atmosférica fatores determinantes no comportamento térmico da cidade. A pesquisa identificou que as ilhas de calor em Fortaleza podem ultrapassar o valor de $5,0^{\circ} \mathrm{C}$, e ocorrem com maior freqüência e intensidade no período diurno, entre as 7:00 e 15:00 horas. As espacializações das ilhas de calor se concentraram nos setores sudoeste, oeste, noroeste e porção central da cidade.

Aguiar (1995) ao investigar o clima urbano da cidade de Manaus, Amazonas, a partir do monitoramento climático durante os meses de agosto de 1994 e março de 1995, através de registros de 14 pontos (mini-abrigos), com 3 leituras horárias (8:00, 14:00 e 21:00 horas), dentro e nos arredores da cidade, identificou a existência de contrastes térmicos horizontais moderados. A intensidade máxima registrada no mês de agosto de 1994 foi de $3,6^{\circ} \mathrm{C}$, às $14: 00$ horas, nas áreas mais urbanizadas, localizadas às margens do rio Amazonas. 
Zamparoni (1995), ao estudar a variação de temperatura e umidade em duas cidades de porte pequeno (Barra do Bugres e Tangará da Serra, Mato Grosso), constatou ilhas de calor em ambas, sendo o período noturno aquele em que se observa sua intensidade máxima. Os resultados mostram que em Barra do Bugres os valores da ilha de calor foram de $2,0^{\circ} \mathrm{C}$ em estação chuvosa e $3,6^{\circ} \mathrm{C}$ na estação seca; já em Tangará da Serra, os valores foram $4,0^{\circ} \mathrm{C}$ da estação chuvosa e $5,4^{\circ} \mathrm{C}$ na estação seca. Para a obtenção dos dados de campo, foram adotados, de forma concomitante, transetos móveis (8:00, 14:00 e 21:00 horas) e as medidas fixas (8:00 às 20:00 horas). Em Barra do Bugres, o transeto contou com 14 pontos, sendo o percurso feito em média de 15 a 20 minutos, num total de $6 \mathrm{~km}$. Já em Tangará da Serra, o mesmo contou com 26 pontos e utilizou 18 a 26 minutos num total de $8 \mathrm{~km}$, Quanto aos pontos fixos apenas dois, servindo de referência, foram utilizados, sendo um em cada cidade.

Sampaio (1981), ao estudar a distribuição espacial da temperatura do ar em Salvador, Bahia, durante o outono e em 11 pontos amostrais, identificou que as temperaturas nos ambientes mais edificados foram $1,3^{\circ} \mathrm{C}$ a $6,0^{\circ} \mathrm{C}$ mais elevadas que as registradas nos ambientes abertos. Porém de acordo com o autor os dados obtidos apesar de atestar claramente a presença da ilha de calor no ambiente urbano não se constataram nenhum indício de correlação linear entre a intensidade do uso da terra e a variação das temperaturas internas no espaço urbano, embora isso estivesse previsto em sua hipótese de trabalho.

Maitelli (1994) identificou os efeitos da urbanização na temperatura e umidade do ar na cidade de Cuiabá, Mato Grosso. Neste estudo, houve a conjugação de três formas de observação: a primeira foi estatística da série temporal (1920-1992), a segunda utilizou experimentos de campo em pontos fixos e transetos móveis, e por último o balanço de energia a área central, usando o método de Bowen.

Os resultados da análise estatística demonstraram uma tendência de elevação da temperatura mínima de $0,073^{\circ} \mathrm{C}$ por ano, enquanto o mesmo não se verificou para as temperaturas máximas e médias compensadas para o mesmo período. As observações móveis revelaram uma intensidade média de $3,8^{\circ} \mathrm{C}$ no período noturno da estação seca, com máxima de $5,0^{\circ} \mathrm{C}$ e de $1,8^{\circ} \mathrm{C}$ no período noturno da estação chuvosa, com valores de até $2,3^{\circ} \mathrm{C}$. As medidas fixas registraram $3,4^{\circ} \mathrm{C}$ e o valor médio de $2,7^{\circ} \mathrm{C}$ na estação seca, no período noturno, e valor médio de $1,8^{\circ} \mathrm{C}$ na estação chuvosa, também no mesmo período noturno. 
Maitelli et. al. (2003) com intuito de identificarem e comparar a configuração e magnitude da ilha de calor entre as cidades, entre os anos de 2001 e 2002, realizaram experimentos de campo, utilizando transetos móveis (7:00; 13:00 e 19:00 horas) em Cuiabá e Várzea Grande, Mato Grosso, a uma velocidade média de $40 \mathrm{~km} \cdot \mathrm{h}^{-1}$ em um tempo de 50 minutos. Em Várzea Grande, Mato Grosso, a ilha de calor atingiu $7,0^{\circ} \mathrm{C}$, enquanto em Cuiabá $5,7^{\circ} \mathrm{C}$, ambos no dia 2 de julho de 2002.

Sette (1996), analisando os resultados verificados em quatro episódios, sendo dois experimentos realizados um período de 24 horas com medidas a cada 30 minutos e os outros dois num intervalo de uma semana com 3 leituras diárias, foram realizadas coletas de dados na área urbana de Rondonópolis, Mato Grosso, em duas estações do ano (seca e chuvosa), identificou a formação de um campo térmico de intensidade máxima de $4,8^{\circ} \mathrm{C}$ às $13: 30$ minutos (27 e 28/2/93).

Os dados dos dois outros episódios nas mesmas estações, com 11 pontos de mensuração e não mais 8 como nos anteriores, durante a semana nos horários das (6:30, 12:00 e 20:00 horas), os resultados demonstraram a mesma tendência das coletas em 24 horas. O horário de maior intensidade foi às 12 horas, com uma média de $2,9^{\circ} \mathrm{C}$ e máxima de $4,5^{\circ} \mathrm{C}$ na estação chuvosa, enquanto na estação seca a média ao meio-dia foi de $3,0^{\circ} \mathrm{C}$ com máxima de $4,1^{\circ} \mathrm{C}$.

Assis (2001), em sua dissertação de mestrado sobre o clima urbano em Belo Horizonte, Minas Gerais, estabeleceu seu trabalho, com base nas interações entre o meio urbano e os parâmetros meteorológicos no sítio. A pesquisa avaliou a cidade em dois níveis escalares. No primeiro, o experimento de campo foi realizado ao longo de 16 pontos amostrais, dentro da mancha urbana distribuída em um segmento norte-sul, abarcando tipos de uso e ocupação da terra diferenciada. Segundo o autor, há uma mobilidade espacial da ilha de calor, ao longo de 24 horas (com leituras a cada 3 horas) com intensidade máxima de $4,7^{\circ} \mathrm{C}$, registrada às 6:00 horas da manhã. No segundo nível, restrito ao centro, foram utilizados 7 pontos amostrais, com leituras a cada 3:00 horas, em 24 horas. Os resultados permitiram verificar a existência de ilha de calor, com intensidade máxima de $3,2^{\circ} \mathrm{C}$ às $17: 00$ horas. Esta intensidade constatada é $1,5^{\circ} \mathrm{C}$, inferior a registrada para toda a cidade.

Anunciação e Sant'anna Neto (2002) procuraram compreender a dinâmica do campo térmico na cidade de Campo Grande, Mato Grosso do Sul, em situações sazonais de inverno e verão. Para isso, utilizaram 8 pontos fixos (mini-abrigos), com leituras às 7:30; 9:00; 12:00; 15:00; e 21:00 horas. Conforme os resultados obtidos, se destaca influência dos sistemas sinóticos na forma e intensidade. No verão a 
intensidade máxima da ilha de calor foi de $6,0^{\circ} \mathrm{C}(12: 00$ horas), sob ação da MTA. Sob a influência da massa equatorial continental, se verificou um pico de $10,0^{\circ} \mathrm{C}(15: 00$ horas), que se manteve até às $18: 00$ horas $\left(9,0^{\circ} \mathrm{C}\right)$, porém às 21:00 o resfriamento foi tão intenso, que a ilha de calor observada foi de $2,0^{\circ} \mathrm{C}$. Com predomínio da massa polar tropicalizada (MPT), a diferença do gradiente da atmosfera não ultrapassou aos $2,0^{\circ} \mathrm{C}$ (entre 18:00 e 21:00 horas). No inverno, sob o domínio da Massa polar atlântica (MPA), a ilha de calor registrou seu pico às $21: 00$ horas $\left(5,0^{\circ} \mathrm{C}\right)$, na base área e não no centro.

Martins (1996), em sua pesquisa de mestrado, analisou a influência do meio urbano sobre a temperatura do ar em Juiz de Fora, Minas Gerais, sob dois níveis de tratamento climático. No primeiro, procurou-se verificar a existência de uma tendência de aquecimento ao longo da série histórica (1893 a 1995) da estação meteorológica. Os resultados, não permitiram identificar uma tendência de aquecimento da temperatura do ar uma vez que houve algumas falhas na série histórica, associadas às mudanças de local da estação, num total de quatro, para sítios distintos.

No segundo nível escalar, já ao nível local (cidade), buscou analisar o campo térmico. Para analisar, foram instalados 6 abrigos térmicos em locais dentro e fora do perímetro urbano, com 3 leituras no verão (9:00, 15:00 e 21:00 horas) e 6 medidas a cada 3 horas no inverno (6:00, 9:00, 12:00, 15:00, 18:00 e 21:00 horas), para situações sazonais de verão e inverno, a cada 3 horas no verão. Segundo o autor, foi constatada a existência de ilhas de calor de forte intensidade.

As ilhas de frescor também verificadas no período da tarde, na região do centro da cidade, estão associadas ao sombreamento gerado pelas construções verticalizadas. Nos períodos da manhã e da noite, eram identificadas as ilhas de calor, onde o primeiro horário se apresentava as de maior intensidade, como foi registrado no dia 16 de julho de 1994, quando a diferença térmica horizontal entre o distrito industrial e o centro da cidade alcançou aos $12,8^{\circ} \mathrm{C}$.

Minaki e Amorim (2005) buscaram compreender o clima urbano de Guararapes, São Paulo, por meio das diferenças térmicas e higrométricas de três pontos fixos (mini-abrigos, com psicrômetros), com três leituras horárias (9:00, 15:00 e 21:00 horas) durante 15 dias no de verão (dezembro de 2004) e 15 dias no inverno (julho de 2005). As maiores diferenças ocorreram na estação chuvosa com $5,8^{\circ} \mathrm{C}(18$ de dezembro às 15:00 horas) e a estação seca, um gradiente de $3,8^{\circ} \mathrm{C}$ (15:00 horas), enquanto à noite a diferença não ultrapassava aos $3,0^{\circ} \mathrm{C}$.

Amorim (2005) ao analisar a intensidade da ilha de calor em Birigui, São Paulo, cidade com uma população de 94 mil habitantes, utilizaram para o registro da 
temperatura um transeto móvel, utilizando-se de termômetros digitais, com os sensores presos a uma haste de madeira com 1,5m de comprimento, acoplados na lateral de um veículo, totalizando 56 pontos de coletas.

As medições foram efetuadas em dezembro de 2004 e janeiro de 2005, entre 20:00 e 20:45 horas, por 8 dias representativos no verão. Esta pesquisa concluiu que Birigui apresenta características de um clima específico e durante os dias representativos de verão ficou comprovada a formação de ilhas de calor e de frescor. Os resultados possibilitaram identificar ilhas com intensidade máxima de $6,2^{\circ} \mathrm{C}$.

Silva et. al. (2002) analisaram o clima urbano de Penápolis, São Paulo, nos 31 dias do mês de julho de 1999, distribuídos em 7 pontos fixos dentro da área urbana (mini-abrigos/psicrômetros), com leituras realizadas entre 1:00 hora da madrugada até às 21:00 horas, com registros a cada 2:00 horas. Para os autores, a mancha urbana mostrou-se mais aquecida nas áreas mais densamente urbanizadas, representadas pela sede da Prefeitura, enquanto as menores foram registradas ao lado estação de tratamento de água. A ilha de calor ficou mais nítida, nos horários noturnos, a partir das 19:00 horas, atingindo o seu pico entre às 3:00 e 5:00 horas da manhã, com $8,0^{\circ} \mathrm{C}$. Nos demais horários, se identifica uma redução da intensidade média da ilha de calor, assim como os gradientes máximos de diferença, que não ultrapassaram os $7,0^{\circ} \mathrm{C}$.

Tavares et. al. (1995) investigaram as tendências à formação de ilha de calor em três cidades médias tropicais (Americana, Jales e Rio Claro) no período do inverno. Para isso foram desenvolvidos transetos móveis, em três horários, cortando as cidades em dois sentidos. Utilizando-se, para isso termistores acoplados a multímetros digitais; a velocidade do veículo não ultrapassava aos $30 \mathrm{~km} \cdot \mathrm{h}^{-1}$ e o tempo do percurso não ultrapassava 20 minutos. Em Jales e Rio Claro foram identificados contrastes térmicos, no período noturno, de $3,0^{\circ} \mathrm{C}$ e $5,0^{\circ} \mathrm{C}$, respectivamente. Em Americana, por problemas técnicos, não foi desenvolvido o transeto noturno. Porém, os autores comentam que, a despeito do sítio urbano da cidade, localizado num fundo de um vale (80 a 90 metros), a mesma não seria favorável à formação de ilha de calor noturna, sendo registrado o gradiente térmico máximo às $14: 00$ horas $\left(2,0^{\circ} \mathrm{C}\right)$.

Pinheiro e Amorim (2009) realizaram uma pesquisa durante 31 dias do mês de Julho de 2007, na cidade de Euclides da Cunha, São Paulo, utilizando para isto 2 pontos fixos com estações automáticas do tipo "Vantage PRO 2" da marca "Davis Instruments", instaladas na área rural (Sede do Parque Estadual Morro do Diabo, que se localiza no município de Teodoro Sampaio-SP) e na área urbana de Euclides 
da Cunha Paulista, entre 1:00 e 7:00 horas da manhã. Com base nos dados foi possível identificar que durante o predomínio de sistemas atmosféricos ideais permitiram melhor visualização das diferenças térmicas e higrométricas entre os dois ambientes. O estudo constatou que apesar da cidade de Euclides da Cunha Paulista ser considerada de pequeno porte, foram encontradas diferenças térmicas e higrométricas de grande magnitude, principalmente no período noturno. Tais diferenças térmicas chegaram a $11,7^{\circ} \mathrm{C}$. Muito embora, que a magnitude mais freqüente oscilou entre 2,0 e $4,0^{\circ} \mathrm{C}$ aquecimento noturno freqüente. As maiores diferenças térmicas e higrométricas foram encontradas nos dias $06 / 07 / 07\left(10,7^{\circ} \mathrm{C}\right.$ e $57,0 \%)$ e $07 / 07 / 07\left(11,7^{\circ} \mathrm{C}\right.$ e $\left.58,0 \%\right)$ às $1: 00$ hora. Já no horário das 7:00 horas as maiores diferenças foram encontradas nos dias 06/07/07 $\left(6,2^{\circ} \mathrm{C}\right.$ e $\left.31,0 \%\right), 07 / 07 / 07$ $\left(5,3^{\circ} \mathrm{C}\right.$ e $\left.25,0 \%\right)$ e $08 / 07 / 07\left(5,5^{\circ} \mathrm{C}\right.$ e $\left.25,0 \%\right)$.

Brandão (1996), em sua tese de doutorado sobre o clima urbano da cidade do Rio de Janeiro, Rio de Janeiro, estabeleceu sua metodologia com base na inter-relação dos parâmetros geoecológicos e dos atributos urbanos do sítio da cidade, a qual foi tratada em três níveis escalares distintos. $\mathrm{Na}$ escala local (cidade), realizaram-se experimentos em 34 pontos amostrais distribuídos em três transetos, partindo do centro da cidade em direção a Santa Cruz, Barra da Tijuca e Irajá. Constatou que a ilha de calor na cidade do Rio de Janeiro obedece a um deslocamento diuturno em conseqüência da taxa de aquecimento e de resfriamento, propiciada pelo grau de diferenciação de sítios e de intensidade de construções.

À tarde, Bangu (Zona Oeste), favorecido por seu sítio, detectou, às 15:00 horas, $4,2^{\circ} \mathrm{C}$ (intensidade máxima neste horário); já à noite, por volta das 21:00 horas, o deslocamento da Ilha de calor se processa em direção ao bairro de Santo Cristo, situado na área central da cidade, que apresenta o maior índice de densidade construída.

Num segundo nível de enquadramento escalar, a autora avaliou a influência dos maciços montanhosos, em especial a Serra da Carioca no campo térmico da cidade e, para isto, fez registros térmicos nesta área simultaneamente na baixada urbanizada. A área central da cidade mereceu um capítulo especial na tese pela autora com experimentos realizados em 15 pontos, divididos em ambientes de praças e ambientes edificados, cujos dados de temperatura foram correlacionados com os índices de SVF obtidos por fotografias tiradas nos pontos de medidas. Os resultados aqui obtidos também revelaram a existência de llha de calor de intensidade máxima de $4,2^{\circ} \mathrm{C}$, semelhante à encontrada para toda a cidade. Seu 
estudo resultou na proposição do mapa síntese das unidades mesoclimáticas urbana para a cidade do Rio de Janeiro.

Em decorrência da pesquisa desenvolvida por Brandão (1996) para a cidade do Rio de Janeiro, a mesma promoveu o surgimento de novas questões que alimentaram novas pesquisas de clima urbano desenvolvidas ao nível mesoclimático, com os trabalhos de Fialho (2002) para a Ilha do Governador e Lucena (2005) para a Zona Oeste do Rio de Janeiro; ao nível de bairros: Maracanã (BEZERRA; BRANDÃO, 1998), Méier (FRANÇA, 2003), Copacabana (MALHEIROS, 2006), Bangu (LUCENA, 2004), Jardim Botânico (BRANDÃO et. al., 2004) e Penha (PEREIRA; BRANDÃO, 2008).

Fialho (2002) analisou o clima urbano da Ilha do Governador, Rio de Janeiro, localiza-se na Baía de Guanabara. Desde a década de 1950, a população apresentou um significativo crescimento urbano. As alterações impingidas ao clima da Ilha do Governador-RJ (200 mil habitantes) refletem-se na configuração de valores térmicos. O estudo procurou concentrar-se em analisar a relação entre o uso do solo e os aspectos geoecológicos, enfatizando os atributos climáticos (térmico e hígrico), em situações sazonais de verão e inverno.

A pesquisa combinou três formas de abordagem: observações móveis e fixas; análise do comportamento térmico da temperatura do ar em 24 horas e o levantamento de inquéritos junto à população insulana. O levantamento do campo utilizou um termohigrômetro digital de leitura direta. As coletas por transetos móveis foram realizadas às 6:00; 13:00 e 21:00 horas, sob condições de massa tropical atlântica e massa polar atlântica. Foram realizados 4 transetos móveis, contendo 63 pontos, e cada percurso variou entre 9 e 12,5km, Quanto aos pontos fixos esses foram num total de 9, com leituras horárias entre às 8:00 e 20:00 horas.

As medidas itinerantes apresentaram o maior gradiente térmico horizontal às 13:00 horas, tanto no verão, quanto no inverno, com intensidade máxima de $4,5^{\circ} \mathrm{C}$ e $5,5^{\circ} \mathrm{C}$, respectivamente. Nesse mesmo horário, foram identificados mais de um núcleo de ilha de calor, e sempre sobre os sub-centros comerciais, tanto no verão quanto no inverno.

De acordo com os pontos fixos (8 pontos amostrais), o campo térmico apresentou elevados contrastes ao longo dos dias dos experimentos de campo, principalmente entre as 11:00 e 14:00 horas, tanto no verão quanto no inverno. A intensidade máxima do gradiente térmico registrado no verão foi da ordem de $4,9^{\circ} \mathrm{C}$, enquanto no inverno $6,1^{\circ} \mathrm{C}$, ambas registradas às $11: 00$ horas. Quanto à análise do 
comportamento térmico em 24 horas, entre a estação do Aeroporto Internacional do Rio de Janeiro (AIRJ) se observou uma tênue correlação entre o desvio padrão e o uso do solo. O ponto da Ribeira apresentou um desvio padrão menor que a estação do AIRJ, o que mostra que a relação entre uso e o armazenamento de energia é pertinente, ou seja, inércia térmica na Ribeira, mesmo esta estando situada próxima a um corpo líqüido. Contudo, essa relação foi verificada no inverno, enquanto no verão o comportamento foi inverso.

Em relação à análise dos inquéritos, foi possível observar a percepção da população, e os resultados mostraram uma correlação positiva, revelando também que as referências recorridas nas citações dos locais mais desconfortáveis e confortáveis do ponto de vista térmico foram às ruas e as vias de acesso principais.

Assim como o trabalho de Brandão (1996) proporcionou frutos, o mesmo ocorrera com Fialho (2002), que iniciou a desenvolver orientações de trabalhos na Zona Sul: Gávea e Lagoa Rodrigo de Freitas (POPE et. al. 2006) e Zona Norte: Maciço da Tijuca (IMBROISI et. al., 2006) e Alto rio Joana, englobando os bairros do Andaraí e Grajaú (FIALHO; IMBROISI, 2005 e ARRUDA et. al., 2006) e a cidade de São Gonçalo (CORRÊA, 2005).

Lucena (2005) procurou em seu trabalho de desvendar o clima urbano da Zona Oeste do Rio de Janeiro, local considerado por Brandão (1996) uma unidade mesoclimática da cidade, procurou aprofundar a análise do campo térmico. Neste sentido, a estratégia de abordagem foi dividida em dois momentos. O primeiro ligado a análise da série histórica da estação meteorológica de Bangu em comparação com a estação Praça XV, Campo dos Afonsos e Santa Cruz. A segunda estratégia foi a adoção de medidas móveis e fixas, no verão e no inverno.

De acordo com a série histórica, a temperatura média anual nas estações de Bangu (1922-1987) e Praça XV (1921-1990), apresentaram um acréscimo de até $1,0^{\circ} \mathrm{C}$ na média anual. Em relação aos pontos fixos (Sepetiba, Santa Cruz, Barra de Guaratiba, Campo Grande, Bangu e Realengo) com leituras horárias entre 8:00 e 20:00 horas, Campo Grande foi o local com maior intensidade da ilha de calor, com $6,0^{\circ} \mathrm{C}$, tanto no verão (26/1/2004), quanto no inverno (29/7/2004), em horários distintos, no verão o pico foi verificado entre 16:00 e 20:00 horas, e no inverno entre 13:00 e 14:00 horas. Já com base nos registros dos 3 transetos móveis $(6: 00,13: 00$ e 20:00 horas), também realizados nos mesmos dias das leituras dos pontos fixos, abrangeu 34 áreas amostrais. 
No verão, primeiro horário atingiu uma ilha de calor de $3,0^{\circ} \mathrm{C}$ (Estrada de Sepetiba), no segundo horário a intensidade alcança $5,3^{\circ} \mathrm{C}$ (Estação Ferroviária de Bangu) e à noite não ultrapassa aos $3,0^{\circ} \mathrm{C}$, exceto o ponto $3 \mathrm{em}$ Sepetiba que registra $4,8^{\circ} \mathrm{C}$. No inverno, as intensidades em todos os horários foram superiores, de manhã $\left(4,0^{\circ} \mathrm{C}\right)$ e tarde $\left(7,2^{\circ} \mathrm{C}\right)$ e noite $\left(5,0^{\circ} \mathrm{C}\right)$.

Vianna (2006) como objetivo de investigar as características da temperatura e umidade relativa do ar intra-urbana e da zona rural em Teodoro Sampaio, São Paulo, localizado, no extremo oeste do Estado de São Paulo. Em 2000, tal cidade apresentava uma população total de 20.003 habitantes, sendo 15.922 vivendo na zona urbana e 4.081, na zona rural.

A coleta de dados meteorológicos utilizou-se tanto medidas móveis quanto fixas. As medidas fixas utilizaram mini-abrigos meteorológicos equipados com psicrômetros e distribuídos em sete pontos, sendo seis na área urbana e um na área rural. Os registros foram realizadas às 7:00, 9:00, 15:00 e 21:00 horas em 13 dias de janeiro de 2005 (verão); e 8 dias em julho de 2005 (inverno). Quanto ao transeto móvel, o sensor foi instalado a uma haste de madeira, totalizando 17 pontos de coleta entre as 20:30 e 21:00 horas.

No verão, o cume da ilha de calor coincide com o horário das 15:00 horas, alcançando o seu pico, no dia 18 de janeiro, com $5,4^{\circ} \mathrm{C}$. Nos horários de 7:00 e 21:00 horas, a ilha de calor foi identificada nas áreas densamente construídas, pouco arborizada e nas áreas densamente ocupadas com vegetação arbórea de grande porte. No inverno, as maiores magnitudes também foram observadas às 15:00 horas, embora os valores apresentados durante a manhã (7:00 horas) e noite (21:00 horas) tenham sido muito similares ao valor encontrado às 15:00 horas.

Os fatores que favoreceram as diferenças térmicas e higrométricas foram: a precipitação abundante, a densidade de construções e os índices de vegetação arbórea e rasteira. A chuva proporcionou dois padrões de distribuição da temperatura e umidade e foi o fator que determinou o ritmo diário desses elementos. A densidade de construções favoreceu na determinação das magnitudes térmicas e higrométricas, entre os pontos. A vegetação rasteira (gramados e jardins) associada ao orvalho e à chuva foi um fator decisivo no comportamento térmico e higrométrico, principalmente, durante a manhã e fins de tarde.

Tarifa (1977) comparou temperatura e umidade na área urbana e rural de São José dos Campos, São Paulo, utilizou como método psicrômetros em pontos fixos, nos quais as leituras foram realizadas no verão. Concluiu que a zona urbana acusou 
valores de temperatura mais elevados que a zona rural $\left(1,0^{\circ} \mathrm{C}\right.$ a $\left.3,4^{\circ} \mathrm{C}\right)$, sob o domínio dos sistemas atmosféricos extratropicais (Frente Polar Atlântica e Massa Polar Atlântica). Por fim, a área urbana de São José dos Campos acusou a existência de uma nítida influência na variação diurna da temperatura e umidade, em relação à área rural. Constataram-se diferenças quantitativas e a existência do fenômeno da "ilha de calor" para uma cidade média do trópico brasileiro.

Amorim (2000) em sua tese de doutorado verificou a influência da urbanização sobre a temperatura do ar e da umidade relativa do ar na cidade de Presidente Prudente, São Paulo. A autora conjugou em seu estudo duas formas de observação. A primeira foi à estatística de série temporal (1969-1998), referente à análise dos dados da estação meteorológica da Faculdade de Ciência e Tecnologia da Universidade Estadual Paulista (FCT-UNESP). A segunda utilizou experimentos de campo em pontos fixos, num total de 12 pontos de mensuração, com leituras horárias das 7:00 às 18:00 horas, durante 29 dias nos meses de Julho de 1998 e janeiro de 1999.

As análises estatísticas demonstram uma elevação da temperatura (média, mínima e máxima), segundo a autora provocada pelo processo de crescimento da cidade, que incorporou a estação meteorológica à malha urbana. Quanto à pluviosidade, a curva de tendência dos totais anuais não demonstra uma relação positiva definida de acordo com o crescimento da cidade, conforme verificado em relação à temperatura.

Para ela este fato é devido, provavelmente, à grande variabilidade sazonal regida pelos sistemas sinóticos regionais. Quanto às observações dos pontos fixos, no inverno as ilhas de calor encontradas apresentaram magnitude média $\left(2,0^{\circ} \mathrm{C}\right.$ a $4,0^{\circ} \mathrm{C}$ ), e os horários das 7:00 e das 18:00 horas apresentaram as ilhas de calor de maior intensidade. No verão a magnitude média foi entre $4,0^{\circ} \mathrm{C}$ e $6,0^{\circ} \mathrm{C}$, observadas entre às 10:00 e 16:00 horas, período de maior insolação.

Pezzuto et. al. (2006) realizaram para a cidade de Campinas, São Paulo, com um contingente populacional próximo a 1 milhão de habitantes, mensurações do campo térmico, para um segmento da cidade por meio do transeto móvel em um percurso de 20km, com 18 pontos nos horários das 9:00, 15:00 e 21:00 horas entre os dias 28-30 de Julho, 1-3 de agosto e 8 de agosto de 2004. Às 9:00 horas a intensidade da ilha de calor foi inferior a $2,0^{\circ} \mathrm{C}$.

Tavares (2002) analisou a diferenciação da temperatura do ar entre o campocidade em Sorocaba, São Paulo, entre 1987 e o primeiro semestre de 1990. As leituras respeitaram os três horários padrões da estação meteorológica (9:00, 15:00 e 21:00 horas). De acordo com o autor o ano de 1987 a cidade refletiu a sua influência no 
mecanismo urbano na produção do clima, comparado à zona rural, com a identificação de ilhas de calor noturnas mais evidentes no inverno, atingiram até $5,3^{\circ} \mathrm{C}$. No ano seguinte a diferença média entre a cidade e o campo à noite era em média de $1,0^{\circ} \mathrm{C}$.

Nos anos de 1989 e 1990, em muitas situações as diferenças ultrapassaram aos $10,0^{\circ} \mathrm{C}$. Mas estes valores instigaram o pesquisador a questionar a origem de tal diferença. Tanto assim, que através da análise rítmica para os referidos anos, foi possível confirmar que as elevadas diferenças térmicas entre a estação urbana e rural foram provocadas pela mudança do tempo e não pelo mecanismo urbano.

Às 15:00 horas os pontos 1, 2, 9 e 10, locais de grande densidade de prédios e perto de um vale apresentaram uma ilha de calor de forte intensidade, pois são as regiões que há uma maior exposição à radiação solar pela tarde. À noite, as localidades mais quentes na área estudada, com uma ilha de calor de intensidade alta foram os pontos 9 e 10, que apresentam ocupação densa e forte impermeabilidade do solo ou de intensa verticalidade, ambos com coberta verde escassa e intenso tráfico de veículo, provavelmente, contribuem para o aumento da intensidade da ilha de calor noturna de $2,9^{\circ} \mathrm{C}$.

Donato (2009) ao estudar o campo térmico de Barbosa Ferra, Paraná, com uma população de 13.655 habitantes (60,0 da população é urbana) localizada na mesorregião Centro-Oeste. Para coletar os dados climáticos foram utilizados: termohigrômetro, luxímetro e anemômetro, durante 5 dias no inverno de 2008, todos marcados às 15:00h em 3 diferentes pontos. O ponto 1 localiza-se na área rural da cidade onde não há nenhum tipo de pavimentação nem moradias. Próximos a esse ponto $(345 \mathrm{~m})$ com cerca de $40 \mathrm{~m}$ de distância há uma pequena mata cercada pela agricultura moderna e temporária. O ponto $2(331,4 \mathrm{~m})$ é uma transição entre a área urbana e a rural localizado na periferia da cidade. Esse contato rural/urbano é marcado por pouca pavimentação e média densidade arbórea. O ponto 3 localizado no centro da cidade tem alto nível de construções, movimento de veículos e pessoas. Nesse local $(343,8 \mathrm{~m})$ encontramos pouca e má distribuída arborização de pequeno porte. Como conclusão o autor, semelhantes às "grandes" cidades. A área urbana apresentou uma média de $2,26^{\circ} \mathrm{C}$ a mais em relação à área rural. Já em relação à umidade relativa ocorreu o inverso com uma média de $4,2 \%$ maior no campo.

Mendonça (1994), ao desenvolver sua tese de doutorado, procurou correlacionar os aspectos geoecológicos e os fatos urbanos a fim de dividir a cidade em ambientes mais ou menos homogêneos, objetivando realizar levantamentos de 
campo. A aplicação desta metodologia ao estudo de campo térmico da cidade de Londrina-PR possibilitou a identificação de ilhas de calor de $10,0^{\circ} \mathrm{C}$ a $13,0^{\circ} \mathrm{C}$ de intensidade, ocorrendo notadamente no período noturno, tanto na estação de inverno, quanto na de verão, apresentaram-se mais intensas quando a área se encontra sob o domínio do sistema tropical atlântico e continental, e menos sob o domínio da MPA, conclui-se que as ilhas de frescor se formaram no período vespertino e matutino.

Pertschi (2005) analisando o campo térmico de São José dos Pinhais, Paraná, com a utilização de 8 pontos fixos (mini-abrigos/sensores HOBO H8RH/TEMP) durante 32 dias (entre 4 de dezembro de 2004 e 5 de janeiro de 2005) identificou a ocorrência de ilhas de calor, na área urbana da cidade, com intensidade máxima de $7,0^{\circ} \mathrm{C}$ entre a área industrial e residencial, sob ação da massa polar atlântica, nos dias 19 e 27 de dezembro de 2004.

$\mathrm{E}$ picos com intensidade média, $5,0^{\circ} \mathrm{C}$, entre o ponto 1 e 3 , ambos na área residencial, ocorreram sob ação da massa polar velha. Um fato curioso observado no trabalho é a não localização do pico da ilha de calor na área central. Esse fato pode ser explicado pelo padrão de ocupação do centro de São José dos Pinhais, com edificações térreas, não verticalizadas, e com grande porcentagem de áreas verdes e livres.

Sezerino e Monteiro (1990) realizaram um estudo do campo térmico na cidade de Florianópolis, Santa Catarina, utilizando mini-abrigos em 3 experimentos. No primeiro, utilizaram a técnica de transetos fixos com 10 pontos de coleta em um segmento linear, que teve duração de 24 horas, com início às 12:00 horas do dia 23 de maio de 1987 até às 12:00 horas do dia seguinte, com registros a cada 3 horas. De acordo com as observações, a ilha de calor se tornou mais nítida à noite, com uma intensidade de $4,0^{\circ} \mathrm{C}$ entre o posto da Ceisa Center e o posto do Morro da Cruz, todavia não podemos desconsiderar o efeito topográfico.

O segundo experimento em 20 pontos foi realizado no corpo principal da cidade, com medidas em 3 horários (9:00, 15:00 e 21:00 horas), realizado no dia e de junho de 1987 , identificou o pico da ilha de calor às $15: 00$ horas, com $3,0^{\circ} \mathrm{C}$. Já o terceiro, na área central da cidade, manteve o mesmo número de pontos do segundo experimento e os mesmos intervalos para as leituras térmicas, fora realizado no dia 26 de junho de 1987, mensurações tanto ao nível da rua, como nos terraços dos prédios da área central. De manhã a diferença em superfície era de $1,6^{\circ} \mathrm{C}$, pouco aumentou às $15: 00$ horas, com $2,0^{\circ} \mathrm{C}$ e à noite o gradiente continuou decrescendo, alcançando a $0,4^{\circ} \mathrm{C}$, Por sua vez, a diferença vertical apresentou uma 
diferença maior, sendo $2,0^{\circ} \mathrm{C}$ pela manhã, $3,0^{\circ} \mathrm{C}$ à tarde e $0,7^{\circ} \mathrm{C}$ à noite. Nas conclusões, os autores alegam o pequeno número de episódios analisados, mas confirmaram que há fortes indícios de formação de ilhas de calor em Florianópolis.

Mendonça (2002) em seu trabalho de doutoramento realizou um estudo do clima urbano da região conurbada de Florianópolis, Santa Catarina, com intuito de compreender a influência dos fatores geo-ecológicos e da urbanização na variação temporal e espacial da temperatura do ar, umidade relativa do ar e os ventos. Para isto, foram coletadas informações meteorológicas em várias localidades da região, utilizando-se equipamento digital para registro da temperatura e umidade relativa do ar, além de observações sensíveis para outros elementos como direção e intensidade do vento, nebulosidade e tráfego.

Os levantamentos efetuados durante quatro dias, um em cada estação do ano, buscando sondar diferentes tipos de tempo. O exame comparativo do material cartográfico demonstrou significativa conservação de calor nos locais com ocupação mais verticalizada, adensada e de maior tráfego.

Não se observou a formação de uma ilha de calor contínua, mas de um "arquipélago", o que reflete bem o caráter multinucleado da urbanização, derivado, em parte, da compartimentação morfológica do sítio urbano. As maiores diferenças de temperatura, caracterizaram ilhas de calor intensas, ocorreram no setor central da região às 6:00 horas, horário que ocorre as temperaturas mínimas, no levantamento episódico de abril, sob domínio polar foi identificado diferenças superiores a $7,0^{\circ} \mathrm{C}$; em 22 de julho com $3,0^{\circ} \mathrm{C}$ e $9,0^{\circ} \mathrm{C}$ em outubro. Em situações de transição, prenúncio frontal e condições de tempo de verão, as maiores diferenças foram registradas às 15:00 horas, porém não alcançando intensidade superior a $5,0^{\circ} \mathrm{C}$.

Collischonn (2007) realizou um experimento de campo, em Santa Cruz do Sul, Rio Grande do Sul, entre os dias 12 e 13 de maio de 2006, ao longo e 24 horas, O início da mensuração foi às 15:00 horas, com intervalos de 3:00 horas, em 4 pontos fixos (sensores MINIPA-MT242) distribuídos ao longo de um perfil. A partir dos resultados, nota-se que a área central é mais quente e menos úmida que os subúrbios até as 9:00 horas. À meia-noite ocorre uma relativa isotermia.

Às 3:00 horas da madrugada, os postos 1, 2 e 3 apresentam novamente um ligeiro aumento de temperatura, enquanto que o posto 4 registra resfriamento contínuo, o que parece indicar o efeito do vento de sudeste, Já às 9:00 horas de sábado, enquanto os postos 1 e 4 registram maior temperatura por estarem recebendo radiação solar direta, os da área central ainda permanecem registrando 
menor temperatura. A umidade relativa do ar, no geral, mostra comportamento inverso ao da temperatura. Ao longo destes registros identificou que o gradiente térmico foi maior às $21: 00$ horas, com $6,0^{\circ} \mathrm{C}$. No registro das $24: 00$ horas a diferença reduziu para $0,7^{\circ} \mathrm{C}$, voltando a aumentar às $3: 00$ horas e se mantendo até às 6:00 horas com intensidade acima dos $4,0^{\circ} \mathrm{C}$.

Danni (1980) analisou a ilha térmica de Porto Alegre, ao longo de 35 pontos móveis, nos horários de 9:00,15:00 e 21:00 horas durante 15 dias dos meses de maio e Junho de 1979. Constatou que dos 15 dias analisados apenas 2 não apresentaram ilhas de calor, sendo estes aos domingos, dias em que as indústrias diminuem seu ritmo de produção. Em seu estudo a autora destaca a importância da topografia nas diferenças térmicas.

Danni (1987), em sua dissertação de mestrado, procurou analisar o campo térmico da cidade de Porto Alegre, Rio Grande do Sul, e para isso utilizou 32 áreas de mensuração, que apresentaram duas leituras diárias (9:00 e 21:00 horas), no mês de janeiro. Com os resultados obtidos foi possível constatar a existência de ilhas de frescor e úmidas, como também grandes contrastes térmicos de até $10,0^{\circ} \mathrm{C}$.

Saydelles (2005) analisou o campo térmico e as ilhas de calor urbano de Santa Maria, Rio Grande do Sul, cidade com cerca de 260 mil habitantes e seu entorno, utilizando uma associação de técnicas (sensoriamento remoto e pontosfixos) relacionando seus comportamentos térmicos e espaciais através da interação das variáveis urbanas e naturais, frente à imposição de tipos de tempos oriundos de condições sinóticas de fase pré-frontal e de domínio polar, no inverno.

No primeiro dia dos experimentos de campo (04/08/2004), o comportamento térmico da cidade ficou condicionado à circulação atmosférica de fase pré-frontal, com elevado aquecimento basal e do ar, e, sobretudo, à ação do "vento norte" de forte intensidade, que atuou como dispersor e homogeneizador das respostas térmicas dos elementos urbanos e naturais que compõem o quadro geográfico da área de estudo. Durante a maior parte do dia, as áreas mais abertas e amplas apresentaram as maiores temperaturas, pois além de estarem mais expostas ao "Vento Norte" mais aquecido, permitiam a incidência solar direta em suas superfícies.

As áreas situadas no extremo oeste da cidade registraram as temperaturas mais altas em boa parte do dia, reflexo de suas altimetrias mais baixas e morfologia mais suave em forma de "coxilhas". Já a área mais central da cidade, até ao meio-dia, apresentou uma "faixa térmica" de menores temperaturas, estendida no sentido $\mathrm{N}-\mathrm{S}$. Durante à tarde, em virtude do maior aquecimento dos materiais urbanos, no bairro 
Centro houve a formação de uma pequena "ilha de calor urbano" de fraca intensidade, apenas $2,0^{\circ} \mathrm{C}$. No dia 10/08/2004, sob domínio da MPA, responsável pelas baixas temperaturas, tempo bom, calmaria, céu limpo, e por conseqüência, máxima insolação.

Este tipo de tempo, aliado às características do sítio, uso e funções urbanas, densidades populacionais, foi responsável pela formação de ilhas de calor urbano de forte intensidade em todos os horários de observação e nos mais diversos locais, muitas vezes não coincidindo, conforma literatura sobre a área central de negócios da cidade. No primeiro horário de observação, houve a formação de uma ilha de calor de $5,0^{\circ} \mathrm{C}$ de intensidade, no bairro $\mathrm{km} \mathrm{3,} \mathrm{certamente} \mathrm{em} \mathrm{função} \mathrm{de} \mathrm{sua} \mathrm{altitude} \mathrm{mais} \mathrm{elevada} \mathrm{e} \mathrm{pela}$ posição do Sol (a leste), privilegiando os bairros situados nesta zona da cidade.

Às 12:00 horas houve o registro da maior amplitude térmica centro-periferia de $10,0^{\circ} \mathrm{C}$, mesmo valor encontrado em outros estudos nas mais diversas capitais do mundo, e desta vez, coincidindo com o modelo proposto por Oke (1982), onde o cume da ilha de calor se localizou na área mais densamente urbanizada (CBD). Durante à tarde (15:00 e 18:00 horas) também foi registrado a formação do fenômeno no CDB, porém, com diferentes intensidades $\left(4,0^{\circ} \mathrm{C}\right.$ e $2,0^{\circ} \mathrm{C}$, respectivamente).

Às 21:00 horas a configuração térmica foi a mais surpreendente, revelando a importância da movimentação diária aparente que o Sol realiza de Leste para Oeste na definição do campo térmico urbano. Assim, em função da trajetória do Sol, as áreas situadas a leste, que têm elevada densidade vegetal e baixa urbanização, resfriaram mais rápido e durante a noite registraram uma significativa "Ilha de Frescor Urbano" de com a magnitude de $-4,0^{\circ} \mathrm{C}$.

Em contraponto, a área mais central da cidade, que apresenta a maior densidade populacional e urbana e menor presença de vegetação, estava em pleno processo de liberação do calor armazenado durante o dia e registrou a formação de uma forte ilha de calor com intensidade de $4,0^{\circ} \mathrm{C}$. Este fato coincide com os resultados obtidos na maioria dos estudos realizados, os quais revelam que a lha de calor destaca-se melhor à noite, sob as mesmas condições de tempo do dia estudado, como o modelo proposto por Oke (1982). 
Tabela 8. Observações realizadas por meio de transeto (Fixos e móveis) no Brasil.

\begin{tabular}{|c|c|c|c|c|c|c|c|c|c|c|c|c|}
\hline \multirow[t]{2}{*}{ Cidade } & \multirow[t]{2}{*}{ Latitude } & \multirow[t]{2}{*}{ Autor } & \multirow[t]{2}{*}{$\begin{array}{l}\text { Pop, } \\
\left(\times 10^{3}\right)\end{array}$} & \multicolumn{2}{|c|}{$\begin{array}{l}\text { Ilha de calor } \\
\text { Máxima }\end{array}$} & \multirow[t]{2}{*}{$\begin{array}{l}\text { Intensidade } \\
\text { média da I.C }\end{array}$} & \multirow[t]{2}{*}{$\begin{array}{c}\mathrm{N}^{\circ} \text { de dias } \\
\text { de } \\
\text { coleta }\end{array}$} & \multirow{2}{*}{$\begin{array}{c}\mathrm{N}^{0} \text { de } \\
\text { pontos } \\
\text { de } \\
\text { coleta }\end{array}$} & \multirow[t]{2}{*}{$\begin{array}{l}\text { Método } \\
\text { de coleta }\end{array}$} & \multirow[t]{2}{*}{ Horários } & \multirow[t]{2}{*}{$\begin{array}{l}\text { Tempo } \\
\text { (minutos) }\end{array}$} & \multirow[t]{2}{*}{$\begin{array}{l}\text { Velocidade, } \\
\quad\left(\mathrm{km} \cdot \mathrm{h}^{-1}\right)\end{array}$} \\
\hline & & & & Diurna & Noturna & & & & & & & \\
\hline Belém & $1^{\circ} \mathrm{S}$ & Nascimento, 1995 & 712 & $2,0^{\circ} \mathrm{C}$ & - & $1,0^{\circ} \mathrm{C}$ & 4 & 16 & Pontos Fixos & $\begin{array}{l}\text { 6-9-12-15- } \\
18-21 \text { hs, }\end{array}$ & - & - \\
\hline Bragança & $2^{\circ} \mathrm{S}$ & Costa e Mattos, 1998 & 50 & $1,0^{\circ} \mathrm{C}$ & - & - & 7 & 2 & Pontos Fixos & - & - & - \\
\hline Fortaleza & $2^{\circ} \mathrm{S}$ & Moura et. al., 2008 & 2473 & $5,0^{\circ} \mathrm{C}$ & - & - & 2 & 12 & Pontos Fixos & - & - & - \\
\hline Manaus & $3^{\circ} \mathrm{S}$ & Aguiar, 1995 & 1600 & $3,6^{\circ} \mathrm{C}$ & - & - & 2 & 10 & Pontos Fixos & $\begin{array}{c}8-14-21 \\
\text { horas }\end{array}$ & - & - \\
\hline Tangará da Serra & $10^{\circ} \mathrm{S}$ & Zamparoni, 1995 & 39 & $\begin{array}{c}3,6^{\circ} \mathrm{C} \\
\text { inverno }\end{array}$ & - & - & 6 & 25 & $\begin{array}{c}1 \text { Transeto } \\
\text { Móveis }\end{array}$ & $\begin{array}{c}8-14-20 \\
\text { horas }\end{array}$ & - & - \\
\hline Salvador & $12^{\circ} \mathrm{S}$ & Sampaio, 1981 & 2000 & - & $\begin{array}{c}6,0^{\circ} \mathrm{C} \\
\text { inverno }\end{array}$ & - & 2 & 11 & Pontos Fixos & - & - & - \\
\hline Barra do Bugre & $15^{\circ} \mathrm{S}$ & Zamparoni, 1995 & 18 & $\begin{array}{c}5,4^{\circ} \mathrm{C} \\
\text { inverno }\end{array}$ & - & - & 6 & 14 & $\begin{array}{l}1 \text { Transeto } \\
\text { Móveis }\end{array}$ & $\begin{array}{c}8-14-20 \\
\text { horas }\end{array}$ & - & - \\
\hline Cuiabá & $15^{\circ} \mathrm{S}$ & Maitelli, 1994 & 500 & $\begin{array}{c}3,4^{\circ} \mathrm{C} \\
\text { inverno }\end{array}$ & $\begin{array}{l}5,0^{\circ} \mathrm{C} \\
\text { verão }\end{array}$ & $\begin{array}{c}2,7^{\circ} \mathrm{C} \\
\text { inverno }\end{array}$ & - & 10 & Pontos Fixos & $\begin{array}{c}6-14-20 \\
\text { horas }\end{array}$ & - & - \\
\hline Cuiabá & $15^{\circ} \mathrm{S}$ & Maitelli et, al, 2003 & 544 & - & $\begin{array}{c}5,7^{\circ} \mathrm{C} \\
\text { inverno }\end{array}$ & - & - & 76 & $\begin{array}{c}1 \text { Transeto } \\
\text { móvel }\end{array}$ & $\begin{array}{c}\text { 7-13-19 } \\
\text { horas }\end{array}$ & 50 & 40 \\
\hline Várzea Grande & $15^{\circ} \mathrm{S}$ & Maitelli et. al., 2003 & 254 & - & $\begin{array}{c}7,0^{\circ} \mathrm{C} \\
\text { inverno }\end{array}$ & - & - & 45 & $\begin{array}{l}1 \text { Transeto } \\
\text { Móvel }\end{array}$ & $\begin{array}{c}\text { 7-13-19 } \\
\text { horas }\end{array}$ & - & - \\
\hline Rondonópolis & $16^{\circ} \mathrm{S}$ & Sette, 1996 & 126 & $\begin{array}{c}4,8^{\circ} \mathrm{C} \\
\text { primav. }\end{array}$ & - & - & - & 11 & Pontos Fixos & $\begin{array}{c}6: 30-13-20 \\
\text { horas }\end{array}$ & - & - \\
\hline Belo Horizonte & $19^{\circ} \mathrm{S}$ & Assis, 2001 & 2000 & $\begin{array}{c}4,7^{\circ} \mathrm{C} \\
\text { inverno }\end{array}$ & - & - & 1 & 16 & Pontos Fixos & - & - & - \\
\hline Campo Grande & $20^{\circ} \mathrm{S}$ & $\begin{array}{c}\text { Anunciação e } \\
\text { Sant'anna Neto, } \\
2002\end{array}$ & 600 & $10,0^{\circ} \mathrm{C}$ & - & - & 3 & 8 & Pontos Fixos & $\begin{array}{c}7: 30-9-12- \\
15-18-21 \\
\text { horas }\end{array}$ & - & - \\
\hline Juiz de Fora & $21^{\circ} \mathrm{S}$ & Martins, 1996 & 400 & $\begin{array}{l}12,8^{\circ} \mathrm{C} \\
\text { inverno }\end{array}$ & - & - & 2 & 6 & Pontos Fixos & $\begin{array}{c}6 \text { às } 21 \text { a } \\
\text { cada } 3 \\
\text { horas }\end{array}$ & - & - \\
\hline Guararapes & $21^{\circ} \mathrm{S}$ & $\begin{array}{c}\text { Minaki e Amorim, } \\
2005 \\
\end{array}$ & 30 & $\begin{array}{l}5,8^{\circ} \mathrm{C} \\
\text { verão }\end{array}$ & - & - & 30 & 3 & Pontos Fixos & $\begin{array}{c}9-15 \text { e } 21 \\
\text { horas }\end{array}$ & - & - \\
\hline Birigui & $21^{\circ} \mathrm{S}$ & Amorim, 2005 & 94 & - & $\begin{array}{c}6,2^{\circ} \mathrm{C} \\
\text { inverno } \\
\end{array}$ & - & 8 & 56 & $\begin{array}{c}1 \text { Transeto } \\
\text { Móvel }\end{array}$ & $\begin{array}{l}20: 00 \\
\text { horas }\end{array}$ & 45 & 30 \\
\hline Penápolis & $21^{\circ} \mathrm{S}$ & Silva et. al., 2002 & 59 & - & $\begin{array}{c}8,0^{\circ} \mathrm{C} \\
\text { inverno }\end{array}$ & - & 31 & 7 & Pontos Fixos & $\begin{array}{c}1-3-5-7-9- \\
11-13-15-15- \\
19-21 \text { horas }\end{array}$ & - & - \\
\hline
\end{tabular}




\begin{tabular}{|c|c|c|c|c|c|c|c|c|c|c|c|c|}
\hline Jales & $22^{\circ} \mathrm{S}$ & Tavares et. al. (1995) & 48 & - & $3,0^{\circ} \mathrm{C}$ & - & 1 & - & $\begin{array}{l}1 \text { Transeto } \\
\text { Móvel }\end{array}$ & $\begin{array}{l}6-13 \text { e } 20 \\
\text { horas }\end{array}$ & $20-30$ & 30 \\
\hline Amaericana & $22^{\circ} \mathrm{S}$ & Tavares et. al. (1995) & 200 & $2,0^{\circ} \mathrm{C}$ & - & - & 1 & - & $\begin{array}{l}1 \text { Transeto } \\
\text { Móvel }\end{array}$ & $\begin{array}{r}6-13 \text { e } 20 \\
\text { horas } \\
\end{array}$ & $20-30$ & 30 \\
\hline Rio Claro & $22^{\circ} \mathrm{S}$ & Tavares et. al. (1995) & 180 & - & $5,0^{\circ} \mathrm{C}$ & - & 1 & - & $\begin{array}{l}1 \text { Transeto } \\
\text { Móvel }\end{array}$ & $\begin{array}{l}6-13 \text { e } 20 \\
\text { horas }\end{array}$ & $20-30$ & 30 \\
\hline Euclides da Cunha & $22^{\circ} \mathrm{S}$ & $\begin{array}{c}\text { Pinheiro e Amorim, } \\
2009\end{array}$ & 10 & - & $11,7^{\circ} \mathrm{C}$ & - & 30 & 2 & Pontos Fixos & 1 às $7 \mathrm{hs}$ & - & - \\
\hline Rio de Janeiro & $22^{\circ} \mathrm{S}$ & Brandão, 1996 & 5000 & $4,2^{\circ} \mathrm{C}$ & - & - & 4 & 34 & Pontos Fixos & $\begin{array}{c}7-13 \text { e } 20 \\
\text { horas }\end{array}$ & - & - \\
\hline $\begin{array}{c}\text { Ilha do } \\
\text { Governador-RJ }\end{array}$ & $22^{\circ} \mathrm{S}$ & Fialho, 2002 & 200 & $\begin{array}{c}5,5^{\circ} \mathrm{C} \\
\text { inverno }\end{array}$ & - & - & 2 & 63 & $\begin{array}{l}4 \text { Transetos } \\
\text { Móveis }\end{array}$ & $\begin{array}{l}6-13 \text { e } 20 \\
\text { horas }\end{array}$ & 50 & 50 \\
\hline Bangu-RJ & $22^{\circ} \mathrm{S}$ & Lucena, 2005 & & & & & & & & & & \\
\hline Teodoro Sampaio & $22^{\circ} \mathrm{S}$ & Vianna, 2006 & 20 & $\begin{array}{l}5,4^{\circ} \mathrm{C} \\
\text { verão }\end{array}$ & - & - & 21 & 17 & $\begin{array}{l}1 \text { Transeto } \\
\text { Móvel }\end{array}$ & $7-9-15-21$ & 30 & 30 \\
\hline $\begin{array}{l}\text { Presidente } \\
\text { Prudente }\end{array}$ & $22^{\circ} \mathrm{S}$ & Amorim, 2000 & 200 & $\begin{array}{l}6,0^{\circ} \mathrm{C} \\
\text { verão }\end{array}$ & - & - & 29 & 12 & Pontos Fixos & $\begin{array}{c}7 \text { às } 18 \\
\text { horas }\end{array}$ & - & - \\
\hline $\begin{array}{c}\text { São José dos } \\
\text { Campos }\end{array}$ & $23^{\circ} \mathrm{S}$ & Tarifa, 1977 & 150 & $\begin{array}{l}3,2^{\circ} \mathrm{C} \\
\text { verão }\end{array}$ & - & - & 7 & 8 & Pontos Fixos & $\begin{array}{c}9-11-13- \\
15-17 \\
\end{array}$ & - & - \\
\hline Campinas & $23^{\circ} \mathrm{S}$ & Pezzuto et. al., 2006 & 1000 & - & $2,9^{\circ} \mathrm{C}$ & - & 1 & 18 & $\begin{array}{l}1 \text { Transeto } \\
\text { Móvel }\end{array}$ & $9-15-21$ & 60 & 50 \\
\hline Londrina & $23^{\circ} \mathrm{S}$ & Mendonça, 1994 & 450 & - & $\begin{array}{c}10,0^{\circ} \mathrm{C} \\
\text { verão- } \\
\text { inverno }\end{array}$ & - & 4 & 1 & $\begin{array}{c}\text { Pontos Fixos } \\
2 \text { Transetos } \\
\text { Móveis }\end{array}$ & $\begin{array}{c}\text { 6-9-15-21 } \\
\text { horas }\end{array}$ & - & - \\
\hline Sorocaba & $23^{\circ} \mathrm{S}$ & Tavares, 2002 & 450 & - & $\begin{array}{l}10,0^{\circ} \mathrm{C} \\
\text { inverno }\end{array}$ & - & 2 & $\begin{array}{c}3,5 \text { anos } \\
1,275 \\
\end{array}$ & Pontos Fixos & $\begin{array}{c}9-15-21 \\
\text { horas }\end{array}$ & - & - \\
\hline Barbosa Ferraz & $24^{\circ} \mathrm{S}$ & Donato, 2009 & 13 & - & & $2,6^{\circ} \mathrm{C}$ & 3 & 5 & Pontos Fixos & 15 horas & - & - \\
\hline $\begin{array}{l}\text { São José dos } \\
\text { Pinhais }\end{array}$ & $25^{\circ} \mathrm{S}$ & Pertschi, 2005 & 205 & $\begin{array}{l}7,0^{\circ} \mathrm{C} \\
\text { verão }\end{array}$ & - & - & 32 & 8 & Pontos Fixos & $\begin{array}{l}\text { Medidas } \\
\text { horárias }\end{array}$ & - & - \\
\hline Florianópolis & $27^{\circ} \mathrm{S}$ & $\begin{array}{c}\text { Sezerino e Monteiro, } \\
1990\end{array}$ & 300 & - & $\begin{array}{c}4,4^{\circ} \mathrm{C} \\
\text { inverno }\end{array}$ & - & 1 & 10 & Pontos Fixos & $\begin{array}{l}12-15-18- \\
21-24-3-6- \\
9-12 \text { horas }\end{array}$ & - & - \\
\hline Santa Cruz do Sul & $29^{\circ} \mathrm{S}$ & Collischonn, 2007 & 107 & - & $\begin{array}{l}6,0^{\circ} \mathrm{C} \\
\text { outono }\end{array}$ & - & 6 & 1 & Pontos fixos & $\begin{array}{c}15-18-21- \\
3-6-9-12 \\
\text { horas }\end{array}$ & - & - \\
\hline Porto Alegre & $30^{\circ} \mathrm{S}$ & Danni, 1980 & 1000 & - & - & $4,0^{\circ} \mathrm{C}$ & 15 & 35 & Pontos Fixos & $9-15-21$ & - & - \\
\hline Porto Alegre & $30^{\circ} \mathrm{S}$ & Danni, 1987 & 1200 & $\begin{array}{l}10,0^{\circ} \mathrm{C} \\
\text { verão }\end{array}$ & - & - & 30 & 32 & Pontos Fixos & $\begin{array}{l}9 \text { e } 21 \\
\text { horas }\end{array}$ & - & - \\
\hline Santa Maria & $36^{\circ} \mathrm{S}$ & Saydelles, 2005 & 260 & $\begin{array}{l}10,0^{\circ} \mathrm{C} \\
\text { inverno }\end{array}$ & - & - & 2 & 19 & Pontos Fixos & $\begin{array}{c}9-12-15- \\
18-21 \\
\end{array}$ & - & - \\
\hline
\end{tabular}

Organizado por Edson Soares Fialho (2008) 


\section{Apresentando a área de estudo.}

Cidade e universidade são complexos interligados por determinações e fecundações recíprocas, Reinvindica-se aqui que tanto a natureza, quanto o destino daquelas instituições, cidade e a universidade, são alguns, mas das melhores promessas da modernidade, promessas de liberdade e emancipação efetiva da humanidade, A cidade é em seu sentido básico e fundante, como espaço da liberdade, a matriz essencial da universidade (PAULA, 2006, p, 35),

O município de Viçosa está localizado na Zona da Mata ${ }^{10}$ Mineira (Figura 32), está situado, nas proximidades da escarpa da Serra da Mantiqueira, denominada regionalmente de Serra de São Geraldo está inserido num prolongamento da Serra da Mantiqueira, drenado pela bacia do rio Doce (VALVERDE, 1958).

A maior parte das nascentes da bacia hidrográfica do Rio Doce se encontra dentro do complexo de planaltos litorâneos, que segundo Ab'Saber (2003) faz parte do domínio morfoclimático denominado de mar de morros.

Neste domínio, predominam solos dos tipos Latossolos amarelos nos topos convexos; Latossolos vermelhos nas encostas das elevações; Argissolos nos terraços; e Neossolos associados aos Vertissolos nos fundos dos vales, onde se encontram os leitos maiores (RESENDE, 1971).

O município de Viçosa está inserido no domínio dos planaltos cristalinos rebaixados ou planalto deprimido central ${ }^{11}$, situando-se próximo a escarpa da Serra da Mantiqueira, em torno de Visconde do Rio Branco e Ubá, a altitude do topo das colinas mantém-se a cerca de 400 a 500 metros. Deste modo, a escarpa, voltada para o sul, possui uma vista, dando aparência de uma serra, tendo sido a mesma batizada de Serra de Santa Maria, Serra do Herval e o nome mais conhecido, Serra de São Geraldo, em decorrência da cidade localizada ao sopé da Serra da Mantiqueira.

Outra particularidade deste planalto é a sua diferenciação interna, variando dentro da própria Zona da Mata, acerca do relevo bastante diversificado, destacando-se áreas planas, onduladas e montanhosas, elevações de topos arredondados com vertentes convexas, terminando em vales planos.

\footnotetext{
${ }^{10}$ A primeira referência ao termo "Zona da Mata" ou "Matos", em ambos os casos fazendo referência à densa floresta que marcava a paisagem é datada do século XVIII, ou seja, anterior à sua ocupação mais efetiva (GIOVANINI, 2006, p. 19).

${ }^{11}$ Tabuteau (1960, p. 69).
} 


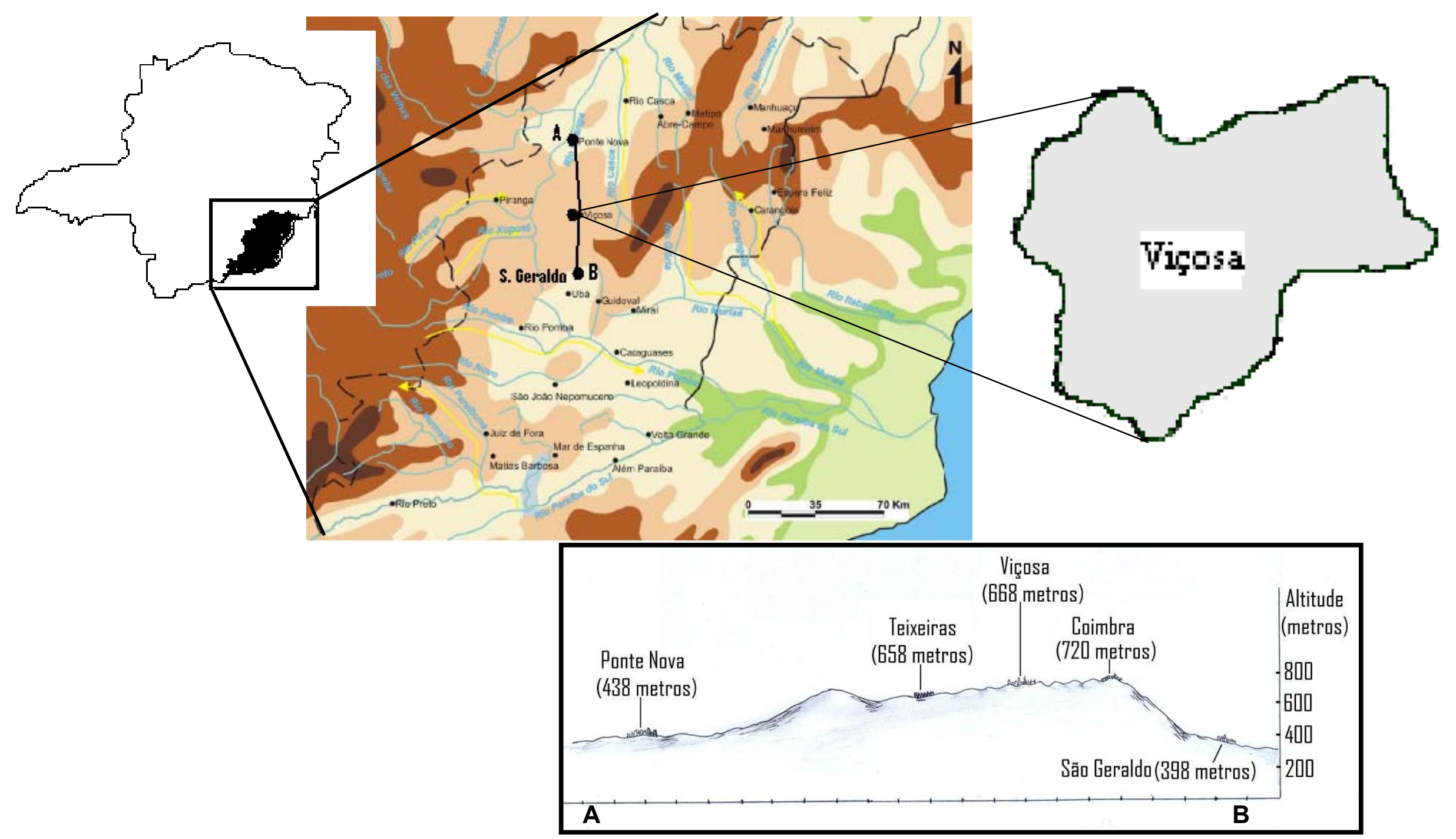

Figura 32. Localização do município de Viçosa-MG, na Zona da Mata Mineira Organizado por Edson Soares Fialho (2008). 
Entre Viçosa e Teixeiras (Figura 33), o relevo “...assume formas alongadas com os topos subaguçados e um nível embutido de colinas..." (IBGE, 2003, p. 355), cujas encostas estão entre convexas e retilinizadas por ravinamentos, com tendência à reativação. Os mantos de alteração são profundos, chegando a sete metros, e não deixam sinais de rocha exposta.

No trecho entre "...Teixeiras e Ponte Nova o aspecto geral do relevo acusa mudança, pois as cristas se sobressaem mais e o nível inferior dissecado em colinas se torna embutido. As colinas são mamelonares e com vertentes bastante ravinadas..." (IBGE, 2003, p. 355).

Com base na altimetria (Figura 32) o município de Viçosa pode ser dividido em três partes. A primeira constitui os espigões com níveis altimétricos variando entre 800 e 970 metros. Eles ocorrem nas regiões sudeste, sul, sudoeste e oeste do município. Os altos espigões da porção oeste (regiões de Sumidouro, Laranjeira e Itaguaçu) se diferenciam por apresentarem vertentes mais intensamente ravinadas pelas redes de afluentes do rio Turvo Limpo.

Há também um alinhamento de espigões, com direção aproximada SE-NW, que constitui o divisor entre a bacia do rio Turvo Limpo e Turvo Sujo. O ponto mais elevado do município $(970 \mathrm{~m})$ encontra-se na região de Sumidouro, a oeste. Neste primeiro conjunto de relevo predominam as declividades médias e fortes (superiores a $12,0 \%$ ) e a altitude relativa (diferença entre o ponto mais alto e o mais baixo da região) chega a ser de 300 metros.

A segunda é formada por espigões e colinas isoladas com níveis altimétricos variando de 700 a 800 metros. Predominam nas porções centro, noroeste, norte, nordeste e leste. Neste conjunto de relevo, a amplitude topográfica regional é de cerca de 100 metros, chegando à ordem de 200 metros nas cabeceiras dos cursos d'agua. Predominam declividades médias (entre 10,0 e 30,0\%) e fracas (entre 0,0 e 9,9\%). A sede do município encontra-se na região de espigões médios, ocupando as margens do rio São Bartolomeu e a parte das vertentes que constituem os espigões.

A terceira região diferenciada é constituída por um grande número de pequenas e médias várzeas que constituem zonas de acumulação de sedimentos aluviais, de solo fértil. Dentre outras se destacam as amplas várzeas do rio Turvo sujo e de seus principais afluentes; no sul do município e de seus afluentes, córregos Mainarte, Pinha e Estiva. 


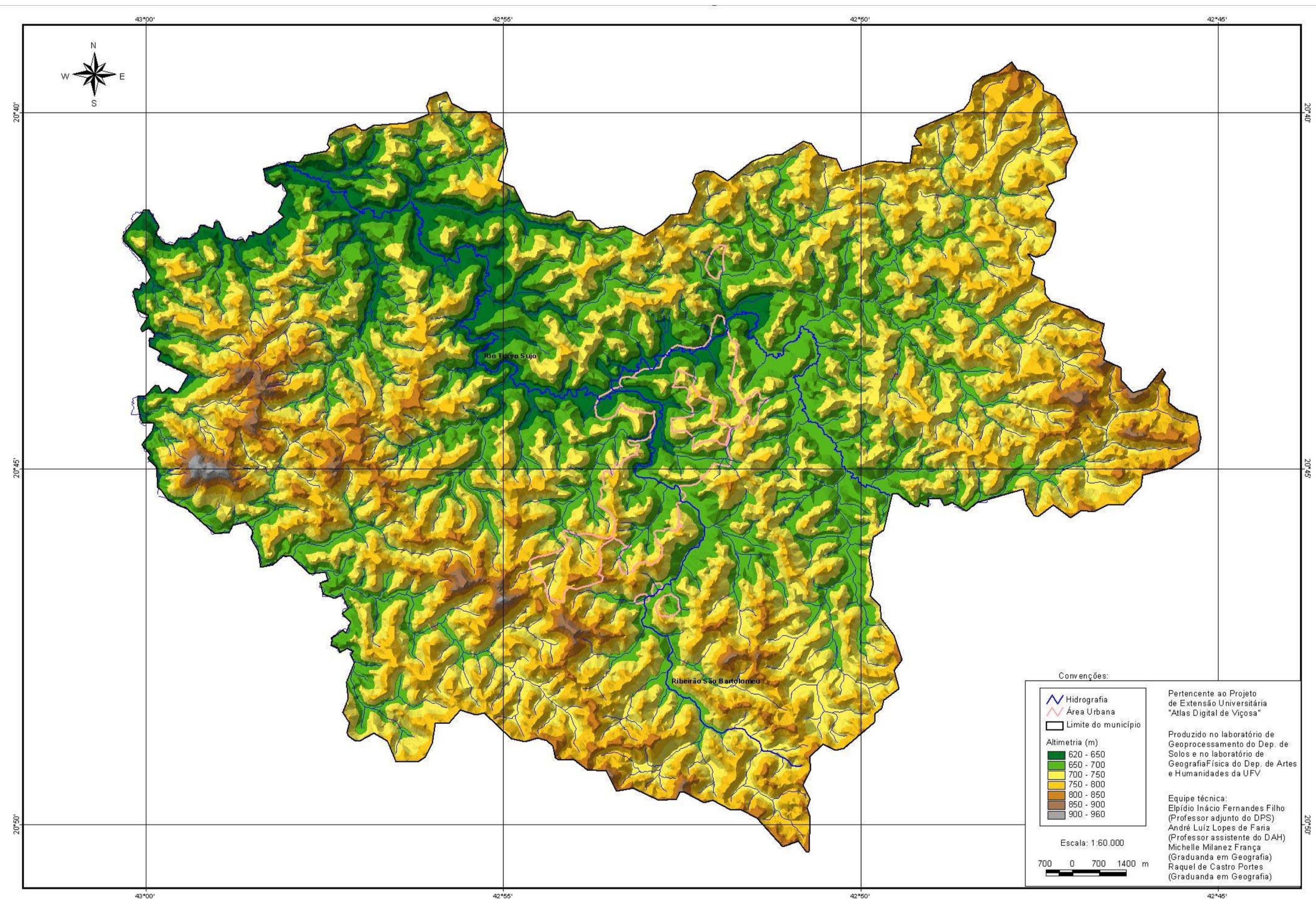

Fonte: IBGE, 2001

Base: IBGE (2001)

Figura 33. Hipsometria do município de Viçosa 


\subsection{A floresta que um dia existiu no sertão do rio Doce.}

A zona da mata mineira, por estar localizada no antigo sertão ${ }^{12}$ do rio Doce, teve preservada a floresta pluvial tropical até a década de 1950 do século $X X$, que ajudou a construir o mito da existência das riquezas minerais (ESPINOLA, 2005, p. 413).

A preservação desta área se deveu a tentativa do Governo Imperial evitar o contrabando de ouro das minas de Ouro Preto. Após o declínio desta atividade mineradora, o governo da época por interesses econômicos, programou uma política de ocupação do território, antes ocupado apenas por indígenas (botocudos, dentre outros), através da construção dos presídios ${ }^{13}$ (unidade militar composta por uma guarnição de soldados pedestres) eram pontos de povoamento isolado e forçado, no meio da floresta, na medida em que a população enviada era composta por degredados e criminosos, que cometiam delitos leves, como vadiagem até os mais graves. Porém, estes mesmos presídios, também, atuavam como pontos de atração de grupos indígenas isolados, em busca de alimento e metal (minério de ferro).

Posteriormente, com as divisões militares do rio Doce, localizadas estrategicamente nos entroncamentos dos rios principais, estas cumpriram o papel de intermediador entre os fazendeiros, posseiros, garimpeiros, aventureiros, negociantes, coletores das drogas do sertão. Ao mesmo tempo em que procuravam proteger os índios (botocudos) contra os seus algozes, que justificavam seu extermínio pelo fato de ser antropófagos (canibais), ou seja, devoradores de homens brancos. Porém, esta argumentação é desmentida por estudos de cunho histórico e antropológico (DUARTE, 2002; KOK, 2004 e AMANTINO, 2006), que demonstram que esta prática cada vez se tornara escassa, e quando praticada era utilizada entre os indígenas em conflito. A prática da antropofagia se justifica pelo fato do povo vencedor acreditar em adquirir a força do seu oponente, ou seja, um sinal de respeito e reconhecimento de sua força.

Além dos índios, considerados um obstáculo a ocupação, não se pode esquecer das doenças endêmicas tropicais. Para ambos os problemas, a brilhante solução aventada na época era a mesma, a derrubada da mata, ou melhor, a higienização do campo que se construía.

\footnotetext{
${ }^{12}$ Sertão é uma denominação que não expressa uma realidade objetiva. Mas serviu para contrapor paisagens consideradas ocupadas e civilizadas daquelas bravias, passíveis de serem ocupadas. (ESPINOLA, 2005, p. 75).

${ }^{13} \mathrm{Em} 1807$ funcionavam no Sertão do rio Doce os presídios de Cuietê, Abre Campo, Ponte nova, Santa Rita do Turvo (atual Viçosa), Pomba e São João Batista (ESPINOLA, 2005, p. 59).
} 
Apesar do trabalho do governo em promover a ocupação do território e criar uma condição de navegabilidade no rio Doce, a tentativa fracassou. Por conta disso, uma nova atividade econômica surgia: o cultivo do café. Este promoveu o desenvolvimento de núcleos urbanos, conforme pode ser visto na Tabela 9 , isto porque a economia cafeeira possibilitou uma maior diversificação do mercado consumidor.

Tabela 9. Relação dos maiores produtores de café na Zona da Mata, com as respectivas datas de criação do município e de elevação a categoria de cidade.

\begin{tabular}{|l|c|c|}
\hline \multicolumn{1}{|c|}{ Municípios } & Ano de criação do município & Ano de elevação da sede à cidade \\
\hline Ubá & 1853 & 1861 \\
\hline Viçosa & 1871 & 1876 \\
\hline Ponte Nova & 1875 & 1876 \\
\hline Juiz de Fora & 1850 & 1856 \\
\hline Muriaé & 1855 & 1873 \\
\hline Além Paraíba & 1880 & 1883 \\
\hline Cataguases & 1878 & 1881 \\
\hline Leopoldina & 1854 & 1861 \\
\hline Rio Casca & 1911 & 1912 \\
\hline
\end{tabular}

Observação: Os municípios listados na tabela no século XIX apresentavam uma maior dimensão territorial. Atualmente, caso levantarmos a produção de café, muitos destes não serão sequer lembrados, como por exemplo, Viçosa, que hoje está reduzida a metade dos seus $700 \mathrm{~km}^{2}$ de área que englobavam os atuais municípios de Araponga e Ervália (maiores produtor de café da Zona da mata mineira), Cannaã, São Miguel do Anta, Pedra do Anta, Coimbra e Teixeiras.

Fonte: Amorim (2004, p. 53).

Agora, cabe salientar que embora o cultivo do café tenha promovido a economia e o surgimento de cidades, também aumentou o desmatamento e desencadeou um processo de erosão intensa, na medida em que, segundo Warren (2004, p. 283):

“...o cultivo insistente e imprudente de encostas íngremes. Grande parte da região de "mar de morros" da serra do Mar não era de forma alguma arável. Trinta por centro do município de Viçosa, em Minas Gerais, por exemplo, apresentava declives entre 20,0 e 40,0\%. Cultivar solos em tais declives, o que era feito universalmente ladeira acima e ladeira abaixo, e não em curva de nível, provocava deslizamentos de lama - arruinando campos nas terras baixas, assoreando córregos e, na estação das chuvas, provocando mortes. Os agricultores, pressionados a aumentar a produção, eliminavam as práticas de pousio longo, acelerando a erosão da camada de húmus..." 
Junto à prática intensa do cultivo do café, outra razão para o desmatamento eram as ferrovias movidas a vapor e mais tarde o consumo de carvão pelas siderurgias. Em Viçosa, embora não existam usinas siderúrgicas, foi cenário de um episódio lamentável, com aval do poder público, que favoreceu a troca do patrimônio público pelo ganho de curto prazo dos interesses privados, segundo Dean (2004, p. 291):

“...Em 1956, a Universidade Rural do Estado de Minas - UREMG (hoje Universidade Federal de Viçosa), foi obrigada a trocar a faixa de mil hectares de floresta primária por uma área equivalente de pasto degradado e insignificante. A floresta foi vendida para a siderúrgica Belgo-mineira para a extração do carvão vegetal...".

Ao longo desse processo, atualmente, Viçosa ainda apresenta a existência de resquícios de Floresta Tropical Atlântica subperenifólia (em estágio secundário), em sua maioria em topo de morro, como pode ser mais visualizado na Figura 34.

Como se observa, o período áureo do café, apesar de criar condições à manutenção do desenvolvimento da economia da Zona da Mata, durante um pequeno período (1880-1930). Com a crise do café deflagrada, as mesmas ferrovias se tornaram obstáculo ao desenvolvimento da região, pois não permitiu o avanço de outras atividades econômicas, em razão da inexistência de articulação entre os sistemas ferroviários implantados, que privilegiaram os produtores locais de importância econômica e não as localidades. Com isto, as pequenas aglomerações urbanas não tiveram a chance de criar novas alternativas econômicas. Agora, como entender, a região com a maior densidade de linhas férreas em Minas Gerais se apequenou?

A explicação para isso, segundo Amorim (2004, p. 52), se deve à lógica das concessões das estradas de ferro, que se pautava na idéia de que as ferrovias criadas deveriam passar em locais onde haviam riquezas para serem transportadas.

Segundo Carrara (1999, p. 27), esta idéia não era consensual, enquanto os fazendeiros e seus representantes do sul da Zona da Mata defendiam a ferrovia como meio de transporte para o café, os políticos da Zona da Mata central (Ubá) viam na estrada de ferro um meio a facilitar o transporte de gêneros, a aglomeração de população, a comunicação rápida de idéias, a civilização e, em última instância, o progresso. Na Figura 35 subentende-se que no jogo de forças venceu a mentalidade dos primeiros, dado que a expansão ferroviária privilegiou, quase que exclusivamente, os interesses particulares de fazendeiros influentes do café e suas localidades. 


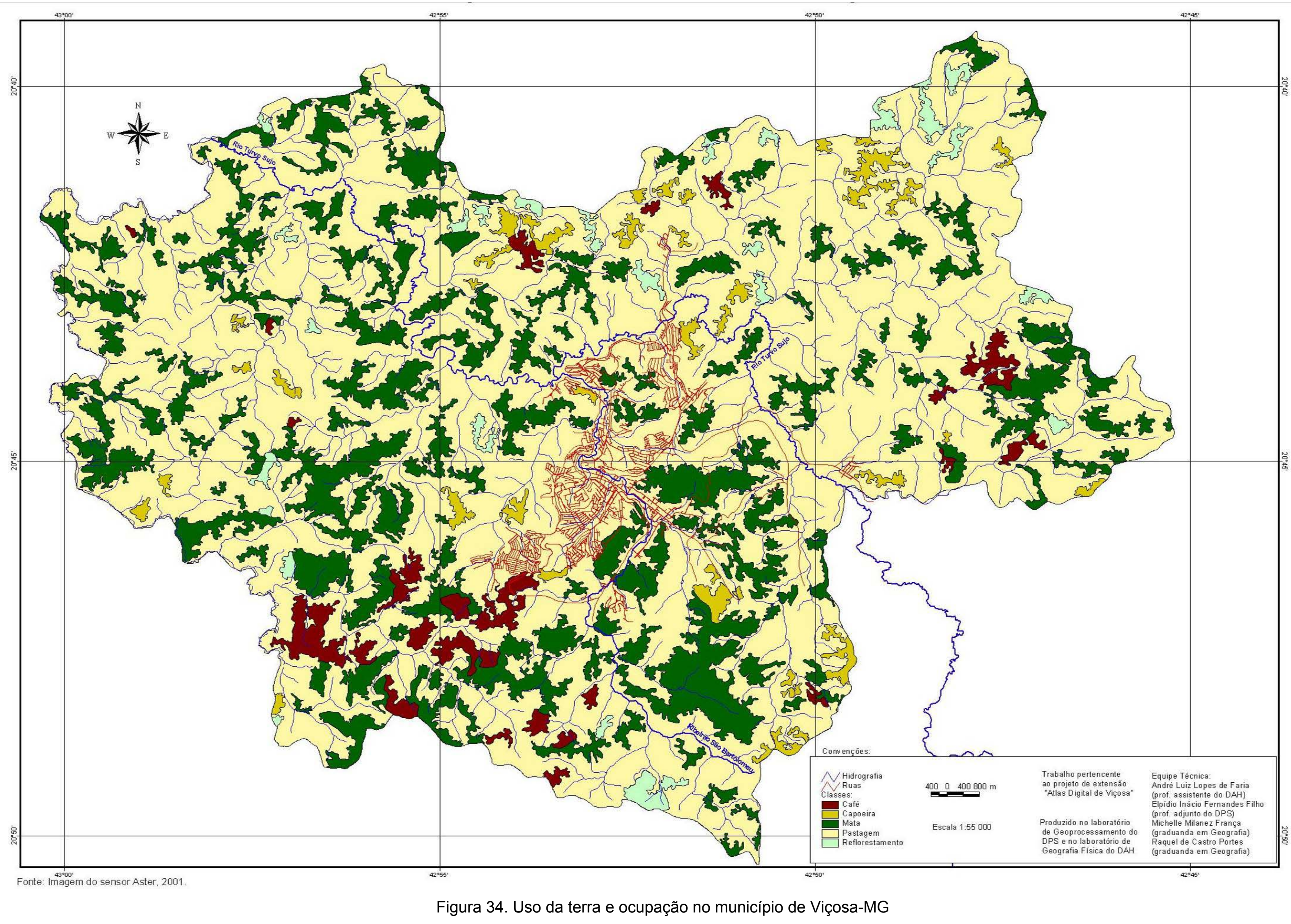




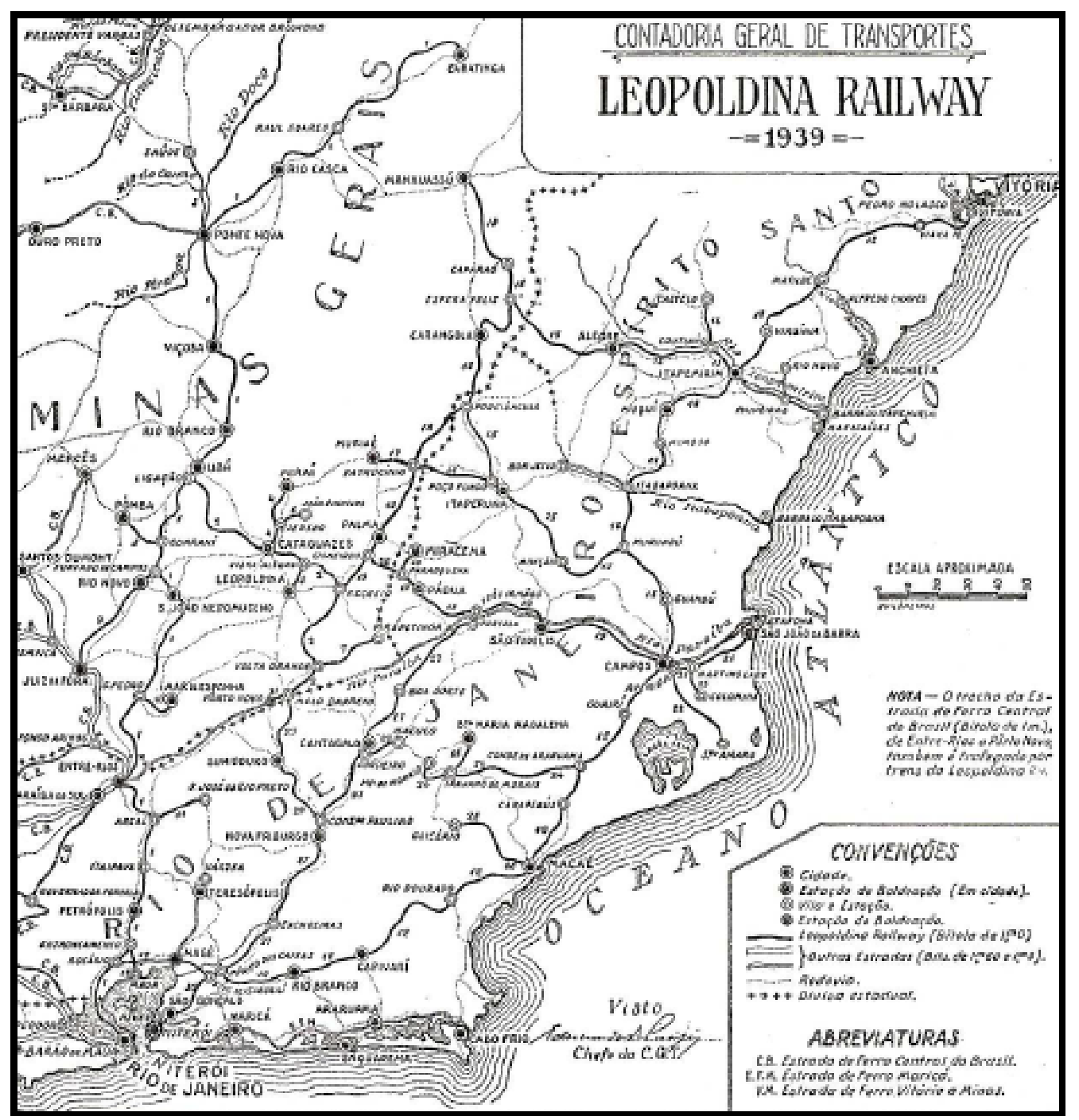

Figura 35. Rede Ferroviária da Leopoldina nos Estados de MG, RJ e ES.

Fonte: Silva (apud CARNEIRO, 2008, p. 39).

As aglomerações urbanas menores, não contempladas pelos ramais, não experimentaram a chance de se desenvolver em função desse transporte. Como resultado, a integração regional não foi favorecida pela implantação da rede ferroviária.

Para materializar esta força política sobre os trilhos, a construção das linhas era financiada pelo Governo Federal via concessões vantajosas o uso dos serviços ferroviários por 30 até 90 anos, por parte dos investidores, além de ressarcir o gasto do empreendimento, garantindo juros de $7,0 \%$ ao ano sobre o capital investido e realizar a doação das terras laterais ao longo das ferrovias. 
De maneira geral, embora o desenvolvimento da cafeicultura tenha promovido uma reorganização do espaço e da economia mineira, tendo também como desdobramento a intensificação do processo de industrialização, entre 1915 e 1920.

Essa industrialização ocorre nos setores têxtil, metalúrgico e, no ramo produção de bens de primeira necessidade (alimentação, calçados, móveis, construção, fumos, tipografia, dentre outras). Mas na década de 1920 ao surgir os sinais da desaceleração da cafeicultura. A estagnação da produção cafeeira se deu em virtude de um conjunto de fatores:

a) o revés econômico sofrido pela região em 1930;

b) A quebra da bolsa de Nova York e a conseqüente depressão econômica mundial, aliadas aos expressivos estoques $\mathrm{e}$

c) Os baixos preços do café no mercado internacional fizeram com que o governo federal adotasse postura extrema, financiando a erradicação de boa parte dos cafezais, incluindo aqueles localizados na Zona da Mata.

Some-se a isso o fato de que a partir da década de 1950 inicia-se, no plano nacional, o processo de industrialização, do tipo substituição de importações, que fez com que a indústria ampliasse sua participação na composição do Produto Interno Bruto (PIB) nacional.

Porém, os principais investimentos passaram ao largo da Zona da Mata, fato que contribuiu ainda mais para a estagnação econômica da região. Tanto assim, que segundo o IPEA et. al. (2000) a mesoregião, que era a terceira mais importante economicamente em Minas Gerais fora em 1985, perdeu sua posição em 1995 e atualmente oscila entre a quinta e sexta.

O setor agropecuário reduziu sua participação no período caracterizado pela não-modernização e baixa produtividade na produção de café, cana-de-açúcar e arroz. O setor industrial, no conjunto da mesoregião, tem como atividades mais significativas o complexo têxtil/vestuário, calçados e produtos alimentícios, nenhum deles podendo ser considerado muito dinâmico.

Merece destaque, entretanto, a cidade de Juiz de Fora, que possui boa infraestrutura urbana, centros de formação que poder ofertar mão-de-obra qualificada, disponibilidade de terrenos a baixo custo e um distrito industrial. Sem esquecer sua posição geográfica privilegiada próximo do Rio de Janeiro e Belo Horizonte.

Outra cidade de destaque é Ubá, considerado o primeiro pólo moveleiro do estado, exportando móveis para diversas partes do país. Além de estar crescendo o 
ramo de indústria de sucos industrializados na microrregião de Ubá (Visconde do Rio Branco, Ubá e Tabuleiro).

\subsection{Caracterização climática}

Quanto à sazonalidade do balanço hídrico, baseado em Thornthwaite (1948), Viçosa apresenta um excedente hídrico entre os meses de novembro a março de $366,3 \mathrm{~mm}$. A partir do mês de abril se inicia o período de retirada hídrica, estendendo-se até setembro, o que acarreta uma deficiência hídrica de 54,5mm, um valor não muito elevado se considerarmos o período de 6 meses (abril a setembro), quando os índices mensais de pluviosidade não ultrapassam a $55 \mathrm{~mm}$ (setembro).

Neste período, o total pluviométrico acumulado é de $195 \mathrm{~mm}$, equivalente a $16,0 \%$ do total pluvial anual. Após o mês de setembro, finda a estação seca, a pluviosidade no mês de outubro, ainda que superior a $100 \mathrm{~mm}$, muito semelhante aos totais das chuvas da estação de verão, não é suficiente para completar a capacidade de armazenamento de água no campo e a vegetação não tem a oferta plena de água que necessitam.

O clima segundo a classificação de Thornthwaite (Figura 36) demonstra a forte influência da continentalidade, pelo fato de existir duas estações definidas: uma chuvosa e de grandes excedentes de água, e outra marcada pela deficiência hídrica.

Resulta daí seu clima primeiro úmido $\left(\mathrm{B}_{1}\right)$ com deficiência hídrica de abril a setembro e moderado déficit hídrico de maio a setembro, sobretudo de junho a setembro (w), E, do ponto de vista da eficiência termal, seu clima é do tipo terceiro mesotérmico $\left(\mathrm{B}^{\prime}{ }_{3}\right)$, com uma eficiência termal no verão de 33,4\% (a').

No inverno (junho, julho e agosto), a precipitação média mensal é inferior a 25 $\mathrm{mm}$, os dias são geralmente claros, com ventos fracos. As madrugadas e as manhãs são muito frias, acentuadas pela inversão térmica, fenômeno capaz de produzir nevoeiros, em razão do relevo acidentado.

Nos dias quentes de verão, há o desenvolvimento de nuvens de bom tempo (Cumulus e Sratus-Cumulus), porém em alguns dias à tarde, dependendo do aquecimento e da umidade disponível na atmosfera, é possível formar nuvens de mau tempo (Cumulus Nimbus), uma particularidade das estações de primavera e verão (outubro a março), capazes de produzir grandes aguaceiros, em decorrência dos episódios de chuva concentrada. 
As precipitações mais fortes ocorrem em dezembro com um total médio de $245 \mathrm{~mm}$. Nesta estação de verão não ocorrem apenas chuvas convectivas, mas, sobretudo chuvas frontais, que embora não tão significativas em razão do seu posicionamento em relação ao sentido de invasão dos sistemas polares (SEREBRENICK, 1962, p. 105) são capazes de produzir grandes prejuízos, como ocorrido em fevereiro de 1948 e janeiro de 2006 (DUTRA, et. al., 2006).

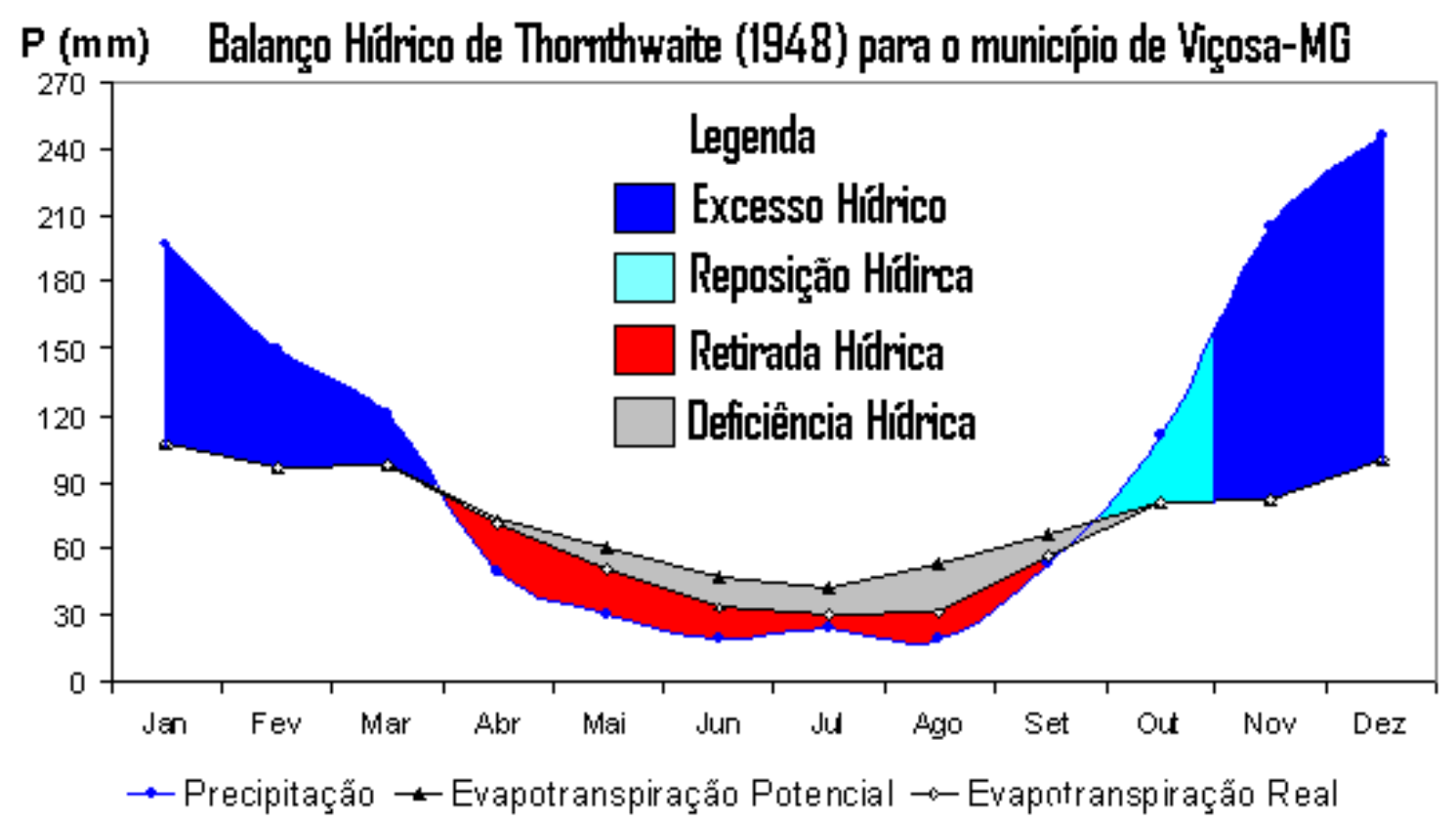

Figura 36. Classificação climática de Thornthwaite para o município de viçosa: $\mathrm{B}_{1} \mathrm{w} \mathrm{B}_{3}{ }_{3} \mathrm{a}^{\star}$ Fonte: Normais Climatológicas (1961-1990)

Elaborado por Edson Soares Fialho (2008).

\subsubsection{Dinâmica atmosférica em Minas Gerais.}

O Estado de Minas Gerais, tem uma extensão territorial de $588.384 \mathrm{~km}^{2}$, ou seja, $7,0 \%$ do território brasileiro. Mais da metade das terras das alterosas integram o Planalto Atlântico, com altitudes médias de $700 \mathrm{~m}$, abrangendo em sua superfície boa parte das terras altas do Sudeste. Com 93,0\% de seu território acima de $300 \mathrm{~m}$ de altitude, 57,0\% acima de $600 \mathrm{~m}$ e quase 20,0\% situados entre 900 e 1500m de altitude é o Estado mais elevado do Brasil (FERREIRA; NERY, 2002).

O relevo apresenta uma grande variedade morfológica. Embora caracterizado por altas superfícies cristalinas e sedimentares com predomínio de 500 a 1200m, entre estas aparecem amplos vales como o do São Francisco, Jequitinhonha, Doce, Paraíba do Sul, Paranaíba, Grande e Paraná. Sobre estas superfícies ergue-se 
numerosas serras onde são comuns os níveis de 1200 a 1800 m como no Espinhaço Mantiqueira e Serra do Mar, cujos pontos culminantes estão acima de $2.700 \mathrm{~m}$ na Mantiqueira e $2.200 \mathrm{~m}$ na Serra do Mar.

Este aspecto da topografia favorece as precipitações, uma vez que ela atua no sentido de aumentar a turbulência do ar, notadamente durante a passagem de correntes perturbadas.

Por apresentar uma localização geográfica, que favorece a influência de fenômenos meteorológicos de latitudes médias e tropicais, o clima tropical de transição (ABREU, 1997) se caracteriza por um regime de duas estações bem definidas podem ser identificadas: uma seca (inverno), na qual atuam a Frente Polar Atlântica (FPA) e o anticiclone Subtropical do Atlântico Sul; e outra chuvosa (verão), na qual predominam os sistemas convectivos associados ao aquecimento continental (como pode ser visto na Figura 37) e a Zona de Convergência do Atlântico Sul (VIANELLO; MAIA, 1986; LADEIA, et. al. 1988 e FERREIRA; NERY, 2002).

Segundo Vianello e Maia (1986) o anticiclone do Atlântico Sul marca sua presença sobre Minas Gerais, trazendo ventos predominantes do quadrante norte e leste. Este centro de ação, induz uma circulação norte e a conseqüente invasão do ar tropical quente e úmido no verão. Diferentemente das massas de ar extratropicais, que apresentam uma direção sudoeste-nordeste, que favorece a entrada da massa polar. A colisão entre estes sistemas é responsável pelas chuvas intensas durante o verão. Esses eventos pluviais, também podem ser de curta duração, são conhecidos como "chuvas de verão", e ocorrem geralmente no final da tarde ou início da noite, em função do forte aquecimento diurno, que intensifica a radiação telúrica e, conseqüentemente, as correntes convectivas.

No inverno, o deslocamento do Anticiclone para o continente acaba induzindo o fenômeno da subsidência, responsável pelo céu azul, ausência de chuvas e o favorecimento de condições de concentração de poluentes atmosféricos.

Freqüentemente, no verão, o atrito diferencial mar-continente acaba por originar um pequeno centro de alta sobre o continente, aparentemente desgarrado do Anticiclone do Atlântico Sul.

Estas configurações se alternam com a chegada das frentes frias provenientes do sul, responsáveis por instabilidades e bruscas mudanças do tempo, geralmente acompanhadas de chuvas. As frentes frias são mais freqüentes e intensas no inverno. Uma situação comum, durante o verão, é o semiestacionamento de sistemas frontais sobre o Sudeste. 
As linhas de instabilidade, relacionadas a núcleos de baixa pressão, são capazes de provocar ascensão do ar quente, causar chuvas e trovoadas e até mesmo tempestades locais severas.

Essas linhas, em suas trajetórias NO-SE, atingem Minas, provocando precipitações. Intensifica-se mais ainda se atravessarem regiões fontes de vapor, tais como áreas líquidas e florestas. No interior destas, o ar encontra-se em convergência dinâmica, sendo capaz de gerar chuvas e trovoadas, às vezes, com granizos e ventos de intensidade moderada. A origem destes fenômenos está ligada ao movimento ondulatório que se verifica na frente polar em contato com o ar quente da zona tropical.

Também a topografia induz o maior desenvolvimento mecânico das linhas, tornando-as mais ativas. Porém, de acordo com Ferreira e Nery (2002) o relevo embora apresente uma relação com a distribuição da precipitação, a mesma, não necessariamente ocorre pela quantidade, mas na distribuição espacial.

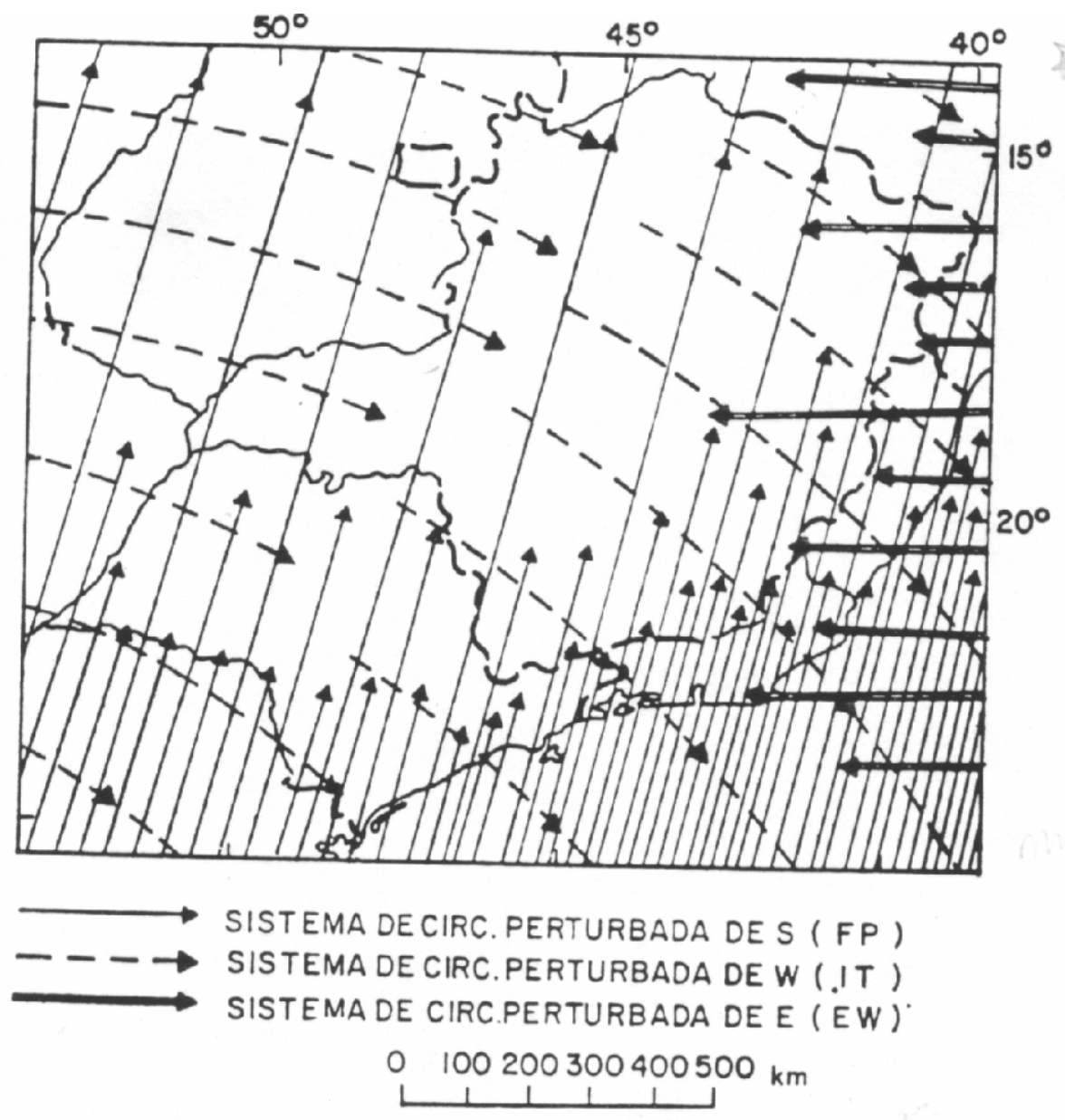

Figura 37. Sistemas de circulação atmosférica perturbada na região sudeste. Fonte: Nimer (1989, p. 269). 


\subsection{De Santa Rita do Turvo à Viçosa dos tempos atuais.}

Viçosa tem sua origem datada no final do século XVIII, durante o declínio do ciclo do ouro, que se desenvolveu na região de Ouro Preto e Mariana. Os pioneiros que se assentaram na área de Viçosa vinham em busca de terras férteis para a agricultura e a pecuária, dada a crescente escassez de alimentos na região das minas.

O assentamento original foi instalado nos arredores da Capela dos Passos, localizada na atual Rua dos Passos, em 8 de março de 1800. Naquela data, foi concedido ao padre São Francisco José da Silva licença para a construção de uma capela, sob a evocação de Santa Rita (MELLO, 2002, p. 43).

O vilarejo foi crescendo e a necessidade de ocupação de novas áreas se tornou cada vez mais iminente. Em razão disso, no ano de 1813, ergueu-se uma ermida no local onde hoje se situa a Praça Silviano Brandão, localizado no centro da cidade (op. cit. 2002, p. 38).

A partir deste marco histórico, o povoado se desenvolveu ao longo dos vales mais planos de uma região preponderantemente montanhosa. Este modelo de desenvolvimento de núcleos urbanos guiados pela orientação do relevo é conhecido como Strassendor (agrupamento linear ao longo de uma rua), que perdurou mesmo com a chegada da ferrovia Leopoldina em 1885, resultado da atividade cafeeira, durante a República velha.

Este novo acesso melhorou o sistema de comunicação, propiciando mudanças, a começar pela maior integração da produção agrícola, ao mesmo tempo esta desenvolvia a expansão das atividades urbanas.

Na década de 1920, o vice-presidente em exercício, Dr. Eduardo Carlos Vilhena do Amaral, de acordo com a Lei $n^{\circ} 761$ de 06 de setembro de 1920, criou a Escola Superior de Agricultura e Veterinária do Estado de Minas Gerais (ESAV), por meio do pelo decreto $n^{\circ} 6.053$ de 30 de março de 1922 (PANIAGO apud MELLO, 2002, p, 52).

Por influência do então presidente Arthur da Silva Bernardes a Escola foi construída em Viçosa. A partir de então, a ESAV, atual UFV, viria a ser o principal elemento a impulsionar o desenvolvimento econômico não só da cidade, mas de toda a micro-região.

Entre os anos de 1920 e 1930, Viçosa possuía cerca de 800 edificações concluídas e algumas em construção, a maior parte na Praça da Matriz e nas ruas Arthur Bernardes, Benjamin Araújo e Bueno Brandão. 
Em 1948 foi aprovado o Código de Postura do Município e 8 anos mais tarde, no dia 18 de maio, criou-se a primeira Lei de parcelamento do solo (Lei $n^{\circ} 280 / 56$ ), que vigorou até 1979 (MELLO, 2002, p. 54). Segundo Ribeiro Filho (apud MELLO, 2002, p. 54), "havia inúmeras lacunas nessa lei, de modo que permitia ao construtor, muitas vezes, infringir determinadas exigências do documento".

Na década de 1960, o processo de urbanização se consolidou ainda mais. Os fundos de vale foram ocupados, como pode se verificado nas Figuras 38 e 39, que retratam dois momentos bem distintos para Viçosa.

O desenvolvimento da cidade se processava em razão das oportunidades de emprego oferecidas pela universidade, fundada em 1926, enquanto ESAV, e federalizada a partir do ano de 1969.

Ao contrário de várias cidades brasileiras, em que a indústria dinamizou a economia, em Viçosa, a UFV é a grande responsável por desempenhar tal função. Até 1960 , a população rural era maior que a população urbana, 11.625 habitantes residindo no campo e 9.221 habitantes na cidade. Na década de 1970 houve a inversão desse quadro, passando a população urbana para 16.997 habitantes e a rural para 8.780 habitantes.

Pode-se observar também na Tabela 10, que de 1950 a 2000 a população urbana de Viçosa quadruplicou. Porém cabe salientar que a população de Viçosa em 1950, desconsidera os antigos distritos, hoje municípios: Cajuri, Canaã, e São Miguel do Anta, que se emanciparam posteriormente a 1950 (Figura 40) do até então município de Viçosa que registrava $736 \mathrm{~km}^{2}$ de extensão territorial e hoje ficou restrito a $300 \mathrm{~km}^{2}$.

Tabela 10: Evolução da população urbana e urbana de Viçosa de 1950 à 2000

\begin{tabular}{|c|c|c|c|c|c|}
\hline \multirow{2}{*}{$\begin{array}{c}\text { Ano } \\
\text { População Total }\end{array}$} & \multicolumn{2}{c|}{ População Rural } & \multicolumn{2}{c|}{ População Urbana } \\
\cline { 2 - 6 } & Absoluta & Relativa (\%) & Absoluta & Relativa (\%) \\
\hline 1950 & 18.325 & 11.901 & 64,9 & 6.424 & 35,0 \\
\hline 1960 & 21.120 & 11.778 & 55,7 & 9.342 & 44,2 \\
\hline 1970 & 25.777 & 8.780 & 34,0 & 16.997 & 65,9 \\
\hline 1980 & 38.686 & 7.507 & 19,4 & 31.179 & 80,6 \\
\hline 1991 & 51.658 & 5.202 & 10,1 & 46.456 & 89,9 \\
\hline 2000 & 64.854 & 5.062 & 8,0 & 59.792 & 92,0 \\
\hline 2007 & 70.704 & & & & \\
\hline
\end{tabular}

Fonte: Censos demográficos do IBGE de 1970, 1980, 1991 e 2000.

Organizado por Edson Soares Fialho (2008). 


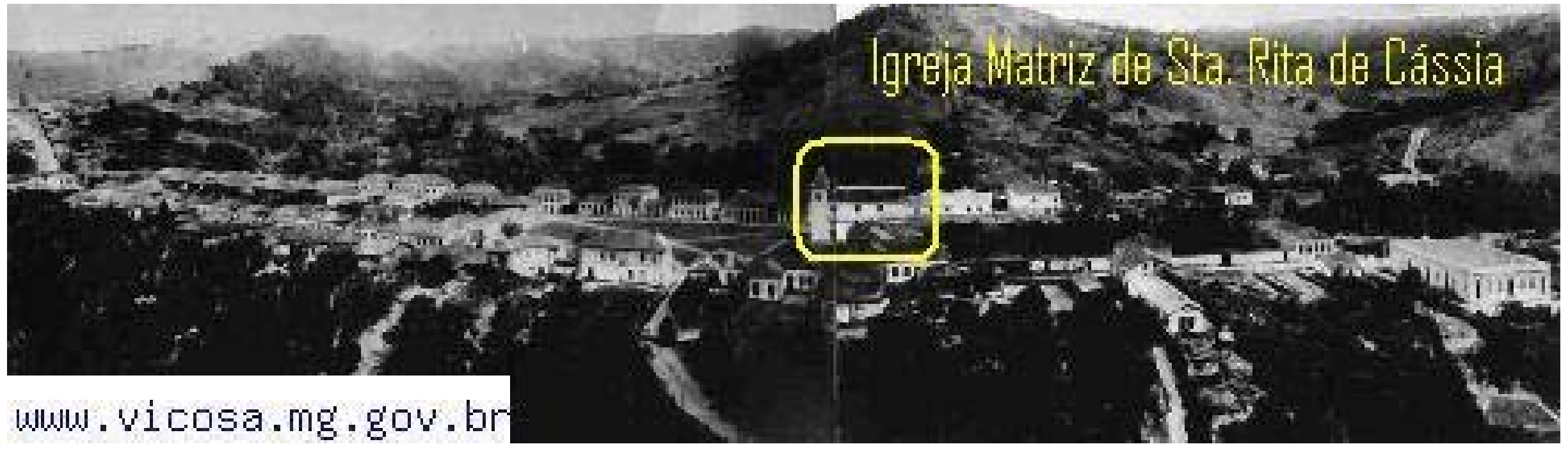

Figura 38. Núcleo inicial, vendo-se a antiga Igreja Matriz, à direita, 1898.

Fonte: RAMOS, Antônio de Pádua C. e MELLO, Tony. Viçosa em fotos. Viçosa, UFV, 1973. Disponível em: http://www.vicosa.mg.gov.br/?area=galeriadefotos

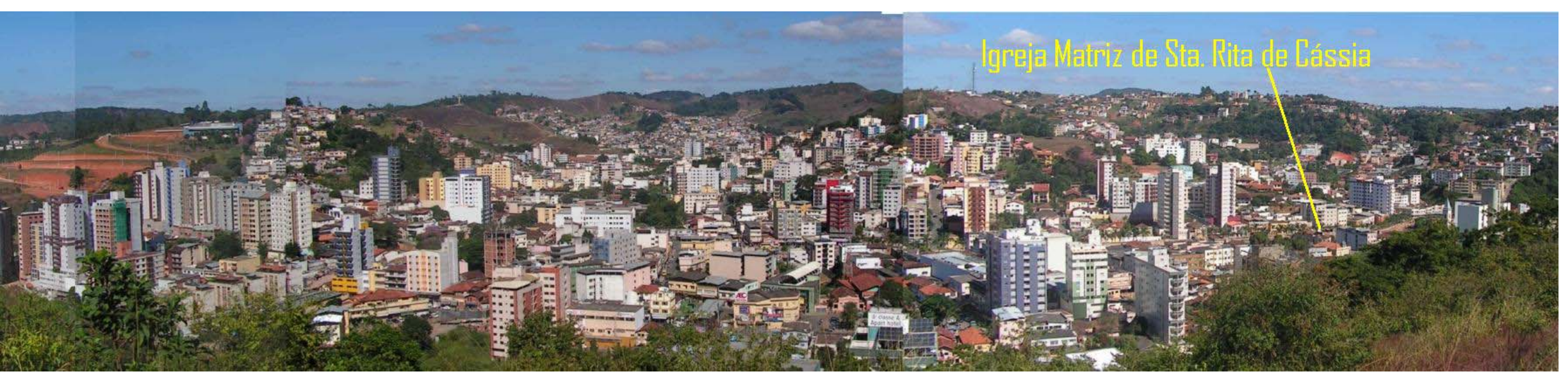

Figura 39. Localização do antigo núcleo inicial, agora no ano de 2007.

Foto: Santos (2007) 


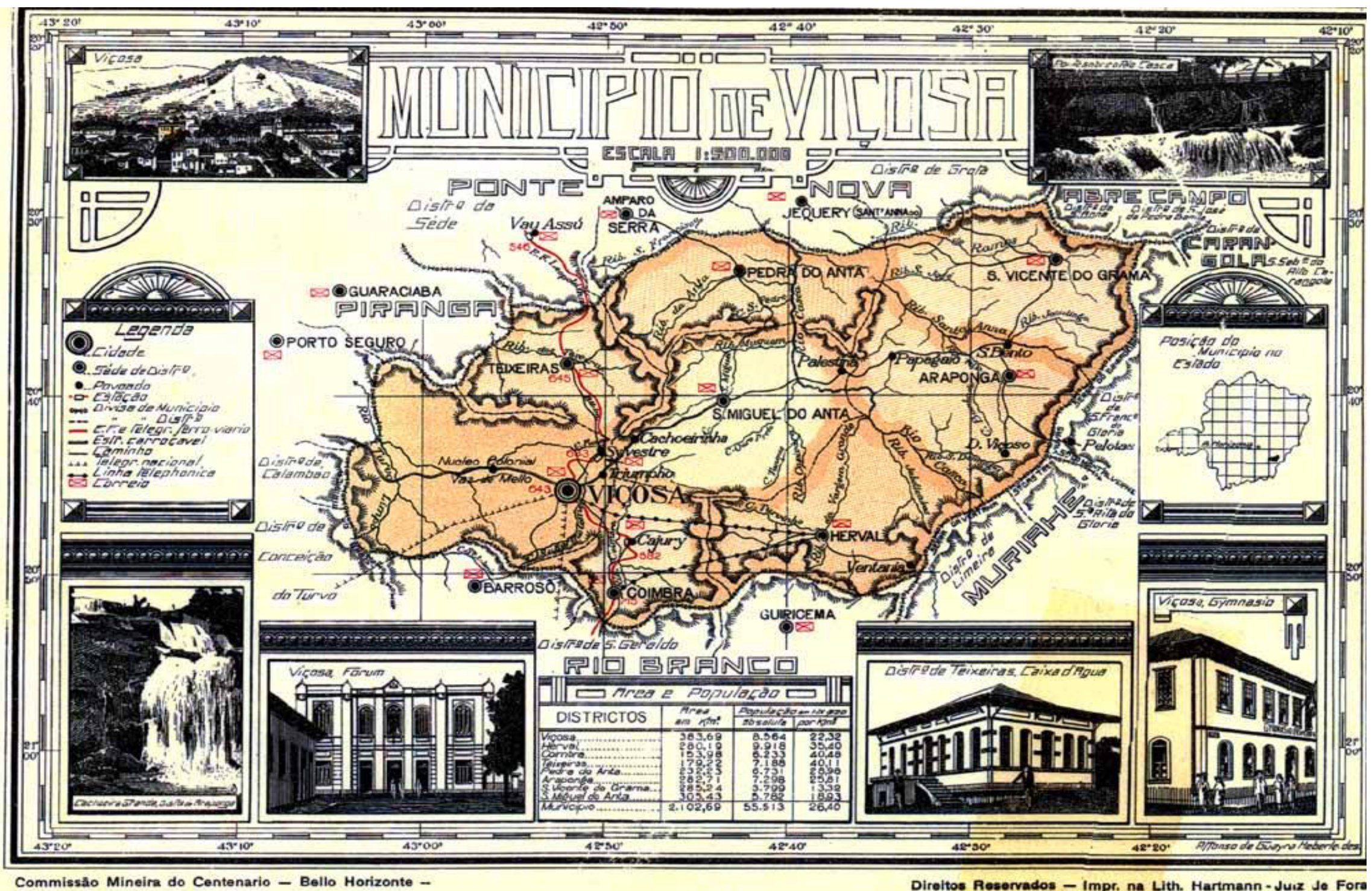

Figura 40. Limite territorial do município de Viçosa antes da década de 1950.

Fonte: http://www.asminasgerais.com.br/Zona\%20da\%20Mata/Biblioteca/Mapas/Antigos/. Acesso em 18 ago. 2008. 
O crescimento foi bastante acelerado e concentrado em uma área de relevo bastante dissecado no vale do pequeno afluente do rio Turvo, o rio ou ribeirão São Bartolomeu, área que dificulta o crescimento horizontal da cidade. Apesar disso, a densidade demográfica do município é relativamente baixa, não atingindo 235 habitantes por $\mathrm{km}^{2}$.

Cabe ressaltar que a estrutura urbana característica de Viçosa não se encontrava preparada para absorver o crescimento populacional. Outro fator que influenciou o crescimento da cidade, segundo Mello (2002, p. 56), "foi à distância entre as demais áreas ocupadas e o núcleo urbano". As regiões onde estão centralizadas as atividades comerciais e administrativas, os serviços e o lazer, condicionam a escolha do local de moradia do cidadão. Nesse sentido, Viçosa possui como pólos de atração o seu centro e o campus universitário (Figura 41).

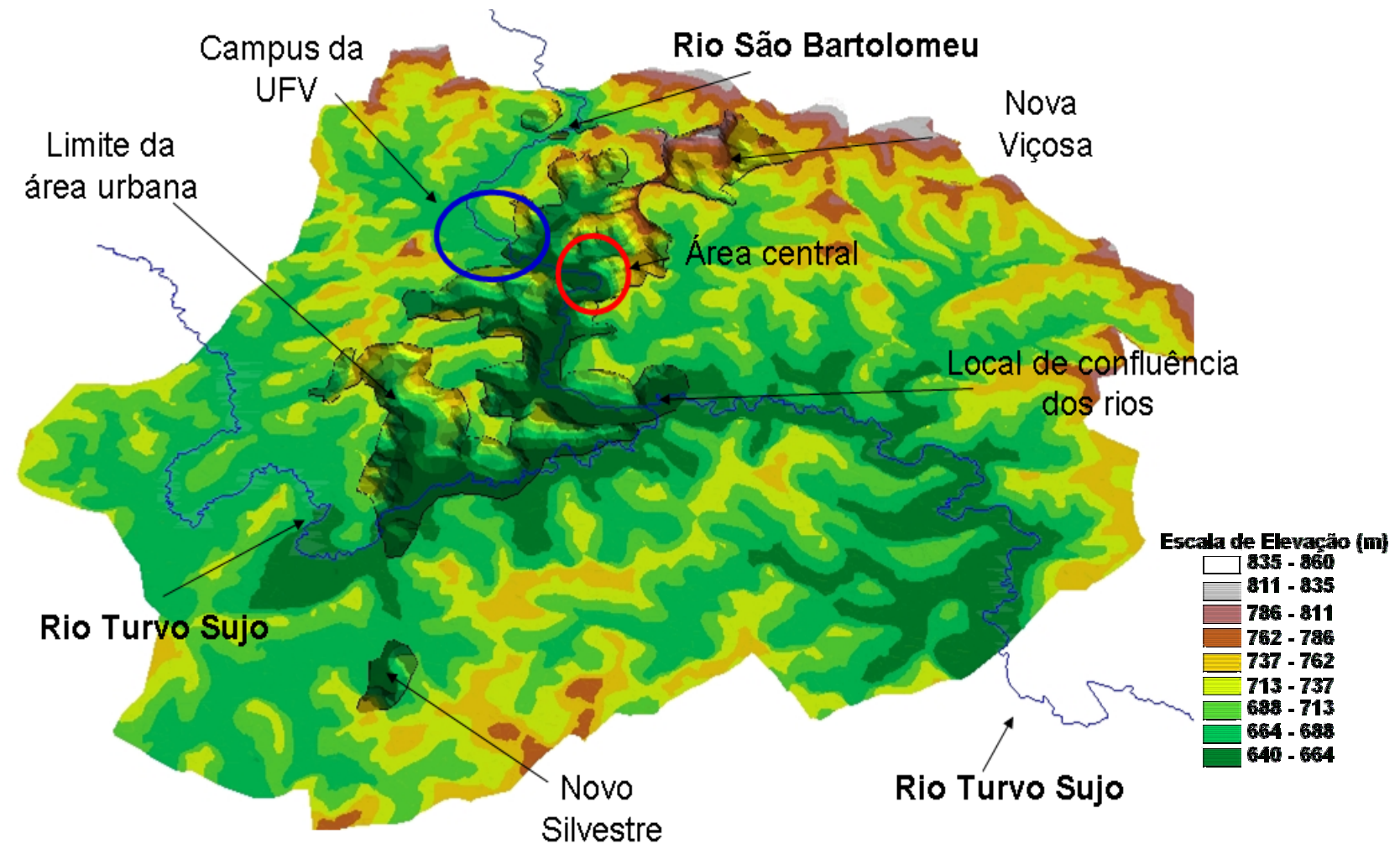

Figura 41. Vista de parcial do município de Viçosa, privilegiando a área urbana e o entorno imediato, com base no Modelo Digital de Elevação (MDE).

Fonte: Departamento de Solo/UFV.

Organizado por Edson Soares Fialho (2008). 
Muitas das áreas ocupadas próximas a esses pólos, nas expansões anteriores, eram, e ainda são consideradas impróprias do ponto de vista ambiental ao processo de urbanização, como as encostas, os topos de morros e ao longo dos cursos hídricos. Partindo das principais vias de acesso ao centro da cidade e ao campus foram registrados loteamentos de ocupação dessas áreas desde a década de 1970 (MELLO, 2002, p. 56).

O campus ocupa uma porção a montante do rio São Bartolomeu, que é plana, tornando-se de tal maneira, uma "barreira" à expansão urbana, obrigando-a a seguir em outras direções (Figura 42 e Figura 43). Ribeiro Filho (1997) corrobora esta idéia de que a universidade se constituiu em um impedimento a expansão da cidade, devido esta ter ocupado uma área privilegiada, obrigando a mesma a buscar outras direções.

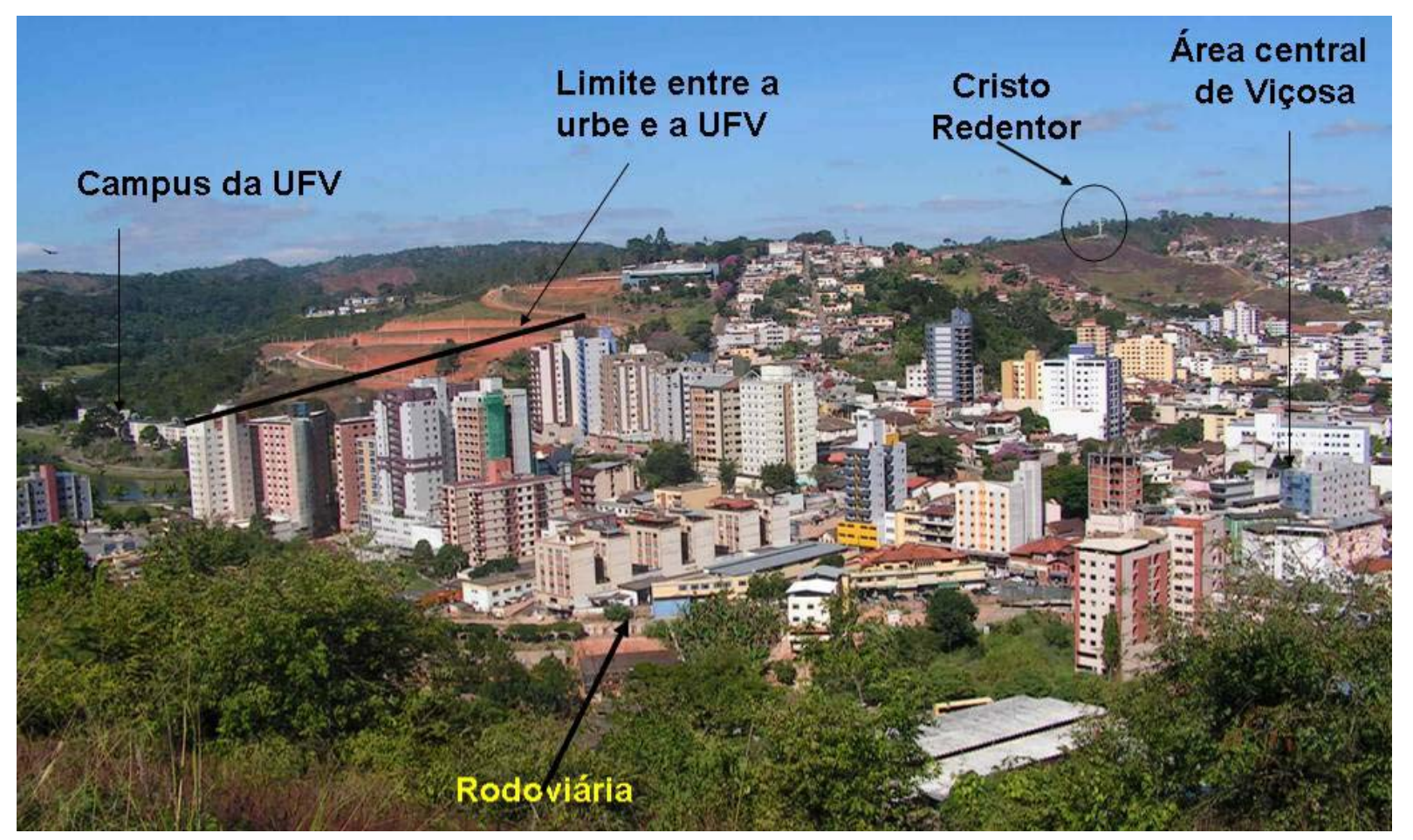

Figura 42. Visão parcial da área urbana e a demonstração do limite a UFV e a cidade.

Foto: Jaime Augusto Alves dos Santos, obtida em 4 de junho de 2007.

A cidade real e a cidade universitária são interdependentes, mas suas administrações são independentes. Isto causa sérios transtornos à cidade real, que vive e se reproduz a partir da demanda da cidade universitária. Esta incapacidade de diálogo é tão flagrante que o poder público quase sempre espera as decisões da primeira, não sendo possível mais afirmar que a cidade real seja o lugar da dignidade, da plena emancipação humana; espaço da liberdade e criatividade. 


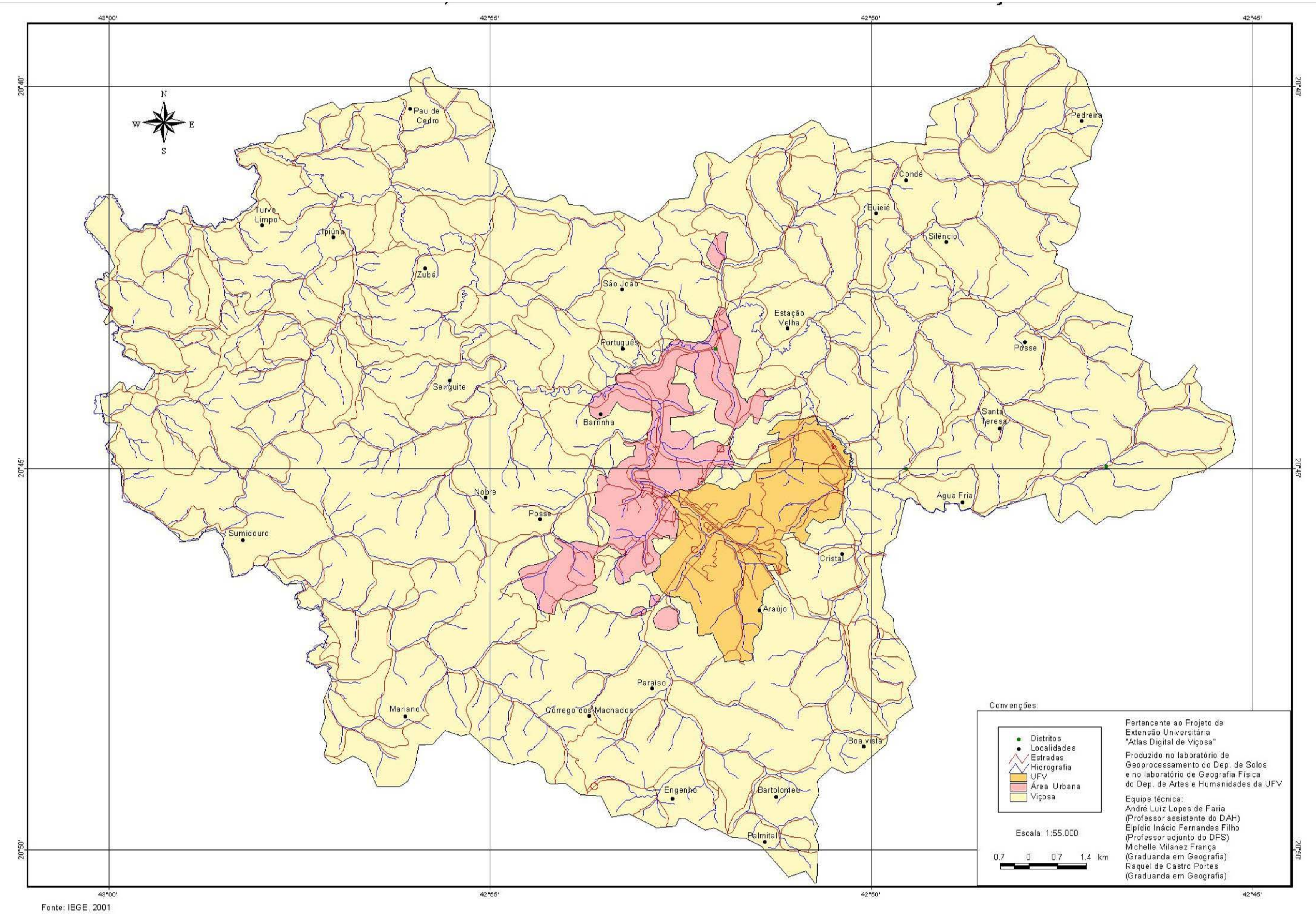

Figura 43. A área urbana e o campus da UFV, no município de Viçosa-MG. 
Pode-se dizer que a universidade não sabe conviver com os problemas que ela mesma gera através da sua visão de ciência. $E$ a cidade real é um testemunho deste processo, com os inúmeros campos de tensões que ocorrem na paisagem urbana, onde o próprio desencadear do processo de urbanização sem planejamento das cidades contribuiu para a emergência dos impactos ambientais urbanos como: desmatamento, destruição das áreas de preservação permanente, intensificação dos processos erosivos e contaminação generalizada dos recursos hídricos ${ }^{14}$ (SANTOS, et. al., 2002), problemas que se relacionam com localização, distância, topografia, características geológicas e geomorfológicas, crescimento populacional, formas de apropriação do espaço e segregação sócio-espacial.

Em suma, nas últimas décadas, a cidade vem apresentando um crescimento populacional urbano até certo ponto carente de um planejamento adequado, pautado no desenvolvimento vertical na área central e numa expansão horizontal indiscriminada das moradias no centro e em direção à periferia e a zona rural.

Tal fato pode ser considerado como fruto da intensa especulação imobiliária, que se faz presente na cidade, em virtude, sobretudo, da UFV e das faculdades particulares que se instalaram na região, como a Universidade de Viçosa (UNIVIÇOSA), Ensino Superior Viçosa (ESUV) e Faculdade de Viçosa (FDV). Ademais, o fato da universidade ser um agente indutor de migração para cidade, contribui para o aumento da especulação imobiliária do centro de Viçosa, que se localiza ao lado do campus universitário.

A conseqüência disso é a verticalização da cidade, a fim de atender a demanda de moradia por parte dos acadêmicos e a expansão da malha urbana, que inicialmente estava restrita ao vale do rio São Bartolomeu.

Ao vislumbrar a Figura 44 identifica-se que há 2 núcleos de alta densidade de prédios, enquanto uma terceira localidade se caracteriza pela presença de sobrados e casas antigas.

A primeira área próxima a UFV se encontra em processo de consolidação da verticalização. Hoje, as poucas áreas disponíveis para construção já estão ocupadas e em processo de construção desde o início do ano de 2009, tanto assim, que a Avenida P. H. Rolfs está sendo escavada para a instalação de rede de fornecimento de água tratada. Para os novos 7 prédios em construção.

\footnotetext{
${ }^{14}$ Pelo fato do rio Bartolomeu receber todos os efluentes oriundos da cidade, a concentração de oxigênio dissolvido na água é baixo, devido às elevadas concentrações de matéria orgânica presente no meio aquático (SANTOS et. al., 2002).
} 
O segundo núcleo de verticalização é mais antigo, consolidado na década de 1980. É hoje visto como longe da universidade (cabe ressaltar que o referencial de distância é baseado no tempo percorrido a pé pelos estudantes), apesar de conter uma boa infra-estrutura de serviços (bares, academias e hospitais).

A terceira área que se apresenta com menor densidade de prédios é uma área de especulação muito forte, pois as residências que lá existem já foram esvaziadas e as edificações restantes, apresentam placas de vende-se.

Como este local é um prolongamento da Av. P. H. Rolfs acredita-se que num prazo de 15 anos esta via de circulação tão importante da cidade estará repleta de prédios de mais de 10 andares em toda a sua extensão, modificando substancialmente as condições de sombreamento, contaminação atmosférica e ruído. Tais condições embora prejudiciais para a qualidade de vida urbana não será empecilho para o aumento da densidade demográfica composta, principalmente, de estudantes universitários.

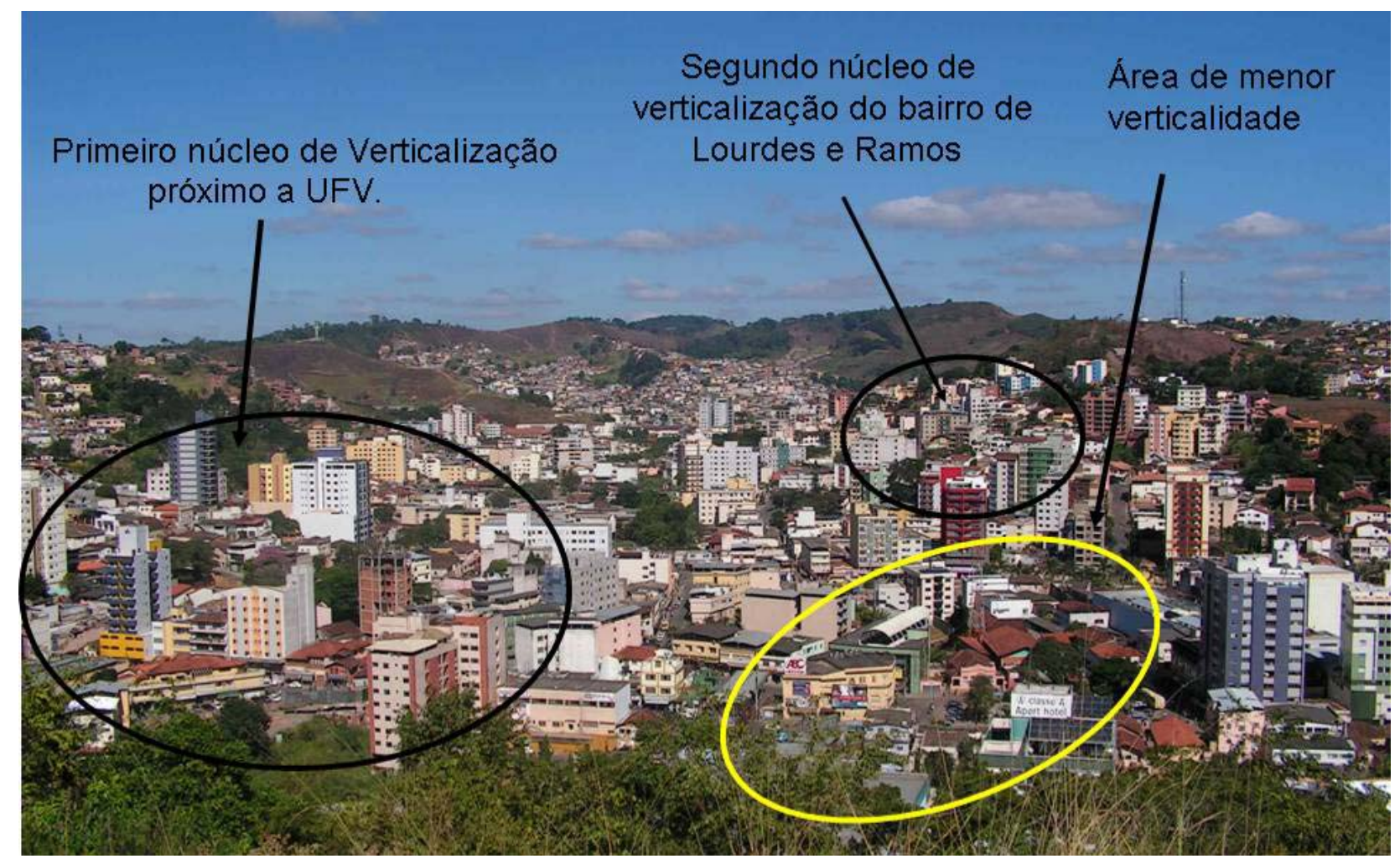

Figura 44. Localização dos núcleos de verticalização em Viçosa-MG.

Foto: Jaime Augusto Alves dos Santos, obtida em 4 de junho de 2007.

O processo de verticalização volta a ganhar força na década de 1990, mais precisamente, no ano de 1997, com a construção dos edifícios Prof. Rolfs (Rainha da Sucata) e Tocqueville, o Profa Jacyra do Valle e o Burle Marx, este último 
construído em cima do leito do rio São Bartolomeu (Figura 44a), mais precisamente ao lado das 4 pilastras, porta de entrada da UFV. Ao longo desse trecho, segue uma vale mais plano (paralelo a Av. P. H. Rolfs), até o Hospital São Sebastião, onde se verifica uma revitalização do processo de verticalização, a partir do ano 2000, quando se criou novos cursos universitários (História, Dança, Comunicação Social e Geografia).

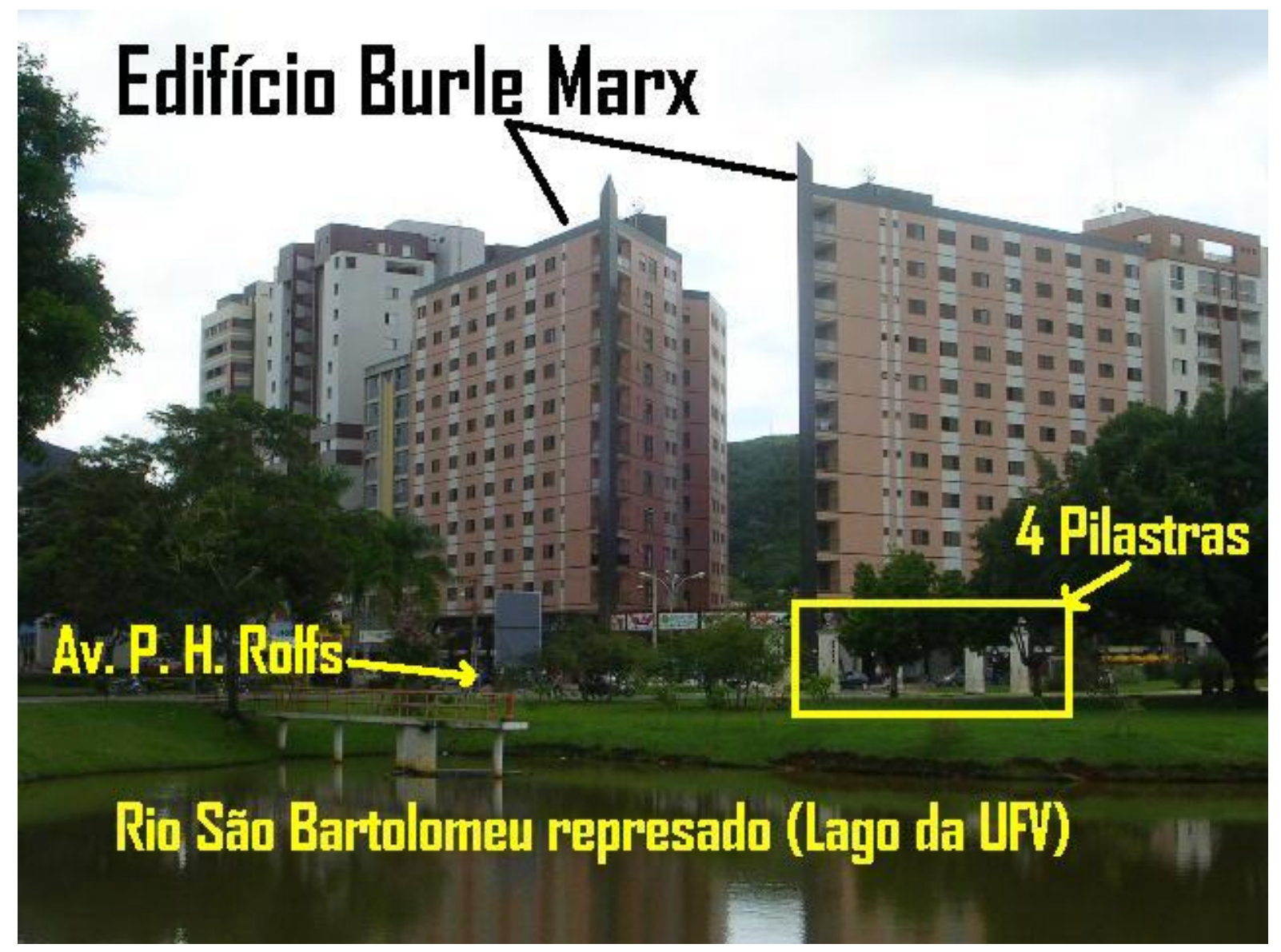

Figura 44a. Visão do Edifício Burle Marx

Observação da Foto: No primeiro plano com os seus dois blocos. Também conhecido como Carandiru, apresenta 12 andares com 120 apartamentos, no formato de quitinetes e 7 salas comerciais. O represamento da UFV, inaugurado em 1982, faz parte do processo de retificação do curso do rio São Bartolomeu dentro da área urbana, o que favoreceu a construção do edifício, que se deu ao "luxo" de permitir a passagem do rio entre os dois blocos, local designado pelo projeto para ser a área de convivência dos moradores, ou seja, em cima do rio, uma vez que o seu leito foi tamponado. Após estas ilegalidades ambientais, liberadas, a partir da flexibilização da legislação ao nível municipal, mesmo contra a Constituição federal, a obra de implementação da área de convivência hoje está embargada.

Foto: Edson Soares Fialho, obtida em 26 de março de 2008. 
A expansão da universidade produz repercussões sobre o espaço geográfico da cidade, agora repleto de edifícios prontos e ainda em construção (Figura 45) e residências, que, visam atender os estudantes, que almejam residir próximo ao campus universitário.

A conseqüência desse processo é o aumento dos preços dos imóveis, que é corroborado com os estudos realizados pelo Departamento de Economia, que divulgou os dados do Índice de Preços ao Consumidor (IPC-Viçosa) no Jornal Tribuna Livre (15/08/2008), com o encarecimento do preço médio do aluguel, que hoje representa $23,1 \%$ da renda do estudante.

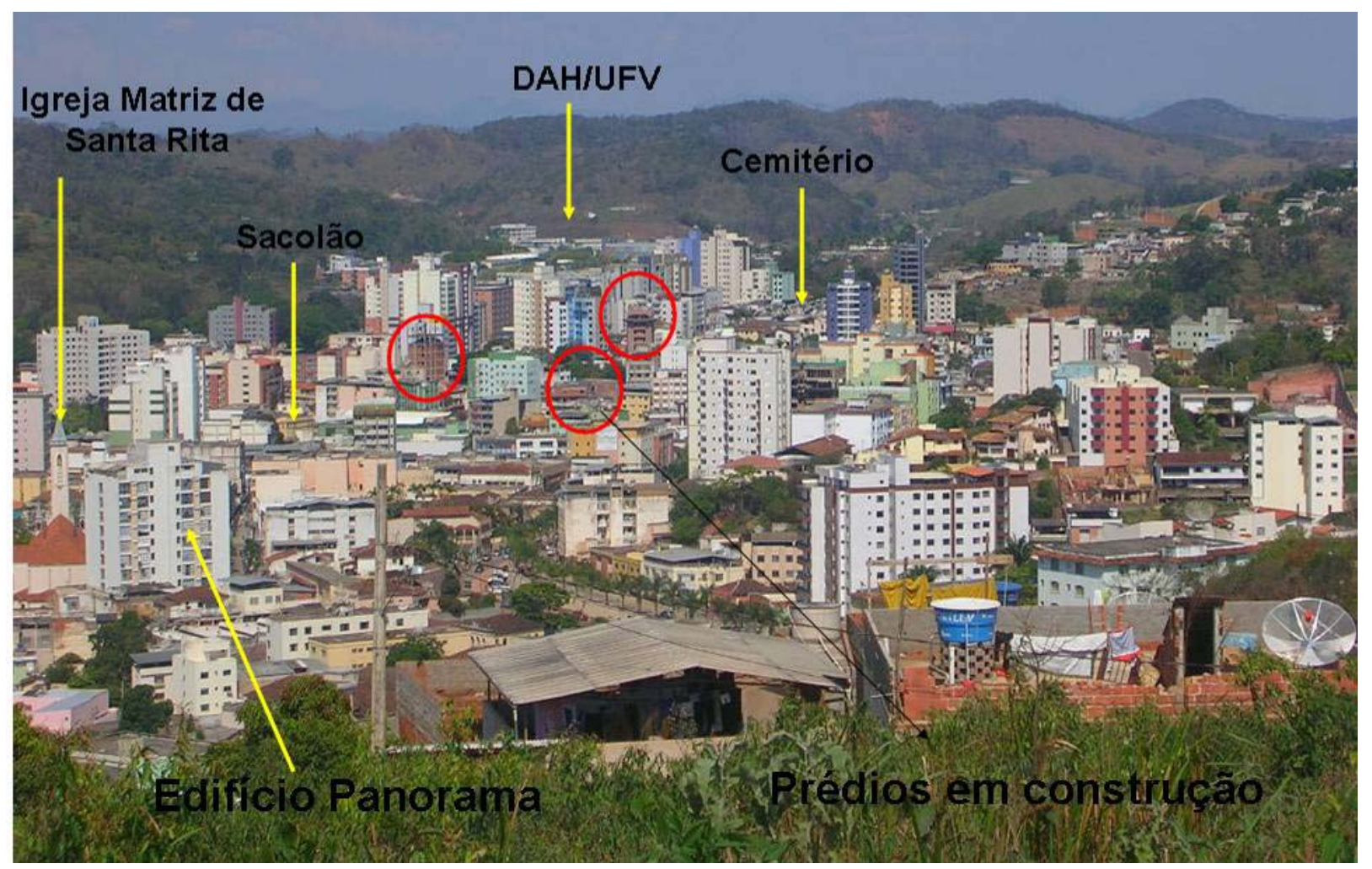

Figura 45. Visão parcial da área central da cidade de Viçosa, a partir do Morro do Cruzeiro, identifica-se alguns prédios em construção e 0 alinhamento das edificações ao longo da AV. P. H. Rolfs que termina na Praça Silviano Brandão, onde se localiza a Igreja matriz de Santa Rita de Cássia.

Foto: Edson Soares Fialho, obtida em 2 de outubro de 2008.

Atualmente, a mancha urbana se espraiou em direção ao vale do rio Turvo Sujo, na altura da antiga estação de Silvestre, antigo núcleo de ocupação do século XIX, conforme registro de Tabuteau (1960) que ainda não se ligava ao núcleo urbano central do município de Viçosa, que distava $4 \mathrm{~km}$ a NNE. 
Agora integrado ao meio urbano, em razão da expansão da área urbana a partir da década de 1970, com a federalização da UFV, que induziu no surgimento de novos bairros na década de 1980, tanto na porção sudoeste, com Nova Viçosa, como na porção nordeste, com os bairros de Santo Antônio e João Braz, conforme pode ser acompanhado na Figura 46.

Porém algumas áreas dentro da mancha urbana, ainda não são consideradas como tais, criando terrenos baldios vazios especulativos, que por força de lei são considerados como rurais, com características rurais. Além da própria área da UFV, que apesar de não ser toda ocupada, tem sua parte próxima a cidade toda urbanizada, mas não é considerada por se tratar de uma instituição federal.

Apesar destas incongruências, o aumento da população universitária (professores, funcionários e estudantes) cria o surgimento de novas oportunidades, acarretando o aumento do número de migrantes, constituídos em sua maioria por pessoas de baixa renda. Estes, devido a sua condição socioeconômica, ao chegarem a Viçosa são impedidos de residirem nas áreas centrais em função do preço dos aluguéis, de imóveis e dos terrenos, ainda vazios, o que acaba direcionando-os a ocupação para locais mais afastados da área de maior oferta de serviços, como é o caso dos bairros de Nova Viçosa, Santo Antônio, Barrinha, Vau-Açu e Romão dos Reis.

Esta mobilidade deu margem para a atuação mais expressiva de pequenos e médios agentes do setor imobiliário, além de pequenos proprietários. Estes, vislumbrando o aumento da demanda de aluguéis e residências, passaram a atuar cada vez mais de forma especulativa, o que contribuiu ainda mais para elevar o preço dos imóveis na cidade.

A elevação de preço dos imóveis, especialmente no centro, e a crescente dificuldade de acesso às terras no mesmo, impulsionaram a formação de áreas periféricas constituídas por população de baixa renda na cidade de Viçosa.

Agora uma nova dinâmica intra-municipal começa a se constituir, com a implantação dos cursos da área da saúde (Medicina e Enfermagem), além dos demais cursos de Licenciatura. No município de Teixeiras, distante cerca de $15 \mathrm{~km}$ do centro de Viçosa está sofrendo uma valorização dos seus terrenos, porque alguns pequenos investidores começam a movimentar para criar casas e prédios para serem alugados por alunos da UFV, o que configura um processo de conurbação em curso. 


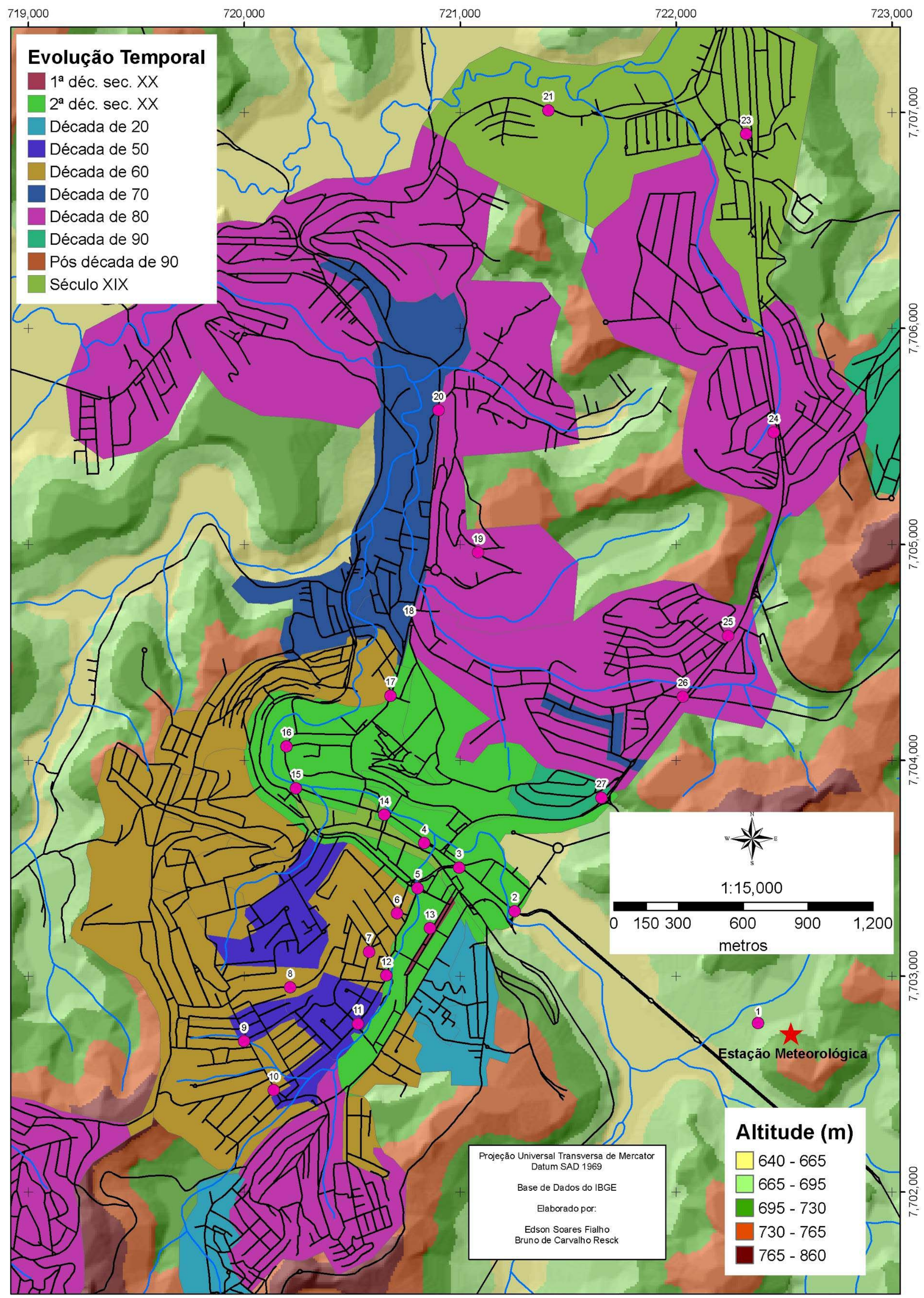

Figura 46. Evolução da mancha urbana de Viçosa.

Organizado por Edson Soares Fialho e Bruno Carvalho Resck (2009). 


\subsection{Viçosa: Uma cidade de pequeno porte}

Dentre as inúmeras reflexões que têm sido realizadas acerca das cidades médias, com objetivo de melhor defini-la, de maneira geral, pode-se agrupá-las em dois grandes conjuntos: o primeiro se fundamenta no critério da dimensão demográfica, desenvolvido inicialmente Rochefort (1957) com fins de analisar a organização territorial das cidades na França. O segundo, diferente do anterior, tem como base as idéias de Michel (1977, p. 642) que critica a noção de cidade média baseada em limites numéricos, pois:

“...A posição de uma cidade na hierarquia urbana e, por conseqüência, seu pertencimento a tal ou qual categoria estatística variam com a época. Uma cidade não nasce média. Ela não permanece média ad aeternam...".

Corroborando este posicionamento, Soares (2007, p. 463) diz que o critério demográfico não consegue dar conta da realidade, porque inclui em uma mesma categoria, cidades muito diversas e sendo assim, este deverá ser estabelecido em conformidade com as particularidades regionais.

Para Corrêa (2007, p. 24) o conceito deve ser construído tendo como base a relação entre tamanho, função e espaço intra-urbano. Apesar disto, o mesmo autor identifica três dificuldades referentes ao tamanho demográfico, que seriam: o tamanho absoluto, a escala espacial e o recorte temporal.

As duas linhas de pensamento procuram definir a cidade média, mas em ambas se percebe a concepção da idéia de cidade ideal, encarando-a como uma entidade econômica e socialmente equilibrada. Efetivamente, esta leitura, tem, de forma indireta, estado sempre ao longo dos tempos nas várias culturas e estados (COSTA, 2002).

Como se observa, as duas correntes, na busca de uma definição do que venha a ser cidade média, se coloca de imediato a questão dos critérios. Estes, embora tenham implícita uma noção de dimensão física e populacional, a diversidade de valores propostos pelas várias organizações internacionais e nos estudos orientados em vários países vem demonstrando a insuficiência de um critério, que assente exclusivamente na dimensão populacional.

Um dos fatores que explicam a dificuldade de encontrar um valor quantitativo que caracterize uma cidade média é o fato da dimensão populacional proposta variar 
de acordo com a escala de análise. Comparando os limites demográficos constatase uma grande heterogeneidade, em intervalo bastante amplo.

Algumas organizações internacionais consideram como limiar mínimo os 100 mil habitantes, como é o caso da Organização das Nações Unidas (ONU). Outros estudos realizados apontam para valores um pouco diferentes, mas igualmente elevados. Assim, no VII Congresso Ibero-Americano de Urbanismo, ocorrido em Pamplona, em 1996, consideram cidades médias todas aquelas com população entre 20 a 500 mil habitantes, enquanto em estudos desenvolvidos no âmbito de um trabalho da União Internacional dos Arquitetos, intitulado “...Cidades intermediárias e urbanização mundial..." considera que as cidades médias estão entre os núcleos pequenos, com menos de 20 mil habitantes (UIA, 1998, p. 2).

Contudo, mesmo reconhecendo a existência de limitações na utilização de um critério quantitativo, é importante identificar esses valores e os fatores subjacentes a essa diversidade, conforme pode ser visto na Tabela 11, que discrimina os totais populacionais das cidades médias européias.

Tabela 11. Comparação entre a dimensão demográfica da maior aglomeração e a dimensão demográfica das cidades médias, em alguns países da União Européia.

\begin{tabular}{|l|c|c|}
\hline \multicolumn{1}{|c|}{ Países } & $\begin{array}{c}\text { Cidade média } \\
\text { Escala de dimensão (habitantes) }\end{array}$ & $\begin{array}{c}\text { Maior aglomeração } \\
\text { (1985) }\end{array}$ \\
\hline Alemanha & $150.000-600.000$ & 3.437 .290 \\
\hline Dinamarca & $<100.000$ & 1.336 .855 \\
\hline Espanha & $30.000-300.000$ & 2.976 .064 \\
\hline França & $20.000-100.000$ & 9.319 .367 \\
\hline Grécia & $50.000-100.000$ e $10.000-50.000$ & 3.072 .922 \\
\hline Portugal & $20.000-100.000$ & 2.561 .225 \\
\hline Irlanda & $50.000-100.000$ & 915.516 \\
\hline Suécia & $50.000-200.000$ & 1.570 .320 \\
\hline Burkina Faso & $10.000-50.000$ & \\
\hline Bolívia & $5.000-35.000$ & \\
\hline Chile & $50.000-200.000$ & \\
\hline
\end{tabular}

Fonte: Amorim Filho e Rigotti (2008) e Costa (2002, p. 110).

A perspectiva funcionalista de cidade média, importante nas décadas de 1960 e 1970, período em que estas começaram a ser entendidas como elementos estratégicos no estabelecimento de redes urbanas equilibradas e motores do processo de desenvolvimento regional, há muito tempo vem sendo alvo de críticas de vários autores. 
As cidades médias desempenham funções de lugar central. Isto significa que suas atividades econômicas e sociais - e assim as próprias cidades - devem servir às pessoas que vivem fora de seus limites. Outros argumentam que as funções devem também ser interativas, conectar-se e servir de canais para o fluxo de bens e serviços, mediar relações sociais e difundir impulsos de desenvolvimento econômico em sua região, pois as mesmas são caracterizadas pelo papel de intermediação funcional nos fluxos de poder, inovação, pessoas e recursos entre lugares.

Com base nestes critérios, determinar a intermediação funcional é muito difícil. Pouca informação está habitualmente disponível sobre as características funcionais de cidades ou sobre fluxos de pessoas e recursos entre elas.

Apesar disto, Garcia e Nogueira (2008) procuraram classificar a rede urbana do estado de Minas Gerais, adotando a perspectiva do ordenamento territorial, associada à adoção da dimensão de natureza econômica, cabendo a aplicação do índice de terceirização (IT) para esse fim (Figuras 47 e 48).

Com base nesta proposta, os autores identificaram 34 cidades mineiras como de médio porte. Diferente do critério quantitativo (a cidade tem que apresentar uma população total na faixa de 100 mil a 500 mil habitantes), que apenas discriminou 23 cidades.

Verifica-se, conforme os dados da Tabela 12, que seus respectivos IT variam de 0,020 (Itajubá) até 0,507 (Belo Horizonte). Ao se considerar somente os municípios sede de pólos mesorregionais o limite superior do IT cai para 0,188 (Uberlândia). Têm-se aí um critério para identificação sob uma ótica econômica, ou seja, os municípios mineiros que, independentemente de seu contingente demográfico urbano, apresentam um IT entre 0,02 e 0,19 são classificados como cidades médias.

Do ponto de vista demográfico, percebe-se ainda que a variação do contingente populacional das localidades consideradas cidades médias foi muito elevado. Por exemplo, enquanto Além Paraíba, apresenta 36 mil habitantes, o se encontra na faixa de 50 e 100 mil (Itajubá, Ituiutaba, Lavras, Manhuaçu, Patrocínio, São João del Rei, Ubá e Viçosa), o terceiro entre 100 e 200 mil (Araguai, Barbacena, Conselheiro Lafaiete, Coronel Fabriciano, Ibirité, Patos de Minas, Poços de Caldas, Pouso alegre e Varginha) e quarto acima de 200 mil até 2 milhões de habitantes (Contagem, Betim, Divinópolis, Governador Valadares, Ipatinga, Juiz de Fora, Montes Claros, Ribeirão das Neves, Santa Luzia, Sete Lagoas e Belo Horizonte) 
indica que o critério adotado flexibiliza o volume populacional enquanto critério para a definição do que sejam cidades médias.

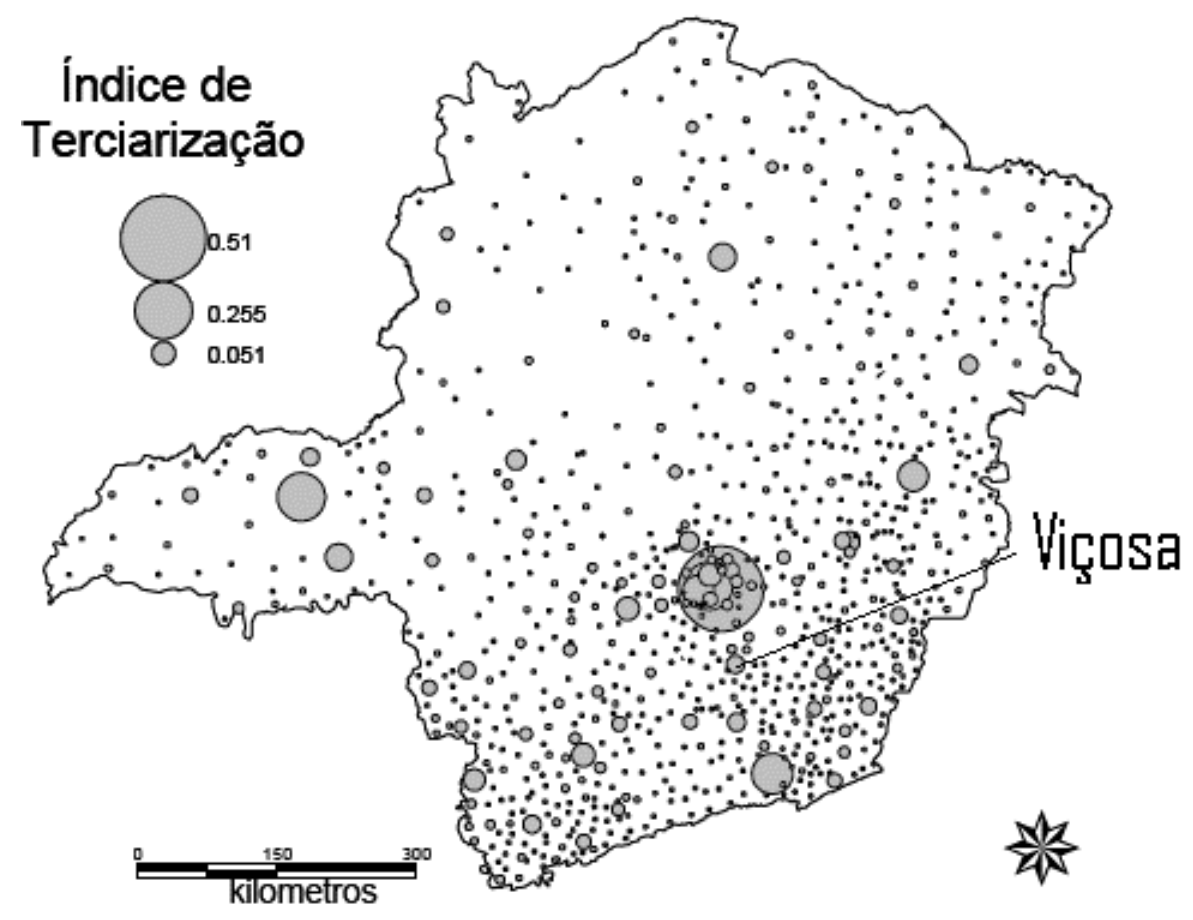

Figura 47. Minas Gerais: 2003. Índice de Terceirização dos municípios mineiros. Fonte: Garcia e Nogueira (2008).

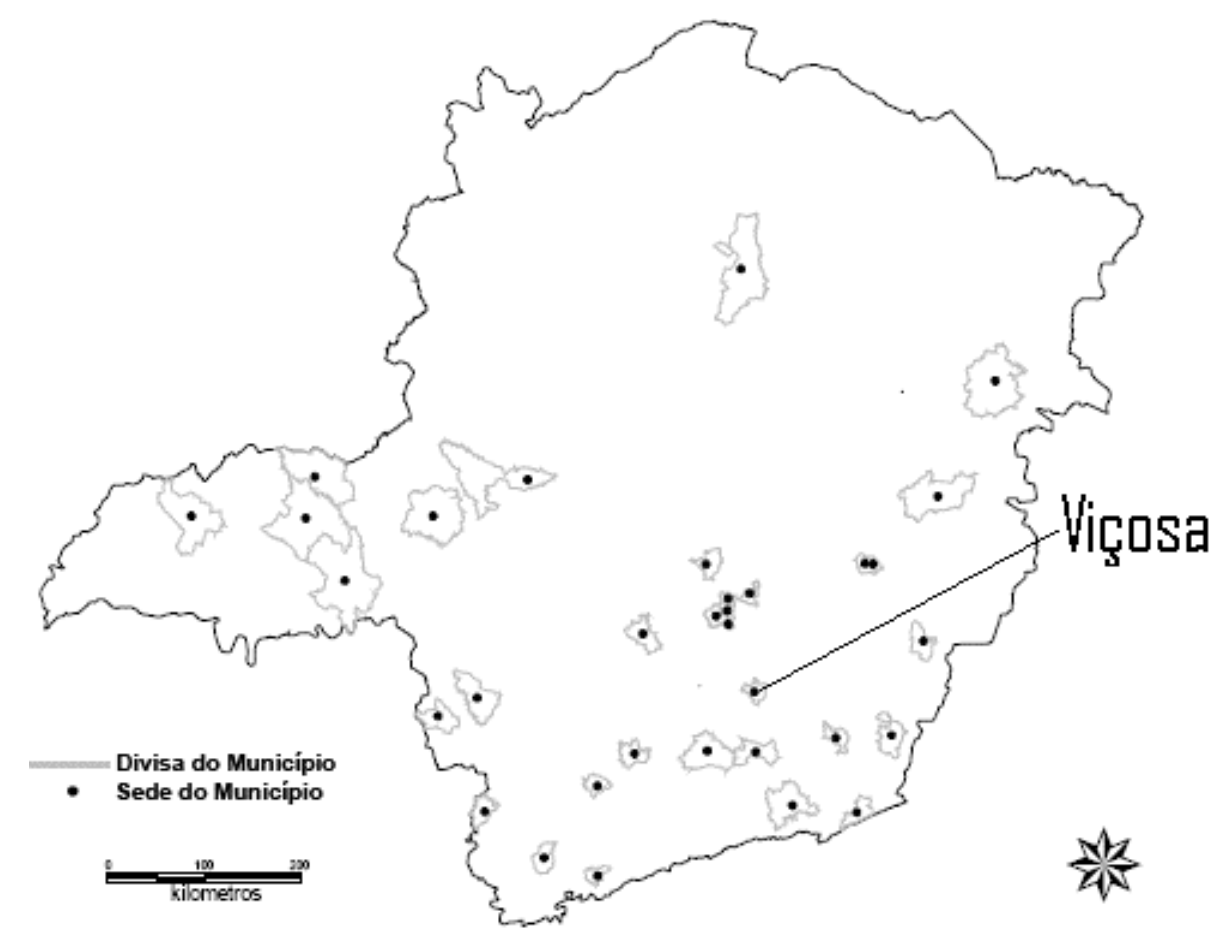

Figura 48. Minas Gerais: 2005. Cidades médias de Minas Gerais, segundo o índice de terceirização.

Fonte: Garcia e Nogueira (2008). 
Tabela 12. Minas Gerais: 2005. População residente, PIB em 2003, relação média trienal (2001, 2001 e 2003) entre o valor adicionado pelo serviço e o PIB e índice de terceirização, municípios mineiros selecionados.

\begin{tabular}{|c|c|c|c|c|}
\hline Município & $\begin{array}{c}\text { População } \\
\text { residente em } \\
2005\end{array}$ & $\begin{array}{c}\text { PIB a preço de } \\
\text { mercado } \\
\text { corrente-2003 }\end{array}$ & $\begin{array}{c}\text { Relação entre o } \\
\text { valor adicionado } \\
\text { pelo serviço e o } \\
\text { PIB }\end{array}$ & $\begin{array}{c}\text { Índice de } \\
\text { Terceirização }\end{array}$ \\
\hline Além Paraíba & 35.985 & 258166 & 0,796 & 0,023 \\
\hline Araguai & 108.386 & 667609 & 0,559 & 0,030 \\
\hline Barbacena & 122.663 & 663980 & 0,572 & 0,030 \\
\hline Belo Horizonte & 2.369 .288 & 21565533 & 0,606 & 0,507 \\
\hline Betim & 395.577 & 12727140 & 0,248 & 0,091 \\
\hline Conselheiro Lafaiete & 111.154 & 383585 & 0,757 & 0,031 \\
\hline Contagem & 591.781 & 376665 & 0,478 & 0,183 \\
\hline Coronel Fabriciano & 104.313 & 316199 & 0,769 & 0,028 \\
\hline Divinópolis & 203.779 & 1423049 & 0,522 & 0,051 \\
\hline Governador Valadares & 257010 & 1483362 & 0,649 & 0,081 \\
\hline Ibirité & 168.714 & 592791 & 0,541 & 0,022 \\
\hline Ipatinga & 232.158 & 3885540 & 0,275 & 0,037 \\
\hline Itajubá & 90054 & 648703 & 0,455 & 0,020 \\
\hline Ituiutaba & 95.415 & 895922 & 0,420 & 0,020 \\
\hline Juiz de Fora & 498.944 & 3674197 & 0,545 & 0,140 \\
\hline Lavras & 84.263 & 567207 & 0,522 & 0,022 \\
\hline Manhuaçu & 71.820 & 445612 & 0,652 & 0,027 \\
\hline Montes Claros & 341.704 & 1843582 & 0,505 & 0,064 \\
\hline Muriaé & 98.569 & 433238 & 0,673 & 0,027 \\
\hline Passos & 104.027 & 570244 & 0,538 & 0,025 \\
\hline Patos de Minas & 136.623 & 842624 & 0,558 & 0,036 \\
\hline Patrocínio & 78.223 & 505584 & 0,573 & 0,022 \\
\hline Poços de Caldas & 151.220 & 2008626 & 0,396 & 0,044 \\
\hline Pouso alegre & 122.194 & 990065 & 0,465 & 0,032 \\
\hline Ribeirão das neves & 313.781 & 753352 & 0,683 & 0,048 \\
\hline Santa Luzia & 214.161 & 1026537 & 0,440 & 0,028 \\
\hline São João Del Rei & 84.176 & 429902 & 0,582 & 0,021 \\
\hline São Sebastião do Paraíso & 62.405 & 375888 & 0,658 & 0,023 \\
\hline Sete Lagoas & 210.051 & 1834892 & 0,391 & 0,037 \\
\hline Teófilo Otoni & 129.077 & 511498 & 0,645 & 0,031 \\
\hline Ubá & 90.938 & 469000 & 0,560 & 0,021 \\
\hline Uberaba & 278.619 & 3975758 & 0,387 & 0,070 \\
\hline Uberlândia & 584.865 & 7485592 & 0,485 & 0,188 \\
\hline Viçosa & 121.836 & 1226300 & 0,580 & 0,055 \\
\hline $\mathbf{6 9 3 4 3}$ & $\mathbf{2 7 3 3 5 8}$ & $\mathbf{0 , 7 1 4}$ & $\mathbf{0 , 0 2 0}$ \\
\hline
\end{tabular}

Fonte: Garcia e Nogueira (2008).

Branco (2007) em trabalho desenvolvido com a mesma finalidade identificar o estrato composto pelas cidades médias e lou intermediárias, na rede urbana de Minas Gerais, considerou como critério, informações que sintetizassem aspectos relativos às características mais relevantes, tais como: tamanho populacional e econômico; qualidade de vida; centralidade administrativa e a vida de relações, que foram pontuados segundo a metodologia de adotada por Rochefort (1957) para classificação de centros urbanos. Com base neste critério, a autora subdividiu as 
cidades médias em três níveis (Tabela 13), a fim de facilitar a análise, o que não significa necessariamente uma hierarquia, uma vez que a busca é identificar o papel dos centros que desempenham, ou têm possibilidade de desempenhar, a função de intermediação entre as diferentes escalas de centros da rede urbana.

Tabela 13. O universo de cidades médias para o estado de Minas Gerais.

\begin{tabular}{|c|c|c|}
\hline Grupo 1 & Grupo 2 & Grupo 3 \\
\hline Uberlândia & $\begin{array}{c}\text { Juiz de Fora } \\
\text { Uberaba } \\
\text { Montes Claros } \\
\text { Governador Valadares } \\
\text { Poços de Caldas } \\
\text { Ipatinga } \\
\text { Araxá } \\
\text { Patos de Minas } \\
\text { Varginha } \\
\text { Divinópolis } \\
\text { João Monlevade }\end{array}$ & $\begin{array}{c}\text { Alfenas } \\
\text { Barbacena } \\
\text { Itabira } \\
\text { Lavras } \\
\text { Passos } \\
\text { Pouso Alegre } \\
\text { Itajubá } \\
\text { Ituiuitaba } \\
\text { Patrocínio } \\
\text { Teófilo Otoni } \\
\text { Três corações } \\
\text { Itapeva } \\
\text { Cataguases } \\
\text { Coronel Fabriciano } \\
\text { Formiga } \\
\text { Muriaé } \\
\text { Ouro Preto } \\
\text { São João Del rei } \\
\text { São Sebastião do Paraíso } \\
\text { Ubá } \\
\text { Viçosa } \\
\text { Caratinga } \\
\text { Curvelo } \\
\text { Manhuaçu } \\
\text { Paracatu } \\
\text { Janaúba }\end{array}$ \\
\hline
\end{tabular}

Fonte: Branco (2007, p, 106-111, Adaptado.)

Já Amorim Filho et. al. (2007) em suas pesquisas que datam do final da década de 1970, que vem acompanhando o perfil e a evolução das cidades médias em Minas Gerais. E neste trabalho, especificamente, busca apresentar uma reflexão sobre as bases teóricas e metodológicas empregadas nas três classificações hierárquicas de redes urbanas mineiras elaboradas e sobre seus principais resultados.

No primeiro trabalho desenvolvido em Amorim Filho (1982) enfrentou um desafio teórico-metodológico, com a necessidade de se definir qual seria o grupo de cidades a ser estudado e classificado, uma vez que não fazia sentido, para a finalidade que os autores se propunham, levantar informações sobre todas as 722 cidades de então, em Minas Gerais. 
Assim, desde o começo das pesquisas, optou-se, por razões teóricas, por não se incluir na pesquisa Belo Horizonte e toda região metropolitana de Belo Horizonte $(\mathrm{RMBH})$, pois as características mais típicas das cidades médias são mascaradas naquelas cidades, por estarem inseridas em um organismo urbano de dimensão e complexidade bem maiores. Um segundo problema dizia respeito à escolha do limiar demográfico inferior, a partir do qual seria formado o grupo de cidades a ser pesquisado, e o contingente populacional limite definido foi de 10 mil habitantes. Terceiro, quais seriam os níveis hierárquicos, no caso o autor optou por 4 que seriam: Grandes centros regionais, Cidades médias de nível superior, Cidades médias propriamente ditas e Centros urbanos emergentes.

O tratamento computacional dos dados recaiu sobre uma técnica até então muito pouco utilizada no Brasil: uma Análise de componentes principais (ACP). Para essa classificação estatística das 102 cidades, 25 variáveis foram selecionadas, referindo-se aos seguintes parâmetros: crescimento da população urbana; migrações; distribuição setorial da população ativa; arrecadação municipal; equipamentos e relações dos setores comerciais e de serviços; equipamentos e relações do setor industrial; infra-estrutura de comunicação em geral e posição da cidade considerada na rede urbana regional.

No segundo trabalho de revisão Amorim Filho (1999) manteve grande parte da metodologia empregada 1982, mas acrescentando dois outros elementos ignorados: o primeiro foi a inclusão, entre as variáveis escolhidas para a classificação, de algumas que permitissem avaliar a importância das iniciativas de algumas cidades médias no campo das tecnologias de ponta e o segundo foi a inclusão de variáveis relacionadas a qualidade de vida urbana, inclusive o índice de desenvolvimento humano (IDH).

Por fim, na terceira revisão da temática Amorim Filho (2007) iniciada em 2005, com sua fase de campo já visitou 60 cidades que fazem parte da lista daquelas que, nas pesquisas anteriores, sempre foram classificadas como cidades médias. Mais uma vez, Belo Horizonte e as demais cidades da RMBH foram descartadas pelos motivos teóricos apresentados em estudos anteriores.

A diferença foi a alteração do limiar demográfico inferior das cidades selecionadas para a de 10 mil habitantes, utilizado em 1982 para 14 mil habitantes. A mudança se deve a uma constatação de campo, a partir do qual esse limiar demográfico começa, em certas regiões, a desenvolver, pelo menos parcialmente, equipamentos e funções próprios de cidades médias. Portanto, as cidades-sedes 
municipais, com populações inferiores a 14 mil habitantes, consideradas estatística e aprioristicamente como cidades pequenas, foram descartadas. A partir da descrição metodológica dos trabalhos desenvolvidos ao longo de mais de 30 anos por Amorim Filho os resultados podem ser visualizados na Figura 49 e Tabela 14. .

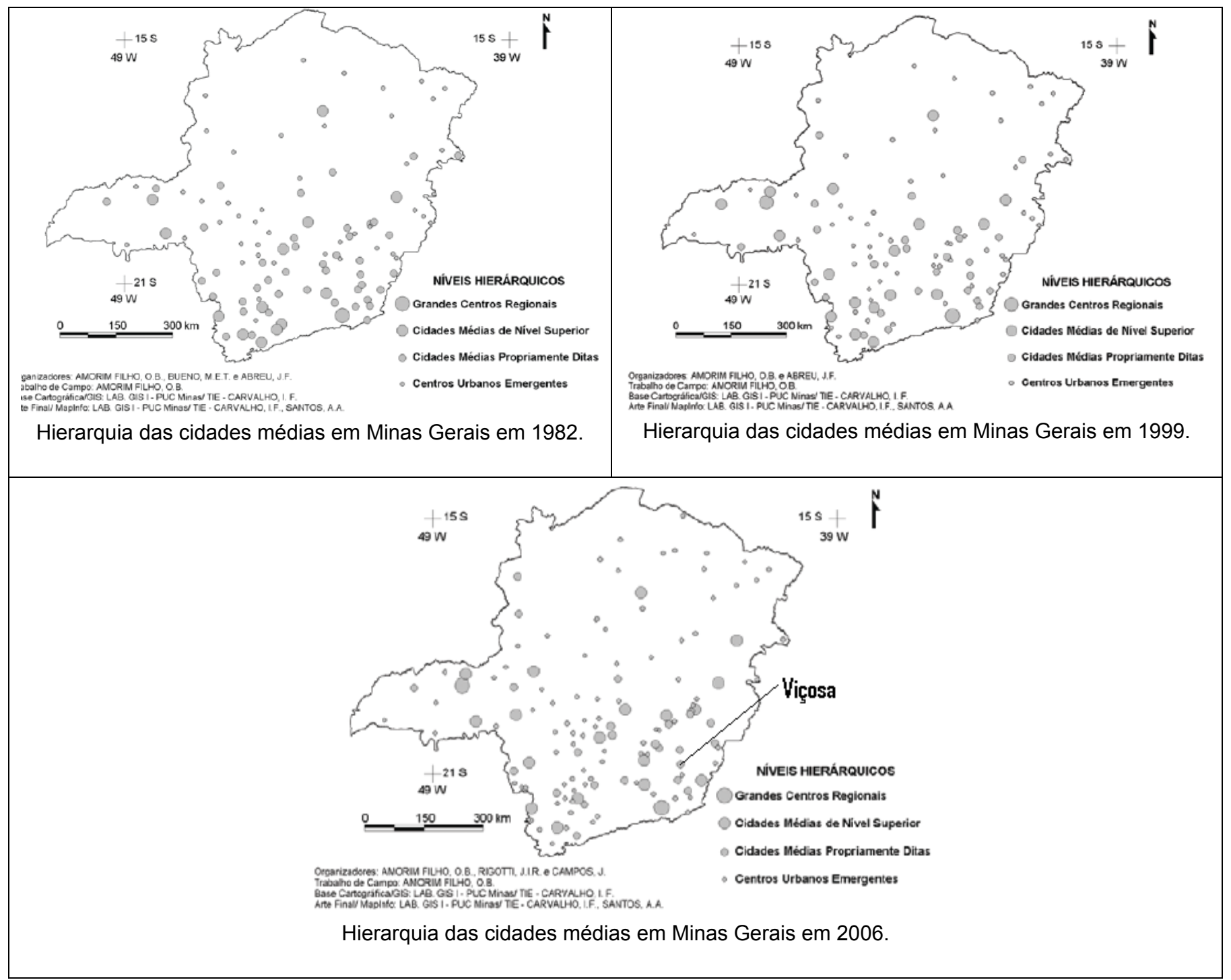

Figura 49. Nível hierárquico das cidades médias, no Estão de Minas Gerais.

Fonte: Amorim Filho et. al. (2007, p. 11-14 e 16).

Dentre os resultados da pesquisa pode-se observar o enquadramento das cidades mineiras de acordo com a classificação hierárquica estabelecida para o ano de 2006, conforme pode ser visualizado na Figura 49.

Além deste novo levantamento, cabe destacar que: as cidades de Juiz de Fora e Uberlândia, que na classificação de 1999 já tinham sido as únicas cidades a se 
colocarem no nível mais alto das cidades médias, mantiveram sua posição. Em relação a essas cidades, quase alcançando enquadrando na categoria de grandes cidades.

Tabela 14. Níveis hierárquicos das cidades médias de Minas Gerais.

\begin{tabular}{|c|c|c|c|}
\hline Grupo 1 & Grupo 2 & Grupo 3 & Grupo 4 \\
\hline $\begin{array}{l}\text { Juiz de Fora } \\
\text { Uberlândia }\end{array}$ & $\begin{array}{c}\text { Alfenas } \\
\text { Araguari } \\
\text { Barbacena } \\
\text { Divinópolis } \\
\text { Governador Valadares } \\
\text { Ipatinga (aglomeração), } \\
\text { Itajubá } \\
\text { Ituiutaba } \\
\text { Lavras } \\
\text { Montes Claros } \\
\text { Passos } \\
\text { Patos de Minas } \\
\text { Poços de Caldas } \\
\text { Pouso Alegre } \\
\text { Sete Lagoas } \\
\text { Uberaba } \\
\text { Varginha. }\end{array}$ & $\begin{array}{c}\text { Araxá } \\
\text { Caratinga } \\
\text { Cataguases } \\
\text { Conselheiro Lafaiete } \\
\text { Curvelo } \\
\text { Formiga } \\
\text { Frutal } \\
\text { Guaxupé } \\
\text { Itabira } \\
\text { Itaúna } \\
\text { João Monlevade } \\
\text { Leopoldina } \\
\text { Muriaé } \\
\text { Ouro Preto } \\
\text { Paracatu } \\
\text { Pará de Minas } \\
\text { Patrocínio } \\
\text { Ponte Nova } \\
\text { Santa Rita do Sapucaí } \\
\text { São João del Rei } \\
\text { São Lourenço, São } \\
\text { Sebastião do Paraíso } \\
\text { Três Corações } \\
\text { Teófilo Otoni } \\
\text { Ubá } \\
\text { Viçosa. }\end{array}$ & $\begin{array}{c}\text { Abaeté } \\
\text { Aimorés } \\
\text { Além Paraíba } \\
\text { Almenara } \\
\text { Andradas } \\
\text { Araçuaí } \\
\text { Arcos } \\
\text { Bambuí } \\
\text { Barão de Cocais } \\
\text { Boa Esperança } \\
\text { Bocaiúva } \\
\text { Bom Despacho } \\
\text { Campo Belo } \\
\text { Carangola } \\
\text { Carlos Chagas } \\
\text { Carmo do Paranaiba } \\
\text { Caxambu } \\
\text { Congonhas } \\
\text { Conselheiro Pena } \\
\text { Corinto } \\
\text { Diamantina } \\
\text { Dores do Indaiá } \\
\text { Ibiá } \\
\text { Itabirito } \\
\text { Itambacuri } \\
\text { Itapecerica } \\
\text { Janaúba } \\
\text { Iturama } \\
\text { Januária } \\
\text { Jequitinhonha } \\
\text { João Pinheiro } \\
\text { Lagoa da Prata } \\
\text { Machado } \\
\text { Manhuaçu } \\
\text { Manhumirim } \\
\text { Mantena } \\
\text { Mariana } \\
\text { Monte Carmelo } \\
\text { Nanuque } \\
\text { Nova Era } \\
\text { Nova Serrana } \\
\text { Oliveira } \\
\text { Ouro Branco } \\
\text { Ouro Fino } \\
\text { Pedra Azul } \\
\text { Pirapora, } \\
\text { Pium-í } \\
\text { Raul Soares } \\
\text { Resplendor } \\
\text { Sacramento } \\
\text { Salinas } \\
\text { Santa Bárbara } \\
\text { Santos Dumont } \\
\text { São Gonçalo do Sapucaí } \\
\text { São Gotardo, } \\
\text { Três Pontas, } \\
\text { Tupaciguara } \\
\text { Unaí } \\
\text { Visconde do Rio Branco. }\end{array}$ \\
\hline
\end{tabular}

Fonte: Filho et. al. (2007, p. 13). 
No patamar das cidades médias de nível superior, houve estabilidade quando se considera o número de cidades que se classificaram nesse nível: ele passou de 17, em 1999, para 18 em 2006. Apesar de haver pouca mudança numérica, houve algumas modificações quanto às cidades incluídas nesse nível hierárquico:

No nível 3, aquele em que se classificam as cidades médias propriamente ditas, o número dessas cidades permaneceu quase inalterado entre as classificações de 1999 e 2006: diminuiu de 26 para 25. Algumas cidades do nível 3 caíram para o nível 4: Frutal, Guaxupé, Leopoldina, Santa Rita do Sapucaí e São Loureço. Outras fizeram o caminho inverso: Coronel Fabriciano, Manhuaçu e Mariana.

Em muitos casos, o crescimento de certas cidades se mantém em vários setores e, mesmo assim, ela perde hierarquia. A razão pode estar no fato de que outras cidades cresceram em um ritmo ainda mais intenso. O mesmo raciocínio vale no caso oposto. Além disso, como já foi dito, embora os indicadores gerais sejam parecidos de uma classificação para a outra, as variáveis se modificam e isso interfere nos resultados, quando comparados.

É preciso lembrar também que, embora as classificações sejam parecidas, algumas de suas motivações foram diferentes. Um exemplo disso está no caso de Santa Rita do Sapucaí, situada no sul de Minas, que obteve maior hierarquia em 1999, quando a finalidade era identificar, entre outras coisas, o potencial tecnopolitano. Em 2006, quando esse critério já não era prioritário, Santa Rita caiu para o nível dos centros urbanos emergentes.

Mesmo com a elevação do limiar demográfico inferior das cidades selecionadas para a pesquisa, de 10 mil habitantes urbanos na sede municipal, usado em 1982, para 14 mil em 2006, o número dos centros emergentes aumentou significativamente, passando de 45, em 1982, para 59 em 1999 e para 86 em 2006; isso quer dizer, provavelmente, que o número de cidades médias mineiras deverá crescer nos próximos anos.

Embora a distribuição geográfica dos centros emergentes venha se mantendo sem grandes alterações geográficas, um fato vem ocorrendo de maneira silenciosa na porção norte de Minas Gerais, que dispõe de tão poucas e mal distribuídas cidades médias (Montes Claros, Teófilo Otoni, Paracatu e Unaí), observa-se um aumento importante de centros urbanos emergentes, e isso é um indício de que, talvez, nas próximas hierarquizações das cidades mineiras, o norte de Minas e os vales do Jequitinhonha e do Mucuri já passem a ter uma rede urbana mais equilibrada do que a da atualidade. 
Estes trabalhos apresentados acima procuram adotar critérios coerentes e consistentes, possibilitando enxergar a cidade média através da escala do município $^{15}$, os mesmos não foram capazes de diferenciar a dinâmica intra-urbana e a espacialidade das construções, elementos importantes para quem pretende analisar a repercussão do meio urbano sobre a baixa troposfera, mesmo que em todas as hierarquizações Viçosa se enquadre como cidade média, com seus 70 mil habitantes.

Cabe relativar os critérios adotados, por exemplo, no trabalho de Garcia e Nogueira (op. cit.) municípios como Além Paraíba, com 35 mil habitantes, foi é enquadrado na mesma classe de Contagem e outros municípios com mais de 500 mil habitantes. Na pesquisa realizada por Branco (op. cit.), apesar de distinguir os níveis das cidades médias, assim como Garcia e Nogueira (op. cit.), englobam um universo muito mais heterogêneo.

Por conta dessa diversidade de critérios e linhas de pensamentos distintos, a melhor perspectiva de entendimento da cidade para o estudo do clima urbano, ainda é o viés quantitativo, que define as cidades pequenas, a partir de um contingente populacional de até 100 mil habitantes; as cidades médias entre 100 mil e 500 mil habitantes e cidades grandes com número superior a 500 mil habitantes.

Este entendimento, por si só, ainda é muito significativo, pois de maneira direta a dimensão do contingente populacional, influenciará no maior ou menor fluxo de veículos, pessoas, capitais e no consumo de energia para iluminação, aquecimento de água e condicionamento do ar. Isto irá se reverter em um maior número de edificações e, por conseguinte, uma expansão da área construída, que demandará serviços e o consumo de energia.

No caso de Viçosa, a expansão da UFV é o fator detonador destes processos imobiliários especulativos. $\mathrm{O}$ argumento mais contundente para reforçar esta idéia, são os momentos de greve na instituição.

Os alunos retornam as cidades de origem e quase que instantaneamente as vendas do comércio e a oferta de serviços reduz bruscamente, mesmo o preço dos aluguéis. Com base nesta compreensão, o presente adota como pequenas, as cidades com menos de 100 mil habitantes.

\footnotetext{
${ }^{15}$ No Brasil o termo município se confunde com cidade.
} 


\section{Materiais e Métodos}

$\mathrm{Na}$ tentativa de abordar de maneira adequada a área de estudo procurou-se dividir o trabalho em quatro etapas.

\subsection{Análise da tendência da temperatura do ar em Viçosa-MG}

A primeira refere-se à análise temporal dos dados da estação meteorológica de Viçosa. Para isso, optou-se em escolher uma das duas estações climáticas oficiais em funcionamento. A primeira pertence ao Instituto Nacional de Meteorologia (INMET) e segunda ao Centro de Previsão do Tempo e Estudo do Clima (CPTEC). Atualmente, ambas funcionam com estações automáticas, porém o INMET apresenta uma série histórica maior e seus registros ainda são realizados pela forma convencional. Em razão disso, a escolha recaiu sobre a estação meteorológica padrão ( $1^{\text {a }}$ Classe) do INMET, gerenciada no campus da UFV pelo Departamento de Engenharia Agrícola (DEA), com intuito de retratar a evolução da temperatura média, máxima e mínima do ar -mensal e anual- (ver a localização na Figura 53, p. 163), relativos ao período de 1968 a 2006.

O teste não-paramétrico de Mann-Kendall foi utilizado para análise das tendências lineares da série. Este teste é recomendado pela Organização Meteorológica Mundial (OMM) em estudos de tendências em séries temporais de elementos climáticos (YU et al., 2002).

De acordo com Silveira e Gan (2006), o teste de Mann-Kendall pode ser usado em séries descontínuas com distribuição desconhecida, com a vantagem de usar a magnitude relativa dos valores da série. Assumindo a hipótese nula $\left(\mathrm{H}_{0}\right)$, ausência de tendência, os dados precisam ser variáveis aleatórias, independentes e identicamente distribuídas.

O teste de Mann-Kendall consiste do cálculo da estatística S dado na Equação 13:

Equação 13:

$$
\mathrm{S}=\sum_{\mathrm{j}=\mathrm{i}+1}^{\mathrm{n}}\left(\mathrm{R}_{\mathrm{j}}-\mathrm{R}_{\mathrm{i}}\right)
$$

onde, $\mathrm{Rj}$ e $\mathrm{Ri}$ representam a ordem relativa de cada elemento da série temporal, As diferenças ( $\mathrm{Rj}-\mathrm{Ri}$ ) recebem valor zero $(0)$ se $(\mathrm{Rj}-\mathrm{Ri})=0$, valor -1 se $(R j-R i)>0$ e 1 se $(R j-R i)<0$, Supondo Ho verdadeira, $S$ apresenta uma distribuição 
aproximadamente normal com média zero e variância $\operatorname{Var}(S)=\left[\left(n^{*}(n-1)^{\star}\left(2^{*} n+5\right)\right] / 18\right.$, Finalmente a estatística de teste $Z$ é dada por:

$$
Z= \begin{cases}\frac{S-1}{\sqrt{\operatorname{Var}(S)}} & \text { se } S>0 \\ \frac{S+1}{\sqrt{\operatorname{Var}(S)}} & \text { se } S>0 \\ 0 \quad \text { caso } & \text { contrário }\end{cases}
$$

Adotando um nível de significância de $95 \%, H_{0}$ é rejeitado se $|Z|>Z_{\alpha / 2}$, em que o valor $z_{\alpha / 2}=1,96$ é obtido da tabela normal padrão. $O$ sinal da estatística $Z$ indicará se a tendência é positiva $(Z>0)$ ou negativa $(Z<0)$.

\subsection{Análise da temperatura do ar em diferentes escalas.}

Na busca de identificar a contribuição da cidade na formação de um clima urbano em Viçosa, nesta etapa da pesquisa foram monitorados os parâmetros de temperatura do ar e umidade relativa em três escalas distintas, por meio da técnica de transetos móveis.

A primeira escala $(1: 100.000)$ de abordagem procura levantar as diferentes existentes entre o campo e a cidade para três horários (7:00; 13:00 e 20:00 horas), assim como busca compreender a dinâmica de perda de temperatura do campo e da cidade ao longo da noite e madrugada.

O segundo nível de abordagem se refere ao meio intra-urbano (1:15.000), se procura investigar a interferência dos diferentes tipos de uso de terra e da topografia sobre o campo térmico da cidade para os horários das 9:00; 15:00 e 21:00 horas. A decisão de seguir os horários de leitura da estação meteorológica padrão se deve a própria dinâmica urbana da cidade e a trajetória aparente do sol.

No terceiro plano escalar, ao nível da área central da cidade (1:10.000) a investigação contou com o auxílio de uma bicicleta para percorrer os pontos de medida, com intuito de escapar dos congestionamentos da tarde e do início da noite, na área central da cidade, uma vez que os horários escolhidos para a realização das leituras foram coincidentes aos horários de rush, correspondente aos momentos de saída para o almoço (12:00 horas) e o momento da troca do turno da noite (19:00 horas) e o momento e fim de expediente para a maioria da população ativa da cidade. Já o primeiro horário corresponde ao instante de menor movimento intra- 
urbano, a cidade está acordando (5:00 horas da manhã). A opção destes horários contrastantes tem como objetivo identificar se há correspondência entre a localização entre os núcleos de calor e atividades humanas (comerciais e locais de pico de trânsito). A fim de confirmar estas suspeitas, as leituras foram realizadas em dias de maior e menor atividade comercial.

\subsection{Entre o campo e a cidade}

No primeiro nível de análise constituído pela diferença entre o campo e a cidade, optou-se por mensurar ao longo de um segmento de pontos, pois grande parte da área rural do município apresenta uma grande homogeneidade entorno da área urbana, como pode ser visto na Figura 34 da página 120, que demonstra o uso da terra no município, predominantemente, de pastagens. Em razão disso, não se julgou necessário mensurar a temperatura e a umidade relativa do ar em outras localidades. $O$ critério de escolha do itinerário se pautou na procura de um caminho que abrangesse uma variedade de densidades de construção e uso distintos (Tabela 15).

Com base nesta prioridade, o percurso recaiu sobre o eixo Paula CândidoPorto Firme. O ponto de partida, localizado na divisa do município de Viçosa e Paula Cândido, nas proximidades da propriedade do sítio dos Vitarelli (área de nascente do rio São Bartolomeu, vale este que sofre uma forte pressão da expansão da mancha urbana da cidade com a presença de casas de veraneio, que são alugadas para festas de finais de semana) ao longo da rodovia MG-280 em direção ao Celeiro do Forró, na rodovia MG-356, que dá acesso ao município de Porto Firme.

O percurso contempla 17 pontos de medidas em $22 \mathrm{~km}$ a uma velocidade de $50 \mathrm{~km} \cdot \mathrm{h}^{-1}$ em um tempo máximo de 60 minutos (Figura 50 ). Os horários de medida foram divididos em dois momentos: o primeiro, de acordo com os horários padrões de leitura de estações climáticas (7:00; 13:00 e 20:00 horas), com a utilização de um termohigrômetro digital (Minipa-Modelo MT 241), acoplado a um sistema de tubos de PVC interligados (Figuras 51) instalado em um veículo (Figura 52) durante os dias de inverno (21/8/2008 e 27/8/2008) e verão (27/2/2009, 1/3/2009, 2/3/2009, 3/3/2009); e o segundo, durante a madrugada, iniciando as medidas logo após o pôr-do-sol até cerca das 4:00 horas da madrugada do dia seguinte, com base nos mesmos procedimentos de coleta. 


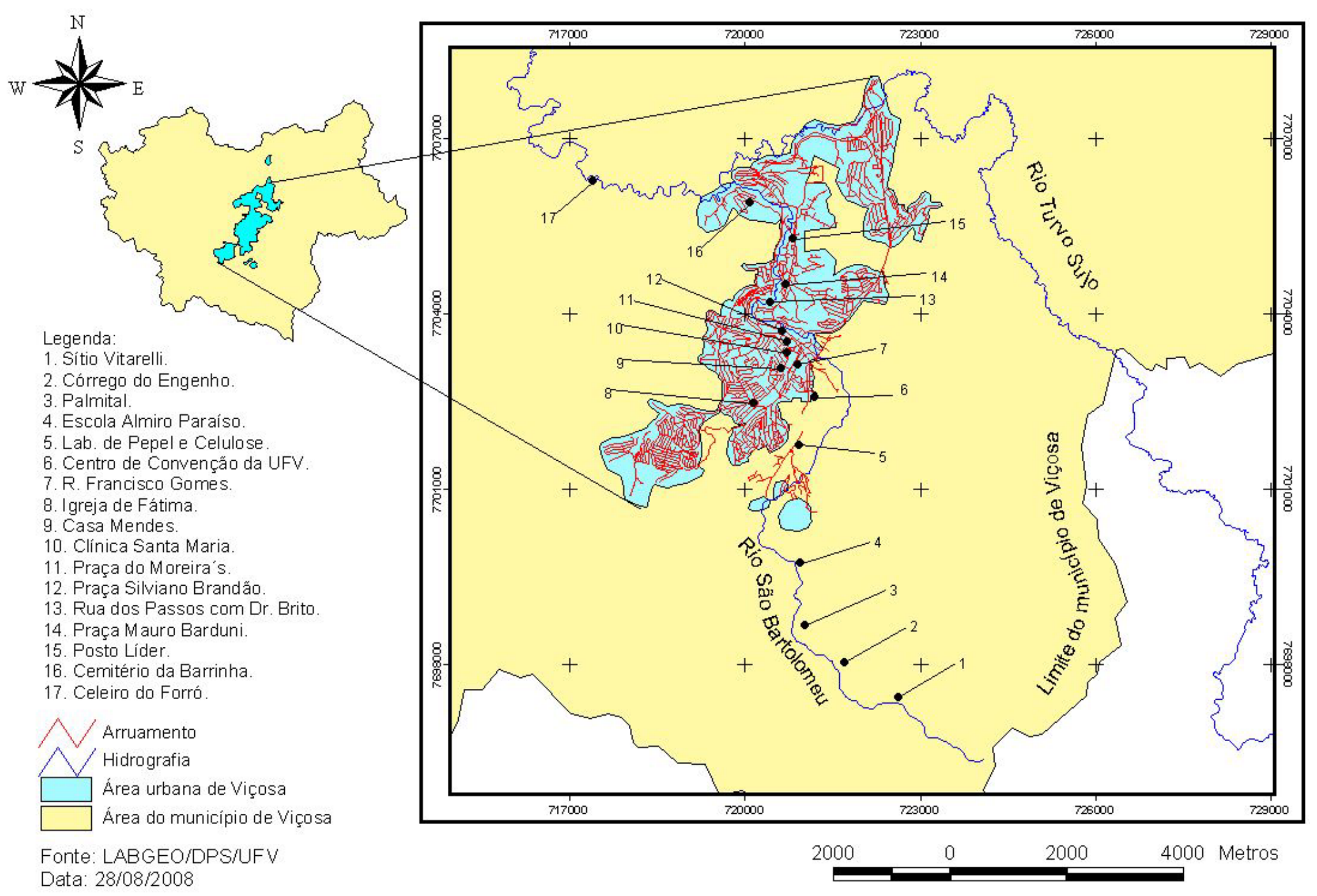

Figura 50. Localização dos pontos de medidas ao longo do transeto Paula Cândido-Porto Firme. 


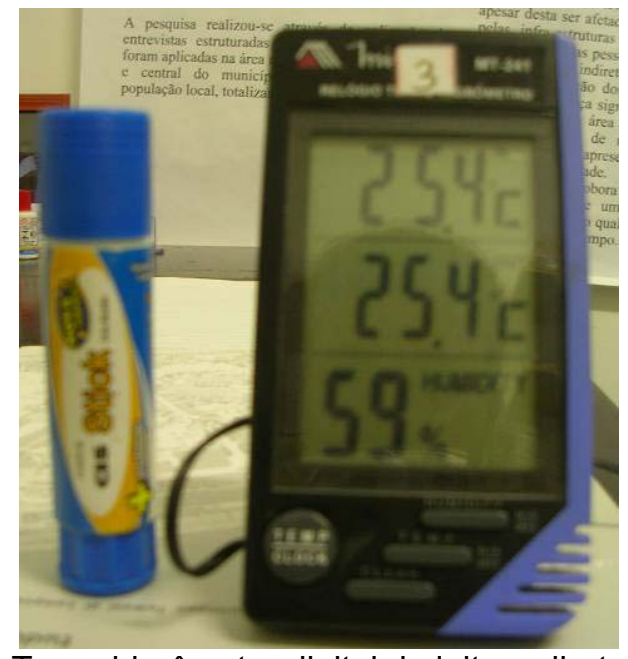

Termohigrômetro digital de leitura direta (MINIPA-MT214).

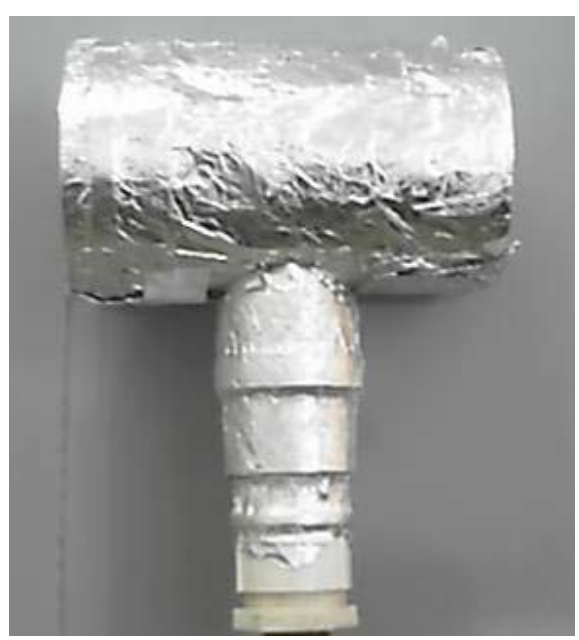

T100 x 50 para encanamento de água envolvido com papel alumínio.

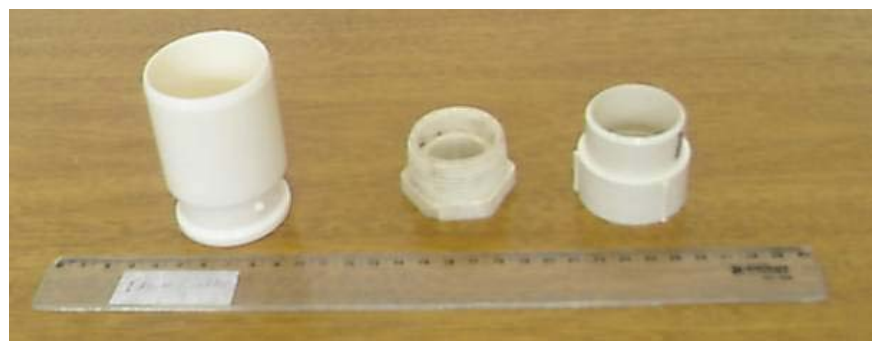

Reduções de encanamento d'agua utilizados para realizar a feitura do receptáculo termohigrométrico da esquerda para direita: Redução $50 \times 40$;

Rosca de $3 / 4$ e Redução de $11 / 4$ x 40

Figura 51. Partes do equipamento utilizado juntamente com o termohigrômetro digital

Foto: Edson Soares Fialho, obtida em Viçosa no dia 9 de abril de 2008.

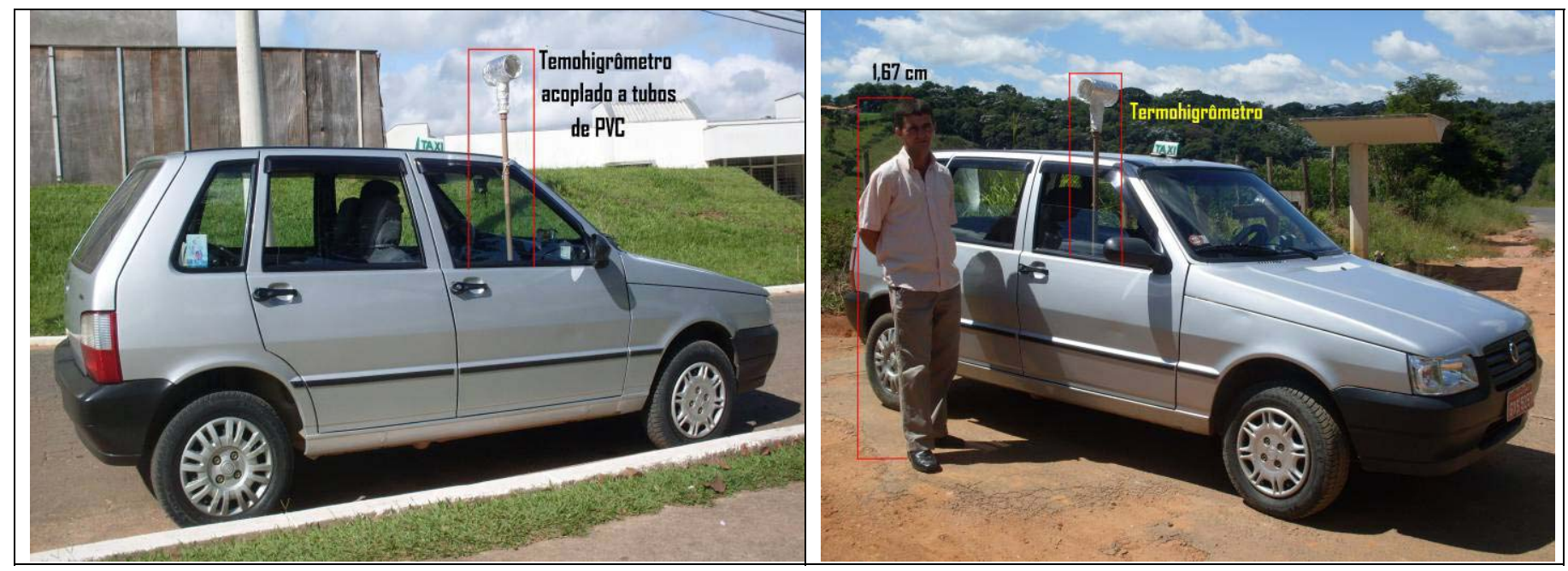

Figura 52. Veículo equipado para a realização das medidas de campo.

Foto: Edson Soares Fialho, obtida em Viçosa no dia 13 de maio de 2009. 
Tabela 15. Caracterização dos pontos de coleta do transeto campo-cidade

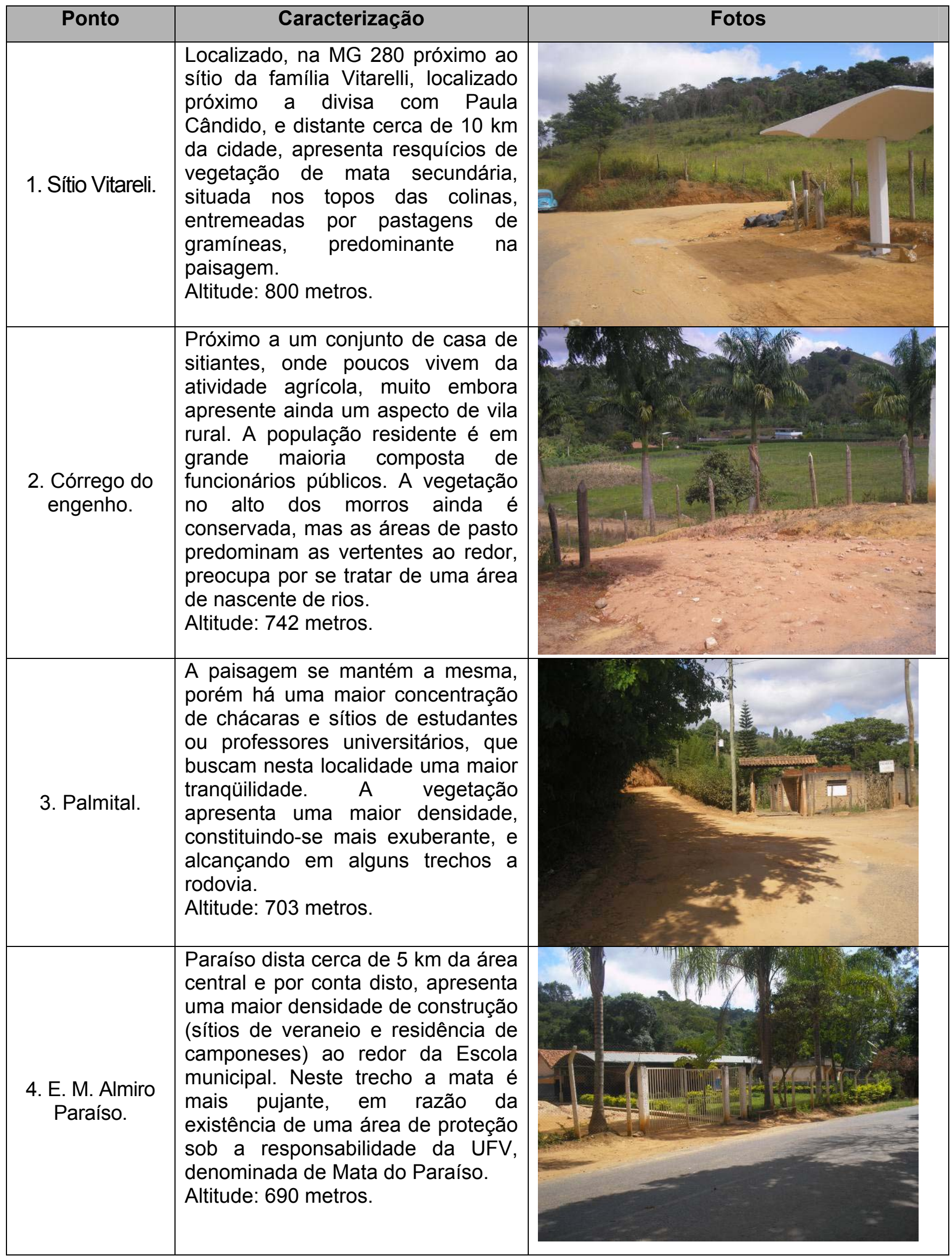


5. Laboratório de Papel e Celulose (LPC).
Localiza-se próximo a entrada do portão 2 da UFV. É cercada por um fragmento de mata, envolvendo esta localidade, que também dá acesso aos condomínios fechados próximos a UFV. Do lado direito da rodovia, se localiza uma represa ao longo do curso do rio São Bartolomeu, administrado pela companhia municipal de abastecimento água e saneamento (SAAE) da cidade.

Altitude: 670 metros.

Localiza-se no topo de morro sem vegetação (responsável pelo assoreamento do lago da UFV). Neste ponto se localiza o novo centro de convenções da UFV, em fase de finalização. Este ponto se localiza bem na faixa de transição entre uma área com baixa ocupação a alguns metros do Tiro de Guerra do Exército brasileiro, porta de entrada da cidade.

Altitude: 685 metros.

Área de edificação intensa na cidade. A rua é composta por paralelepípedos e apenas algumas árvores espaçadas de modo irregular entre si e pouco desenvolvida. O fluxo de veículos é intenso ao longo do dia, pois é um dos acessos as 4 pilastras da UFV, numa rua relativamente larga, com predomínio de prédios residenciais altas entremeados de casas e sobrados antigos.

Altitude: 680 metros.

Intenso grau de urbanização, mas diferentemente da maioria dos bairros, há presença de uma praça, que embora seja arborizada, não é capaz de amenizar o seu entorno imediato. É o local de confluência de ruas muito íngrimes, que favorecem 0 acúmulo de água durante as chuvas, causando alagamentos das casas próximas. Altitude: 665 metros.
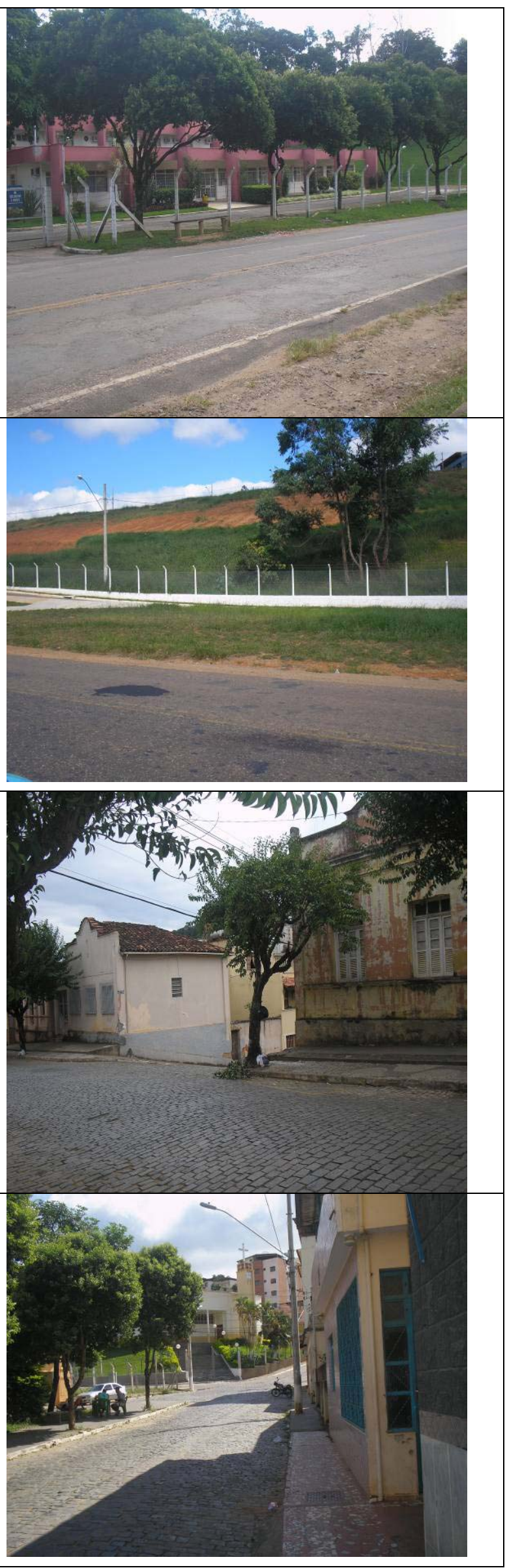


\begin{tabular}{|c|c|c|}
\hline 9. Casa Mendes. & $\begin{array}{l}\text { Localiza-se no bairro Cléa } \\
\text { Bernardes, um dos mais procurados } \\
\text { para o estabelecimento de } \\
\text { residência pelos graduandos da } \\
\text { UFV. Há uma grande concentração } \\
\text { de prédios, acima dos } 7 \text { andares, e } \\
\text { fica próximo ao centro. Ausência de } \\
\text { vegetação. A rua é composta de } \\
\text { pedras hexagonais de concreto e } \\
\text { registra um intenso fluxo de } \\
\text { veículos durante o dia e à noite, em } \\
\text { razão das } 2 \text { academias existentes. } \\
\text { Altitude: } 660 \text { metros, }\end{array}$ & (1)골 \\
\hline $\begin{array}{l}\text { 10. Clínica } \\
\text { Santa Maria. }\end{array}$ & $\begin{array}{l}\text { Localizado na periferia do bairro } \\
\text { centro, a rua Alberto Pacheco, } \\
\text { apresenta um intenso tráfego de } \\
\text { veículos e uma pequena praça } \\
\text { arborizada de frente a clínica. } \\
\text { Grande parte dos edifícios é } \\
\text { comercial com mais de } 10 \text { andares } \\
\text { e casas de alto padrão. A rua } \\
\text { embora registre uma boa } \\
\text { arborização, a mesma é inócua, em } \\
\text { razão do sombreamento dos } \\
\text { edifícios à tarde. } \\
\text { Altitude: } 660 \text { metros. }\end{array}$ & 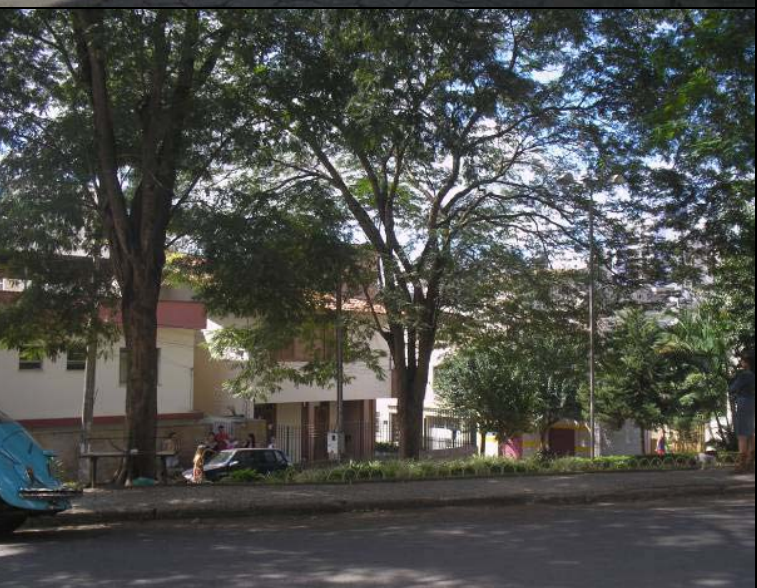 \\
\hline $\begin{array}{l}\text { 11. Praça do } \\
\text { Moreira's } \\
\text { (Mário del } \\
\text { Guidice) }\end{array}$ & $\begin{array}{l}\text { Localidade situada em ambiente } \\
\text { mais aberto, cercado por } \\
\text { edificações de baixo patamar, é } \\
\text { pouco arborizada e apresenta forte } \\
\text { incidência da luz solar. A praça tem } \\
\text { uma vegetação de gramínea } \\
\text { predominante e a inexistência de } \\
\text { árvores adultas de médioe grande } \\
\text { porte. O tráfego de veículos é } \\
\text { intenso o dia todo e registra } \\
\text { engarrafamentos freqüentes nos } \\
\text { horários de rush. } \\
\text { Altitude: } 659 \text { metros. }\end{array}$ & \\
\hline $\begin{array}{l}\text { 12. Praça } \\
\text { Silviano } \\
\text { Brandão. }\end{array}$ & $\begin{array}{l}\text { Endereço do Santuário da Santa } \\
\text { Rita de Cássia, a praça 9recoberta } \\
\text { por pedras portuguesas) é bem } \\
\text { arborizada, com presença de } \\
\text { indivíduos arbóreos semidecíduos. } \\
\text { É a localidade central da cidade. As } \\
\text { ruas do entorno são estreitas, o que } \\
\text { facilita a ocorrência de } \\
\text { congestionamento ao longo de todo } \\
\text { o dia. Além disto, a forte } \\
\text { concentração da atividade } \\
\text { comercial também favorece o } \\
\text { elevado tráfego de transeuntes. } \\
\text { Altitude: } 650 \text { metros. }\end{array}$ & 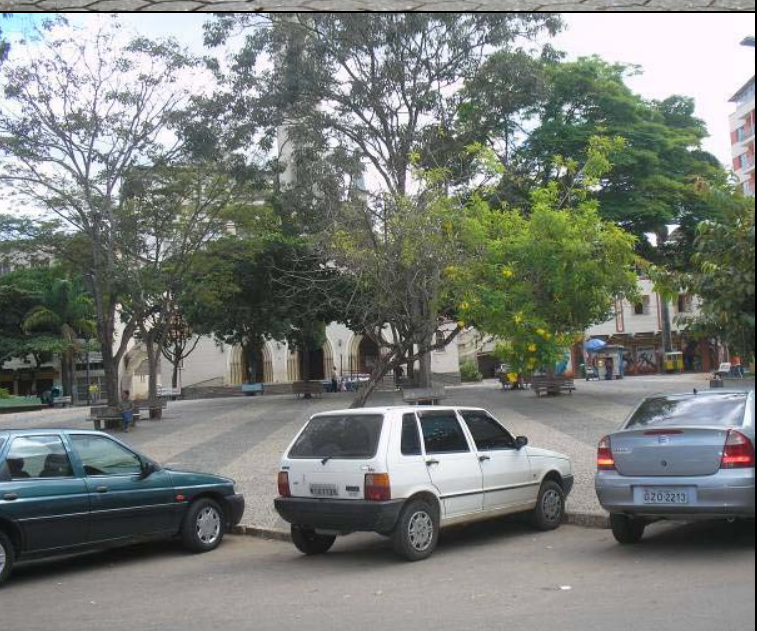 \\
\hline
\end{tabular}




\begin{tabular}{|c|c|c|}
\hline $\begin{array}{l}\text { 13. Esquina da } \\
\text { rua dos Passos } \\
\text { com Dr de Brito }\end{array}$ & $\begin{array}{l}\text { Local inicial do processo de } \\
\text { ocupação da cidade de Viçosa. As } \\
\text { edificações são compostas de } \\
\text { casas de sobrados antigos variando } \\
\text { entre } 2 \text { e } 3 \text { pavimentos. A rua é } \\
\text { estreita e de elevado tráfego de } \\
\text { caminhões, ônibus e carros de } \\
\text { passeio, o que lhe dá um aspecto } \\
\text { de engarrafamento constante. Até } \\
\text { porque liga o centro a periferia da } \\
\text { cidade (bairros: Laranjal, Amoras e } \\
\text { Vau-Açu). Não há arborização nas } \\
\text { calçadas dessa rua. } \\
\text { Altitude: } 640 \text { metros. }\end{array}$ & ${ }_{1}^{1}$ \\
\hline $\begin{array}{l}\text { 14. Entrada do } \\
\text { Julia Mollá }\end{array}$ & $\begin{array}{l}\text { O bairro Júlia Mola tem } \\
\text { características de um condomínio } \\
\text { residencial unifamiliar, entre } 2 \text { e } 3 \\
\text { pavimentos e uma densidade de } \\
\text { arborização maior. Do outro lado da } \\
\text { rua, apenas casas simples, com } 2 \\
\text { pavimentos no máximo. Próxima a } \\
\text { E. M. Alice Loureiro, registra picos } \\
\text { de transeuntes nos horários de } \\
\text { entrada e saída da Escolar. } \\
\text { Altitude: } 636 \text { metros. }\end{array}$ & 8 \\
\hline 15. Posto Líder & $\begin{array}{l}\text { Localizado nas proximidades das } \\
\text { indústrias Pif-Paf, apresenta uma } \\
\text { menor densidade de construção, } \\
\text { situada entre os bairros menor } \\
\text { intensidade de construções (Inácio } \\
\text { Martins, Laranjal, Amoras e } \\
\text { Barrinha) e maior área vegetada. } \\
\text { Apresenta casas pequenas e } \\
\text { terrenos baldios. } \\
\text { Altitude: } 635 \text { metros. }\end{array}$ & \\
\hline $\begin{array}{l}\text { 16. Cemitério } \\
\text { da Barrinha }\end{array}$ & $\begin{array}{l}\text { Vegetação arbórea de um lado da } \\
\text { rua, localizada dentro do cemitério, } \\
\text { Às margens da rodovia Viçosa- } \\
\text { Porto Firme, com pequenas } \\
\text { construções do outro lado da rua, } \\
\text { espaçado entre si. Este bairro foi } \\
\text { destinado pela prefeitura a ser o } \\
\text { distrito industrial da cidade, embora } \\
\text { ainda não tenha atraído um número } \\
\text { de empresas capaz de justificar a } \\
\text { existência do distrito. } \\
\text { Altitude: } 629 \text { metros. }\end{array}$ & (1) \\
\hline
\end{tabular}




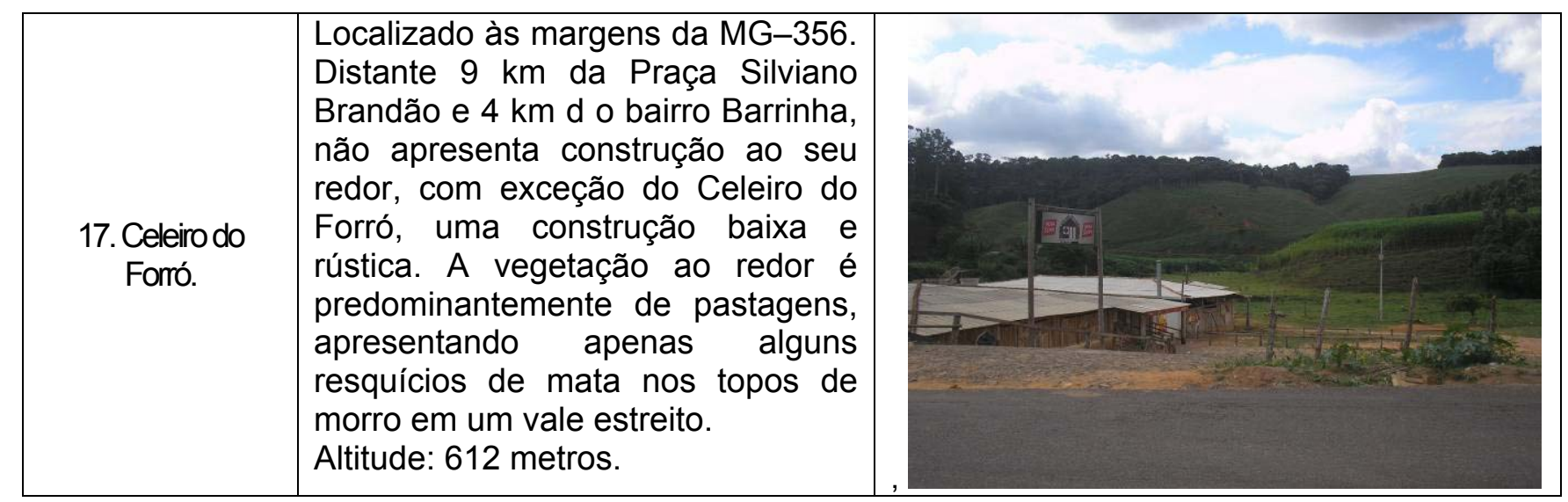

Organizado por Edson Soares Fialho, (2008).

O segundo momento se refere às medidas noturnas. A escolha em se fazer registros, logo após o pôr-do-sol até a madrugada do dia seguinte, fundamenta-se na necessidade de se verificar qual é verdadeiramente o horário de maior intensidade da ilha de calor noturna.

$\mathrm{Na}$ literatura, de modo geral, indica entre 2 a 3 horas após o crepúsculo. Por conta disso, muitos estudos realizados com base nessa premissa, definem um horário a priori em que ocorrerá a intensidade máxima. Isso para nós é um equívoco, pois cada cidade tem suas particularidades.

Quanto à rotina dos registros, o percurso foi realizado entre 6 a 9 vezes (Tabela 16) durante à noite e madrugada. Este número é mais do que o recomendado por Lomas et. al. (apud PERSSON, 1997) que seriam de 5 a 14 transetos para determinar mais fielmente as diferenças de temperatura ${ }^{16}$.

Tabela 16. Data, local e horários das mensurações noturnas em Viçosa-MG.

\begin{tabular}{|c|c|c|c|c|c|}
\hline Número & Data & $\begin{array}{c}\text { Estação do } \\
\text { ano }\end{array}$ & Pôr-do-sol & $\begin{array}{c}\text { Número de } \\
\text { transetos }\end{array}$ & $\begin{array}{c}\text { Tempo de } \\
\text { referência }\end{array}$ \\
\hline 1 & $6-7 / 5 / 2008$ & Outono & $17: 27$ & 7 & $20: 00-3: 26$ \\
\hline 2 & $7-8 / 5 / 2008$ & Outono & $17: 27$ & 7 & $19: 49-3: 10$ \\
\hline 3 & $9-10 / 5 / 2008$ & Outono & $17: 26$ & 9 & $18: 33-4: 14$ \\
\hline 4 & $12-13 / 5 / 2008$ & Outono & $17: 24$ & 9 & $20: 19-4: 02$ \\
\hline 5 & $27-28 / 8 / 2008$ & Inverno & $17: 43$ & 6 & $19: 30-2: 30$ \\
\hline 6 & $4-5 / 3 / 2009$ & Verão & $19: 18$ & 8 & $19: 30-3: 50$ \\
\hline 7 & $15-16 / 5 / 2009$ & Outono & $17: 22$ & 8 & $20: 37-3: 20$ \\
\hline
\end{tabular}

Fonte: Organizado por Edson Soares Fialho (2008).

16 Apesar do autor demonstra que o transeto para ganhar uma maior consistência deva ser repetido pelo menos 5 vezes, o mesmo não se atém a questão da escala de análise, criando uma dúvida. Por exemplo, se durante o dia, a temperatura é registra em três momentos, mas como a análise procura analisar a variação da temperatura em três momentos, as medidas devem se repetir por mais 4 dias, totalizando, 15 transetos. Apesar do autor sugerir que o transeto deva ser repetido cinco vezes, 0 mesmo não se atém à questão da escala de análise, criando uma dúvida." 


\subsection{Dentro da área urbana}

O segundo nível escalar é o meio intra-urbano. A cidade como um todo é monitorada por meio de transeto móvel. A seleção das áreas para os levantamentos de campo buscou a máxima variedade em termos de áreas diferenciadas em relação à topografia e orientação das vertentes (Figura 53) e ao uso da terra (Figura 54 e Tabela 17), totalizando 27 pontos amostrais ao longo da malha urbana de Viçosa (Tabela 18).

Os horários de coleta foram: 9:00, 15:00 e 21:00 horas para as estações de outono (7, 8, 9, 10 e 13 de maio de 2008 e 1 e 3 de março de 2009) e verão (17 e 19 de março de 2009) . O primeiro horário se explica por ser considerado o momento em que a cidade está em plena atividade, o comércio e as demais funções urbanas já estão em curso, além do sol já ter chegado às partes baixas dos vales.

O segundo horário se justifica, por ter as maiores temperaturas, muito embora as diferenças apresentadas tenham forte influência da topografia na iluminação das ruas em razão do sombreamento produzido pelas vertentes. No último horário, o comércio a as demais atividades humanas estão fechadas, restando na cidade, o pulsar do trânsito. E como já decorre pelo menos 3:00 horas do pôr-do-sol, o levantamento de campo procura confirmar ou não a evidência do calor antropogênico na definição do clima urbano de Viçosa.

Tabela 17. Tipos do uso da Terra urbana.

\begin{tabular}{|c|c|c|c|}
\hline Tipo de uso & Sigla & $\begin{array}{l}\text { Pontos } \\
\text { de coleta }\end{array}$ & Caracterização \\
\hline Zona Central & ZC & $\begin{array}{c}2,3,4,5 \\
13,14,15 \\
16 \text { e } 17\end{array}$ & $\begin{array}{l}\text { Caracteriza-se pela predominância de uso misto } \\
\text { (comercial/residencial), admitindo-se a instalação de } \\
\text { indústrias que não incomodem, com área construída } \\
\text { máxima de } 200 \mathrm{~m}^{2} \text {. O trânsito é intenso com } \\
\text { engarrafamentos freqüentes, nos horários de início e fim } \\
\text { das aulas na UFV. Os prédios em média têm } 8 \\
\text { pavimentos, com o máximo de } 14 \text {, na rua Dr. Milton } \\
\text { Bandeira. Em sua maioria, os prédios antigos não têm } \\
\text { estacionamentos, agravando o problema de } \\
\text { estacionamento na cidade. A taxa de permeabilização } \\
\text { mínima é de } 10,0 \% \text {. Área pouco arborizada. Calçadas } \\
\text { estreitas. }\end{array}$ \\
\hline Zona Residencial & ZR1 & $\begin{array}{c}6,7,11 \\
12,19,21 \\
23 \text { e } 24\end{array}$ & $\begin{array}{l}\text { Caracteriza-se pela predominância de uso residencial e } \\
\text { de adensamento controlado. Apesar de extensa, guarda } \\
\text { diferenças significativas. Os pontos } 6,7,11 \text { e } 12 \text {, s } \\
\text { localizam numa área de edificações consolidada na } \\
\text { década de } 1980 \text {, ao longo dos bairros Cléia Bernardes, } \\
\text { Ramos e Fátima. Enquanto os demais pontos, } \\
\text { principalmente, o, ponto, } 20 \text { e } 21 \text {, se apresenta em local } \\
\text { de menor taxa de ocupação (frente de expansão), nos } \\
\text { bairros de Silvestre e Vau-Açu. Admite-se a instalação de }\end{array}$ \\
\hline
\end{tabular}




\begin{tabular}{|c|c|c|c|}
\hline & & & $\begin{array}{l}\text { indústrias não-incômodas, com área construída máxima } \\
\text { de } 120 \mathrm{~m}^{2} \text {. A taxa de permeabilização é de } 10,0 \% \text {. }\end{array}$ \\
\hline Zona Residencial & ZR2 & $\begin{array}{c}8,9,10 \\
18,25 \mathrm{e} \\
26\end{array}$ & $\begin{array}{l}\text { Caracteriza-se pela predominância de uso residencial e } \\
\text { de restrição à verticalização e ao adensamento, por conta } \\
\text { da declividade do terreno e ser uma área em grande parte } \\
\text { situada em interflúvio. Apesar de ser limítrofe a área rural } \\
\text { ZR3, há loteamentos em construção por iniciativa de } \\
\text { pequenos e médios proprietários, As ruas são estreitas. } \\
\text { Muitas delas são íngremes e sem asfalto. Os bairros são } \\
\text { populares, com população de baixa renda. Admite-se a } \\
\text { instalação de indústrias não incômodas, com área } \\
\text { construída máxima de } 200 m^{2} \text {. A taxa de permeabilização } \\
\text { é de } 10,0 \% \text {. }\end{array}$ \\
\hline Zona Residencial & ZR3 & - & $\begin{array}{l}\text { Caracteriza-se por sua destinação agrária, admitindo-se a } \\
\text { realização de outras atividades, desde que compatíveis } \\
\text { com a preservação do ambiente natural e o } \\
\text { desenvolvimento das atividades agrárias. Na Zona Rural, } \\
\text { não é permitido parcelamentos para fins urbanos. De } \\
\text { maneira geral, a vegetação predominante é de pastagens } \\
\text { degradadas, com resquícios de mata nos topos de } \\
\text { morros. Os rios são de pouca vazão e a maioria é } \\
\text { assoreada e contaminada por resíduos agrícolas ou } \\
\text { urbanos. A taxa de permeabilização é de } 30,0 \% \text {. }\end{array}$ \\
\hline Zona Residencial & ZR4 & 27 & $\begin{array}{l}\text { Caracteriza-se pela predominância de uso residencial e } \\
\text { restrição à verticalização. Porém as habitações são de } \\
\text { alto padrão, diferente da ZR2. As ruas ficam vazias a } \\
\text { maior parte do tempo, pois os moradores, em sua maioria } \\
\text { têm carro e ao sair para trabalhar deixam seus imóveis } \\
\text { vazios. A população é de classe média e média alta. Não } \\
\text { se admite a instalação de indústrias e a construção de } \\
\text { mais de duas unidades por lote. A taxa de } \\
\text { permeabilização é de } 20,0 \% \text {. }\end{array}$ \\
\hline $\begin{array}{l}\text { Zona de Proteção } \\
\text { Ambiental }\end{array}$ & ZPA & - & $\begin{array}{l}\text { Caracteriza-se pela restrição ao uso e à ocupação, como } \\
\text { forma de proteção, manutenção e recuperação. Localiza- } \\
\text { se em área de mata secundária, próximo a saída da UFV, } \\
\text { próximo ao Laboratório de Papel e Celulose e a sede do } \\
\text { IEF, às margens da rodovia MG-280. Quanto aos } \\
\text { parâmetros urbanísticos: Taxa de permeabilização } \\
\text { mínima de } 95,0 \% \text {; coeficiente de aproveitamento máximo } \\
\text { de um décimo, inexistindo coeficiente de aproveitamento } \\
\text { mínimo e Taxa de ocupação de } 2,0 \% \text {. }\end{array}$ \\
\hline $\begin{array}{l}\text { Zona de Unidade } \\
\text { Federal }\end{array}$ & ZUF & 1 & $\begin{array}{l}\text { Predominância de uso institucional. Quanto à intensidade } \\
\text { do uso, esta destoa de maneira significativa da ZC } \\
\text { localizada ao lado, com prédios altos e pouca área verde. } \\
\text { No campus da UFV, há uma cobertura vegetal um pouco } \\
\text { maior do que a cidade, com bosques localizados nos } \\
\text { topos de morros (recanto das cigarras) e alguns talhões } \\
\text { na área plana (horto florestal), intercalada por jardins, } \\
\text { gramados e um lago (represamento do rio São } \\
\text { Bartolomeu). Os prédios são próximos e não ultrapassam } \\
\text { a } 5 \text { pavimentos. }\end{array}$ \\
\hline
\end{tabular}

Fonte: Plano Diretor da cidade de Viçosa. Disponível em: Acesso em 16 jun. 2009.

Organizado por Edson Soares Fialho (2009) 


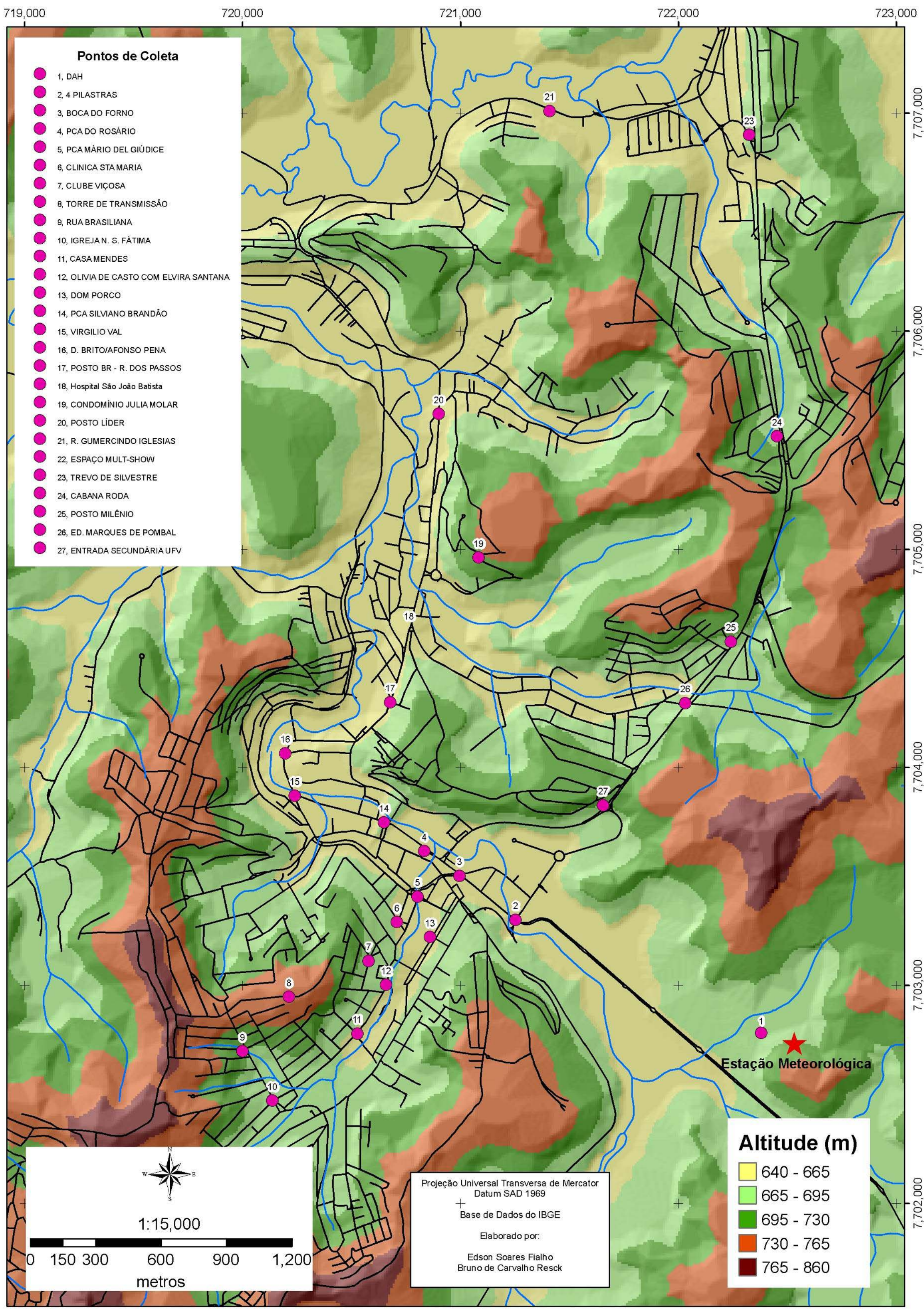

Figura 53. Localização dos pontos de medida de temperatura do ar dentro da área urbana de Viçosa-MG. 


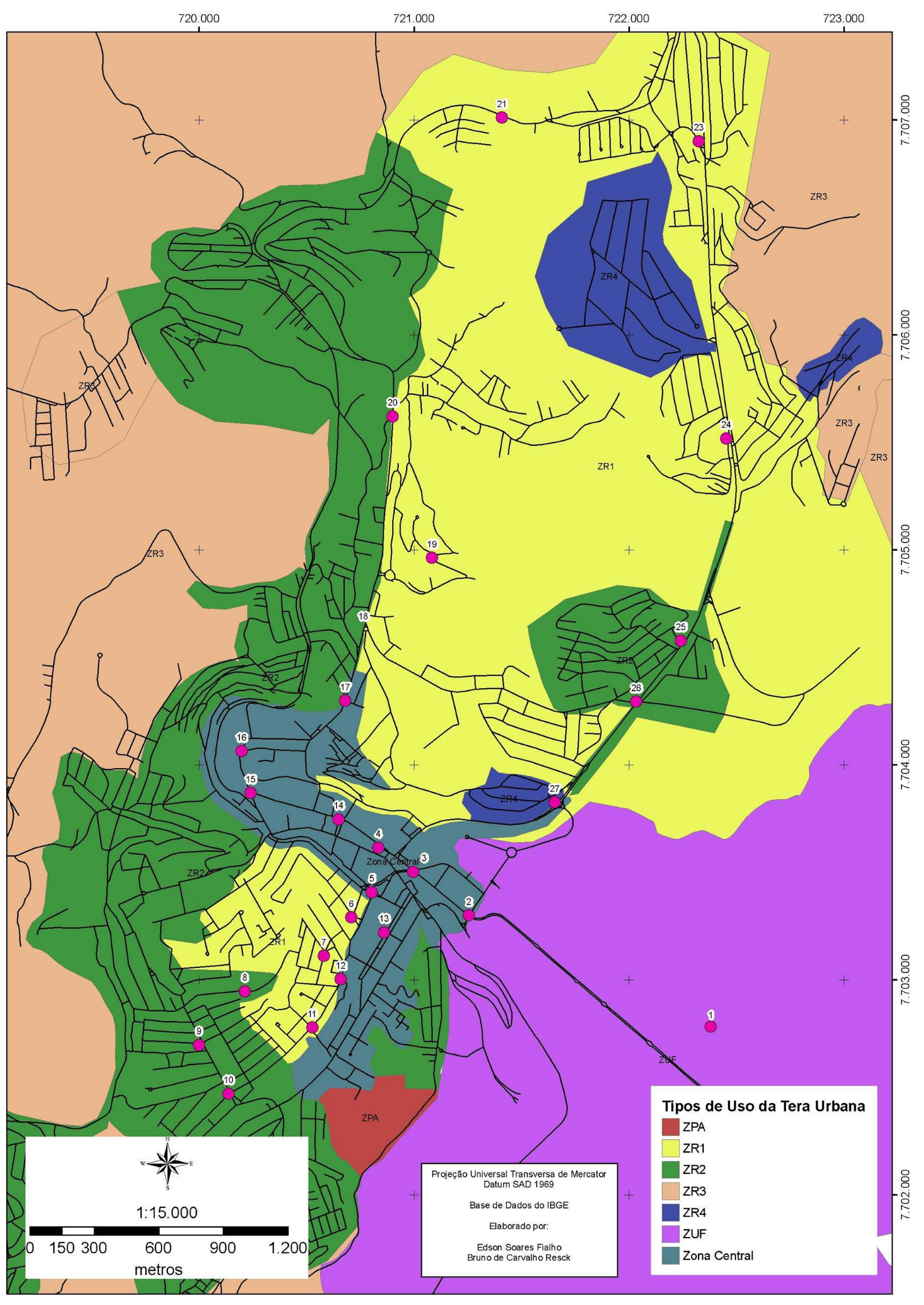

Figura 54. Unidades do Uso da Terra na área urbana do município de Viçosa. 
Tabela 18. Caracterização dos pontos de coleta do transeto campo-cidade.

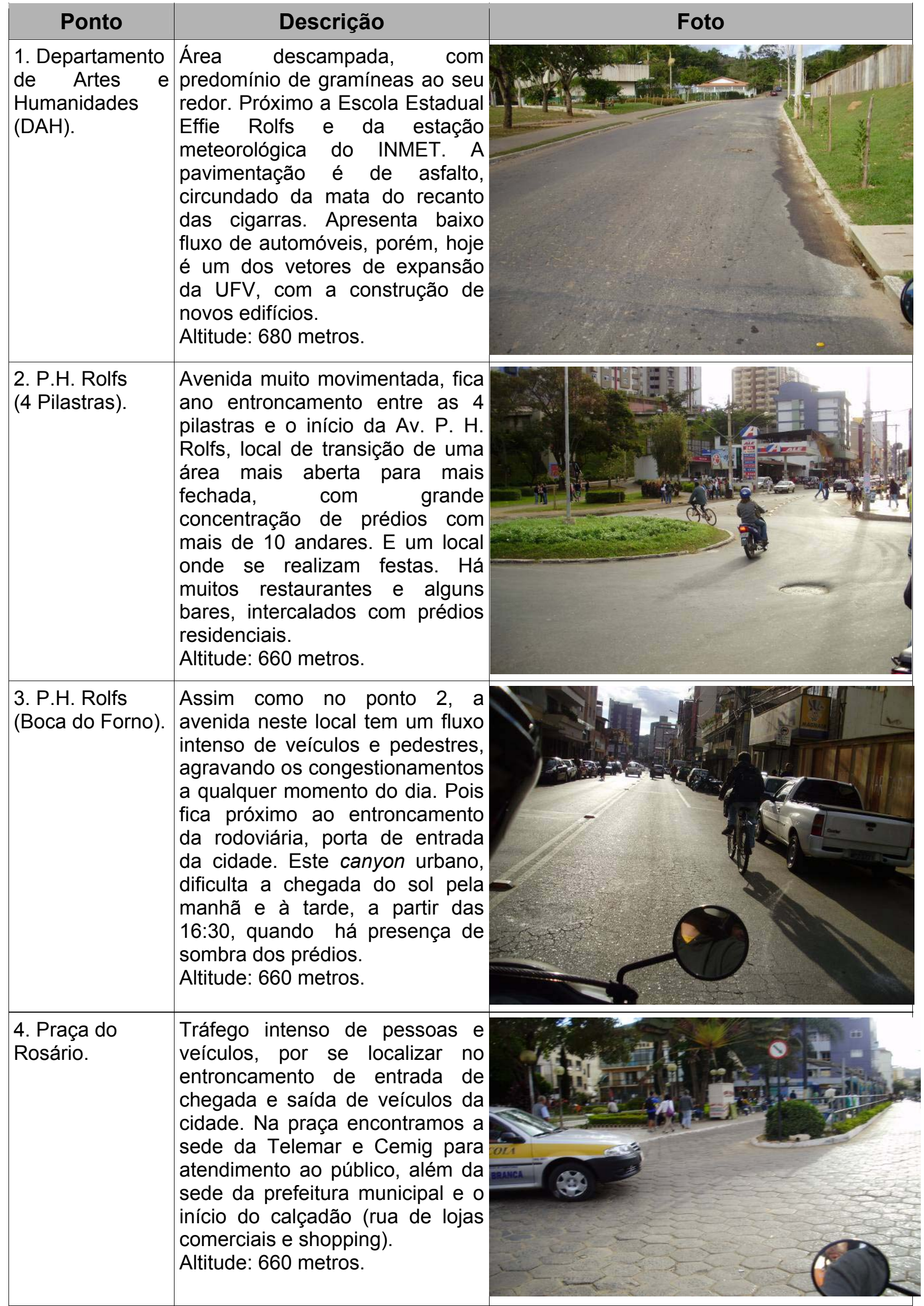




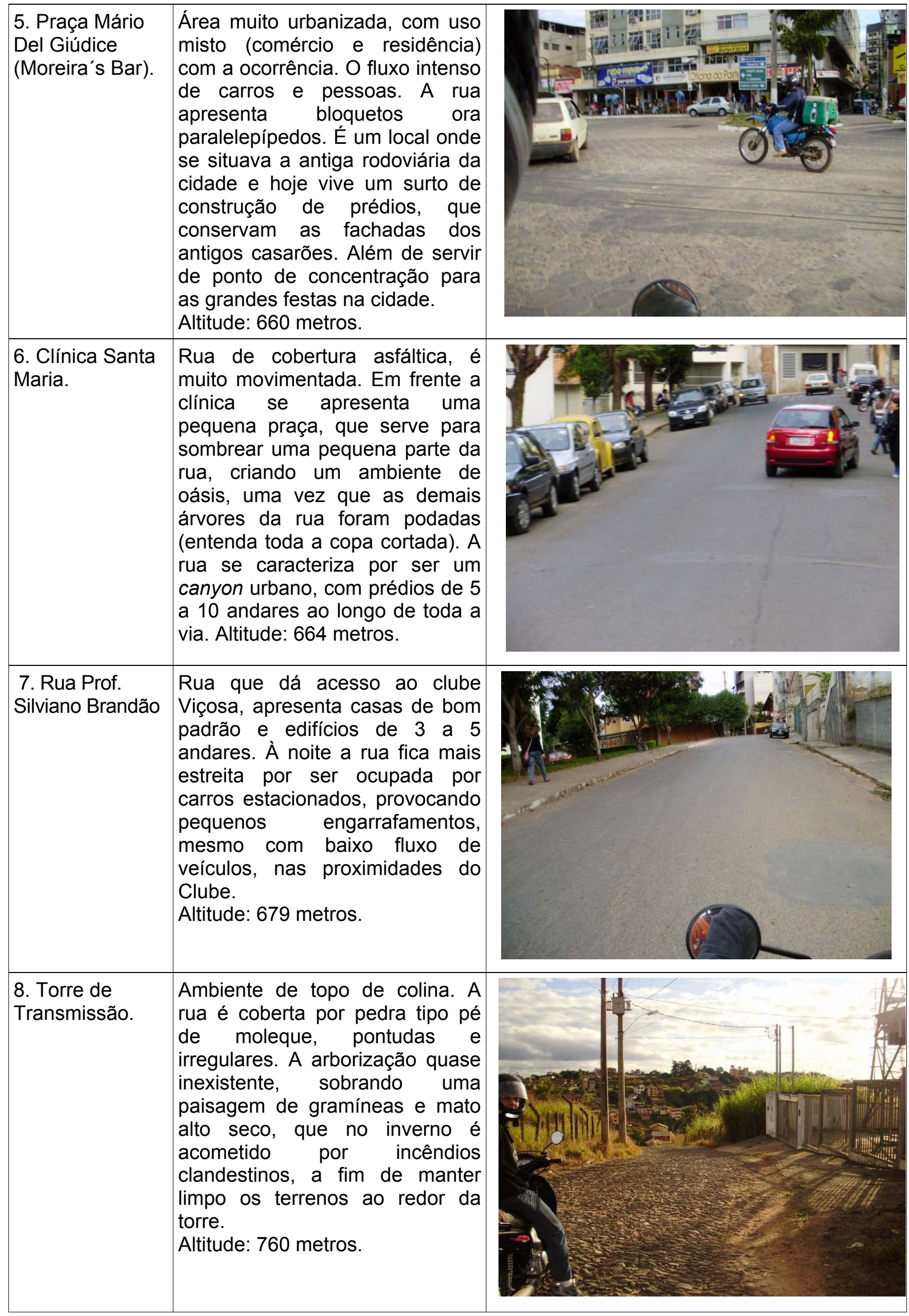




\begin{tabular}{|c|c|c|}
\hline $\begin{array}{l}\text { 9. Av. Brasília } \\
\text { com rua } \\
\text { sobradinho. }\end{array}$ & $\begin{array}{l}\text { Rua bastante íngreme, com mais } \\
\text { de } 35^{\circ} \text { de declividade, próxima a } \\
\text { divisou, é recoberta com pedra } \\
\text { de pé de moleque, com presença } \\
\text { de terrenos baldios intercalados } \\
\text { entre as habitações existentes.. } \\
\text { As suas calçadas são estreitas. } \\
\text { O Fluxo de veículos reduzido. } \\
\text { Localiza-se no bairro de Fátima, } \\
\text { com característica residencial. } \\
\text { Altitude: } 697 \text { metros. }\end{array}$ & 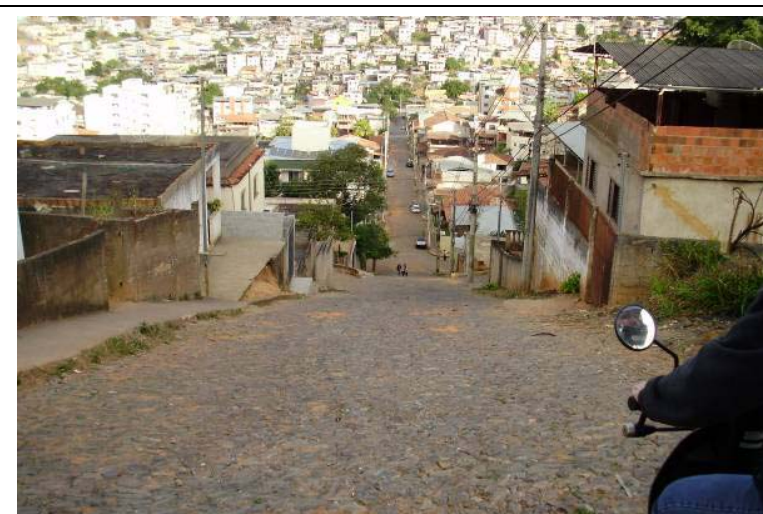 \\
\hline $\begin{array}{l}\text { 10. Igreja Nossa } \\
\text { Senhora de } \\
\text { Fátima. }\end{array}$ & $\begin{array}{l}\text { Muito urbanizado, e com } \\
\text { presença de uma praça, algo } \\
\text { muito difícil de encontrar na } \\
\text { cidade. Mesmo assim, é pequena } \\
\text { e suas árvores apenas criam um } \\
\text { sombreamento para dentro da } \\
\text { praça. O local é de confluência } \\
\text { de outras ruas muito íngremes, o } \\
\text { que favorece o acúmulo de água } \\
\text { durante o período de fortes } \\
\text { chuvas, a partir do escoamento } \\
\text { rápido da água pelas vertentes. } \\
\text { Altitude: } 665 \text { metros. }\end{array}$ & \\
\hline $\begin{array}{l}\text { 11. Casa } \\
\text { Mendes. }\end{array}$ & 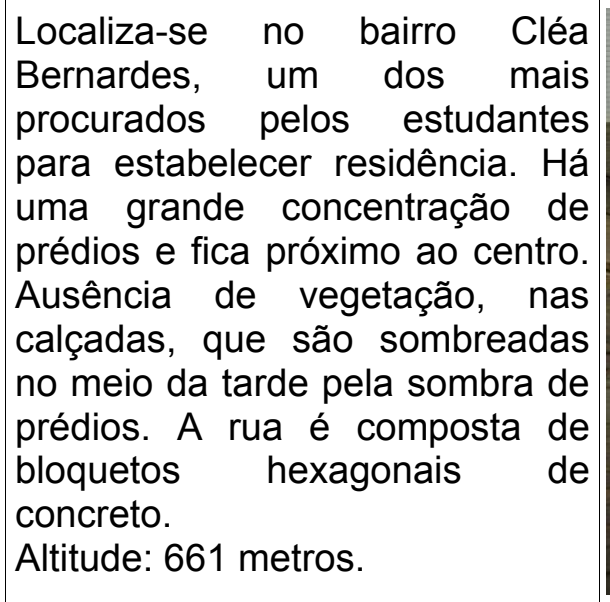 & \\
\hline $\begin{array}{l}\text { 12. Rua Olívia } \\
\text { de Castro com } \\
\text { Elvira Santana. }\end{array}$ & $\begin{array}{l}\text { Área residencial, com algumas } \\
\text { edificações verticais, calçamento } \\
\text { de bloquetes. Intenso fluxo de } \\
\text { veículos durante à tarde, por se } \\
\text { localizar próximo a academias de } \\
\text { ginástica e do Clube Viçosa, que } \\
\text { tem seu fluxo mais forte após o } \\
\text { final das aulas na UFV. } \\
\text { Altitude: } 660 \text { metros. }\end{array}$ & \\
\hline
\end{tabular}




\begin{tabular}{|c|c|c|}
\hline $\begin{array}{l}\text { 13. Av. Sana } \\
\text { Rita (Dom } \\
\text { Porco). }\end{array}$ & $\begin{array}{l}\text { Uma das principais vias de } \\
\text { circulação da cidade. Serve de } \\
\text { ligação entre os bairros de São } \\
\text { José, Bom Jesus, Fátima, Cléia } \\
\text { Bernardes até o centro. O fluxo e } \\
\text { carros e transeuntes é intenso. A } \\
\text { pavimentação é de bloquetos e } \\
\text { diferentemente das demais vias, } \\
\text { esta é a mais larga, com duas } \\
\text { pistas de rolamento. Porém isto } \\
\text { não impede congestionamento } \\
\text { no horário do rush, por conta dos } \\
\text { bares que ocupam as calçadas. } \\
\text { Altitude: } 660 \text { metros. }\end{array}$ & 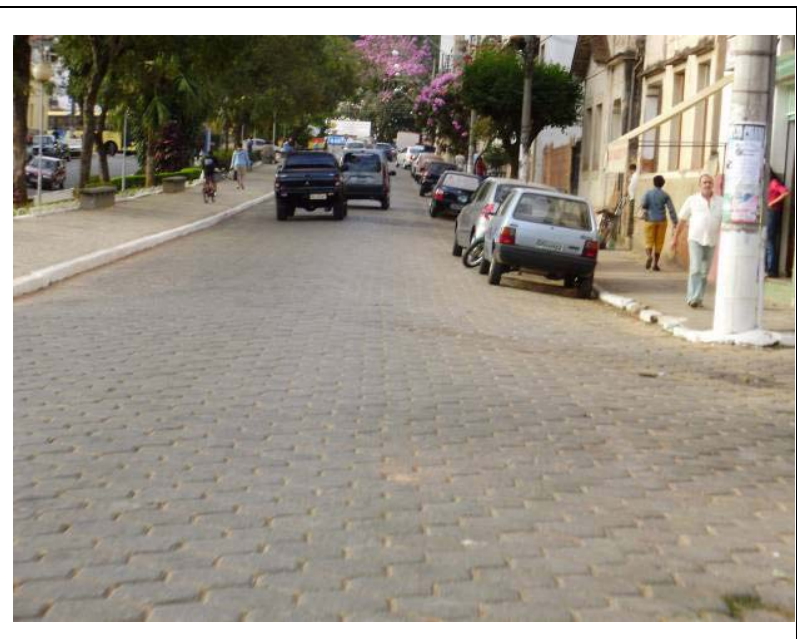 \\
\hline $\begin{array}{l}\text { 14. Praça } \\
\text { Silviano } \\
\text { Brandão. }\end{array}$ & 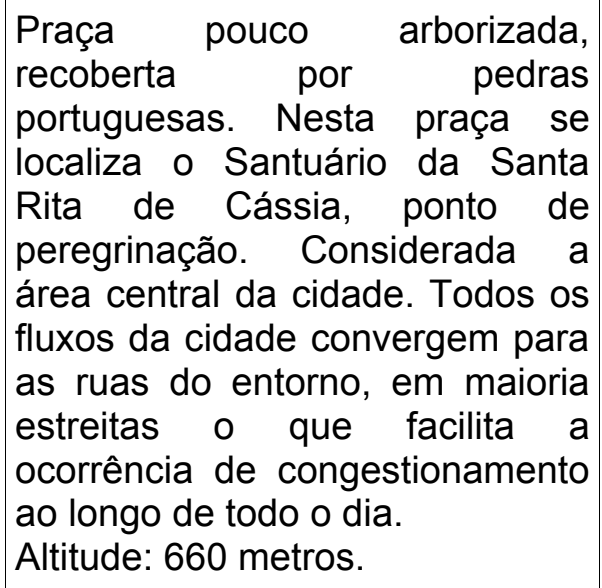 & 9) \\
\hline $\begin{array}{l}\text { 15. Rua Virgilio } \\
\text { Val com Tenente } \\
\text { Kümmel. }\end{array}$ & $\begin{array}{l}\text { Esquina movimentada durante os } \\
\text { horários de entrada e saída de } \\
\text { alunos das Escolas do Carmo e } \\
\text { Gênesis. Tem características de } \\
\text { uso residencial, mas ao longo da } \\
\text { rua ainda se encontra um } \\
\text { estacionamento e r um } \\
\text { supermercado de porte médio } \\
\text { (Amantino), próximo a Praça } \\
\text { Silviano Brandão. } \\
\text { Altitude: } 646 \text { metros }\end{array}$ & 5 \\
\hline $\begin{array}{l}\text { 16. Rua Dr. Brito } \\
\text { com Afonso } \\
\text { Pena. }\end{array}$ & $\begin{array}{l}\text { Área limítrofe entre os bairros } \\
\text { centro e os bairros periféricos } \\
\text { (Laranjal e São Sebastião). Fluxo } \\
\text { de veículos intenso no período } \\
\text { diurno, sendo inexistente à noite. } \\
\text { O local já apresenta construção } \\
\text { de edifícios intercalados por } \\
\text { casas e sem arborização. } \\
\text { Altitude: } 650 \text { metros }\end{array}$ & rit \\
\hline
\end{tabular}




\begin{tabular}{|c|c|}
\hline $\begin{array}{l}\text { 17. Rua dos } \\
\text { Passos - Posto } \\
\text { BR. }\end{array}$ & $\begin{array}{l}\text { Rua com características de uso } \\
\text { misto (comercial/residencial). } \\
\text { Próximo ao Hospital São João } \\
\text { Batista. É de tráfego intenso de } \\
\text { caminhões } \\
\text { estacionamento e e calçadas } \\
\text { adequadas, o que cria um } \\
\text { ambiente } 4 \text { confuso } \\
\text { desorganizado. O trânsito por } \\
\text { sua vez fica lento o dia todo e o } \\
\text { ar fica mais pesado com a maior } \\
\text { concentração de gases na rua. } \\
\text { Altitude: } 660 \text { metros. }\end{array}$ \\
\hline $\begin{array}{l}\text { 18. Rua dos } \\
\text { Passos com } \\
\text { Hospital São } \\
\text { Sebastião. }\end{array}$ & $\begin{array}{l}\text { Situado em frente a um } \\
\text { entroncamento entre a rua dos } \\
\text { passos e a Av. Brasil. O local } \\
\text { apresenta forte tráfego de carros } \\
\text { e caminhões, apesar de ser uma } \\
\text { área residencial, em ruas estritas } \\
\text { de paralelepípedos, que logo em } \\
\text { seguida dá acesso a indústria } \\
\text { PIF-PAF frios e congelados. A } \\
\text { pavimentação da rua é de } \\
\text { bloquetos. } \\
\text { Altitude: } 650 \text { metros. }\end{array}$ \\
\hline $\begin{array}{l}\text { 19. Condomínio } \\
\text { Julia Mollá. }\end{array}$ & $\begin{array}{l}\text { O bairro Júlia Mola tem } \\
\text { características de um condomínio } \\
\text { residencial unifamiliar, porém } \\
\text { algumas casas são alugadas } \\
\text { para a criação de repúblicas. } \\
\text { Localiza-se em uma micro-bacia, } \\
\text { o bairro tem muitos terrenos } \\
\text { vazios ainda, com muito pasto } \\
\text { entre casas situadas próximas ao } \\
\text { divisor, que dá vista pra o bairro } \\
\text { Santo Antônio. } \\
\text { Altitude: } 721 \text { metros. }\end{array}$ \\
\hline $\begin{array}{l}\text { 20. Av. Jacob } \\
\text { Lopes - Posto } \\
\text { Líder. }\end{array}$ & $\begin{array}{l}\text { Ponto de entroncamento que dá } \\
\text { acesso a MG } 356 \text { em direção } \\
\text { Porto Firme e próximo a indústria } \\
\text { PIF-PAF. O tráfego de veículos é } \\
\text { moderado, porém predomina o } \\
\text { trânsito de ônibus e caminhões. } \\
\text { Os moradores locais utilizam } \\
\text { mais a bicicleta. Quanto as } \\
\text { construções estas são mais } \\
\text { intercaladas com existência de } \\
\text { vegetação exuberante em alguns } \\
\text { morros. } \\
\text { Altitude: } 652 \text { metros. }\end{array}$ \\
\hline
\end{tabular}




\begin{tabular}{|c|c|c|}
\hline $\begin{array}{l}\text { 21. Rua } \\
\text { Gumercindo } \\
\text { Iglesias. }\end{array}$ & $\begin{array}{l}\text { Avenida recém asfaltada interliga } \\
\text { o bairro do Vau-Açu com } \\
\text { Silvestre. Ainda há poucas casas } \\
\text { e apresenta características } \\
\text { rurais. Poucas construções, } \\
\text { predominando a cobertura de } \\
\text { pastagem. O acesso é difícil por } \\
\text { não ter muitos horários de } \\
\text { ônibus, atendendo a população } \\
\text { local, que já vive com a } \\
\text { especulação do preço dos } \\
\text { terrenos. } \\
\text { Altitude: } 640 \text { metros. }\end{array}$ & 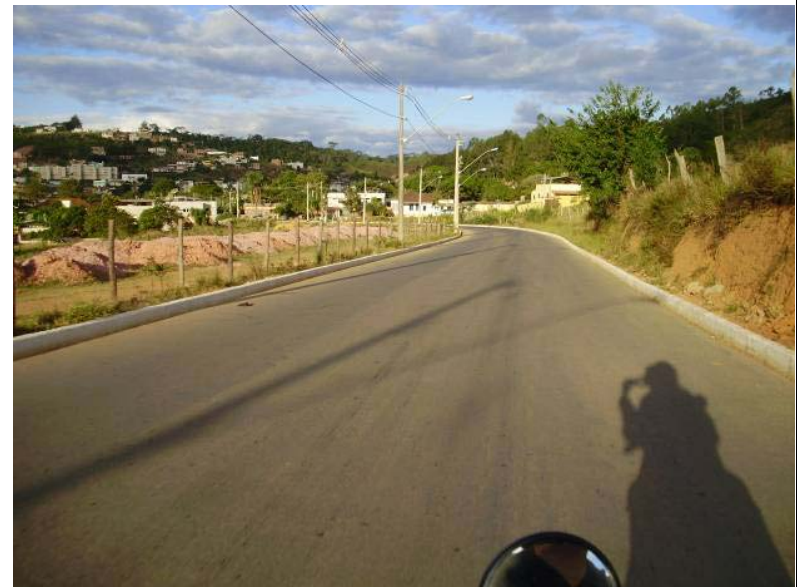 \\
\hline $\begin{array}{l}\text { 22. Espaço } \\
\text { multishow. }\end{array}$ & $\begin{array}{l}\text { Área relativamente afastada da } \\
\text { área central da cidade. Próximo } \\
\text { ao clube recanto das águas e ao } \\
\text { trevo de Silvestre, local da antiga } \\
\text { estação ferroviária. Registra } \\
\text { movimento intenso, quando da } \\
\text { realização de eventos de música, } \\
\text { geralmente, à noite. A vegetação } \\
\text { predominante é de pastagens. } \\
\text { Altitude: } 658 \text { metros. }\end{array}$ & A \\
\hline $\begin{array}{l}\text { 23. BR-120 } \\
\text { Trevo de } \\
\text { silvestre. }\end{array}$ & $\begin{array}{l}\text { Via de acesso para a cidade de } \\
\text { Viçosa, BR-120, na altura do } \\
\text { trevo é limite entre os bairros de } \\
\text { silvestre e inconfidência, locais } \\
\text { de forte crescimento com a } \\
\text { construção da FDV e Univiçosa, } \\
\text { às margens da rodovia., } \\
\text { propiciando a recém conectado à } \\
\text { mancha urbana da cidade, que } \\
\text { antes não alcançava o bairro do } \\
\text { João Braz. } \\
\text { Altitude: } 672 \text { metros. }\end{array}$ & is \\
\hline $\begin{array}{l}\text { 24. BR-120 } \\
\text { Cabana Roda. }\end{array}$ & $\begin{array}{l}\text { Local conhecido antigamente } \\
\text { como buraco frio, hoje a cabana } \\
\text { não é mais sozinha, apresenta } \\
\text { uma vizinhança de prédios e } \\
\text { casas, que ocupam as margens } \\
\text { da rodovia e as vertentes } \\
\text { íngremes dos morros dos bairros, } \\
\text { que não tem uma rede de coleta } \\
\text { de água de chuva eficiente, } \\
\text { agravando a vazão da água no } \\
\text { meio fio } \\
\text { Altitude: } 679 \text { metros. }\end{array}$ & 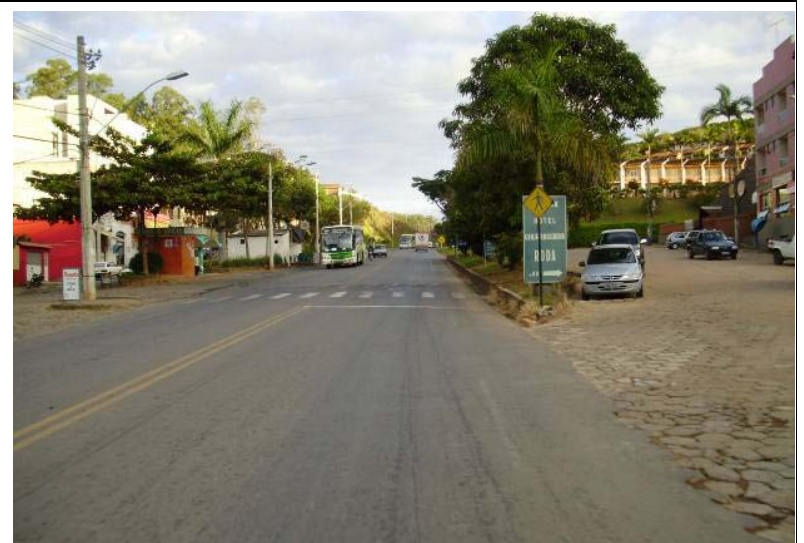 \\
\hline
\end{tabular}




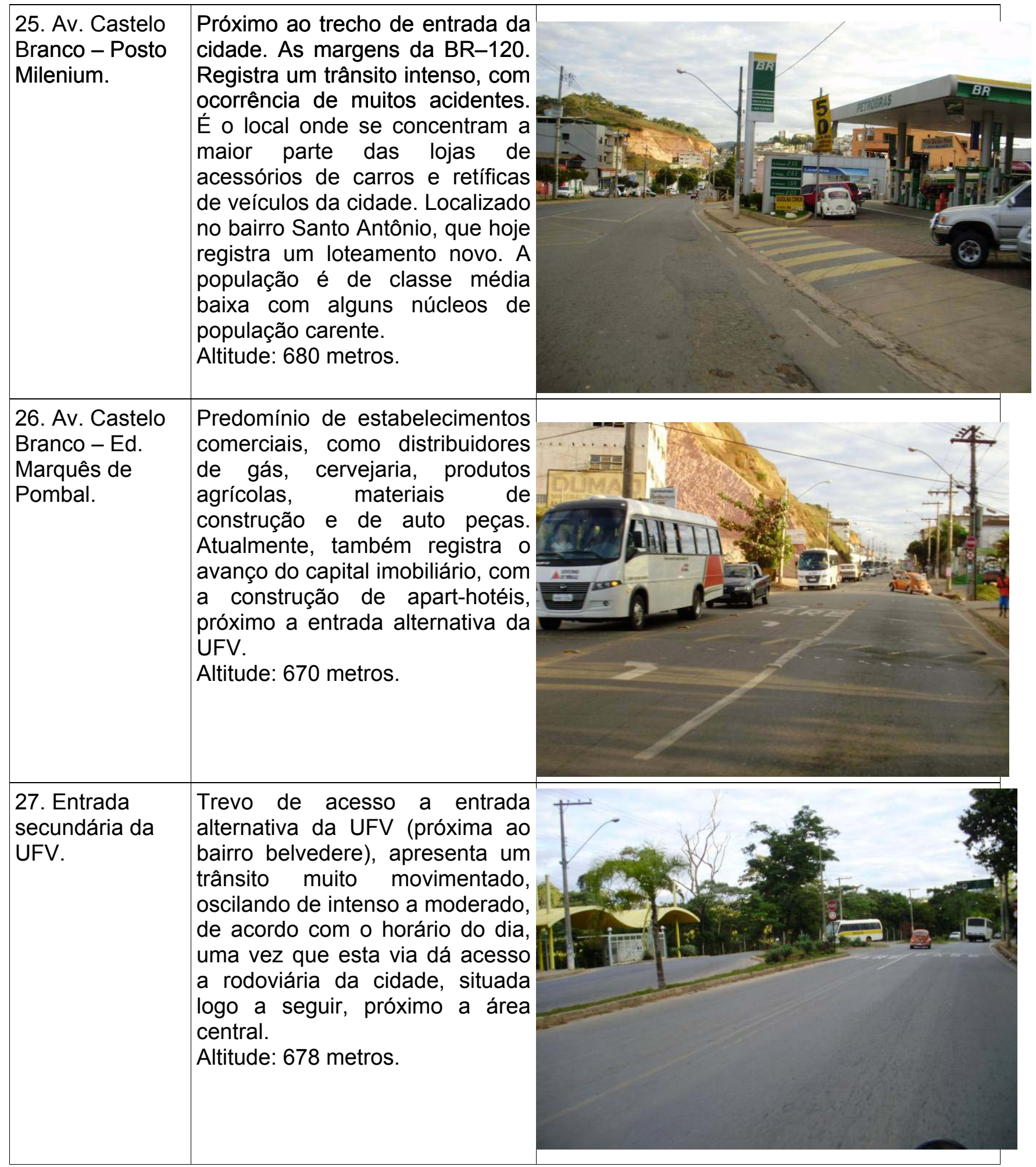

Organizado por Edson Soares Fialho (2008), 


\subsection{Dentro da área central da cidade}

O terceiro nível escalar compreende o núcleo central da área urbana. Em razão das especificidades da área de estudo, no domínio de mar de morros, a trajetória do sol, dependendo do horário do dia, pode estar sob efeito de sombras.

A escolha dos horários e dos pontos respeitou tal influência, tanto assim, que as medida foram determinadas para as 5:00 horas da manhã, 12:00 horas e 19:00 horas, momentos em que o sombreamento parcial da superfície não está influenciando nos registros de temperatura do ar.

Além da influência do sítio, os horários estipulados para a realização das leituras são de grande fluxo de veículos, o que ocasiona algumas retenções, agravadas pelo fato da cidade não apresentar a existência de um sinal de trânsito, um orgulho para os citadinos, que acreditam que Viçosa, ainda é uma cidade pacata, como no final da década de 1970, quando a cidade ainda tinha uma vida tranqüila. Por conta disto, optou-se em utilizar uma bicicleta como instrumento multiplicador de pontos de coleta, o mesmo equipamento, utilizado nos transetos móveis (Figura 55) assim como utilizado por Melhuish e Pedder (1996), para a cidade de Reading no Canadá.

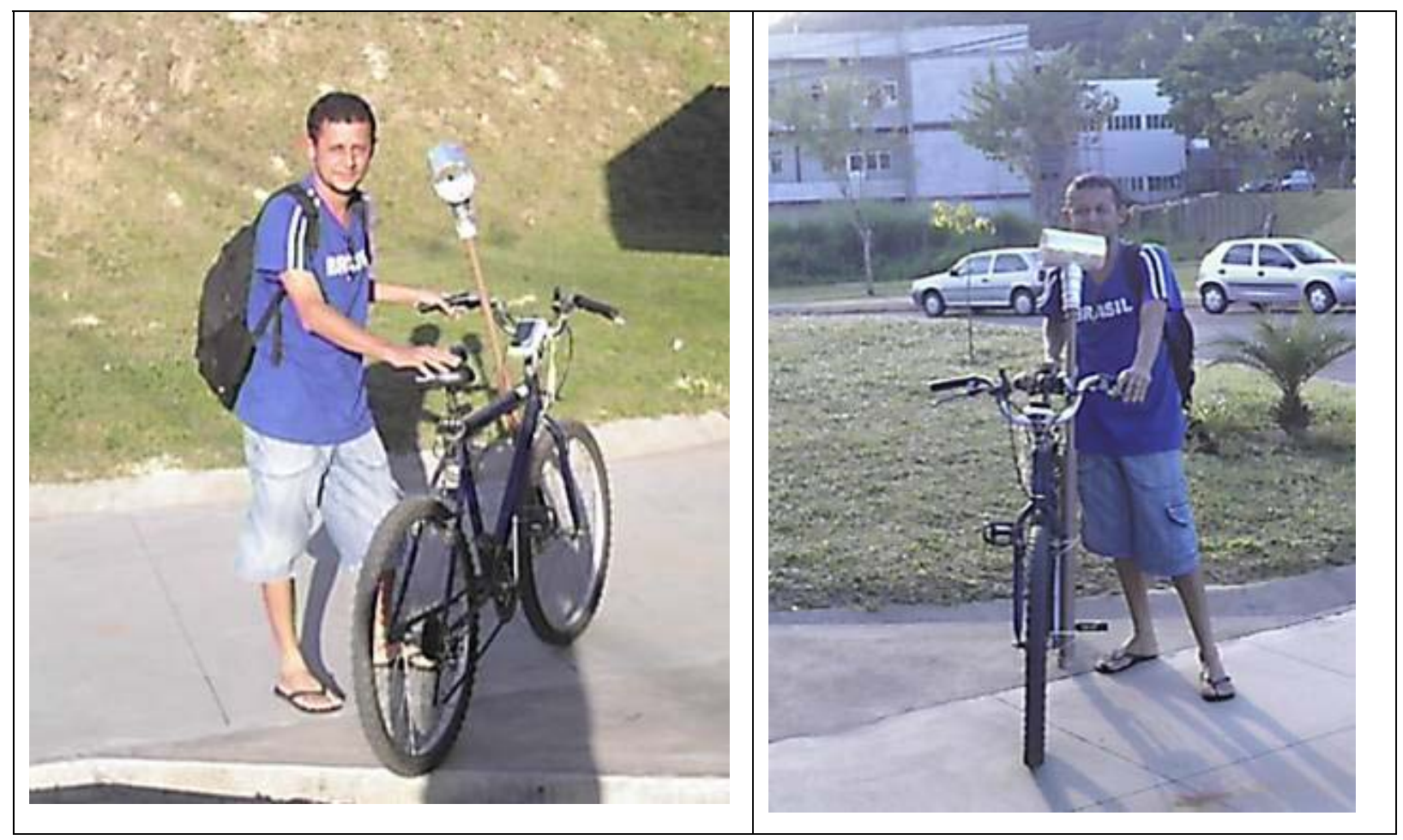

Figura 55. Equipamento de monitoramento de campo, acoplado a uma bicicleta.

Foto: Edson Soares Fialho, obtida em 8 de maio de 2007. 
O equipamento utilizado é o mesmo que foi utilizado nos transetos móveis campo-cidade e intra-urbano, para o outono (4, 5, 6 e 7 de maio de 2007); inverno (6, 7, 9313 de setembro de 2008) e verão (7 e 8 de março de 2009), registrou-se a temperatura do ar e da umidade relativa em 20 pontos, conforme a Figura 56 e Tabela 19.

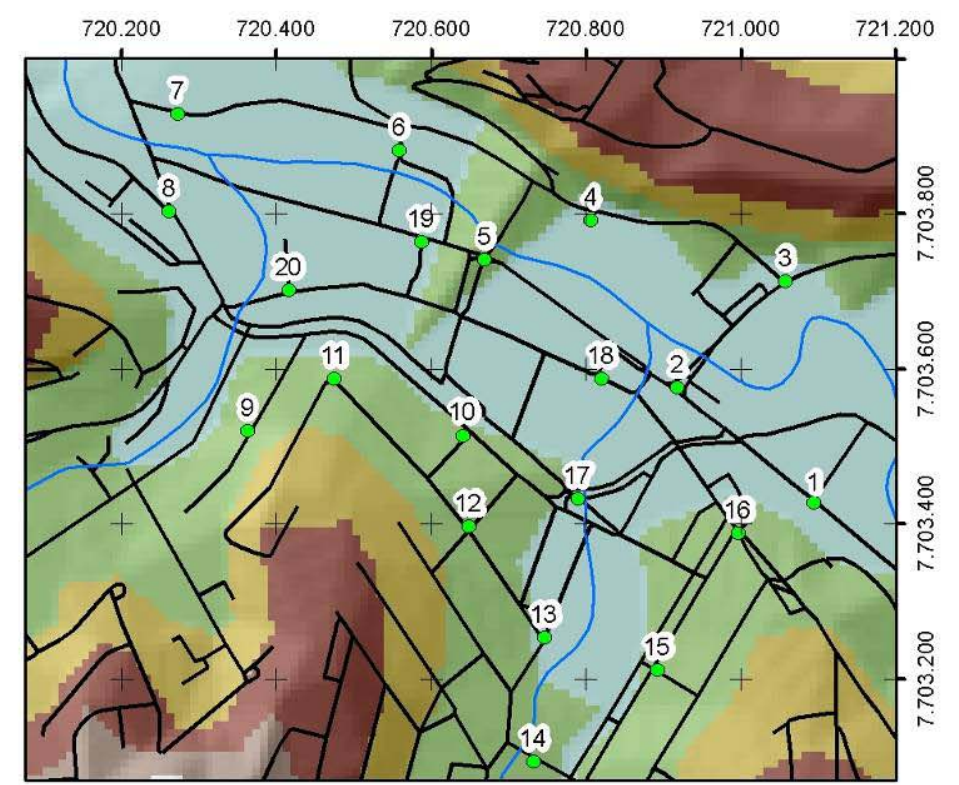

\section{Pontos de Coleta}

- 1, Av. PH Rolfs

- 2, Av. Marechal Castelo Branco/Av. PH Rolfs

- 3, Av. Marechal Castelo Branco/Rua Milton Bandeira

- 4, Rua Milton Bandeira

- 5, Pca Silviano Brandão

- 6, Rua Dona Gertrudes/Rua dos Passos

- 7, Rua Dona Gertrudes

- 8, Rua Tenente Kummel

- 9, Rua Floriano Peixoto

- 10, Av. Bueno Brandão

- 11, Rua Professor Alberto Pacheco

- 12, Rua Prof. Alberto Pacheco/Rua Silviano Romeu

- 13, Rua Prof. Alberto Pacheco/Rua Francisco Machado

- 14, Travessa Prudue

- 15, Av. Santa Rita

- 16, Rua Padre Serfim

- 17, Pca Mário Del Giudice

- 18, Pca do Rosário

- 19, Rua Artur Bernardes

- 20, Rua Benjamim Araújo

Figura 56. Localização dos pontos de coleta de temperatura na área central de Viçosa. 
Tabela 19. Caracterização dos pontos de coleta dos pontos na área central de Viçosa-MG.

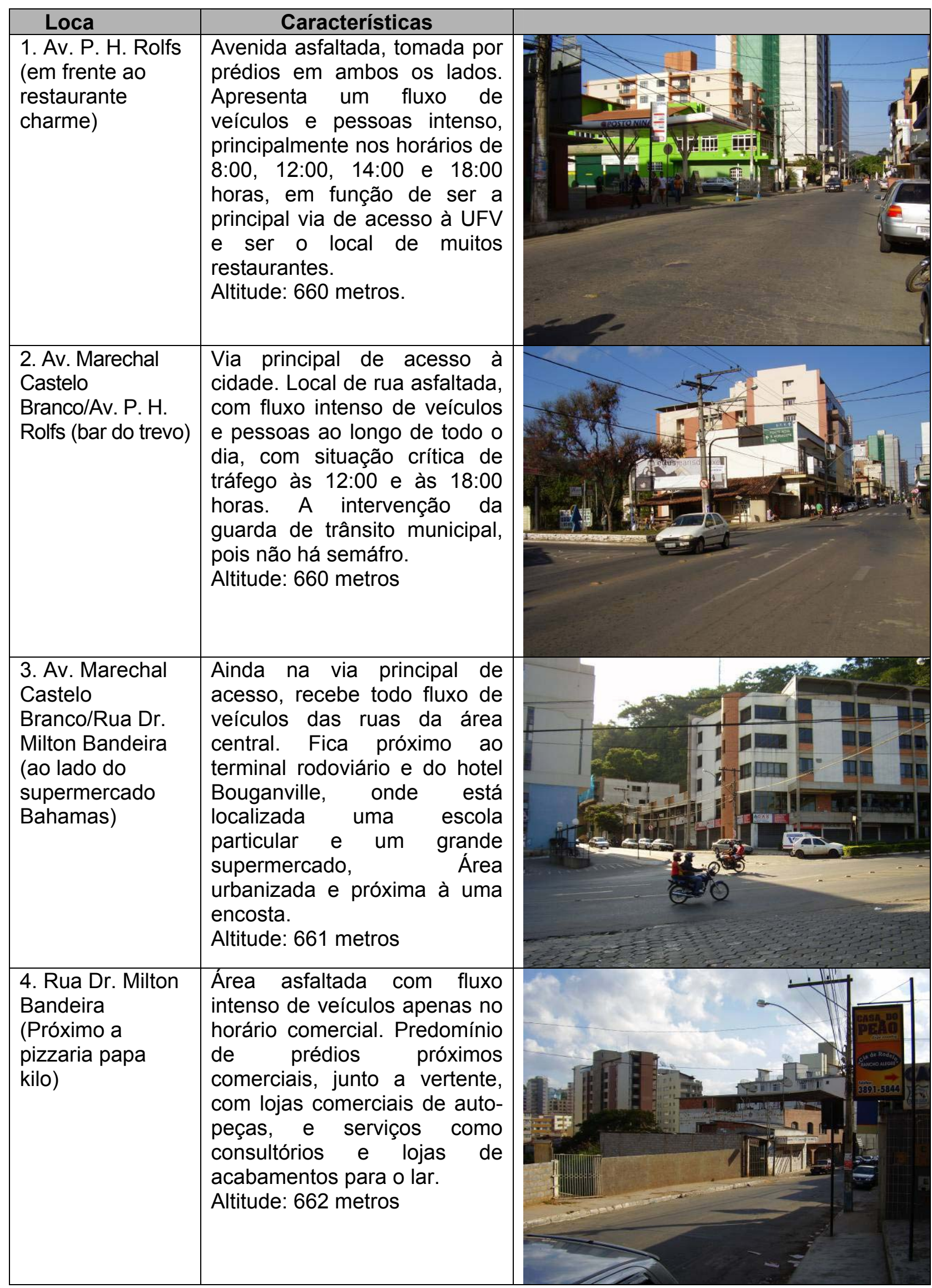




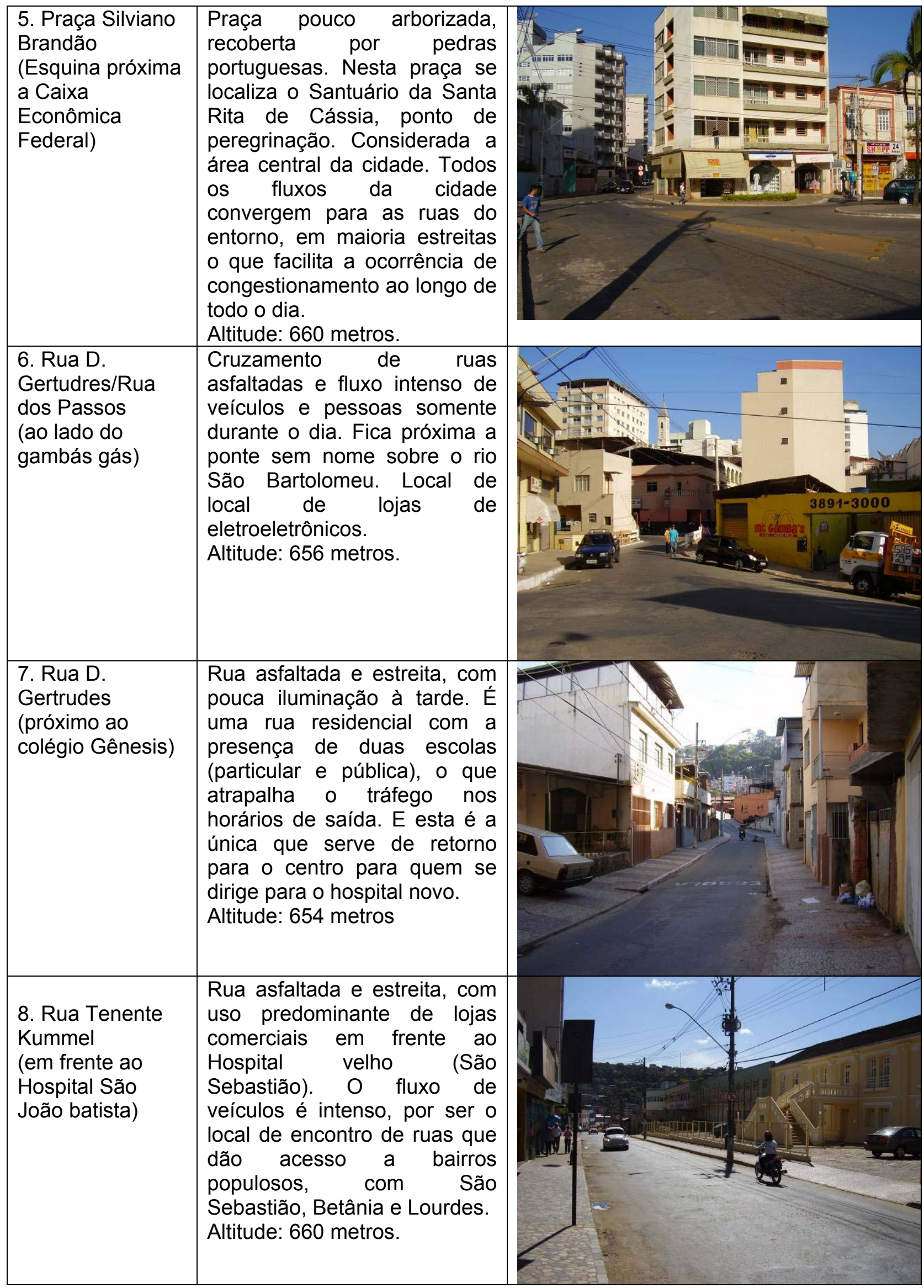




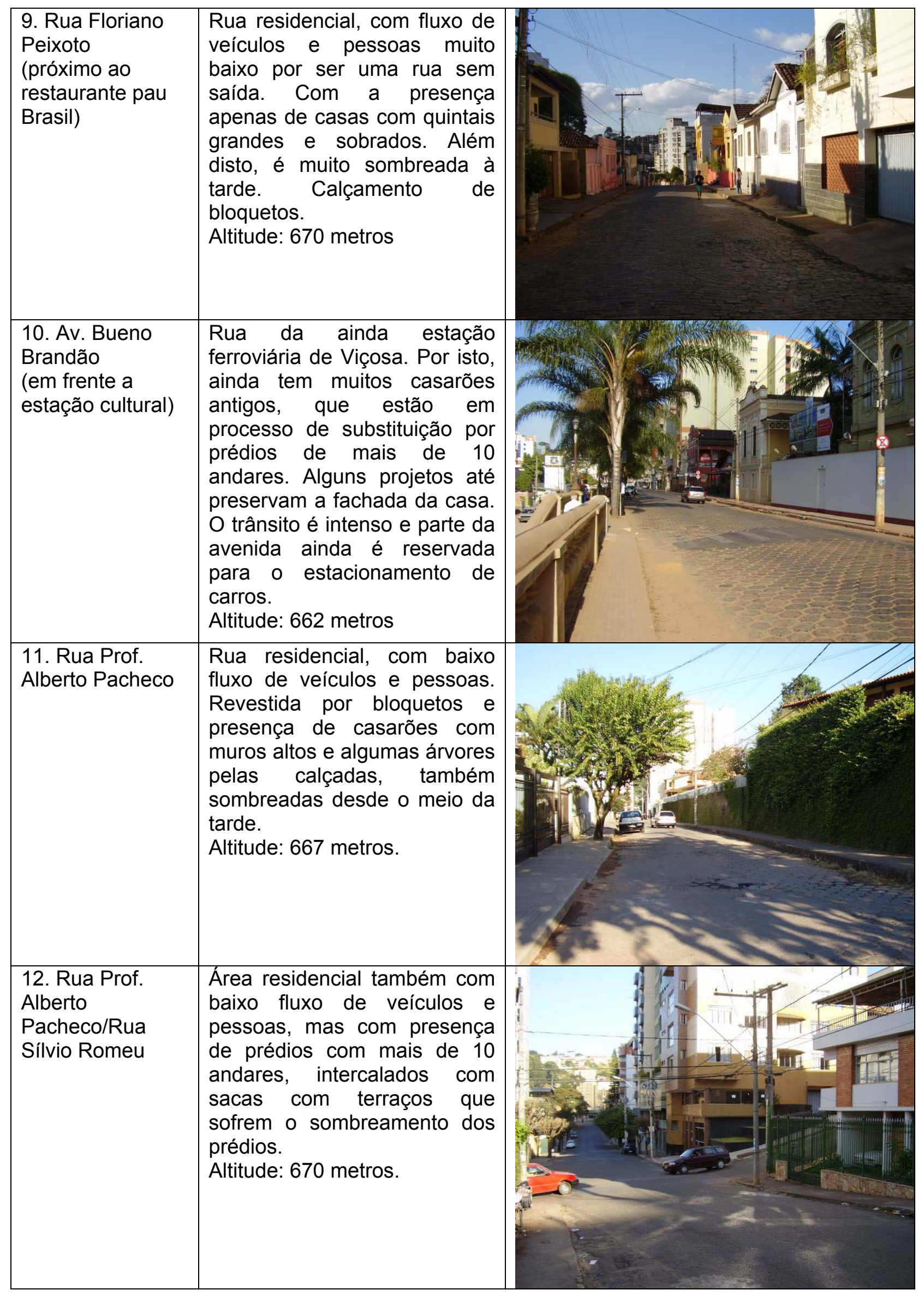




\begin{tabular}{|c|c|c|}
\hline $\begin{array}{l}\text { 13. Rua Prof. } \\
\text { Alberto } \\
\text { Pacheco/Rua } \\
\text { Francisco } \\
\text { Machado }\end{array}$ & $\begin{array}{l}\text { Localizado na periferia do } \\
\text { bairro centro, a rua, apresenta } \\
\text { um intenso tráfego de veículos } \\
\text { e uma pequena praça } \\
\text { arborizada de frente a clínica } \\
\text { santa maria. Grande parte dos } \\
\text { edifícios é comercial com mais } \\
\text { de } 10 \text { andares. Embora } \\
\text { registre uma boa arborização, } \\
\text { a mesma é inócua, em razão } \\
\text { do sombreamento dos } \\
\text { edifícios à tarde. } \\
\text { Altitude: } 660 \text { metros. }\end{array}$ & 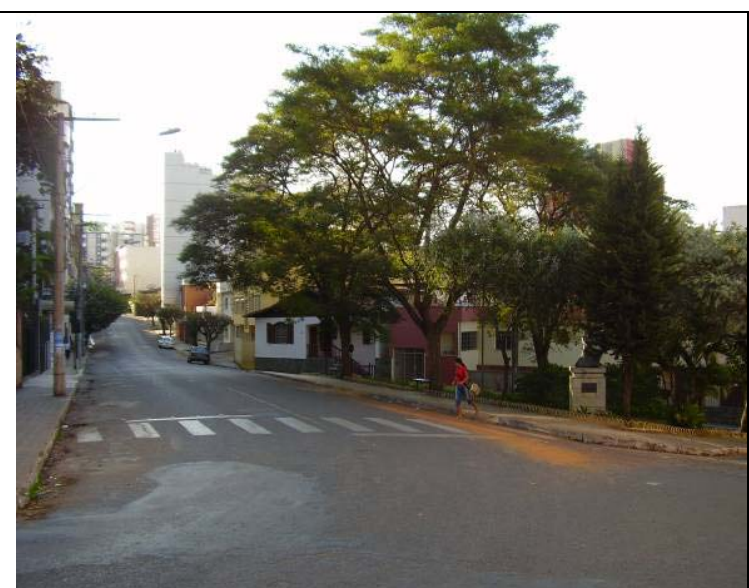 \\
\hline $\begin{array}{l}\text { 14. Travessa } \\
\text { Purdue }\end{array}$ & $\begin{array}{l}\text { Rua que interliga o bairro de } \\
\text { Ramos com o centro, a } \\
\text { mesma não apresenta } \\
\text { edificações ao longo da } \\
\text { quadra, que registra a } \\
\text { presença de dois terrenos } \\
\text { baldios grandes. O } \\
\text { revestimento da superfície é } \\
\text { de bloquetos, quase todos } \\
\text { tortos, em função do trânsito } \\
\text { forte em qualquer hora do dia. } \\
\text { Altitude: } 658 \text { metros. }\end{array}$ & \\
\hline $\begin{array}{l}\text { 15. Av. Santa } \\
\text { Rita }\end{array}$ & $\begin{array}{l}\text { Vias de grande circulação com } \\
\text { uma largura maior, com duas } \\
\text { pistas de rolamento. Serve de } \\
\text { ligação entre os bairros de } \\
\text { São José, Bom Jesus, Fátima, } \\
\text { Cléia Bernardes até o centro. } \\
\text { O fluxo é intenso. A } \\
\text { pavimentação é de bloquetos. } \\
\text { Porém isto não impede } \\
\text { congestionamento no horário } \\
\text { do rush, por conta dos bares } \\
\text { que ocupam as calçadas. } \\
\text { Altitude: } 662 \text { metros. }\end{array}$ & 基) \\
\hline $\begin{array}{l}\text { 16. Rua Padre } \\
\text { Serafim/Av. } \\
\text { Santa Rita }\end{array}$ & $\begin{array}{l}\text { Próximo ao trevo de acesso a } \\
\text { Paula Cândido, e via de } \\
\text { acesso a Av. Santa Rita. Tem } \\
\text { uso predominantemente, } \\
\text { comercial, com lojas e material } \\
\text { de construção e mercadinhos. } \\
\text { Esta rua sempre tem } \\
\text { congestionamentos, em razão } \\
\text { das faixas de trânsito pintado } \\
\text { no chão deixar dúvidas quanto } \\
\text { a preferência do motorista. } \\
\text { Altitude: } 661 \text { metros }\end{array}$ & $\sum^{2}=4 k^{2}$ \\
\hline
\end{tabular}




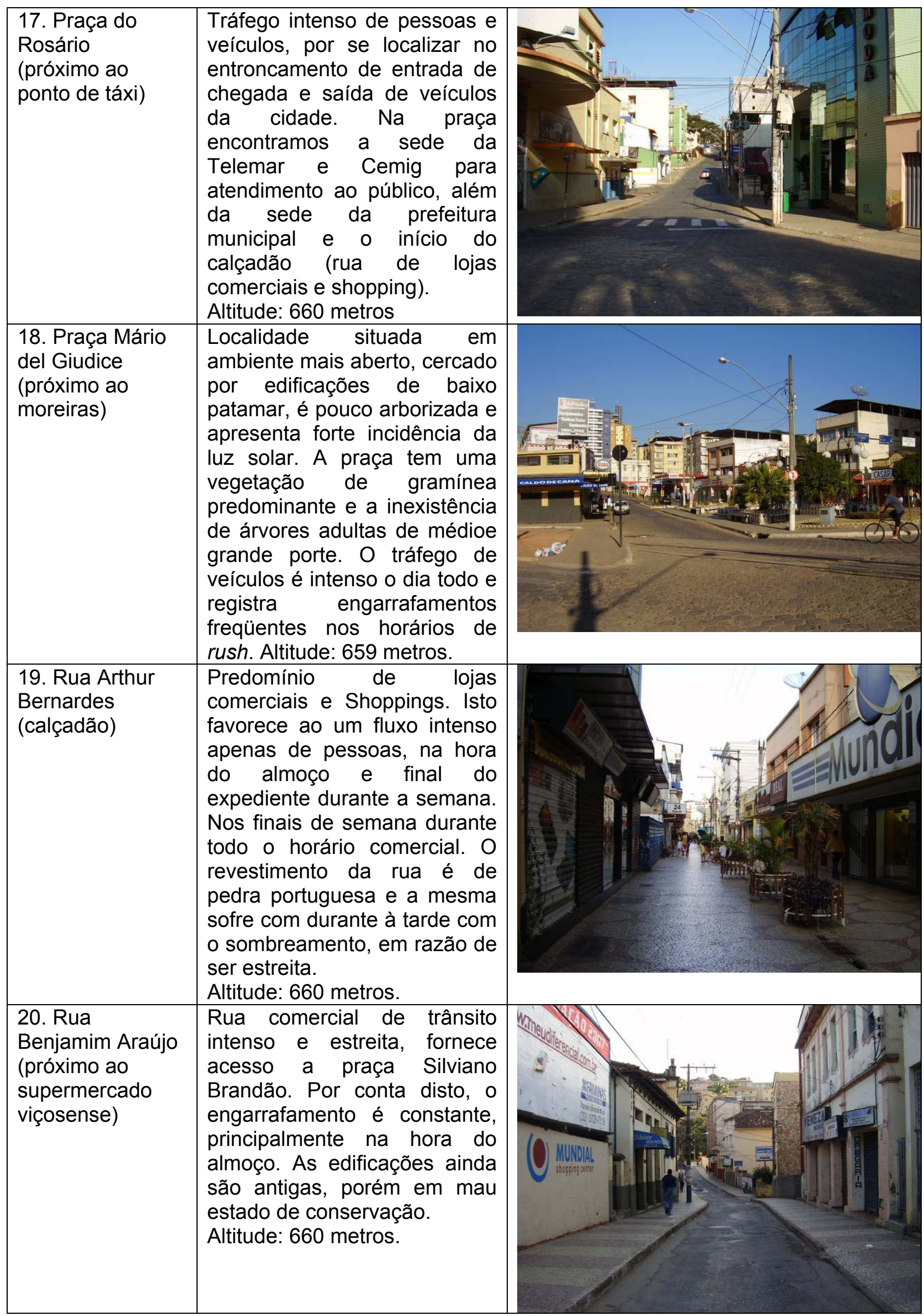

Organizado por Edson Soares Fialho (2008). 


\subsection{Análise da condição sinóptica do tempo}

A ilha de calor atmosférica apresenta como fatores controladores endógenos para sua existência, a densidade de construções, a geometria das ruas, o tamanho da população, a intensidade dos fluxos de veículos, dentre outros.

Porém, dentre os fatores exógenos, os tipos de tempo são o principal fator controlador da intensidade do fenômeno de ilha de calor atmosférica, conforme Sundborg (1950), Tarifa (1977), Landsberg (1981), Figuerola e Mazzeo (1998) Szegedi e Kircsi (2003), Fialho e Imbroisi (2005), pois a condição de tempo regula a entrada e saída de energia disponível no sistema urbano, o que acaba influenciando na velocidade da perda de energia de superfícies distintas.

Faz-se necessário o acompanhamento da dinâmica do tempo durante a semana da realização dos experimentos de campo, na área de experimento, inserida na região da Zona da Mata, influenciada pela dinâmica sazonal da região Sudeste.

Para o acompanhamento do ritmo da seqüência dos tipos de tempo, foram obtidas as informações referentes às cartas sinóticas, as imagens de satélite e de carta de nebulosidade, juntamente nos sítios da Diretoria de Hidrografia e Navegação (DHN) - http://www.mar.mil.br/dhn -; no Instituto Nacional de Pesquisas Espaciais (INPE) - http://www.inpe.br- e na Rede de Meteorologia do Comando da Aeronáutica (REDEMET) - http://www.redemet.aer.mil.br-, respectivamente.

Quanto aos parâmetros climáticos estes foram colhidos no site do Instituto Nacional de Meteorologia (INMET) - http://www.inmet.gov.br-, na plataforma estações automáticas.

\subsection{Tratamento e correção dos dados de campo}

O registro dos dados de temperatura do ar e umidade relativa ao longo da realização das medidas por meio do transeto móvel apresenta uma defasagem de tempo. Por conta disto, os valores obtidos em campo passaram por uma correção.

Para as medidas realizadas em três momentos do dia, utilizou-se a estação meteorológica da UFV/INMET, que acompanha a evolução horária dos parâmetros climáticos, especialmente, a temperatura do ar. Como isso, toda mudança de temperatura foi possível retirar o aquecimento ou o resfriamento das leituras. Como pode ser visto na Tabela 20. 
Tabela 20. Exemplo de correção da temperatura do ar.

\begin{tabular}{|c|c|c|c|c|c|}
\hline Ponto & Hora & Temp. & Temp. 1 & DIF. & Temp. Corrigida \\
\hline 1 & $9: 00$ & 20,0 & 21,0 & 0,0 & 20,0 \\
\hline 2 & $9: 10$ & 21,0 & 21,3 & 0,3 & 20,7 \\
\hline 3 & $9: 20$ & 21,2 & 21,6 & 0,6 & 20,6 \\
\hline 4 & $9: 30$ & 21,8 & 22,0 & 1,0 & 20,8 \\
\hline 5 & $9: 40$ & 21,6 & 22,3 & 1,3 & 20,3 \\
\hline 6 & $9: 50$ & 22,0 & 22,6 & 1,6 & 20,4 \\
\hline 7 & $10: 00$ & 21,8 & 23,0 & 2,0 & 19,8 \\
\hline
\end{tabular}

Temp. - Temperatura observada em campo.

Temp. 1 - Temperatura da Estação Automática.

DIF - Diferença da Temp. 1 ao longo do tempo de 1:00 hora.

Temp. Corrigida - Subtrai a DIF da Temp. para o caso das medidas diurnas, quando se registra uma tendência de aumento da temperatura e o inverso para à noite, que se verifica um resfriamento.

Organizado por Edson Soares Fialho (2009).

\subsubsection{Correção dos dados de campo noturno}

Para as medidas realizadas, durante à noite e madrugada, o procedimento de correção foi diferente, pois como o mesmo trajeto, os registros foram realizados durante a ida e a volta, entre 6 a 9 vezes.

Isto nos permitiu acrescentar o resfriamento da atmosfera, registrada pela estação meteorológica automática, na temperatura observada de campo (Figura 57). Por conta disto, a conseqüência era a redução do número de transetos, ou seja, em vez de 9 medidas, apenas 8 seriam utilizadas.

De acordo com a Figura 57, as medidas da estação automáticas são compostas de uma unidade de memória central ("data logger"), ligada a vários sensores dos parâmetros meteorológicos, que integra os valores observados minuto a minuto automaticamente a cada hora. Portanto, no caso da temperatura, o valor registrado é a média do intervalo horário (INMET, 2009).

No caso observado pela Figura 57, as temperaturas observadas em campo: $22,0^{\circ} \mathrm{C} ; 21,0^{\circ} \mathrm{C}$ e $21,2^{\circ} \mathrm{C}$ seriam corrigidas por $22,0^{\circ} \mathrm{C} ; 22,0^{\circ} \mathrm{C}$ e $23,2^{\circ} \mathrm{C}$, respectivamente. 


\section{Tempo (minutos)}
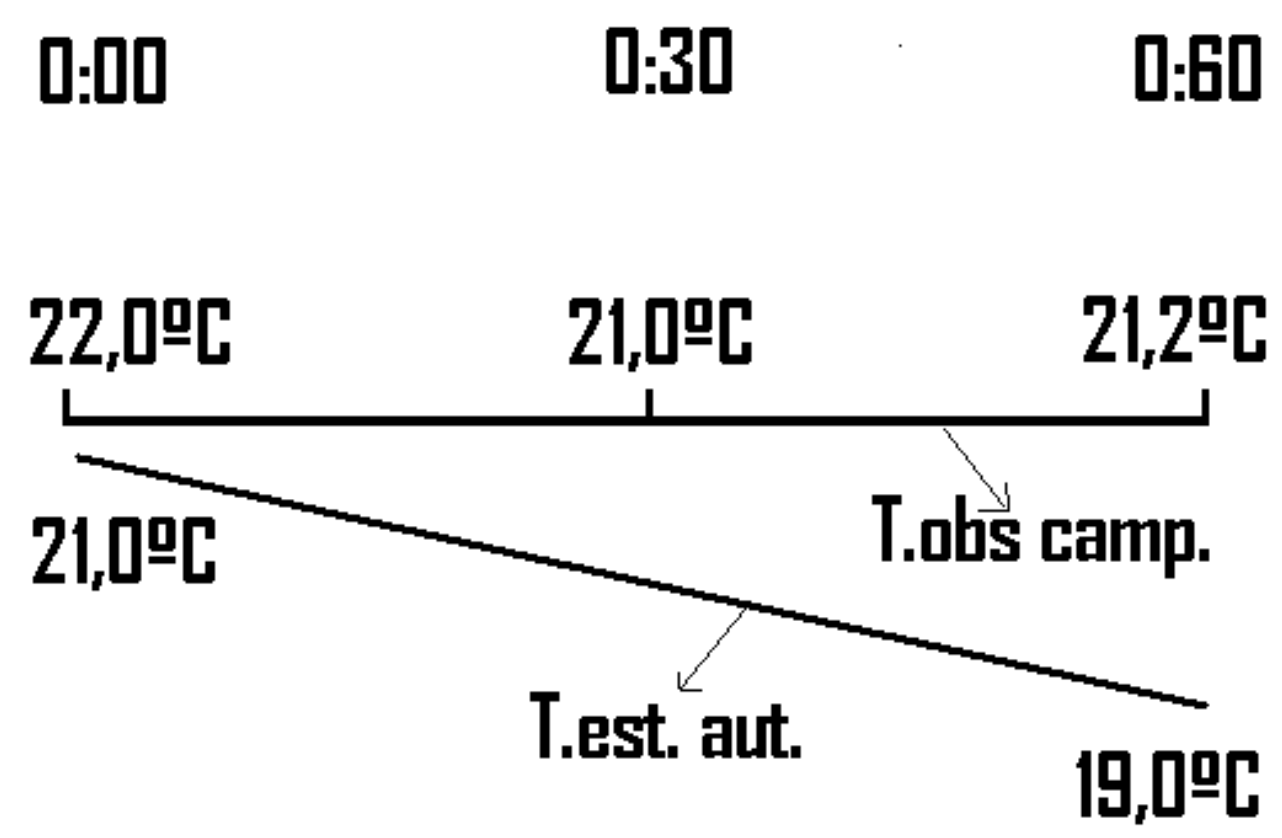

Figura 57. Diferença entre a temperatura observada em capo ao longo da realização de um transeto e a temperatura registrada pela estação automática em uma hora. Organizado por Edson Soares Fialho (2009).

\subsection{Uso de recursos técnicos e análise dos dados.}

Os dados obtidos nos experimentos de campo (temperatura do ar e umidade reativa) e junto às estações climatológicas serviram de base para a elaboração dos transetos temporoespaciais e os mapeamentos do campo térmico. Para isso, utilizaram-se os programas Microsoft Surfer v. 8.0 e ArcGis v. 9.

O primeiro software tem sua aplicação voltada a de gráficos, que valorizem o comportamento diário e/ou sazonal da temperatura do ar e da umidade do ar ao longo do perfil campo-cidade. O segundo, auxiliará na elaboração dos mapas de contrastes térmicos intra-urbanos, na escala de 1:15.000 para mancha urbana da cidade e 1:10.000 para a área central. Em ambos foram digitalizados os limites, arruamentos e os pontos de medida em cada "layer".

Os pontos de coleta definidos como valores de $Z$ (valores de temperatura dos pontos móveis) na base cartográfica conforme a numeração de cada ponto nos roteiros das médias móveis. 
Com o intuito de alcançar os resultados, o presente trabalho procurou integras as informações disponíveis (dados secundários, obtido em instituições públicas, como Instituto de Planejamento municipal - IPLAM, a prefeitura, DEA e o DPS) com os dados primários, obtidos, durante a realização dos experimentos de campo.

Mas, para uma melhor organização o trabalho foi ordenado em 4 etapas, sugeridas de acordo com Jardim (2007, p. 39).

A primeira foi a comparação dos dados de campo entre si. Em segundo lugar, o levantamento e caracterização das características físicas da área de estudo. A terceira etapa constitui na identificação dos sistemas atmosféricos atuantes durante a realização dos trabalhos de registro. A quarta etapa, por sua vez, procura identificar os fatores controladores envolvidos na estruturação do fato geográficoclimático. 


\section{Resultados e Discussões}

Neste item os dados obtidos, junto à estação meteorológica de Viçosa e dos experimentos de campo serão apresentados de acordo com a seqüência sugerida no tópico materiais e métodos.

\subsection{Variação da temperatura média do ar no período de 1968-2006}

Segundo a classificação de Köppen, o clima de Viçosa (Figura 58) é enquadrado no clima mesotérmico, ou seja, Cwa, que apresenta como característica verões quentes (o mês mais quente tem temperatura média maior do que $22,0^{\circ} \mathrm{C}$ ) e úmidos e estação seca, no inverno.

Porém, cabe salientar que de acordo com os critérios de Koppen, Viçosa que se enquadra em uma faixa de transição entre o Clima Cwa e Cwb. Isto porque se considerarmos o verão como sendo os meses de Janeiro, Fevereiro e Março, com temperatura média mensal de $22,1^{\circ} \mathrm{C}, 22,3^{\circ} \mathrm{C}$ e $21,8^{\circ} \mathrm{C}$, respectivamente, a temperatura média do verão quente será de $22,1^{\circ} \mathrm{C}$, valor este superior ao limite definido por Koppen para um clima Cwa.

Todavia, se o verão for definido pelos meses de Dezembro, Janeiro e Fevereiro, com $21,3^{\circ} \mathrm{C}, 22,1^{\circ} \mathrm{C}$ e $22,3^{\circ}$, respectivamente. A temperatura média do verão cai para $21,9^{\circ} \mathrm{C}$, valor este embora próximo, é inferior ao limite estipulado de $22,0^{\circ} \mathrm{C}$, o que enquadra Viçosa no clima Cwb. Esta pequena diferença, por sua vez, poderia explicar as diferenças encontradas em inúmeras citações bibliográficas, que oscilam entre o clima Cwa (chuva de verão e verão quente) e Cwb (chuva de verão e verão moderadamente quente).

Apesar do esforço em compreender a razão para tal dúvida. A explicação apresentada no parágrafo anterior se torna frágil, quando nos deparamos com a leitura de Valverde (1958), sobre o clima de Viçosa, analisado no período de 1920 1942. Segundo os resultados pelo autor, a temperatura média anual era de $18,5^{\circ} \mathrm{C}$ e uma temperatura média de verão inferior aos $22,0^{\circ} \mathrm{C}$, o que enquadra a região no clima Cwb. Quando confrontamos com a temperatura média da última normal climatológica (1961-1990) observa-se que possivelmente ocorreu uma tendência de aquecimento da temperatura do ar, uma vez que a mesma se encontra na casa dos $19,5^{\circ} \mathrm{C}$. 


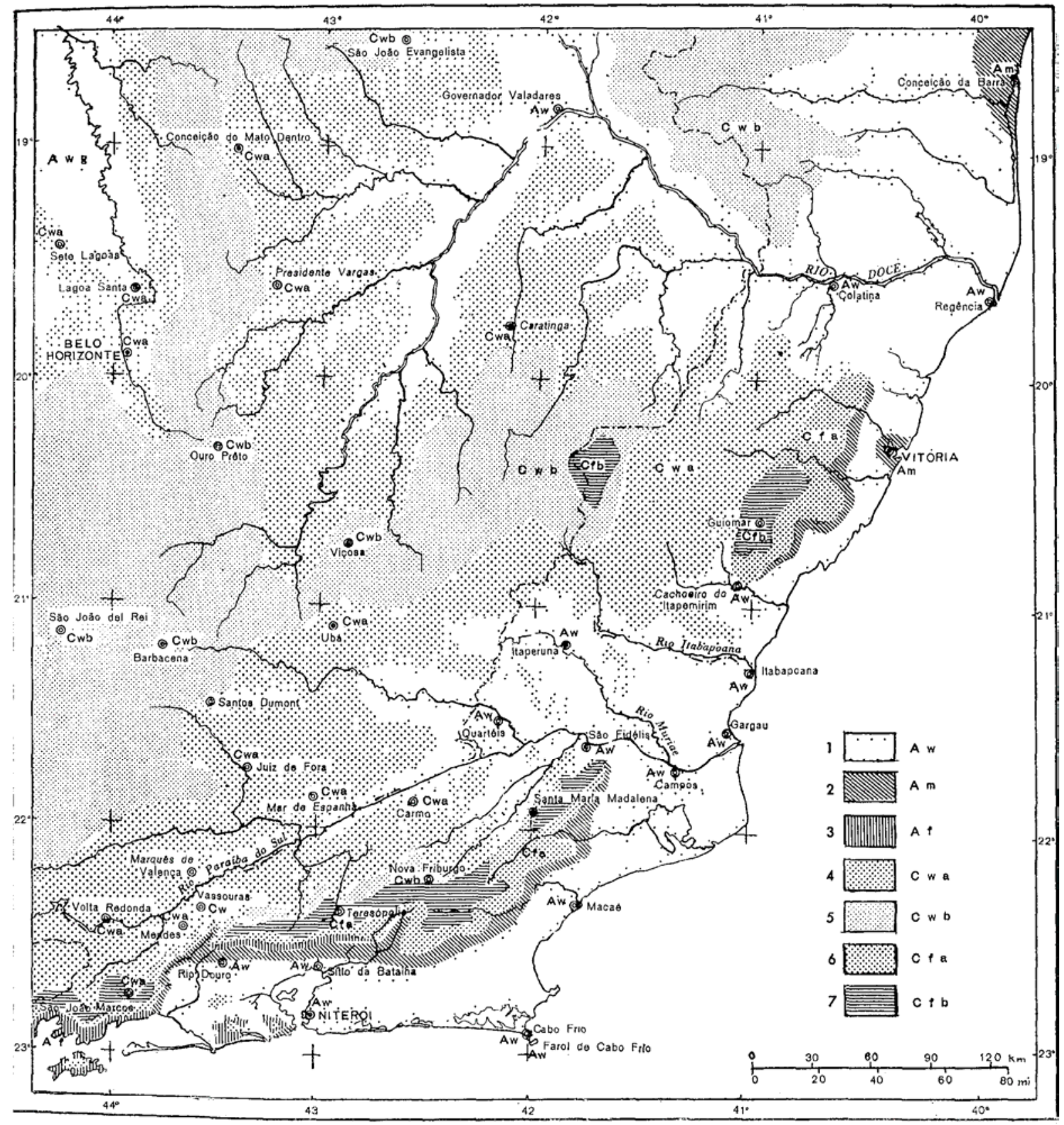

Figura 58. Classificação climática de Koppen para a porção leste da região sudeste do Brasil.

Fonte: Valverde (1958, p. 21).

Os dados da estação climatológica de Viçosa, como se verifica na Figura 59, mostram que o município, no período entre 1970 e 2006, apresentou uma tendência de aumento nos valores referentes à temperatura do ar.

Ao comparar a evolução do contingente populacional de Viçosa entre 1970 ao ano de 2000, as taxas de crescimento foram de 83,29\% (entre 1970 e 1980), 58,4\% (entre 1980 e 1990) e 21,3\% (entre 1990 e 2000). O valor da temperatura média anual na década de 1970 era de $19,4^{\circ} \mathrm{C}$. Já na década de 1990 a temperatura média oscila entre $20,0^{\circ} \mathrm{C}$ e $21,5^{\circ} \mathrm{C}$. 
Com base apenas na visualização da Figura 59, então podemos ser convencidos de que Viçosa registrou um aumento da temperatura média do ar. Porém quando se observa o $\mathrm{R}^{2}$ (coeficiente de determinação múltipla) de 0,5562. Isto quer dizer que a relação entre a variação explicada pela equação de regressão múltipla e a variação total da variável dependente foi de 55,0\%.

Fazendo uma analogia, a probabilidade de Viçosa apresentar realmente um aquecimento da temperatura média, relacionado ao processo de urbanização é a mesma de dar cara ou coroa, quando se lança uma a moeda.

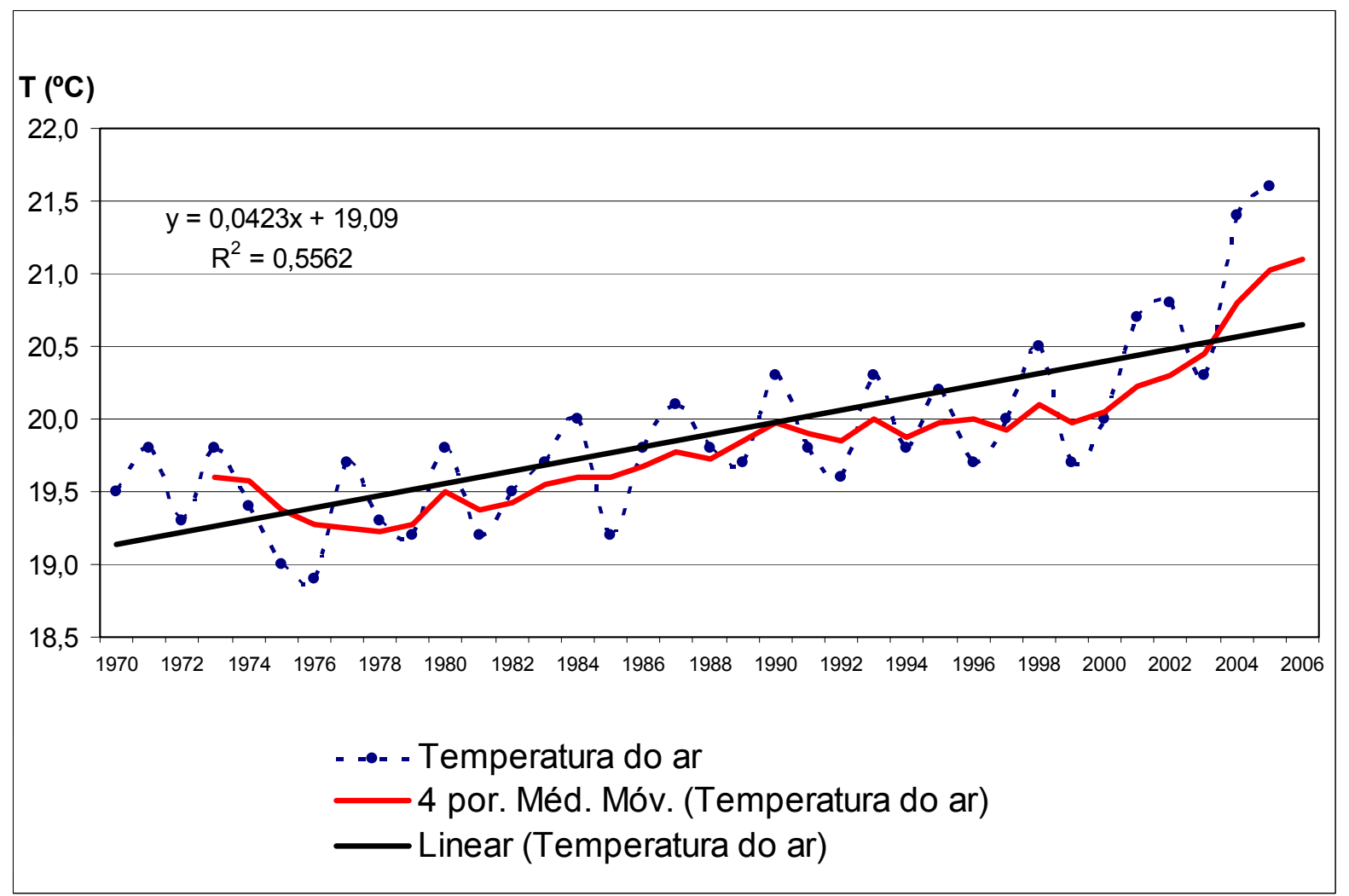

Figura 59. Evolução da temperatura média do ar na estação meteorológica de Viçosa entre 1970 e 2006

Fonte: INMET-DEA/UFV (2007).

Embora, o modelo de classificação de Köppen, em sua simplicidade tenha identificado uma mudança na tipologia climática. Com base nos argumentos apresentados no parágrafo anterior, não há como afirmar que há um aumento da temperatura média. E muito menos que o crescimento da cidade tenha influenciado no comportamento da mesma.

Tal afirmativa é corroborado por Rodrigues (2009) quando analise o comportamento das séries históricas das temperaturas médias da região Sudeste, 
Minas Gerais e de Viçosa-MG. Segundo o autor não há significativas alterações nos comportamentos das séries, ou seja, o comportamento da temperatura média, na região Sudeste e no estado de Minas Gerais, não destoa das observações verificadas em Viçosa. Desta forma, o mesmo autor conclui a série de temperatura média em Viçosa não apresenta alterações que também não sejam observadas nas escalas superiores. Isto quer dizer, que Viçosa é apenas influenciada apenas pelo comportamento da circulação regional associada às características fisiográficas como altitude e latitude.

Porém, quando nos deparamos com as Figuras 60 e 61, que representam o comportamento médio anual das séries de temperatura máxima e mínima. Ambas as séries apresentaram tendência positiva significativa pelo teste de Mann-Kendall, com valor de Z-calculado de 4,31 para a temperatura mínima e 2,23 para a temperatura máxima.

Observou um aumento de aproximadamente $1,0^{\circ} \mathrm{C}$ comparando a média do período de 2000-2006 em relação à média da década de 1970 na temperatura mínima. Para a temperatura máxima, esse aumento foi em torno de $0,6{ }^{\circ} \mathrm{C}$.

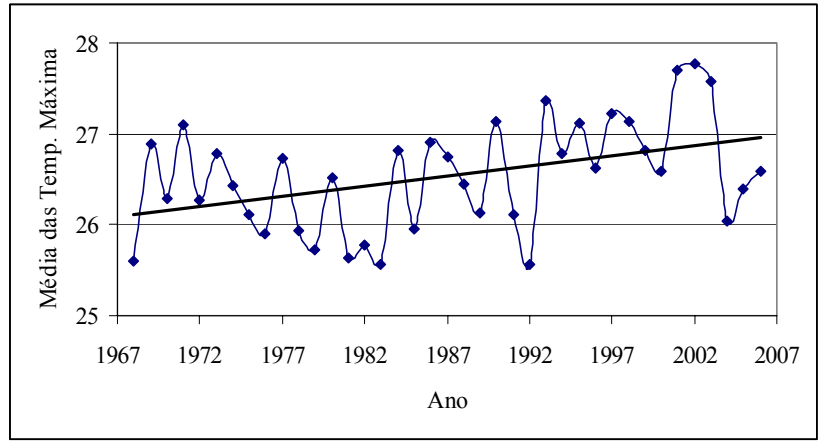

Figura 60: Médias anuais da temperatura máxima diária de 1968 a 2006 em Viçosa,.

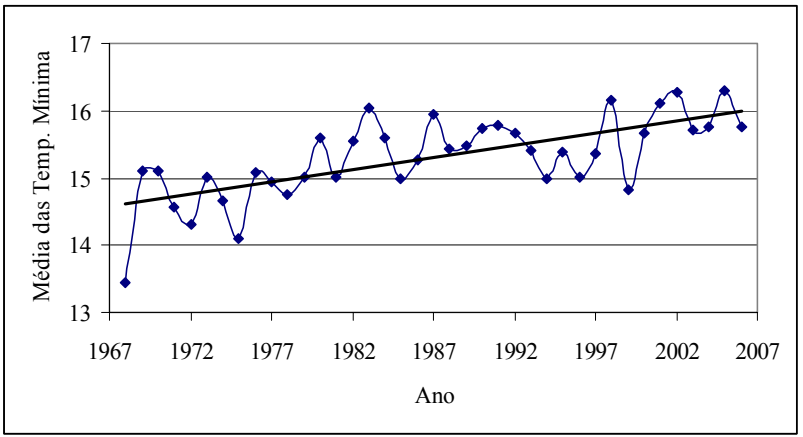

Figura 61: Médias da temperatura mínima diária de 1968 a 2006 em Viçosa.

Os resultados mensais observados na temperatura mínima foram diferentes em relação à temperatura máxima, na maioria dos casos, as séries de temperatura mínima apresentam tendências positivas. Essa diferença de aumento entre a temperatura máxima e mínima é refletida nos valores da amplitude térmica (diferença entre a temperatura máxima e mínima) ao longo dos anos, isto significa que caso essa tendência se mantenha, espera-se uma diminuição na amplitude térmica. 
Os testes de Mann-Kendall para as médias mensais de temperatura mínima e máxima diária são apresentados na Tabela 21 e Figura 62, respectivamente. Verificou-se uma tendência positiva na temperatura mínima em quase todos os meses, com exceção dos meses de junho, agosto e novembro que não apresentaram tendência significativa. $\mathrm{O}$ mesmo se constata para a temperatura máxima, com exceção dos meses de abril, setembro e outubro, que apresentaram tendência positiva.

Os resultados apresentados indicam uma tendência crescente positiva nas séries de temperatura mínima do ar. Para a temperatura máxima, a tendência se mostra relevante quando se considera a média anual.

Tabela 21. Resultados das análises de tendência para a temperatura média mínima de cada mês

\begin{tabular}{l|r|r}
\hline $\begin{array}{l}\text { Temperatura } \\
\text { Mínima }\end{array}$ & $\begin{array}{l}\text { Teste de } \\
\text { Mann_Kendall } \\
\text { (Z Calculado) }\end{array}$ & $\begin{array}{l}\text { Tendência } \\
\alpha=0,05\end{array}$ \\
\hline Janeiro & 3,92 & $\mathrm{~S}+$ \\
Fevereiro & 3,65 & $\mathrm{~S}+$ \\
Março & 2,92 & $\mathrm{~S}+$ \\
Abril & 3,34 & $\mathrm{~S}+$ \\
Maio & 2,18 & $\mathrm{~S}+$ \\
Junho & 1,74 & $\mathrm{NS}$ \\
Julho & 2,11 & $\mathrm{~S}+$ \\
Agosto & 1,40 & $\mathrm{NS}$ \\
Setembro & 2,13 & $\mathrm{~S}+$ \\
Outubro & 2,00 & $\mathrm{~S}+$ \\
Novembro & 1,86 & $\mathrm{NS}$ \\
Dezembro & 3,85 & $\mathrm{~S}+$ \\
\hline
\end{tabular}

NS = Tendência não significativa; S+ = Tendência significativa positiva; S- = Tendência significativa negativa

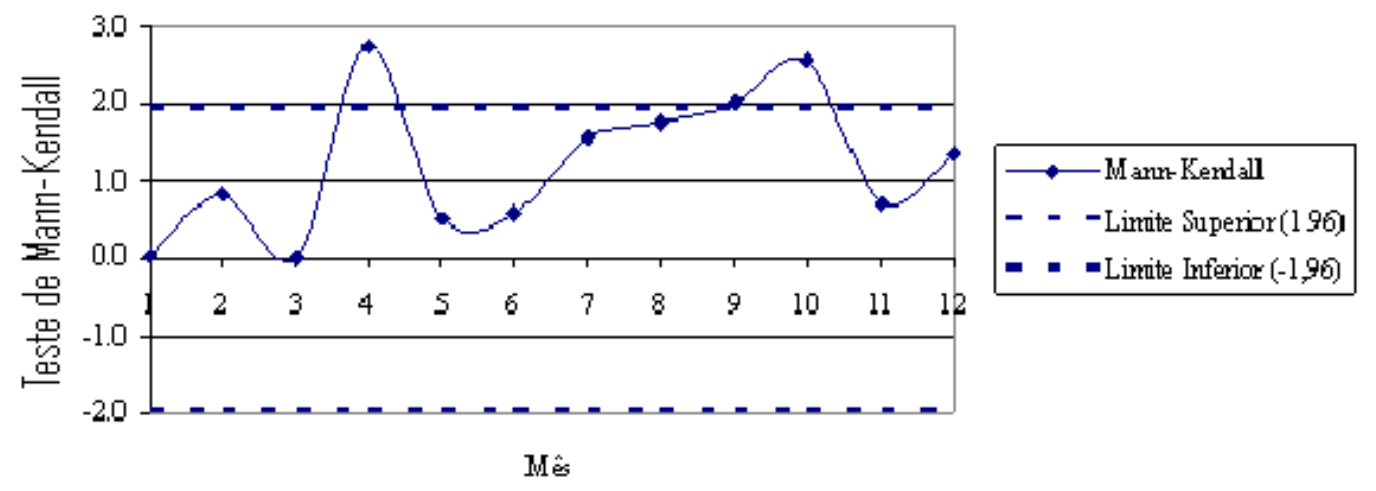

Figura 62 - Teste de Mann-Kendall para a temperatura máxima mensal 


\subsection{Transetos noturnos entre o campo e a cidade.}

O período do mês de maio de 2008 (Figura 63), em que foram realizadas as coletas de campo foi marcado pela ocorrência de ciclones extratropicais. A primeira frente fria ocorreu no dia 2 de maio sobre o Rio Grande do Sul. $\mathrm{O}$ ar frio que atuava no país foi reforçado provocando vento e chuvas fortes nos primeiros dias, apresentando rajadas de vento de até $100 \mathrm{~km} \cdot \mathrm{h}^{-1}$. Nos dias 3 e 4 essa frente deslocou-se para o Sudeste, perdendo suas características. Apesar de enfraquecido, a MPA, manteve as baixas temperaturas, influenciando os estados da região sul do Brasil, São Paulo e sul de Minas Gerais. No dia 7 chegou ao sul da Bahia, tomando de vez características subtropicais.

Outro sistema atuou, a partir do dia 7, chegando ao litoral do Rio de Janeiro no dia 10. O sistema anticiclonal conseqüente da passagem do segundo sistema frontal do mês provocou geada no sul do Brasil e na Serra da Mantiqueira.

A partir do dia 9, uma alta pós-frontal localizou-se sobre o oceano, reforçando a alta subtropical do atlântico. A permanência deste sistema favoreceu a advecção do ar úmido para a faixa leste da região sudeste, promovendo a ocorrência de chuvas e nebulosidade. Os outros sistemas ocorrentes no mês de maio não afetaram o sudeste, ficando restritas ao Uruguai e Argentina, ou se formando depois do dia 12.

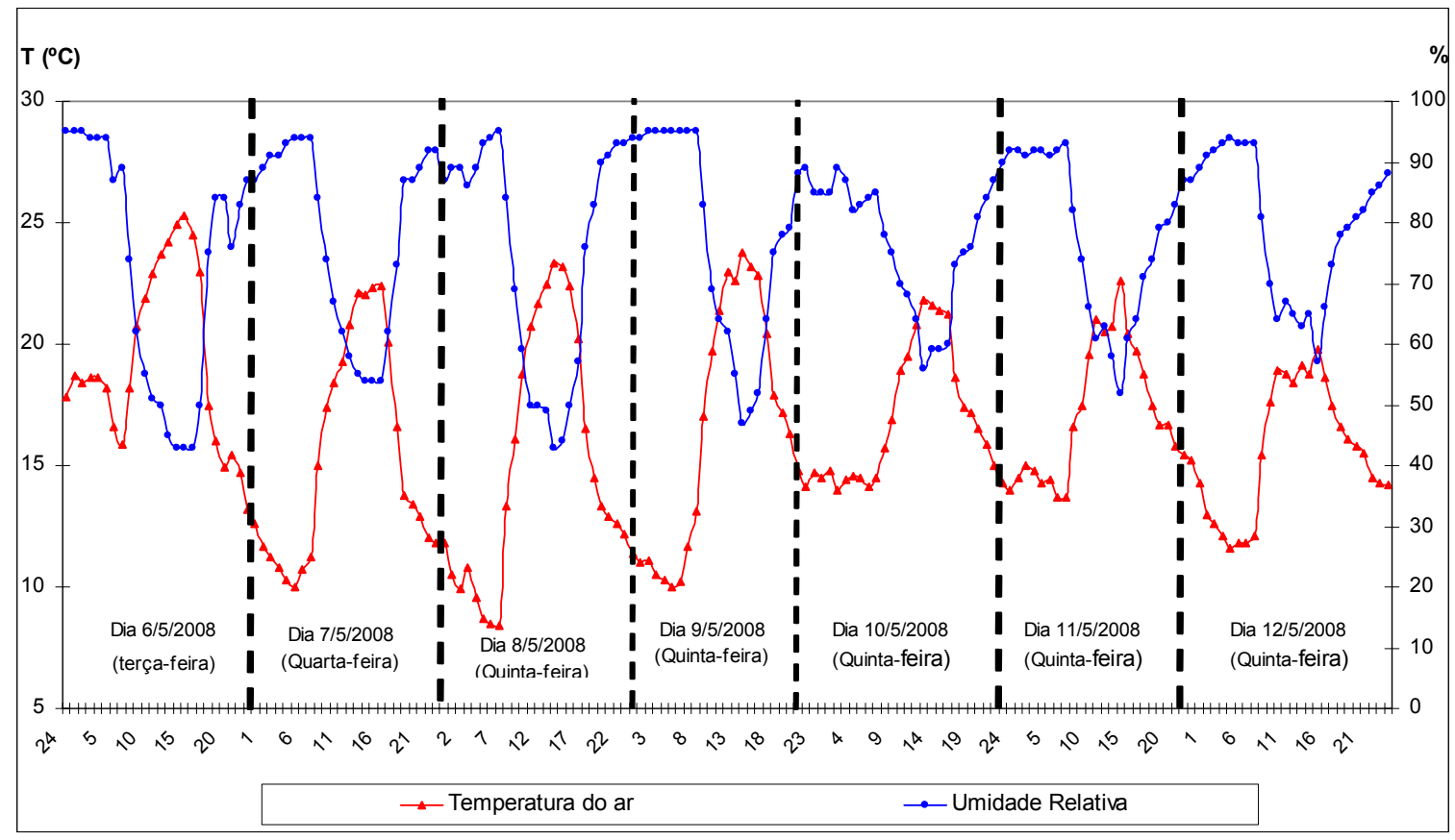

Figura 63. Evolução da temperatura do ar e da umidade relativa horária entre os dias 6/5/2008 e 12/5/2008 para estação meteorológica de Viçosa.

Fonte: INMET (2008). 


\subsubsection{Outono}

No dia do primeiro experimento (6-7 de maio) as temperaturas se localizaram nos pontos 3,4 e 17 e as áreas mais quentes foram do ponto 8 ao 13. A maior temperatura foi no primeiro horário no ponto 9 registrou o maior gradiente horizontal térmico desta campanha $4,0^{\circ} \mathrm{C}$. Ao longo da noite a intensidade foi diminuindo, mas se manteve na zona central, chegando a $3,0^{\circ} \mathrm{C}$ na última medida. Entre os pontos 5 e 6, identifica uma área de transição do campo para a cidade. A partir do ponto 7 as características de uso da terra se alteram substancialmente, pois se inicia a área urbanizada.

A variação espacial ao longo da noite e madrugada demonstra que o núcleo de maior aquecimento se restringe entre os pontos 8 e 12. Enquanto o menor se estabelece entre os pontos 3, 4 e 17. Esta configuração corrobora o modelo da hipótese de que áreas mais construídas retêm calor na sua estrutura e o libera lentamente durante a noite, enquanto no campo o calor é perdido mais rapidamente, mantendo-se frio durante toda a noite.

A umidade manteve-se praticamente constante em todos os pontos e os horários, com variação um pouco mais acentuada.

Durante a noite do dia 7 (Figura 64), o céu permaneceu aberto o tempo todo e dados da estação de Viçosa indicaram ausência de ventos nos horários medidos, Verificou-se a aparição de neblina aproximadamente entre 22:00 e 23:00 horas entre os pontos 16 e 17, intensificando-se pela madrugada. Esse dia apresentou maior calmaria, tanto de dia quanto a noite. De 10:00 às 15:00 horas foi o período com maior velocidade, chegando a máxima de $2,0 \mathrm{~m} \cdot \mathrm{s}^{-1}$ às 10:00 horas com direção SW. Durante o período de mensuração a estação registrou calmaria. Nesse dia as direções SW e SE. O maior gradiente horizontal térmico foi no terceiro horário no ponto 11 alcançando $3,9^{\circ} \mathrm{C}$. As maiores diferenças nesta noite permaneceram entre os pontos 8 ao 12 . Um núcleo de $2,0^{\circ} \mathrm{C}$ aparece no ponto $1 \mathrm{em}$ vários momentos, Os pontos mais frios situaram-se quase sempre nos pontos 3,4 e 17, que são áreas de sítios ou de baixo grau de urbanização. A umidade começou na casa dos 70,0\% e manteve-se assim no primeiro horário. Nos outros ela diminuiu para valores entre $40,0 \%$ e $50,0 \%$, mantendo-se em todos os pontos. A taxa de resfriamento desse dia apresentou uma queda brusca no ponto 4 e uma subida considerável a partir daí. Teve seu maior valor no ponto 14 , mas com pouca diferença dos pontos mais próximos. 
No dia 9 de maio, terceiro dia da campanha, apresentou nebulosidade oscilando entre 2 e 4/8 até por volta das 20:00 horas, voltando à situação de parcialmente nublado depois das 2:00 horas da madrugada. Comparado aos outros dias que tiveram calmaria, durante quase toda a noite, nesse dia apresentou uma pequena variação, não passando dos $0,7 \mathrm{~m}^{-1} \mathrm{~s}^{-1}$ às $5: 00$ horas, Durante o dia, os ventos alcançaram a velocidade de $1,8 \mathrm{~m} \cdot \mathrm{s}^{-1}$, na direção SW. Os ventos predominantes na maior parte dos horários foram NE e SE. Formou-se um núcleo de $4,0^{\circ} \mathrm{C}$ dos pontos 7 ao 12 no segundo horário. Um núcleo de $3,0^{\circ} \mathrm{C}$ ficou até o quarto horário e depois disso não apresentou uma ilha de calor intensa nem concentrada num horário especifico.

A partir do quinto transeto ela se manteve a mesma e praticamente constante no espaço, representando uma dificuldade na perda de calor nesses horários. Assim como nos outros dias, a umidade não se comportou da maneira esperada, mantevese constante em torno dos $70,0 \%$ no primeiro horário para todos os pontos, caindo lentamente e voltando a se estabilizar.

No dia 12 (Figura 65) foi o que apresentou o comportamento mais diferenciado. Registrou dois núcleos mais intensos de calor, um no segundo horário e outro no sétimo, ambos de $2,0^{\circ} \mathrm{C}$. No quinto horário a maior variação de temperatura foi de $0,9^{\circ} \mathrm{C}$ nas áreas dentro da cidade que têm características de um espaço um pouco mais aberto e com alguma vegetação.

A forma das isotermas apresentou características bem peculiares: os primeiros transetos mostraram uma variação térmica espacial relativamente pequena quando comparada aos dias anteriores, mas seguindo a mesma lógica, as temperaturas iam subindo na direção do centro, formando as ilhas de calor. As linhas indicando as intensidades foram feitas de $1,0^{\circ} \mathrm{C} \mathrm{em} 1,0^{\circ} \mathrm{C}$.

No quinto horário não é possível observar uma variação maior que esse valor. Dessa forma eu considero não haver a presença de uma ilha de calor significativa em nenhum dos pontos. Nos horários subseqüentes volta a surgir uma pequena variação da temperatura, não configurando um núcleo perfeito. Lentamente formouse um núcleo localizado na área central. A umidade começou alta, no segundo trajeto ela variou e caiu, mantendo-se baixa durante o resto da noite.

O céu estava parcialmente encoberto, principalmente por volta de 2:00 horas, quando era feito o sétimo trajeto. A velocidade dos ventos se reduziu, comparando com o dia 9, ainda permanecendo com uma pequena variação ao longo de todo o dial A direção predominante foi tanto a NE quanto SE. Os pontos 5,14 e 15 
demonstraram um pico na taxa de resfriamento. Houve um aumento a partir do ponto 6 , caindo bruscamente no ponto 17 .

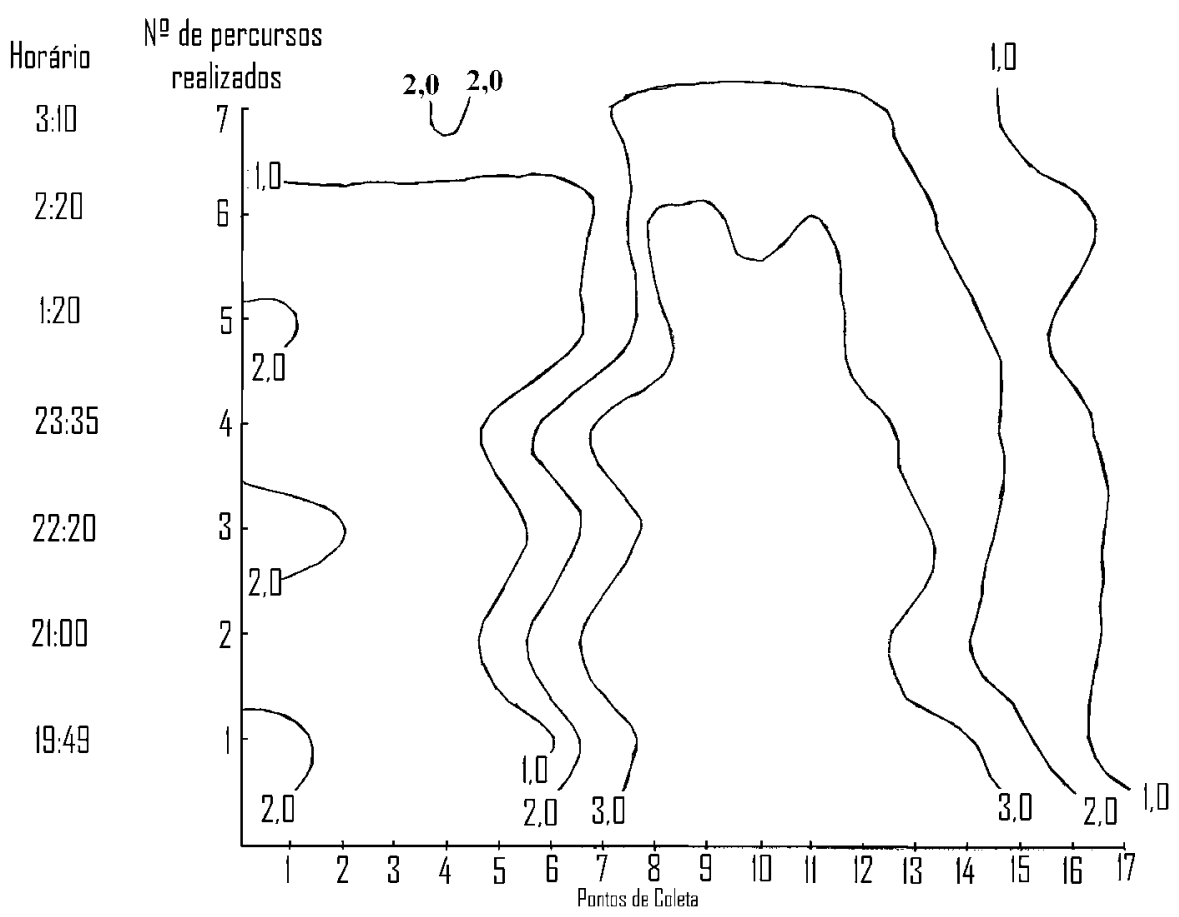

Figura 64. Evolução da ilha de calor noturna em Viçosa entre os dias 7 e 8 de maio de 2008

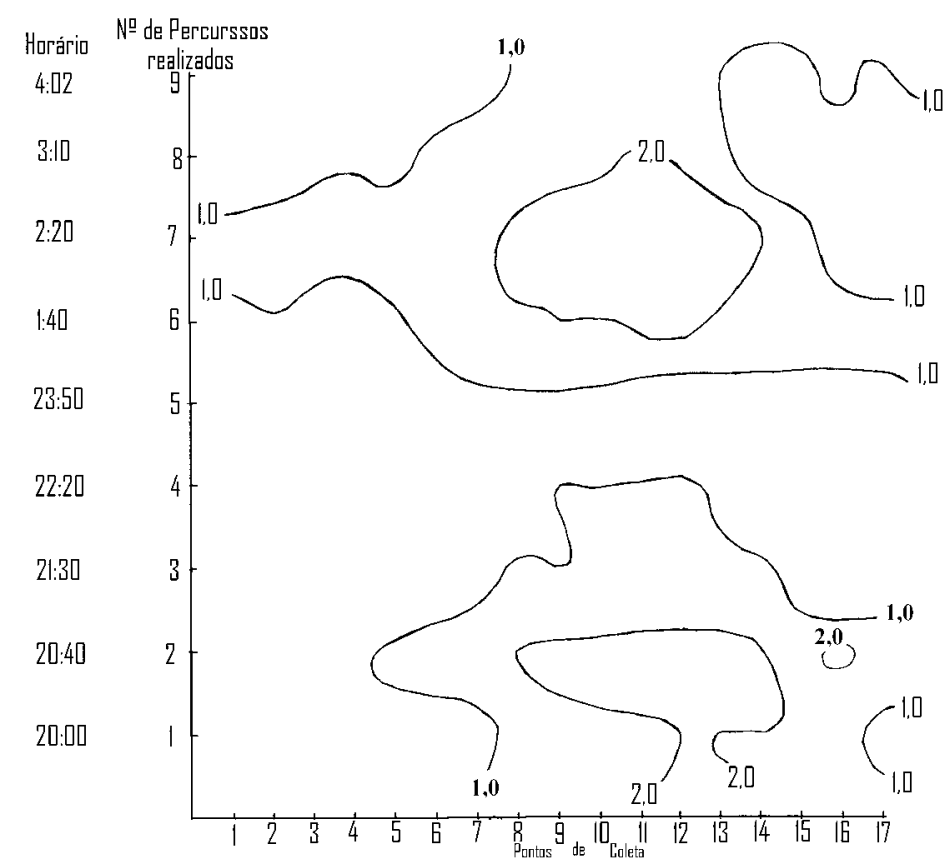

Figura 65. Evolução da ilha de calor noturna em Viçosa entre os dias 12 e 13 de maio de 2008 


\subsubsection{Inverno de 2008}

Entre os dias 23 e 24 houve o deslocamento de uma perturbação ciclônica pela região Sul. Este sistema favoreceu a formação de uma área de baixa pressão em superfície entre sul do RS e Uruguai no dia 24, formando uma onda frontal na tarde deste dia (oitavo sistema do mês). O ramo frio deste sistema teve uma componente oceânica, afetando principalmente o litoral sul entre os dias 25 e 26, respectivamente. Durante o processo de formação desta onda frontal, houve ocorrência de tempo severo sobre o leste do RS, onde foram registradas fortes rajadas de vento, descargas elétricas e queda de granizo (vide tabela de casos significativos).

A passagem do oitavo sistema polar pelo Sudeste no dia 26 causou um aumento de nebulosidade, mas logo em seguida a MPA predominou o controle das condições do tempo. Características estas que favoreceram a realização do trabalho, mesmo tendo as manhãs com nuvens baixas, decorrentes do maior resfriamento noturno, ocasionado pelas noites frias e longas do inverno.

Durante os dias 27 e 28 de agosto de 2008 (Figura 66) o comportamento térmico, sob condição do sistema atmosférico MPA, o gradiente térmico horizontal máximo foi de $4,4^{\circ} \mathrm{C}$ entre o primeiro e segundo horário entre os ponto 9 e 11 . Esta diferença perdurou até a quinta medida, quando o campo e a cidade apresentavam temperaturas muito semelhantes. As medidas subseqüentes que aparecem na figura a seguir apresentam valores dos pontos 7 e 10 que foram extrapolados pelo programa Surfer. Quanto às localidades com as menores temperaturas, estas assim como no outono também se verificou que são as mesmas: entre os pontos 1 e 5 e o ponto 16 e 17. Ambas localidades são caracterizadas como sendo de ambiente rural ou com particularidade mista.

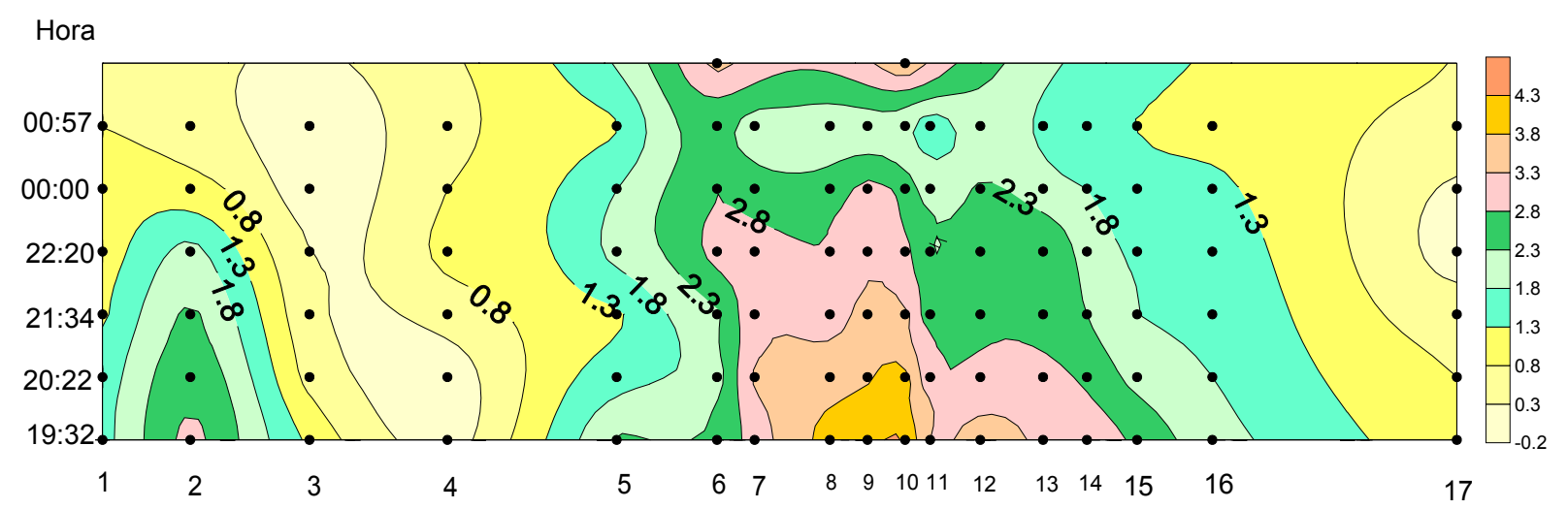

Figura 66. Evolução da ilha de calor noturna em Viçosa entre os dias 27 e 28 de agosto de 2008.

Organizado por Edson Soares Fialho (2009). 


\subsubsection{Verão de 2008}

A primeira frente fria do mês trouxe queda nas temperaturas na região Sul. Ela se deslocou até Florianópolis entre os dias 2 e 3 de fevereiro. Este sistema deslocou-se de Florianópolis-SC chegando à Vitória-ES durante o dia 5 , mas como subtropical, pois o suporte em altitude está relacionado ao Jato Subtropical. A partir do dia 4, a Zona de Convergência do Atlântico Sul (ZCAS) ganhou força e novamente provocou chuvas fortes em Minas Geras e o Rio de Janeiro. Durante o dia 5, o ar frio que ingressou sobre o RS e SC provocou temperaturas mínimas baixas extremas que oscilaram entre 4 e 6 graus. A ZCAS ficou ativa até o dia 9.

Neste dia 4 de março de 2009 (Figura 67), ocorreu um show de rock da Banda O RAPPA, no trevo de saída para o Rio de Janeiro no espaço FAMA. Assim como em todas as festas de grandes proporções na cidade, o ponto de concentração dos estudantes é na Praça Mário del Giudice. Apesar desta não registrar o funcionamento de vários bares e restaurantes, pois todos fecham cedo, exceto o bar Moreira's. A localidade apresenta uma grande concentração de repúblicas que de certa forma gerenciam a concentração de estudantes e determinam o horário de saída em procissão ao local da realização do show.

Comparando os resultados observados com a estação de inverno, constatase que a intensidade máxima verificada foi de $3,1^{\circ} \mathrm{C}$ no ponto 7 , uma rua de esquina com a Av. Santa Rita, no segundo horário de coleta dos dados. Entre a quarta e quinta medida as diferenças térmicas diminuíram em cerca de $1,5^{\circ} \mathrm{C}$, o que quase levou redução da diferença cidade e o campo, porém esta discrepância voltou a aumentar, na penúltima medida realizada, ficando na casa de $2,5^{\circ} \mathrm{C}$.

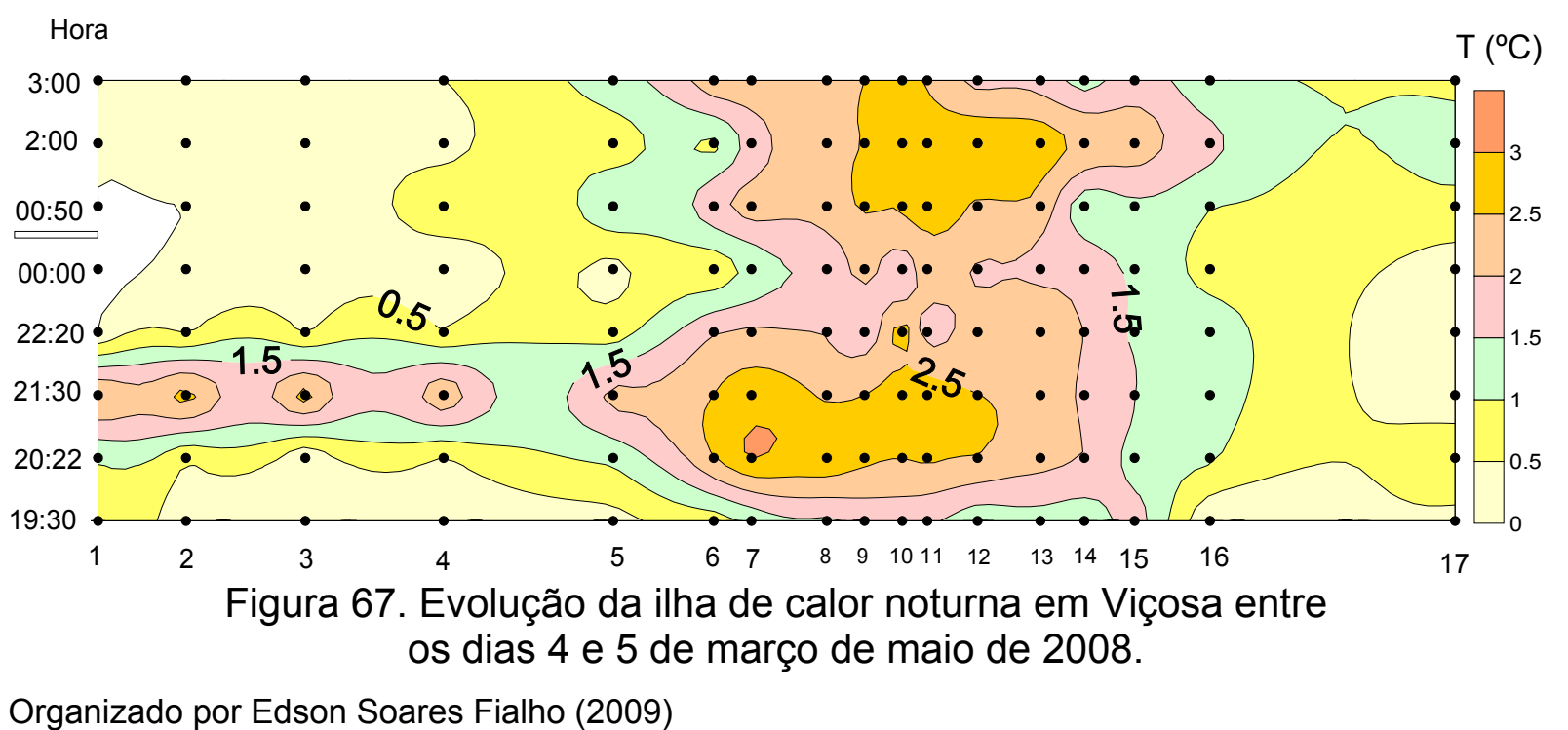




\subsection{Transetos dia-noite entre o campo e a cidade.}

Oke (1973) demonstrou que existe uma relação reconhecível entre tamanho de uma cidade e a intensidade da ilha de calor urbana. Os dados da pesquisa que obteve sob condições de tempo ideais, regidas por sistemas de circulação anticiclonal, favoreceu o registro por meio de transeto móvel, cujo trajeto abarcava 10 cidades, com população variando de 1000 a 2 milhões de habitantes.

Com este experimento, o autor descobriu que o excesso de temperatura urbana é o inverso da velocidade do vento regional e o logaritmo do total do contingente populacional. A intensidade da ilha de calor parecia ser aproximadamente proporcional à quarta raiz da população.

A partir desta proposta de identificação da intensidade máxima da ilha de calor, inúmeros pesquisadores replicaram esta possibilidade metodológica em inúmeras cidades, utilizando transetos móveis (Tabela 22) ou apenas com as estações meteorológicas (Tabela 23).

Tabela 22. Comparação dos resultados obtidos, a partir da diferença de temperatura do ar entre o campo e a cidade com outros estudos, que utilizaram transetos móveis.

\begin{tabular}{|l|c|c|c|l|c|}
\hline \multicolumn{1}{|c|}{ Autores } & $\begin{array}{c}\Delta \mathbf{T}_{\text {u-r }} \\
(\text { média) }\end{array}$ & & & & $\begin{array}{c}\text { População. } \\
\text { (x10 }\end{array}$ \\
\hline Alcoforado (1988) & $4,0-5,0^{\circ} \mathrm{C}$ & - & $7,8^{\circ} \mathrm{C}$ & Lisboa (Portugal) & 830 \\
\hline Ganho (1992) & - & $5,0^{\circ} \mathrm{C}$ & $6,0^{\circ} \mathrm{C}$ & Coimbra (Portugal) & 98 \\
\hline Bello Fuentes (1994) & $2,5^{\circ} \mathrm{C}$ & $4,5^{\circ} \mathrm{C}$ & $5,6^{\circ} \mathrm{C}$ & Guadalajara (Espanha) & 66 \\
\hline Tavares et. al (1995) & - & $5,0^{\circ} \mathrm{C}$ & $6,5^{\circ} \mathrm{C}$ & Americana (Brasil) & 200 \\
\hline Tavares et. al (1995) & - & $3,0^{\circ} \mathrm{C}$ & $5,3^{\circ} \mathrm{C}$ & Jales (Brasil) & 48 \\
\hline Zamparoni (1995) & - & $3,6^{\circ} \mathrm{C}$ & $5,1^{\circ} \mathrm{C}$ & Tangará da Serra (Brasil) & 36 \\
\hline Zamparoni (1995) & - & $5,4^{\circ} \mathrm{C}$ & $4,5^{\circ} \mathrm{C}$ & Barra do Bugre (Brasil) & 18 \\
\hline Ripley et. al. (1996) & $4,6^{\circ} \mathrm{C}$ & $8,0^{\circ} \mathrm{C}$ & $6,6^{\circ} \mathrm{C}$ & Saskatoon (Canadá) & 200 \\
\hline Monteiro (1997) & $2,5-3,0^{\circ} \mathrm{C}$ & $7,9^{\circ} \mathrm{C}$ & $6,9^{\circ} \mathrm{C}$ & Porto (Portugal) & 300 \\
\hline Izquierdo et. al. (1998) & $1,7^{\circ} \mathrm{C}$ & $2,8^{\circ} \mathrm{C}$ & $6,2^{\circ} \mathrm{C}{ }^{\circ}$ & Logroño (Espanha) & 126 \\
\hline Szegedi e Kircsi (2003) & $2,3^{\circ} \mathrm{C}$ & $5,8^{\circ} \mathrm{C}$ & $6,6^{\circ} \mathrm{C}$ & Debrecen (Hungria) & 220 \\
\hline Amorim (2005) & - & $6,2^{\circ} \mathrm{C}$ & $5,9^{\circ} \mathrm{C}$ & Birigui (Brasil) & 94 \\
\hline Vianna (2006) & - & $5,4^{\circ} \mathrm{C}$ & $6,6^{\circ} \mathrm{C}$ & Teodoro Sampaio (Brasil) & 20 \\
\hline Ruiz Flaño et. al. (2008) & $3,4^{\circ} \mathrm{C}$ & $5,3^{\circ} \mathrm{C}$ & $7,1^{\circ} \mathrm{C}$ & Lãs Palmas (Espanha) & 377 \\
\hline O presente estudo & $?$ & $?$ & $5,6^{\circ} \mathrm{C}$ & Viçosa (Brasil) & 70 \\
\hline
\end{tabular}

$\Delta \mathrm{T}_{\mathrm{u}-\mathrm{r}}\left({ }^{\circ} \mathrm{C}\right)=\mathrm{A}$ intensidade da ilha de calor dos trabalhos apresentados nesta tabela, é obtida pela diferença entre os pontos de coleta localizados na zona rural e urbana.

$\Delta \mathbf{T}_{\mathrm{u}-\mathrm{r}(\text { Prevista) }=}$ Utilizou-se a equação para cidades européias $\Delta \mathrm{T}_{\mathrm{u}-\mathrm{r}}=2,01 \log \mathrm{P}-4,06\left(\mathrm{r}^{2}=0,74\right)$.

Organizado por Edson Soares Fialho (2009).

Ao compararmos os resultados esperados com os obtidos, se identifica uma superestimativa dos resultados esperados, muito provavelmente pelo fato das condições consideradas ideais, nunca se reproduzem de maneira idêntica no mundo real, tendo interferências de mecanismos locais. Por exemplo, um local com 
topografia acidentada, que seja capaz de modificar o cenário de estabilidade em razão da mudança da posição do sol, modificando o fornecimento de energia para as vertentes de uma bacia hidrográfica.

Apesar das críticas que este método sofre, o mesmo ainda serve, pelo menos, como parâmetro de comparação ou expectativa do que pode encontrar.

Tabela 23. Comparação entre as diferenças temperatura do ar entre o campo e a cidade, que utilizaram pontos fixos.

\begin{tabular}{|c|c|c|c|}
\hline Autores & $\Delta \boldsymbol{T}_{\mathrm{u} \text {-r(média) }}$ & Área de estudo & (x10 ${ }^{3}$ hab.) \\
\hline Tarifa (1977) & $3,2^{\circ} \mathrm{C}$ & São José dos campos (Brasil) & 150 \\
\hline Danni (1980) & $4,0^{\circ} \mathrm{C}$ & Porto Alegre (Brasil). & 1200 \\
\hline Moreno-Garcia (1994) & $2,9^{\circ} \mathrm{C}$ & Barcelona (Espanha) & 1750 \\
\hline Maitelli (1994) & $2,7^{\circ} \mathrm{C}$ & Cuiabá (Brasil) & 500 \\
\hline Aguiar (1995) & $3,6^{\circ} \mathrm{C}$ & Manaus (Brasil) & 1600 \\
\hline Brandão (1996) & $4,2^{\circ} \mathrm{C}$ & Rio de Janeiro (Brasil) & 5000 \\
\hline Martins (1996) & $12,8^{\circ} \mathrm{C}$ & Juiz de Fora (Brasil) & 400 \\
\hline Unger (1997) & $1,5-2,0^{\circ} \mathrm{C}$ & Szged (Hungria) & 180 \\
\hline Figuerola e Mazzeo (1998) & $4,3^{\circ} \mathrm{C}$ & Buenos Aires (Argentina) & 712 \\
\hline Magee et. al (1999) & $0,4^{\circ} \mathrm{C}$ & Fairbanks (Alaska, EUA) & 30 \\
\hline Amorim (2000) & $6,0^{\circ} \mathrm{C}$ & Presidente Prudente-SP & 200 \\
\hline Silva et. al. (2002) & $8,0^{\circ} \mathrm{C}$ & Penápolis (Brasil) & 59 \\
\hline Hinkel et. al. (2003) & $2,2^{\circ} \mathrm{C}$ & Barrow (Alaska, EUA) & 4,6 \\
\hline Robaa (2003) & $3,0^{\circ} \mathrm{C}$ & Grande Cairo (Egito) & 15000 \\
\hline Minaki e Amorim (2005) & $5,8^{\circ} \mathrm{C}$ & Guararapes (Brasil) & 30 \\
\hline Lokoshchenko e Isave (2006) & $1,5^{\circ} \mathrm{C}$ & Moscow (Rússia) & 8.500 \\
\hline Yow e Carbone (2006) & $3,0^{\circ} \mathrm{C}$ & Orlando (EUA) & 213 \\
\hline Fortuniak et. al. (2006) & $2,0-4,0$ & Lodz (Polônia) & 780 \\
\hline Erell e Williamson (2007) & $4,8^{\circ} \mathrm{C}$ & Adelaide (Austrália) & 1124 \\
\hline Bulut et. al. (2008) & $1,7^{\circ} \mathrm{C}$ & Erzurum (Turquia) & 366 \\
\hline
\end{tabular}

$\Delta \mathrm{T}_{\mathrm{u}-\mathrm{r}}\left({ }^{\circ} \mathrm{C}\right)=\mathrm{A}$ intensidade da ilha de calor dos trabalhos apresentados nesta tabela, é calculada com base em estações meteorológicas (urbanas e rurais) de longas séries.

Organizado por Edson Soares Fialho (2009)

Em Viçosa, as medidas móveis foram realizadas em 3 estações: inverno (21 e 28 de agosto de 2008), verão (27 de fevereiro e 1, 2 e 3 de março de 2009) e outono (11 de maio de 2005), sob predomínio de sistemas anticiclonais (Tabela 24), porém como a área de estudo se localiza em uma região serrana, de clima tropical de altitude, as condições de tempo com forte estabilidade do tempo estimulam a formação de nevoeiros e nuvens baixas, por conta da drenagem do ar junto as vertentes até o fundo do vale.

Observando as amplitudes máximas ao longo do transeto para o universo de amostras, constata-se que a maior intensidade ocorre nos dois primeiros experimentos realizados no inverno, com $4,7^{\circ} \mathrm{C}(21 / 8 / 2008)$ nos pontos 8 e 9 e $4,4^{\circ} \mathrm{C}$ (27/8/2008), no ponto 9 , ambos à noite. A localidade dos pontos 8 e 9 se localizam em área verticalizada e elevada densidade de construção (zona residência - ZR1). A 
única medida que destoa se encontra às $7: 00$ horas no dia $21 / 8 / 22008 \operatorname{com} 4,4^{\circ} \mathrm{C}$, nos pontos 15, 16 e 17. Como se percebe ao nos depararmos com a Tabela 21, o contraste térmico máximo esperado era de $5,6^{\circ} \mathrm{C}$, e não $4,7^{\circ} \mathrm{C}$. Outra curiosidade ao nos atentarmos à tabela é a existência de cidades com um menor contingente populacional que Viçosa, que apresentam um contraste térmico maior, como Teodoro Sampaio e Penápolis. Em contrapartida, cidades maiores apresentam uma diferença menor, como: São José dos Campos, Porto Alegre, Barcelona e Manaus.

De maneira geral as diferenças térmicas são menores de manhã e vão aumentando até a noite. Dependendo das condições do tempo, nem sempre registra a maior diferença no último horário, como nos dias 2 de março e 11 de maio, que apresentaram uma tarde com menos nebulosidade do que à noite.

Durante o período de medidas no verão, a região Sudeste ficou sob a condição de um veranico, que predominou entre o final da primeira quinzena de fevereiro até o dia 10 de março, quando voltou atuar a Zona de Convergência do Atlântico Sul (ZCAS).

Tabela 24. Intensidades das amplitudes térmicas máximas observadas ao longo do transeto Paula Cândido-Porto Firme.

\begin{tabular}{|c|c|c|c|c|}
\hline \multirow{2}{*}{ Dia } & \multirow{2}{*}{$\begin{array}{c}\text { Sistema } \\
\text { Atmosférico }\end{array}$} & $\mathbf{7 : 0 0}$ horas & $\mathbf{1 3 : 0 0}$ horas & $\mathbf{2 0 : 0 0}$ horas \\
\cline { 3 - 5 } & & 4,4 & 3,9 & 4,7 \\
$21 / 8 / 2008$ & MTA & 3,0 & 4,0 & 4,4 \\
$27 / 8 / 2008$ & MPA & 2,6 & 2,7 & 4,0 \\
$27 / 2 / 2009$ & MTA & 2,8 & 2,8 & 3,4 \\
$01 / 3 / 2009$ & MTA & 1,7 & 3,7 & 3,6 \\
$02 / 3 / 2009$ & MTA & 1,5 & 3,3 & 4,0 \\
$03 / 3 / 2009$ & MTA & 2,3 & 3,4 & 3,0 \\
$11 / 5 / 2009$ & MPA & $\mathbf{2 , 6}$ & $\mathbf{3 , 4}$ & $\mathbf{3 , 8}$ \\
Média & & &
\end{tabular}

Organizado por Edson Soares Fialho (2009).

Em relação à espacialidade das temperaturas a Figura 68, que vem acompanhada pelo perfil topográfico percorrido, constata-se que as maiores temperaturas, ou melhor, intensidades se encontram entre os pontos 6 e 16, que abarcam a área urbana central e a periferia imediata da cidade.

Em contrapartida do ponto 1 ao 5, as menores intensidades são observadas, seguidas de perto pelo ponto 16 (situado no bairro da Barrinha, local limite entre a área urbana e rural) 17 (área rural localizada ao lado da casa de espetáculos Celeiro do Forró). 
Em todas as estações do ano, a área central sempre se apresenta mais quente que o entorno, porém em alguns dias a dimensão da área aquecida era menor, como ocorreu nos dias 1 de março, 27 de agosto e 11 de maio. Nestes dias, o núcleo mais aquecido, oscilou entre os pontos 8 e 16; 7 a 15 e 7 a 14, respectivamente, com diferenças máximas de $3,0^{\circ} \mathrm{C}, 3,5^{\circ} \mathrm{C}$ e $3,0^{\circ} \mathrm{C}$.

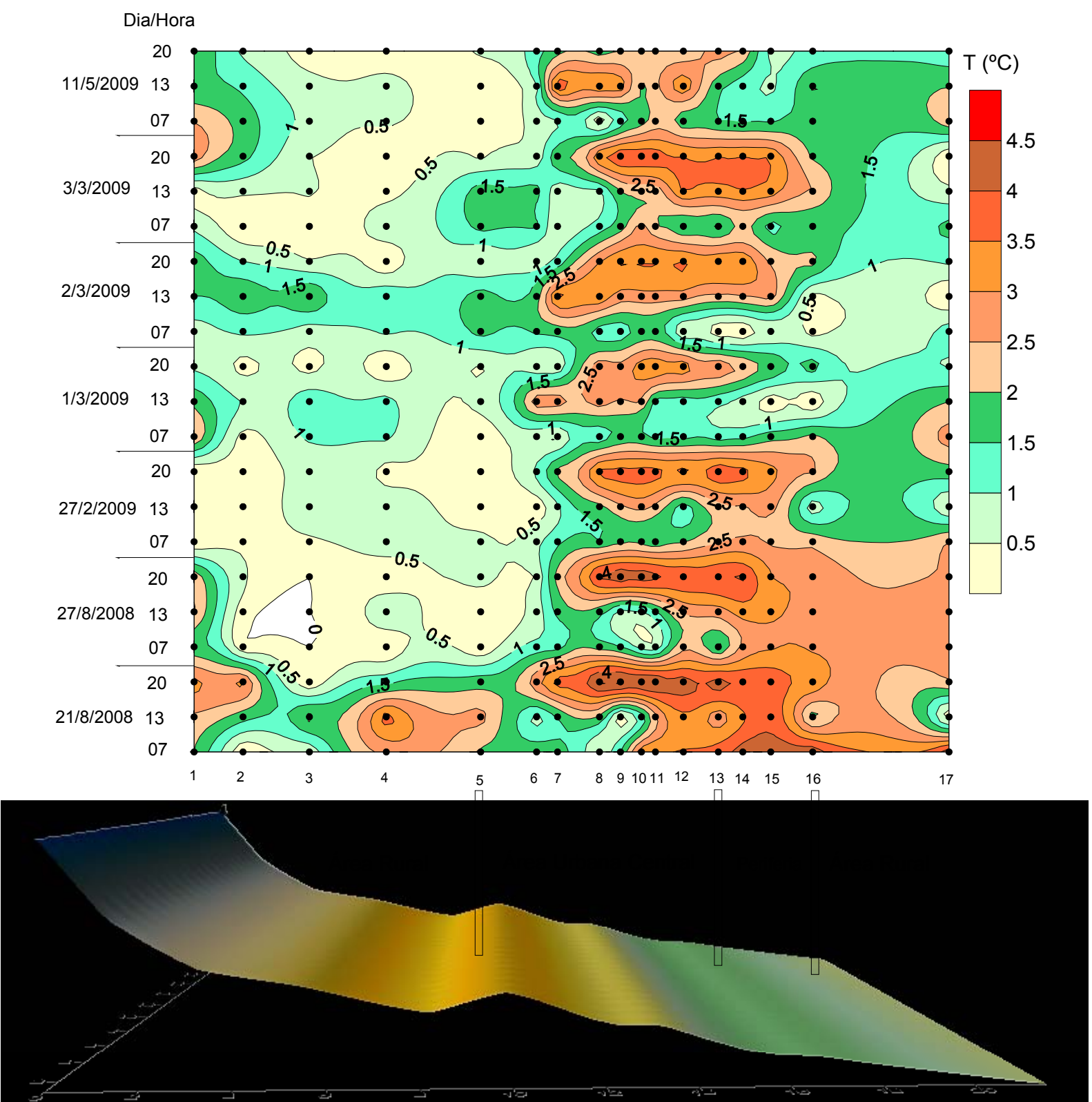

Perfil Topografico

Figura 68. Variabilidade da temperatura do ar no transeto campo-cidade sentido Paula Cândido-Porto Firme (S-N) durante as estações de inverno, verão e outono

Organizado por Edson Soares Fialho (2009).

Em relação à umidade relativa entre o campo e a cidade (Figura 69), em linhas gerais demonstra um ritmo semelhante de variação temporal, assim como a 
temperatura, exceto para os episódios de inverno. Nestes experimentos observa-se que a umidade relativa diminui de maneira contínua entre o ponto 1 e 17.

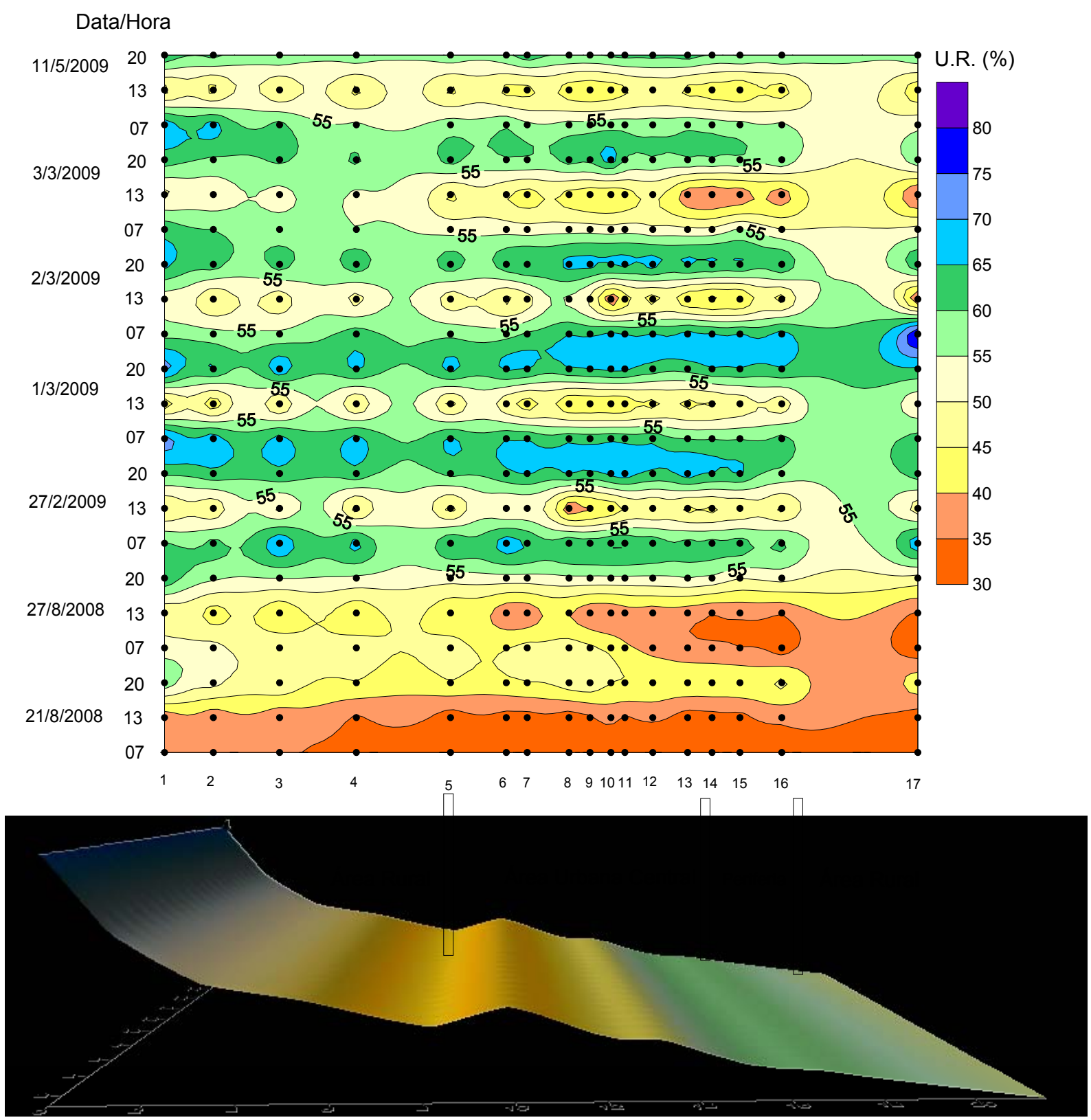

Perfil Topografico

Figura 69. Variabilidade da umidade relativa no transeto campo-cidade sentido Paula Cândido-Porto Firme (S-N), durante as estações de inverno, verão e outono Organizado por Edson Soares Fialho (2009).

Quanto aos resultados obtidos, estes não vão de encontro às informações contidas na literatura, que sugerem que a atmosfera urbana é mais seca do que o seu entorno, em alguns estudos, especialmente à noite.

De acordo com os dados, a umidade relativa do ar, a cidade é sempre menor do que o campo durante o período da tarde. A diferença oscilou entre 5,0\%, no dia 1 de março de 2009 
a 15,0\% no dia 3 de março, como fora observado em Belgadro, Romênia por Unkašević et. al. (2001). Já para os demais horários (7:00 e 20:00 horas) não há uma diferença significativa entre o campo e a cidade, em grande parte das vezes não passa de 5,0\% sem ter uma tendência a apresentar um padrão constante.

\subsection{O campo térmico na área urbana do município de Viçosa}

Antes de iniciar a análise das diferenças de temperatura verificadas durante as observações de campo na mancha urbana. É importante destacar a Tabela 25, pois a mesma demonstra previamente, as diferenças encontradas antes e depois das correções térmicas. Outro ponto que deve ser mencionado é a opção de se representar em um mapa as diferenças térmicas, por meio de símbolos proporcionais (Figura 70), conforme Sakaida e Egoshi (2006) utilizaram para Sendai, Japão, associado aos tipos de usos da terra e o modelo digital de elevação transparente em 45,0\%, com intuito de melhor comunicar a relação que se busca apresentar no trabalho em questão.

Tabela 25. Amplitudes térmicas máximas

\begin{tabular}{|l|c|c|c|c|c|c|}
\hline \multirow{2}{*}{ Dia } & \multicolumn{7}{|c|}{ Horário } \\
\cline { 2 - 7 } & \multicolumn{2}{|c|}{$\mathbf{9 : 0 0}$ horas } & \multicolumn{2}{c|}{$\mathbf{1 5 : 0 0}$ horas } & \multicolumn{2}{c|}{$\mathbf{2 1 : 0 0}$ horas } \\
\cline { 2 - 7 } & $\mathrm{T}_{1}$ & $\mathrm{~T}_{2}$ & $\mathrm{~T}_{1}$ & $\mathrm{~T}_{2}$ & $\mathrm{~T}_{1}$ & $\mathrm{~T}_{2}$ \\
\hline $7 / 5 / 2008$ & $4,0^{\circ} \mathrm{C}$ & $3,9^{\circ} \mathrm{C}$ & $3,0^{\circ} \mathrm{C}$ & $2,7^{\circ} \mathrm{C}$ & $2,7^{\circ} \mathrm{C}$ & $2,9^{\circ} \mathrm{C}$ \\
\hline $8 / 5 / 2008$ & $4,4^{\circ} \mathrm{C}$ & $4,1^{\circ} \mathrm{C}$ & $3,0^{\circ} \mathrm{C}$ & $3,3^{\circ} \mathrm{C}$ & $2,3^{\circ} \mathrm{C}$ & $2,5^{\circ} \mathrm{C}$ \\
\hline $9 / 5 / 2008$ & $1,6^{\circ} \mathrm{C}$ & $1,4^{\circ} \mathrm{C}$ & $2,0^{\circ} \mathrm{C}$ & $2,2^{\circ} \mathrm{C}$ & $3,4^{\circ} \mathrm{C}$ & $3,4^{\circ} \mathrm{C}$ \\
\hline $10 / 5 / 2008$ & $4,8^{\circ} \mathrm{C}$ & $3,8^{\circ} \mathrm{C}$ & $4,5^{\circ} \mathrm{C}$ & $4,9^{\circ} \mathrm{C}$ & $2,0^{\circ} \mathrm{C}$ & $2,2^{\circ} \mathrm{C}$ \\
\hline $13 / 5 / 2008$ & $1,7^{\circ} \mathrm{C}$ & $2,3^{\circ} \mathrm{C}$ & $4,0^{\circ} \mathrm{C}$ & $4,0^{\circ} \mathrm{C}$ & $2,2^{\circ} \mathrm{C}$ & $2,5^{\circ} \mathrm{C}$ \\
\hline $17 / 3 / 2009$ & $1,6^{\circ} \mathrm{C}$ & $1,3^{\circ} \mathrm{C}$ & $2,5^{\circ} \mathrm{C}$ & $2,5^{\circ} \mathrm{C}$ & $1,7^{\circ} \mathrm{C}$ & $0,7^{\circ} \mathrm{C}$ \\
\hline $19 / 3 / 2009$ & $2,6^{\circ} \mathrm{C}$ & $3,0^{\circ} \mathrm{C}$ & $4,3^{\circ} \mathrm{C}$ & $3,7^{\circ} \mathrm{C}$ & $2,3^{\circ} \mathrm{C}$ & $2,6^{\circ} \mathrm{C}$ \\
\hline $1 / 5 / 2009$ & $3,2^{\circ} \mathrm{C}$ & $3,0^{\circ} \mathrm{C}$ & $1,1^{\circ} \mathrm{C}$ & $2,0^{\circ} \mathrm{C}$ & $1,3^{\circ} \mathrm{C}$ & $1,3^{\circ} \mathrm{C}$ \\
\hline $3 / 5 / 2009$ & $3,0^{\circ} \mathrm{C}$ & $2,7^{\circ} \mathrm{C}$ & $2,2^{\circ} \mathrm{C}$ & $3,5^{\circ} \mathrm{C}$ & $2,2^{\circ} \mathrm{C}$ & $2,5^{\circ} \mathrm{C}$ \\
\hline
\end{tabular}

$\mathrm{T}_{1}$ - Diferença da temperatura registrada em campo sem correção dos dados.

$\mathrm{T}_{2 \text { - }}$ Diferença da temperatura registrada em campo com correção dos dados.

Organizado por Edson Soares Fialho (2009).

Inicialmente, o planejamento para elaboração do mapeamento se baseou na proposta desenvolvida por Galvani et. al. (2008), em que se estabelecia a relação entre temperatura do ar e altitude ${ }^{17}$ (Figura 71), através de um modelo de regressão linear simples.

${ }^{17}$ A imagem contendo as cotas altimétrica foi obtida em um modelo digital de elevação (MDE), desenvolvido no Laboratório de Geoprocessamento do DPS, com base no programa ARCGIS 9.0. 


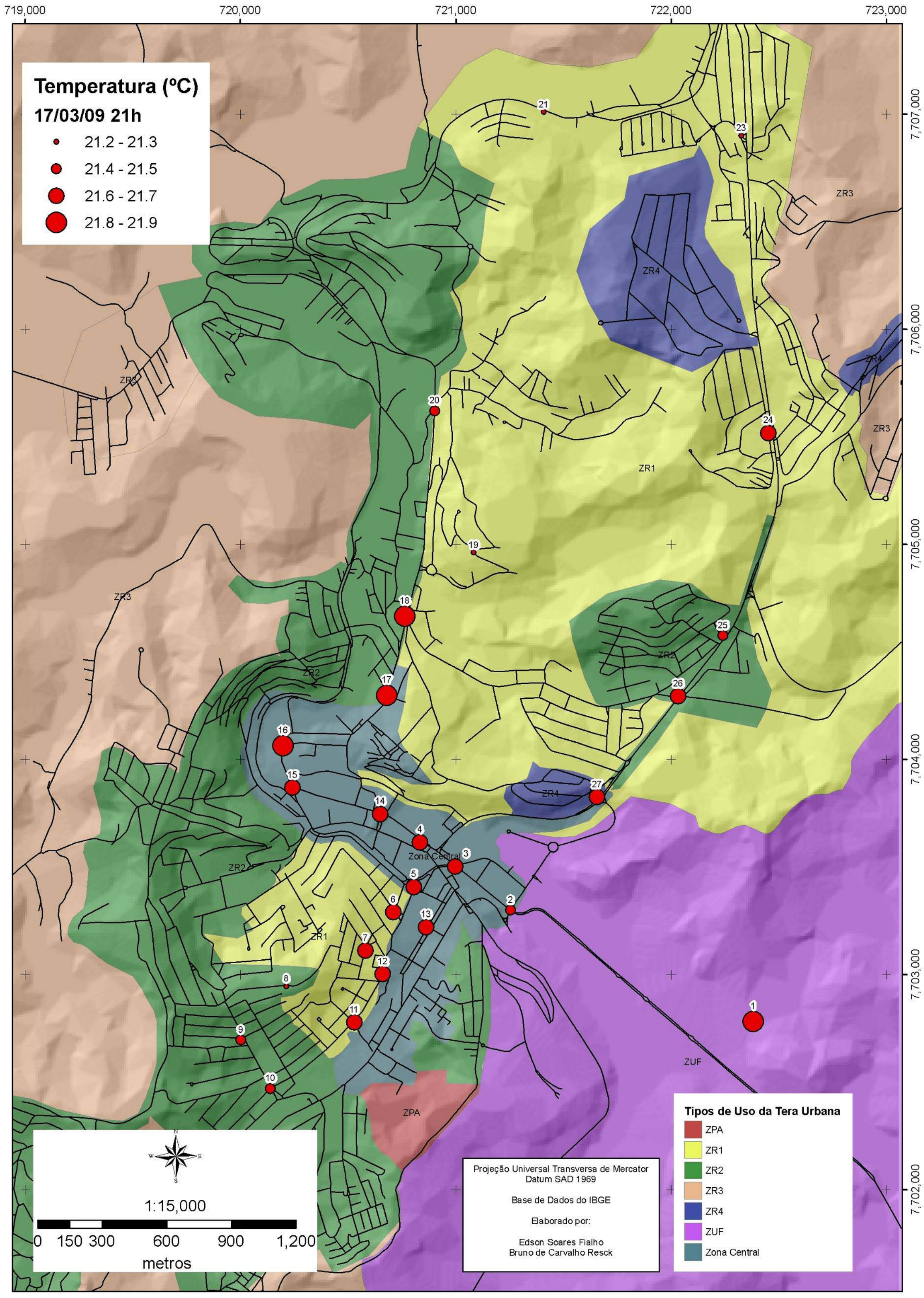

Figura 70 . Mapeamento da temperatura do ar no dia 17/3/2009, às 21:00 horas. 


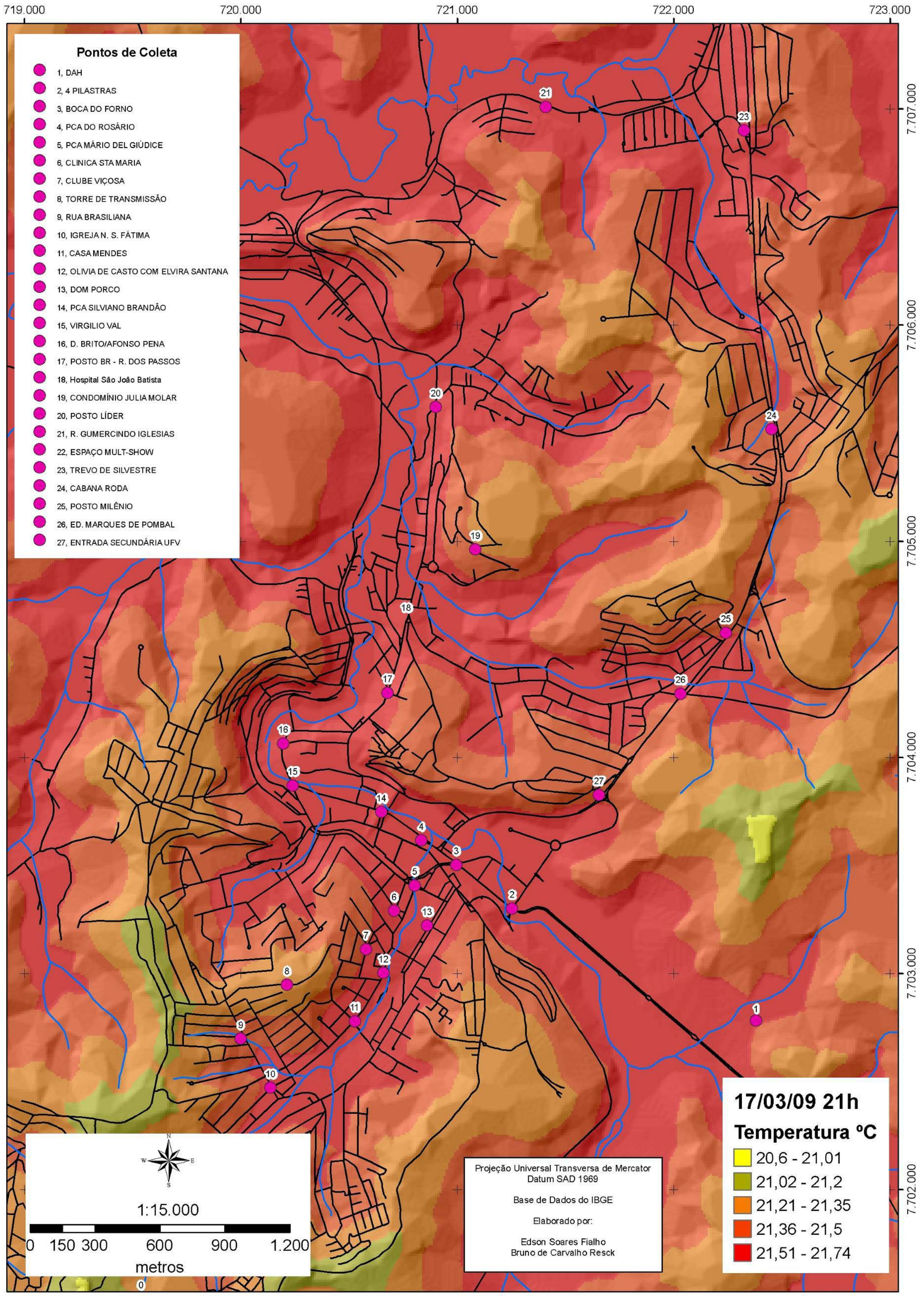

Figura 71. Mapeamento da temperatura do ar no dia 17/3/2009, às 21:00 horas. 
Entretanto, a correlação entre temperatura do ar e altitude não foi significativa, sendo impossível ter um mapeamento por estimativa, utilizando o modelo de regressão linear simples. As equações desenvolvidas (Tabela 26) para cada horário de medida apresentaram um baixo coeficiente de determinação $\left(R^{2}\right)$, que alcançou o seu melhor resultado, no dia 17/3/2009 com 0,22.

Tabela 26. Equação de regressão linear para às 9:00 horas.

\begin{tabular}{|c|c|l|}
\hline Dia & $\mathbf{R}^{2}$ & \multicolumn{1}{|c|}{ Equação. } \\
\hline $10 / 5 / 2008$ & 0,002 & $\mathbf{Y}=\mathbf{0 , 0 0 0 5 + 2 1 , 8 9 2}$ \\
\hline $13 / 5 / 2008$ & 0,0014 & $\mathbf{Y}=\mathbf{- 0 , 0 0 1 7 x + 2 2 , 6 0 3}$ \\
\hline $17 / 3 / 2009$ & 0,0477 & $\mathbf{Y = 0 , 0 0 3 6 x + 2 2 , 1 6 2}$ \\
\hline $19 / 3 / 2009$ & 0,0593 & $\mathbf{Y}=\mathbf{- 0 , 0 0 6 x + 2 9 , 7 7 1}$ \\
\hline $01 / 5 / 2009$ & 0,024 & $\mathbf{Y}=\mathbf{0 , 0 0 4 8 x}+\mathbf{1 9 , 2 7 5}$ \\
\hline $03 / 5 / 2009$ & 0,0015 & $\mathbf{Y = - 0 , 0 0 0 9 x + 2 1 , 3 4 1}$ \\
\hline
\end{tabular}

Organizado por Edson Soares Fialho (2009).

\subsection{1. $O$ campo térmico às $9: 00$ horas}

Pela manhã, a diferença de temperatura dentro da área urbana (Anexo 1) alcançou seu máximo, no dia 8 maio (quinta-feira): $4,1^{\circ} \mathrm{C}$. A diferença se estabeleceu entre os pontos $21\left(23,3^{\circ} \mathrm{C}\right)$ e $3\left(19,2^{\circ} \mathrm{C}\right)$.

No dia 17/3/2009, por sua vez, apresentou as menores diferenças térmicas, com $1,3^{\circ} \mathrm{C}$ de intensidade, estabelecido entre os pontos 2 e 19 , local influenciado pelo sombreamento dos prédios no início da manhã, e a densidade de edificações, repercutiu em um ritmo de aquecimento mais lento.

Cabe salientar que, neste dia, a situação sinóptica era de uma alta pósfrontal, localizado sobre o oceano atlântico, reforçando a alta subtropical do atlântico. Este sistema favoreceu a advecção de ar úmido para o interior do continente, o que aumentou a nebulosidade ao longo do dia. O experimento realizado no dia 7/5/2008 foi marcado também, por uma forte variabilidade entre os pontos 3 e 15 , a temperatura oscilou de $20,0^{\circ} \mathrm{C}$ a $22,8^{\circ} \mathrm{C}$.

O ponto 3, quase supere acusou as menores temperaturas do ar. Cercado de prédios altos e rua estreita, apesar do forte trânsito de veículos ao longo do dia. O sombreamento associado à massa de materiais de construção dos edifícios, favorece o surgimento de um ambiente propício de menor aquecimento. Enquanto os pontos 15,24 e 25 se alternaram com os picos de maior temperatura. Todos estes situados no centro imediato (Rua Virgílio Vall - ponto 15) e a porção nortenordeste. 


\subsubsection{0 campo térmico às $15: 00$ horas}

No segundo horário de registros (Anexo 2) a configuração do contraste térmico se alterou, em comparação ao primeiro horário, por conta da influência da topografia, obstáculo natural a chegada da radiação solar à superfície.

No dia $7 / 5 / 08$ a intensidade da ilha de calor foi de $3,4^{\circ} \mathrm{C}$ no ponto 17 , local de maior registro de temperatura $\left(23,5^{\circ} \mathrm{C}\right)$, em comparação aos menores registros verificados nos pontos 25 e 27, localizado na BR-120, com grande fluxo de veículos, porém sombreada pelo morro do café.

Em relação ao segundo horário de medida, que coincide com a leitura das temperaturas máximas do dia. Os mapeamentos elaborados identificam que a maior incidência de temperatura mais atas neste horário, destaca-se por ser o momento de maior emissão da radiação terrestre e, por conseguinte, 0 de registro das temperaturas máximas.

Assim, como no primeiro horário, o dia de maior diferença foi o dia 10/5/08, porém com intensidade um pouco menor $\left(4,5^{\circ} \mathrm{C}\right)$. Os pontos 1,5 e 13 foram os locais com os maiores valores na ordem de $32,0^{\circ} \mathrm{C}$, por se localizar em área mais abertas (ponto 5 e 13), associado ao intenso tráfego de veículos e predomínio de edificações baixas (ponto 1).

Os menores registros de temperatura encontrados foram entre os pontos $24 \mathrm{e}$ 27 , com cerca de $27,0^{\circ} \mathrm{C}$, que demonstrou mais uma vez a influência do relevo, que afeta o jogo de luz e sombra nas vertentes no sombreamento sobre a temperatura mais especificamente para os dias: 7/5/2008, 9/5/200813/5/2008, 1/5/2009, 3/5/2009, que apresentaram baixa nebulosidade e ventos calmos abaixo de $2 \mathrm{~m} . \mathrm{s}^{-1}$ intensidades dos gradientes registrados foram em grande parte. As diferenças de temperatura, nos dias diferentemente, do primeiro horário.,

Ao observar o mapa do dia 13/5/2005 se desconsiderarmos as medidas das temperaturas corrigidas dos pontos $19\left(26,6^{\circ} \mathrm{C}\right)$ e $24\left(22,6^{\circ} \mathrm{C}\right)$, que se encontram em lados opostos das vertentes, recebem uma quantidade de energia solar diferente, tanto assim que os pontos voltados localizado s na BR-120 (23, 24, 25 e 26) já começam a apresentar sinais de sombreamento mais cedo, enquanto os pontos 21 , 12 e 19 ainda são agraciados pela luz do sol. Este cenário, por sua vez, somente vem corroborar que pelo menos $50,0 \%$ deste gradiente tem participação da orientação das vertentes. 


\subsubsection{O campo térmico às $21: 00$ horas}

No período noturno (Anexo 3), a intensidade da ilha de calor somente foi superior as duas anteriores no dia $9 / 5 / 08$, com $3,2^{\circ} \mathrm{C}$. Neste dia ocorreu um aumento da nebulosidade de manhã e foi diminuindo ao longo do dia, sendo que à noite o céu estava limpo. Nos demais dias a intensidade foi inferior.

Cabe destacar, que no dia 8 as diferenças foram muito semelhantes, sob condição de temperatura elevada, em decorrência da influência da entrada de um sistema frontal, muito embora tenha sua atuação tenha sido mais evidente no litoral, produziu como repercussão um aumento da temperatura do ar.

Espacialmente, o gradiente térmico demonstrou boa correlação com o uso da terra. Os locais de maior temperatura, se localizando em lugares com maior densidade de edificações, como os situados entre os pontos 6 e 18, localizados entre o bairro de Fátima e o Hospital São João Batista, registraram picos de intensidade máxima, oscilando entre os pontos 9 (rua Brasília), no bairro de Fátima e 14 no centro.

Entre os pontos 19 e 22, locais de menor temperatura do ar, ao longo de todos os transetos, exceto no dia 8/5/2008, se caracterizam por apresentar uma paisagem predominantemente de pastagens, pouca árvores, e com características de zona de expansão da mancha urbana.

Logo em seguida, as leituras do ponto 23 ao 27 foram realizadas ao longo da rodovia BR-120, porta de entrada da cidade, para quem vem de Ponte Nova e Belo Horizonte, se constatou um acréscimo na temperatura entre $1,0^{\circ} \mathrm{C}$ e $1,5^{\circ} \mathrm{C}$.

Verificando as localidades, a partir da ocorrência das temperaturas mínimas e máximas, pode-se concluir que os pontos 21 ao 24 oscilam entre os de menor temperatura, predominando o ponto 21 , localizado nas proximidades do bairro Silvestre, até o ano de 2006 as ruas entorno do ponto de medida não eram asfaltas, fato que ocorrera apenas no ano de 2006, causando forte especulação imobiliária e a construção de casas para famílias de baixa renda. Enquanto os de maior temperatura se encontram na periferia do centro, próximo ao bairro de Cléia Bernardes, Fátima e Lourdes. 


\subsection{O campo térmico na área central}

\subsubsection{O campo térmico às 5:00 horas}

O campo térmico às 5:00 horas da manhã do dia 4/5/2007 (Figura 72) apresentou um gradiente térmico de fraca magnitude com temperaturas oscilando entre $16,1^{\circ} \mathrm{C}$ (ponto 17 e 18 ) e $17,3^{\circ} \mathrm{C}$ (ponto 1). Nas proximidades dos pontos 5,18 e 19 registraram-se as menores temperaturas, e uma intensidade fraca com valor de $0,2^{\circ} \mathrm{C}$.

Nas localizadas da porção sudeste do centro, se encontra o ponto 1 e 16, com intensidade de $1,0^{\circ} \mathrm{C}$. Cabe lembrar que neste horário o fluxo de pessoas e veículo é muito pequeno. $\mathrm{E}$ ao longo da noite anterior ao ar frio da brisa de montanha foi drenado para a parte baixa do vale, onde se localiza a área de estudo em questão.

No dia 5/5/2007 (Figura 73) a configuração espacial é fortemente influenciada pelos pontos 2, 3, 15 e 16 com intensidade baixa registrando $0,6^{\circ} \mathrm{C}$. O núcleo mais aquecido se manteve na mesma área, no entanto, os de menor temperatura não são coincidentes, ficando agora nas áreas limites do centro.

No dia 6/5/2007 (Figura 74) um fato importante ocorreu na condição do tempo, uma vez que o sistema produtor de tempo, não mais era a Massa Polar Atlântica, mas uma Massa Polar Tropicalizada, com características de transição para a massa tropical atlântica, Em conseqüência disso, o campo térmico às 5:00 horas da manhã já apresentou uma configuração espacial distinta aos dias 4 e 5.

Os pontos de maior intensidade pela manhã se localizaram nos pontos $11,12,13$, $14,15,17$ e 18 , que variaram entre $0,8^{\circ} \mathrm{C}$ e $1,0^{\circ} \mathrm{C}$, formando uma mancha que se estendia para parte oeste e sudoeste da área central, enquanto nos dia 4/5/2007, o núcleo de calor se situava na porção sudeste e no dia 5 na porção centro-sudeste.

No dia 7/5/2009 (Figura 75) o ponto 3 apresentou a menor diferença térmica com intensidade de $0,2^{\circ} \mathrm{C}$, seguido por um núcleo secundário de $0,6^{\circ} \mathrm{C}$, que o circunda e toda a área central ao longo das vertentes leste e oeste. A configuração espacial neste dia se aproxima muito ao do dia 4, quando estava sob o predomínio de um anticiclone, só que de origem extra-tropical (MPA). O anticiclone predominante é o semifixo do oceano atlântico (massa tropical atlântica), que embora tenha características distintas, são sistemas produtores de estabilidade de tempo, o que permite que a circulação de brisas atue de maneira mais significativa.

Tanto assim, que no primeiro horário, tanto no dia 4 , quanto no dia 7 , as menores intensidades se localizaram no eixo central do vale o rio São Bartolomeu, o 
que demonstra que a circulação de brisa de montanha ao longo da madrugada, influencia a dinâmica espacial da temperatura do ar. Durante o horário das 5:00 horas, quando se espera que se alcance a menor temperatura do dia, pois estamos próximo do momento das menores emissões de radiações de onda longa (radiação terrestre), que se situa próximo ao nascer do sol.

Entre os dias 6 e 7 de setembro de 2008 (Figuras 74 e 75) a predominância de uma MPA favoreceu condições para um dia de poucas nuvens, o que auxiliou no superaquecimento durante o dia. Neste período o dia 6 (sábado) alcançou um pico de $1,4^{\circ} \mathrm{C}$ e no dia seguinte, $2,2^{\circ} \mathrm{C}$. Se observarmos a Figura 74 , identificaremos um corredor interligado da Av. Santa Rita até Praça Silviano Brandão, corredor de trânsito, que auxilia para os bairros da Barrinha, Laranjal e Silvestre, como para o Santo António, mais próximo ao trevo de acesso ao Rio de Janeiro. Além de ser uma área de forte densidade construída.
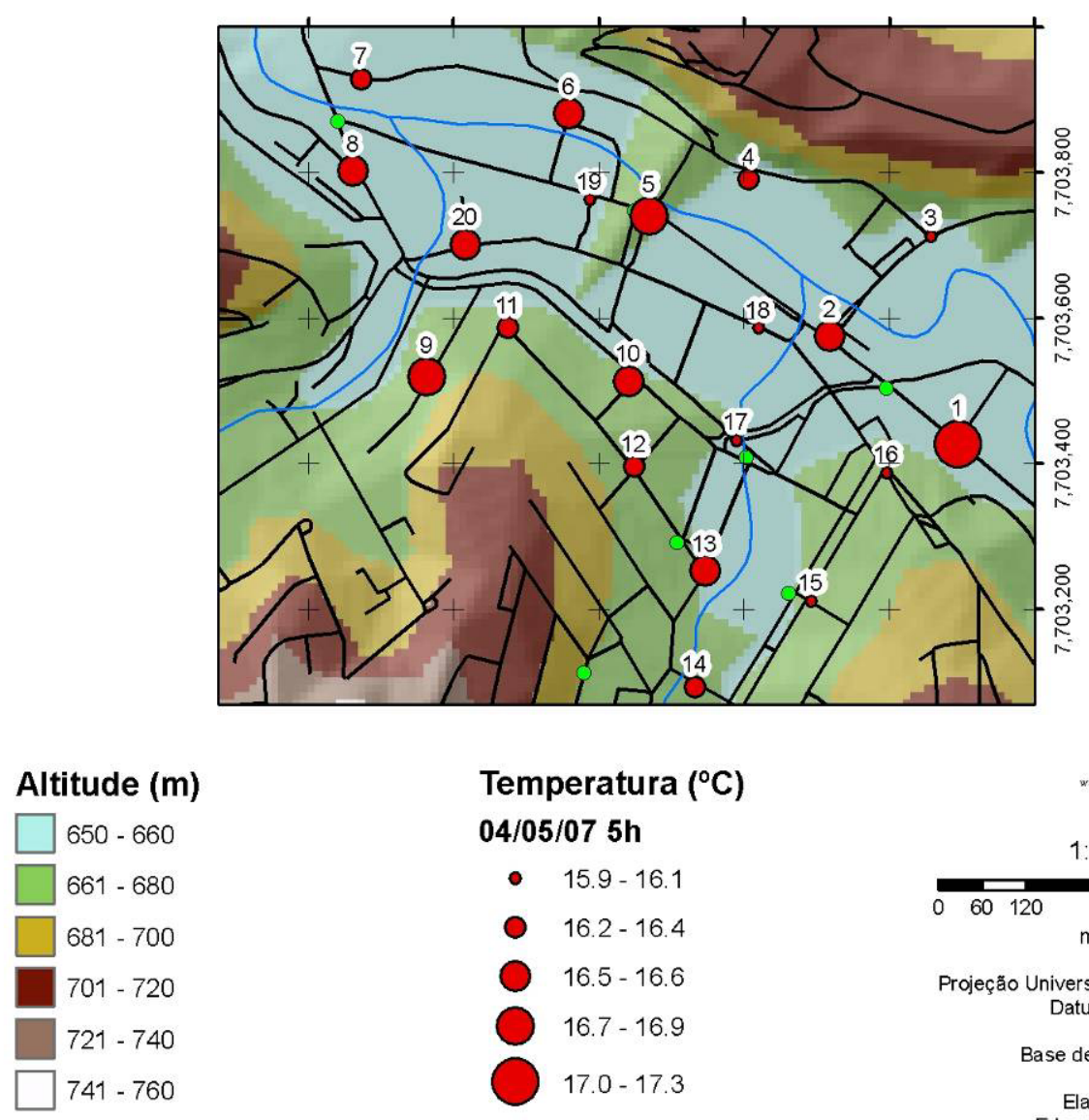
Temperatura $\left({ }^{\circ} \mathrm{C}\right)$
04/05/07 5h
- $15.9-16.1$
- $16.2-16.4$
$16.5-16.6$
$16.7-16.9$
$17.0-17.3$

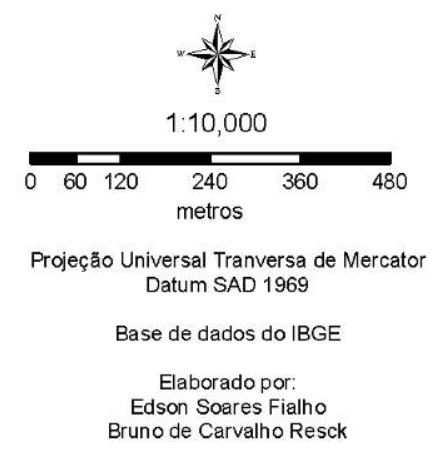

Figura 72. Distribuição da temperatura do ar às 5:00 horas, na área central de Viçosa em 4/5/2007. 

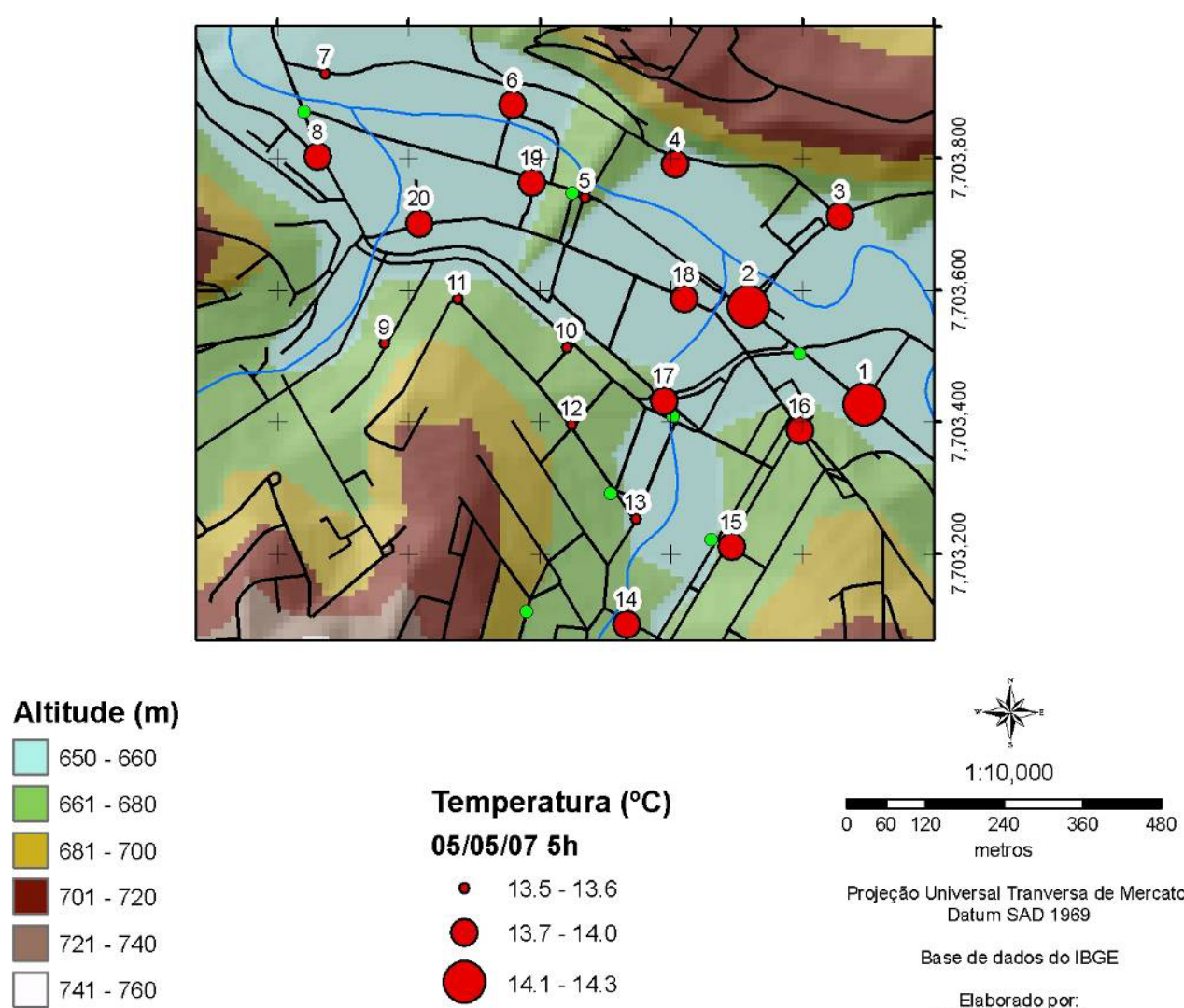

Projeção Universal Tranversa de Mercato Datum SAD 1969

Base de dados do IBGE

Elaborado por:

Edson Soares Fialho Edson Soares Fialho
Bruno de Carvalho Resck

Figura 73. Distribuição da temperatura do ar às 5:00 horas, na área central de Viçosa em 5/5/2007.
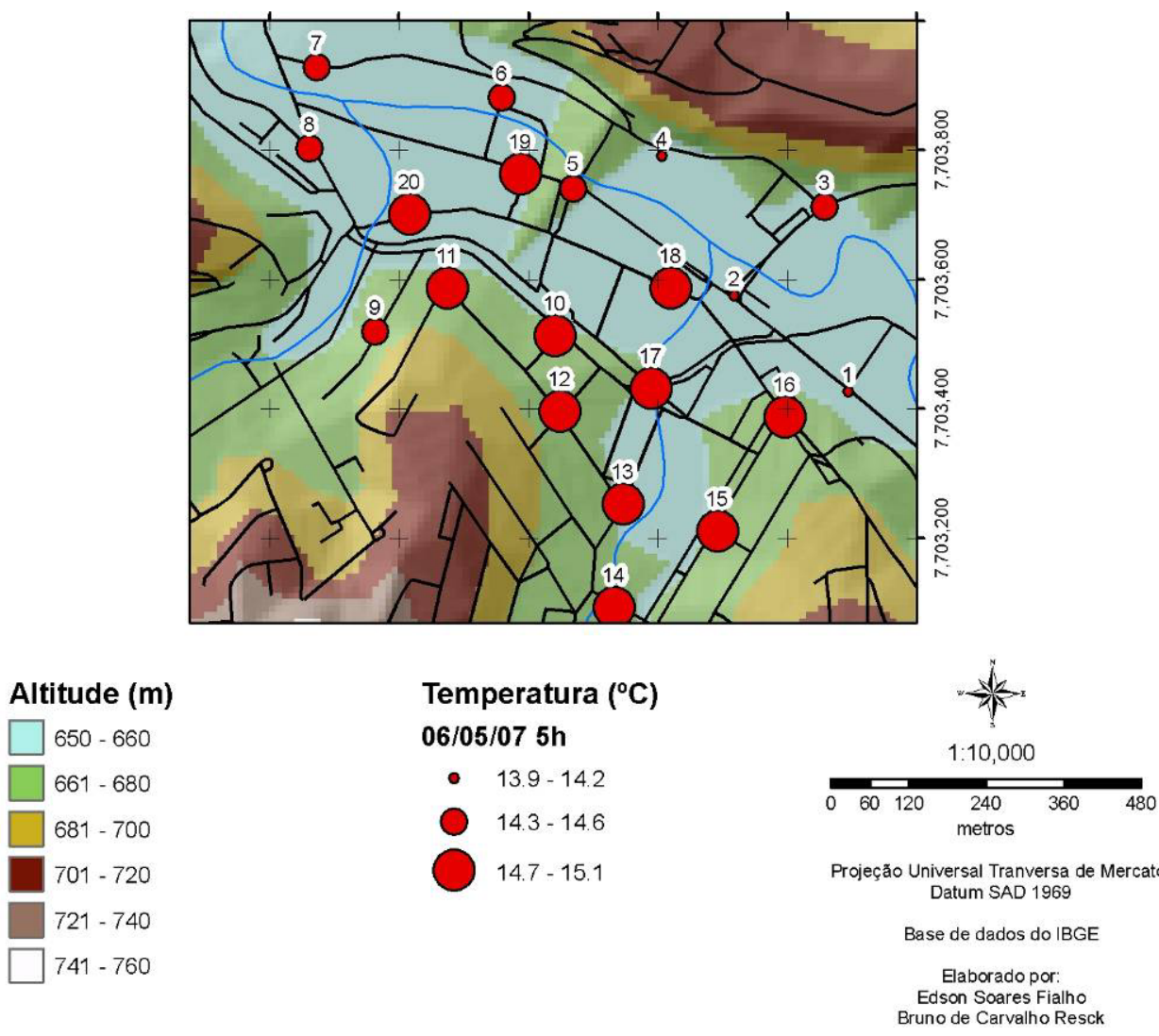

Figura 74. Distribuição da temperatura do ar às 5:00 horas, na área central de Viçosa em 6/5/2007. 

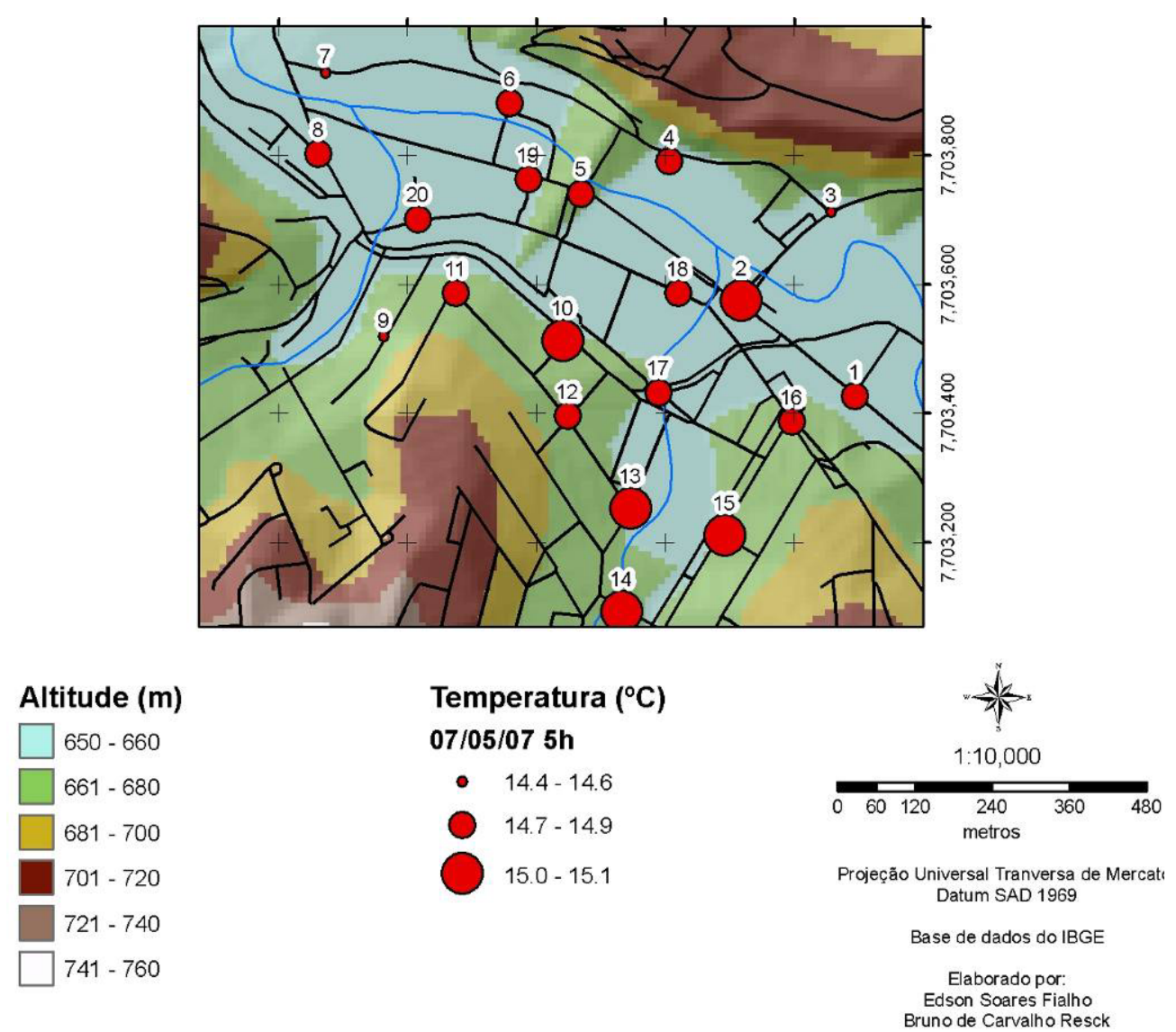

Figura 75. Distribuição da temperatura do ar às 5:00 horas, na área central de Viçosa em 7/5/2007.

A espacialidade das intensidades do dia 6/9/2008 (Figura 76) demonstra que a porção norte do mapa, situado ao longo da rua Dr. Milton Bandeira (pontos 3, $4 \mathrm{e}$ 6) rua Dr. Gertrudes (ponto 7) se localiza os menores gradientes. Estas ruas ficam no sopé do morro do Belverere. Já as maiores intensidades se restringem na porção meridional do mapa, mais precisamente na vertente oposta e ao longo da Av. Santa Rita, que faz parte da bacia do córrego Conceição. O mesmo se verifica também para o dia 7/9/2008 (Figura 77).

Para a estação de inverno, as diferenças térmicas foram às maiores para todos os experimentos realizados, tendo a maior contraste verificado no dia 7/9/2009 (Figura 77), sob condições de MPA, com $2,2^{\circ} \mathrm{C}$.

No dia 9/9/2008 (terça-feira - Figura 78) a intensidade do gradiente térmico diminui para $0,8^{\circ} \mathrm{C}$, assim como a distribuição dos maiores registros, que se concentram ao longo do eixo UFV e a Praça Silviano Brandão, faixa de grande circulação ao longo do dia, voltando ao padrão anterior no dia 13/9/2008 (Figura 79), assim como uma maior intensidade: $1,6^{\circ} \mathrm{C}$. 
No verão a medidas foram realizadas apenas nos dias 7 -sábado- (Figura 80) e 8 domingo- (Figura 81). Neste dias, se consegue observas algumas curiosidades, primeiramente, quanto a intensidade. A Figura 81 do domingo constata-se um gradiente horizontal muito baixo, a maioria inferior a $1,0^{\circ} \mathrm{C}$, exceto os pontos $5,19 \mathrm{e}$ 13, que correspondem, a praça Silviano Brandão e ao Clube Viçosa

Enquanto no sábado a dinâmica espacial ser completamente diferente, pois na Av. Santa Rita existe uma movimentação, já desde cedo para organização da feira livre da cidade, que leva os agricultores e pequenos produtores a vender seus produtos na cidade.
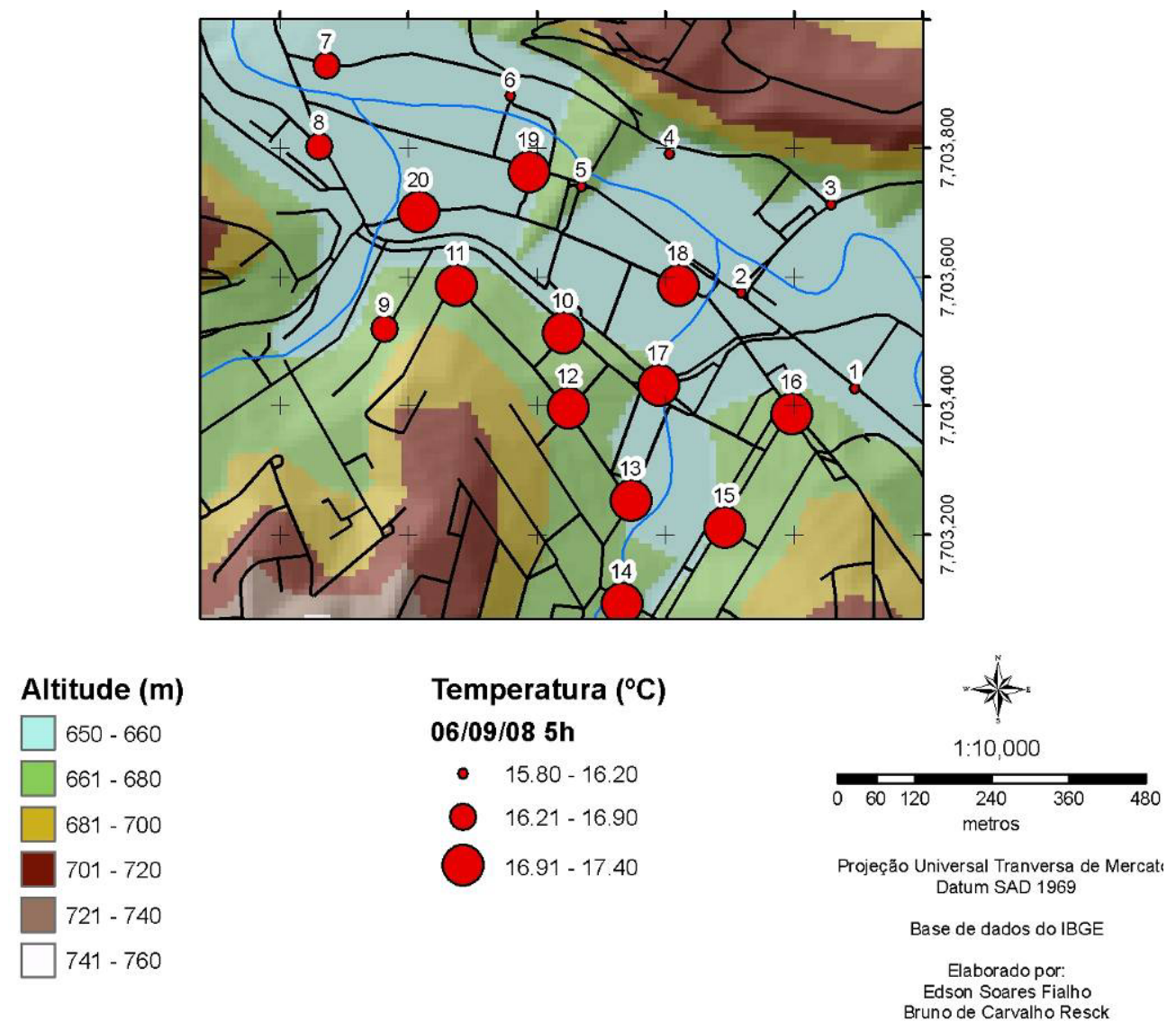

Figura 76. Distribuição da temperatura do ar às 5:00 horas, na área central de Viçosa em 6/9/2008. 

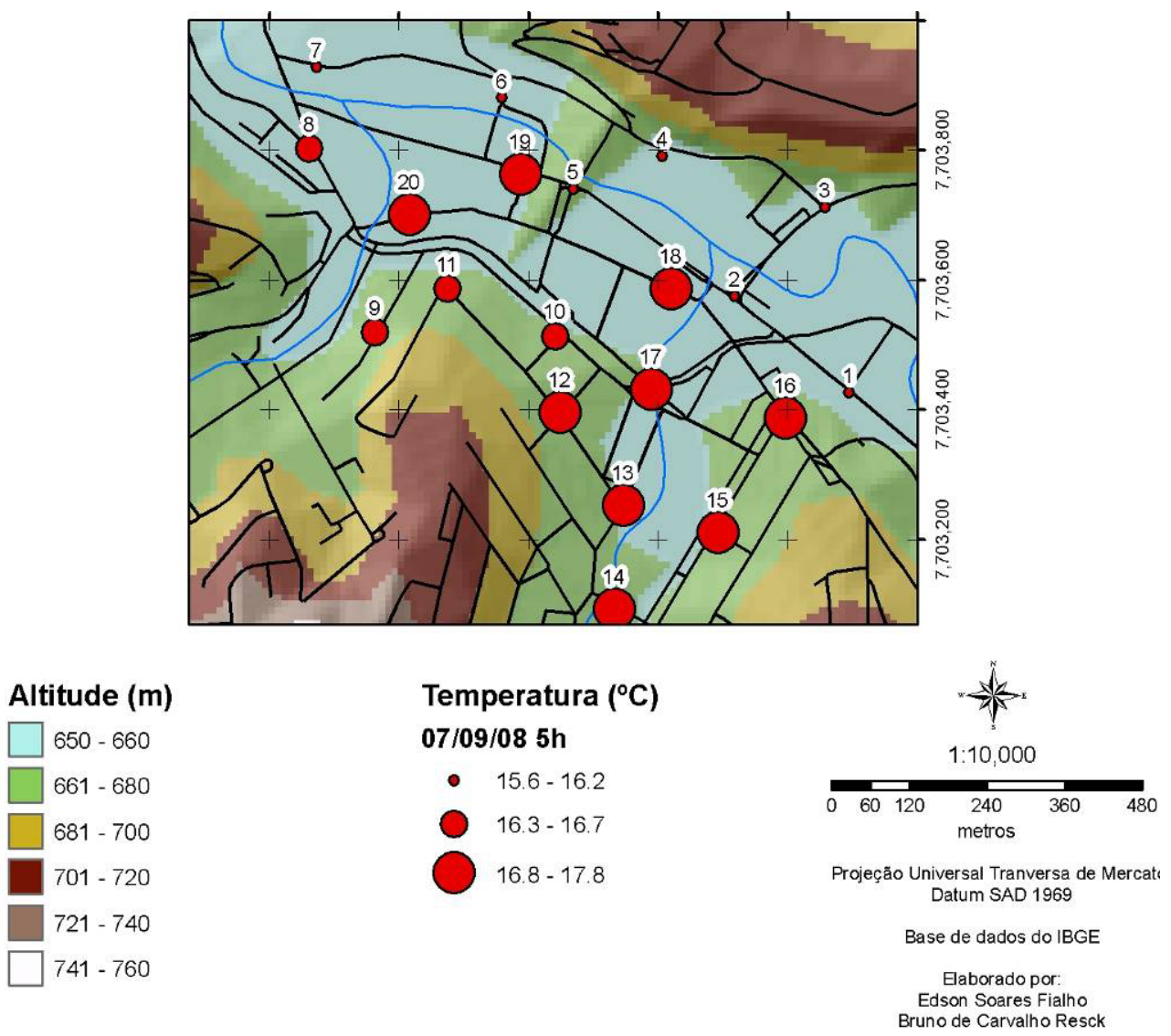

Figura 77. Distribuição da temperatura do ar às 5:00 horas, na área central de Viçosa em 7/9/2008.
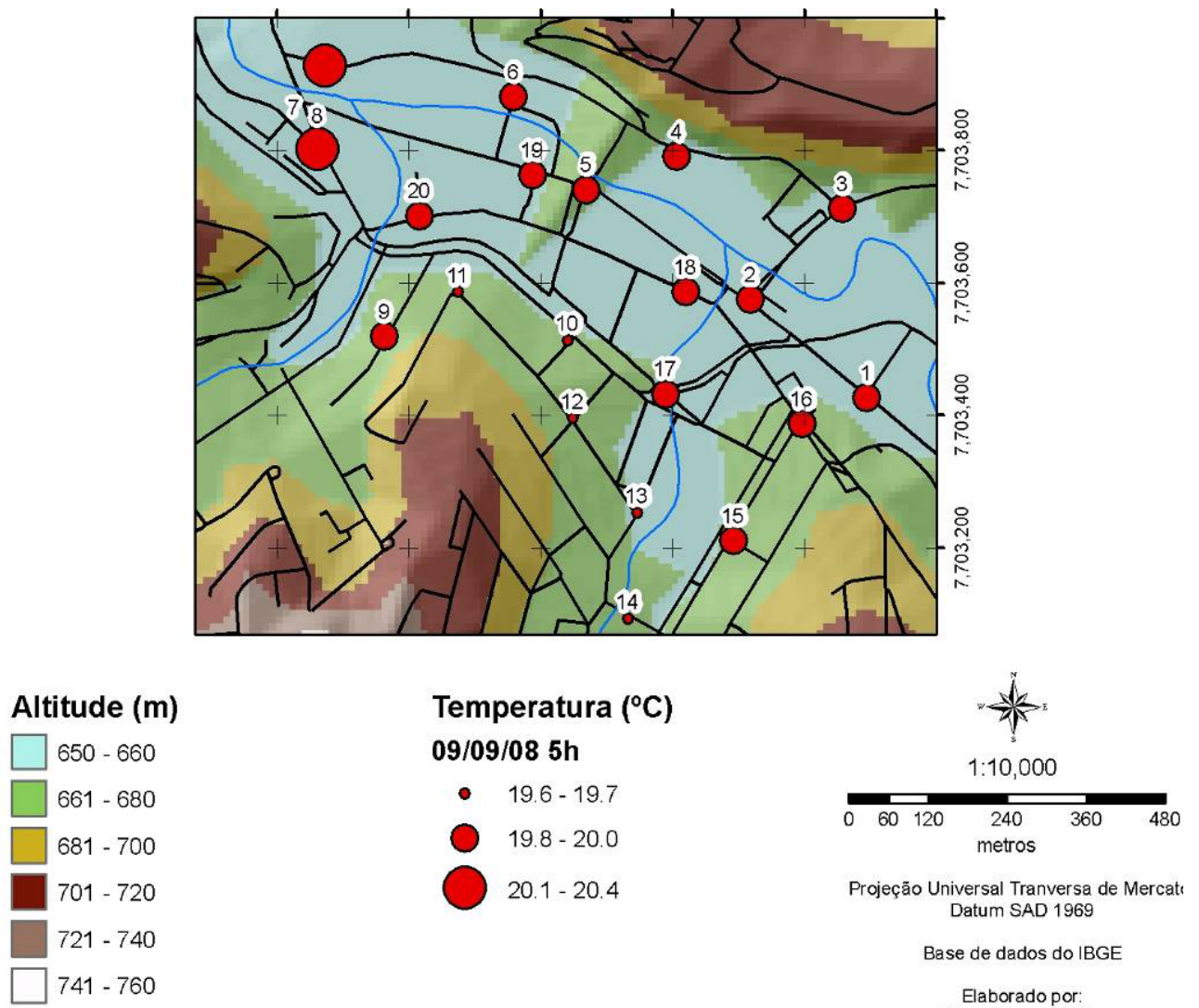

$$
\begin{gathered}
\text { Base de dados do IBGE } \\
\text { Elaborado por: } \\
\text { Edson Soares Fialho } \\
\text { Bruno de Carvalho Resck }
\end{gathered}
$$

Figura 78. Distribuição da temperatura do ar às 5:00 horas, na área central de Viçosa em 9/9/2008. 

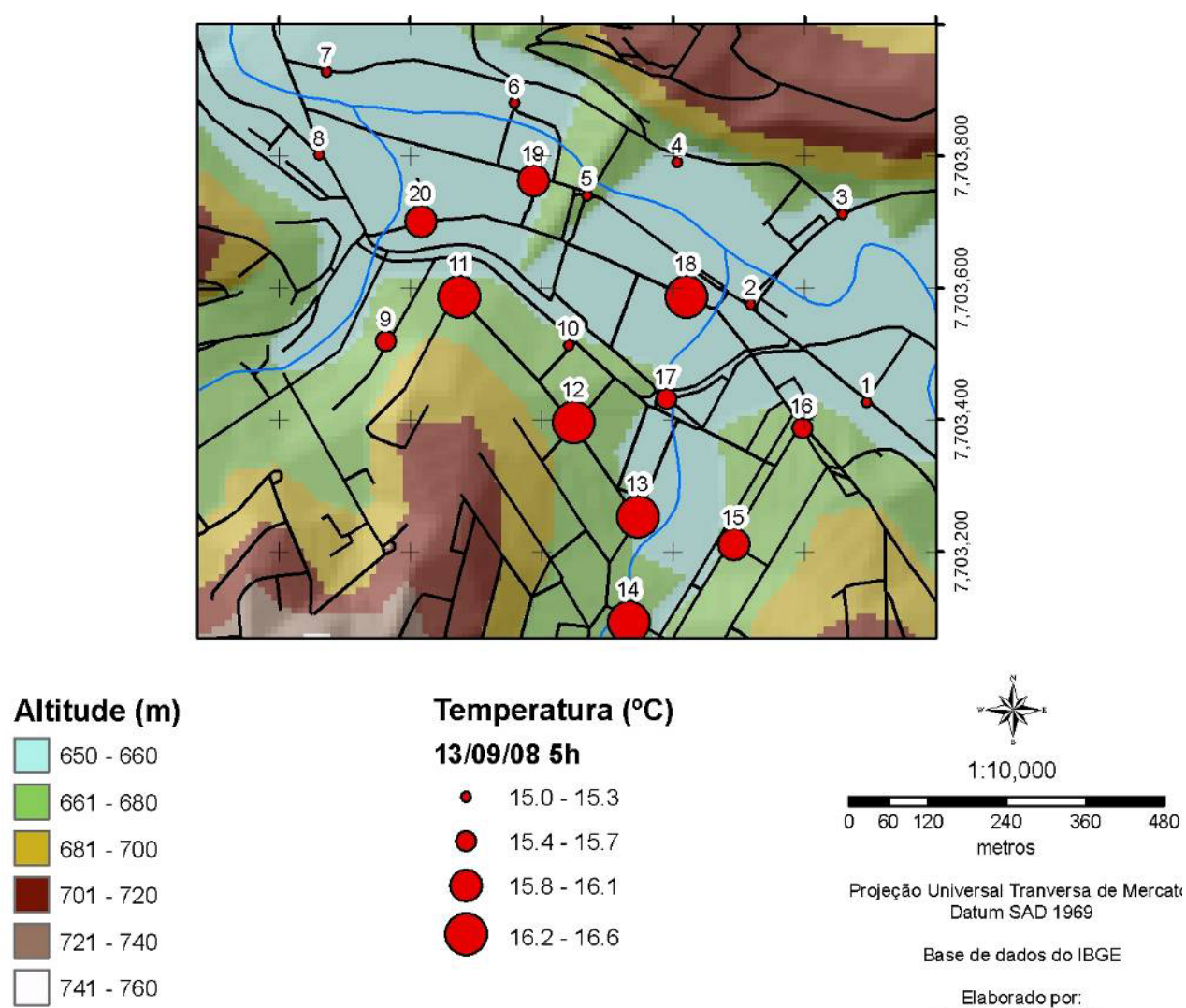

Projeçăo Universal Tranversa de Mercat Datum SAD 1969

Base de dados do IBGE

Elaborado por:

Edson Soares Fialho

Bruno de Carvalho Resck

Figura 79. Distribuição da temperatura do ar às 5:00 horas, na área central de Viçosa em 13/9/2008.
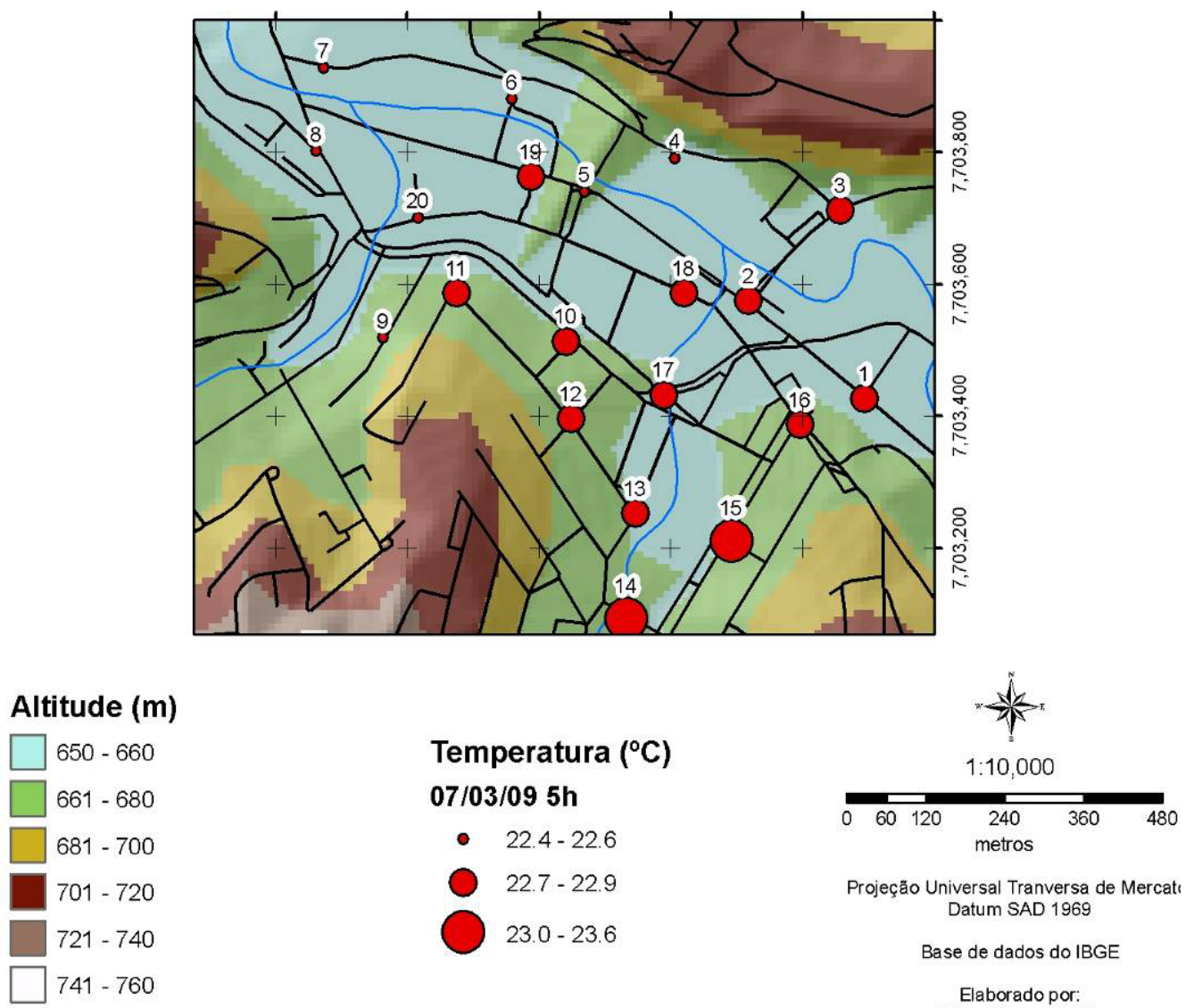

Elaborado por: Edson Soares Fialho

Figura 80. Distribuição da temperatura do ar às 5:00 horas, na área central de Viçosa em 7/3/2009. 

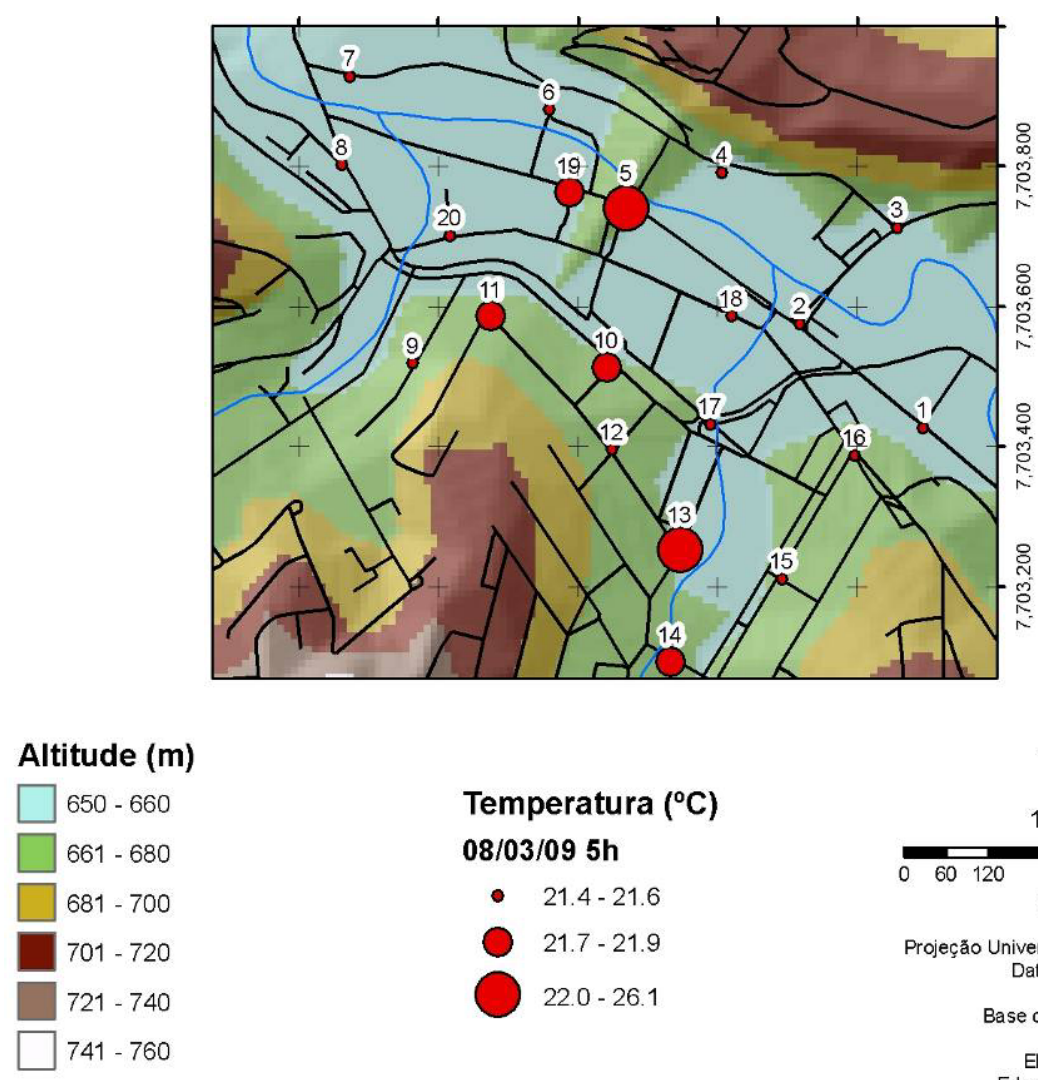

$$
\begin{aligned}
& \text { Temperatura }\left({ }^{\circ} \mathbf{C}\right) \\
& \text { 08/03/09 } \mathbf{5 h} \\
& \begin{array}{l}
\text { - } 21.4-21.6 \\
\text { 21.7- } 21.9 \\
22.0-26.1
\end{array}
\end{aligned}
$$

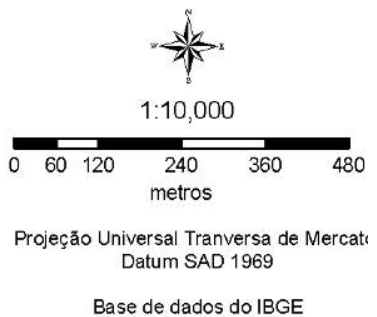

Elaborado por:

Figura 81. Distribuição da temperatura do ar às 5:00 horas, na área central de Viçosa em 8/3/2009.

\subsubsection{O campo térmico às $12: 00$ horas}

No dia 4/5/2007 às 12:00 horas o campo térmico (Figura 82) mudou sua configuração e os pontos 2 e 18 apontaram uma maior intensidade que atingiu os $4,0^{\circ} \mathrm{C}$. Verifica-se que estes pontos, que apresentaram as maiores diferenças térmicas, são aqueles onde as atividades humanas acontecem com maior intensidade neste horário.

Isto devido, ao fluxo intenso de pessoas e veículos nas ruas. Além disso, cabe salientar, que de acordo com a orientação das encostas, neste horário o sol ilumina toda a extensão do vale do rio São Bartolomeu, na altura da P. H. Rolfs, que percorre os trechos que vai das quatro pilastras (portão de entrada da UFV) até o Hospital São Sebastião.

Nesse sentido, pode-se dizer que a localização do núcleo de calor de maior intensidade está associada a fatores de ordem natural e humana, visto que o ponto 2 se localiza numa área de entroncamento viário, onde o fluxo de veículos é intenso, pois é sua porta de entrada. Além disso, este local apresenta prédios mais baixos 
que aqueles no início da P. H Rolfs, próximo da UFV e há um alargamento das ruas, o que favorece a maior chegada de radiação solar a este local.

No dia 5/5/2007 (Figura 83) a intensidade da diferença térmica foi de $2,5^{\circ} \mathrm{C}$, valor este 50,0\% inferior ao mesmo horário do dia anterior para o mesmo ponto 2, A explicação para tal fato pode ser encontrada na dinâmica dos fluxos urbanos, uma vez que o dia 5 foi um sábado, quando a maioria das lojas de comércio da área central de cidade fecham suas portas às 12:00 horas.

No dia 6/5/2007 (Figura 84), a intensidade se constituiu em um núcleo isolado de $4,7^{\circ} \mathrm{C}$ situado no ponto 15 e também numa extensa faixa que se estendeu por toda margem direita do Ribeirão São Bartolomeu até a encosta compreendendo os pontos 3, 4, 6 e 7.

Em relação às taxas de aquecimento, os pontos $15,10,19$ e 9 , com 2, $1^{\circ} \mathrm{C} \cdot \mathrm{h}^{-1}$, $1,87^{\circ} \mathrm{C} \cdot \mathrm{h}^{-1}, 1,78^{\circ} \mathrm{C} \cdot \mathrm{h}^{-1}$ e $1,77^{\circ} \mathrm{C} \cdot \mathrm{h}^{-1}$, respectivamente, foram os que apresentaram a maior velocidade de aquecimento. Assim como nos dias 4 e 5 , os núcleos de calor mais uma vez foram os pontos que apresentaram a maior taxa de aquecimento.

No entanto, a diferença desta vez se reporta a localização do núcleo de calor, que no dia 6 às 12:00 horas se encontrava deslocado para porção oeste, onde se localiza o ponto 15 .

No segundo horário do adia 7/5/2008 (Figura 85), o campo térmico sofreu uma influência da forte variação da nebulosidade ao longo do horário de registro, Isto explica porque o ponto 19 foi o local de maior intensidade da ilha de calor, apresentando $4,7^{\circ} \mathrm{C}$, enquanto o ponto 2 , que sempre esteve entre o primeiro e o segundo ponto de maior intensidade ao longo dos outros dias, registrou uma intensidade de $1,7^{\circ} \mathrm{C}$.

Todavia, cabe ressaltar, que mesmo numa condição de maior estabilidade não se pode dizer que o ponto 2 registraria a maior intensidade de ilha de calor, uma vez que sempre o ponto de maior ritmo de aquecimento fora o local central da ilha de calor, como ocorreu desta vez com o ponto 19, localizado no calçadão que registrou $2,5 .{ }^{\circ} \mathrm{C} \cdot \mathrm{h}^{-1}$ de taxa de aquecimento.

O inverno por sua vez, na área central, não identificou as maiores intensidades do gradiente térmico horizontal, diferente da escala do campo-cidade e na dimensão de toda a área urbana da cidade. 

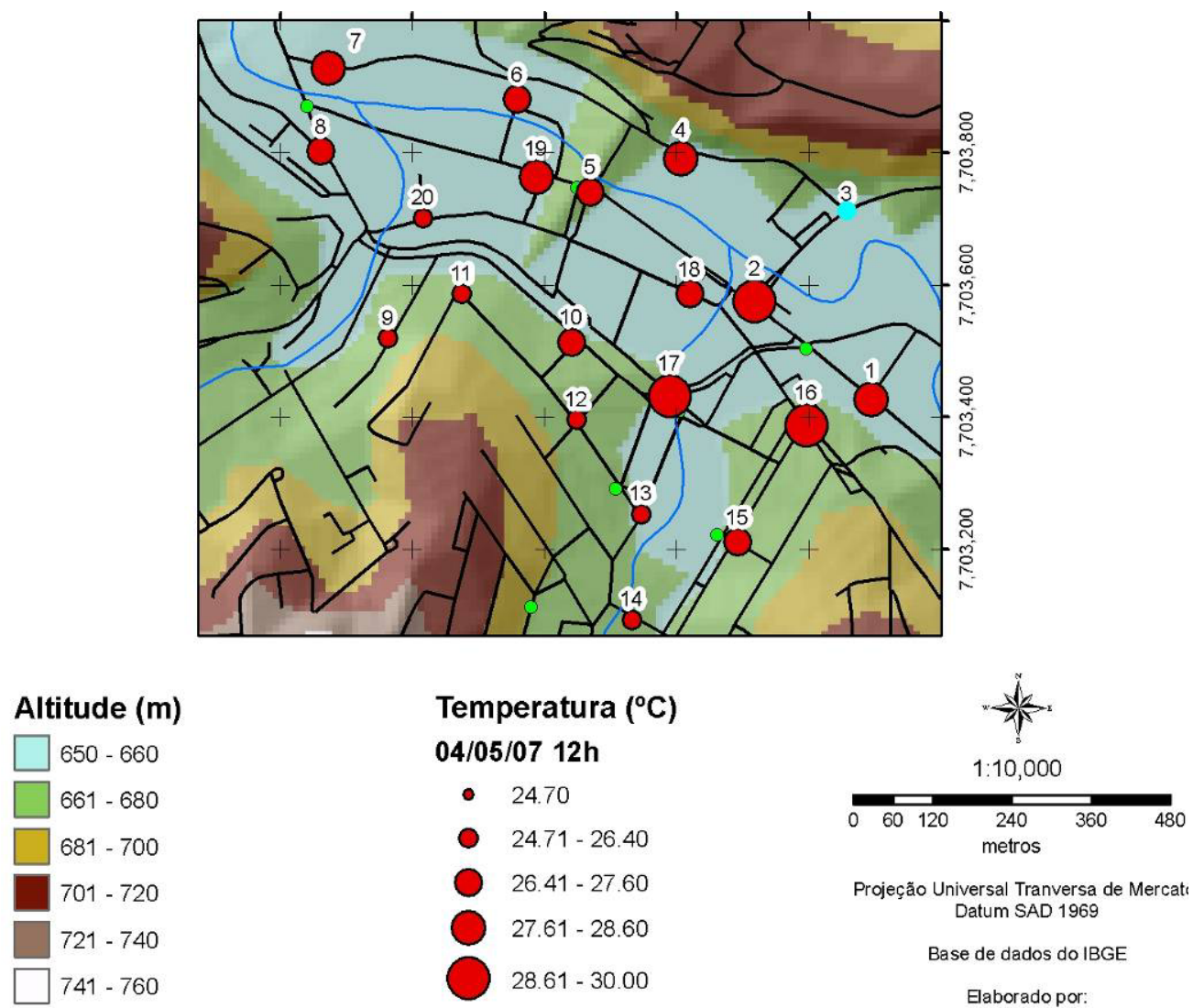

Projeção Universal Tranversa de Mercatı Datum SAD 1969

Base de dados do IBGE

Elaborado por:

Edson Soares Fialho

Edson Soares Fialho
Bruno de Carvalho Resck

Figura 82. Distribuição da temperatura do ar às 12:00 horas, na área central de Viçosa em 5/5/2007.
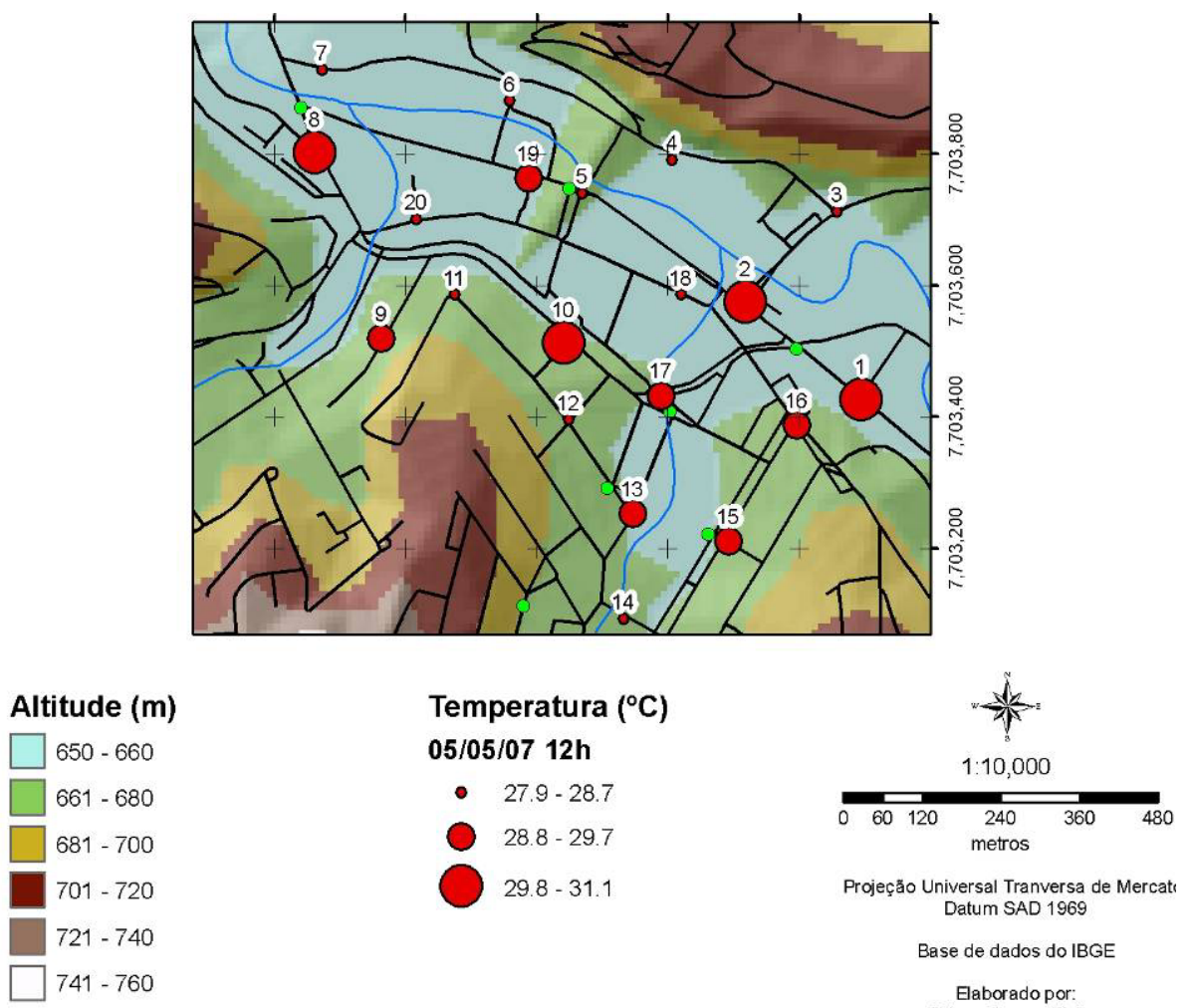

Base de dados do IBGE

Elaborado por:

Edson Soares Fialho

Bruno de Carvalho Resck

Figura 83. Distribuição da temperatura do ar às 12:00 horas, na área central de Viçosa em 5/5/2007. 

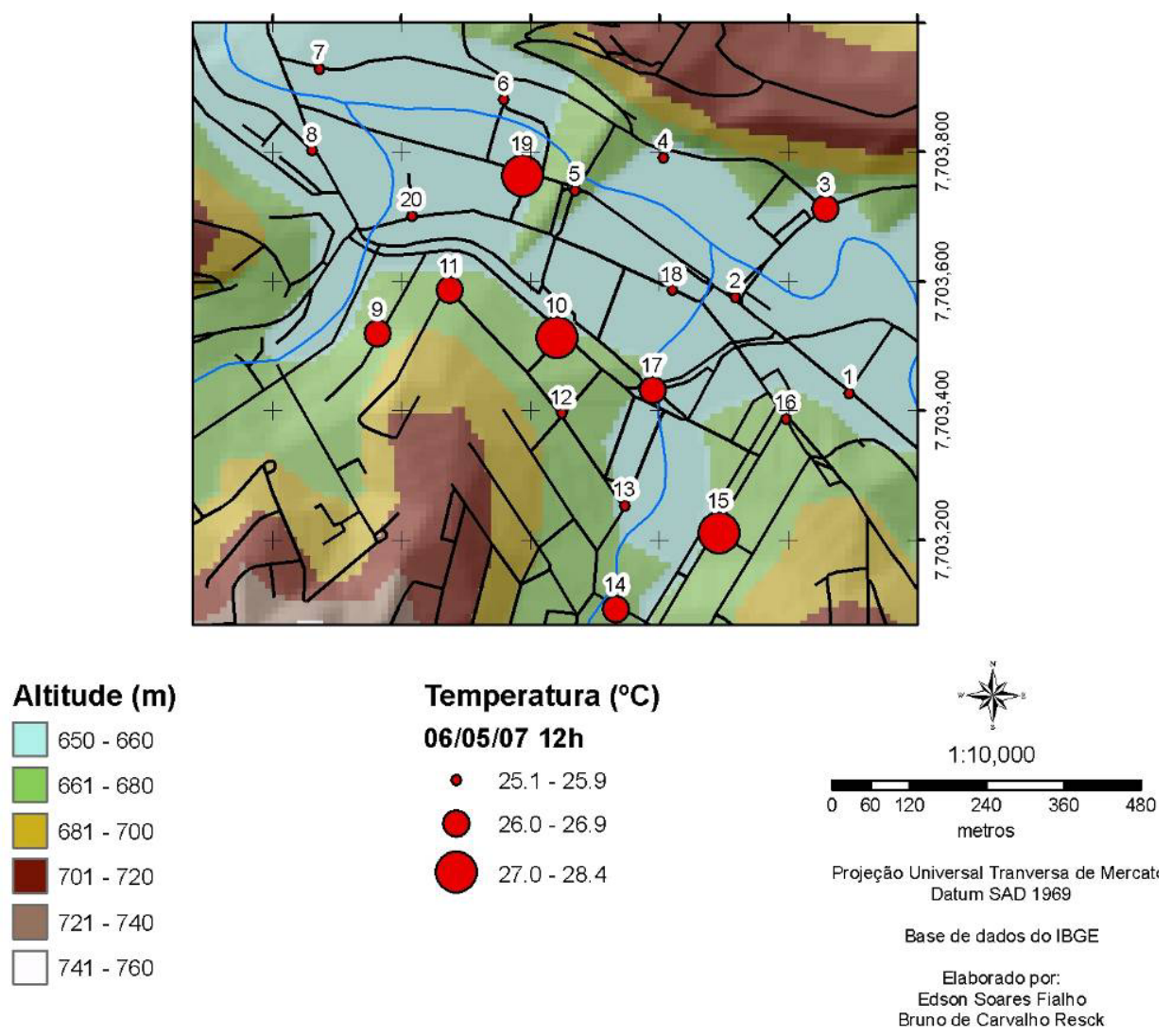

Figura 84. Distribuição da temperatura do ar às 12:00 horas, na área central de
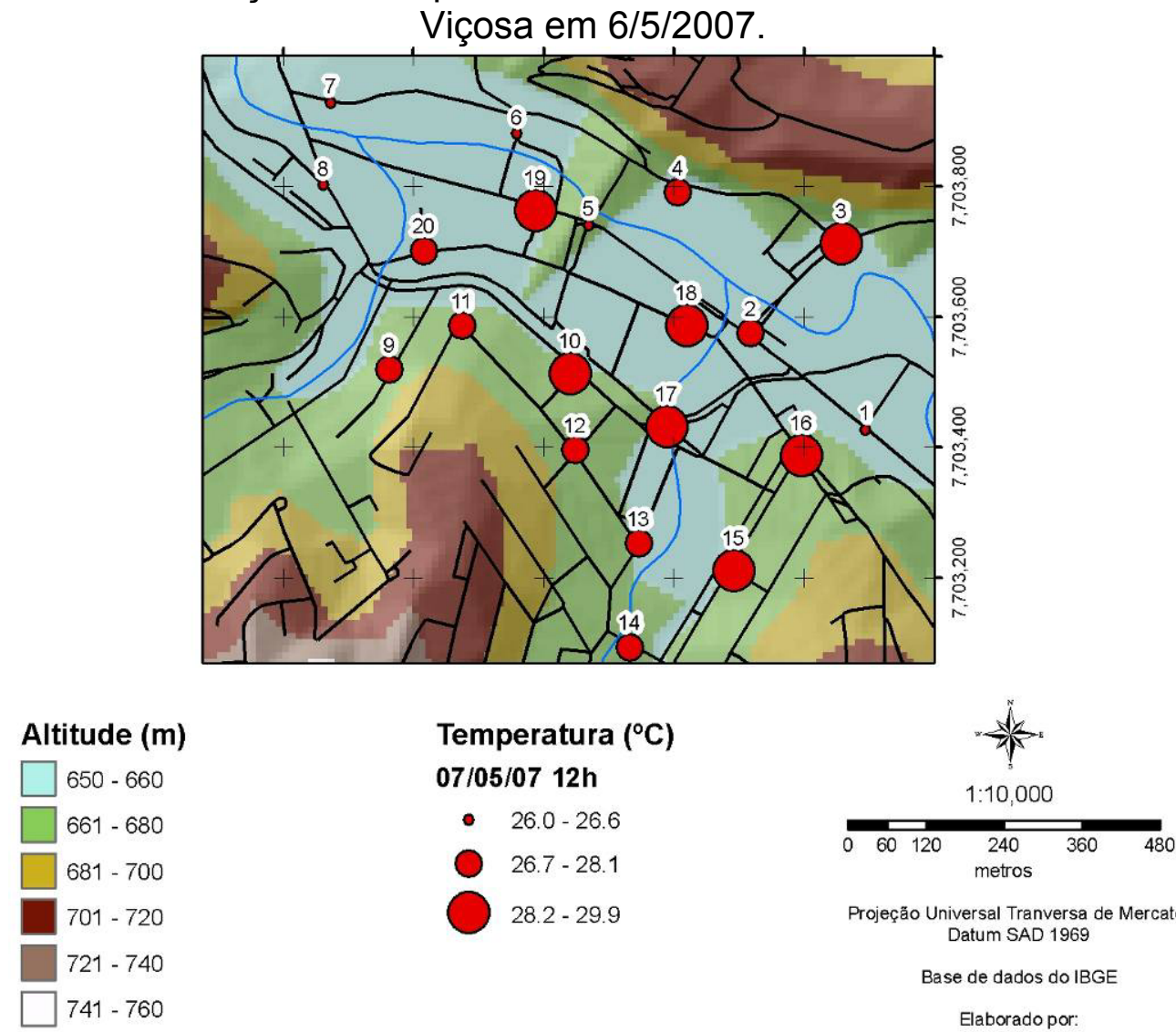

Projeção Universal Tranversa de Mercatı Datum SAD 1969

Base de dados do IBGE

Elaborado por:

Edson Soares Fialho

Bruno de Carvalho Resck

Figura 85. Distribuição da temperatura do ar às 12:00 horas, na área central de Viçosa em 7/5/2007. 

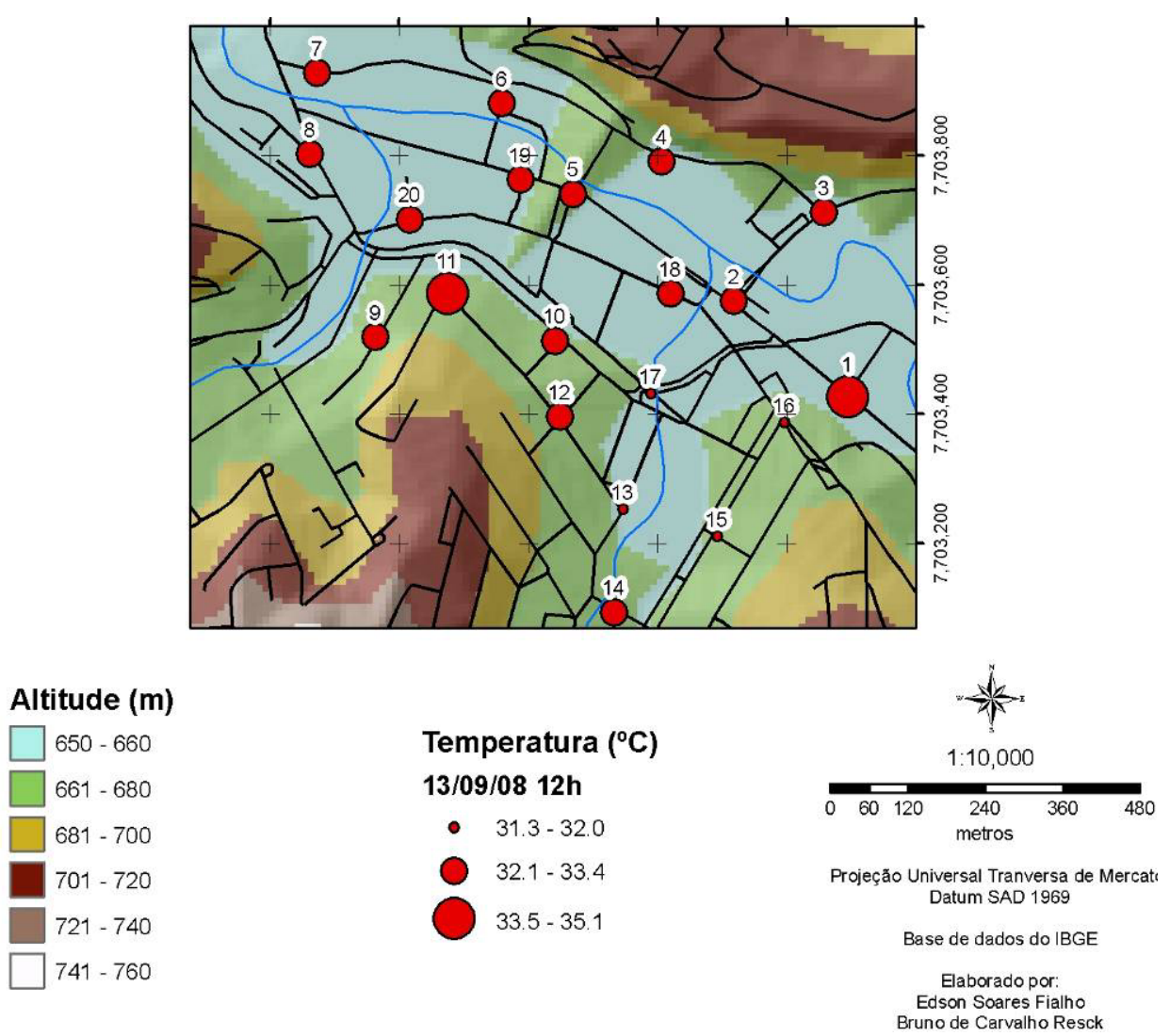

Figura 86. Distribuição da temperatura do ar às 12:00 horas, na área central de Viçosa em 13/9/2008.
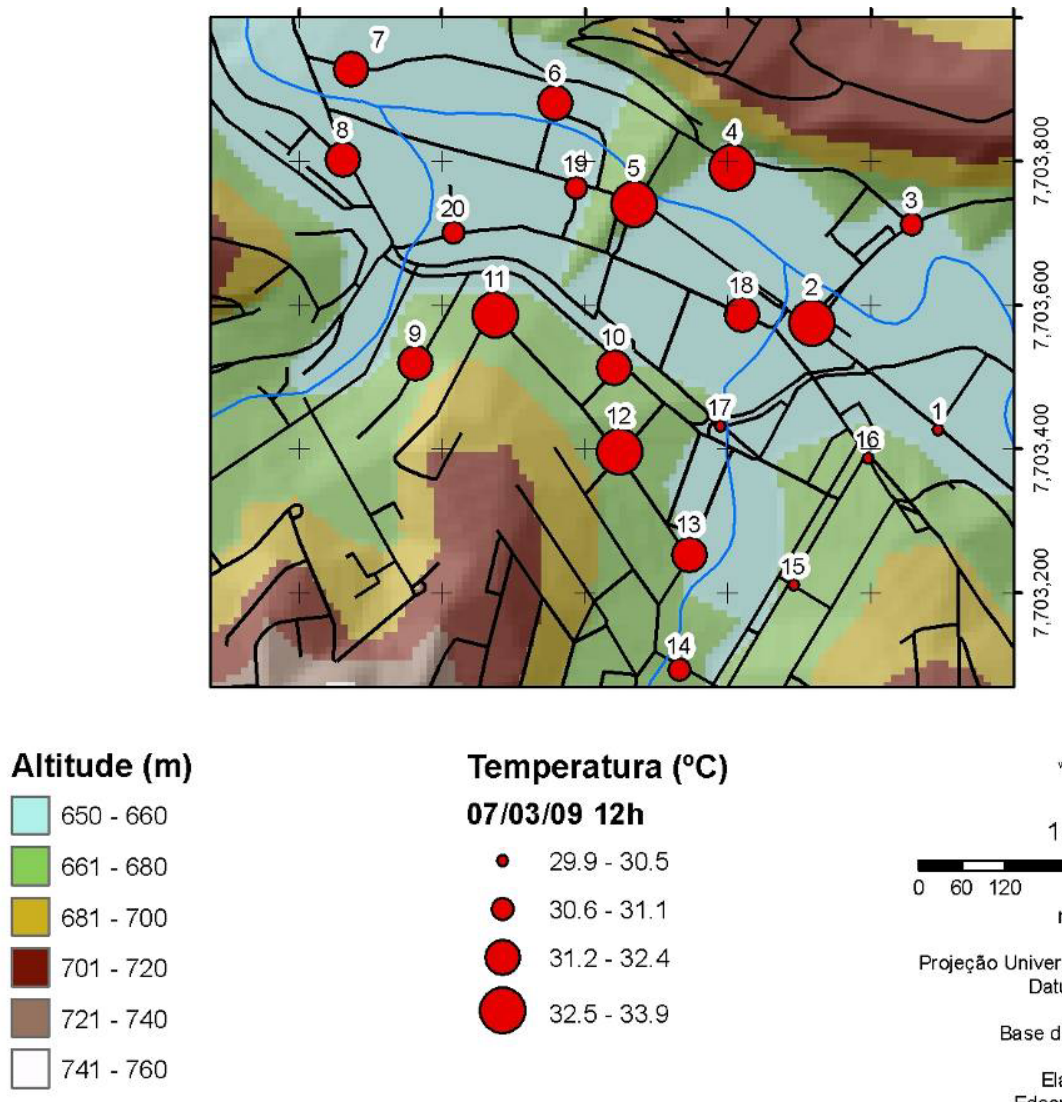

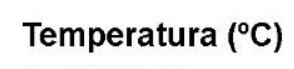

07/03/09 12h

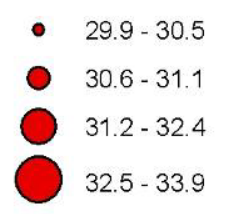

- $29.9-30.5$

$30.6-31.1$

$32.5-33.9$

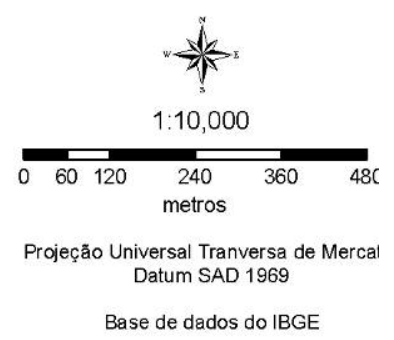

Elaborado por:

Edson Soares Fialho Bruno de Carvalho Resck

Figura 87. Distribuição da temperatura do ar às 12:00 horas, na área central de Viçosa em 7/3/2009 

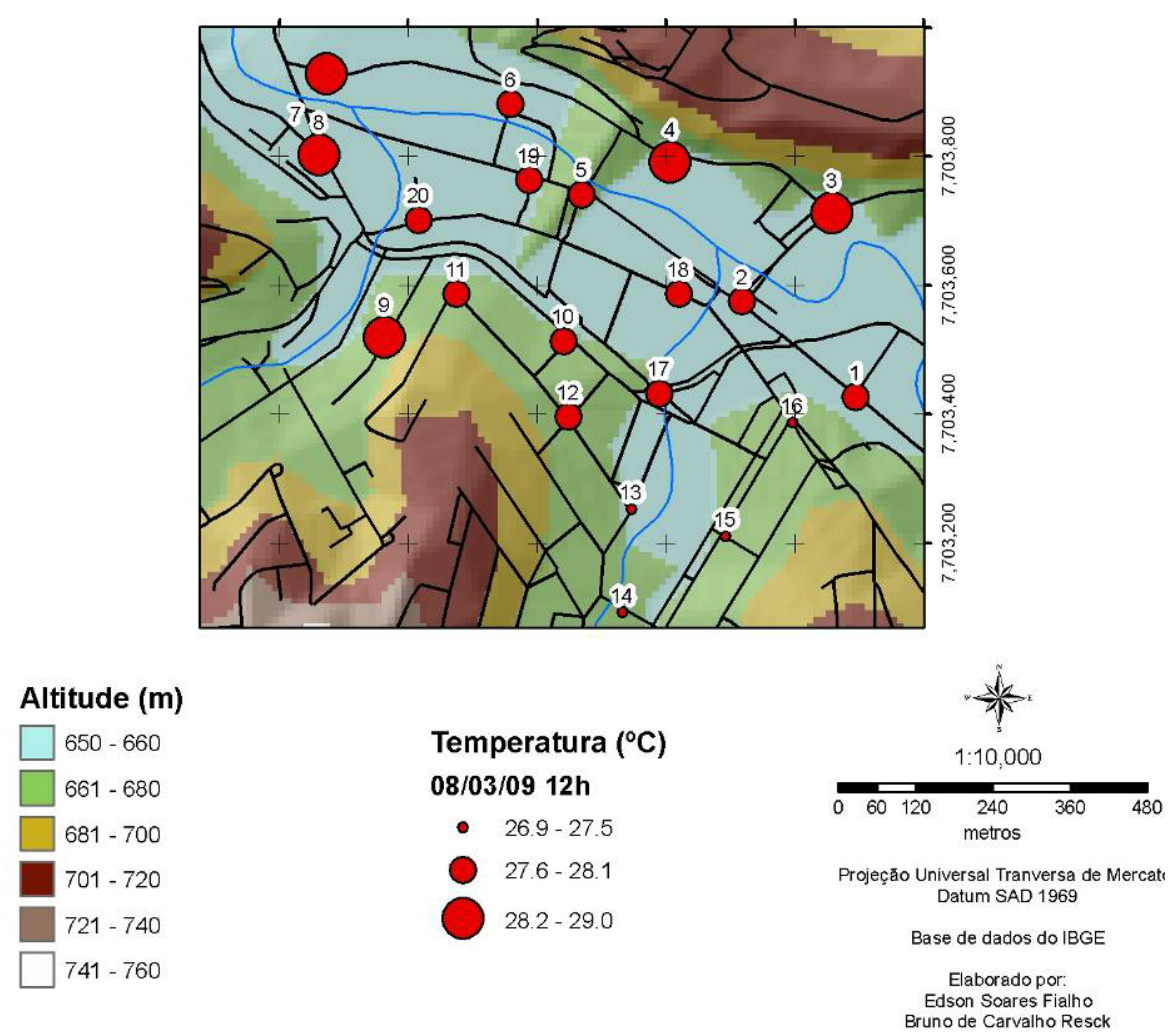

Figura 88. Distribuição da temperatura do ar às 12:00 horas, na área central de Viçosa em 8/3/2009

\subsubsection{O campo térmico às $19: 00$ horas}

Já às 19:00 horas, a espacialidade do campo térmico (Figura 89) apresentou diferenças mais baixas atingindo $1,2^{\circ} \mathrm{C}$ ao longo dos pontos 1,2 , 4, e 6 , que compreendem áreas próximas a encosta nordeste do vale, Em relação a taxas de aquecimento, pode-se perceber que os pontos 2 e 17, registraram os maiores valores, com $2,1^{\circ} \mathrm{C} \cdot \mathrm{h}^{-1}$ e $2,0^{\circ} \mathrm{C} . \mathrm{h}^{-1}$, respectivamente, por estarem em áreas mais abertas do que, por exemplo, o ponto 18, que embora esteja localizado entre os pontos 2 e 17, apresenta um maior sombreamento decorrente das edificações, o que justifica o seu valor ser mais baixo, na casa de $1,6^{\circ} \mathrm{C} \cdot \mathrm{h}^{-1}$.

De maneira geral, pode-se dizer que o comportamento do campo térmico às 12 horas foi fortemente influenciado pelas taxas de aquecimento, uma vez que os pontos 2 e 17 apresentaram as maiores intensidades e comungam da uma menor densidade de edificação, o que não dificulta a chegada da radiação solar.

Em relação à taxa de resfriamento constatou-se que os pontos de mensuração com maiores valores do índice de resfriamento se localizaram na área com menor intensidade de ilha de calor, com $0,4^{\circ} \mathrm{C}$, como se pode observar na figura 15, Essa área se caracteriza por um tipo de uso mais residencial, 
compreendendo os bairros de Lourdes, Ramos e o Centro 3, onde fica a encosta oeste do ribeirão São Bartolomeu,

Ainda referente às taxas de resfriamento, pode-se verificar que os pontos $2 \mathrm{e}$ 17, que apresentaram as maiores taxas de aquecimento, foram os mesmos que tiveram um maior ritmo de perda de energia noturna, na faixa de $1,47^{\circ} \mathrm{C} \cdot \mathrm{h}^{-1} \mathrm{e}$ $1,48^{\circ} \mathrm{C} \cdot \mathrm{h}^{-1}$, respectivamente, Todavia, isto não significou que os mesmos tivessem as mesmas intensidades de ilha de calor, $\mathrm{O}$ ponto 17 ficou com uma intensidade inferior a $0,4^{\circ} \mathrm{C}$, enquanto o ponto 2 apresentou um valor de $1,2^{\circ} \mathrm{C}$.

Embora apresentassem índices de resfriamento semelhantes, a temperatura às 12 horas entre os dois pontos registrava uma diferença de $0,9^{\circ} \mathrm{C}$, que se manteve até as 19:00 horas, Acredita-se que tal diferença pode estar vinculada ao tipo de calçamento, O ponto 19 apresenta um calçamento de asfalto, enquanto o 17 são blocos de concreto, embora ainda seja preliminar tal afirmativa.

No dia 5/5/2007 (Figura 90), a área central registrou as menores intensidades, cerca de $0,2^{\circ} \mathrm{C}$, Já as temperaturas com medidas mais altas se concentraram ao longo dos pontos 1 e 15 , com intensidade registrada de $1,2^{\circ} \mathrm{C}$.

Ao comparar os valores das taxas de aquecimento do dia $5 \mathrm{com}$ o dia 4, o ponto 2 continuou a apresentar a maior taxa de aquecimento, cujo o valor era de $2,4^{\circ} \mathrm{C} \cdot \mathrm{h}^{-1}$, seguido pelos pontos 10,8 e 17 , com taxas de $2,4^{\circ} \mathrm{C} \cdot \mathrm{h}^{-1}, 2,3^{\circ} \mathrm{C} . \mathrm{h}^{-1} \mathrm{e}$ $2,2^{\circ} \mathrm{C} \cdot \mathrm{h}^{-1}$, respectivamente, Mais uma vez se verificou que o núcleo de intensidade máxima da ilha de calor coincidiu com o ponto de maior aquecimento, neste caso, o ponto 2 a diferença entre os dias 4 e 5 refere-se à intensidade, que no caso foi de $3,0^{\circ} \mathrm{C}$, no dia 5 e $4,5^{\circ} \mathrm{C}$, no dia 4 .

Quanto às taxas de resfriamento, estas apresentaram 0 mesmo comportamento do dia anterior, o que acabou refletindo numa espacialização do campo térmico às 19 horas muito semelhante. Embora as escalas de intervalos dos mapas do dia 4 e 5 sejam um pouco diferentes, se considerarmos ambos com a escala de $0,4^{\circ} \mathrm{C}$, é possível perceber grande semelhança entre os dois, Cabe salientar que o tempo atmosférico para ambos os dias é o mesmo, o que explicaria o mesmo comportamento espacial,

No dia 6/5/2009 a área central (Figura 91) apresentou uma espacialidade com gradiente térmico com variações mais baixas, As áreas de maior intensidade ficaram localizadas na porção oeste das áreas centrais, que se situam próximo aos pontos 9 e 14 , com intensidade de $1,2^{\circ} \mathrm{C}$, enquanto os localizados nas proximidades da praça do Rosário, registraram as menores intensidades. 
Os pontos 15, 19 e 10 com maior taxa de resfriamento foram coincidentes aos pontos de maior taxa de aquecimento, exceto o ponto 9, que registrou o núcleo de maior calor à noite, $\operatorname{com} 1,2^{\circ} \mathrm{C}$, conforme dito no parágrafo anterior.

No dia 7/5/2007 (Figura 92), os pontos 2, 10, 17 e 18, apresentaram a menor temperatura, ou seja, abaixo de $0,6^{\circ} \mathrm{C}$, enquanto na porção noroeste, onde se situam os pontos 8 e 9, localizaram-se as maiores intensidades da ilha de calor, com $1,6^{\circ} \mathrm{C}$.

Durante o inverno (Figuras 93, 94, 95 e 96) as medidas não demonstraram uma mudança no comportamento espacial significativo em comparação aos meses de outono e verão. Porém, a dinâmica espacial foi fortemente influenciada pelo deslocamento das atividades humanas da cidade, quando da realização das feiras livres no domingo na AV. Santa Rita, local de trânsito intenso durante a semana.

No dia 7/7/2009 (sábado) a partir da Figura 97 é possível identificar que as áreas mais quentes se localizam nas vias de acesso a cidade (pontos 2, 17 e 18) e no local de bares e butiques, que são freqüentados por muitos acadêmicos (pontos 14, 15 e 16). Já no domingo (8/3/2009) há uma maior homogenização da temperatura entre os pontos observados, porém o gradiente é maior, ficando na ordem de $1,1^{\circ} \mathrm{C}$.
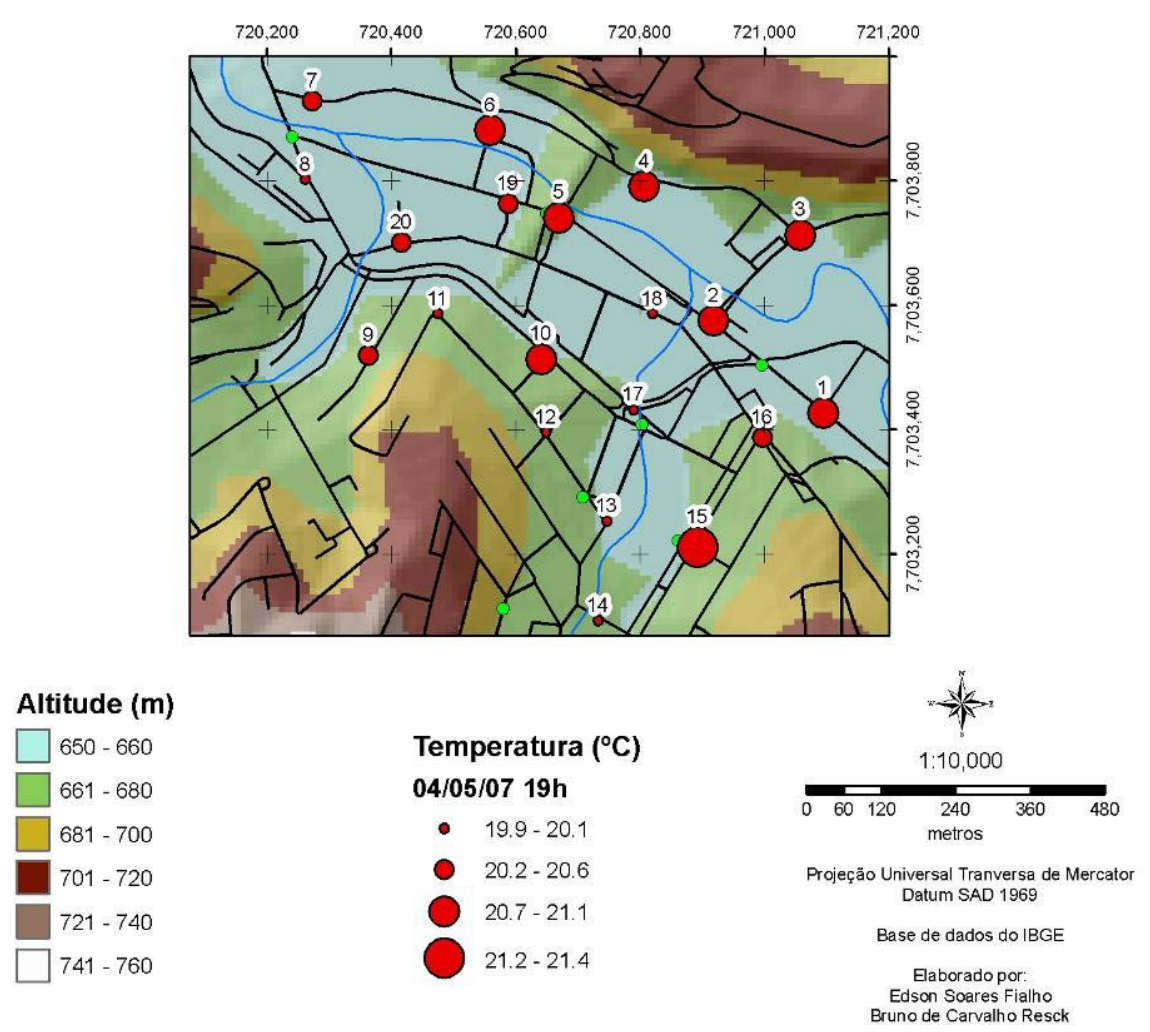

Figura 89. Distribuição da temperatura do ar às 19:00 horas, na área central de Viçosa em 4/5/2007 


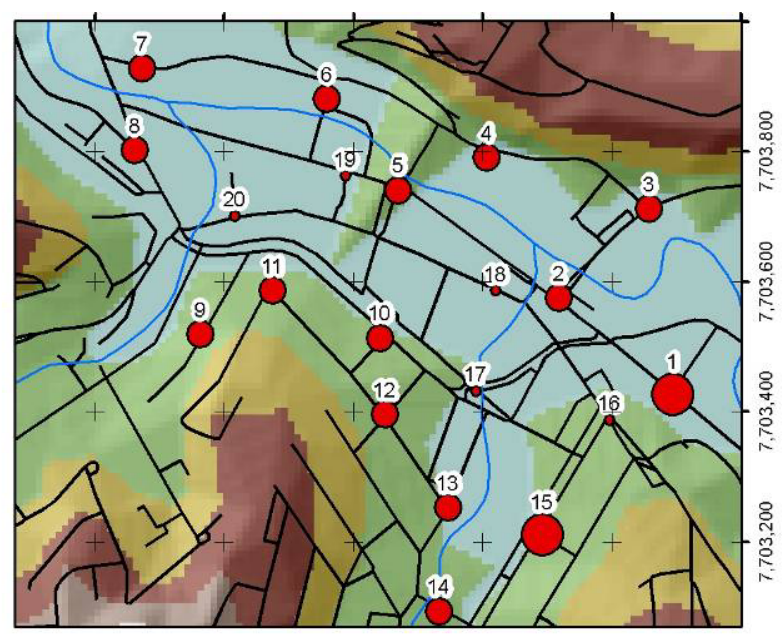

Altitude (m)
\begin{tabular}{|l}
$\square 650-660$ \\
$\square 661-680$ \\
$\square 681-700$ \\
$\square 701-720$ \\
$721-740$ \\
$\square 741-760$
\end{tabular}

Temperatura $\left({ }^{\circ} \mathrm{C}\right)$ 05/05/07 19h

- $19.0-19.2$

$19.3-19.6$

- $19.7-20.3$

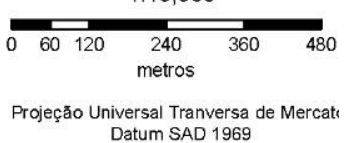

Base de dados do IBGE

Elaborado por:

Edson Soares Fialho

Figura 90. Distribuição da temperatura do ar às 19:00 horas, na área central de Viçosa em 5/5/2007
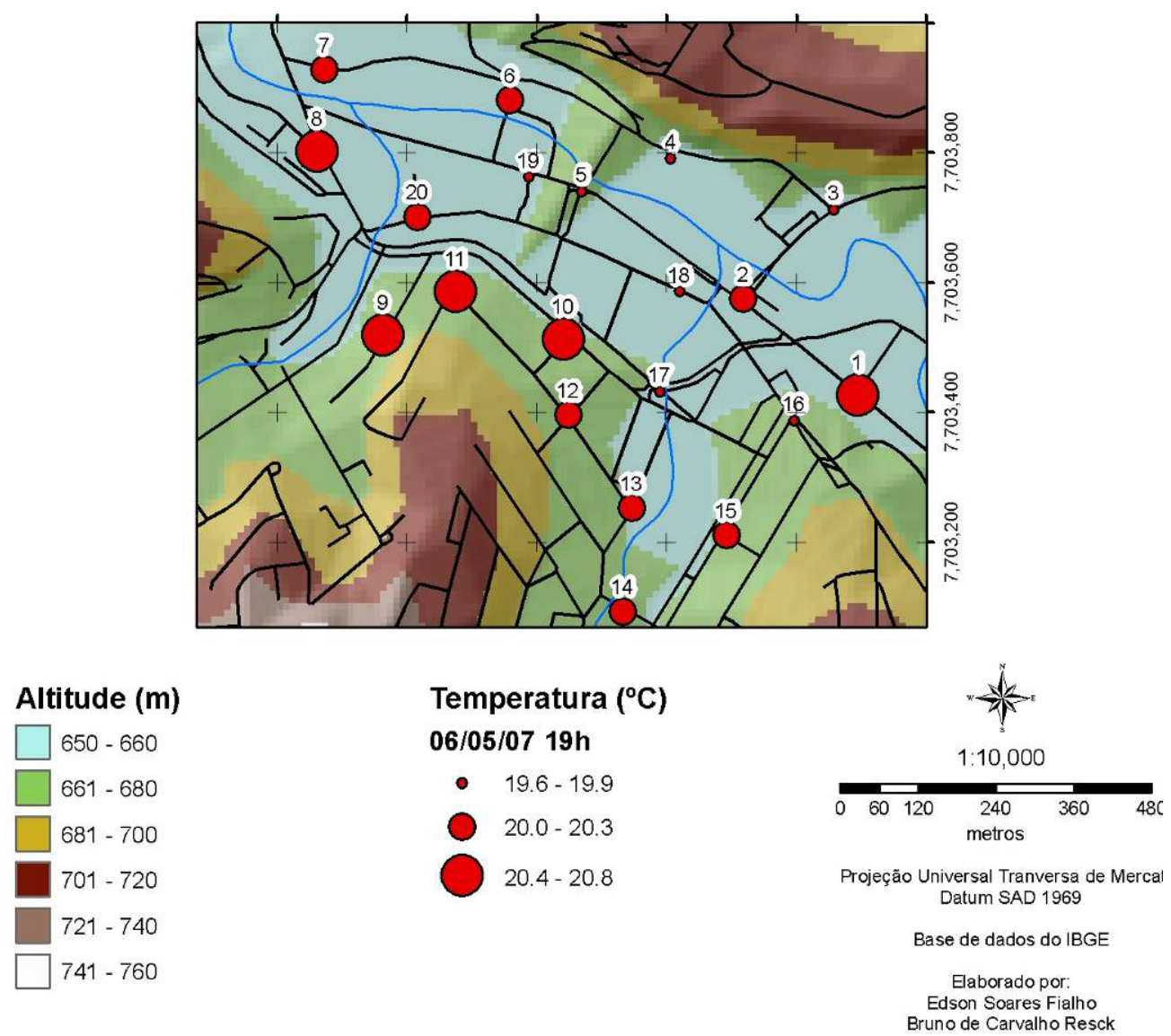

Figura 91. Distribuição da temperatura do ar às 19:00 horas, na área central de Viçosa em 6/5/2007 

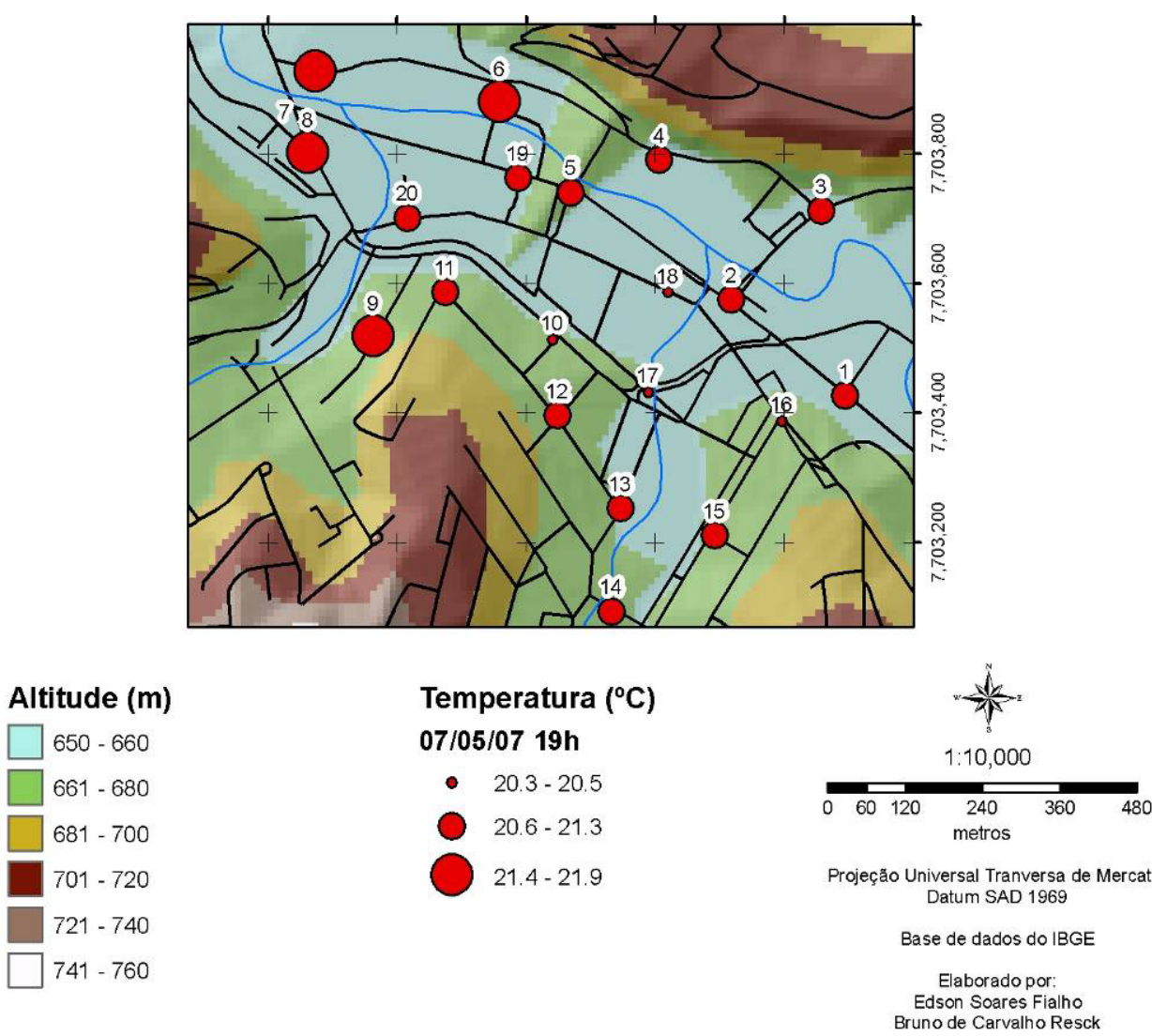

Figura 92. Distribuição da temperatura do ar às 19:00 horas, na área central de Viçosa em 7/5/2007
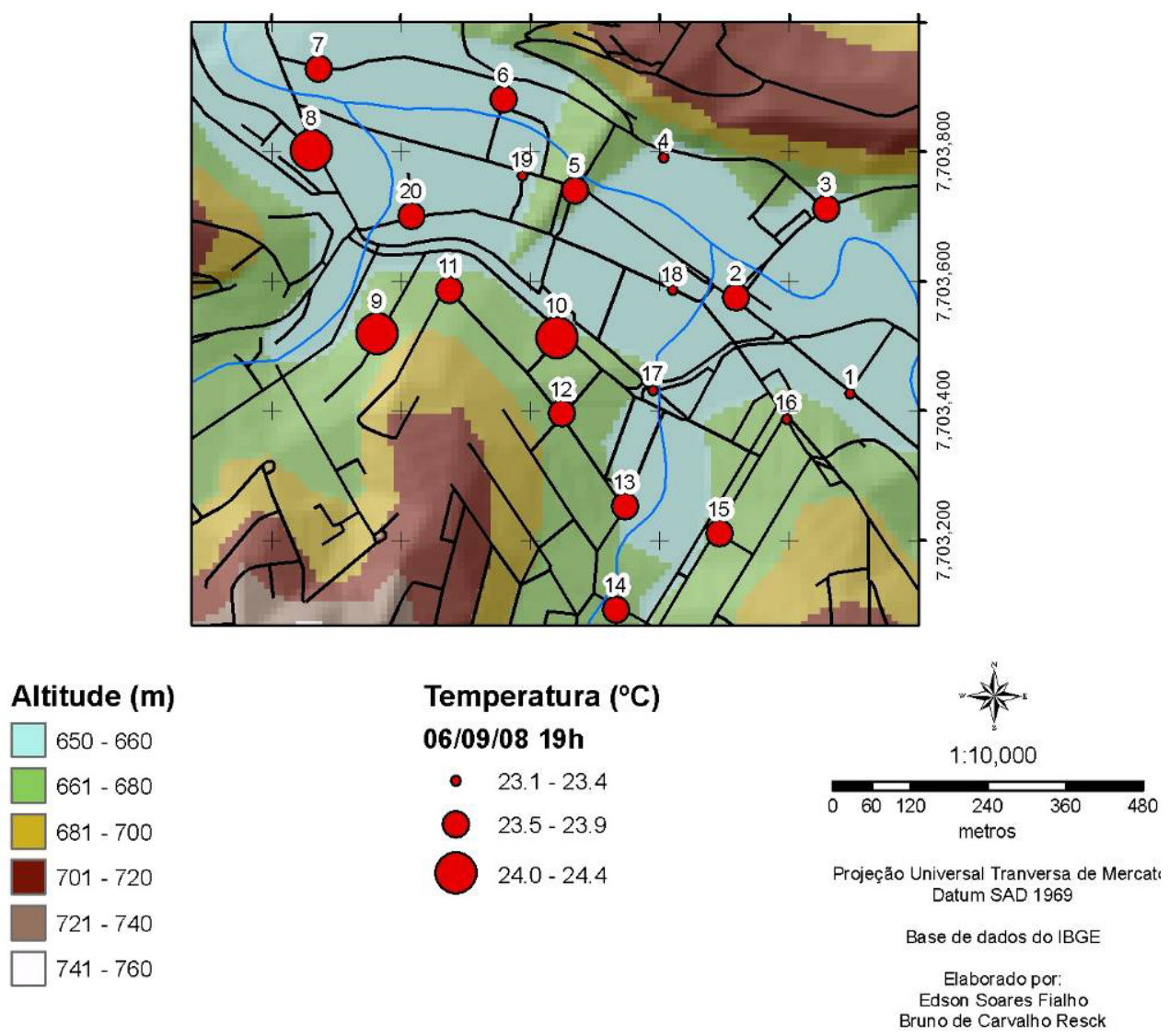

Figura 93. Distribuição da temperatura do ar às 19:00 horas, na área central de Viçosa em 6/8/2008 

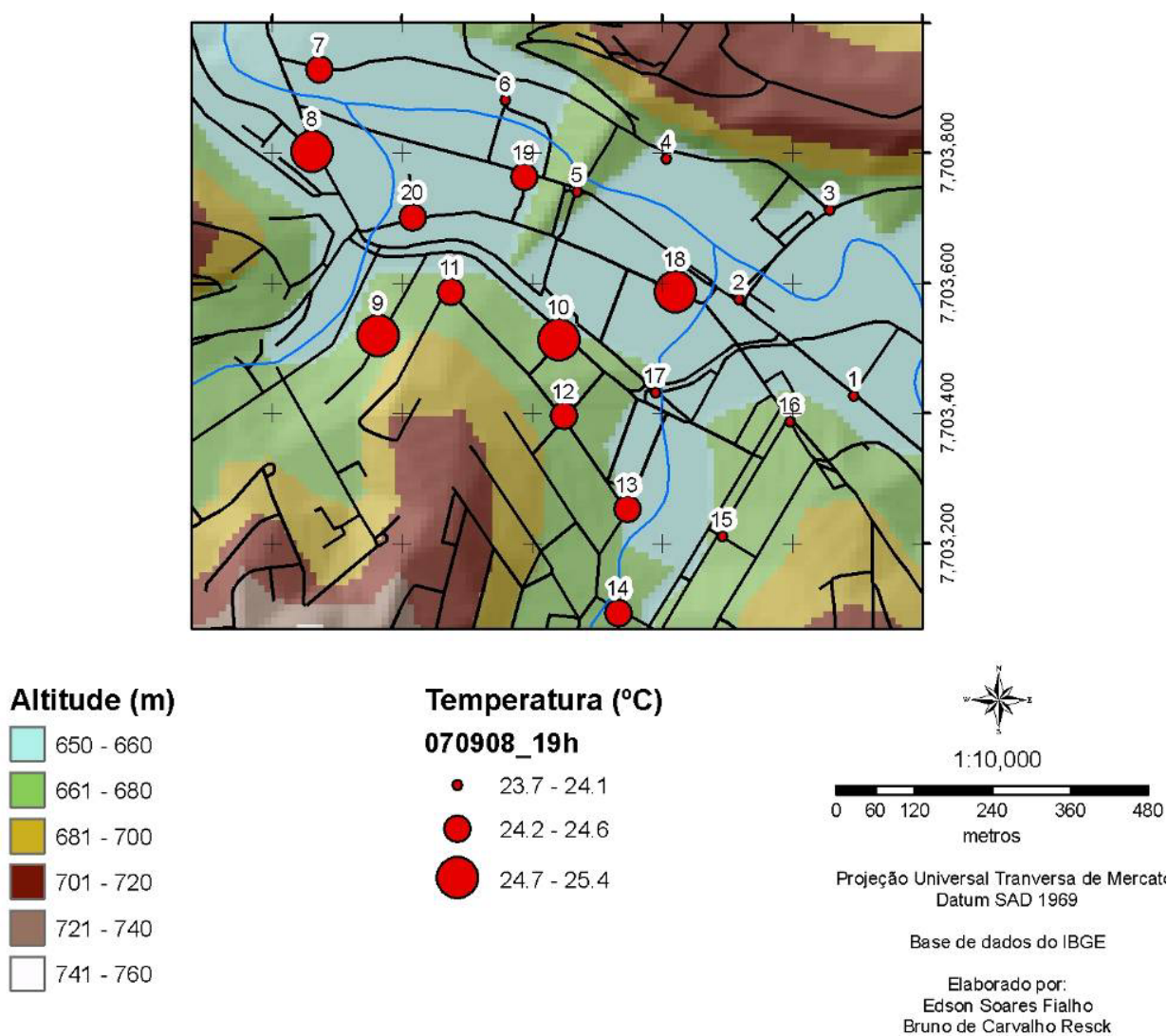

Figura 94. Distribuição da temperatura do ar às 19:00 horas, na área central de
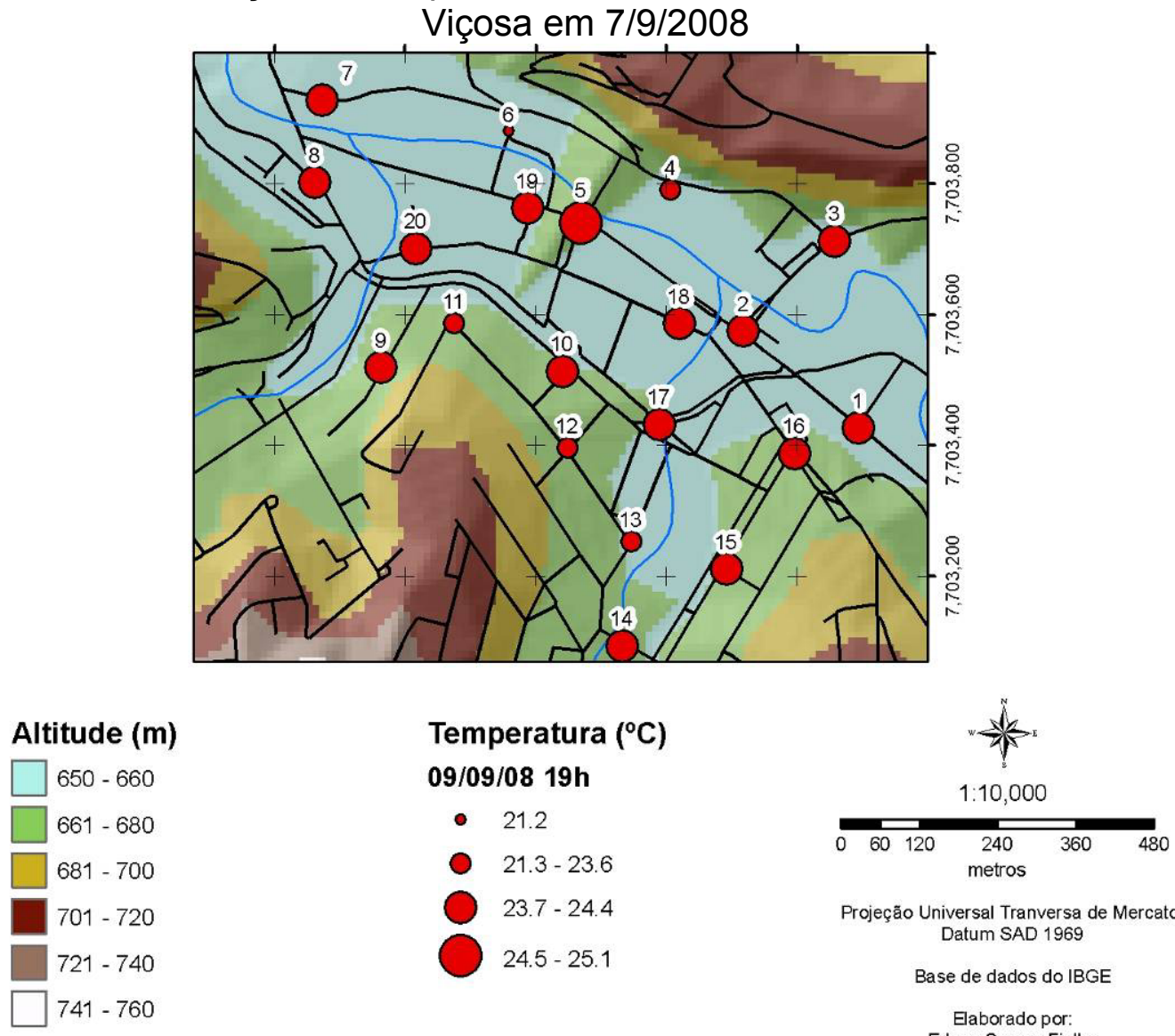

Projeção Universal Tranversa de Mercato Datum SAD 1969

Base de dados do IBGE

Elaborado por:

Edson Soares Fialho

Bruno de Carvalho Resck

Figura 95. Distribuição da temperatura do ar às 19:00 horas, na área central de Viçosa em 9/9/2008 


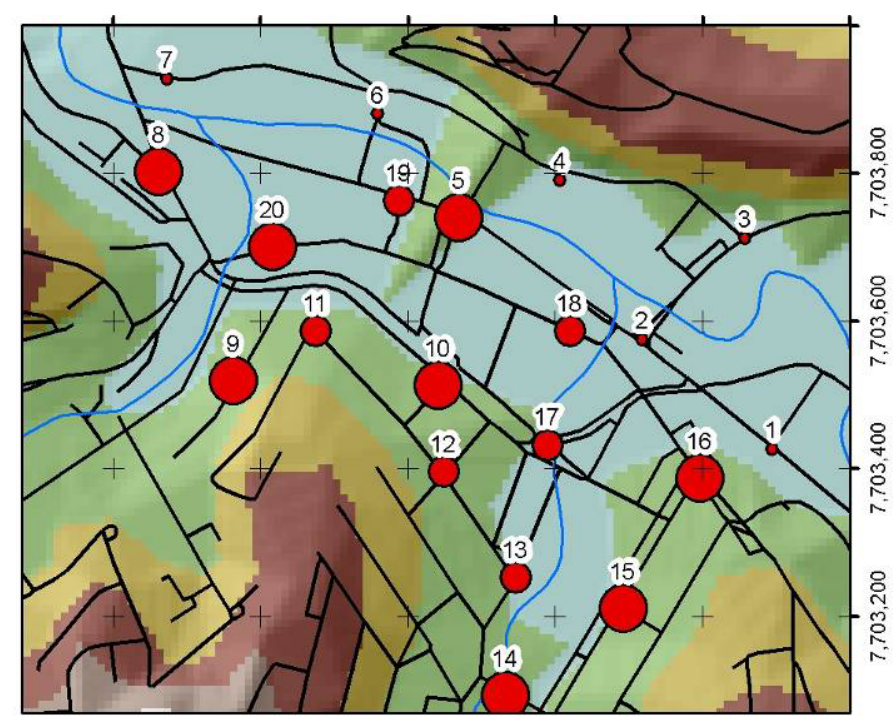

Altitude (m)

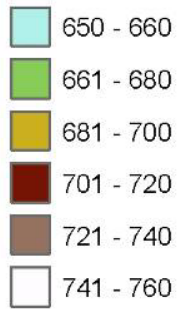

Temperatura $\left({ }^{\circ} \mathrm{C}\right)$

13/09/08 19h

- $25.1-25.9$

26.0-26.6

(26.7-27.1
來.

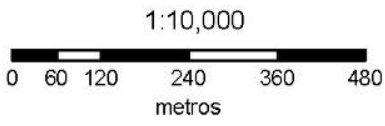

Projeção Universal Tranversa de Mercato Datum SAD 1969

Base de dados do IBGE

Elaborado por

Edson Soares Fialno

Bruno de Carvalho Resck

Figura 96. Distribuição da temperatura do ar às 19:00 horas, na área central de Viçosa em 13/9/2008

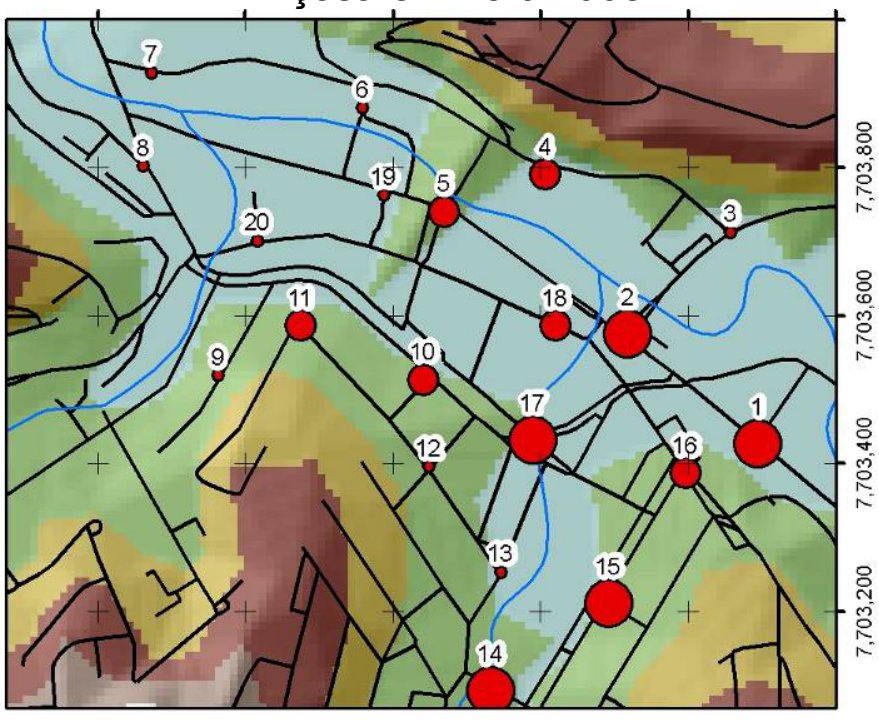

\section{Altitude (m)}

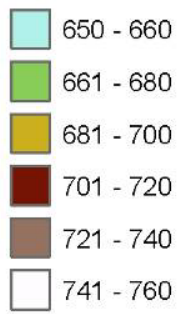

Temperatura $\left({ }^{\circ} \mathrm{C}\right)$

07/03/09 19h

- $22.9-23.1$

23.2-23.4

(23.5- 23.9

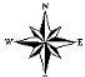

$1: 10,000$

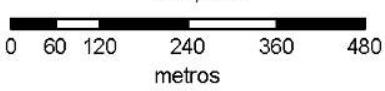

Projeçäo Universal Tranversa de Mercatı Datum SAD 1969

Base de dados do IBGE

Elaborado por:

Edson Soares Fialho Bruno de Carvalho Resck

Figura 97. Distribuição da temperatura do ar às 19:00 horas, na área central de Viçosa em 7/3/2009 

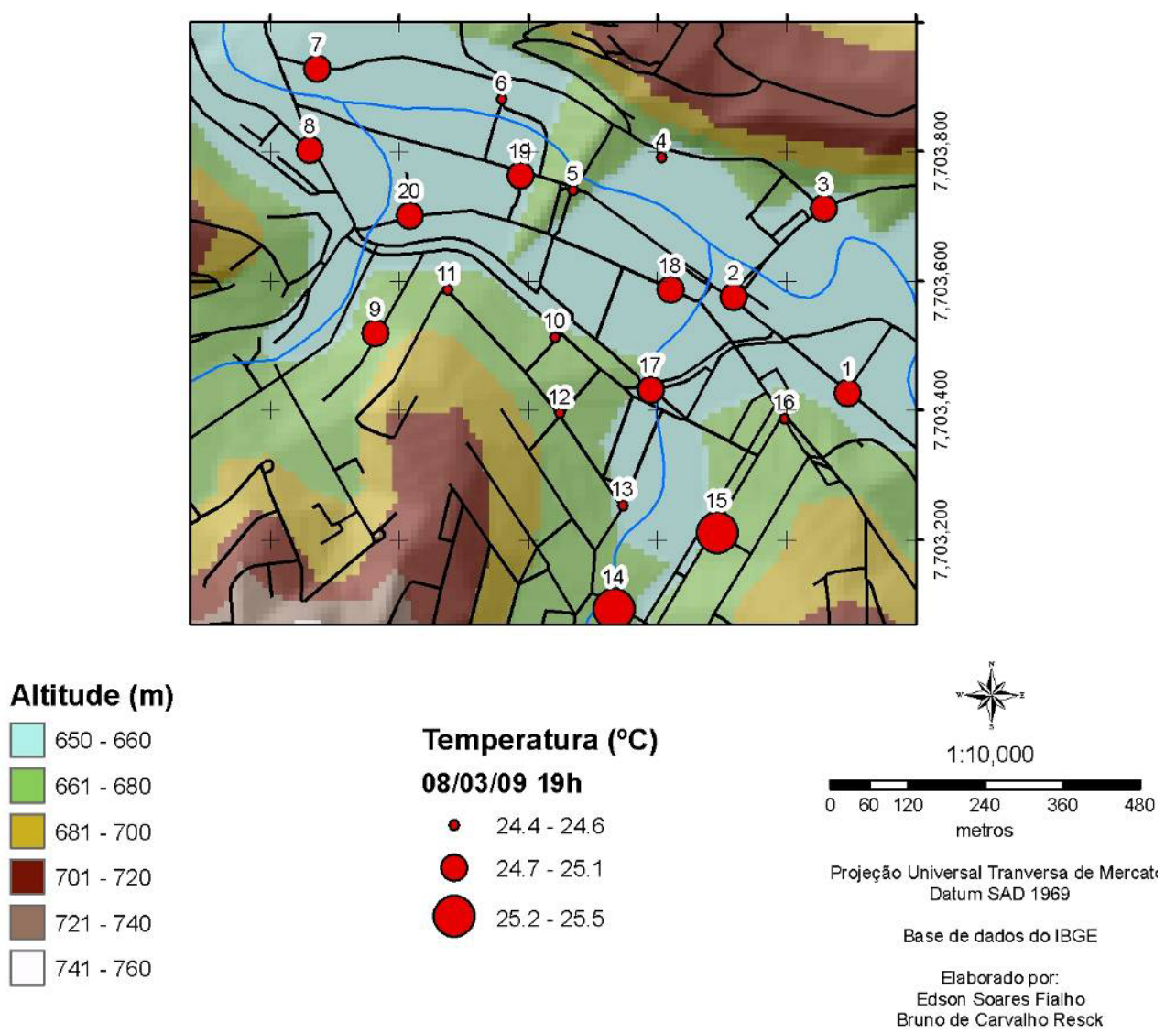

Figura 98. Distribuição da temperatura do ar às 19:00 horas, na área central de Viçosa em 8/3/2009

\section{Discussão dos resultados e considerações finais.}

De acordo com os resultados encontrados nesta pesquisa, pode-se dizer que a técnica de transetos móveis foi de significativa importância para os levantamentos de temperatura do ar, assim como fora verificado nos estudos de Izquierdo et. al. (1989), Bello Fuentes (1994), Maitelli (1994), Zamparoni (1995), Amorim (2005), Brandão (1996), Sümeghy e Unger (2003) e Vianna (2006).

Com relação às medidas noturnas sob a condição da MTA e MPA, o núcleo urbano se apresentou mais quente durante a noite e a madrugada, não sendo destituído o núcleo de calor.

Como Garnett (apud SMITH, 1975, p. 57) afirma que as cidades, assim como Viçosa, abrigadas em vale podem ter uma extraordinária freqüência de intensas ilhas de calor, como documentou em Sheffield, uma diferença de temperatura noturna de até $7,8^{\circ} \mathrm{C}$ entre o CBD e as margens da cidade.

Será então que Viçosa pode-se dizer tem ilhas de calor noturna, ou o gradiente termal, é apenas reflexo do aquecimento diferenciado das vertentes ao longo do dia, em face da exposição ao sol das mesmas ou da entrada de sistemas 
extra-tropicais, conforme relatam os estudos realizados por Tavares (2002), Jardim (2007) e Fialho e Imbroisi (2005).

Segundo os cálculos sugeridos por Oke (1973) a intensidade máxima da ilha de calor atmosférica, com 70 mil habitantes, seria de $5,6^{\circ} \mathrm{C}$ de acordo com a Equação 12 para as cidades européias. Porém, o resultado encontrado foi um gradiente máximo de $4,7^{\circ} \mathrm{C}$, no dia $21 / 8 / 2008$.

Pelo fato de se localizar em um sítio convergente, Viçosa de acordo com nossa reflexão, apresenta uma dinâmica atmosférica muito própria ligada ao mecanismo de ventos locais. Conforme este raciocínio, pode-se dizer que perfil topográfico demonstrado nas Figuras 69 e 70 nos permite fazer uma análise rápida e constatar que a drenagem do ar frio, durante a noite e madrugada segue do ponto 1 , a montante da cidade, até o ponto 17, a jusante da cidade. A partir disto, a lógica, demonstra que o local de maior acúmulo de ar frio seria ao final do perfil topográfico, enquanto em direção a montante a temperatura tenderia a aumentar (isto em condições de funcionamento das brisas de montanha).

Porém este raciocínio não é verificado, pois no meio do caminho, pois entre os pontos 6 e 16, que compreendem a área urbana de Viçosa, as temperaturas sempre são superiores ao meio rural, representado pelos ponto de 15 e o ponto 17 .

A partir disto, pode-se dizer que ao nível campo-cidade, durante à noite e madrugada a cidade de Viçosa é capaz de produzir ilhas de calor, que se localizam com maior propriedade na zona central de comércio $(Z C)$ e a porção ocidental da ZR1, onde se encontram os bairro de Fátima, Cléia Bernardes e o Alto do Santa Clara. Apesar das dimensões restritas do núcleo urbano de Viçosa (Figura 99), representado pela área central da cidade, que não ultrapassa aos seus $14 \mathrm{~km}^{2}$, valor este muito distante de outras realidades, que apresentam uma dimensão de mancha urbana muito superior, tais como: Barcelona $\left(99 \mathrm{~km}^{2}\right)$, Regina $\left(115 \mathrm{~km}^{2}\right)$, Paris $\left(93 \mathrm{Km}^{2}\right)$, Reykavik $\left(38 \mathrm{~km}^{2}\right)$ e Lodz $\left(214 \mathrm{~km}^{2}\right.$ a cidade e $15 \mathrm{~km}^{2}$ o centro). 


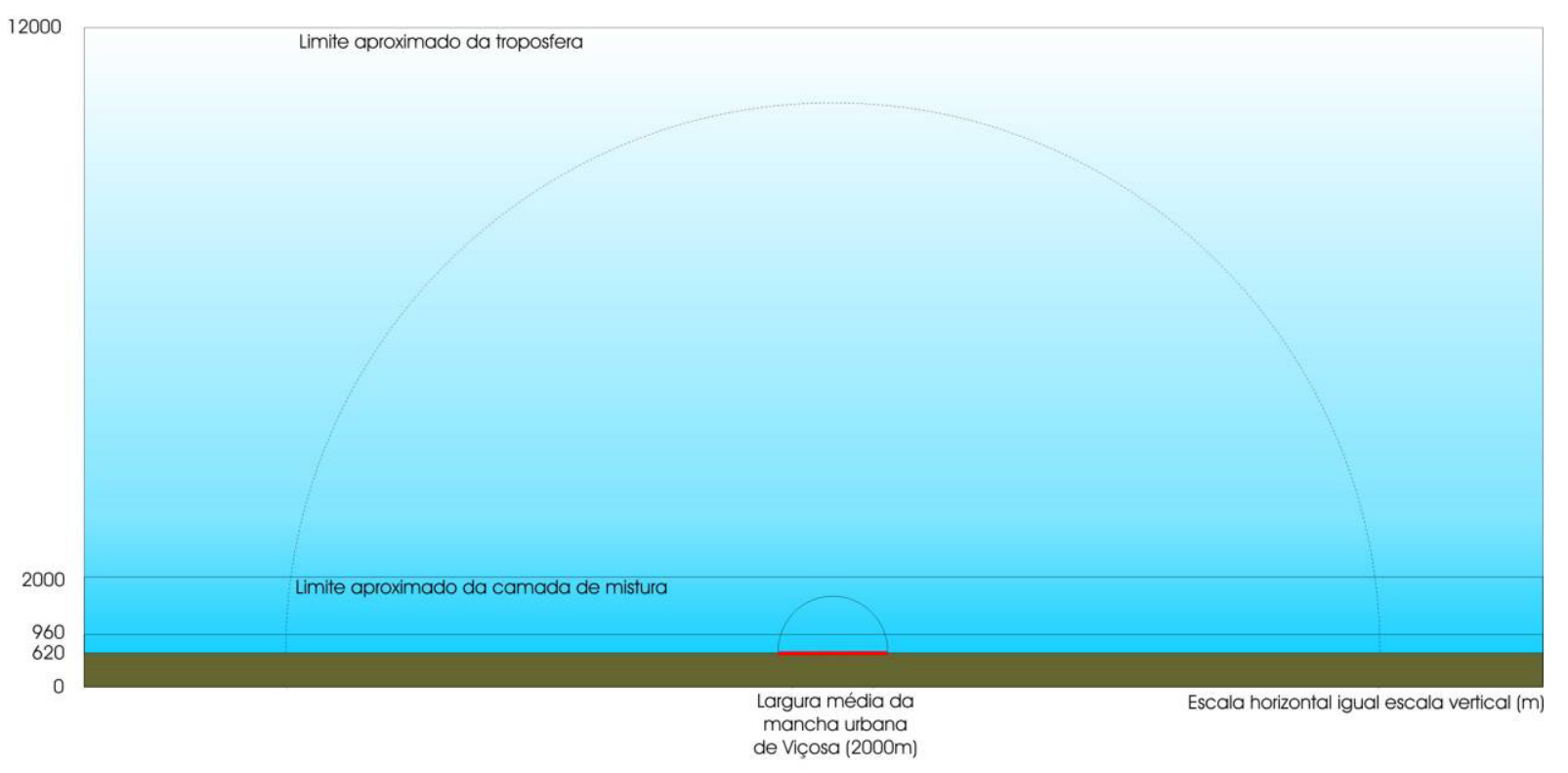

Figura 99. Representação esquemática da dimensão da mancha urbana de Viçosa.

Organizado por Tarik Rezende de Azevedo (2009).

A correlação entre as maiores intensidades da ilha de calor estar associada a localidade de maior densidade urbana, assim como apresentado por Sümeghy e Unger (2003), o horário de maior contraste de temperatura do ar foi verificado entre uma e duas horas após o pôr-do-sol, diminuindo de maneira lenta esta diferenciação térmica entre campo e cidade, permanecendo significativa ao longo de quase todos os horários de medida, sempre oscilando entre $2,0^{\circ} \mathrm{C}$ e $4,0^{\circ} \mathrm{C}$, exceto nos últimos horários, entre 3:00 e 4:00 horas da madrugada, quando a diferença chegava a $1,0^{\circ} \mathrm{C}$.

Já em relação às medidas dentro mancha urbana, os registros térmicos permitiram identificar uma forte influência da orientação das vertentes na distribuição espacial do campo térmico, principalmente no horário das 15:00 horas, quando os pontos de medida localizados ao longo da rodovia BR-120 sofrera o sombreamento das encostas do Morro do Café e do Escorpião. Mas, apesar disso, os pontos localizados na área central (entre os pontos 8 e 14) apresentaram quase sempre a existência do núcleo de calor principal ou secundário.

$\mathrm{Na}$ área central, as medidas realizadas por bicicleta foram de grande valia como instrumento, não identificando influência no processo de aquisição, leitura e registro da informação, permitindo no conjunto de dados, se mostraram consistentes. 
A utilização da bicicleta serviu aos propósitos do trabalho de pesquisa, principalmente, por se tratar uma área de extensão reduzida e de apresentar engarrafamentos no horário da tarde (12:00 horas) e noite (19:00 horas).

Em relação às observações verificadas na área central, o campo térmico se mostrou influenciável, de acordo com os sistemas produtores de tempo; entretanto, o núcleo de calor sempre foi constatado no horário da tarde, coincidentes com os pontos de menor verticalidade, que apresentaram as taxas de aquecimento e de resfriamento. Com relação ao ritmo das atividades semanais, foi verificado que há uma mudança do núcleo de calor, com variabilidade espacial entre a sexta-feira e o domingo.

As dinâmicas temporais da ilha de calor observadas nos permitiram dizer que sazonalmente, o fenômeno da ilha de calor é mais intenso no inverno, confirmando resultados de outras pesquisas tanto em cidades de clima tropical, quanto temperado. Ao nível diário, o resultado deste estudo acompanha os resultados de trabalhos recentes, que confirmam que a ilha de calor é um fenômeno noturno. 


\section{Desdobramentos futuros}

Durante a caminhada desta pesquisa muitos obstáculos surgiram no meio do percurso. Isto acarretou em supressões, até mesmo porque a tese fora desenvolvida mais fortemente nos dois últimos anos, conforme relatado no prólogo.

Uma delas foi a não elaboração de um mapa de unidades climáticas para Viçosa. Mas isto não nos impossibilita de refletir neste momento, esta temática tão importante para os estudos de clima urbano.

Diante das diversas abordagens de clima urbano e, suas contribuições específicas ao planejamento, uma delas é a elaboração de mapas de unidades climáticas, muito utilizado por Arquitetos e ainda pouco desenvolvido metodologicamente pelos Geógrafos do clima. Tanto assim, que até hoje existem apenas os trabalhos desenvolvidos para São Paulo (TARIFA; ARMANI, 2001), rio de Janeiro (BRANDÃO, 1996), Ilha do Governador (FIALHO, 2002), Zona Oeste do Rio de Janeiro (LUCENA, 2005) e a bacia hidrográfica do rio Aricanduva, em São Paulo (JARDIM, 2007).

O fator climático apresenta limitações de acordo com o recorte espacial utilizado, uma vez que processos de saída podem não ser contabilizados na avaliação da sustentabilidade das ocupações. Por exemplo, a alteração no regime hídrico entre a cidade e os arredores menos urbanizados provoca a jusante, alterações de ordem ambiental na quantidade e qualidade da água. Aliada à concentração das chuvas, a impermeabilização do solo provoca um aumento na taxa de escoamento superficial e aceleração da velocidade dos cursos d'água, provocando enchentes e diversos outros impactos na área da foz.

Nessas condições, embora os parâmetros climáticos não apontem alterações significativas, o ambiente onde se imprime a ação impactante encontra-se em franco processo de modificação.

Cabe nesse ponto, discutir a relevância que a adoção dos conceitos de escala nos estudos climáticos toma. Ainda que haja grande discussão sobre a classificação das escalas, tomaremos que a estratificação das escalas não é uma atividade restrita à somente a um recorte espacial, mas este, integrado a uma duração de um evento climático (JESUS, 1995, p.153).

Infelizmente, ainda não há uma categorização de escalas climáticas, capaz de gerar consenso entre os autores, como pode ser visto nos Quadros 4 e 5, desenvolvidos por Monteiro (1976) e Linacre (1981), respectivamente. 
Quadro 4. Hierarquização das Escalas climáticas segundo Monteiro (1976).

\begin{tabular}{|c|c|c|c|c|c|c|c|}
\hline \multirow[b]{2}{*}{$\begin{array}{l}\text { Ordens de } \\
\text { Grandeza }\end{array}$} & \multirow[b]{2}{*}{$\begin{array}{l}\text { Unidades de } \\
\text { Superfície }\end{array}$} & \multirow[b]{2}{*}{$\begin{array}{c}\text { Escalas } \\
\text { Cartográficas } \\
\text { de tratamento. }\end{array}$} & \multirow[b]{2}{*}{$\begin{array}{l}\text { Espaços } \\
\text { Climáticos }\end{array}$} & \multirow[b]{2}{*}{ Espaços Urbanos } & \multicolumn{3}{|c|}{$\begin{array}{l}\text { Estratégias de } \\
\text { Abordagem }\end{array}$} \\
\hline & & & & & Meios de Observação & $\begin{array}{c}\text { Fatores de } \\
\text { Organização }\end{array}$ & Técnicas de análise \\
\hline & $10^{6}$ (milhões & $1: 45000000$ & Zonal & & Satélites & Latitudes & Caracterização \\
\hline II & de $\mathrm{km})$. & $1: 10000000$ & & - & Nefanálises & Centros de Ação & geral comparativa \\
\hline
\end{tabular}

\begin{tabular}{|c|c|c|c|c|c|c|c|}
\hline III & $\begin{array}{c}10^{4} \text { (milhões } \\
\text { de } \mathrm{km} \text { ) }\end{array}$ & $\begin{array}{l}1: 5000000 \\
1: 2000000\end{array}$ & Regional & - & $\begin{array}{c}\text { Cartas sinóticas. } \\
\text { Sondagens. } \\
\text { Rede Meteorológica }\end{array}$ & $\begin{array}{c}\text { Sistemas } \\
\text { Meteorológicos }\end{array}$ & $\begin{array}{c}\text { Rede } \\
\text { Transectos }\end{array}$ \\
\hline
\end{tabular}

\begin{tabular}{|c|c|c|c|c|c|c|c|}
\hline IV & $\begin{array}{l}10^{2} \text { (cente- } \\
\text { nas de } \mathrm{km})\end{array}$ & $\begin{array}{c}1: 1000000 \\
1: 500000\end{array}$ & $\begin{array}{c}\text { Sub-regional } \\
\text { (fácies) }\end{array}$ & $\begin{array}{l}\text { Megalópolis, } \\
\text { grandes áreas } \\
\text { metropolitanas }\end{array}$ & & fatores geográficos & $\begin{array}{l}\text { Mapeamento } \\
\text { sistemático }\end{array}$ \\
\hline $\mathrm{V}$ & $\begin{array}{c}10 \text { (dezenas } \\
\text { de } \mathrm{km})\end{array}$ & $\begin{array}{l}1: 250000 \\
1: 100000\end{array}$ & Local & $\begin{array}{c}\text { Metrópolis } \\
\text { Área Metropolina }\end{array}$ & $\begin{array}{c}\text { Posto Meteorológico } \\
\text { Rede } \\
\text { Complementar }\end{array}$ & $\begin{array}{c}\text { Integração } \\
\text { Geoecológica } \\
\text { Ação Antrópica. }\end{array}$ & Análise espacial \\
\hline
\end{tabular}

\begin{tabular}{|c|c|c|c|c|c|c|}
\hline & $10^{-2}$ (cente- & $1: 50000$ & & Cidade Grande, & & Urbanismo \\
VI & $\begin{array}{c}\text { nas de milha- } \\
\text { res de metros }\end{array}$ & $1: 25000$ & Mesoclima & $\begin{array}{r}\text { bairro ou subúr- } \\
\text { bio de Metrópole. }\end{array}$ & & \\
\hline
\end{tabular}

\begin{tabular}{|c|c|c|c|c|c|c|}
\hline VII & $\begin{array}{c}\text { Dezenas de } \\
\text { metros }\end{array}$ & $1: 10000$ & Topoclima & $\begin{array}{c}\text { Pequena cidade. } \\
\text { Fácies de bairro/ } \\
\text { subúrbio de } \\
\text { cidade }\end{array}$ & $\begin{array}{c}\text { Registros móveis } \\
\text { (episódicos) }\end{array}$ & $\begin{array}{c}\text { Detalhe } \\
\text { (arquitetura) }\end{array}$ \\
\hline VII & metros & $1: 2000$ & Microclima & $\begin{array}{c}\text { Edificação } \\
\text { Habitação }\end{array}$ & $\begin{array}{c}\text { Baterias de } \\
\text { instrumentos } \\
\text { especiais }\end{array}$ & Habitação \\
\hline
\end{tabular}

Fonte: Monteiro (1976).

Talvez a pouca discussão sobre a questão das escalas seja a responsável pelo pouco interesse em se desenvolver procedimentos de elaboração de cartas climáticas, que se faz necessário muito hoje na questão do planejamento. E quando tal interesse ocorre se utiliza a proposta de Monteiro (op. cit.), muitas vezes, sem uma avaliação das reais necessidades do objetivo do trabalho. Isto porque, a mesma hierarquização foi concebida durante a década de 1970. Esta ponderação não desmerece o trabalho do autor, mas apenas chamar a atenção da necessidade de se repensar, a fim de melhor atender as atuais demandas de produção de mapas climáticos para o planejamento urbano.

Uma primeira reflexão à luz da nossa área de estudo. Admitindo que Viçosa apresentasse um clima urbano, a mesma cidade não poderia ser enquadrada na escala local, pois esta é definida com sendo de abrangência das áreas metropolitanas. 
Mas se o clima urbano, segundo o próprio Monteiro (1999) diz que o clima local responde pela "individualização" dos espaços climáticos. Uma cidade qualquer, que apresente comprovadamente se enquadra nesta escala do local. E a partir desta viriam às categorias inferiores: Mesoclimática, Topoclimática e Microclimática.

Quadro 5. Hierarquização das Escalas climáticas segundo Linacre (1981).

\begin{tabular}{|c|c|c|c|c|c|c|}
\hline $\begin{array}{c}\text { Ordens de } \\
\text { Grandeza }\end{array}$ & $\begin{array}{c}\text { Influências } \\
\text { meteorológicas }\end{array}$ & Área & $\begin{array}{c}\text { Extensão } \\
\text { (Km) }\end{array}$ & Processos relevantes & Prazo caracterísitco & $\begin{array}{c}\text { Altitude da camada de } \\
\text { uniformidade horizontal } \\
\text { (metros) }\end{array}$ \\
\hline Planetário & $\begin{array}{c}\text { sol, serras, } \\
\text { oceanos, } \\
\text { sistemas sinóticos }\end{array}$ & O mundo todo & 40.000 & Circulação geral & 1 ano & \\
\hline Sinótico & $\begin{array}{c}\text { Circulação geral, } \\
\text { latitude e } \\
\text { Climas regionais }\end{array}$ & Parte do mundo & 4.000 & $\begin{array}{c}\text { Circulações gerais e } \\
\text { ondas de Rosby }\end{array}$ & 1 semana & $2.000-15.000$ \\
\hline
\end{tabular}

\begin{tabular}{|c|c|c|c|c|c|c|}
\hline Mesoclima & $\begin{array}{c}\text { Circulação } \\
\text { secundária, } \\
\text { elevação, estação } \\
\text { e } \\
\text { topoclimas }\end{array}$ & região & 200 & $\begin{array}{c}\text { Ventos } \\
\text { geostróficos,n } \\
\text { nebulosidade e } \\
\text { subsidência }\end{array}$ & 8 horas & $500-2.000$ \\
\hline Topoclima & $\begin{array}{c}\text { Mesoclima, } \\
\text { topografia } \\
\text { adveção e } \\
\text { ventos nos altos } \\
\text { níveis }\end{array}$ & zonal & 10 & $\begin{array}{c}\text { Chuva, estabilidade } \\
\text { Dispersão de } \\
\text { poluição, convecção } \\
\text { e furacões. }\end{array}$ & 20 minutos & $10-500$ \\
\hline
\end{tabular}

\begin{tabular}{|c|c|c|c|c|c|c|}
\hline Microlcima & $\begin{array}{c}\text { Topoclima, } \\
\text { albedo, } \\
\text { umidade, } \\
\text { aspereza e } \\
\text { obstrução da } \\
\text { superfície }\end{array}$ & local & 0,10 & $\begin{array}{c}\text { Temperatura no } \\
\text { abrigo, umidade, } \\
\text { vento superficial, } \\
\text { radiação } \\
\text { turbulências e fluxos } \\
\text { verticais }\end{array}$ & Ao acaso & $0,1-10$ \\
\hline
\end{tabular}

\begin{tabular}{|c|c|c|c|c|c|c|}
\hline Superficial & $\begin{array}{c}\text { temperatura da } \\
\text { superficie } \\
\text { vento }\end{array}$ & $\begin{array}{c}\text { camada } \\
\text { limite da } \\
\text { superfície }\end{array}$ & 0,0001 & Difusão molecular & Ao acaso & $0-0,1$ \\
\hline
\end{tabular}

Fonte: Linacre (1981).

Mills (2007) ao discutir tal questão abordar o clima como mecanismo orientador de táticas a fim de alcançar uma sustentabilidade urbana. Esta última, derivada do conceito mais amplo de sustentabilidade, prevê o uso mais eficiente dos recursos, de forma a reduzir a degradação do meio ambiente e melhor as condições de vida e acesso da população.

Dentre os fatores de clima local, estão os parâmetros estabilizados em certa medida, que conferem um caráter similar a determinado recorte. Neste, pode ser apontado muitas vezes o nível municipal. Como no Brasil, as cidades são as sedes 
dos municípios, a proposta de Mills incorpora a idéia da cidade, seja a escala do local. Para a sub-regional ou macroescala, são reservadas as condições de clima que atingem uma caracterização mais geral do clima, com menos especificidades e, uma área maior.

Para Mills (op. cit.) o planejamento da cidade deve focar suas atenções à forma, função e organização dos sistemas urbanos, sendo que dentro deste sistema o clima atua nos papéis de receptáculo e influenciador.

Contudo, a incapacidade do recorte local responder por alterações de saída do sistema urbano, pode-se apontar as escalas mais abrangentes como dotadas de maior relevância do fator clima, paradoxalmente, com a diminuição das suas especificidades e aumento da complexidade de fatores. Compreender o clima em mesoescala permite ao planejador observar não somente a dinâmica interna à cidade, mas também externa.

O ato passa a abarcar informações relevantes como o grau de alterações climáticas e ambientais ao redor de determinado município e, possíveis impactos já localizados em um segundo município. Como o exemplo, a formação de uma ilha de calor, bem como alterações no regime da drenagem, não possuem impactos restritos àquele sistema urbano onde são produzidos e, por isso devem ser encarados numa escala de análise maior. 


\section{Lista de Referências}

ABREU, M. L. climatologia da estação chuvosa de Minas Gerais: de Nimer (1977) à Zona de Convergência do Atlântico Sul. Geonomos, Belo Horizonte, v. 6, n. 2, p. 17-22, 1997

AB'SABER, A. N. Províncias geológicas e domínios morfoclimáticos no Brasil. Geomorfologia, São Paulo, n. 20, 1970, 26p.

ACKERMAN, B. Temporal march of the Chicago heat island. Journal climate and applied meteorology, New York, v. 4, n. 6, p. 547-554, 1985.

AGUIAR, F. E. O. As alterações climáticas em Manaus no século XX. 150f. Dissertação (Mestrado em Geografia)-Centro de Ciências Matemáticas e da Natureza-Instituto de Geociências da UFRJ, Rio de Janeiro, 1995.

ALCOROFADO, M. J. O Clima da região de Lisboa: Contrastes e ritmos térmicos. Lisboa: Centros de Estudos de Lisboa/Universidade de Lisboa, 1993, 347p.

ALCOFORADO, M. J.; ANDRADE, E.; NEVES, M.; VIEIRA, G. H. Climas locais da Arrábia no inverno. Finisterra, Lisboa, v. 28, n. 55-56, p. 215-228, 1993.

ALCOFORADO, M. J.; ANDRADE, H. Nocturnal urban heat island in Lisbon (Portugal): main features and modeling attempts. Theoretical and applied climatology, Viena, v. 84, n. 1-3, p. 151-159, 2006.

ALONSO, M. S.; LABAJO, J. L.; FIDALGO, M. R. Characteristics of the urban heat island in the city of Salamanca (Spain). Atmosfera, Cuidad do México, v. 16, n. 3, p. 137-148, 2003.

AMANTINO, M. Escravidão Indígena em Minas Gerais nos séculos XVIII e XIX. Varia História, Belo Horizonte, v. 22, n. 35, p.189-206, 2006.

AMORIM, C. C. Leituras geográficas da Zona da Mata Mineira. 140f. Dissertação (Mestrado em Geografia) - Programa de Pós-graduação em Geografia da Universidade Federal Fluminense, UFF, 2004.

AMORIM, M. C. C. T. O clima urbano de Presidente Prudente-SP. 378f. Tese (Doutorado em Geografia Física) - Faculdade de Filosofia, Letras e Ciências Humanas, Programa de Pós-graduação em Geografia Física, USP, 2000.

AMORIM, M. C. C. T. Ilhas de calor em Birigui-SP. Revista brasileira de climatologia, Presidente Prudente, v. 1, n. 1, p. 121-130, 2005.

AMORIM, M. C. C. T. Diagnóstico da temperatura em cidades de pequeno e médio porte no Estado de São Paulo: Uma contribuição aos estudos de clima urbano. in: SIMPÓSIO BRASILEIRO DE GEOGRAFIA FÍSICA APLICADA, 11, 2005, São Paulo, Anais... São Paulo: USP, 2005, cd-rom.

AMORIM FILHO, O. B.; RIGOTTI, J. I. R. Os limiares demográficos na caracterização das cidades médias, Disponível em: http://www.abep.nepo.unicamp.br/docs/anais/pdf/2002/GT_MIG_ST25_Amorim_texto.pdf. Acesso em 12 dez. 2008.

AMORIM FILHO, O. B.; RIGOTTO, J. I. R.; CAMPOS, J. Os níveis hierárquicos das cidades médias de Minas Gerais. Revista RA ÉGA, Curituba, n. 13, p. 7-18, 2007.

ANDRADE, H. O clima urbano: Natureza, escalas de análise e aplicabilidade. Finisterra, Lisboa, v. 50, n. 80, p. 67-91, 2005.

ANDRADE, L. L.; SOUZA, L. H. SAKURAGI, J.; CASTRO, R. M. Estudo de ilhas de calor na cidade de São José dos Campos utilizando o canal infravermelho termal do Landsat-5 e o aerotransportado HSS. in: SIMPÓSIO BRASILEIRO DE SENSORIAMENTO REMOTO, 13, 2007, Santa Catarina, Anais... Florianópolis: INPE, 2005, cd-rom.

ANUNCIAÇÃO, V. S.; SANT'ANNA NETO, J. L. O clima urbano da cidade de Campo Grande-MS. in: SANT'ANNA NETO, J. L (org.).: OS climas das cidades brasileiras: São Luís (MA), Aracajú (SE), Campo Grande (MS), Petrópolis (RJ), Sorocaba (SP), Penápolis (SP) e Presidente Prudente (SP), Presidente Prudente: UNESP-Presidente Prudente/Faculdade de Ciências e Tecnologia/Programa de Pós-graduação em Geografia e Laboratório de Climatologia, p. 61-87, 2002, 227p. 
ARRAU, C. P.; PEÑA, M. A. Urban heat islands. Disponivel em http://uww.urbanheatislands.com/authors. Acesso em 4 jun. 2009

ARNIFIELD, A. J. Micro and mesoclimatology. Progress in physical geography, New York, v. 24, n. 2, p. 261-271, 2000.

ARNIFIELD, A. J. Micro and mesoclimatology. Progress in physical geography, New York, v. 25 , n. 1, p. 123-1339, 2001a.

ARNIFIELD, A. J. Micro and mesoclimatology. Progress in physical geography, New York, v. 25 , n. 4 , p. $560-569,2001$ b.

ARNIFIELD, A. J. Two decades of urban climate research: A review of turbulence, exchanges of energy and water, and the urban heat island. International journal of climatology, London, v. 23, n. 1, p. 1-26, 2003.

ARNIFIELD, A. J. Micro and mesoclimatology. Progress in physical geography, New York, v. 30, n. 5, p. 677-689, 2006.

ARNIFIELD, A. J. How to do urban climatology: a Personal View of the Legacy of Professor Tim Oke. Disponivel em: www.geography.ohio-state.edu/faculty/amfield/Arnfield_icuc6b.ppt Acesso em 26 mar. 2009.

ARRUDA, P. L.; PINTO, A. C. M. C.; FIALHO, E. S. O campo térmico da Grande Tijuca em situação sazonal de outono. in: SIMPÓSIO BRASILEIRO DE GEOGRAFIA FÍSICA, 11, São Paulo. Anais..., São Paulo: USP, 2005, cd-rom.

ASSIS, W. L. Análise do campo térmico e Hígrico em Belo Horizonte. 107f. Dissertação (Mestrado em Geografia)-Instituto de Geociências da UFMG, Belo Horizonte, 2001.

ASSIS, E. S. Urban climate applications on city planning: Reviewing the Brazilian studies In: INTERNATIONAL CONFERENCE ON URBAN CLIMATE, ICUC, 6, Proceedings..., Göteborg, Sweden, p. 663-666, 2006.

AYOADE, J. O. Introdução à Climatologia para os trópicos. 5 ed. Rio de Janeiro: Bertrand Brasil, 1998, 332p.

AZEVEDO, T. R. Derivação antrópica do clima na região metropolitana de Sap Paulo abordada como função do ritmo semanal das atividades humanas. 475f. Tese (Doutorado em Geografia Física), Faculdade de Filosofia, Letras e Ciências Humanas, Programa de Pós-graduação em Geografia Física, USP, 2001.

AZEVEDO, T. R.. Fluxos de calor gerado pelas atividades humana. in: TARIFA. J. R.. AZEVEDO. T. R. de (orgs.). Os climas na cidade de São Paulo: Teoria e prática. São Paulo: Pró-reitoria de cultura e Extensão. Universidade de São Paulo, p. 71-93, 2001, 199p.

AZEVEDO, T. R. Teste piloto do mapeamento das unidades topo e/ou microclimáticas de São Paulo. Disponível em http://www.geografia.fflch.usp.br/inferior/laboratorios/lcb/az/TA017.pdf. Acesso em 28 de ago. 2008

BAI, Y.; MIKAMI, T. Meansurement and mitigation of urban heat islands in Shanghai. China, In: INTERNATIONAL CONFERENCE ON URBAN CLIMATE, ICUC, 6, Proceedings..., Göteborg, Sweden, p. 362-365, 2006.

BEJARÁN, R. A.; CAMILLONI, I. A. Objective method for classifying air masses: an application to the analysis of Buenos Aires (Argentina) urban heat island intensity. Theoretical and applied climatology, Viena, v. 74, n. 1-2, p. 93-103, 2003.

BERNATZKY, A. The contribution of trees and green spaces to a town climate. Energy and buildings, New York, v. 5, n. 1, p. 1-10, 1982.

BELLO FUENTES, V. La isla de calor y solos del suelo en Guadalajara. Serie geográfica, Alcalá/Madrid, v. 4, p. 83-97, 1994.

BELLO FUENTES, V. La isla de calor nocturna y los usos del suelo en Alcalá de Hernares. Anales de geografia de la universidad complutense, Madrid, n. 15, p. 119-130, 1995. 
BEZERRA, T. S.; BRANDÃO, A. M. P. M. O clima do bairro Maracanã-RJ in: SIMPÓSIO BRASILEIRO DE CLIMATOLOGIA GEOGRÁFICA, 3, 1998, Salvador, Anais..., Bahia: UFBA, 1998, cd-rom.

BIAS, E. S.; BAPTISTA, G. M.; LOMBARDO, M. A. Análise do fenômeno de ilhas de calor urbanas, por meio da combinação de dados Landsat e Ikonos. in: SIMPÓSIO BRASILEIRO DE SENSORIAMENTO REMOTO, 12, 2005, Goiânia, Anais..., Goiás: INPE, 2005, cd-rom.

BORNSTEIN, R. D. Observations of the heat island effect in New York city. Journal of applied meteorology, New York, v. 7, n. 4, p. 575-582, 1968.

BORNSTEIN, R. D.; LIN, Q. Urban heat islands and summertime convective thunderstorms in Atlanta: three case studies. Atmospheric environment, New York, v. 34, n. 3, p. 507-516, 2000.

BORSATO, V. A.; BORSATO, F. H.; SOUZA FILHO, E. E. Análise ritmica e a variabilidade têmporo-espacial. in: SIMPÓSIO BRASILEIRO DE CLIMATOLOGIA GEOGRÁFICA, 6, 2004. Aracajú. Anais..., Sergipe: UFS, 2004, cd-rom.

BOTTYÁN, Z.; KIRCSI, A.; SZEGEDI, S.; UNGER, J. The relationship between built-up areas and the spatial development of the mean maximum urban heat island in Debrecen, Hungary. Internacional journal of climatology, Viena, v. 25, n. 3, p. 405-418, 2005.

BRANCO, M. L. G. C. Algumas considerações sobre a identificação de cidades médias. In: SPOSITO, M. E. B. (org.).: Cidades medias: espaços em transição. São Paulo: Expressão popular, p. 89-111, 2007, 632p.

BRANDT, K. Does an "ideal" urban climate exist? In: INTERNATIONAL CONFERENCE ON URBAN CLIMATE, ICUC, 6, Proceedings..., Göteborg, Sweden, p. 443-445, 2006.

BRANDÃO, C. A. L. A natureza da cidade e a natureza humana. in: BRANDÃO, C. A. L. (org.).: As cidades da cidade. Belo Horizonte: EdUFMG, p. 9-20, 2006, 197 p.

BRANDÃO, A. M. P. M. Tendências e oscilações climáticas na área metropolitana do Rio de Janeiro. 319f. Dissertação (Mestrado em Geografia Física)- Faculdade de Filosofia, Letras e Ciências Humanas, Programa de Pós-graduação em Geografia Física, USP, 1987.

BRANDÃO, A. M. P. M. As alterações climáticas na área metropolitana do Rio de Janeiro: uma provável influência do crescimento urbano. in: ABREU, M. A. (org.).: Natureza e sociedade no Rio de Janeiro. 3ed. Rio de Janeiro: Secretaria municipal de cultura, turismo e esportes/Departamento geral de documentação e informação cultural, p. 143-191, 1992, 336p.

BRANDÃO, A. M. P. M. O clima urbano da cidade do Rio de Janeiro. 362f. Tese (Doutorado em Geografia Física), Faculdade de Filosofia, Letras e Ciências Humanas, Programa de Pós-graduação em Geografia Física, USP, 1996.

BRANDÃO, A. M. P. M.; RUSSO, P. R.; FIALHO, E. S. Planejamento e clima urbano. Revista de Pós-graduação em geografia, Rio de Janeiro, v. 4, n. 4, p. 9-23, 2000.

BRANDÃO, A. M. P. M. A ilha de calor de outono na cidade do Rio de Janeiro: configuração em situações sinóticas contrastantes. in: SANT'ANNA NETO, J. A.; ZAVATINI, J. A. (orgs.).: Variabilidade e mudanças climáticas: Implicações ambientais e socioeconômicas. Maringá: UEM, p. 193-210, 2001, 259p.

BRANDÃO, A. M. P. M.; FERREIRA, J. L. N. C.; FERREIRA, L. C. F.; FARIAS, H. S. O clima da cidade do Rio de Janeiro: Comparação entre os bairros do Maracanã e Jardim Botânico. in: SIMPÓSIO BRASILEIRO DE CLIMATOLOGIA GEOGRÁFICA, 6, 2004, Aracajú, Anais..., Sergipe: UFS, 2004, cd-rom.

BROWN, G. Z.; DEKAY, M. Sol, vento e luz: Estratégias para o projeto de arquitetura, Traduzido por: Alexandre Ferreira da Silva Salvaterra. 2ed. Porto Alegre: Bookman, 2004, 415p.

CABRAL, E. Análise das alterações climática da cidade de São Paulo (1887-1995) no contexto da expansão de sua mancha urbana. 278f. Dissertação (Mestrado em Geografia Física), Faculdade de Filosofia, Letras e Ciências Humanas, Programa de Pós-Graduação em Geografia Física, USP, 1996. 
CANTAT, O. L'îlot de chaleur urbain parisien selon les types de temps. Revue norois, Viena, n. 191, p. 75-102, 2004.

CARDOSA, A. C.; MENDOZA, J. A. S. P.; ANGULO, G. V.; URÍAS, H. Q. Determinación de la isla de calor urbano en Ciudad Juarez mediante programa de cómputo. CULCYT (Cultura Científica y tecnológica), Ciudad Juárez, v. 5, n. 26, p. 3-16, 2008. Disponível em: http://www.uacj.mx/IT/CULCYT/Mayojunio2008/3\%20Artículo_1\%20Rev\%2026.pdf. Acesso em 20 nov. 2008.

CARNEIRO, P. A. S. Conquista e povoamento de uma fronteira: A Formação Regional da Zona da Mata no Leste da Capitania de Minas Gerais (1694-1835). 278f. Dissertação (Mestrado em Geografia)- Instituto de Geociências, Programa de Pós-graduação em Geografia, UFMG, 2008.

CARRARA, A. A. Estruturas Agrárias e Capitalismo: contribuição para o estudo da ocupação do solo e da transformação do trabalho na Zona da Mata mineira (séculos XVIII e XIX). Mariana: UFOP, 1999.

CARRERAS, C.; MARIN, M.; MARTIN VIDE, J. M.; MORENO, M. C.; SABI, J. Modificaciones térmicas en las ciudades. Avance sobre la isla de calor en Barcelona. Documents d'análisi geográfica, Barcelona, v. 17, p. 51-77, 1990.

CASÉ, P. A cidade desvendada: Reflexões e polêmicas sobre o espaço urbano, seus mistérios e fascínios. Rio de Janeiro: Ediouro, 2000, 301p.

CASELLES, V.; LÓPEZ GARCIA, M. J.; MÉLIA, J.; PÉREZ CUEVA, A. J. Analysis of the heat island effect of the city of Valencia, Spain, through air temperature transects and NOAA satellite data. Theoretical and applied climatology, Viena, v. 43, n. 4, p. 195-203, 1991.

CHANDLER, T. J. London's urban climate. The geographical journal, London, v. 128, n. 3 , p. 279-298, 1965.

CHANDLER, T. J. Absolute and relative humidities in towns. Bulletin of the American meteorological society, New York, v. 48, n. 6, p. 394-399, 1967.

CHANDLER, T. J. Urban climatology: Inventory and prospect. In: PROCEEDINGS OF THE SYMPOSIUM ON URBAN CLIMATES AND BUILD CLIMATOLOGY. World Meteorological Organization, Brussels, n. 254, p. 1-13, 1968.

CHRISTOFOLETTI, A. Impactos no meio ambiente ocasionados pela urbanização no mundo tropical. in: SOUZA, M. A. A. ; SANTOS, M.; SCARLATO, F. C.; ARROYO, M. (orgs.):: Natureza e sociedade de hoje: Uma leitura geográfica. 3ed. São Paulo: HUCITEC-ANPUR, p. 127-138, 1997, 244p.

CHOW, W. T. L.; ROTH, M. Temporal dynamics of the urban heat island of Singapore. International journal of climatology, Viena, v. 26, n. 15, p. 2243-2260, 2006.

CLARKE, J. F. Nocturnal urban boundary layer over Cincinnat. Ohio. Monthly weather review, New York, v. 97, n. 8, p. 582-589, 1969.

COLTRI, P. P.; VESLASCO, G. N.; POLIZEL, J. L.; DEMETRIO, V. A.; FERREIRA, $\mathrm{N}$. J. Ilha de calor na estação de inverno na área urbana do município de Piracicaba-SP. in: SIMPÓSIO BRASILEIRO DE SENSORIAMENTO REMOTO, 13, 2007, Santa Catarina, Anais..., Florianópolis: INPE, p. 5151-5157, 2005, cd-rom.

CORREA, D. O clima urbano no município de São Gonçalo: Uma análise episódica (28/7/2004) da influência do complexo topográfico patronato-mineiro, no campo térmico do quarto distrito de São Gonçalo-Neves, em situação sazonal de inverno. 2005. $75 f$. Dissertação (Monografia em Geografia). Departamento de Geografia, UERJ-FFP.

CORREAA, R. L. Construindo o conceito de cidade média. In: SPOSITO, M. E. B. (org.):: Cidades medias: Espaços em transição. São Paulo: Expressão popular, p. 23-34, 2007. 632p.

COLLISCHONN, E. O campo térmico da região metropolitana de Porto Alegre: Uma Análise a partir da Interação das Variáveis Ambientais na Definição do Clima Local. 1998. 155f. Dissertação (Mestrado em Geografia) - Departamento de Geografia/CFCH/UFSC. Florianópolis, 1998.

COLLISCHONN, E. Superando a educação bancária na formação de professores de Geografia através da experimentação. Revista ágora, Santa Cruz do Sul, v. 13, n. 1, p. 187-204, 2007. 
COSTA, A. C. L.; MATTOS, A. Estudo da ilha d calor em uma pequena cidade na região equatorial de in: SIMPÓSIO BRASILEIRO DE CLIMATOLOGIA GEOGRÁFICA, 3, 1998, Salvador, Anais..., Bahia: UFU, 1998, cd-rom.

COSTA, E. M. Cidades médias: contributos para sua definição. Finisterra, Lisboa, v. 27, n. 74, p. 101-128, 2002.

CUADRAT, J. M.; PITA, M. F. Climatologia. 2ed. Madrid: Cátedra, 496p.

DANNI, I. M. A ilha térmica de Porto Alegre: Contribuição ao estudo do clima urbano. Boletim gaúcho de geografia, Porto Alegre, n. 5, p. 33-48, 1980.

DEAN, W. A ferro e fogo: A história e a devastação da Mata Atlântica brasileira. São Paulo: Companhia das Letras, 2004, 484p.

DETTWILLER, J. Deep soil temperature trends and urban effects at Paris. Journal of applied meteorology, New York, v. 9, n. 1 p. 178-180, 1970.

DEOSTHALI, V. Impact of rapid urban growth on heat and moisture islands in Pune city, India. Atmospheric environment, New York, v. 34, n. 7 p. 2745-2745, 2000.

DREW, D. Processos interativos homem e meio ambiente. 6ed. Rio de Janeiro: Bertrand Brasil, 2005, 206p.

DOLFUS, O. O Espaço geográfico. 5ed. Rio de Janeiro: Bertrand Brasil, 1991, 121p.

DONATO, L. Variações termo-higrométricas decorrentes das diferentes formas de uso do solo em uma cidade de pequeno porte - Barbosa Ferraz-PR. In: ENCUENTRO DE GEÓGRAFOS DA AMÉRICA LATINA, 9, EGAL: Anais...,. Montevidéu, Uruguai, 2009. Disponível em: http://egal2009.easyplanners.info/programaExtendido.php. Acesso em 17 jun. 2009.

DU, M.; UENO, K.; YOSHINO, M. Heat island of a small city and its influences on the formation of a cold air lake and radiation fog in Xishuangbanna, Tropical China. Energy and buildings, London, v.15, p. 157-164, 1990/1991.

DUARTE, R. H. Olhares Estrangeiros. Viajantes no vale do rio Mucuri. Revista Brasileira de História, São Paulo, v. 22, n. 44, p. 267-288, 2002.

DUTRA, C. A.; COUTINHO, E. A.; FIALHO, E. S. As alterações climáticas e o crescimento desordenado das cidades: um estudo de caso da cidade de Viçosa/MG. In: SIMPÓSIO BRASILEIRO DE CLIMATOLOGIA GEOGRÁFICA, 7, Rondonópolis, Anais..., Mato Grosso: UFMT, 2006, cd-rom.

EAST, C. Comparaison du rayonnement solaire em ville et à la campagne. Cahiers de géographie de québec, Quebéc, v. 12, n. 25, p. 81-89, 1968.

ELIASSON, I.; HOLMER, B. Urban heat island circulation in Göteborg, Sweden. Theoretical and applied climatology, Viena, v. 42, n. 3, p. 187-196, 1990.

ELIASSON, I.; KNEZ, I.; WESTERBERG, U.; THORSSON, S.; LINDBERG, F. Climate and behaviour in a nordic city. Landscape and urban planning, New York, v. 82, v. 1, p. 72-82. 2007.

ELY, D. F. Teoria e método da climatologia geográfica brasileira: Uma abordagem sobre seus discursos e práticas. 208f. Tese (Doutorado em Geografia) - Faculdade de ciência e Tecnologia, Programa de Pós-graduação em Geografia. UNESP, Presidente Prudente, 2006.

ENDLICHER, W. Le îlot de chaleur d'Annecy, quelques remarques sur le climat local une ville alpine. Revue de géographie alpine, Paris, v. 69, n. 3, p. 407-420, 1981.

ERELL, E.; WILLIAMSOM, T. Intra-urban differences in canopy layer air temperature at a midlatitude city. International journal of climatology, Viena, v. 27, n. 9, p. 1243-1255, 2007.

ESCOURROU. G. La spécificité du climat de l'ágglomération parisiense. Revue de géographie de Lyon, Lyon, v. 65, n. 2, p. 20-27, 1990.

ESPINOLA, H. S. Sertão do rio Doce. Bauru: EDUSC, 2005, 485p.

EVANS, J. M.; SCHILLER, S. La isla de calor em ciudades com clima cálido-humedo: El caso de Tampico, México. Avances em energias renovables y médio ambiente, Buenos Aires, v. 9, p. 11.37-11.42, 2005. 
FIALHO, E. S. Análise temporoespacial do campo térmico na llha do Governador-RJ em situações sazonais de verão e inverno. 164f. Dissertação (Mestrado em Geografia)-Centro de Ciências Matemáticas e da Natureza-Instituto de Geociências da UFRJ, Rio de Janeiro, 2002.

FIALHO. E. S.; IMBROISI. E. G. A influência dos fragmentos verdes intra-urbanos no campo térmico no alto rio Joana-RJ. In: ENCONTRO DE GEÓGRAFOS DA AMÉRICA LATINA, 10, 2005. São Paulo, Anais..., São Paulo: USP, 2005, cd-rom.

FIALHO, E. S.; AZEVEDO, T. R. Uma análise da produção climatológica, na ciência geográfica brasileira entre 1992 e 2004. in: SIMPÓSIO BRASILEIRO DE CLIMATOLOGIA GEOGRÁFICA, 7, 2006. Rondonópolis, Anais..., Mato Grosso: UFMT, 2006, cd-rom.

FIALHO, E. S. Uma análise da produção climatológica, na ciência geográfica brasileira entre 1992 e 2006. in: SEMINÁRIO DE PESQUISA EM GEOGRAFIA FÍSICA - PROGRAMA DE PÓS-GRADUAÇÃO EM GEOGRAFIA FÍSICA-USP, 3, 2006. São Paulo, Anais..., São Paulo: USP, p. 91-102, 2006, cd-rom.

FIALHO. E. S. Práticas do ensino de climatologia através da observação sensível. Revista ágora, Santa Cruz do Sul, v. 13, n. 1, p. 105-123, 2007.

FIALHO, E. S.; SOUZA, J. J. L. L. Utilização do clima no planejamento com reflexo das condições ambientais nos centros urbanos. Acta geográfica, Boa Vista, v. 1, n. 2, p. 29-41, 2007.

FERNANDES, E. Direito e gestão na construção da cidade democrática no Brasil. in: BRANDÃO, C. A. L. (org.).: As cidades da cidade. Belo Horizonte: EdUFMG, p. 123-139, 2006, 197p.

FERREIRA, J. H. D.; NERY, J. T. Análise de componentes principais da precipitação do estado de Minas Gerais. In: CONGRESSO BRASILEIRO DE METEOROLOGIA, 12, 2002, Foz do Iguaçu, Anais... Disponível em: http://www.cbmet.com/edicoes.php?cgid=11. Acesso em 13 jun. 2009.

FIGUEROLA, P. I.; MAZZEO, N. A. Urban-rural temperature differences in Buenos Aires. International journal of climatology, Viena, v. 18, n. 15, p. 1709-1723, 1998.

FLANNERY, T. Os senhores do clima. Tradução de Jorge Calife. Rio de Janeiro: Record, 2007, 388p.

FRANÇA, D. A. Clima e percepção no bairro do Mérier-RJ. 75f. Dissertação (Graduação em Geografia)Centro de Ciências Matemáticas e da Natureza-Instituto de Geociências da UFRJ, Rio de Janeiro, 2003.

GARCIA, R. A.; NOGUEIRA, M. A inserção das cidades médias mineiras na rede urbana de Minas Gerais. Disponível em: http://www.cedeplar.ufmg.br/seminarios/seminario_diamantina/2008/D08A100.pdf. Acesso em 18 ago. 2008.

GARCIA-CUETO, O. R.; JAUREGUI-OSTOS, E.; TOUDERT, D.; TEJADA-MARTINEZ, A. Detection of the heat island in Mexicali. B. C. México and its relationship with land use. Atmosfera, Cuidad de México, v. 20, n. 2, p. 111-131, 2007.

GEDZELMAN, S. D.; AUSTIN, S.; CERMARK, R.; STEFANO, N.; PARTRIDGE, S.; QUESENBERRY, S.; ROBINSON, D. A. Mesoscala aspects of the urban heat island around New York city. Theoretical and applied climatology, Viena, v. 75, n. 1-2, p. 93-103, 2003.

GEIGER, R. Manual de microclimatologia: O clima da camada de ar junto ao solo. 4ed. Tradução de Ivone Gouveia. Lisboa: Fundação Calouste Gulbenkian, 1961, 556p.

GIRIDHARAN, R.; GANESAN, S.; LAU, S. S. Y. Daytime urban heat island effect in high-rise and high-density residential developments in Hong-Kong. Energy and buildings, New York, v. 36, n. 5, p. 525-534, 2006.

GIOVANINI, R. R. Regiões em movimento: Um olhar sobre a geografia histórica do sul de Minas e da Zona da mata mineira (1808-1897). 250f. Dissertação (Mestrado em Geografia) - Instituto de Geociências, UFMG, 2006.

GOLDREICH, Y. Urban climate studies in Johannesburg: a sub-tropical city located on a ridge: Review. Atmospheric environment, London, v. 26b, n. 3, p. 407-420, 1992. 
GUSTAVSSON, T.; KARLSSON, M. BOGREN, J.; LINDQVIST, S. Development of temperature patterns during clear nights. Journal of applied meteorology, New York, v. 37, n. 6, p. 559-571, 1998.

GUIDUGLI, M. M. B. A interação homem-natureza na questão da valorização dos recursos naturais. Revista de Geografia, São Paulo, v.3, p. 77-85, 1984.

GUIMARD, D. Les îlots de chaleur dans l'agglomération anncienne (Haute-Savoie). Revue de géographie alpine, Paris, v. 72, n. 4, p. 299-30, 1997.

GRIMMOND, C. S. B.; KING, T. S.; ROTH, M.; OKE, T. R. Aerodynamic roughness of urban areas derive from wind observations. Boundary-layer meteorology, Amsterdan, v. 89, n. 1, p. 1-24, 1998.

GRIMMOND, C. S. B. Progress in measuring and observing the urban atmosphere. Theoretical and applied climatology, Viena, v. 84, n. 1-3, p. 3-22, 2006.

KARL, R. R.; DIAZ, H. F.; KUKLA, G. Urbanization: Its detection and effect in the United States climate record. Journal of climate, New York, v. 1, n. 11, p. 1099-1123, 1988.

HAGE, K. D. Nocturnal temperatures in Edmonton, Alberta. Journal of applied meteorology, New York, v. 11, n. 2, p. 123-129

HASENACK, H; FLORES, F. E. V. O ambiente urbanizado e o clima urbano. Boletim gaúcho de geografia, Porto Alegre, n. 19, p. 57-90, 1994.

HASENACK, H; FLORES, F. E. V. Relações entre temperatura do ar e obstrução do horizonte local em Porto Alegre, RS sob tempo anticiclônico. Pesquisas, Porto Alegre, n. 21, n. 1, p. 12-16, 1994.

HINKEL, K. M.; NELSON, F. E.. KLENE, A. F.; BELL, J. H. The urban heat island in winter at Barrow. Alaska. International journal of climatology, Viena, v. 23, n. 15, p. 1889-1905, 2003.

HISSA, C. E. V. Ambiente e vida na cidade. in: BRANDÃO, C. A. L. (org.).: As cidades da cidade. Belo Horizonte: EdUFMG, p. 81-92, 2006, 197p.

HUTCHEON, R. J. Observations of the urban heat island in a small city. Bulletin of the american meteorological society, Boston, v. 48, n. 1 p. 7-9, 1967.

HSU, S. I. Variation of an urban heat island in Phoenix. Professional geographer, New York, v. 36, n. 2, p. 196-200, 1984.

HOLMER, B.; THORSSON, S.; ELIASSON, I. Cooling rates, sky view factors and the development of intra-urban air temperature differences. Geografiska annaler: Series A. Physical Geography, Göteborg, v. 89A, n. 4, p. 237-248, 2007.

INSTITUTO DE PESQUISAS ECONÔMICAS APLICADAS; INSTITUTO BRASILEIRO DE GEOGRAFIA E ESTATÍSTICA; UNIVERSIDADE DE CAMPINAS. Caracterização e Tendências da Rede Urbana do Brasil : Estudos Básicos para a Caracterização da Rede Urbana. Rio de Janeiro e São Paulo: IPEA/IBGE/UNICAMP, 2000, 48p.

KATSOULIS, B. D.; THEOHARATOS, G. A. Indications of the heat island in Athens. Greece. Journal of climate applied meteorology, New York, v. 24, n. 12, p. 1296-1302, 1985.

KANDA, M. Progress in urban meteorology: A review. Journal of the meteorological society of Japan, Tokyo, v. 85b, p. 363-383, 2007.

KIFLE, B. Urban heat island and its feature in Addis ababa (a case study). In: INTERNATIONAL CONFERENCE ON URBAN CLIMATE. 5, ICUC: Proceedings...,. Lodz, Poland, 2003. Disponível em: http://www.geo.uni.lodz.pl/ icuc5/text/P_6_11.pdf. Acesso em 15 nov. 2008.

KLYSIK, K.; FORTUNIAK, K. Temporal and spatial characteristics of the urban heat island of Lodz, Poland. Atmospheric environment, New York, v. 33, n. 24-25, p. 3885-3895, 1999.

KOK. G. Resenha do livro: Civilização e revolta: os Botocudos e a catequese na Província de Minas. Bauru, SP: EDUSC, 2004. 491p. Espaço Ameríndio, Porto Alegre, v. 1, n. 1, p. 211-214, jul./dez. 2007.

KOPEC, R. J. Further observations of the urban heat island in a small city. Bulletin of the american meteorological society, New York, v. 51, n. 7, 602-606, 1970. 
KOPEC, R. J Daily spatial and secular variations of atmospheric humidity in a small city. Bulletin of the american meteorologigal society, New York, v. 12, n. 4, 639-648, 1973.

IMBROISI, E. G.; JOSÉ, F. C.; FIALHO, E. S. A importância da orientação das vertentes nas áreas adjacentes do Maciço da Tijuca em situação sazonal de outono. in: SIMPÓSIO BRASILEIRO DE CLIMATOLOGIA GEOGRÁFICA, 6, 2004. Aracajú. Anais..., Sergipe: UFS, 2004, cd-rom.

INSTITUTO BRASILEIRO DE GEOGRAFIA E ESTATÍSTICA. Projeto RADAMBRASIL: Folhas SF.23/24 Rio de Janeiro/Vitória. Rio de Janeiro: IBGE, 2003, 780 p. 6 mapas. Disponível em cd-rom.

INSTITUTO NACIONAL DE METEOROLOGIA. Normais climatológicas (1961-1990). Brasília: Ministério da agricultura e reforma agrária, 1992, 84p.

IZQUIERDO, L. O.; GARCIA, I. S.; VILLAR, A. G. Em microclima urbano de Logroño em invierno: Um modelo espacial de comportamiento higrotérmico. Cuadernos de investigacion geográfica, Logroño, v. 15, n. 1-2, p. 87-98, 1989.

JARDIM, C. H. Proposta de síntese climática a partir do comportamento térmico e higrométrico do ar em áreas urbanas. 338f. Dissertação (Doutorado em Geografia)Instituto de Geociências da UNICAMP, Campinas, 2007.

JARDIM, C. H.; FERREIRA, M. A correlação dos fato geográficos em climatologia a partir da noção de sítio e "situação".. In: ENCONTRO DE GEÓGRAFOS DA AMÉRICA LATINA, 10, 2005. São Paulo, Anais..., São Paulo: USP, 2005, cd-rom.

JAUREGUI, E. The urban climate of Mexico city. Erdkunde, Berlin, v. 27, p. 289-307, 1973.

JAUREGUI, E. Mexico city's urban heat island revisited. Erdkunde, Berlin, v. 47, p. 185-195. 1993.

JESUS, E. F. R. Espaço, tempo e escala em climatologia. 203f. Tese (Doutorado em Geografia Física ), Faculdade de Filosofia, Letras e Ciências Humanas, Programa de PósGraduação em Geografia Física, USP, 1995.

JONES, P. D. Maximum and minimum temperature trends in Ireland, Italy, Thailand, Turkey and Bangladesh. Atmospheric research, New York, v. 37, n. 1-3, p. 67-78, 1995.

JONHSON, D. B. Urban modification of diurnal temperatures cycles in Birmingham, UK. Journal of climatology, London, v. 5, p. 221-225, 1985.

LADEIA, L. C. E.; MOREIRA. J. L. B.; SILVA, P. E. M.; SILVA, H. Z. Aspectos meteorológicos brasileiros: Minas gerais e caracteres urbanos de drenagem. In: CONGRESSO BRASILEIRO DE METEOROLOGIA, 5, 1988, Brasília, Anais... Disponível em : http://www.cbmet.com/edicoes.php?cgid=11. Acesso em 10 jun. 2009.

LANDSBERG, H. E.; MAISEL, T. N. Micrometeorological observations in an area of urban growth. Boundary-layer meteorology, London, v. 2, n. 3, p. 365-370, 1972.

LANDSBERG, H. E. The urban climate. New York: Academic Press, 1981, 275p.

LANDSBERG, H. E. Man-made climatic changes: Man's activities have altered the climate of urbanized areas and may affect global climate in the future. Science, New York, v. 170, n. 3964, p. 1265-1274, 1970.

LANDSBERG, H. E. O Clima das cidades. Revista do departamento de geografia, São Paulo, v. 18, p. 95-111, 2006.

LIMA, M. D. V. de.; RONCAGLIO, C. Degradação socioambiental urbana, políticas públicas e cidadania. Desenvolvimento e meio ambiente, Curitiba, n. 3, p. 53-63, 2001.

LIVADA, I.; SANTAMOURIS, M.; NIACHOU, K.; PAPANIKOLAOU, N.; MIHALAKAKOU, G. Determination of places in the Athens area where the heat island effect is observed. Theoretical and applied climatology, Viena, v. 71, n. 3-4, p. 219-230, 2002.

LEE, D. O. Urban warming? An analysis of recent trends in London's heat island. Weather, London, v. 47, n. 2, p. 50-56, 1992. 
LEE, D. O. Urban-rural humidity differences in London. International journal of climatology, Viena, v. 11, n. 5, p. 577-582, 1991.

LOMBARDO. M. Ilha de calor nas metrópoles: O exemplo de São Paulo. São Paulo: Hucitec, 1985, 244p.

LOPES, A. Drenagem e acumulação de ar frio em noites de arrefecimento radiativo. Um exemplo no vale de Barcarena (Oeiras). Finisterra, Lisboa, v. 30, n. 59-60, p. 149-164, 1995.

LOKOSHCHENKO, M. A.; ISAEV, A. A. Influence of Moscow city on the air temperature in central Russia. In: INTERNATIONAL CONFERENCE ON URBAN CLIMATE, 5, ICUC. Proceedings..., Lodz, Poland, 2003. Disponível em: http://www.geo.uni.lodz.pl/ icuc5/. Acesso em 21 abr. 2008.

LYNCH, K. A cidade como meio ambiente. In: DAVIS. K. et. al. (orgs.):: Cidades: A urbanização da humanidade. 2ed. Tradução de José Rezenik. Rio de Janeiro: Zahar, p. 205-216, 1972, 221p.

LOPEZ GOMEZ, A.; ALMENDROS, M. G.; Y FERNANDES GARCIA, F. El clima urbano de Madrid: Tipologias de la isla de calor. in: CLIMATOLOGY AND AIR POLLUTION, 1, 1995. Mendóza. Proceedings..., Argentina: Universidad Nacional de Cuyo, p. 19-35, 1995.

LUCENA, A. J. O clima de Bangu no contexto do clima urbano da cidade do Rio de Janeiro. 91f. Dissertação (Graduação em Geografia)-Centro de Ciências Matemáticas e da Natureza-Instituto de Geociências da UFRJ, Rio de Janeiro, 2004.

LUCENA, A. J. O campo térmico na Zona oeste do Rio de Janeiro: uma contribuição ao estudo do clima urbano. 143f. Dissertação (Mestrado em Geografia)-Centro de Tecnologia e CiênciasInstituto de Geociências-Programa de Pós-graduação em Geografia da UERJ, Rio de Janeiro, 2005.

MENDONÇA, M. A dinâmica têmporo-espacial do clima subtropical na região conurbada de Florianópolis-SC. 343f. Tese (Doutorado em Geografia Física). Faculdade de Filosofia, Letras e Ciências Humanas. Programa de Pós-graduação em Geografia Física, USP, 2002.

MAGEE, N.; CURTIS.; J.; WENDLER, C. The urban heat island effect at Fairbanks, Alaska. Theoretical and applied climatology, Viena, v. 64, n. 1-2, p. 39-47. 1999.

MCKENDRY, I. G. Applied Climatology. Progress in physical geography, New York, v. 27, n. 4, p. 597-606, 2003.

MAITELLI, G. T. Uma abordagem tridimensional de clima urbano em área tropical continental: $O$ Exemplo de Cuiabá-MT. 197f. Tese (Doutorado em Geografia Física). Faculdade de Filosofia, Letras e Ciências Humanas. Programa de Pós-Graduação em Geografia Física, USP, 1994.

MAITELLI. G. T.; SOUZA. S. C.; PINHO. J. G. The magnitude of urban heat island in the tropical continental areas in Brazil. In: INTERNATIONAL CONFERENCE ON URBAN CLIMATE., 5, ICUC: Proceedings...,. Lodz, Poland, 2003. Disponível em: http://uww.geo.uni.lodz.p/ -icuc5/ textP_2_17.pdf. Acesso em 15 nov. 2008.

MALHEIROS. A geografia do clima em Copacabana: $O$ campo térmico e a percepção da população enquanto subsídio a programas de educação ambiental. $74 \mathrm{f}$. Dissertação (Graduação em Geografia)-Centro de Ciências Matemáticas e da Natureza-Instituto de Geociências da UFRJ, Rio de Janeiro, 2003.

MARSH, W. M. Landscape planning: Environmental applications. 2 ed. New York:: Jonh Wiley, 1991, 340p.

MARTINS, L. A. A temperatura do ar em Juiz de Fora-MG: Influências do sítio e da estrutura urbana. 1996. 168f. Dissertação (Mestrado em Geografia). Instituto de Geociências e Ciências Exatas - UNESP, Rio Claro, 1996.

MARTINS, L. A.; FIALHO, E. S. As possíveis alterações climáticas na cidade de Juiz de Fora-MG (1915-2000). In: SEMINÁRIO NACIONAL DE IMPACTOS SÓCIOAMBIENTAIS URBANOS: DESAFIOS E SOLUÇÕES, 1, 2002. Paraná. Anais..., Curitiba, 2002, cd-rom.

MASSON, V. Urban surface modeling and the meso-scale impact cities. Theoretical and applied climatology, Viena, v. 84, n. 1-3, p. 35-45, 2006.

MARTIN. F. P.; POWELL. G. L. The urban heat island. Ohio. in: CONFERENCE ON METROPOLITAN PHYSICAL ENVIRONMENT, 1, 1975. New York. Proceedings..., EUA: Northeastern Forest Experiment Station/Forest Service. U.S. Department of Agriculture/ College of Environmental Science and Forestry/ State University of New York at Syracuse/ American Meteorology Society, p. 94-97, 1977. 
MELHUISH, E.; PEDDER, M. Observing an urban heat island by bicycle. Weather, London, v. 53, n. 4, p.121-128, 1998.

MELLO, F. A. O. Análise do processo de formação da paisagem urbana do município de Viçosa. Minas Gerais. 103f. Dissertação (Mestrado em Ciência Florestal)-Departamento de Engenhara Florestal, UFV, Viçosa, 2002.

MÉNDEZ, C. C. M. Diferencias térmicas em la ciudad de Toluca. México. In: COLÓQUIO GEOGRÁFICO. AMERICA LATINA e SIMPÓSIO MEXICANO-POLACO, 1, Anais..., Faculdad de Geografia. U.A.E.M, Toluca, p. 139-148, 1993.

MÉNDEZ, C. C. M.; URIBE, D. M.; BECERRIL, L. A. G. Isla de calor em Toluca, México. Ciência ergo sum, Toluca, v. 14, n. 3, p. 307-316, 2008.

MENDONÇA, F. de A. O Clima e o planejamento urbano das cidades de porte médio e pequeno: Proposições Metodológicas para Estudo e sua Aplicação à Cidade de Londrina/PR. 1994. 322f. Tese (Doutorado em Geografia Física) - Faculdade de Filosofia. Letras e Ciências humanas. Programa de Pós-graduação em Geografia Física, USP, 1994.

MENDONÇA, F. de A. O clima urbano de cidades de porte médio e pequeno: aspectos teórico-metodológicos e estudos de caso. in: SANT'ANNA NETO. J. A.; ZAVATINI. J. A. (orgs.):: Variabilidade e mudanças climáticas: implicações ambientais e socioeconômicas. Maringá: UEM, p. 167-192, 2001, 259p.

MENDONÇA. F. de A. O estudo do clima urbano no Brasil: Evolução, tendência e alguns desafios. In: MONTEIRO. C. A. F.; MENDONÇA. F. (orgs.).: Clima urbano. São Paulo: Contexto, p. 175-192, 2003, 192p.

MICHEL, M. Ville moyenne. ville moyen. Annales de géographie, Paris, v. 86, n. 478. p. 641-685, 1977.

MILLS, G. Progress toward sustainable settlements: a role for urban climatology. Theoretical and applied climatology, Viena, v. 84, n. 1-3, p. 69-76, 2006.

MILLS, G. Luke Howard and The climate of London. Weather, London, v. 63, n. 6, p. 153-157, 2008.

MINAKI, C.; AMORIM, M. C. C. T. Comparação da temperatura e da umidade relativa do ar na área urbana e rural de Guararapes-SP. In: SIMPÓSIO BRASILEIRO DE GEOGRAFIA FÍSICA APLICADA, 11, 2005. São Paulo. Anais..., São Paulo: USP, 2005, cd-rom.

MONTEIRO, C. A. F. El estudio de los climas urbanos en las regiones tropicales de America del sur: La contribución brasileña In: PROCEEDINGS TECH. CONFERENCE URBAN CLIMATOLOGY AND ITS APPLICATIONS WITH SPECIAL REGARD TO TROPICAL AREAS, Mexico City, Mexico, 22p. 1984.

MONTEIRO, C. A. F. Teoria e clima urbano. São Paulo: IGEOG/USP, 1976, 181p.

MONTEIRO. C. A. F. A cidade como processo derivador ambiental e a geração de um clima urbano: Estratégias na abordagem Geográfica. Revista geosul, Florianópolis, n. 9, p. 81-113, 1990.

MONTEIRO, C. A. F. Teoria e clima urbano: Um projeto e seus caminhos. in: MONTEIRO. C. A. F.; MENDONÇA. F. (orgs.).: Clima urbano. São Paulo: Contexto, p. 9-67, 2003, 192p.

MONTEIRO, C. A. F. O homem, a natureza e a cidade: Planejamento do meio físico. Revista eletrônica geografar, Curitiba, v. 3, n. 1, p. 73-101, 2008.

MONTEIRO. A. O clima urbano do Porto: contribuição para a definição das estratégias de planejamento e ordenamento do território. Fundação Calouste Gulbenkian-Junta Nacional de Investigação Científica e Tecnológica: Lisboa, 1997, 485p.

MORENO GARCIA, M. C. Climatologia urbana. Barcelona: Edicions universitat de Barcelona, 1999, 71p.

MORGAN, D.; MYRUP, L.; ROGERS, D.; BASKETT, R. Microclimates wthin an urban area. Annals of the association of american geographers. New York, v. 67, n. 1, p. 55-65. 1977.

MOURA, M. O.; ZANELLA, M. E.; DALES, M. C. L. Ilhas térmicas na cidade de FortalezaCE. Boletim Goiânia de Geografia, Goiânia, v. 28, n. 2, p. 33-44, 2008.

NIMER, E. Climatologia do Brasil. 2 ed. Rio de Janeiro: IBGE, 1989, 421p. 
NISHIZAWA, T. Clima, hidrologia e ecologia urbana. Rio de Janeiro: EDUERJ, 1983I 83p. NASCIMENTO, C. C. Clima e morfologia urbana em Belém. Belém: UFPA/NUMA, 1995, 157p.

NOVO, E. M. L. de M. Utilização de dados de sensoriamento remoto em estudos ambientais. Geografia, Rio Claro, v. 13, n. 25, p. 43-51, 1988.

OJIMA, T.; MORIYAWA, M. Earth surface heat balance changes caused by urbanization. Energy and buildings, London, v. 4, n. 2, p. 99-114, 1982.

OKE, T. R.; EAST, C. The urban boundary layer in Montreal. Boundary-layer meteorology, London, v. 1, n. 4, p. 411-437, 1971.

OKE, T. R. City size and urban heat island. Atmospheric environment, New York, v. 7, n. 8, p. 769-779, 1973

OKE, T. R. Boundary-layer climates. London: Methuen, 1978, 372p.

OKE, T. R. Canyon geometry and the nocturnal urban heat island: Comparison of scale model and field observations. Journal of climatology, New York, v. 1, n. 3, p. 237-254, 1981.

OKE, T. R. The energetic basis of the urban heat island. Quarterly journal of the royal meteorological society, London, v. 108, n. 455, p. 1-24, 1982.

OKE, T. R. The urban energy balance. Progress in physical geography, New York, v. 12. n. 4, p. 471-508, 1988.

OKE, T. R. Thermal remote sensing of urban climates. Remote sensing of environment, New York, v. 86, n. 3, p. 371-384, 2003.

OKE, T. R. Towards better scientific communication in urban climate. Theoretical and applied climatology, Viena, v. 84, n. 1-3, p. 179-190, 2006.

OLIPHANT, A. J.; SPRONKEN-SMITH, R. A.; STURMAN, A. P.; OWENS, I. F. Spatial variability of surface radiation fluxes in mountainous Terrain. Journal of applied meteorology, New York, v. 42, n. 1, p. 113-128, 2003.

OSTOS, E. J. Impact os land-use changes on the climate of the Mexico city region. Investigaciones geograficas, Cuidad del Mexico, v. 55, p. 46-60, 2004.

YAMASHITA, S. The urban dimate of Tokyo. Geographical review of Japan, Tokyo, v. 63b, n. 1, p. 98-107, 1990.

YU. P.; YANG. T.; WU. C. Impact of climate change on water resources in southern Taiwan. Journal of hydrology, Amsterdan, v. 260, p.161-175, 2002.

PARK, $H$. Features of the heat island in Seoul and its surrounding cities. Atmospheric environment, London, v. 20, n.10, p. 1859-1866, 1986.

PARRY, M. Local temperature variations in the Reading area. The quaterly journal of the royal meteorological society, London, v. 82, n. 351, p. 45-57, 1956.

PAULA, J. A. A cidade e a universidade. in: BRANDÃO. C. A. L. (org.).: As cidades da cidade. Belo Horizonte: UFMG, p. 35-53, 2006, 197p.

PEASE, R. W.; LEWIS, J. E.; OUTCALT, S. I. Urban terrain climatology and remote sensing, Annals of the Association of American Geographers, New York, v. 66, n. 4, p. 557-569, 1976.

PEREIRA, P. V. S.; BRANDÃO, A. M. P. M. Urbanização e derivações no clima local: Estudos de cano no bairro da Penha in: SIMPÓSIO BRASILEIRO DE CLIMATOLOGIA GEOGRÁFICA, 8, 2008. Alto Caparaó. Anais...., Minas Gerais: UFU, 2008, cd-rom.

PERSSON, P. Differential nocturnal cooling in the landscape detected by mobile measurements. Theoretical and applied climatology, Viena, v. 56, p. 215-224, 1997.

PETRALI, M.; MORABITO, M.; BARTOLONI, G.; TORRIGIANI, T.; CECCHI, L.; ORLANDINI, S. Air temperature distribution at pedestrian level in Florence (Italy) through fixed and mobile sensor measurements. In: INTERNATIONAL CONFERENCE ON URBAN CLIMATE. ICUC, 6, Proceedings...,. Göteborg, Sweden, p. 454-457, 2006. 
PERTSCHI, S. C. Aspectos do campo térmico da área urbana de São José dos Pinhais-PR: situação de verão. 172f. Dissertação (Mestrado em Construção Civil). Setor de Tecnologia. Programa de Pós-Graduação em Construção Civil, UFPR, 2005.

PEZUTO, C. C; LABAKI, L. C.; FRANCISCO FILHO, L. L. Urban environment analysis through móbile measurements and city maps: Example in Campinas. Brazil. In: INTERNATIONAL CONFERENCE ON URBAN CLIMATE. ICUC, 6, Proceedings...,. Göteborg. Sweden, p. 505-508, 2006.

PHILANDRAS, C. M.; METAXAS, D. A.; NASTOS, P. T. Climate variability and urbanization in Athens. Theoretical and applied climatology, Viena, v. 63, n. 1, p. 65-72, 1999.

PINHO, O. S.; MANSO ORGAZ, M. D. The urban heat island in a small city in coastal Portugal. International journal of biometeorology, London, v. 44, n. 4, p. 198-203, 2000.

PINHEIRO, G. M.; AMORIM, M. C. C. T. Estudo de clima urbano em cidade de pequeno porte do oeste paulista: o caso de Euclides da Cunha paulista-SP- Brasil. In: ENCUENTRO DE GEÓGRAFOS DA AMÉRICA LATINA, 9, EGAL, Anais...,. Montevidéu, Uruguai, 2009. Disponível em: http://egal2009.easyplanners.info/programaExtendido.php. Acesso em 17 jun. 2009.

POPE, A. M. G.; PINTO, A. C. M. C.; BARROS, F. S. M.; ARRUDA, P. L.; CAMPOS, M. A. C.; FIALHO, E. S. O campo térmico na bacia hidrográfica do rio rainha em situação sazonal de outono. in: SIMPÓSIO BRASILEIRO DE CLIMATOLOGIA GEOGRÁFICA, 6, 2004. Aracajú. Anais..., Sergipe: UFS, 2004, cd-rom.

POPULATION REFERENCE BUREAU. Population bulletin. World population highlights. v. 62, n. 3, 2007. Disponível em http://www.prb.org. Acessado em 28 out. 2008.

POTCHTER, O.; YAAKOV, Y.; GODON, O. The magnitude of the urban heat island of a city in an arid zone: The case of Beer Sheva. Israel. In: INTERNATIONAL CONFERENCE ON URBAN CLIMATE. ICUC, 6, Proceedings...,. Göteborg, Sweden, p. 450-453, 2006.

PRATIS CUADRAT; DE LA RIVA, J.; LOPEZ, F.; MARTI, A. EI médio ambiente urbano em Zaragoza: Observaciones sobre la isla de calor. Anales de geografia de la universidad complutense, Madrid, n. 13, p. 127-138, 1993.

RAO, P. K. Remote sensing of urban heat islands from an environmental satellite. Bulletin of the american meteorological society, Boston, v. 53, n. 8, p. 647-648, 1972.

RAZUVAEV, V. N.; APASOVA, E. G.; BULYGINA, O. N.; MARTUGANOV, R. A. Variations in the diurnal temperature range in the European region of the former USSR during the cold season. Atmospheric research, New York, v. 37, n. 1-3, p. 45-51, 1995.

RESENDE, S. B. Estudo de crono-toposeqüência em Viçosa - Minas Gerais. 71f. Dissertação (Mestrado em Solos) - Departamento de Solos, Universidade Federal de Viçosa, 1971.

RUIZ, J. M. G.; IZQUIERDO, L. M. O.; VADILO, J. A.; VILLAR, A. G. Organization espacial de las temperaturas en la ciudad de Logroño. Cuadernos de investigacion geográfica, Logroño, v. 15, n. 1-2, p. 87-98, 1989.

RIBEIRO FILHO, G. A Formação do espaço construído: Cidade e legislação urbanística em Viçosa. MG. 244f. Dissertação (Doutorado em Arquitetura e Urbanismo). Departamento de Arquitetura, Universidade Federal do Rio de Janeiro, 1997.

RIZWAN, A. M.; DENNIS, Y.C; LIU, C. A review on the generation. determination and mitigation of Urban Heat Island. Journal of Environmental Sciences, Tokyo, v. 20, n. 1, p. 120-128. 2008.

ROBAA. S. M. Urban-suburban/rural differences over greater Cairo, Egypt. Atmosfera, Cuidad del México, v. 16, n. 3, p. 157-171, 2003.

ROCHA, V. M. Influências antrópicas no campo termohigrométrico do município de Viçosa - MG em situações sazonais de primavera no ano de 2006. 75f. Dissertação (Monografia em Geografia). Departamento de Artes e Humanidades-Curso de Geografia, UFV.

ROCHEFORT, M. Méthodes d'études dês réseaux urbaisn: intérêt de l'analyse du secteur tertiaire de La population active. Annales de géographie, Paris, v. 66, n. 354, p. 125-143. 1977. 
RODRIGUES, J. M. Impacto da urbanização no clima da cidade de Viçosa-MG. 49f. Dissertação (Monografia em Geografia). Departamento Geografia, UFV.

ROMERO, M. A. B. Arquitetura Bioclimática do espaço público. Brasília: UnB, 2001, 225p.

ROSENFELD, A. H.; AKBARI, H.; BRETZ, S; FISHMAN, B. L.; KURN, D. M.; SAILOR, D.; TAHA, $\mathrm{H}$. Mitigation of urban heat islands: materials, utility programs updates. Energy and buildings, New York, v. 22, p. 255-265, 1995.

ROTH, M. Review of atmospheric turbulence over cities. Quarterly journal of the royal meteorological society, London, v. 126, n. 564, p. 941-990, 2000.

$\mathrm{ROTH}, \mathrm{M}$. Review of urban climate research in (sub)tropical regions. International journal of climatology, London, v. 27, n. 14, p. 1859-1873, 2007.

RUIZ-FLAÑO, P.; ROMERO MARTÍN, L.; MÁYER SUÁREZ, P.; HERNÁNDEZ CORDERO, A. The urban heat island in Las Palmas de Gran Canaria: Intensity distribution and conditioning factors. Boletín de la Asociación de Geógrafos Españoles, Barcelona, n. 47. p. 393-396, 2008. Disponível em: http://age.ieg.csic.es/boletin/47/23-RUIZ\%20FLAÑO.pdf. Acesso em: 19 nov. 2008.

RUNNALS, K.; OKE, T. R. Dynamics and controls of the near-surface heat island of Vancouver. Bristish Columbia. Physical geography, New York, v. 21, n. 4, p. 283-304, 2000.

SACHWEH. M.; KOEPKE, P. Fog dynamics in urbanized area. Theoretical and applied climatology, Viena, v. 58, n. 1, p. 87-93. 1997.

SAKAIDA, K.; EGOSHI, A. Influences of sea breeze on urban heat island in Sendai. Japan. In: INTERNATIONAL CONFERENCE ON URBAN CLIMATE. ICUC, 6, Proceedings...,. Göteborg, Sweden, p. 388-391, 2006.

SALVI-SAKAMOTO, L. L. Relações entre temperatura e a configuração do céu na área central da metrópole paulistana: Análise de dois episódios diários. 157f. Dissertação (Mestrado em Geografia Física), Faculdade de Filosofia, Letras e Ciências Humanas, Programa de Pós-graduação em Geografia Física, USP, 1994.

SALVI-SAKAMOTO, L. L. Os microclimas e a "configuração do céu" na área central. in: TARIFA. J. R.. AZEVEDO. T. R. de (orgs.). Os climas na cidade de São Paulo: Teoria e prática. São Paulo: Pró-reitoria de cultura e Extensão. Universidade de São Paulo, p. 165187, 2001, 199p.

SAMPAIO, A. H. L. Correlações entre uso do solo e ilha de calor no ambiente urbano: $\mathrm{O}$ caso de Salvador. 88f. Dissertação (Mestrado em Geografia Física), Faculdade de Filosofia, Letras e Ciências Humanas, Programa de Pós-graduação em Geografia Física, USP, 1981.

SANT'ANNA NETO, J. L. Decálogo da climatologia do sudeste brasileiro. Revista brasileira de climatologia, Presidente Prudente, v. 1, n.1, p. 43-60, 2005.

SANTAMOURIS, M.; PAPANIKOLAOU, N.; LIVADA, I.; KORONAKIS,I.; GEORGAKIS, C. ARGIRIOU, A.; ASSIMAKOPOULOS, D. N. On the impact of urban climate on the energy consumption of buildings. Solar Energy, London, v. 70, n. 3, p. 201-216, 2001.

SANTOS, J. A. A. dos. O campo térmico na área central da cidade de Viçosa-MG em situação sazonal de outono em 2007. 57f. Dissertação (Monografia em Geografia). Departamento de Artes e Humanidades-Curso de Geografia, UFV.

SANTOS, A. R.; SEDIYAMA, G. C.; ATOS, A. T.; SOARES, V. P.; PEZZOPANE, J. E. M.; REIS, E. F. Caracterização química, física e bioquímica dos três principais cursos d'água da bacia hidrográfica do rio Turvo sujo, microrregião de Viçosa (MG), no inverno de 2001. Geografares, Vitória, n. 3, p. 25-40, 2002.

SAYDELLES, A. P. Estudo do campo térmico e das ilhas de calor urbano em Santa Maria-RS. 2005. 218f. Dissertação (Mestrado em Geografia e geociências) - Centro de Ciências Exatas. Programa de Pós-graduação em Geografia. Universidade Federal de Santa Maria, Santa Maria, 2005. 
SCHMIDLIN. T. W. The urban heat island at Toledo. The Ohio journal of science, Ohio, v. 89, n. 3, p. 38-41, 1989.

SEARA. B. Um rio cheio de ilhas de calor. In: Jomal O Globo. Cademo Rio. Rio de Janeiro, 25/12/1997. p. 8.

SEGAWA. H. Clave de sol: notas sobre a história do conforto ambiental. Ambiente construído, Porto Alegre, v. 3, n. 2, p. 37-46, 2003.

SERENBRENICK, S. O clima do vale do rio doce. Revista brasileira de geografia. Rio de Janeiro, v. 24, n. 2, p. 258-267. 1962.

SETTE. D. M. O Clima urbano de Rondonópolis-MT. (2v). v. 137f. Dissertação (Mestrado em Geografia Física) - Faculdade de Filosofia Letras e Ciências Humanas. Programa de Pós-graduação em Geografia Física. USP. 1996.

SEZERINO. M. L.; MONTEIRO. C. A. F. O campo térmico na cidade de Florianópolis: Primeiro experimento. Revista geosul, Florianópolis, v. 5, n. 9, p. 20-60, 1990.

SILVA. L. T.; TOMMASELLI. J. T. G.; AMORIM. M. C. C. T. O clima urbano de PenápolisSP: um episódio de inverno. in: SANT'ANNA NETO. J. L (org.).: Os climas das cidades brasileiras: São Luís (MA). Aracajú (SE). Campo Grande (MS). Petrópolis (RJ). Sorocaba (SP). Penápolis (SP) e Presidente Prudente (SP). Presidente Prudente: UNESP-Presidente Prudente/Faculdade de Ciências e Tecnologia/Programa de Pós-graduação em Geografia e Laboratório de Climatologia, p. 145-163, 2002, 227p.

SILVA. A. L.; SANTOS. P. C. B.; CAMARGO. S. C. SETTE. D. M. O clima das cidades tropicais de pequeno porte na região sudeste de Mato Grosso: Pedra Preta. Dom Aquino e Guiratinga. In: ENCONTRO NACIONAL DE GEÓGRAFOS, 13, 2002. Paraíba. Anais...., João Pessoa: UFPB, 2002, cd-rom.

SILVEIRA, V. P.; GAN, M. A. Estudo de tendência das temperaturas mínimas na Região sul do Brasil. In: CONGRESSO BRASILEIRO DE METEOROLOGIA, 14, 2006. Anais..., Florianópolis: UFSC, 2006.

SISTERSON. D. L.; DIRKS. R. A. Structure of the daytime urban moisture field. Atmospheric environment, New York, v. 12, n. 10, p. 1943-1949, 1978.

SMITH, K. Principles of applied climatology. New York: Jonh Wiley and Sons, 1975, 233p.

SOARES. B. R. Pequenas e médias cidades: Um estudo sobre as relações socioespaciais nas áreas de cerrado em Minas Gerais. In: SPOSITO. M. E. B. (org.).: Cidades medias: espaços em transição. São Paulo: Expressão popular, p. 461-494, 2007, 632p.

SOFER, M.; POTCHTER, O. The urban heat island of a city in an arid zone: The case of Eliat, Israel. Theoretical and applied climatology, Viena, v. 85, n. 1-2, p. 81-88, 2006.

SOUCH. C.; GRIMMOND. S. Applied climatology: Urban climate. Progress in physical geography, New York, v. 30, n. 2, p. 270-279, 2006.

SOUZA, M. L. A. B. C do desenvolvimento urbano. Rio de Janeiro: Bertrand Brasil, 2003, 192p.

SOUSA, D. O.; BAPTISTA, G. M. M. Análise da influência da resolução espacial na determinação das ilhas de calor em São Paulo. por meio dos sensores Aster e Modis. in: SIMPÓSIO BRASILEIRO DE SENSORIAMENTO REMOTO, 12, 2005. Goiânia. Anais.... Goiás: INPE. 2005. cd-rom.

SPRIN. A. W. O Jardim de granito: A natureza no desenho da cidade. São Paulo: Edusp, 1996, 345p.

STEFFES, A. C. de.; PICCOLO. M. C.; GONZÁLEZ. J. H.; NAVARRETE. G. La isla de calor estival em Temuco, Chile. Papelez de geografia, Murcia, n. 33, p. 49-60, 2001.

STEWART. I. D. Influence of meteorological conditions on the intensity and form of the urban heat island effect in Regina. The canadian geographer, Quebéc, v. 44, n. 3, p. 271-285, 2000.

STURMAN. A. P. Applied climatology. Progress in physical geography, New York, v. 24, n. 1, p. 129-139, 2000.

SUCKLING. P. W.; MITCHELL. M. D. Fog climatology of the Sacramento urban area. The professional geographer, New York, v. 40, n. 2, p. 186-194, 1988. 
SÜMEGHY, Z.; UNGER, J. Seasonal case estudies on the urban temperature crossection. Acta climatologica et chorological, Szeged, v. 36-37, p. 101-109, 2003.

SUNDBORG, A. Local climatological studies of the temperature conditions in an urban áreas. Tellus, Stockholm, v. 2, n. 3, p. 222-232, 1950.

SZEGEDI, S.; KIRCSI, A. Effects of the synoptic conditions on the development of the urban heat island in Debrecen. Hungary. Acta climatologica et chorological, Szeged, v. 36-37, p. 111-120. 2003.

SZEGEDI. S. Heat islands in small and medium-sized towns in Hungary. In: INTERNATIONAL CONFERENCE ON URBAN CLIMATE. ICUC, 6, Proceedings...,. Göteborg, Sweden, p. 439-442, 2006.

TABUTEAU. M. Notas sobre a região de Ponte Nova e Viçosa. Boletim carioca de geografia, Rio de Janeiro, v. 13, n. 1-2, p. 69-91, 1960.

TARIFA. J. R. Análise comparativa da temperatura e umidade na área urbana e rural de São José dos Campos (SP). Geografia, Rio Claro-SP, v. 2, n. 4, p. 59-80, 1977.

TARIFA, J. R.. ARMANI, G. Os climas urbanos. in: TARIFA. J. R.. AZEVEDO. T. R. de (orgs.). Os climas na cidade de São Paulo: Teoria e prática. São Paulo: Pró-reitoria de cultura e Extensão. Universidade de São Paulo, p. 47-70, 2001, 199p.

TAVARES. R. O clima de Sorocaba-SP: Aspectos regionais, locais e urbanos. in: SANT'ANNA NETO. J. L (org.):: Os climas das cidades brasileiras: São Luís (MA). Aracajú (SE). Campo Grande (MS). Petrópolis (RJ). Sorocaba (SP). Penápolis (SP) e Presidente Prudente (SP). Presidente Prudente: UNESP-Presidente Prudente/Faculdade de Ciências e Tecnologia/Programa de Pós-graduação em Geografia e Laboratório de Climatologia, p. 115-143, 2002, 227p.

TEZA, C. T. V.; BAPTISTA, G. M. M. Identificação do fenômeno ilhas de calor por meio de dados ASTER on demand 08 - Kinetic temperatura (III): metrópoles brasileiras. in: SIMPÓSIO BRASILEIRO DE SENSORIAMENTO REMOTO, 12, 2005, Goiânia. Anais...., Goiás: INPE, 2005, cd-rom.

TOROK, S. J.; MORRIS, C. J. G.; SKINNER, C.; PLUMMER, N. Urban heat island features of southeast Australian tows. Australian meteorological magazine, Melboure, v. 50, p. 1-13, 2001.

TROPPMAIR, H. Condições geoambientais, ocorrência de neblina e acidentes em rodovias paulistas. Geografia, Rio Claro, v. 23, n. 3, p. 25-38, 1998.

TROPPMAIR, H. Biogeografia e meio ambiente. 6ed. Rio Claro: Divisa, 2004, 205p.

UIA. Ciudades intermedias y urbanizacion mundial. Programa de Trabajo do XX Congresso de Union Internationale dês Archietes. Ajuntament de Lleida. Lleida, 1998.

UNGER, J. Wind and heat island intensity. In: CLIMATE AND ENVIRONMENTAL CHANGE. 1. 1998. Évora. Proceedings..., Portugal: Intemational Geographical Union Comission on Climatology, p. 11-12. 1998.

UNKAŠEVIĆ, M. JOVANOVIĆ, O; POPOVIĆ, T. Urban-suburban/rural vapour pressure and relative humidity differences at fixed hours over the area of Belgrade city. Theoretical and applied climatology, Viena, v. 68, n. 1, p. 67-73, 2001.

UNGER, J. Intra-urban relationship between surface geometry and urban heat island: review and new approach. Climate research, Nordbünte, v. 23, n. 3, p. 253-264, 2004.

UNWIN, D. J. The synoptic climatology of Birmingham's urban heat island. 1963-1974. Weather, London, v. 35. n. 1. p. 43-50, 1980.

VALVERDE. O. Estudo Regional da Zona da Mata de Minas Gerais. Revista brasileira de geografia, Rio de Janeiro, v.20, n.1, p. 3-82, 1958.

VENTURA, F.; ROSSI PIAL, P.; ARDIZZONI, E. Temperature and precipitation trends in Bologna (Italy) from 1952 to 1999. Atmospheric Research, London, v. 61, n.1, p. 203-214, 2002.

VEYRET, Y. Os riscos: O homem como agressor e vítima do meio ambiente. Traduzido por Dílson Ferreira da Cruz. São Paulo: Contexto, 2007, 319p. 
VIANNA, S. S. M. Caracterização do clima urbano em Teodoro Sampaio/SP. 190f. Dissertação (Mestrado em Geografia)- Faculdade de Ciências e Tecnologia. Programa de Pós-graduação em Geografia, Unesp-PP, 2006.

VIANELLO, R. L.; MAIA, L. F. P. G. Estudo preliminar da climatologia dinâmica de Minas Gerais. In: CONGRESSO BRASILEIRO DE METEOROLOGIA, 4, 1986, Brasília, Anais... Disponível em : http://www.cbmet.com/edicoes.php?cgid=11. Acesso em 10 jun. 2009.

VOOGT, J. A.; OKE, T. R. Compete urban surface temperatures. Journal of applied meteorology, New York, v. 36, n. 9, p. 1117-1132, 1997.

WANNER, H.; HERTIG, J. A. Studies of urban climates and air pollution in Switzerland. Journal of climate and applied meteorology. New York, v. 23, n. 12, p. 1614-1625, 1984.

WIENERT, U.; KUTTLER, W. Statistical analysis of the dependence of urban heat island intensity on Latitude In: INTERNATIONAL CONFERENCE ON URBAN CLIMATE, 5, ICUC, Proceedings..., Lodz, Poland, 2003. Disponível em: http://www.geo.uni.lodz.pl/ icuc5/. Acesso em 21 abr. 2008.

WILLIAMS, R. O campo e a cidade: Na história e na literatura. Traduzido por BRITTO, P. H. São Paulo: Companhia das Letras, 1990, 439p.

World Resource Institute. Disponível em www.wri.org.br. Acesso em abr. 2008.

YOSHINO, M. M.; TANAKA, M.; NAKAMURA. K. Formation of a cold air lake and it's effects on agriculture. Journal of natural disastre science, Tokyo, v. 3, n. 2, p. 1-14. 1981.

YOW. D. M.; CARBONE. G. J. the urban heat island and local temperature variations in Orlando. Florida. Southeastern geographer, London,v. 46, n. 2, p. 297-321, 2006.

YU, P.; YANG, T.; WU. C. Impact of climate change on water resources in southern Taiwan. Journal of hydrology, Amsterdam, v. 260, p.161-175, 2002.

ZACCHI, R. C. Verticalização do espaço urbano de Viçosa (MG), pós década de 1970: Produção e consumo. Relatório Final de Pesquisa apresentado ao Cnpq. Mimeografado, 2009, 58p.

ZAMPARONI, C. A. G. P. Ilha de calor em Barra do Bugres e Tangará da Serra-MT: Uma contribuição ao estudo do clima urbano em cidades de pequeno porte em área tropical. 1995. 99f. Dissertação (Mestrado em Geografia Física). Faculdade de Filosofia. Letras e Ciências Humanas. Programa de Pós-graduação em Geografia Física, USP, 1995.

ZAVATINI, J. A. O tempo e o espaço nos estudos do ritmo do clima no Brasil. Geografia, Rio Claro, v. 27, n. 3, p. 101-131, 2002. 
Anexo 2 


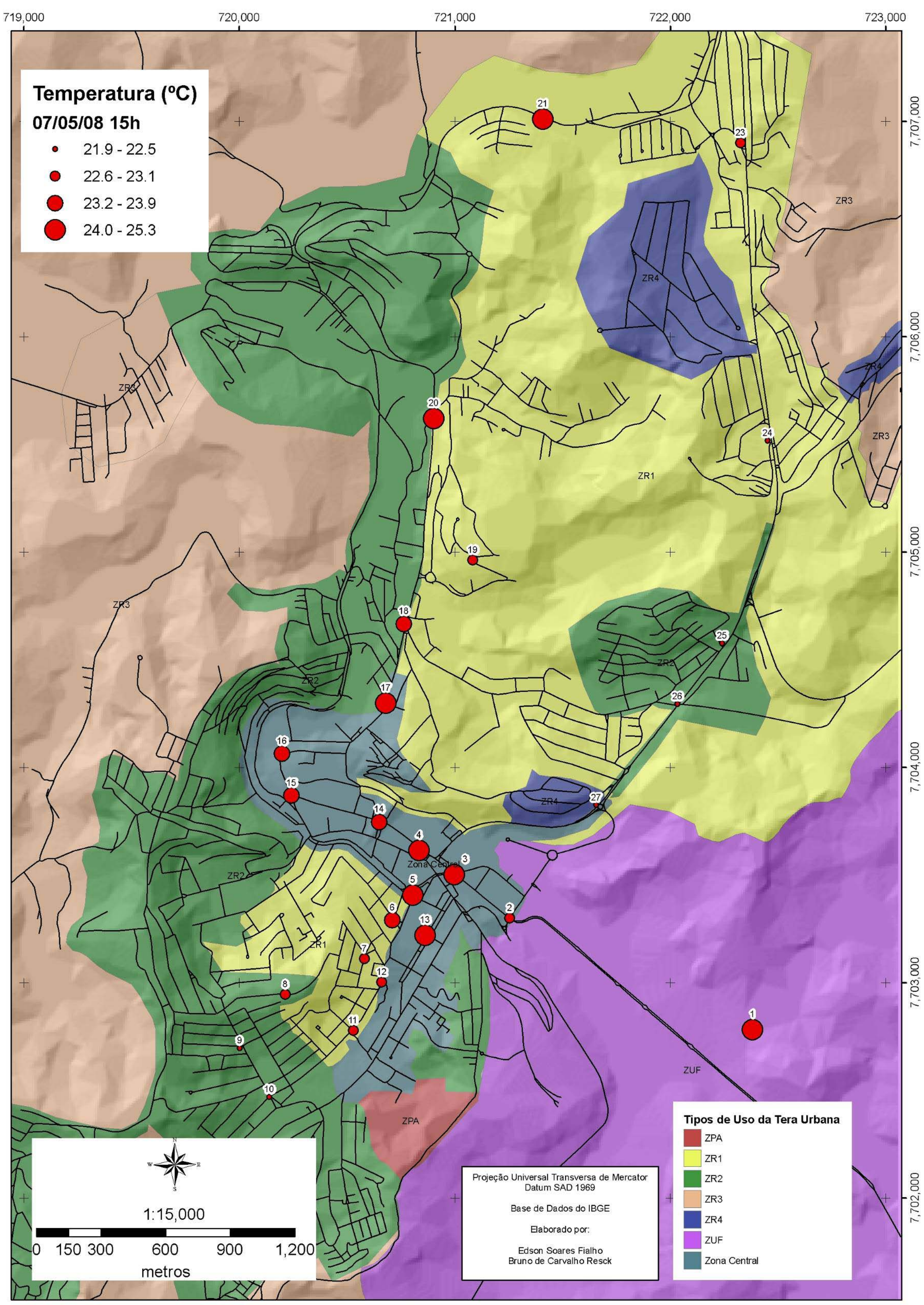




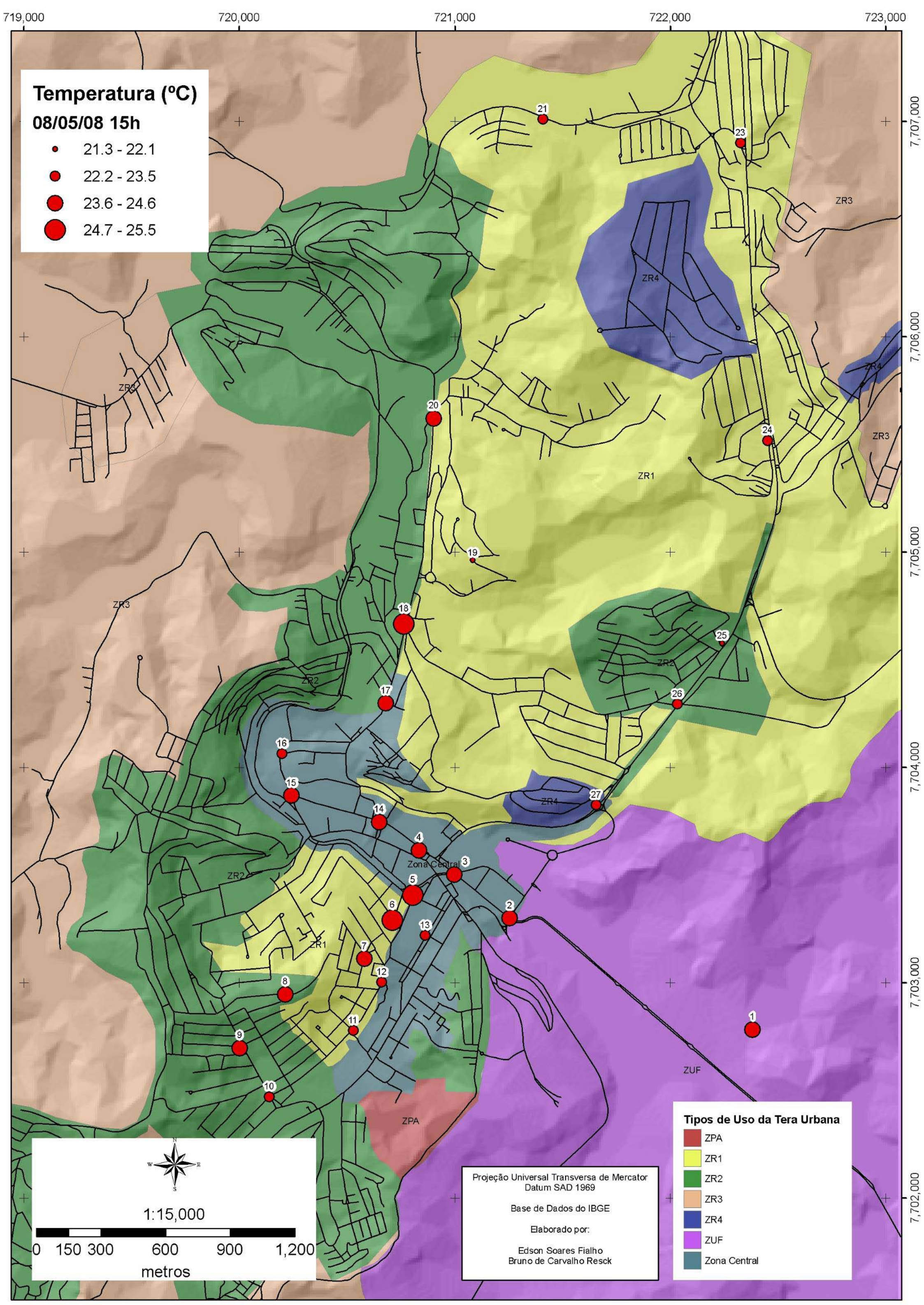




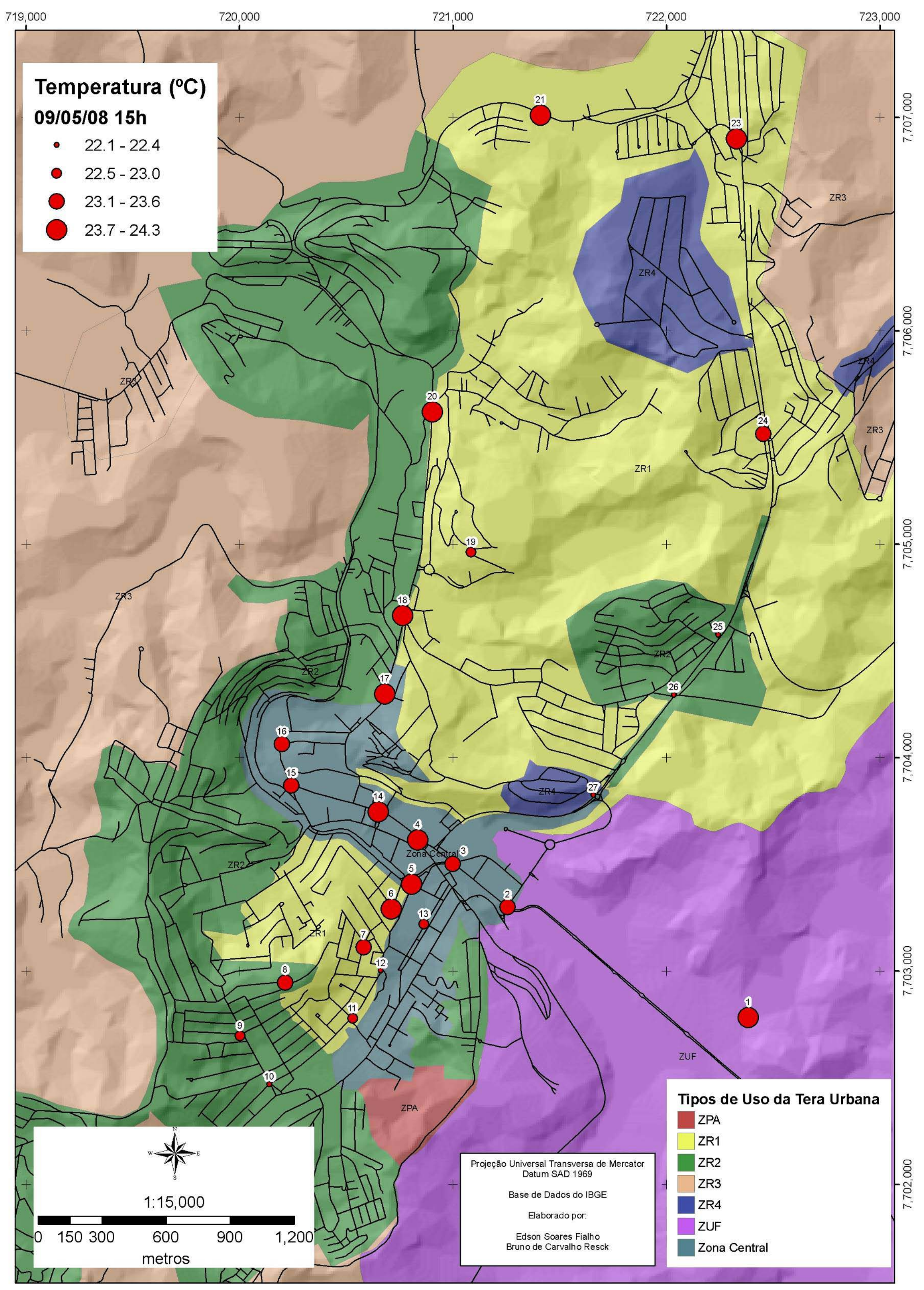




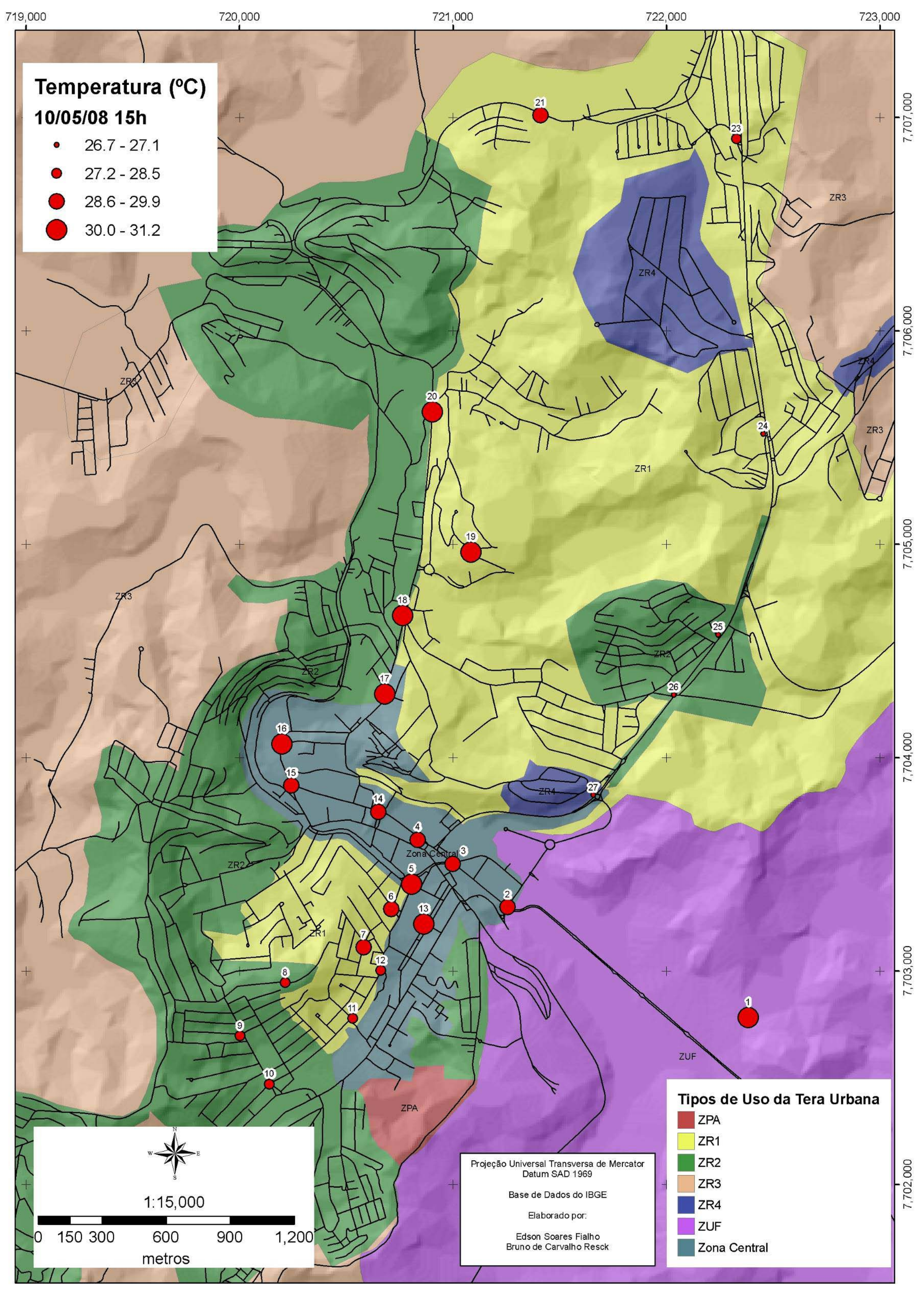




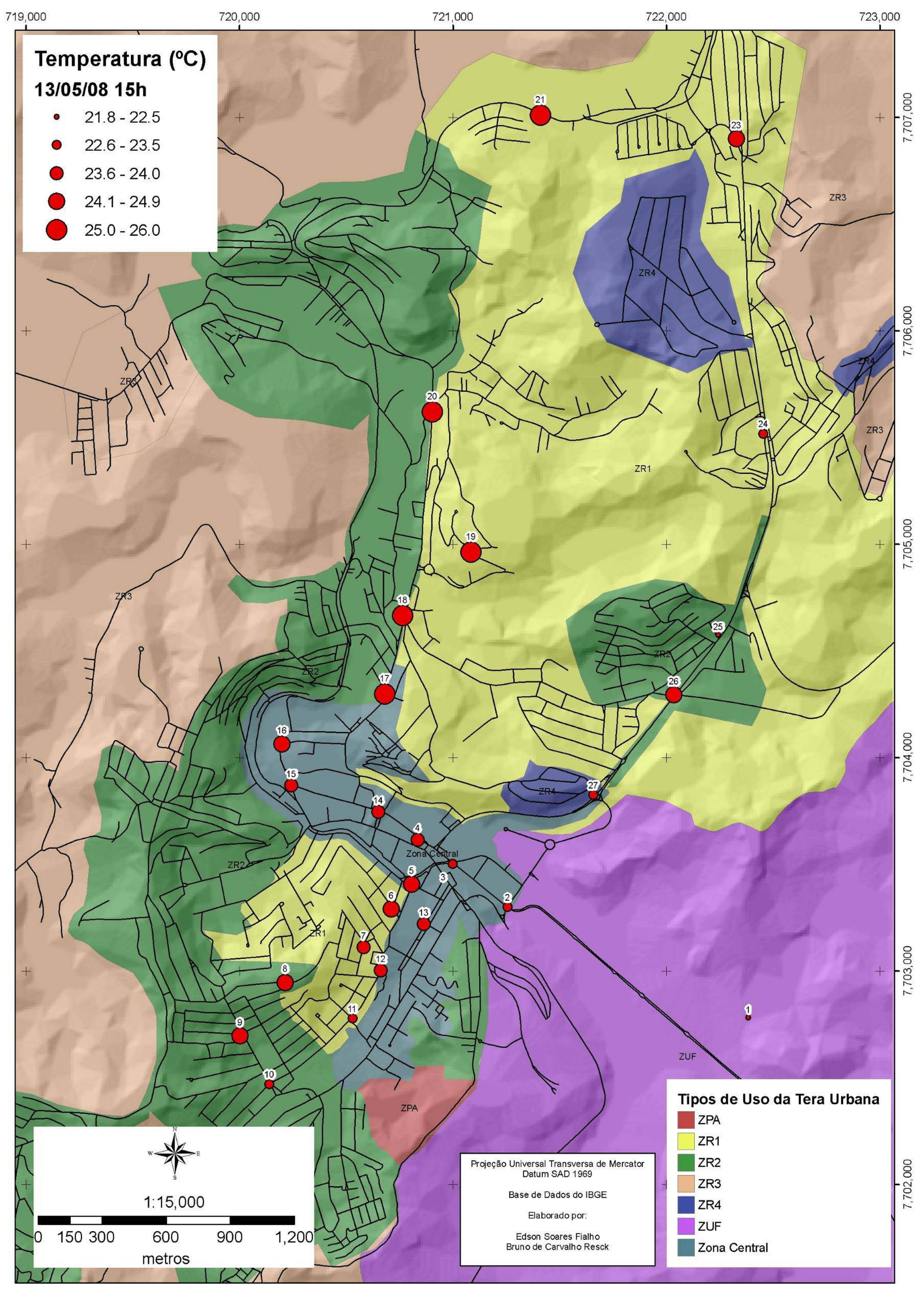




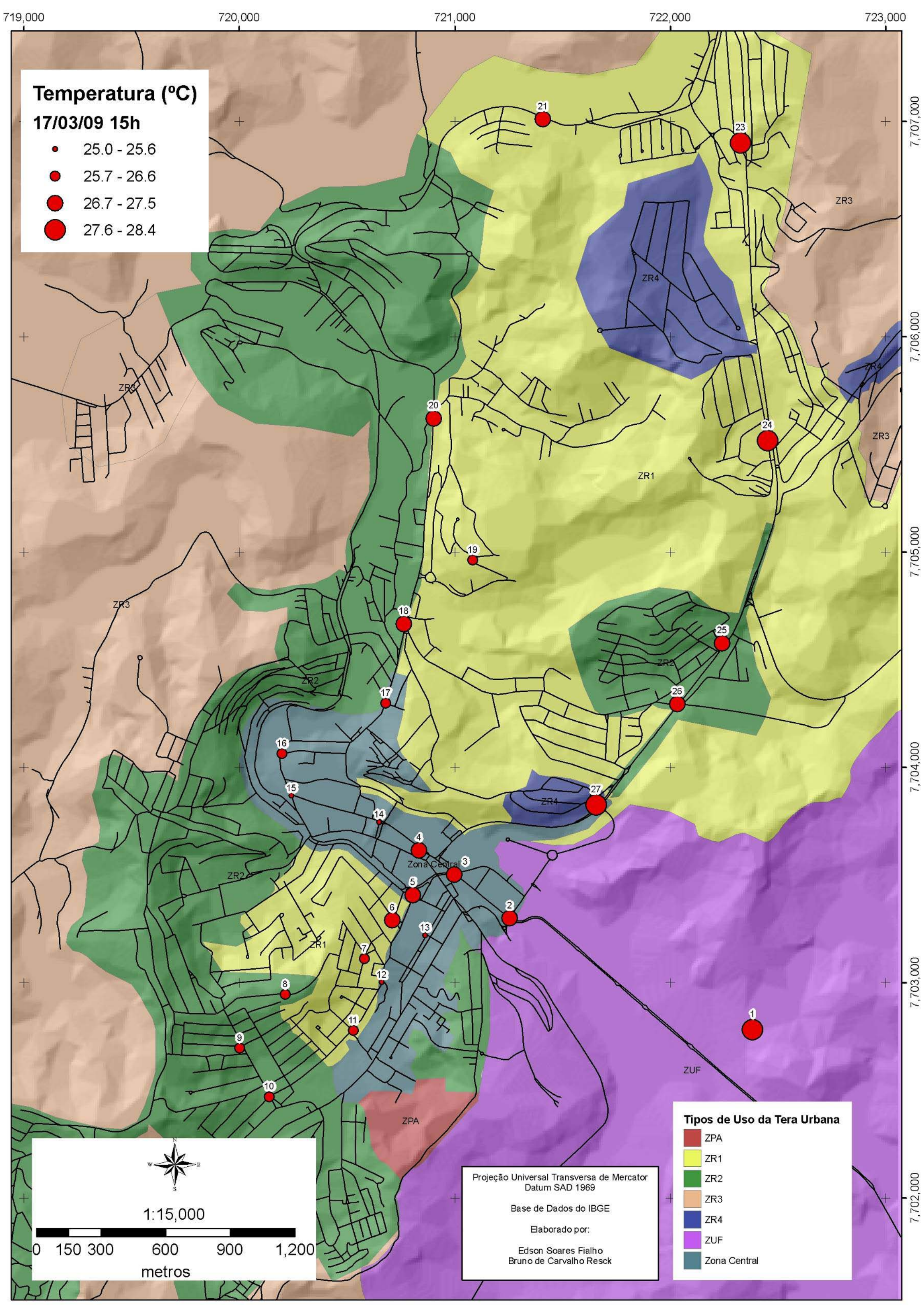




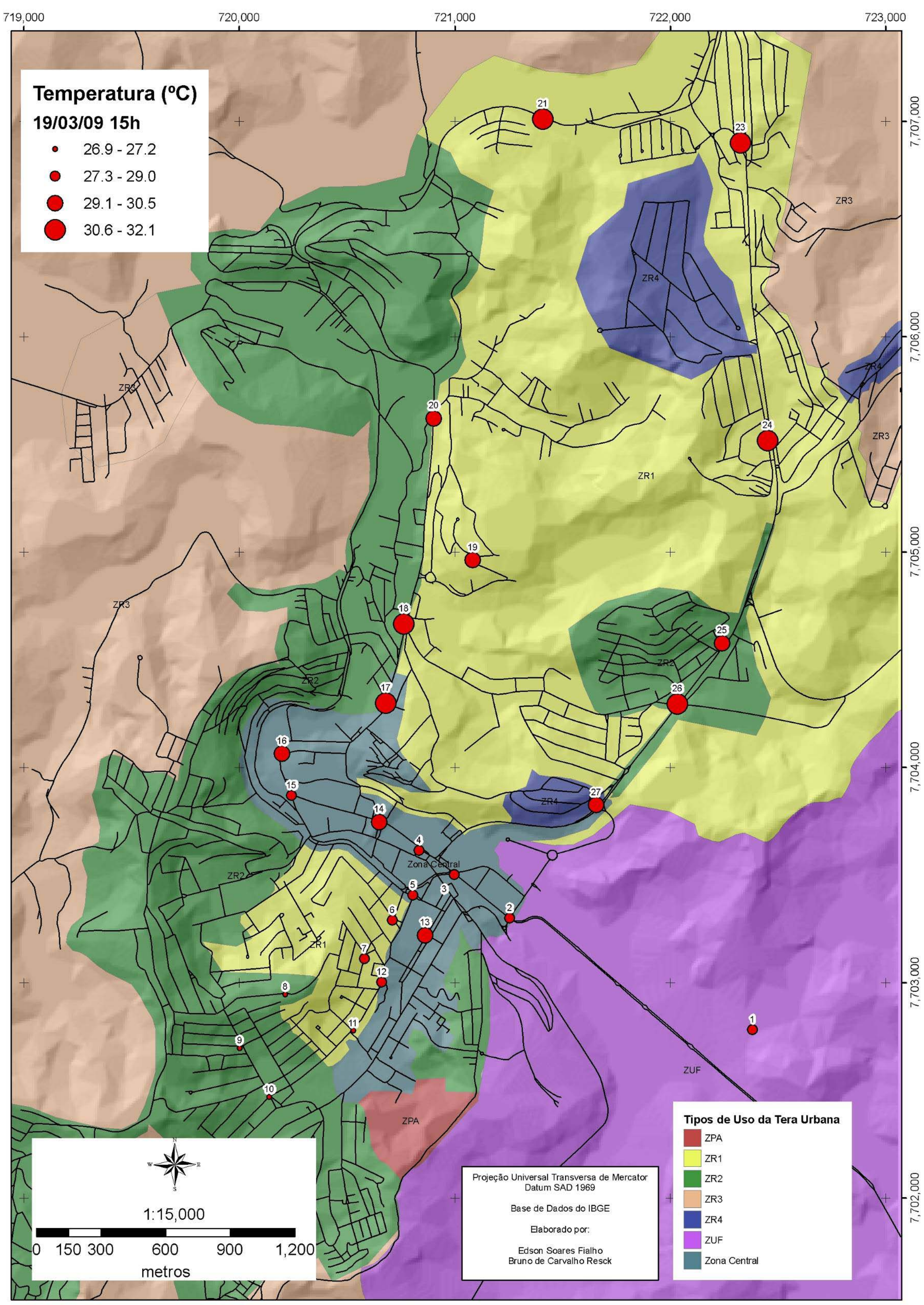




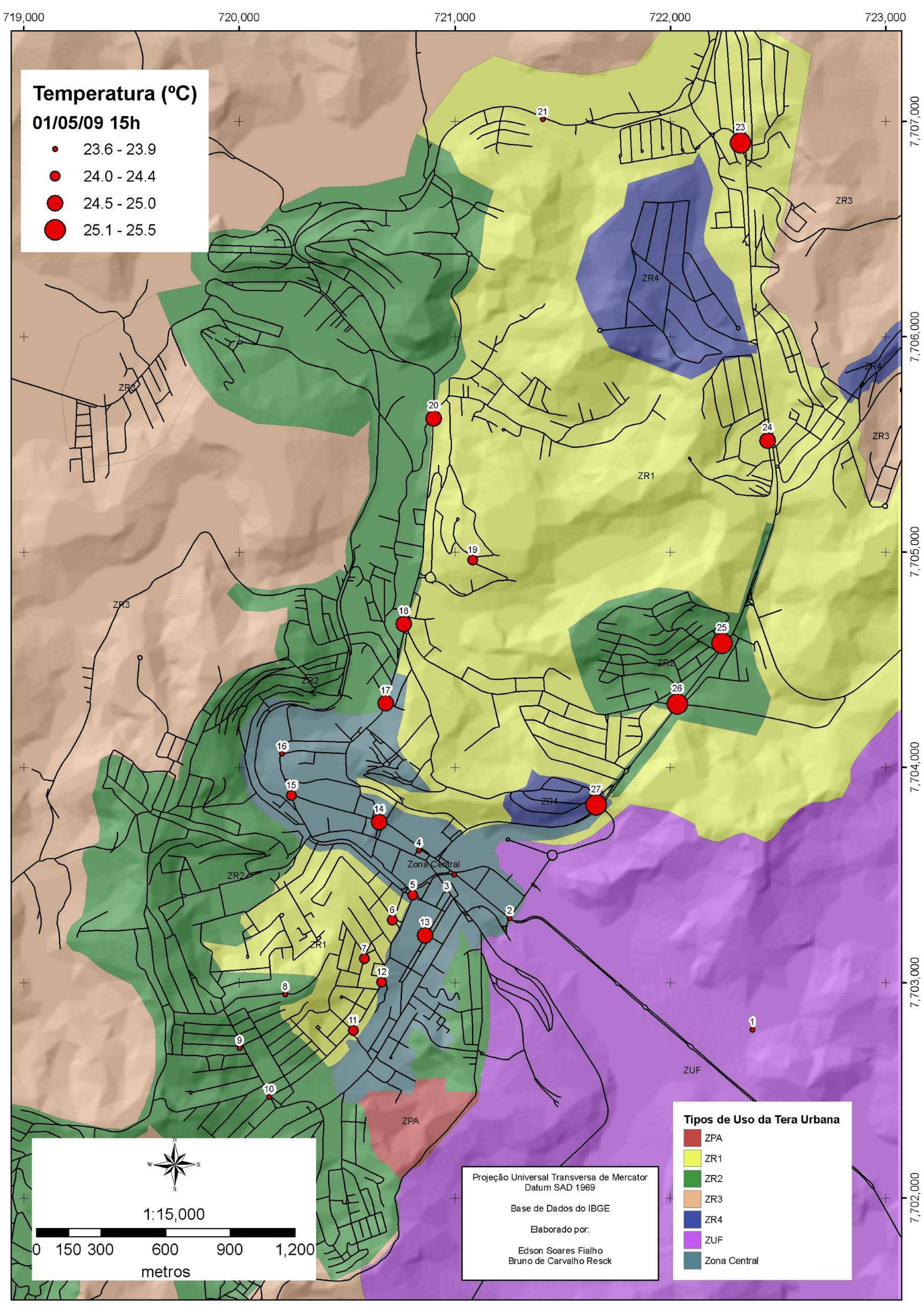




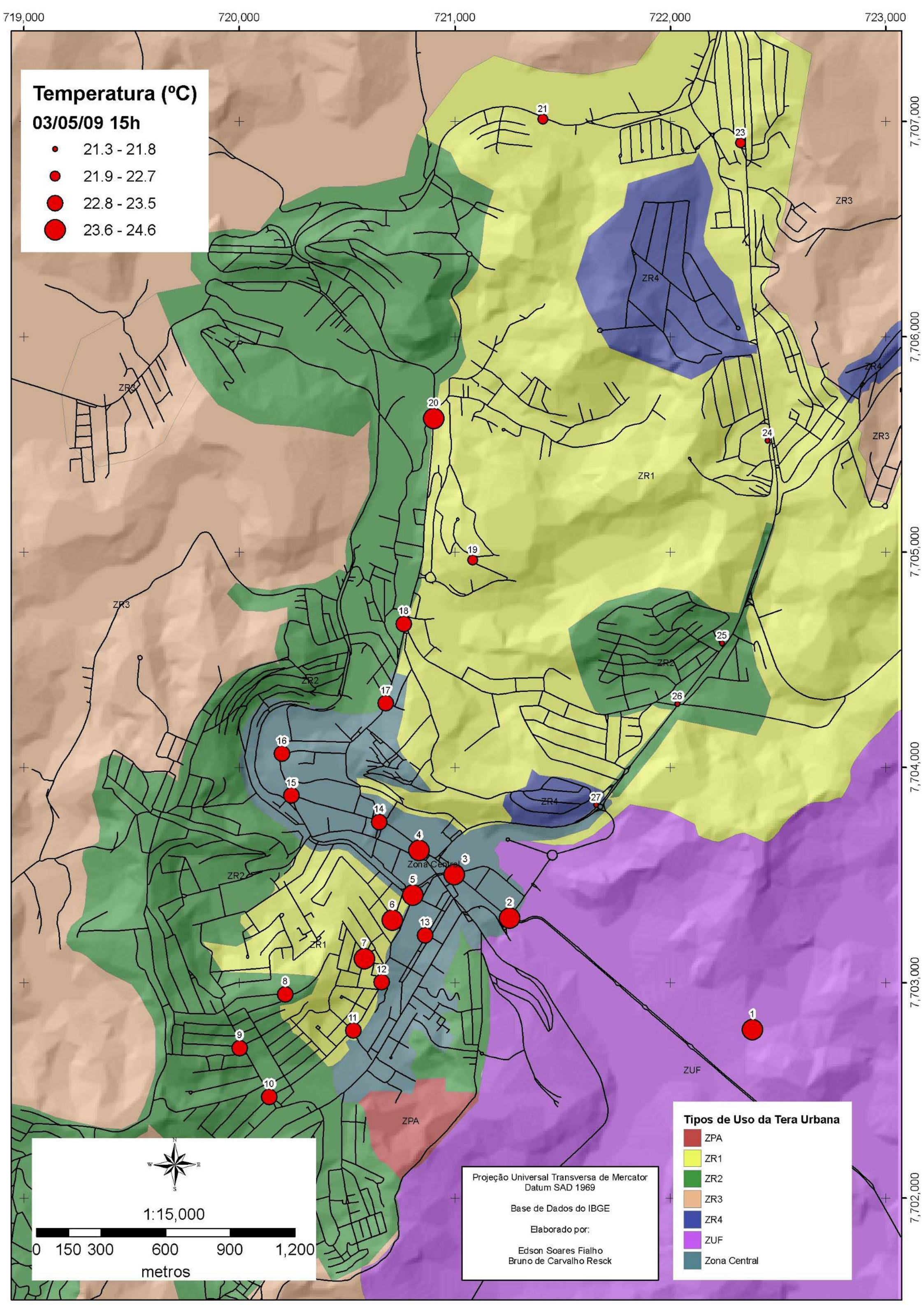


Anexo 3 


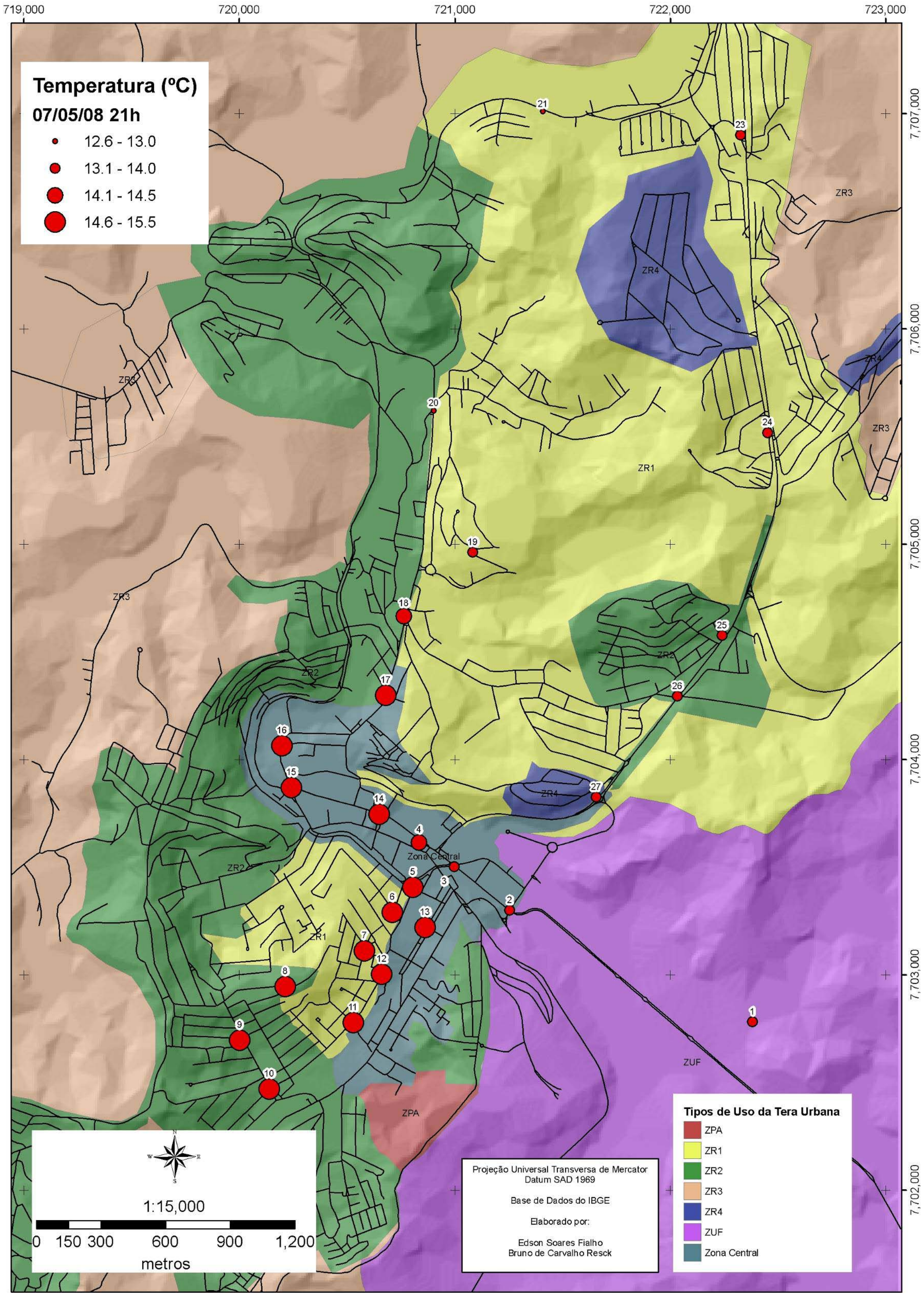




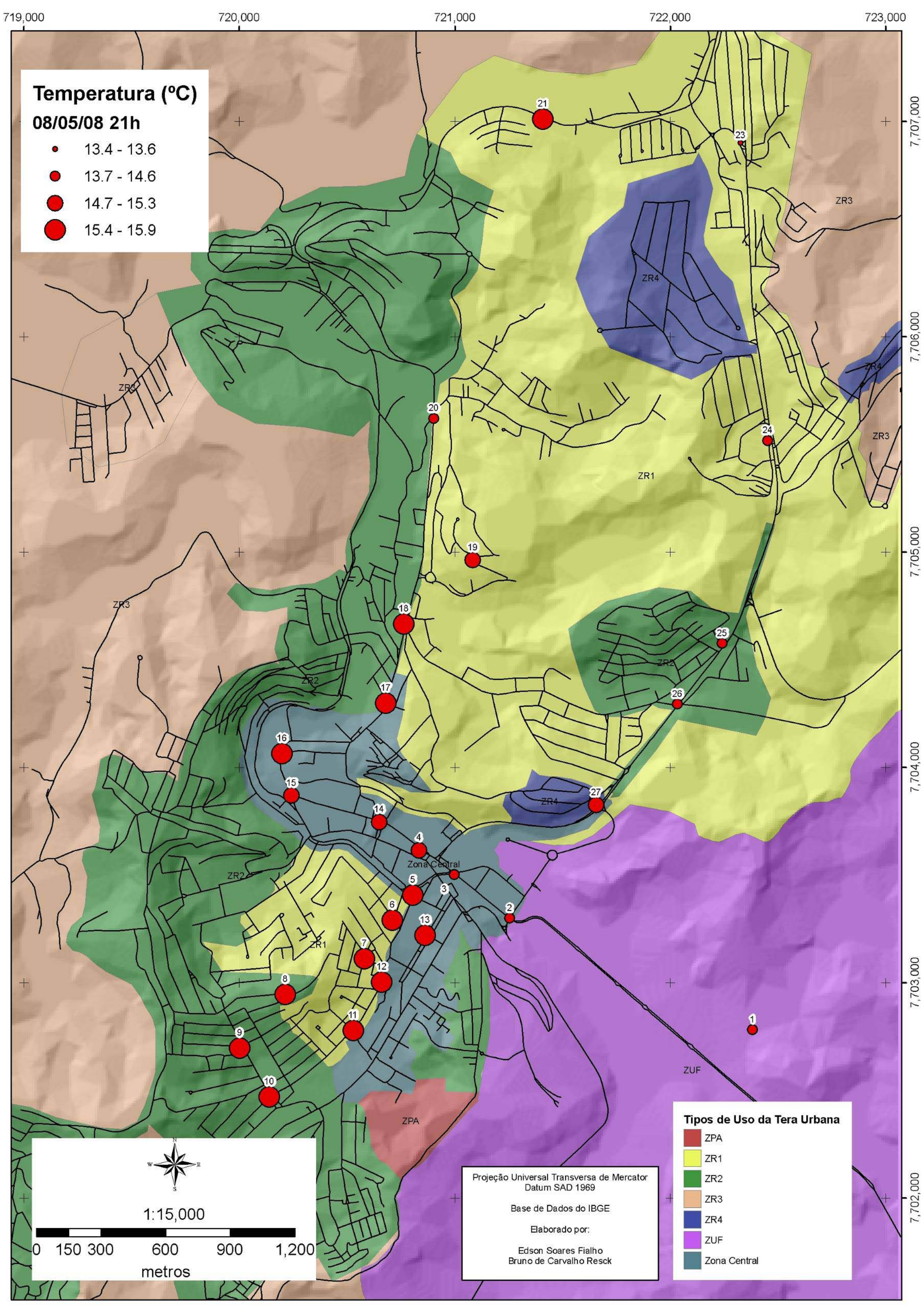




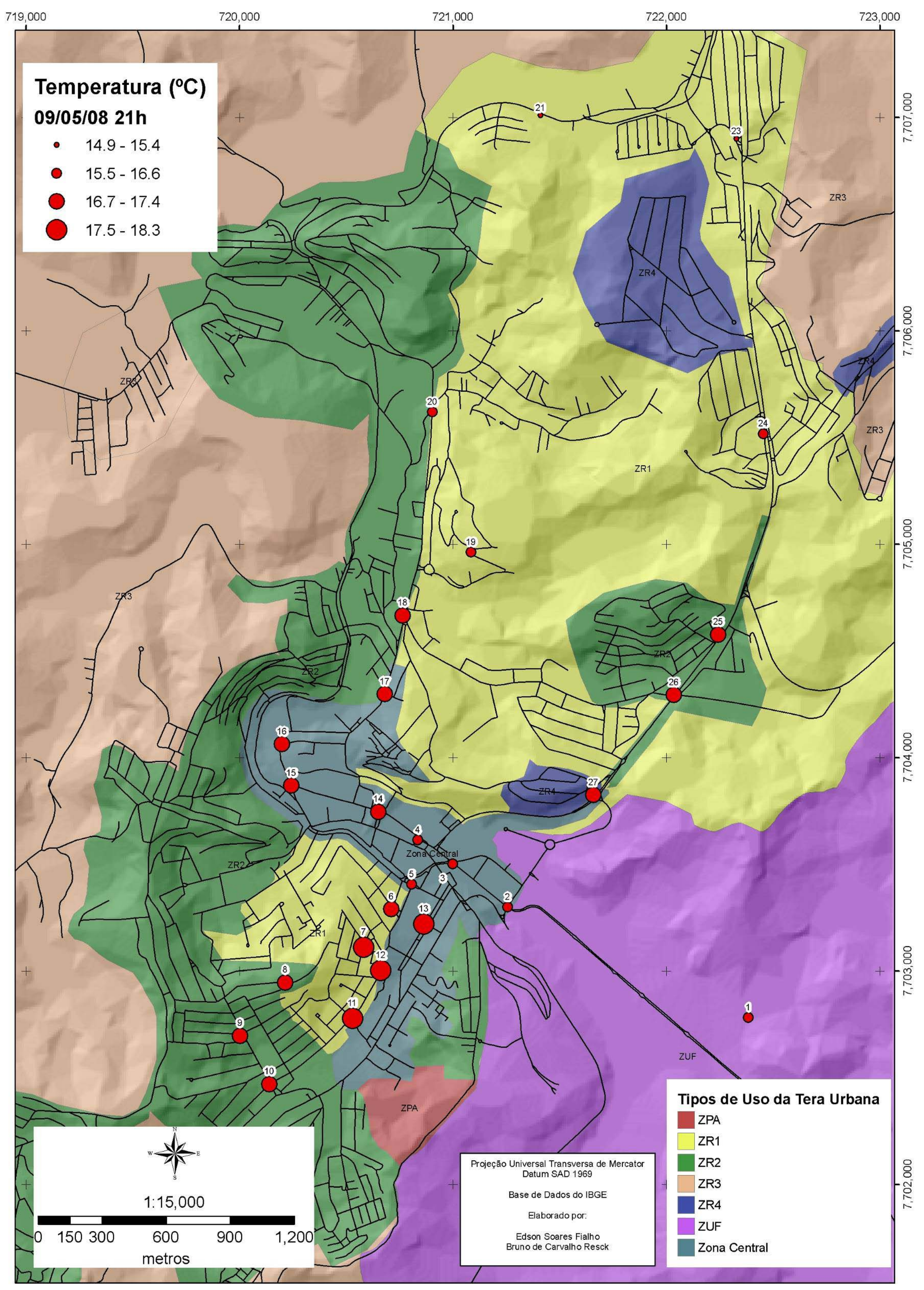




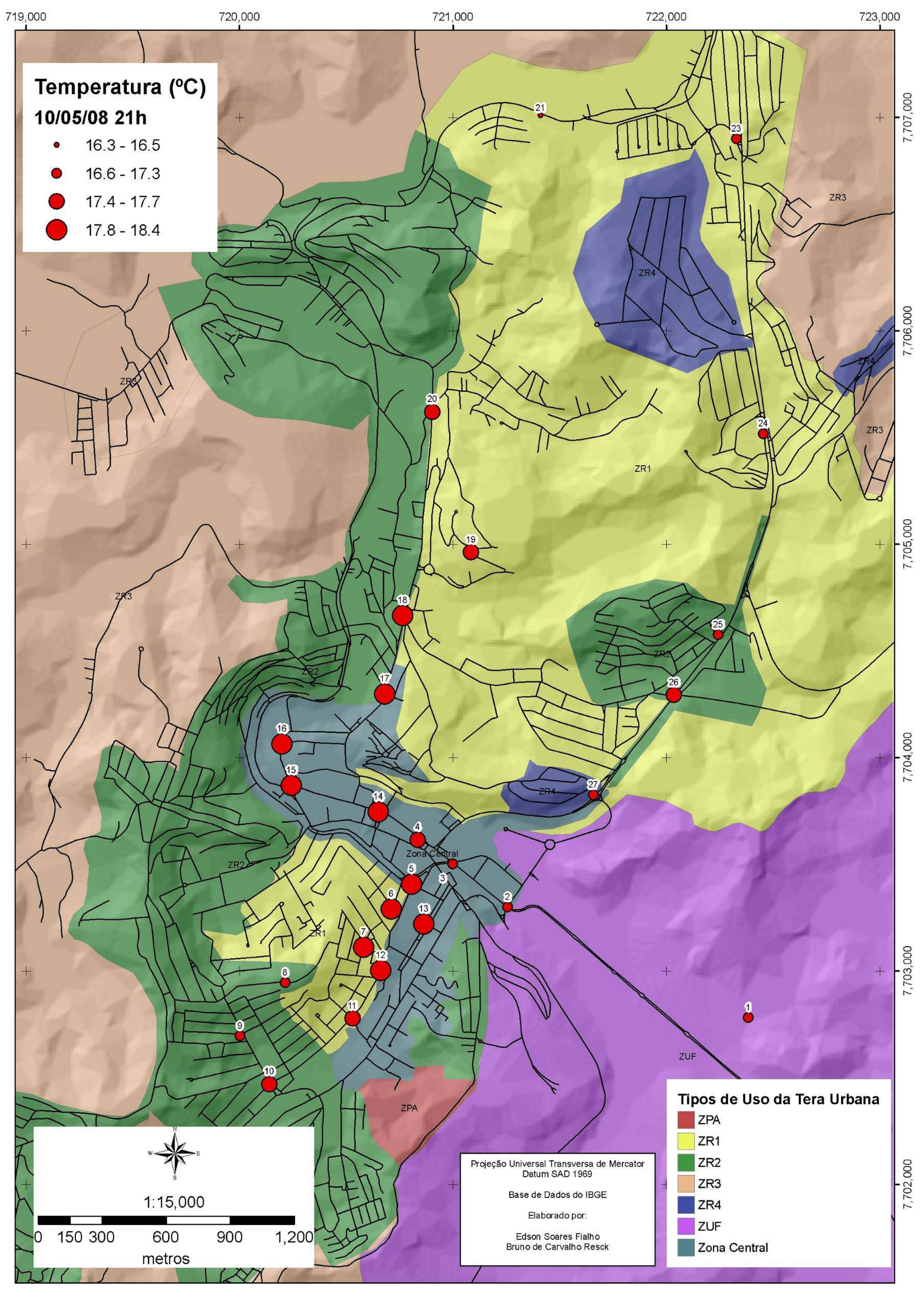




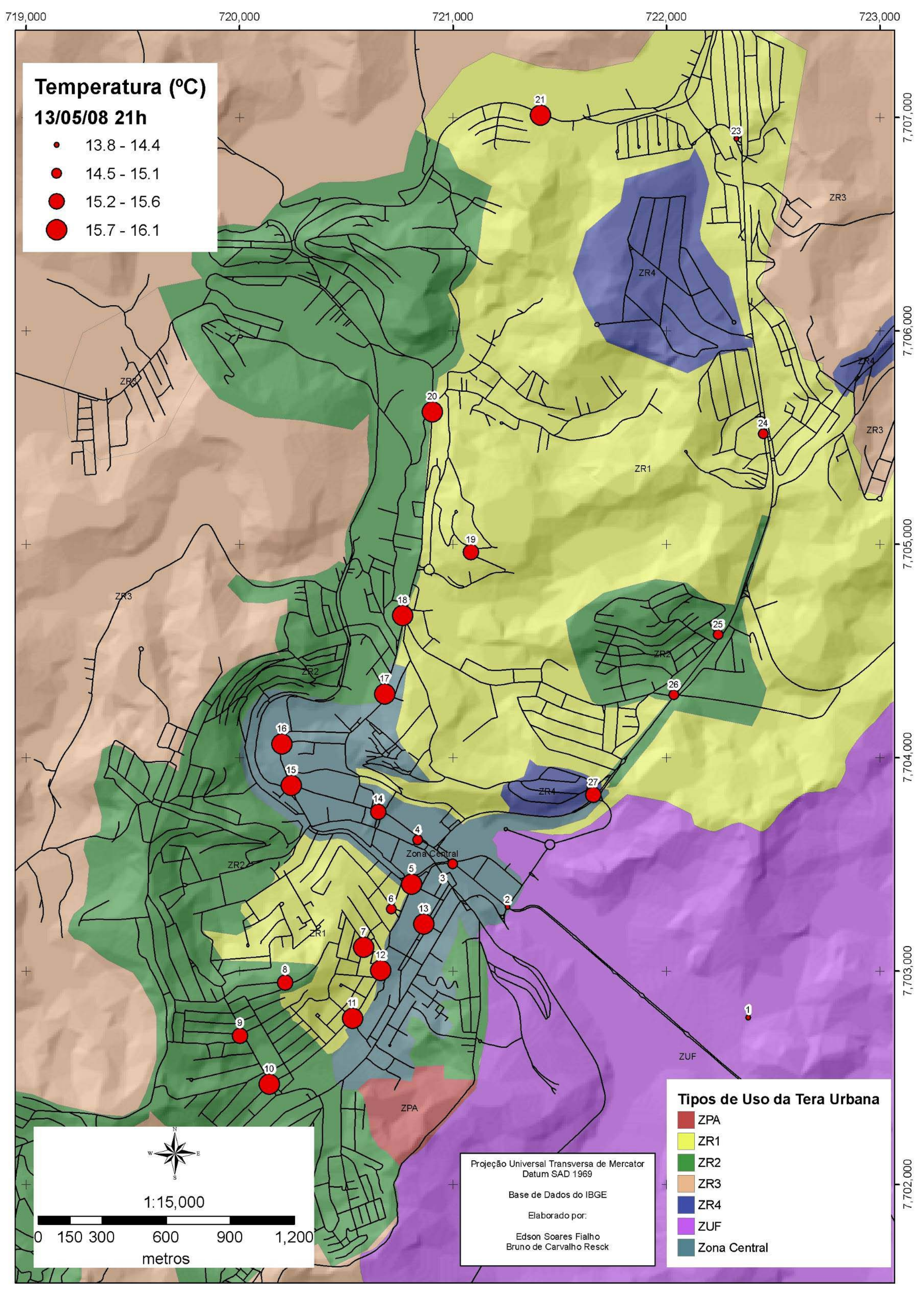




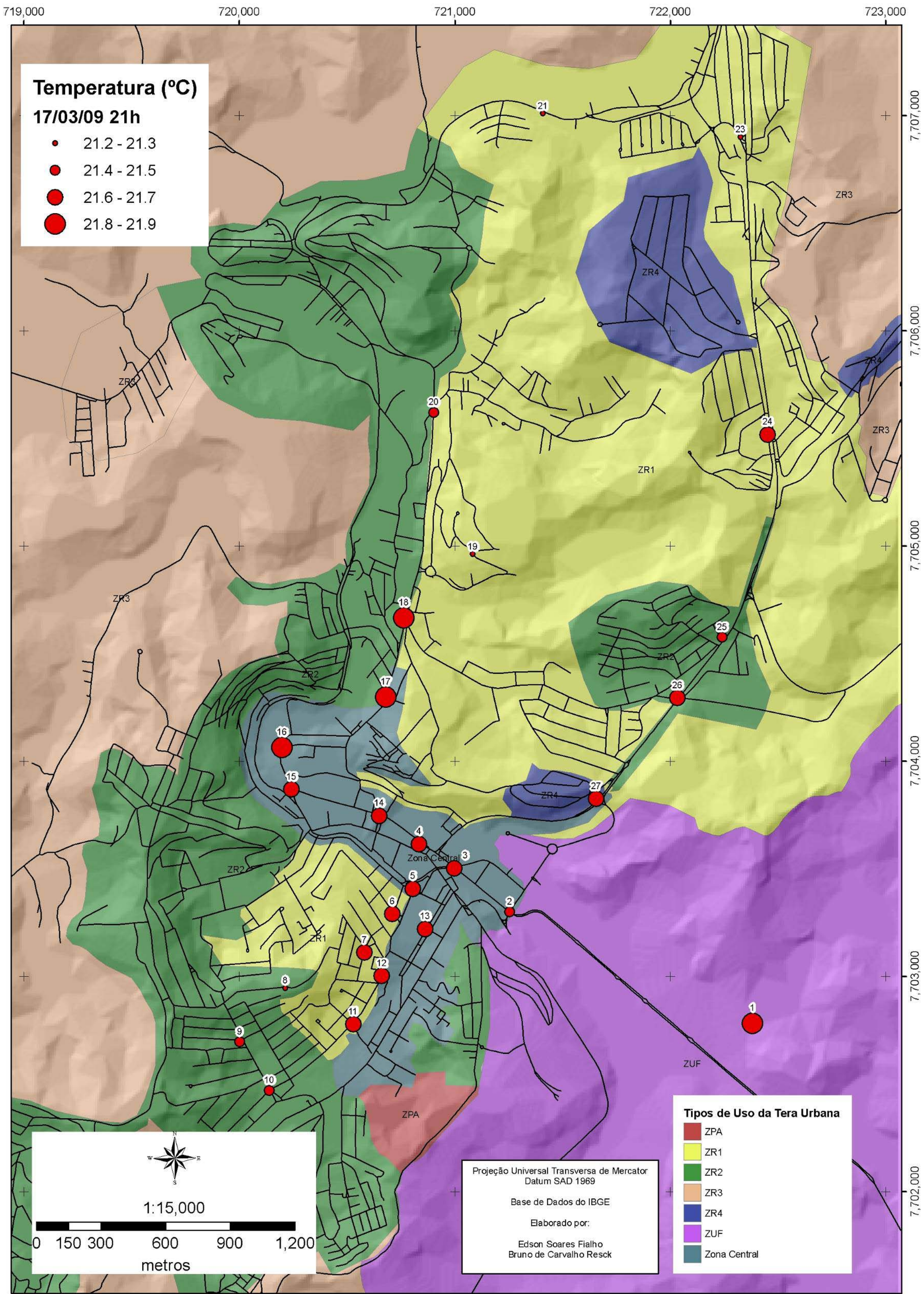




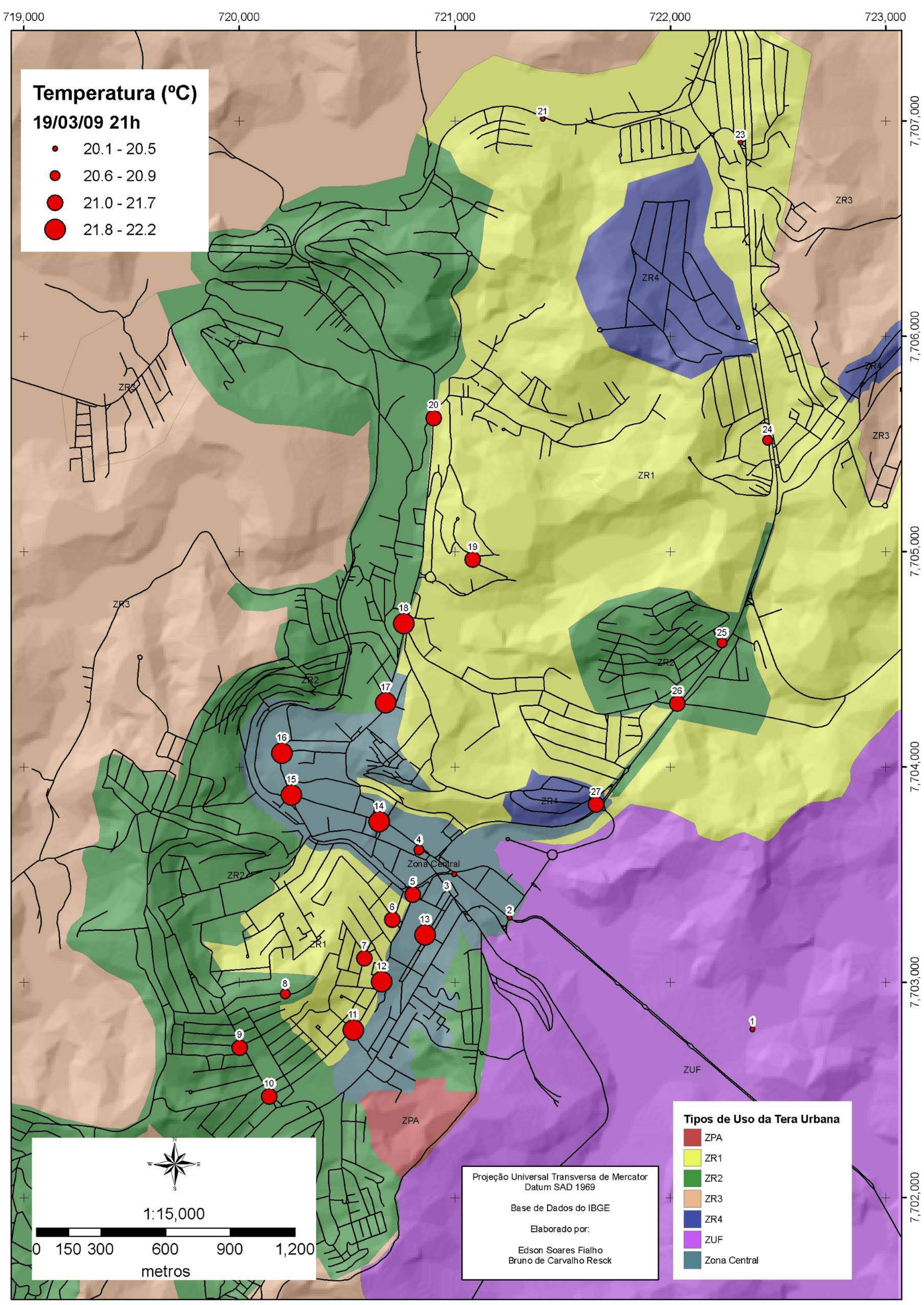




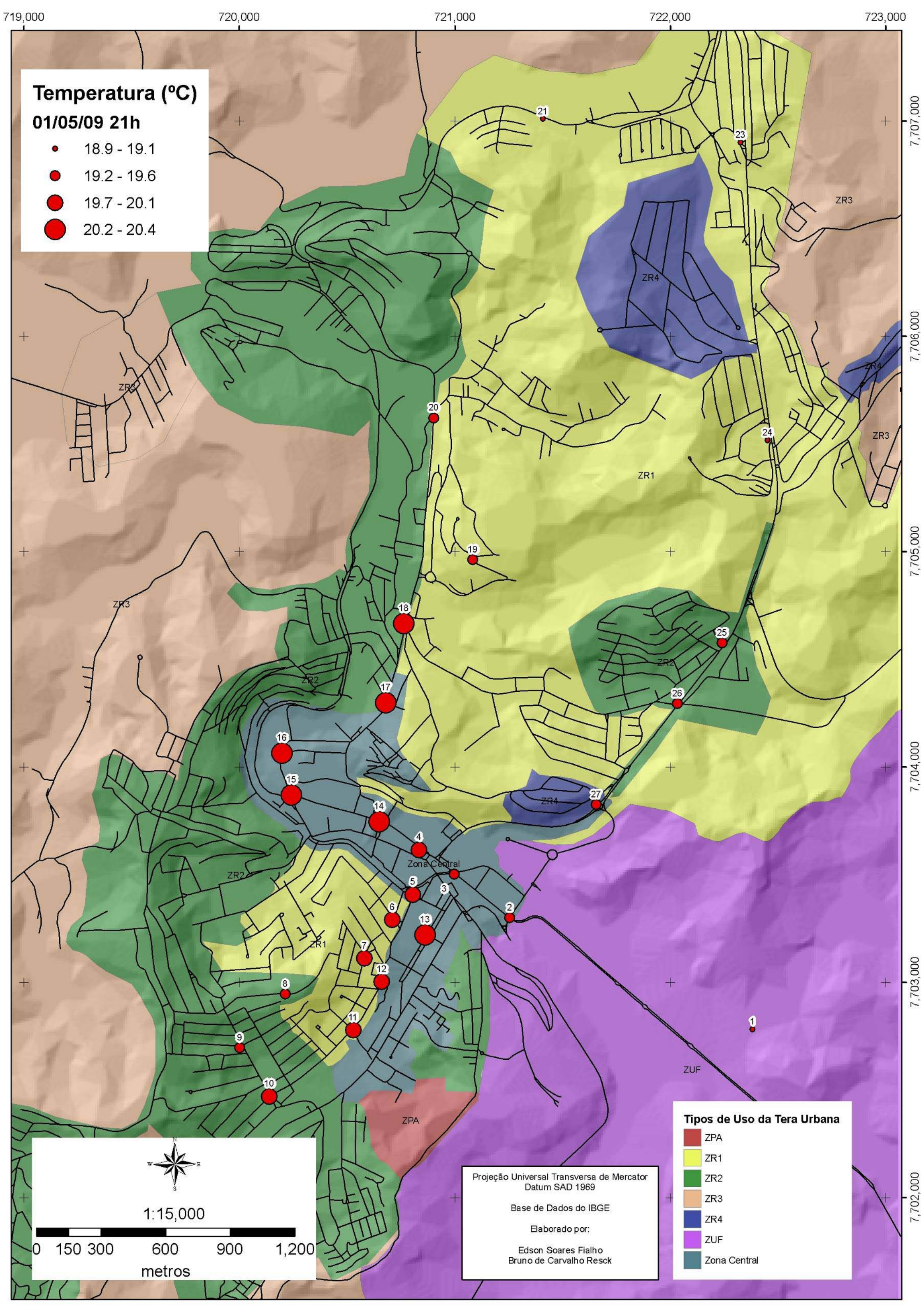




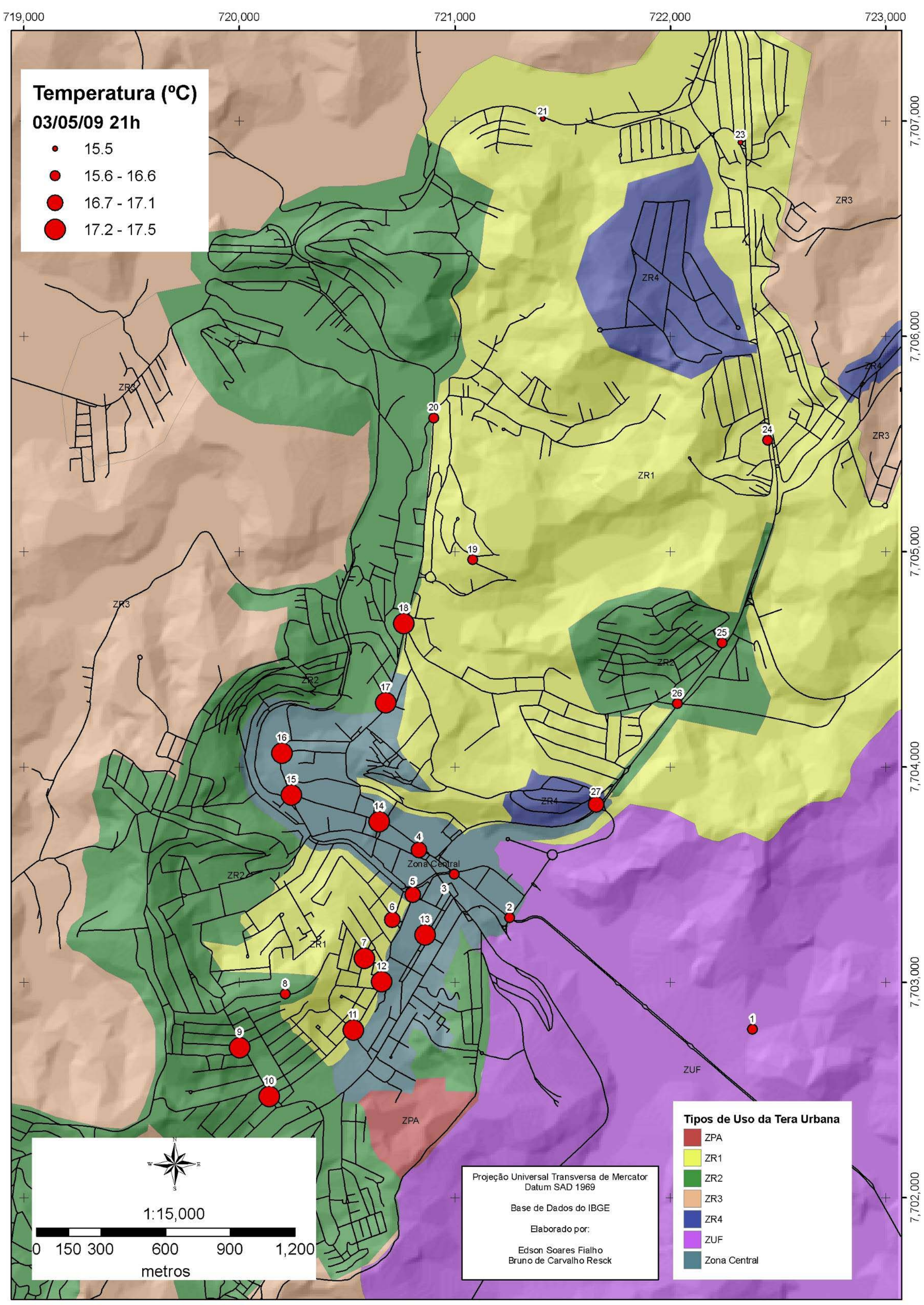


Anexo 1 


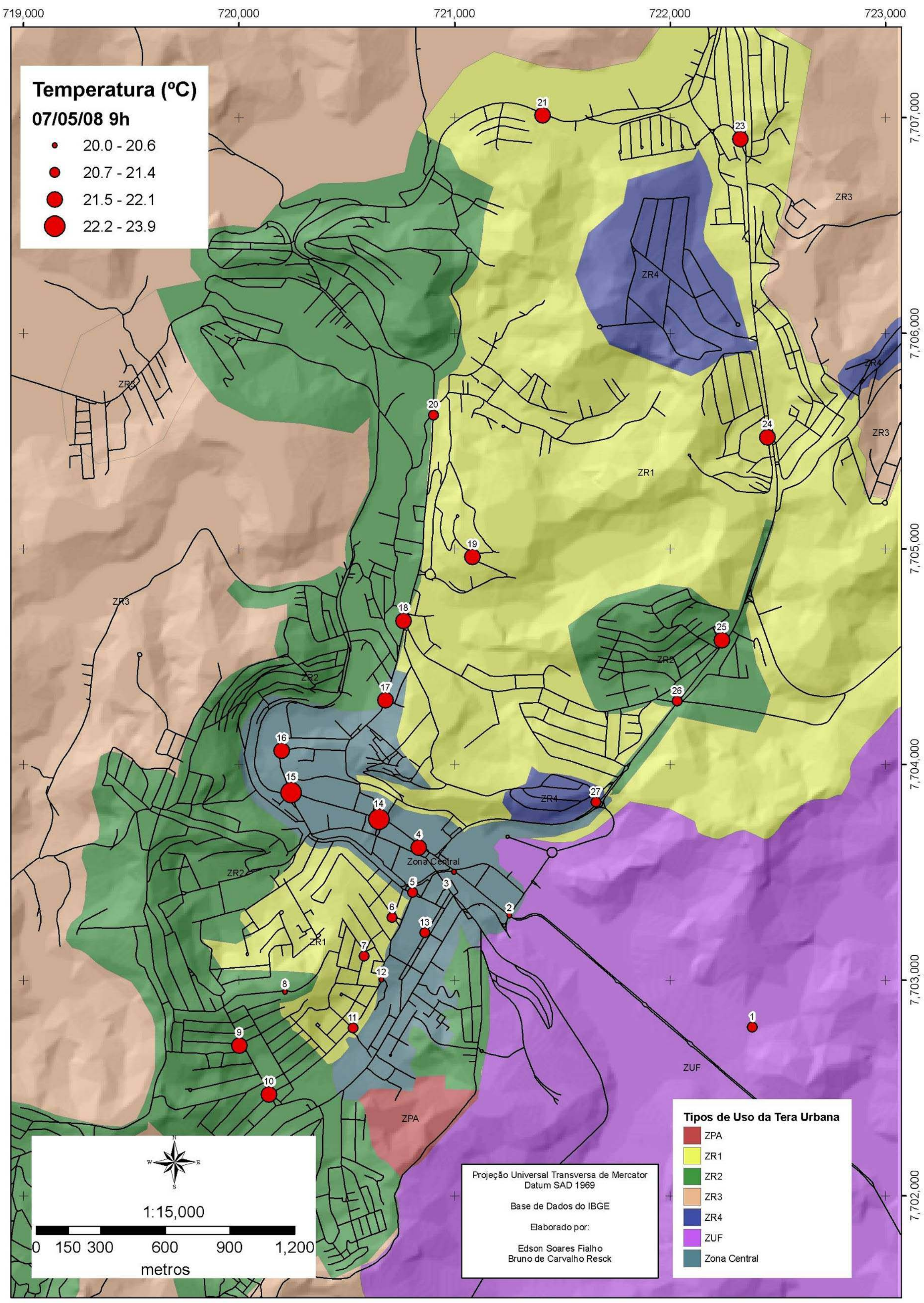




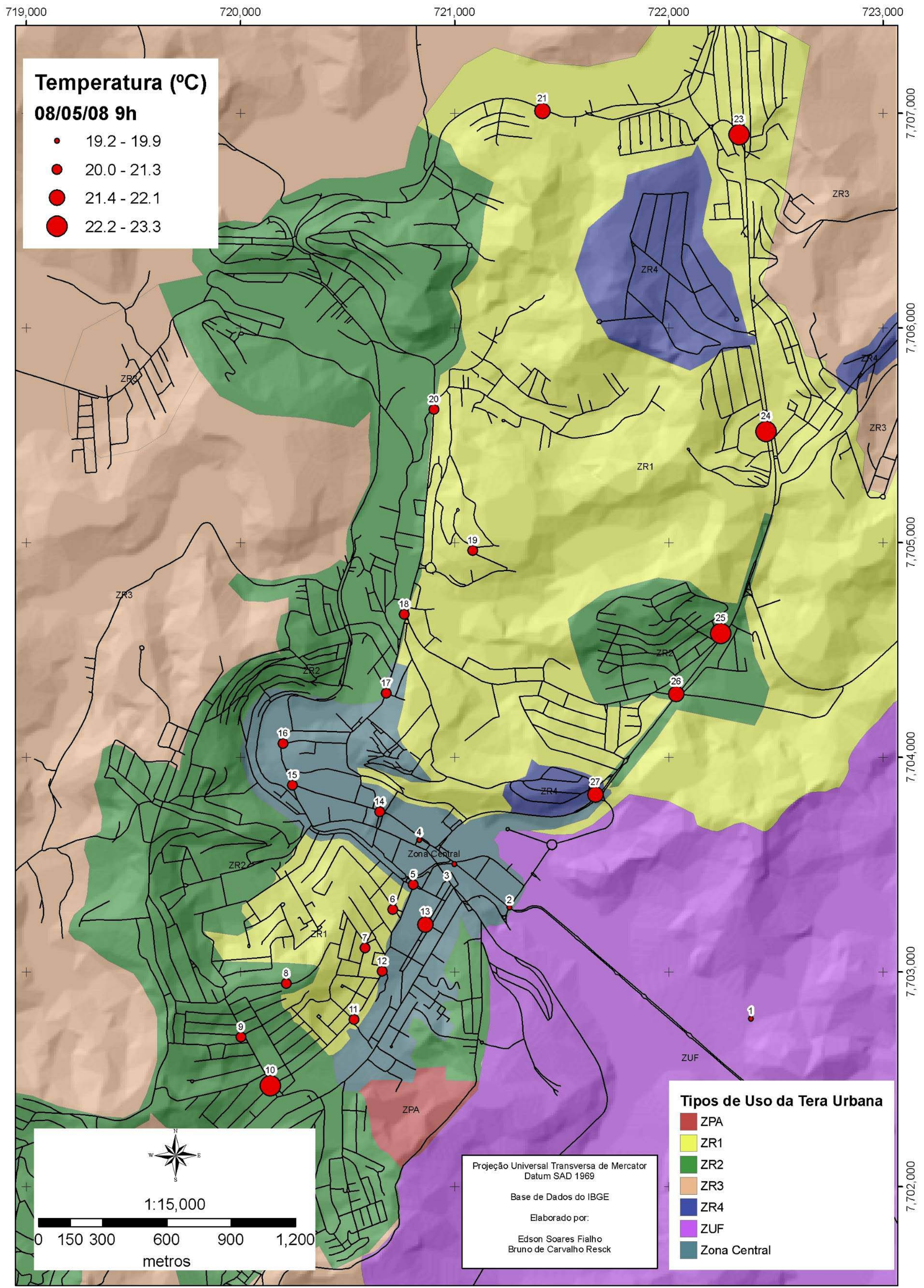




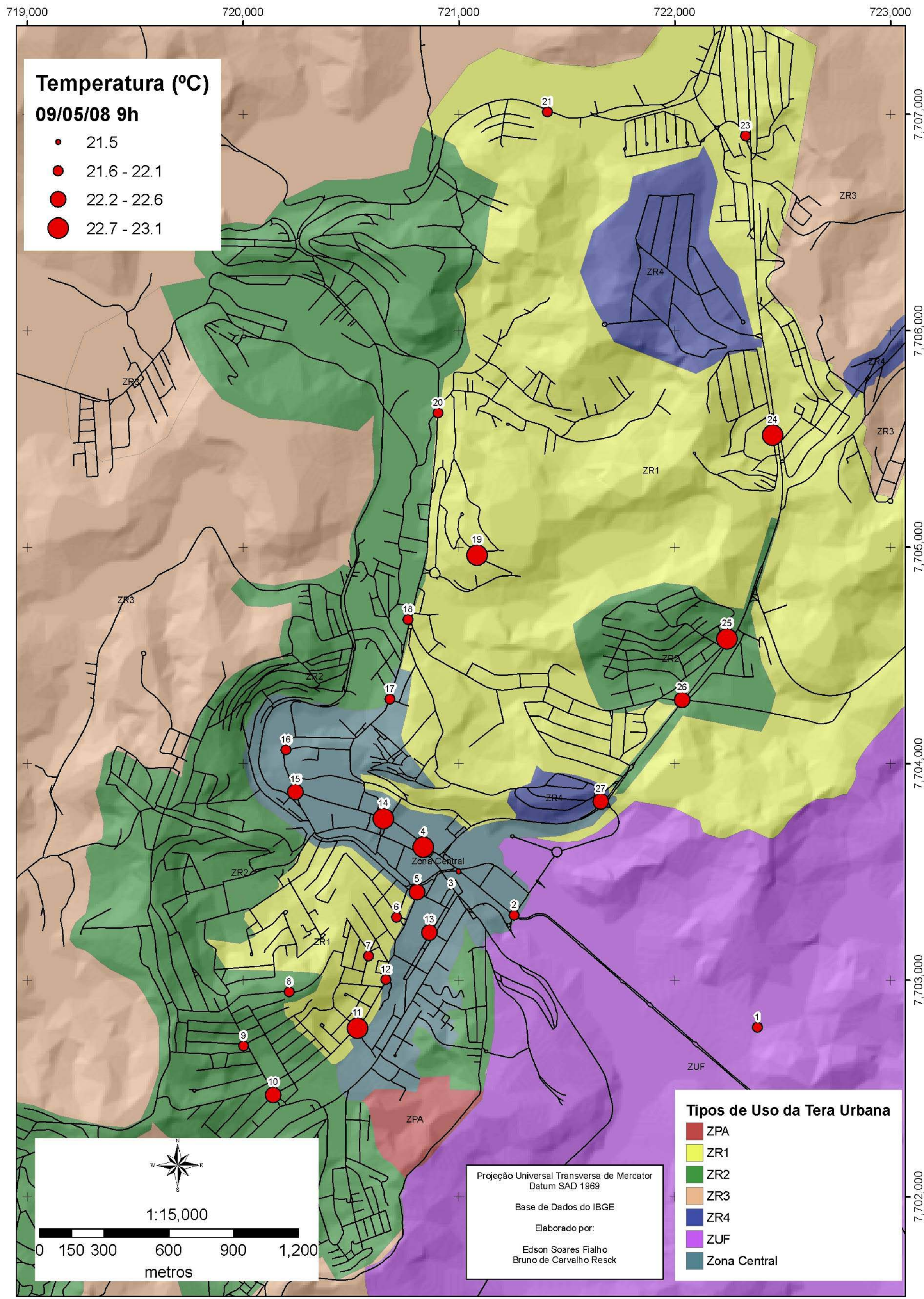




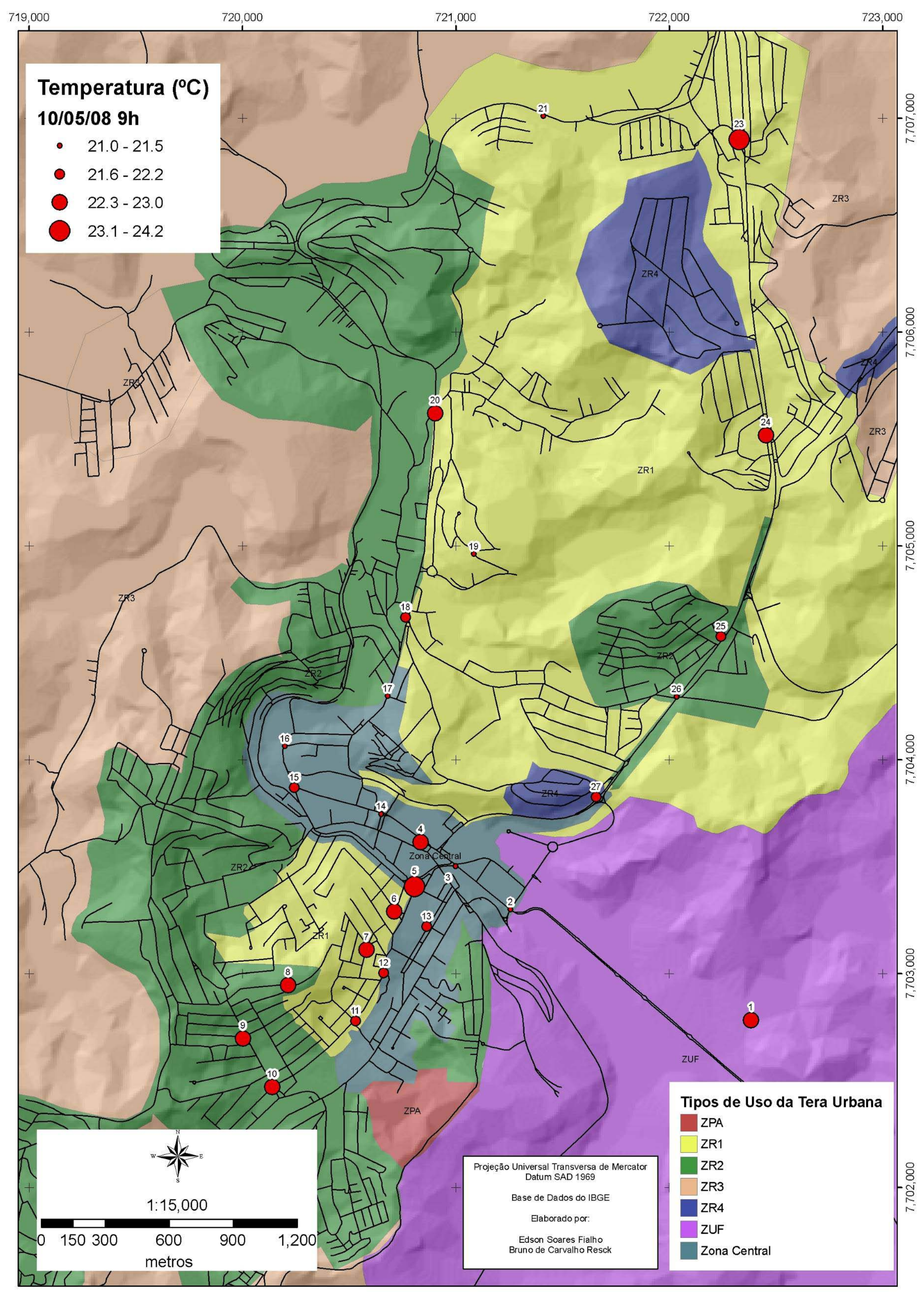




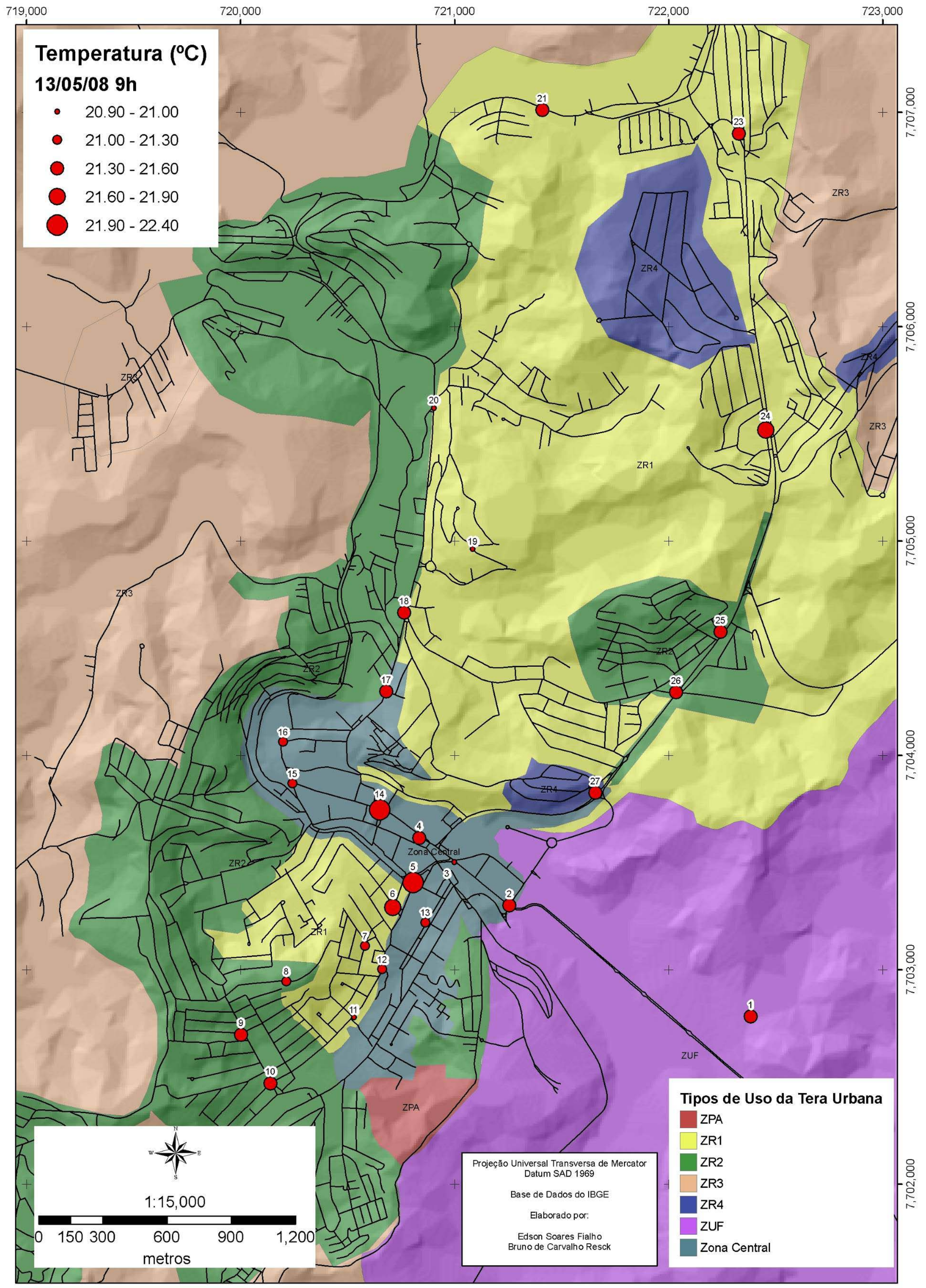




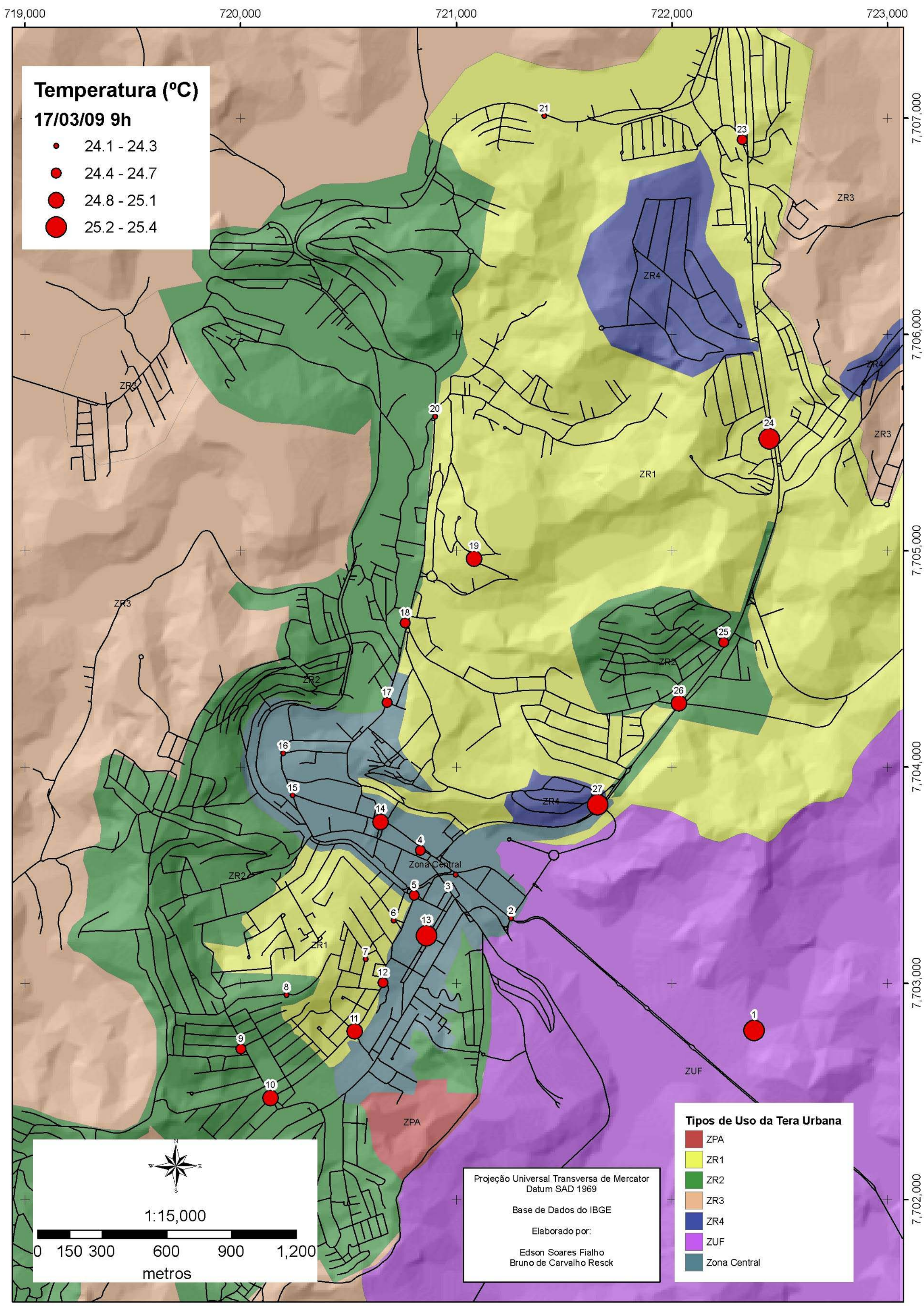




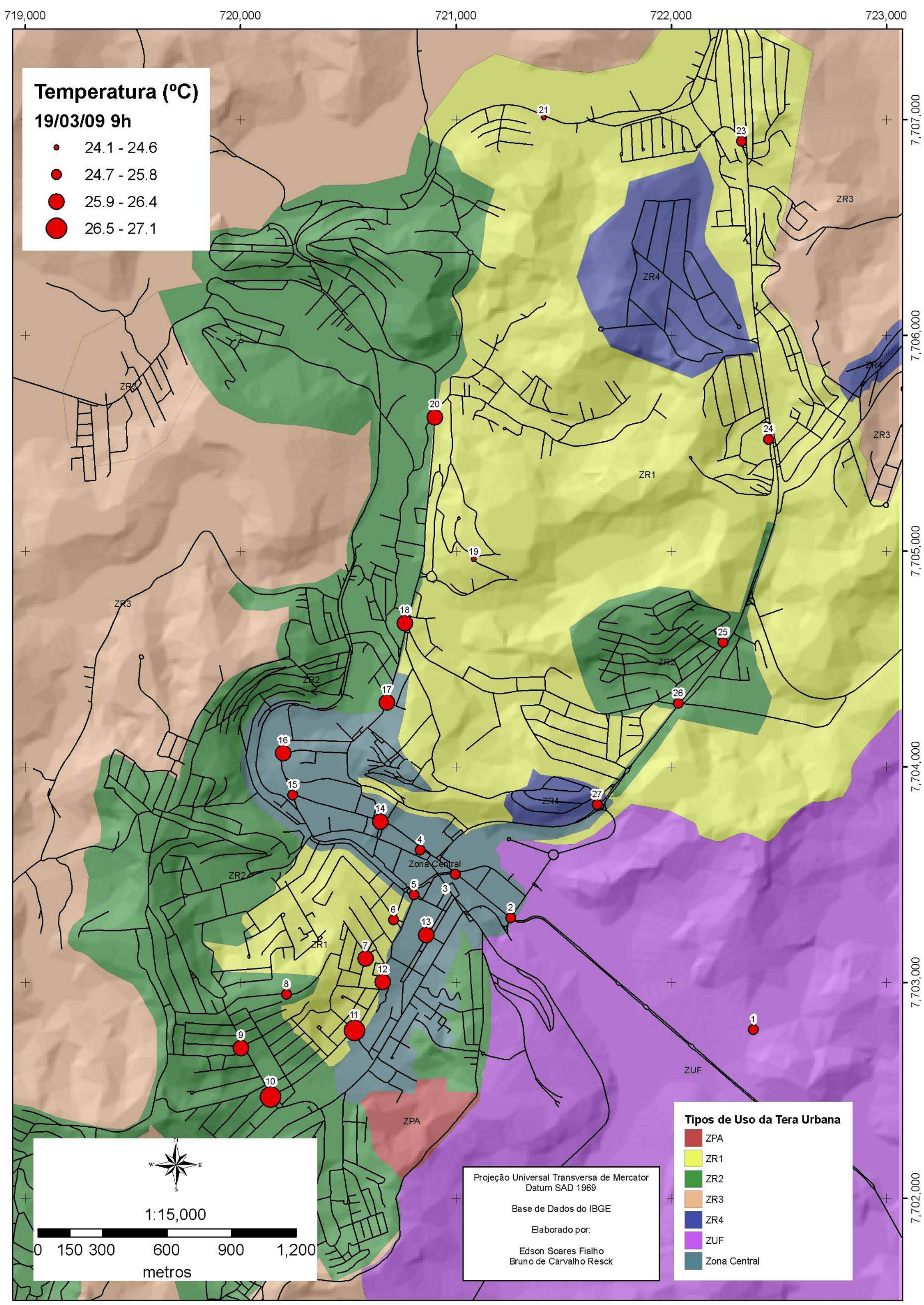




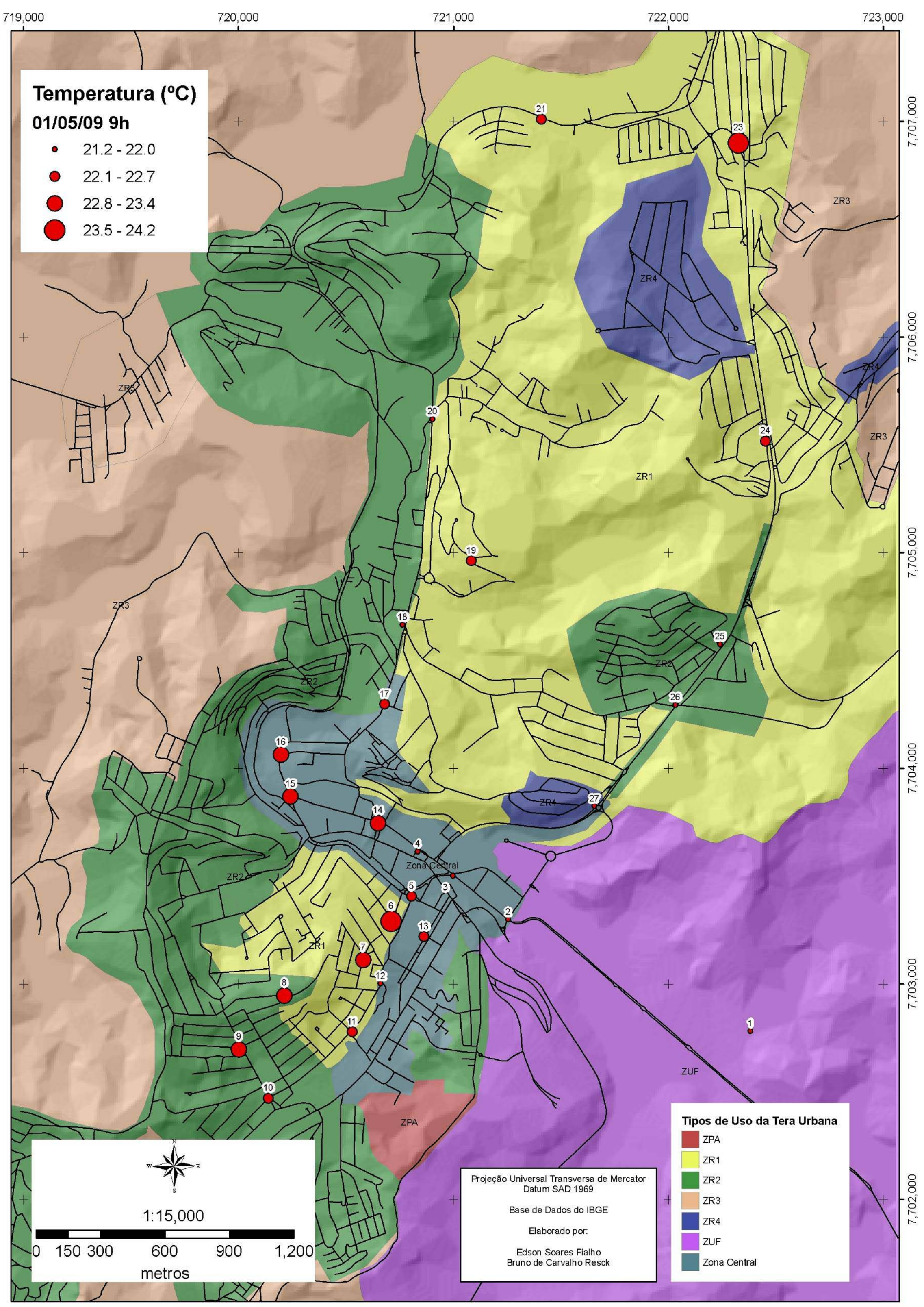




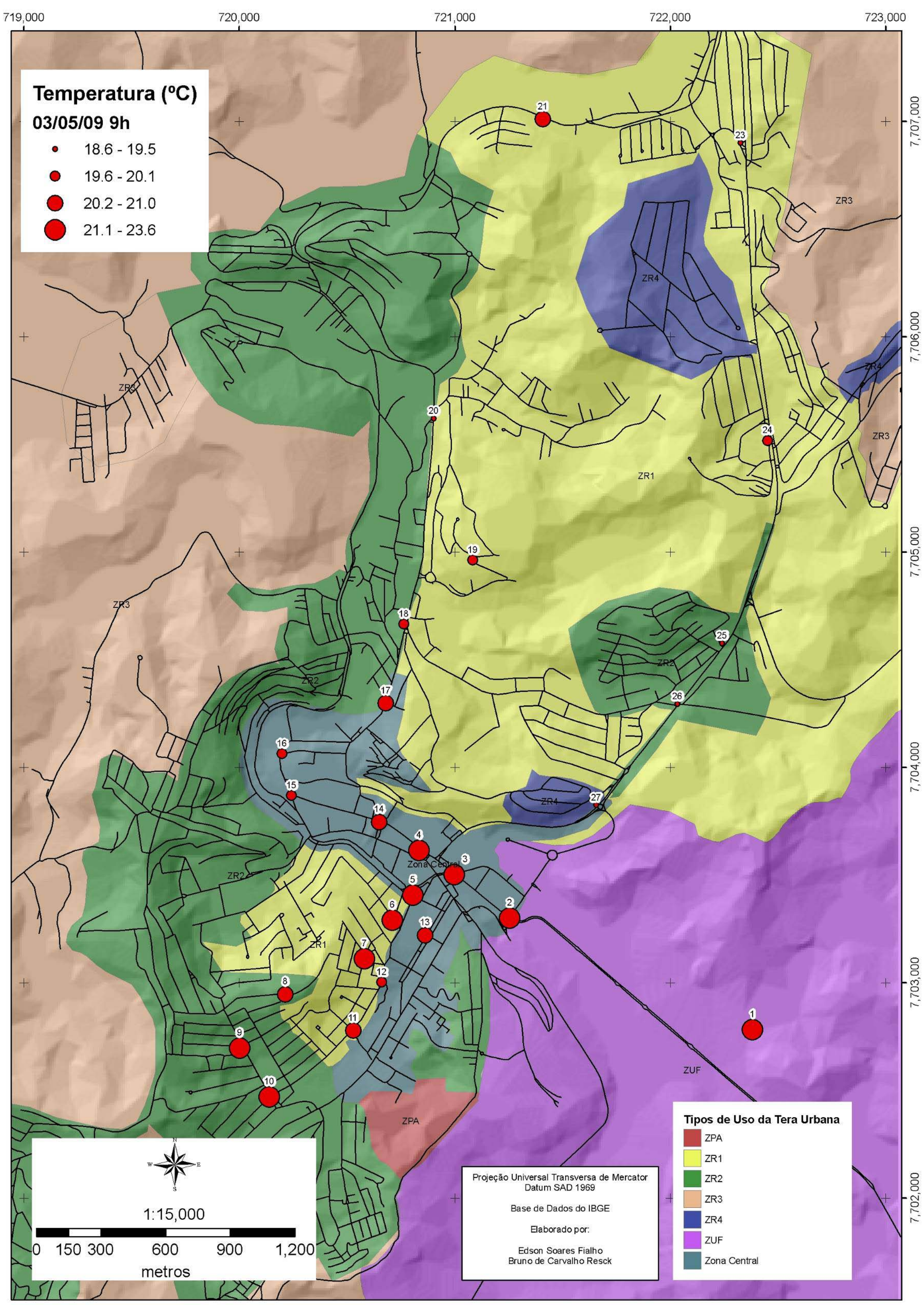

